\title{
Bedrijfsgezondheidszorg, aspecten van kwaliteit
}

\author{
Citation for published version (APA):
}

van Attekum, A. M. N. G. (1993). Bedrijfsgezondheidszorg, aspecten van kwaliteit. [Doctoral Thesis, Maastricht University]. Rijksuniversiteit Limburg. https://doi.org/10.26481/dis.19930917aa

Document status and date:

Published: 01/01/1993

DOI:

10.26481/dis.19930917aa

Document Version:

Publisher's PDF, also known as Version of record

\section{Please check the document version of this publication:}

- A submitted manuscript is the version of the article upon submission and before peer-review. There can be important differences between the submitted version and the official published version of record.

People interested in the research are advised to contact the author for the final version of the publication, or visit the DOI to the publisher's website.

- The final author version and the galley proof are versions of the publication after peer review.

- The final published version features the final layout of the paper including the volume, issue and page numbers.

Link to publication

\footnotetext{
General rights rights.

- You may freely distribute the URL identifying the publication in the public portal. please follow below link for the End User Agreement:

www.umlib.nl/taverne-license

Take down policy

If you believe that this document breaches copyright please contact us at:

repository@maastrichtuniversity.nl

providing details and we will investigate your claim.
}

Copyright and moral rights for the publications made accessible in the public portal are retained by the authors and/or other copyright owners and it is a condition of accessing publications that users recognise and abide by the legal requirements associated with these

- Users may download and print one copy of any publication from the public portal for the purpose of private study or research.

- You may not further distribute the material or use it for any profit-making activity or commercial gain

If the publication is distributed under the terms of Article $25 \mathrm{fa}$ of the Dutch Copyright Act, indicated by the "Taverne" license above, 
BEDRIJFSGEZONDHEIDSZORG, ASPECTEN VAN KWALITEIT 


\section{BEDRIJFSGEZONDHEIDSZORG,}

\section{ASPECTEN VAN KWALITEIT}

\section{PROEFSCHRIFT}

ter verkrijging van de graad van doctor aan de Rijksuniversiteit Limburg te Masstricht, op gezag van de Rector Magnificus, Prof. Mr. M.J. Cohen, volgens het besluit van het College van Dekanen, in het openbaar te verdedigen op vrijdag 17 september 1993 om 14.00 uur

door

Antonius Maria Nicolaas Gerardus van Attekum 


\section{Promotores:}

Prof. Dr. Tj. de Boorder

Prof. Dr. H.W.C. van der Hart (Technische Universiteit Eindhoven)

Co-promotor:

Dr. F.J.N. Nijhuis

\section{Beoordelingscommissie:}

Prof. Dr. H. Philipsen (voorzitter)

Prof. Dr. F.J.H. van Dijk (Universiteit van Amsterdam)

Prof. Dr. J.D.P. Kasper

Prof. Dr. E. Reerink

Prof. Mr. F.B.C. van Wijmen

\section{Druk:}

Datawyse Maastricht / Krips Repro Meppel

CIP-GEGEVENS KONINKLIJKE BIBLIOTHEEK, DEN HAAG

Attekum, Antonius Maria Nicolaas Gerardus van

Bedrijfsgezondheidszorg, aspecten van kwaliteit / Antonius

Maria Nicolaas Gerardus van Attekum. - [S.I. : s.n.]. -

III.

Proefschrift Maastricht. - Met lit. opg. - Met

samenvarting in het Engels.

ISBN $90-9006341-2$

Trefw.: bedrijfsgezondheidszorg / kwaliteitszorg in organisaties. 


\section{Inhoudsopgave}

1. Inleiding

2. Bedrijfsgezondheidszorg gewikt en gewogen 17

$\begin{array}{ll}\text { 2.1. Inleiding } & 17\end{array}$

$\begin{array}{ll}\text { 2.2. De positie van BGD'en in de gezondheidszorg } & 18\end{array}$

$\begin{array}{ll}\text { 2.2.1. Inleiding } & 18\end{array}$

2.2.2. De (gewenste) plaats van BGD'en in de gezondheidszorg 18

$\begin{array}{lll}\text { 2.2.2.1. Het Rapport "De plaats en organisatie van de BGZ in de } & \\ & \text { Nederlandse gezondheidszorg van de toekomst" (1975) }\end{array}$

2.2.2.2. Rapport "De toekomst van de BGZ" (DGA 1979) 19

2.2.2.3. Advies Arboraad "deskundige diensten" (Arboraad 1984) 19

2.2.2.4. Advies NRV "Bedrijfsgezondheidszorg" (NRV 1987) 20

2.3. Organisatie BGZ 20

2.3.1. Inleiding 20

2.3.2. Organisatievormen BGD'en 21

2.3.2.1. Enkelvoudige BGD'en (EVD'en) 21

2.3.2.2. Gezamenlijke BGD'en (GD'en) 22

2.3.2.3. Overeenkomsten met bedrijfsartsen c.q. ondernemingen met EVD 23

2.3.2.4. Overeenkomsten met artsen of instellingen 23

$\begin{array}{ll}2.4 . & \text { Takenpakket BGD'en }\end{array}$

2.4.1. Inleiding 23

2.4.2. Het kerntakenpakket BGZ 24

2.4.3. Het BGZ-takenpakket in de Arbowet 24

2.5. Spanningsvelden bedrijfsarts 25

2.6. Veranderingen in de arbeid en de organisatie van de arbeid 26

2.7. Veranderingen in de gezondheidszorg 27

2.8. Verwachtingen ten aanzien van BGZ 28

2.8.1. Een korte historische schets van de ontwikkeling van BGZ 29

2.8.2. Ervaringen met en wensen van werkgevers ten aanzien van BGZ 30

2.8.3. Ervaringen met en wensen van werknemers ten aanzien van BGZ 32

2.8.4. Ervaringen met en wensen van de beroepsgroep ten aanzien van BGZ 35

2.8.5. Overheid en BGZ: rol en verwachtingen 38

2.8.5.1. Verplichting $\quad 38$

2.8.5.2. Taken voor BGD'en 39

2.8.5.3. De disciplines in het BGZ-team 42

2.9. Suggesties voor BGD'en om in te spelen op de veranderingen in de door de klanten en haarzelf geformuleerde wensen $\quad 43$

2.9.1. Marktgerichtheid 43

2.9.2. Multidisciplinaire samenwerking (Palukeng

2.9.3. Professionaliteit en identiteit 44 
2.9.4. Beroepscode

2.9.5. (Na)scholing en wetenschap 46

2.9.6. Het takenpakket BGZ en sociaal-medische begeleiding 47

2.10. Samenvatting

3. Aspecten van kwaliteit van BGZ, de visie van de professional.

3.1. Inleiding

3.2. Wat is kwaliteit?

3.3. Aspecthenadering van kwaliteit van zorg $\quad 50$

3.1.1. 52

3.3.1. Aspecten van kwaliteit van zorg 52

3.3.2. De samenhang tussen aspecten van kwaliteit van zorg 53

3.4. Kwaliteitszorg in de gezondheidszorg 54

\begin{tabular}{ll} 
3.4.1. Inleiding & 54 \\
\hline
\end{tabular}

3.4.2. Kwaliteitbevordering en medische professie $\quad 55$

3.4.3. Kwaliteitszorg binnen de BGZ 56

$\begin{array}{ll}\text { 3.5. Professionalisering en BGZ } & 56 \\ 3.5 .1 . & 58\end{array}$

$\begin{array}{ll}\text { 3.5.1. Inleiding } & 58\end{array}$

3.5.2. Professionalisering 5

3.5.3. De plaats in het relatienetwerk en de beoordeling van de kwaliteit van $B G Z$

3.6. Protocollering in de BGZ 61

3.6.1. Inleiding 62

3.6.2. Begripsbepaling 62

3.6.3. Kernelementen van enige BGZ-taken 63

3.6.3.1. Het aanstellingsonderzoek $\quad 65$

$\begin{array}{ll}\text { 3.6.3.2. Het spreekuur } & 66 \\ 3.6 .3 & 68\end{array}$

$\begin{array}{ll}\text { 3.6.3.3. Het periodiek onderzoek } & 68 \\ 3.63\end{array}$

$\begin{array}{ll}\text { 3.6.3.4. Het werkplekonderzoek } & 73 \\ 3.7 & 77\end{array}$

$\begin{array}{ll}\text { 3.7. Samenvatting } & 81\end{array}$

4. Aspecten van kwaliteit van BGZ, de visie van de klant.

$\begin{array}{ll} & \text { Marketing en BGZ }\end{array}$

4.2. Het begrip marketing 83

4.2.1. Inleiding marketing $\quad 84$

4.2.2. Definitie marketing $\quad 84$

4.2.2.1. Marketing als mentaliteit $\quad 84$

4.2.2.2. Marketing als

4.2.2.3. Marketing als een verzameling van activiteiten 46

4.23. 187

4.2.3. De marketing-mix $\quad 87$

$\begin{array}{ll}\text { 4.2.3.1. Het personeel } & 87\end{array}$

4.2.3.2. De dienst (het "produkt") $\quad 88$

$\begin{array}{lll}\text { 4.2.3.3. De plaats } & 88\end{array}$ 
4.2.3.4. Communicatie $\quad 89$

4.2.3.5. De prijs (tariefstelling) 90

4.2.4. Kwaliteit van dienstverlening 91

4.2.4.1. Inleiding 91

4.2.4.2. Het SERVQUAL-model 92

4.3. Marketing in de dienstverlenende sector 95

4.4. Knelpunten bij de toepassing van marketing in de BGZ 98

4.4.1. Inleiding $\quad 98$

4.4.2. Knelpunten 99

4.4.2.1. Het produkt BGZ 99

4.4.2.2. Opstelling BGD 100

$\begin{array}{ll}\text { 4.4.2.3. Kwaliteit van BGZ } & 100\end{array}$

4.4.2.4. Scholing 101

4.4.2.5. Marketing-mix 101

4.5. Marketing en BGD 102

4.6. Samenvatting en conclusies 104

5. Wettelijk kader BGZ 105

5.1. Inleiding 105

5.2. Relevantie arbeids(omstandigheden)-wetgeving 105

5.2.1. Inleiding 105

5.2.2. De geschiedenis van de arbeidswetgeving 106

5.2.3. Invoering van de Arbowet: fasen en consequenties 108

5.3. Ontwikkeling BGZ. Relevante wetgeving 109

5.3.1. Inleiding 109

5.3.2. Wet op de Bedrijfsgeneeskunde $1959 \quad 110$

5.3.3. Wijziging Veiligheidswet $1971 \quad 111$

5.3.4. Wijziging Arbowet en andere relevante wetgeving 111

5.3.5. Kwaliteitsinstrumenten in de Arbowet 114

5.3.6. Uitbouw BGZ 116

5.4. $\quad B G Z$ in het buitenland 119

5.4.1. Inleiding $\quad 119$

5.4.2. Internationale bepalingen $\quad 119$

5.4.3. BGZ in andere Europese landen $\quad 121$

5.5. Samenvatting $\quad 121$

6. Het onderzoeksmodel 123

$\begin{array}{lr}\text { 6.1. Inleiding } & 123\end{array}$

$\begin{array}{lr}\text { 6.2. } & 123\end{array}$

$\begin{array}{ll}\text { 6.3. Relatienetwerk BGD } & 124\end{array}$

$\begin{array}{ll}\text { 6.4. Vooronderzoek } & 125\end{array}$

6.5. Verloop van het onderzoek 125

6.6. Respons 127

$\begin{array}{lr}\text { 6.7. Operationalisatie } & 129\end{array}$ 


\subsubsection{Inleiding}

6.7.2. Operationalisatie van het begrip

6.7.2.1. Aspecten van professionele kwaliteit 129

6.7.2.2. Aspecten van klantgerichte kwalit

6.7.3. Operationalisatie van de bedrijfsarts 131

6.7.3.1. Verantwoording selectie bedrijfsarts- en bedrijsvariabelen 132

6.7.3.2. Operationalisatie bedrijfsarts-variabelen 132

6.7.3.3. Operationalisatie van bedrijfsgebonden varabelen 133

6.8. Het onderzoeksmodel

6.9. Samenvatting

7. Beschrijving van het BGZ-relatienetwerk

7.1. Inleiding

7.2. Beschrijving van de bedrijven

7.2.1. Arbeidsomstandigheden

7.2.2. Verzuim en arbeidsongeschiktheid

7.2.3. Voedingsbodem Arbeidsomstandigheden

7.2.4. Contract BGZ

7.2.4.1. Initiatief tot aansluiting bij cen $B G D$

7.2.4.2. Redenen tot aansluiting bij een BGD

7.2.4.3. De "onderhandelingen" over het

7.2.4.4. Kosten BGZ: praktijk en wensen 141

7.2.4.5. Inhoud van het contract tussen BGD en bedrijf 142

7.2.4.6. Opinies m.b.t. de orat ussen BGD en bedrijf 143

7.2.5. Samenvatting

7.3. Organisatie BGD

7.3.1. Interne organisatie

7.3.2. Personeel en middelen

7.3.3. Samenvatting

7.4. Bedrijfsarts, een profielschets

7.4.1. Overlegpartners van de bedrijfsarts

7.4.2. De opvattingen van 148

7.4.1. Kenmerken van van de bedrijfsarts over zijn vak 149

7.4.2. Kenmerken van kwaliteit volgens de bedrijfsarts 150

7.4.2.3. Beleid en werkwijze van be bedrijfsarts 150

7.4.2.4. De visie van de bedrijfarts overijfsarts 150

7.4.3. Samenvatting

7.5. Samenvatting 
8. Aspecten van kwaliteit van BGZ.

De visie van de leverancier en de ontvanger van BGZ over professionaliteit en klantgerichtheid

8.1. Inleiding

8.2. Professionele aspecten van kwaliteit van BGZ 154

8.2.1. Werkwijze van de BGD c.q. de bedrijfsarts 155

8.2.2. Werkterrein van de BGD 156

$\begin{array}{ll}\text { 8.2.3. De advisering van de BGD } & 157\end{array}$

8.2.4. Uitvoering van de BGZ-kerntaken 157

8.2.4.1. Het aanstellingsonderzoek 157

$\begin{array}{ll}\text { 8.2.4.2. Het spreekuur } & 158\end{array}$

8.2.4.3. Het periodiek onderzoek 159

$\begin{array}{ll}\text { 8.2.4.4. Het werkplekonderzoek } & 160\end{array}$

8.2.5. Rendement van de kerntaken 161

$\begin{array}{ll}\text { 8.2.5.1. Rendement van het aanstellingsonderzoek } & 161\end{array}$

8.2.5.2. Het rendement van het spreekuur 162

8.2.5.3. Het rendement van het periodiek onderzoek 163

8.2.5.4. Het rendement van het werkplekonderzoek 163

8.3. Klantgerichte aspecten van kwaliteit van BGZ 164

8.3.1. De ondersteunende rol van de BGD 164

8.3.2. De houding van de BGD 165

8.3.3. Ervaring met taakuitvoering 166

8.3.4. De samenwerking tussen BGD en bedrijf 168

$\begin{array}{ll}\text { 8.3.5. De afstemming van de taakuitvoering } & 169\end{array}$

$\begin{array}{ll}\text { 8.3.5.1. Prioriteitsstelling BGZ-activiteiten } & 169\end{array}$

8.3.5.2. De wensen ten aanzien van de uitvoering van het aanstellingsonderzoek

8.3.5.3. De wensen ten aanzien van de uitvoering van het spreekuur 172

8.3.5.4. De wensen ten aanzien van de uitvoering van het periodiek onderzoek

8.3.5.5. De wensen ten aanzien van de uitvoering van het werkplekonderzoek 174

$\begin{array}{lll}\text { 8.4. Samenvatting } & 174\end{array}$

9. Analyses.

De samenhang tussen bedrijfsarts- en bedrijfsvariabelen en aspecten van kwaliteit van BGZ

9.1. Inleiding

177

9.2. Correlaties tussen de variabelen onderling $\quad 179$

9.2.1. Correlaties onafhankelijke variabelen onderling $\quad 180$

9.2.2. Correlaties afhankelijke variabelen onderling $\quad 180$

$\begin{array}{lll}\text { 9.2.2.1. Correlaties per kwaliteitsaspect } & 181\end{array}$

9.2.2.2. Correlaties tussen kwaliteitsaspecten $\quad 184$

9.3. Bedrijfsarts- en bedrijfsvariabelen en hun invloed op professionaliteit 186

9.3.1. Inleiding 186

$\begin{array}{ll}\text { 9.3.2. Bedrijfsarts-variabelen en professionaliteit } & 186\end{array}$ 
9.3.2.1. De werkwijze van de bedrijfsarts 186

$\begin{array}{ll}\text { 9.3.2.2. Het werkterrein van de BGD } & 186\end{array}$

9.3.2.3. De (professionele) uitvoering van BGZ-kerntaken 187

$\begin{array}{ll}\text { 9.3.2.4. De bruikbaarheid van advisering } & 188\end{array}$

9.3.2.5. Het rendement van BGZ-kerntaken 188

$\begin{array}{ll}\text { 9.3.3. Bedrijfsvariabelen en professionaliteit } & 198\end{array}$

9.3.3.1. De werkwijze van de bedrijfsarts 190

$\begin{array}{ll}\text { 9.3.3.2. Het werkterrein van de BGD } & 190\end{array}$

9.3.3.3. De (professionele) uitvoering van BGZ-kerntaken 191

$\begin{array}{ll}\text { 9.3.3.4. De bruikbaarheid van advisering } & 191\end{array}$

9.3.3.5. Het rendement van BGZ-kerntaken 191

9.4. Bedrijfsarts- en bedrijfsvariabelen en hun invloed op klantgerichtheid 192

9.4.1. Inleiding 192

$\begin{array}{ll}\text { 9.4.2. Bedrijfsarts-variabelen en klantgerichtheid } & 192\end{array}$

9.4.2.1. De ondersteuning door de BGD 192

$\begin{array}{ll}\text { 9.4.2.2. De houding van de BGD } & 193\end{array}$

9.4.2.3. Ervaring van de klant met de uitvoering van BGZ-taken 193

9.4.2.4. De samenwerking tussen BGD en bedrijf 194

9.4.2.5. De afstemming tussen klant en BGD m.b.t. taakuitvoering 194

$\begin{array}{lll}\text { 9.4.3. Bedrijfsvariabelen en klantgerichtheid } & 197\end{array}$

9.4.3.1. De ondersteuning door de BGD 197

$\begin{array}{ll}\text { 9.4.3.2. De houding van de BGD } & 197\end{array}$

9.4.3.3. Ervaring van de klant met de uitvoering van BGZ-taken 197

9.4.3.4. De samenwerking tussen BGD en bedrijf 198

9.4.3.5. De afstemming tussen klant en BGD m.b.t. taakuitvoering 198

9.5. BGD-organisatievorm en kwaliteit van BGZ 199

9.5.1. Inleiding 199

$\begin{array}{ll}\text { 9.5.2. Bedrijfsgrootte en kwaliteit: GD en EVD } & 199 \\ 9.5 .3 & 200\end{array}$

9.5.3. Verzuim en kwaliteit: GD en EVD 200

9.5.4. Ervaring van de bedrijfsarts en kwaliteit: GD en EVD 204

$\begin{array}{ll}\text { 9.5.5. Takopvatting van de bedrijfsarts en kwaliteit: GD versus EVD } 205 & 204\end{array}$

$\begin{array}{ll}\text { 9.6. Samenvatting en conclusie } 208 & \end{array}$

10. Beschouwing.

De twee sporen van kwaliteitszorg: professionaliteit en klantgerichtheid

10.1. Inleiding

10.2. De belangrijkste conclusies 213

10.3. Beries 214

\begin{tabular}{ll} 
10.3.1. De betekenis van marketing & 215 \\
\hline
\end{tabular}

10.3.2. BGD en

10.3.3. BGD en marketing op tactisch niveau: het realiseren van de 
10.3.4. BGD en marketing op operationeel niveau: het leveren van $B G Z$. in de praktijk

10.4. Bespiegelingen rond het vraagstuk: spanningsveld professionaliteitklantgerichtheid

10.4.1. BGZ volgens de snit van de klant

10.4.2. BGZ volgens de snit van de professional

10.4.3. BGZ, een kwestie van een andere takopvatting.

Sociaal-medische begeleiding als voorbeeld?

10.5. Aanbevelingen

10.5.1. De overheid

10.5.2. De beroepsgroep

10.5.3. De BGD'en

Samenvatting

Summary

Literatuurlijst

Bijlage 1. Afkortingen

Bijlage 2. Constructie variabelen

Bijlage 3. Correlatiematrix: GD en EVD samen

Bijlage 4. Correlatiematrix: Onafhankelijke en afhankelijke variabelen: onderlinge correlaties

Dankwoord

Curriculum Vitae 
14. The thisuringe

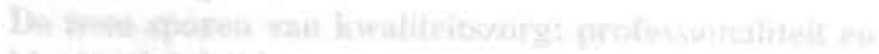

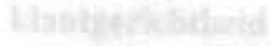

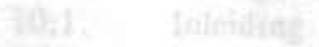

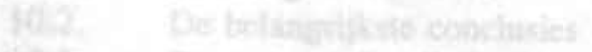

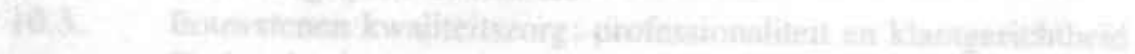

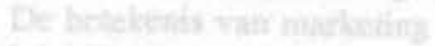

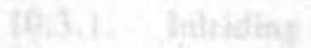

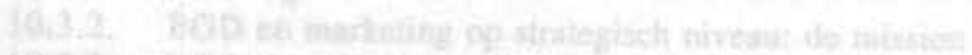

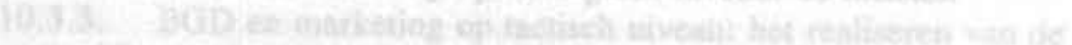

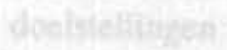




\section{Hoofdstuk 1}

\section{Inleiding}

Over kwaliteit van zorg is de afgelopen jaren binnen de gezondheidszorg regelmatig gediscussieerd. Verschillende pogingen om vorm en inhoud te geven ann kwaliteitszorg binnen de diverse artsengroeperingen zijn beschreven. De meeste aandacht gaat daarbij uit naar het uitwerken van de professionele kwaliteit, d.w.z. de kwaliteit van de zorg zelf, gezien vanuit de optiek van de professional. Te weinig $00 \mathrm{~g}$ is er voor de wijze waarop zorg wordt verleend, en of er wel behoefte bestaat an de betrokken zorg bij de klant. Anders gezegd, er is wel aandacht voor "technische" kwaliteit, maar in veel mindere mate voor "functionele" kwaliteit (Grönroos 1990b).

Ook binnen de bedrijfsgezondheidszorg (BGZ) is kwaliteitszorg een issue geworden. De kritiek op de kwaliteit van BGZ, die in de loop van de jaren tachtig uit verschillende hoeken, zowel van zijde van de leveranciers van zorg zelf (de bedrijfsgezondheidsdiensten (BGD'en)), als de ontvangers van zorg (de bedrijven), werd geuit, en de sterke veranderingen in de maatschappij en de gezondheidszorg, waren mede debet aan een herbezinning van BGD'en op hun taken en takuitvoering. De kern van de kritiek was dat BGD'en te weinig oog zouden hebben voor en onvoldoende zouden inspelen op wensen van de klant.

BGD'en kunnen worden gekarakteriseerd als dienstverlenende professionele organisaties. Dienstverlening onderscheidt zich van (industriële) produktie in een aantal essentiēle opzichten, die het zondermeer toepassen van (industriële) marketingprincipes of kwaliteitsbevorderende activiteiten moeilijk(er) maken. Diensten zijn immers niet tastbaar, telkenmale uniek, niet op voorraad leverbaar, niet te standaardiseren, en direct beïnvloedbaar door de klant zelf, omdat deze onderdeel uitmaakt van de dienstverlening.

In hoofdstuk $2 \mathrm{komt}$ aan de orde hoe BGD'en in de jaren tachtig omgingen met deze "crisis", deze verandering in het verwăchtingspatroon? Benadrukt moet worden dat zelfreflectie binnen BGD'en permanent plaatsvindt. In de geschiedenis van de BGZ kunnen voortdurende aanpassingen vastgesteld worden door BGD'en aan veranderende wensen en behoeften binnen hun doelgroepen. Hoofdstuk 2, getiteld "BGZ, gewikt en gewogen", beschrijft de mening van werkgevers, werknemers, overheid en beroepsgroep over de huidige stand van zaken van BGZ en de gewenste koers. Welke aspecten worden van belang geacht voor de kwaliteit van BGZ? Enerzijds is hierbij sprake van een bestendiging en actualisatie van reeds bestaande aspecten van kwaliteit, anderzijds wordt de noodzaak van een goede afstemming tussen vraag en aanbod als een essentieel aspect van kwaliteit van BGZ 
geẻxpliciteerd. Het hoofdstuk start met een beschrijving van de plaats, de organisatic en het takenpakket van BGD'en.

Het onderzoek beschrijft de ervaren kwaliteit van BGZ vanuit een tweetal perspectieven. Aan de ene kant worden aspecten onderzocht die de professie zelf van betekenis acht voor de kwaliteit van BGZ (professionele aspecten). Aan de andere kant worden aspecten onderzocht die de "klanten" van belang (zouden kunnen) achten voor de kwaliteit van BGZ (klantgerichte aspecten). In het onderzoek worden verder de termen professionaliteit en klantgerichtheid gebruikt. Klantgerichtheid heeft hier de betekenis van "voldoen aan de wensen van de kJant" zowel wat betreft de diensten die geleverd worden als de wijze waarop de dienstverlening plaatsvindt. Het bevat elementen als: het begrijpen van de behoeften van de klant, de gestelde doelen ten aanzien van klantentevredenheid en de mate waarin produkten zijn gebaseerd op ideeěn van klanten (Kasper 1990).

Maar wie zijn de klanten van de BGD'en? Met wie onderhouden BGD'en in het kader van hun werk relaties? Aan de ene kant betreft dit het bedrijf met zijn werkgever en werknemers (het klantensysteem in strikte zin). Aan de andere kant betreft dit andere zorginstanties, de beroepsgroep en de overheid. Binnen het klantensysteem hebben we nog te maken met diverse klanten, met gedeeltelijk tegengestelde belangen (werkgever, werknemers, ondernemingsraad). Met de werkgever gaat de BGD in formele zin de overeenkomst aan. BGD'en adviseren ook aan de werkgever, bijvoorbeeld in beleidsmatige zin bij herinrichting van een afdeling van het bedrijf. Het grootste deel van haar activiteiten richt de BGD echter op de werknemers binnen het bedrijf, zij vormen primair de doelgroep. BGZ wordt hierbij ingekaderd in het sociale beleid van de onderneming, dat op zijn beurt een onderdeel vormt van het totale beleid van de onderneming.

Deze zogenaamde aspectbenadering van de kwaliteit van BGZ betekent dat de aspecten die mogelijk een positieve invloed hebben op het kwaliteitsniveau worden beschreven, zonder dat hiermee kwaliteit in strikte zin gedefinieerd wordt. Kwaliteit blijkt immers een moeilijk te definiëren begrip (Harteloh en Casparie 1991). De conceptualisatie van het begrip kwaliteit is gerelateerd aan een bepaald object ("kwaliteit van iets"), is gericht op het bereiken van een bepaald doel, maar het doel dat nagestreefd wordt varieert met degene die dit vaststelt (in ons onderzoek bijvoorbeeld de eventuele discrepantie in doelformulering door leveranciers van BGZ en de ontvangers). Het idee bestaat dat binnen de BGZ te zeer de nadruk ligt op de professionele definiëring van kwaliteit, en dat de beroepsgroep te veel vanuit een ivoren toren opereert. Dit eenzijdig denken zou ongunstig kunnen werken bij het formuleren van een antwoord op de "crisis" binnen de BGZ. Tevens biedt een dergelijke benadering onvoldoende ruimte om in te spelen op veranderende vraagstellingen binnen de BGZ. Het opbouwen van een samenwerkingsrelatie met het klanten-systeem blijkt in de dienstverlenende sector een belangrijke voorwaarde voor een positief oordeel van de klant over de dienstverlening. 
Hoofdstuk 3 beschrijft een aantal professionele aspecten van kwaliteit van BGZ. Het gaat bijvoorbeeld om aspecten zoals intercollegiale toetsing, professionalisering en protocollering.

Hoofdstuk 4 draagt op basis van literatuuronderzoek elementen aan die als aspecten van klantgerichte kwaliteit van BGZ kunnen gelden. Centraal hierbij staat de vraag of en zo ja welke marketingprincipes toepasbaar zijn binnen de BGZ.

De overheid heeft het afgelopen decennium gekozen voor een terughoudende positie. Welke consequenties heeft dit voor de uitbreiding en ontwikkeling van de BGZ? Wat betekent dit voor de kwaliteit van BGZ? Aan de hand van een beschrijving van de ontwikkeling van arbeidsomstandighedenwetgeving wordt het wettelijk kader waarbinnen BGZ opereert in hoofdstuk 5 beschreven. Gegeven het toenemende belang voor nationale wetgeving, wordt in dit hoofdstuk ook kort ingegaan op internationale ontwikkelingen.

Hiermee zijn de belangrijkste partijen bij de totstandkoming van BGZ genoemd: de $B G D$, het bedrijf (werkgever en werknemers) en overheid.

Kwaliteit wordt in dit onderzoek gedefinieerd als: het op professioneel verantwoorde wijze (dat wil zeggen passend binnen de mogelijkheden van de BGD en getoetst aan normen binnen de beroepsgroep) leveren van BGZ, zodanig dat wordt ingespeeld op vastgelegde en zich veranderende behoeften en wensen bij de klant, en zodanig dat de dienstverlening plaatsvindt op een klantgerichte wijze. Anders gezegd, er wordt een onderscheid gemaakt tussen "technische" en "functionele" aspecten van kwaliteit (Grönroos 1990b), of in de termen van het onderzoek tussen professionaliteit en klantgerichtheid.

Het onderzoek tracht een antwoord te geven op de volgende twee vragen:

1. Hoe ervaren leveranciers en ontvangers van BGZ (een aantal aspecten van) de kwaliteit van BGZ. Meer specifiek, hoe wordt kwaliteit van BGZ ervaren op de respectieve aspecten professionaliteit en klantgerichtheid?

2. Welke bedrijfs- en bedrijfsartsgebonden variabelen hangen samen met de onderzochte aspecten van kwaliteit?

Het onderzoek heeft een exploratief karakter. Behalve dat bovenstaande vraagstellingen worden onderzocht voor de gehele onderzoekspopulatie, wordt ook onderzocht of er verschillen bestaan tussen gezamenlijke (GD) en enkelvoudige BGD'en (EVD) met betrekking tot de genoemde vraagstellingen.

GD'en en EVD'en verschillen in organisatie, en in positie in en ten opzichte van het bedrijf. EVD'en vervullen in vergelijking met GD'en binnen het bedrijf cen andere rol, er is ook sprake van een ander verwachtingspatroon van de organisatie richting EVD, hetgeen tot uiting komt in werkwijze en takenpakket van de BGD. De (beperkte) omvang van de respons en het aantal variabelen maken het echter noodzakelijk dat er kritisch wordt gekeken naar de statistische betrouwbaarheid van eventuele verschillen in samenhang tussen GD'en en EVD'en ten aanzien van de verschillende variabelen. 
Het onderzoek heeft plaatsgevonden door schriftelijke enquêtering van relevante participanten in het klantsysteem. Aan de kant van de leverancier van BGZ zijn dat de directie van de BGD en de uitvoerend bedrijfsarts. Aan de kant van de ontvangers van BGZ zijn dat het hoofd personeelszaken, alsmede een aantal werknemers en de voorzitter van de werknemersvertegenwoordiging (ondernemingsraad). Hoofdstuk 6 werkt het onderzoeksmodel verder uit.

Hoofdstuk 7 beschrijft het operationele kader waarbinnen BGD'en werken. Enige relevante kenmerken van de bedrijven, de BGD'en, en de bedrijfsartsen worden aangegeven.

In hoofdstuk 8 wordt de mening van de diverse participanten over een aantal aspecten van de ervaren kwaliteit van BGZ beschreven. Professionele en klantgerichte aspecten van $k w a l i t e i t$ van $B G Z$ worden geïnventariseerd.

Hoofdstuk 9 onderzoekt welke factoren van invloed zijn op enkele aspecten van de ervaren kwaliteit. Welke factoren in het bedrijf, welke bedrijfsartsgebonden factoren hebben hier invloed op?

Hoofdstuk 10 tenslotte beschouwt de belangrijkste conclusies van het onderzoek. 


\section{Hoofdstuk 2}

\section{Bedrijfsgezondheidszorg gewikt en gewogen}

\subsection{Inleiding}

De BGD functioneert in een maatschappelijk spanningsveld. Vandaar dat veranderingen en ontwikkelingen binnen de maatschappij in het algemeen, en het bedrijfsleven en de gezondheidszorg in het bijzonder asnleiding vormden een onderzoek in te stellen naar de wijze waarop BGD'en met het hieruit voortvloeiende veranderde wensen- en behoeftenpatroon omgingen en wat hiervan het resultaat is. Omdat er sprake is van het op diverse fronten tegelijk, en blijkbaar onverwacht optreden, van ingrijpende veranderingen, wordt het woord "crisis" gebruikt. Het woord crisis wordt hier gebruikt in haar authentieke betekenis, zijnde een breukpunt in een verwachtingspatroon (Van Schendelen 1984). Ingrijpende veranderingen deden zich enerzijds in het bedrijfsleven voor, waarbij de eind zeventiger jaren ingezette economische crisis versnellend gewerkt heeft. Paragraaf 2.6 werkt dit verder uit. Anderzijds is er ook sprake van evidente veranderingen binnen het gezondheidszorgsysteem, deels autonoom ontstaan, deels geluxeerd door de genoemde economische crisis. Paragraaf 2.7 beschrijft enige relevante ontwikkelingen op dit terrein.

De verwachtingen en wensen die voortvloeiden uit de hiervoor genoemde veranderingen binnen het klantsysteem van de BGD (werkgever en werknemer), de beroepsgroep (BGD'en en NVAB) en de overheid worden in paragraaf 2.8 beschreven.

Figuur 2.1 geeft een overzicht van de partijen die betrokken zijn bij de totstandkoming van BGZ.

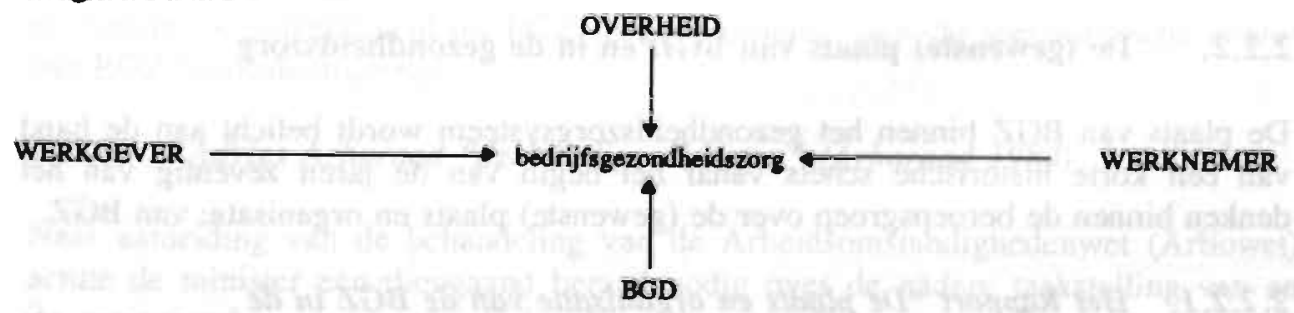

Figuur 2.1. Partijen die betrokkea zijn bij de totstandkoming van BGZ 
Ook in het buitenland wordt een bexinning gezien over doelstellingen en opdrachten van de BGZ (Lahaye 1984, Collings 1984).

Alvorens dit hoofdstuk in paragraaf 2.10 af te sluiten met een samenvatting, worden in paragraaf 2.9 enige uit de literatuur gedestilleerde suggesties gegeven hoe BGD'en adequaat het veranderingsproces kunnen doorvoeren.

Dit hoofdstuk start met een beschrijving van de positie, de organisatie en het takenpakket van de BGD (paragraaf 2.2 tot en met 2.4), gevolgd door een korte schets van de specifieke positie van de bedrijfsarts (paragraaf 2.5). Naast de individuele arts-patient relatie is er binnen de BGZ sprake van een relatie tussen bedrijf en bedrijfsarts, en tussen BGD en bedrijfsarts. Betrokken relaties zullen in de praktijk niet altijd op hetzelfde doel gericht zijn. Dit leidt tot een aantal spanningsvelden.

\subsection{De positie van BGD'en in de gezondheidszorg}

\subsubsection{Inleiding}

Gezond zijn, ziek worden en ziek zijn moeten worden opgevat als processen waarvan begin en verloop multiconditioneel zijn bepaald en die op ieder moment een weergave zijn van de complexe relatie mens-omgeving (NRV 1987). In deze zin zijn bedoelde processen onderwerp voor de gezondheidszorg in het algemeen, waarbij naar gelang van het domineren van bepaalde aspecten bij deze processen dan wel van beïnvloedende factoren, specifieke onderdelen van zorgverlening zich hierop kunnen richten.

Voor de BGZ is met name van belang de relatie mens-arbeid. BGZ dient dan ook opgevat te worden als dat deel van de gezondheidszorg dat primair betrekking heeft op de relatie tussen mens en arbeid, voor zover deze relatie relevant is voor de gezondheid. Als vorm van sociale gezondheidszorg heeft BGZ als doelstelling de collectieve en individuele gezondheidsbescherming en -bevordering van werknemers. Zij hanteert hierbij een voornamelijk preventieve benaderingswijze, die gestalte krijgt in een actief en anticiperend onderzoek van (groepen) mensen en arbeidsomstandigheden.

\subsubsection{De (gewenste) plaats van BGD'en in de gezondheidszorg}

De plaats van BGZ binnen het gezondheidszorgsysteem wordt belicht aan de hand van een korte historische schets vanaf het begin van de jaren zeventig van het denken binnen de beroepsgroep over de (gewenste) plaats en organisatie van BGZ.

\subsubsection{Het Rapport "De placats en organisatie van de BGZ in de Nederlandse gezondheidszorg van de toekomst" (1975)}

Mede onder invloed van ontwikkelingen als herstructurering van de gezondheidszorg en regionalisatie, ontwikkelingen die een impuls kregen na de Structuurnota 
gezondheidszorg van staatssecretaris Hendriks in 1974, kwam een door de NVAB ingestelde Studiegroep in 1975 met en Rapport, getiteld: "De plaats en de organisatie van de BGZ in de Nederlandse gezondheidszorg van de toekomst" (NVAB 1975) dat tot doel had een onderzoek in te stellen naar de plaats, de rol en de gewenste organisatie van de BGZ in de totaliteit van de Nederlandse gezondheidszorg in de nabije toekomst. Het rapport werd aangeboden als een bijdrage tot een discussie binnen, maar ook buiten de eigen kring. Er werden voorstellen gedaan om het verzorgingsgebied van BGZ uit te breiden, om samenwerking met andere gezondheidszorginstanties vorm te geven, en om BGZ te financieren.

Door de Studiegroep werd geconstateerd dat BGZ buiten de eigen kring weinig bekendheid genoot. BGZ werd gezien als complementair in relatie tot de curatieve gezondheidszorg door het opsporen en het signaleren van gezondheidsbedreigingen in de arbeid, door preventie van ziekteverzuim en arbeidsongeschiktheid.

\subsubsection{Rapport "De toekomst van de Bedriifsgezondheidszorg" (DGA 1979)}

In 1979 wordt het rapport "De toekomst van de bedrijfsgezondheidszorg" uitgebracht. In dit rapport wordt gesignaleerd dat bedrijfsgeneeskundige activiteiten zich hebben ontwikkeld van een zuiver preventieve zorg naar een positieve zorg, met name door het streven van de BGZ naar optimalisering van de arbeidssituatie. Om dit tot uiting te brengen in de naamgeving, wordt sinds die tijd in plaats van het begrip bedrijfsgeneeskunde meestal het begrip BGZ gebruikt. In dit begrip wordt tot uitdrukking gebracht:

1. dat de taak van de bedrijfsgeneeskundige preventief gericht is op behoud, bescherming en bevordering van de gezondheid in de arbeidssituatie en niet in de eerste plaats op het genezen van zieken;

2. dat BGZ de inbreng en deskundigheid van vele disciplines vereist: naast medische deskundigheid is ook inbreng vereist van arbeidshygiënische, technische, sociaal-psychologische en bedrijfsorganisatorische aard.

Het in de Structuurnota Hendriks voorgestelde echelonneringsmodel is voor de BGZ niet goed toepasbaar, omdat BGZ kenmerken vertoont van meerdere echelons: basisechelon, door de actieve en op collectiviteit gerichte preventie-activiteiten, eerste echelon door de levering van individuele zorg in een specifiek bedrijf en de directe toegankelijkheid tot BGZ, tweede echelon door de specialistische kennis van BGZ (consulentfunctie).

\subsubsection{Advies Arboraad "deskundige diensten" (Arboraad 1984)}

Naar aanleiding van de behandeling van de Arbeidsomstandighedenwet (Arbowet) achtte de minister een diepgaand beraad nodig over de nadere taakstelling van en de samenwerking tussen de deskundige diensten. Hierover werd advies gevraagd aan de Arboraad. De Arboraad beperkt haar advies tot de deskundigen genoemd in artikel 18 tot en met 20 van de Arbowet, en geeft aan dat over de Arbodienst (artikel 17) separaat zal worden geadviseerd. 
De Arboraad acht samenwerking van BGD'en en bedrijfsveiligheidsdiensten essentieel voor een doeltreffend arbobeleid. Coördinatie binnen de onderneming is gewenst. Over de specifieke taken en verantwoordelijkheden van de diensten en de daarin werkzame deskundigen moeten zoveel mogelijk afspraken worden gemaakt.

\subsubsection{Advles NRV "Bedrijssgezondheidszorg" (NRV 1987)}

De bijdrage van BGZ aan de gezondheidszorg, is aldus een advies van de NRV uit 1987, gelegen in een verruiming van het inzicht in de relatie tussen werk en gezondheid en de implicaties daarvan. BGZ draagt hiertoe onderzoeksmethoden en denkbeelden aan. Daarnaast draagt BGZ in belangrijke mate bij aan een goed sociaal beleid in de individuele onderneming, mits zij hiervoor binnen het bedrijf ook de ruimte krijgt. Naar de individuele werknemer toe kan BGZ een bijdrage leveren door bevordering van het welbevinden en ontplooiingsmogelijkheden van de werkende mens. Het belang van BGZ in relatie met de overige organisaties in de gezondheidszorg is vooral gelegen in het beperken van de medische consumptie. Door het voorkomen van arbeidsgebonden problematiek (primaire preventie) en door het vroegtijdig signaleren en adviseren (secundaire preventie), kan een vermindering van het gebruik van curatieve voorzieningen worden bewerkstelligd. Tevens kan hierdoor het ziekteverzuim worden verminderd, waarmee BGZ ook in dit opzicht voor de gehele samenleving een belangrijke functie heeft.

\subsection{Organisatie BGZ}

\subsubsection{Inleiding}

Ondernemingen zijn vrij in de manier waarop zij vorm geven aan de verplichting tot het hebben van BGZ. Bij een GD geldt wel de eis dat de rechtspersoon aan wie het beheer van de BGD is opgedragen niet beoogt winst te maken en geen ander doel heeft dan de bevordering van de preventieve gezondheidszorg. Ook moeten in het bestuur van deze rechtspersoon één of meer vertegenwoordigers van de werknemers, die werkzaam zijn in de onderneming of de ondernemingen, waaraan de BGD is of wordt verbonden, zitting hebben. Naar verwachting zal de gewijzigde Arbowet hierin verandering brengen.

Bij de behandeling van de Arbowet (zie verder hoofdstuk 5) is uitvoerig gediscussieerd over het gezamenlijk onderbrengen van de zorg voor veiligheid, gezondheid en welzijn in één organisatie. In het kader van certificatie wordt deze gedachte weer actueel. Ook de wijziging van de Arbowet, die 1/1/93 noodzakelijk wordt om de EG-richtlijn 89/391 in de Nederlandse wetgeving te implementeren, stelt eisen aan de samenstelling en werkwijze van BGD'en. Los van het feit dat de term "BGD'en" verdwijnt - er wordt gesproken over arbodiensten - zullen betrokken diensten zorg op maat (gerelateerd aan de aanwezige arborisico's) moeten leveren, 
en tegelijkertijd wel het brede arbeidsornstandighedenterrein moeten kunnen bestrijken.

\subsubsection{Organisatievormen BGD'en}

In deze paragraaf wordt ingegaan op de mogelijkheden om BGZ te organiseren. Wat zijn de voor- en nadelen van de diverse organisatievormen?

In zijn algemeenheid wordt door de overheid geen uitspraak gedaan over de gewenste organisatievorm van BGZ. Wel worden er eisen gesteld aan de onafhankelijke positie, de vereiste omvang en kwaliteit (zie ook DGA 1979, NRV 1987). De AMvB Arbodiensten, die eind 1992 aan de respectievelijke adviesorganen werd voorgelegd, zal naar verwachting tot ingrijpende wijzigingen in de organisatie van BGZ leiden. Zie verder hoofdstuk 5.3.4.

\subsubsection{Enkelvoudige BGD'en (EVD'en)}

Dit zijn diensten die door een werkgever (particulier of (semi)overheid) in stand worden gehouden. De grootte van de EVD'en varieert van die waaraan één arts is verbonden tot een dienst met enkele tientallen artsen.

De organisatorische positie van BGD'en in ondernemingen is zeer verschillend, variërend van een onderdeel vormend van een afdeling personeelszaken tot een zelfstandige rechtstreeks onder de directie vallende afdeling. Een particuliere onderneming met een eigen BGD is vrijwel altijd van een dergelijke omvang dat in die onderneming voldaan moet worden aan de verplichting tot het instellen van een Ondernemingsraad. Ingevolge de WOR behoeft de werkgever de instemming van de ondernemingsraad ten aanzien van de beleidsbepaling op het gebied van de BGZ.

Ten aanzien van (semi)overheidslichamen kan worden gesteld, dat de inspraak over de BGZ kan plaatsvinden via daartoe aangewezen interne overlegorganen (DGA 1979).

Binnen EVD'en is vrijwel altijd sprake van een combinatie van bedrijfsgeneeskundige activiteiten in strikte zin èn verzekeringsgeneeskundige begeleiding (begeleiding in kader Ziektewet c.q. ARAR).

Door de NRV (1987) wordt op een tweetal mogelijke problemen geattendeerd. Het eerste heeft betrekking op de organisatie van BGZ bij grote, verspreid opererende ondernemingen. Daarnaast wordt geduid op het leveren van BGZ door EVD'en aan derden. Bezwaarlijk hieraan is dat invloed of medezeggenschap door werknemers ontbreekt, de kwaliteit vaak minder zou zijn, en dat geen continuïteit gegarandeerd is.

De BGZ bij gemeente brengt problemen met zich mee over de positie van de bedrijfsarts, de zelfstandigheid van de gemeentelijke BGD, en de regeling van inspraak en medezeggenschap. De Arboraad bracht in 1986 hierover advies uit (nr.15). 
De Arboraad pleit ervoor, dat de binnen de afdeling BGZ werkzame arts wordt aangesteld als bedrijfsarts conform artikel 18 Arbowet, en niet, zoals op dat moment gebruikelijk was, als gemeentearts (met ook andere dan BGZ-taken).

Het hoofd van de afdeling BGZ dient rechtstreeks te vallen onder de werkgever (college van B\&W of verantwoordelijke wethouder), en niet onder de directeur van de GGD. Het zou wenselijk zijn als de afdeling BGZ ook in organisatorisch opzicht als diensteenheid herkenbaar is.

Als de gemeente een eigen BGD onderhoudt, zijn er - nog steeds aldus de Arboraad - geen nadere voorzieningen nodig voor inspraak en medezeggenschap van de werknemers, orndat de vigerende inspraakorganen dienaangaande invloed kunnen hebben. Als echter BGZ wordt betrokken van een afdeling BGZ elders, bijvoorbeeld van een DGD, dan dienen aanvullende maatregelen te worden getroffen om betrokken inspraak te garanderen. De Arboraad ziet twee mogelijkheden om deze inspraak gestalte te geven. De eerste oplossing zou zijn de omvorming van de afdeling BGZ (van een DGD) tot een juridisch en organisatorisch zelfstandige eenheid. De tweede oplossing zou zijn dat in het "Besluit nadere eisen gezamenlijke BGD'en" een bijzondere voorziening wordt opgenomen (op basis van artikel 25 van de Wet gemeenschappelijke regelingen, Staatsblad 1991,242), waarmee toelating geregeld wordt. Deze bijzondere voorziening zou tenminste moeten inhouden dat aan het bestuur van de DGD een adviescommissie wordt verbonden die het DGDbestuur adviseert in BGZ-aangelegenheden, en waarin vertegenwoordigers zijn opgenomen van het personeel van de aangesloten gemeenten. In het Besluit van 10 december 1991 tot wijziging van het Arbeidsomstandighedenbesluit burgerlijke openbare dienst (Staatsblad 686) wordt de voor erkenning noodzakelijke organisatie van BGZ bij gemeenten aangegeven.

De door de NVAB voorgestelde oplossing (NVAB 1984a), namelijk de vorming van een commissie ex artikel 61 van de Gemeentewet, wordt door de Arboraad van de hand gewezen.

Aparte vermelding verdient de regeling van BGZ voor het Rijksoverheidspersoneel. In het Algemeen Rijksambtenaren Reglement (ARAR), Besluit van 12 juni 1931 (Staatsblad nr. 248), frequent bijgesteld en gewijzigd, worden in hoofdstuk VI ARAR de bedrijfsgeneeskundige begeleiding en voorzieningen in verband met ziekte geregeld. Deze regeling, die overigens in afgeleide vorm ook in met de Rijksoverheid gelieerde organisaties wordt toegepast, geeft aan alle ambtenaren het recht van BGZ (artikel 35) en werkt het takenpakket BGZ uit (artikel 36).

\subsubsection{Gezamenlijke $B G D^{\prime} e n(G D$ 'en)}

GD'en zijn diensten, die aan verscheidene in een regio gevestigde ondernemingen BGZ verlenen. In de praktijk blijkt dat een groot aantal van de aangesloten bedrijven en instellingen niet valt onder de verplichting een erkende BGD aan zich te verbinden. Met name het collectief onder de BGZ brengen van de bouw, heeft aan 
de uitbreiding van BGD'en een enorme impuls gegeven, zodanig dat er nu een sluitend netwerk van GD'en over ons land bestaat (DGA 1988).

Het beheer van een GD moet - ingevolge de wettelijke bepaling - worden opgedragen aan $e n$ afzonderlijke rechtspersoon, die niet beoogt winst te maken (vereniging of stichting). De bedrijfsartsen en het personeel werkzaam bij een GD zijn in dienst van de rechtspersoon. De omvang van de GD varieert wat betreft het aantal daaraan verbonden artsen van 1 tot meer dan 10, en wat betreft het antal aangesloten ondernemingen van minder dan 10 tot meer dan 100. De eindverantwoordelijkheid voor de beleidsbepaling en de uitvoering van de BGZ door een GD berust - afgezien van de verantwoordelijkheid van de werkgever in de eigen onderneming - bij het bestuur van de rechtspersoon. De inspraak van de werknemers in het bestuur van de BGD is geregeld door het voorschrift dat in het bestuur van de rechtspersoon een of meer vertegenwoordigers van de werknemers zitting moeten hebben. In 1990 (Arboraad 1990a) is voorgesteld de samenstelling van het bestuur paritair (werkgevers en werknemersleden) te doen zijn. Daarnaast bestaat op ondernemingsniveau inspraak via de ondernemingsraad.

Door de NRV (NRV 1987) worden bij GD'en problemen gesignaleerd bij de kwaliteit van zorg (met name voor de niet-verplichte bedrijven), en grote verschillen in omvang van geleverde zorg (zogenaamde deelpakketten) en tarifering.

\subsubsection{Overeenkomsten met bedrijfsartsen c.q. ondernemingen met een EVD}

Door bedrijven en instellingen wordt in een aantal gevallen cen contract afgesloten met een elders aangestelde bedrijfsarts of met een werkgever die cen EVD aan zich verbonden heeft. In deze gevallen is er geen sprake van een GD omdat de zeggenschap over de BGD blijft berusten bij een ander.

\subsubsection{Overeenkomsten met artsen of instellingen}

Vele bedrijven maken gebruik van de diensten van bijvoorbeeld huisartsen of instellingen voor het doen verrichten van aanstellingskeuringen, ad-hoc adviezen, begeleiding van werknemers die aan potentiële gezondheidsrisico's worden blootgesteld of voor periodieke gezondheidskeuringen. Uit eigen onderzoek (Van Attekum 1983) bleek ongeveer $30 \%$ van de huisartsen bedrijfsgeneeskundige en/of verzekeringsgeneeskundige activiteiten te verrichten.

\subsection{Takenpakket BGD'en}

\subsubsection{Inleiding}

Er zijn reeds meerdere pogingen gedaan om de taken van de bedrijfsarts te omschrijven: rapport commissie Luyten 1948, rapport commissie Govaert 1961, 
KNMG 1969, NVAB 1975, NRV 1987. De gewenste afbakening van BGZ met de curatieve sector speelde hierbij een belangrijke rol. Daarnaast speelde een rol de noodzakelijk geachte aansluiting bij internationale ontwikkelingen, zoals Aanbeveling 112 van de ILO.

\subsubsection{Het kerntakenpakket BGZ}

In het rapport "Plaats en de organisatie van de BGZ in de Nederlandse gezondheidszorg van de toekomst" (NVAB 1975), wordt gesproken over een zogenaamd kerntakenpakket. Dit pakket bevat de meest essentiële zorgelementen van BGZ. Het zou met name ingezet moeten worden om de gewenste uitbreiding van BGZ naar de gehele beroepsbevolking te kunnen realiseren. Een dergelijk kerntakenpakket bevatte de volgende elementen:

- $\quad$ het geneeskundig onderzoek bij in dienst treden;

- het periodiek geneeskundig onderzoek bij bijzondere gevaren van de arbeid voor de gezondheid;

- het uitbrengen van aanbevelingen ter voorkoming van beroepsziekten;

- het meewerken aan het voorkómen van ongevallen;

- het meewerken aan revalidatie;

- het meewerken aan het weren en bestrijden van schadelijke of hinderlijke factoren van de arbeid;

- het houden van een bedrijfsgeneeskundig spreekuur;

- het verrichten van werkzaamheden en het bevorderen van maatregelen ter beperking van het ziekteverzuim;

Als belangrijkste bezwaar tegen deze benadering van "deelzorg", wordt aangevoerd het ontbreken van continuïteit van zorg en samenhang in zorgverlening (NRV 1987).

\subsubsection{Het BGZ-takenpakket in de Arbowet}

Het takenpakket van een BGD staat expliciet vermeld in artikel 18 van de Arbowet. Globaal gesproken kan er een onderscheid worden gemaakt in adviserende taken (in de tekst sub a, $c$ en $g$ ) en uitvoerende taken (sub e, f, $m, k, l, i, p, d$ ). De taken grijpen in elkaar en vullen elkaar aan, waarbij het geheel meer is dan de som der delen. Mede met het oog op erkenning van BGD'en kan het noodzakelijk worden geacht dat een BGD in beginsel in staat is, zorginhoudelijk bezien, het gehele takenpakket uit te voeren. In de praktijk zal het dienstenaanbod evenwel toegesneden moeten zijn op de omvang en aard van de bestaande problematiek en de daaruit voortvloeiende behoefte aan zorg (zorg op maat) (NRV 1987).

Naast het aangeven van een aantal taken, stelt de Arbowet ook een aantal taakuitoefeningen verplicht, zoals de jaarlijkse rapportage aan de ondernemingsraad (artikel 18, lid 3). In paragraaf 5.3.4. wordt op recente wettelijke ontwikkelingen verder ingegaan. 


\subsection{Spanningsvelden bedrijfsarts}

Van de Vliert (1986) biedt een goed theoretisch kader waarbinnen de diverse spanningsvelden voor de BGZ beschreven kunnen worden. Voor het klantsysteem, en met name de werknemers, wordt cen onafhankelijke positie van de bedrijfsarts ten opzichte van het bedrijf, als cen belangrijke voorwaarde gezien voor kwaliteit van BGZ-dienstverlening. De bedrijfsarts krijgt echter te maken met tegenstrijdige verwachtingen uit dit klantsysteem. Tevens ligt er een mogelijk spanningsveld tussen de eigen professionele verwachtingen en gewenste invulling van BGZ-problemen tussen enerzijds bedrijfsarts en bedrijf, en anderzijds bedrijfsarts en BGD. In termen van Van de Vliert (1986) is er dan sprake van rolconflicten. Naar zijn mening is ontkenning van deze spanningsvelden zinloos. Hij stelt dat hoe meer de bedrijfsarts betekent voor alle geledingen in de organisatie, hoe meer hij betrokken zal zijn in mogelijke rolconflicten. Hij gelooft dat de bedrijfsarts er zelfs zijn voordeel mee kan doen, mits hij hier adequaat mee omgaat. Zal de primaire reactie vaak zijn dat men spanning, tweestrijd en soms machteloosheid ervaart, middels intercollegiaal overleg kan spanningsvermindering optreden. Immers, onderlinge informatieverschaffing en sociale ondersteuning maken een betere anticipatie op problemen mogelijk. Echter ook minder gunstige reactiewijzen zijn voorstelbaar en in de praktijk ook herkenbaar, variërend van zich volledig schikken naar de wens van de sterkste, middels compromissen en vermijdingsgedrag naar het spelen van het zwarte-pieten-spel.

Van Wely (1974) drukt het als volgt uit: de bedrijfsarts zit midden in het ondernemingsgebeuren als een van de velen; van de ivoren toren kan dan geen sprake meer zijn; anderzijds dient gewaakt te worden voor een huisje met teveel glas.

Wolvetang (1984) stelt met betrekking tot het afhankelijkheidsvraagstuk dat de bedrijfsarts als onafhankelijk deskundige verantwoordelijk is voor de inhoud van zijn advies, de verantwoordelijkheid voor de uitvoering van het advies berust bij het bedrijf. De consequentie van deze stellingname is, aldus Wolvetang, dat er meestal wel een teleurgestelde partij zal zijn. Die teleurstelling is mede het gevolg van een spanningsveld waarin de advisering plaatsvindt. Dit veld heeft als kenmerken dat niet alles wat gewenst is mogelijk is; niet alles wat noodzakelijk is, op korte termijn realiseerbaar is; niet alles wat gevaarlijk is, ook riskant is bij zorgvuldig handelen; en dat niet alles wat hinderlijk is, ook een risico voor de gezondheid is (zie ook Brandt Rauf 1989, Jenniskens 1974). De Beer (1986) pleit voor een genuanceerde opstelling ten aanzien van onafhankelijkheid. De duidelijkheid daarover zal gegeven kunnen worden in de vorm van een beroepscode.

In paragraaf 2.9 wordt verder ingegaan op mogelijkheden voor de professie om met dit spanningsveld om te gaan. Hier wordt volstaan met het opsommen van enige mogelijkheden. Gedacht kan worden aan intercollegiale toetsing, het vergroten van de medische deskundigheid (Meyer 1987), het wettelijk vastleggen van bevoegdheden, het vaststellen en aanvaarden van een beroepscode (De Beer 1986), probleemgericht en strategisch handelen (Dijkstra 1985, Plomp 1987b, Razenberg, 1990, Spijkerboer-Mons 1990, Vrooland 1990). 


\subsection{Veranderingen in de arbeid en de organisatie van de arbeid}

\section{De "crisis" in het bedrijfsleven}

Het denken over organisaties kenmerkte zich tot vrij recent als het beschouwen van organisaties als systemen die zich niet of nauwelijks naar buiten, naar hun omgeving richten (Van der Berg 1984, De Leeuw 1982). Nu eens ligt de nadruk op de structuur van de organisatie zelf (er kunnen de namen worden genoemd van Taylor, Fayol, Weber), dan weer eens op de mensen, de groepen die binnen het bedrijf werken (bekende namen in dit kader zijn die van Hawthorne, Mc.Gregor, Agyris, Likert). Pas in het laatste decennium wordt het belang van de omgeving steeds meer als essentieel voor het overleven van een organisatie beschouwd. De zgn. contingentietheorieën zijn hiervan een voorbeeld. Onder deze term worden al die benaderingen geschaard die de optimale structuur afhankelijk (contingent) stellen van een aantal factoren, met als voornaamste de organisatieomgeving en organisatiedoelen (strategie).

Bij het beschouwen van de raakvlakken van organisaties met hun omgeving, gaat het om twee belangrijke raakvlakken: het raakvlak organisatie-omgeving en het raakvlak individu-organisatie. Voor de organisatie zijn voor het eerste raakvlak de strategie en structuur belangrijke invalshoeken. Op het tweede raakvlak is de cultuur van de organisatie, het klimaat een belangrijk gegeven (Lammers 1983, Koot 1981, In 't Veld 1983, Van Dyck en Van Hoof 1977 en 1980, Kumpe en Bolwijn 1990, Kuipers 1990).

Oorzaak en noodzaak van anders gaan denken in het bedrijfsleven over de organisatic werd ingegeven door een aantal tegelijk optredende veranderingen in het maatschappelijk gebeuren. Allereerst is dat de begin zeventiger jaren ingezette economische crisis, die leidde tot stagnerende groei van het nationaal inkomen, een sterk toenemen van het tekort op de overheidsbegroting en een snelle aanwas van het aantal werklozen. Daarnaast is de maatschappij de laatste decennia complexer geworden. In plaats van de betrekkelijk ordelijke en voorspelbare zuilenmaatschappij met relatief passieve en afhankelijke burgers die zich binnen hun levensbeschouwelijke groepering bleven gedragen, kwam een samenleving van elkaar doorkruisende lidmaatschappen en wisselvallige loyaliteiten. Dit betekende ook dat het bedrijfsleven in zijn functioneren door meer gevarieerde en vaak ook meer talrijke omgevingsprikkels beinvloed werd: men kreeg te maken met vakbonden, mondige burgers, actiegroepen. Anders gezegd, de samenleving veranderde van een gezagsordening naar een onderhandelingsordening. Dit leidt onder andere tot een afnemende macht en veranderende rol van de overheid, een verschuiving van verantwoordelijkheden (op arbeidsomstandighedengebied van de overheid naar de sociale partners).

Het bedrijfsleven speelde op de hiervoor beschreven veranderingen o.a. in door zich te gaan concentreren op kerntaken (reductie van complexiteit en interdepen- 
dentie). Ook ontstond er meer ruimte voor informeel gedrag, voor lobbyen (Pool 1987), voor nieuwe coalitievorming (bijvoorbeeld het in een aantal opzichten vanuit een wat meer gesloten front tegenover de overheid opereren van werkgevers- en werknemersorganisaties). Gemeenschappelijk kenmerk van de opgetreden innovatie is het weer centraal stellen van het "menselijk kapitaal" (echter beslist niet alleen om humanitaire redenen, maar evenzo vanuit een puur economische en pragmatische benadering. Buyse 1990). Vanuit een effectieve beïnvloeding van de mens kan de vereiste flexibiliteit en kwaliteitsverbetering verkregen worden. Dit heeft tot gevolg gehad dat zich niet alleen op technisch gebied innovaties voordeden, maar ook op sociaal gebied (zoals individualisering, nadruk leggen op zelfontplooiing, nadruk op verandervaardigheid van mensen) en op economisch gebied (informatisering, andere wijze van het organiseren van werk, waarbij veelal gekozen wordt voor decentralisatie en het creëren van business units met eigen verantwoordelijkheden en bevoegdheden, Wissema 1988). Veel gehoorde en gehanteerde begrippen in dit kader zijn: human resources management, management nieuwe stijl (MANS/MENS, Lammeren 1985, Bollen 1987, Hage 1990), een pro-actieve opstelling (Van Gils 1988), humanisering van de arbeid (Geers 1988).

BGD'en zullen met hun diensten en dienstverlening op de hiervoor geschetste veranderingen moeten inspelen, om een voor het bedrijfsleven relevante bijdrage te kunnen leveren. Vragen die daarbij rijzen zijn: zijn BGD'en hiervoor geëquipeerd, willen zij hierop inspelen? Een flink deel van de in paragraaf 8 van dit hoofdstuk genoemde kritiek van buitenaf door het klantsysteem en van binnenuit door de BGD'en zelf, is terug te voeren op het niet of onvoldoende ingespeeld zijn van BGD'en op deze ingrijpende veranderingen in het bedrijfsleven. Dit zal negatieve effecten hebben op de beoordeling van de ervaren kwaliteit van BGZ.

Hoewel het wettelijk kader van de BGZ grotendeels afwijkt van de algemene gezondheidszorg, en BGZ onder een ander departement valt, zal ook de BGZ als impliciet onderdeel van de gezondheidszorg zich niet aan veranderingen in de gezondheidszorg kunnen onttrekken. Daarom worden in de volgende paragraaf de effecten van de "crisis" in de gezondheidszorg geschetst.

\subsection{Veranderingen in de gezondheidszorg}

\section{De "crisis" in de gezondheidszorg}

Ook de gezondheidszorg wordt in het laatste decennium gekenmerkt door sterke veranderingen. Enerzijds werd dit ingegeven door de reeds gememoreerde economische crisis, die ook grenzen stelde aan de mogelijkheden binnen de gezondheidszorg. Anderzijds echter kwamen discussies op gang, die raken aan het fundament van de gezondheidszorg. Het gaat hier om aspecten als de menselijkheid van de gezondheidszorg: welke eisen mag men stellen aan vorm en inhoud van zorg? Met name door de overheid worden grenzen aan de gezondheidszorg gesteld (Tweede Kamer 1983-1984,18100; Tweede Kamer 1985-1986,19500; KNMG 1986, KNMG 1990d). Reeds vanaf 1974 (Structuurnota Gezondheidszorg) tracht de 
overheid vorm te geven aan de gewenste organisatie en inhoud van gezondheidszorg. De discussie over wat nog wel gezondheidszorg is en wat niet, waar ethische grenzen liggen, waar de grens ligt tussen effectieve en niet-effectieve zorg, waar de grens ligt van niet meer financierbare zorg, en hoever de grondwettelijke plicht van de overheid tot bevordering van de gezondheid reikt, is nog niet afgerond (Kerndocument Gezondheidsbeleid, Dekker 1985, Verandering Verzekerd 1988, Nota "Werken aan zorgvernieuwing" 1990). De overheid legt in haar beleidsintenties sterk de nadruk op preventie van gezondheidsschade, al laat zij met betrekking tot de financižle onderbouwing en concrete invulling nog vele vragen onbeantwoord (KNMG 1989a).

De meer fundamentele kritiek op de gezondheidszorg richt zich op de onmenselijkheid van het gezondheidszorgsysteem (zie onder andere Van den Bergh-Braam 1986), op het medicaliseren van allerlei maatschappelijke problemen, op het eenzijdig somatisch-curatief gericht bezig zijn (Lapre 1983, Kuiper 1975, Hattinga Verschure 1977, Ten Have 1987 en 1988, De Jong 1981 en 1984). Mogelijke oplossingen worden gezocht in een andere gezondheidscultuur waarin individuele verantwoordelijkheid voor eigen lichaam en gezondheid voorop staat, alsook in het verleggen van zorg door professionals naar zelfzorg en mantelzorg. De enorme vlucht die alternatieve geneeswijzen genomen hebben, zou ook een antwoord op de crisis in de gezondheidszorg kunnen zijn. Het vertrouwen in de professional om centrale levens- en maatschappelijke problemen op te lossen is tanende (Plomp 1987c).

De BGZ zal met deze gewijzigde opvattingen over gezondheid en gezondheidszorg rekening dienen te houden. De nadruk komt steeds meer te liggen op preventieve gezondheidszorg. Voor de BGZ betekent dit een uitbreiding van haar werkterrein en mogelijkheden. Opvallend is dat, wanneer er wordt gesproken over de crisis in de gezondheidszorg, de BGZ zelden genoemd wordt. Uitzonderingen hierop zijn Kuiper (1985) en Van Dijk (1990b), die van mening zijn dat het veelvuldig binnen de BGZ gehanteerde model belasting-belastbaarheid aanpassing behoeft. Metz (1987) en Mertens (1982) zetten vraagtekens bij het "traditionele denken" binnen de sociale geneeskunde, waarin het menselijk lichaam tot object werd.

\subsection{Verwachtingen ten aanzien van BGZ}

\section{De visie van de klant en van de professional}

In de vorige paragrafen werden enige veranderingen geschetst die de afgelopen jaren plaatsvonden in het bedrijfsleven enerzijds en de gezondheidszorg anderzijds. Hoe gingen BGD'en hiermee om? Speelden zij hier adequaat en op tijd op in? Welke wijzigingen in verwachtingspatroon bij het klantsysteem en bij BGD'en zelf waren het gevolg?

Deze paragraaf begint met een korte historische schets van het omgaan door de BGZ met crises, veranderingen in het verwachtingspatroon bij haar doelgroepen. Dit dient ter onderstreping van het feit dat bezinning op welke BGZ-activiteiten het 
best aansluiten bij bestaande behoeften permanent heeft plaatsgevonden en niet alleen in het laatste decennium (NVAB 1968, Bedrijfsgeneeskundige Dagen 1988, Baas 1989, Vrooland 1990, NVAB 1987a en 1990a).

$\mathrm{Na}$ deze korte historische schets, worden in de volgende paragrafen de ervaringen met en de verwachtingen ten aanzien van BGZ bij achtereenvolgens het klantsysteem, de beroepsgroep en de overheid beschreven.

\subsubsection{Een korte historische schets van de ontwikkeling van BGZ}

In hoofdstuk 5 komt de inhoud en het ontstaan van arbowetgeving meer uitgebreid aan de orde. Deze paragraaf dient slechts als illustratie van reactiewijzen van BGZ op veranderingen in het vraag-patroon (Van Griensven 1987, Reynierse 1983).

Van oudsher heeft de BGZ zich in volledige vrijwilligheid ontwikkeld, vanuit een initiatief van werkgevers en bedrijfsartsen. De tijd dat bedrijfsartsen in het bedrijfsleven hun intrede deden en de jaren erma was de tijd van het paternalisme, de tijd dat de werknemer nog werd beschouwd als een te beschermen "object". De fabrikant, de ondernemer, vonden in de dokter een zeer goede partner. Zij voelden zich verantwoordelijk en wilden goed zorgen voor hun mensen; en ze wilden (of moesten) veel en goedkoop produceren. En daar was de dokter die weliswaar voor het eerste was ingehuurd, maar dat was duidelijk ook ten gunste van het laatste (Van Wely 1982).

Het gegeven dat door de aanstelling van een "fabrieksarts" de premie voor de Ongevallenwet sterk kon worden verlaagd, was in het begin van deze eeuw een belangrijke stimulans "BGZ" te entameren. De functic van de bedrijfsarts kreeg meer inhoud nadat Burger in 1928 als bedrijfsarts werd aangesteld. Als belangrijk element in de functie gold het adequaat herplaatsen van herstelde zieken of tijdelijk invaliden in een aangepaste functie, een taak die voordien ongecoördineerd en via vele wegen uitgevoerd werd (vanuit het curatieve circuit). De in de dertiger jaren optredende crisis ging ook niet ongemerkt aan de BGZ voorbij. Men paste zich echter aan de moeilijke omstandigheden aan, niet door taken af te stoten, maar juist door twee nieuwe activiteiten te ontplooien, namelijk bevordering van de bescherming van de grote groep beperkt-arbeidsgeschikten, en de tuberculosebestrijding. wat een nog onbekend terrein was. In de naoorlogse periode kwam er meer aandacht voor de mens in de organisatie; Vanuit de BGZ moest een bijdrage worden geleverd aan de zorg voor optimale arbeidsbevrediging, zo groot mogelijke aanpassing van het werk aan de capaciteiten van de mens: de BGZ met een duidelijke plaats en rol in het sociaal beleid van de onderneming. De beroepsgroep stelde hier een rol tegenover, waarin veel waarde werd gehecht aan zelfstandigheid en onafhankelijkheid.

Pas in 1959 zijn de eerste wettelijke regelingen op het gebied van de preventieve gezondheidszorg in verband met de arbeid verschenen. Deze sloten nauw aan bij de tot dan toe gegroeide praktijk: bepaalde categoriez̈n bedrijven, waarvan bekend was dat er reeds op grote schaal BGZ verleend werd, werden "verplicht" tot oprichting van of aansluiting bij een BGD. Daarnaast ging de ontwikkeling van vrijwillige 
aansluiting van bedrijven door. Vreemd genoeg ging de groei van BGZ niet gepaard met een toename van de belangstelling voor het onderwerp BGZ. Was BGZ in de prille beginjaren nog een vrucht van enthousiasme van bedrijfsartsen èn werkgevers, in latere jaren was er eigenlijk alleen nog maar sprake van een grote medische betrokkenheid, wat natuurlijk het risico inhield van versterking van de "ivoren toren positie". Betrokkenheid van individuele werkgevers bij BGD'en beperkte zich feitelijk tot de organisatie en financiën van de BGD. Kenmerkend was dat de aansluiting bij een BGD voor veel bedrijven een soort automatisme was geworden. De kosten van een aansluiting waren gering (een bekende kreet in die tijd was: "U heeft BGZ al voor de prijs van een kopje koffie per dag"), het deed het goed in het door een onderneming gevoerde sociaal beleid (Baas 1989), de ondernemingsraad vroeg erom, en wat ook heel belangrijk was, de onderneming had er in feite weinig hinder van. De vraag wat nu eigenlijk de toegevoegde waarde was voor de organisatie werd zelden indringend gesteld. BGZ werd als sociaal-wenselijk ervaren. Een directe relatie met kwaliteit van de arbeid en arbeidsorganisatie werd niet gelegd.

Dit veranderde het laatste decennium, toen de terugtredende overheid de Arbowetgeving lanceerde, en toen bedrijven zich steeds meer gingen richten op het rendement van het zakendoen, op het direct inspelen op de behoeften en wensen van de klant op de markt, op snelheid en flexibiliteit en vooral op kwaliteit (Van Griensven 1987).

\subsubsection{Ervaringen met en wensen van werkgevers ten aanzien van BGZ}

Begin zeventiger jaren raakte het denken over de taak en functie van BGZ aan werkgeverskant vrij plotseling in een stroomversnelling. Een belangrijke reden hiervoor was de invoering van de Arbowet. Door deze wet groeide bij werkgevers het besef dat BGZ, en meer in het bijzonder de bedrijfsarts, door allerhande wettelijke regelingen een geheel eigen, onafhankelijke positie in bedrijven begon te krijgen. Daarnaast waren veel ondernemingen door de economische recessie gedwongen met een stofkam door hun uitgavenpatroon te gaan en daarbij ontkwam men niet aan de vraag wat er nu eigenlijk aan baten stond tegenover de uitgaven op het terrein van BGZ. Dat weinig bedrijven deze vraag echt bevredigend wisten te beantwoorden bewijst in ieder geval dat de BGD'en weinig aandacht hebben besteed aan het overdragen van de redenen waarom activiteiten werden uitgevoerd. Natuurlijk kunnen ook vraagtekens worden geplaatst bij deze activiteiten zelf (Fraterman 1986). Fraterman vat de visie van de werkgevers als volgt samen: "Kwaliteit en kwantiteit van BGZ moeten gestalte krijgen aan de hand van de individuele bedrijfssituatie, op basis van een verrichtingentarief: maatwerk dus". De sociaalmedische begeleiding tijdens ziekte behoort een hoofdtaak voor de bedrijfsarts te zijn; meer aandacht is gewenst voor de kwetsbaarheid van arbeidsverhoudingen binnen een organisatie en de inspanningen die de betrokkenen hiervoor moeten leveren. Bovenal moet de bedrijfsarts meer oog hebben voor zijn eigen positie binnen de organisatie. De bedrijfsarts maakt deel uit van een bedrijfsgemeenschap, moet goede relaties met het management onderhouden, in staat zijn in zijn afwegin- 
gen naast gezondheidkundige, ook bedrijfsmatige aspecten te betrekken, en in zijn relatie tot de ondernemingsraad dient hij zeer zorgvuldig te werk te gaan. Wettelijke legitimering wordt niet langer als voldoende en uitsluitende bestaansgrond aanvaard (Cottaar 1989, Scheurer 1988).

De ontwikkeling van BGZ in de bouwnijverheid illustreert het veranderde denken van en de gewenste invloed op vorm en inhoud van het BGZ-pakket door werkgevers. Tevens is de organisatie van BGZ in de bouw trendsettend geweest voor de organisatie van BGZ voor kleine bedrijven, al hebben ook anderen hiervoor suggesties gedaan (Leuftink 1980, Lahaye 1981, De Boorder 1986, Baas 1989).

Een goed inzicht in wensen en verwachtingen bij werkgevers ten aanzien van BGZ, wordt verkregen door het onderzoek van Van Rijssen-Moll (1982). Uit dit exploratieve onderzoek onder ruim 700 bedrijven komt 0.a. naar voren dat bedrijven voornamelijk aansluiting hebben gezocht bij een BGD als element van het sociaal beleid van de onderneming, of omdat er een wettelijke verplichting bestond. In beduidend mindere mate had men met het invoeren ook een vermindering van het verzuim beoogd. Aanwezigheid van gezondheidsrisico's als reden voor aansluiting werd zelden genoemd. Overigens geven bedrijven die geen BGZ hadden hiervoor nu juist aan dat de belangrijkste redenen waren het ontbreken van gezondheidsrisico's en het financiële aspect. Het bedrijfsgezondheidkundig pakket dat geleverd wordt, voldoet in zo'n tweederde van het aantal bedrijven niet aan door haar gestelde "volledigheids-eisen", waarvan het kerntakenpakket (aanstellingsonderzoek, spreekuur, periodiek onderzoek en werkplekactiviteiten) het centrale element vormt. Het is dan ook niet verrassend dat een groot aantal bedrijven aanvullende wensen heeft ten aanzien van BGZ, met name met betrekking tot periodiek onderzoek en werkplekactiviteiten. Bedrijven die (nog) niet over een of andere vorm van BGZ beschikken, leggen vooral de nadruk op het aanstellingsonderzoek, periodiek onderzoek naar en advisering over arbeids(on)geschiktheid. Deze verschillen zijn interessant omdat zij iets zeggen over hoe BGZ blijkbaar ervaren wordt, alsmede welke verwachtingen er bestaan bij potentiële klanten (zie ook Baas 1989).

Werkgevers geven zelf enige wegen aan hoe de BGD'en beter kunnen inspelen op wensen van de klant, en daarmee de kwaliteit van dienstverlening kunnen opvoeren. Schreurer (1988) adviseert BGD'en een zgn. portfolio-analyse te maken, d.w.z. dat zij moeten onderzoeken (en natuurlijk zichtbaar maken) welke bijdrage een bepaalde BGZ-activiteit levert aan de kernactiviteit (en doelstelling) van de onderneming, waaraan zij haar diensten verleent, en wat haar toegevoegde waarde, haar nut is. BGD'en kunnen hierbij een directe bijdrage leveren, bijvoorbeeld een actief verzuimbeleid, of een indirecte bijdrage door het creëren van omstandigheden waaronder en waarin mensen beter kunnen functioneren. Op basis van zorgvuldige registratie, adequate toepassing van epidemiologische en statistische methoden van gegevensverzameling, multidisciplinair verzameld en geanalyseerd, dient de BGZ pragmatisch en oplossingsgericht te adviseren over gezondheidsthema's. De BGZ moet hierbij niet blijven steken in signaalberichten als "er is onrust", "er is 
spanning". Voor Schreurer (1988) kan het individuele consult blijven fungeren als "vangnet voor problemen", die zich niet meer in de werksituatie laten oplossen en, mits een verantwoorde registratie voorhanden is, als signaal voor arbeidsplekgezondheidsproblemen die systematische aandacht vragen. Meer aandacht en kennis zal er moeten komen binnen en vanuit de BGZ over de relatie tussen werk en gezondheidsvariabelen. Het bestrijden van verzuim zal ook in de toekomst van belang blijven. Wil de BGZ blijven bestaan dan zal ze het hiervoor geschetste takenpakket niet alleen moeten (kunnen) vervullen, maar ook beter uitdragen, bijv. middels GVO. Een marktgerichte, multidisciplinaire benadering stelt duidelijk eisen aan de organisatievorm van de BGD. Bij bedrijven bestaat behoefte aan een geintegreerde en gecoördineerde dienstverlening op het gebied van gezondheid, veiligheid en welzijn. Dat vertaling hiervan in de praktijk niet eenvoudig is, blijkt uit de ervaringen die opgedaan zijn met het omvormen van een GD tot een Arbodienst (Jakobs 1989).

Er kan ook worden gewezen op het dilemma waarmee de BGZ zit: enerzijds past de wettelijke opdracht van de BGZ meer bij een instituut voor zorgverlening dat met relatieve autonomie zelfstandig bepaalt welke zaken gedaan en nagelaten moeten worden om tot optimale vervulling van haar doelstelling te komen (de professionaliteit). Anderzijds past de financiële basis van BGZ veel meer bij een dienstverlenend bedrijf, waarbij de afnemer mee "produceert" en de rol van de mens, het personeel essentieel is.

Bij de discussies over de gewenste taken van de BGZ bleef overigens grosso modo toch wel de wens/noodzaak overeind dat er BGZ voor bedrijven moest zijn, maar dan wel goede BGZ, BGZ op maat en met mate. De zorg moest worden aangepast aan de specifieke bedrijfssituatie. Kortom er moest sprake zijn van een gedifferentieerde aanpak. De onafhankelijke deskundige moet echter niet op de stoel van de ondernemer gaan zitten (Spit 1986, Van de Veerdonk 1988, Van Wely 1984).

\subsubsection{Ervaringen met en wensen van werknemers ten aanzien van BGZ}

In maart 1980 organiseerde de Industriebond FNV in samenwerking met de Stichting Arbeid en Gezondheid een studieconferentie over BGZ (FNV 1980). Deze conferentie werd voorafgaan door een enquete onder bedrijfsledengroepen en bedrijfscorrespondenten. Het aantal reacties was onverwacht hoog. De belangrijkste conclusies uit deze enquête kunnen als volgt verwoord worden:

a. Over de organisatie van de BGZ bestaat er bij werknemers een duidelijke voorkeur voor aansluiting bij een GD.

b. Men heeft de indruk c.q. de ervaring dat de BGD de meeste tijd besteedt aan geneeskundig onderzoek. Er wordt veel te weinig tijd en aandacht besteed aan onderzoek van werkplekken. Nog steeds worden er- in tegenstelling met de wensen van de FNV dienaangaande- op uitgebreide schaal ziektewet-controles uitgevoerd door bedrijfsartsen. 
De wens tot uitbreiding van het periodiek onderzoek tot alle leeftijdsgroepen en met een hogere onderzoeksfrequentie wordt alom geuit.

c. Er bestaat grote ontevredenheid bij werknemers over de al dan niet, via de overlegorganen van de onderneming, beschikbare informatie over BGZ-activiteiten en adviezen. Dit geldt zowel ten aanzien van individu-gebonden gegevens, als - zelfs in extremere mate - met betrekking tot de algemene verslaglegging over gezondheidssituaties in het bedrijf. Slechts in ongeveer een kwart van de ondernemingen krijgen werknemers deze gegevens. De slotbeoordeling door werknemers van BGZ valt dan ook niet onverdeeld positief uit. Slechis cen op de drie werknemers beoordeelt deze als voldoende, maar liefst $60 \%$ komt tot de beoordeling "onvoldoende", waarbij de werknemers nog het meest tevreden zijn met het functioneren van een GD.

De BGD'en lijken vooralsnog hier weinig mee te doen. Immers, uit beschrijvingen van het functioneren van BGD'en in de praktijk (Smulders 1980, Haas 1980, Ruinen 1985a, Tanke 1985, Weyenberg 1985, Smid 1988, Levie 1988) komt duidelijk naar voren dat werknemers geen duidelijk zicht hebben op de BGD, op de (on)mogelijkheden van de BGD, dat voorlichting onvoldoende is, dat de BGD op de werkplek te weinig actief is, en dat BGD'en teveel de nadruk blijven leggen op het medisch-individu gebonden bezig zijn. De aanbevelingen die de FNV dan ook in een brochure uit 1986 onder de titel "Werknemers en BGZ" doet, vertonen een grote gelijkenis met die uit 1980 . Ze kunnen in een zestal stellingen worden samengevat.

a. Een bedrijfsarts is er voor de werknemers, hij bewijst zijn bestaansrecht door die werknemers te helpen gezond te blijven op het werk.

b. Het produkt van een bedrijfsarts is geen behandeling, maar inzicht in de relatie arbeid-gezondheid en adviezen over het verbeteren van de arbeidsomstandigheden.

c. De onafhankelijkheid van de bedrijfsarts is geen gegeven, maar iets waar voortdurend aan gewerkt moet worden.

d. Er zijn twee prima indicaties voor de kwaliteit van BGZ: het percentage direct op de arbeid gerichte activiteiten van de BGD en de openbaarheid van het werk van die BGD.

e. BGZ en verzekeringsgeneeskunde zijn onverenigbaar, althans in hetzelfde bedrijf, door dezelfde persoon.

f. De medische vooropleiding van een bedrijfsarts levert naast voordelen 3 grote handicaps op: te zeer gericht op individuen, te zeer gericht op gevolgen en te voorzichtig.

BGD'en dienen hierbij meer en beter in te spelen op ontwikkelingen in de arbeid en verschuivingen van aandachtsterreinen (Vreeman 1986, Vrooland 1990, FNV 1986).

Opmerkelijk bij al deze kritische geluiden is dat bij werknemersorganisaties de wens van BGZ voor alle werknemers overeind blijft, en zij hun leden oproepen om met een positieve instelling samenwerkingsrelaties met BGD'en op te bouwen 
(FNV 1980, FNV 1986, CNV 1985). Voor De Boorder (1983) blijft men echter hierbij teveel steken op het beleidsniveau, en blijft de belangstelling voor arbeidsomstandigheden op de werkvloer hierbij sterk achter (zie ook Kolks en Levie 1991a/1991b).

Onderzoek van Plomp (1986) steunt deze visie. Niet alleen bestaat er verschil van inzicht tussen BGD en werknerner over de werkgebondenheid van klachten, maar ook zullen werknemers uit angst voor mogelijke consequenties, werkgebonden problematiek niet gauw spontaan presenteren. Dit is niet zozeer terug te voeren op een gebrek aan vertrouwen in de leverancier van zorg. Aan diens integriteit wordt meestal niet getwijfeld, wederzijdse beïnvloeding tussen bedrijfsarts en bedrijf wordt als vanzelfsprekend beschouwd en niet als onjuist. Het uitsluitend benadrukken van de onafhankelijkheid van de bedrijfsarts en het scheppen van allerlei procedures die dit zouden moeten garanderen, is misschien wel een noodzakelijke maar zeker niet voldoende voorwaarde om vertrouwen van werknemers te verkrijgen. Juist door het ontkennen of miskennen van het dualistische karakter van de positie van de bedrijfsarts wordt onduidelijkheid gecreēerd, waardoor onnodige afbreuk wordt gedaan aan de geloofwaardigheid en de toegankelijkheid van de BGD. Werknemers verwachten van de bedrijfsarts uitspraken die uitsluitend en primair zijn gericht op de medische invalshoek, het meewegen van economische implicaties wordt niet wenselijk geacht (in tegenstelling tot de mening van werkgevers) (zie Bloemarts 1988, Van Kesteren 1988).

De waardering van een bedrijfsarts zal mede afhankelijk zijn van de klacht of ziekte waarmee een klant de bedrijfsarts consulteert, alsmede het feit of men al eens contact heeft gehad met de bedrijfsarts (Haas 1980). Werknemers zonder of met lichte klachten beoordelen de bedrijfsarts vooral op professionele aspecten van zijn handelen, namelijk de deskundigheid van de bedrijfsarts als medicus. Werknemers met chronische aandoeningen hechten sterker aan de relationele aspecten in het optreden van de bedrijfsarts. Voor werknemers met werkgerelateerde problemen zijn met name de intentionele en de positionele aspecten van belang. Met intentioneel aspect wordt bedoeld de mate waarin de bedrijfsarts zich voor betrokkene wil en kan inzetten. Onder positioneel aspect wordt verstaan de mate waarin de bedrijfsarts invloed kan uitoefenen vanuit zijn positie, en contacten in het bedrijf. Individuele belangen kunnen hierbij eventueel niet sporen met bedrijfsbelangen. Tevens is voor de oplossing van werkgerelateerde problemen de medewerking van bedrijfszijde nodig (Plomp 1986). Uit hetzelfde onderzoek blijkt dat werknemers als primaire taak voor de BGD zien het opsporen en elimineren van gezondheidsrisico's vanuit het werk, waarbij contacten op vele niveaus binnen en buiten het bedrijf noodzakelijk zijn. De praktijk is echter dat werknemers de BGD voornamelijk gebruiken, raadplegen voor algemeen medische zaken.

Hoewel nog weinig benut, kan een ontwikkeling vastgesteld worden, waarin de zorg voor en het niveau van arbeidsomstandigheden zelf middels de CAO geregeld wordt (Korevaar en Soeterbroek 1989). De Bouw- en Houtbond FNV kwam in de 
CAO 1989 een aantal belangrijke Arbo-bepalingen overeen, zoals een verbod op het verwerken en bewerken van asbesthoudende materialen met ingang van 1/1/91. Hoewel de bond van mening is dat arbeidsomstandigheden in beginsel wettelijk geregeld dienen te worden, acht deze toepassing van het $\mathrm{CAO}$-instrument toch gewenst als cen vooruitlopen op invoering van de Arbowet, een vertaling van de Arbowet naar de bedrijfstaksituatie, en een opvulling van gaten die de Arbowet voor betrokken sector laat vallen. De bepalingen ten aanzien van BGZ en de verplichting tot het maken van een Arbobeleidsplan hebben vooral de eerste twee overwegingen als achtergrond. Door de FNV is in dit kader zelfs een zgn. CAO. matrix ontwikkeld, die kan dienen als denkmodel voor CAO-besprekingen (Rozemond en Felser 1990).

De door de Stichting van de Arbeid (1990) voorgestane decentralisatie van het arbobeleid, een op maat voor individuele bedrijven snijden van BGZ, brengt met zich mee dat vakbonden buiten spel komen te staan bij de concrete onderhandelingen, al kunnen zij wel een coördinerende rol spelen en "minimum-normen" voor een arbobeleid formuleren.

\subsubsection{Ervaringen met en wensen van de beroepsgroep ten aanzien van BGZ}

Een groot deel van de door werkgevers en werknemers geuite kritiek wordt door de beroepsgroep (h)erkend, zowel door de beroepsbeoefenaren zelf als de beroepsgroep, de NVAB.

Onder de veelzeggende titel "Bedrijfsgezondheidszorg, een stap achteruit, twee stappen vooruit?" somt van Dijk (1989) een aantal redenen op waarom de groei van de BGZ tenminste stagneert. Het heeft zowel te maken met het produkt BGZ, als met de organisatie en werkwijze van BGD'en, alsook met de landelijke organisatie. Het produkt BGZ is te eenzijdig gericht op fysieke inspanning en fysisch-chemische arbeidsomstandigheden, en bijvoorbeeld te weinig op stressverschijnselen. De BGZ zou verder te weinig gericht zijn op de gevolgen van automatisering en van flexibilisering van de arbeid. De rol die de BGZ speelt en wil spelen bij de verzuimbegeleiding in het kader van de Ziektewet wordt gekenmerkt door onduidelijkheid en tegenstrijdigheid. Samenhangend met het produkt bestaat er de wens tot differentiatie van het BGZ-pakket, maar dan wel minstens op bedrijfstakniveau/schaal, en met oog voor de voor wetenschappelijk onderzoek noodzakelijke uniformiteit en onderlinge vergelijkbaarheid en uitwisselbaarheid van gegevens. Hierbij zal voor de kleine bedrijven (dat wil zeggen met minder dan 30 werknemers), als zij zich bijvoorbeeld bedrijfstakgewijs aansluiten bij BGZ, een adequaat werkmodel ontwikkeld moeten worden.

Met betrekking tot de organisatie en werkwijze van BGD'en bestaat er de kritiek dat doelstellingen en daarvan afgeleide taakstellingen in de meeste BGD'en niet duidelijk onderkend, geformuleerd, geoperationaliseerd en geëvalueerd zouden worden. Mede daardoor zouden BGD'en te weinig probleemgericht werken. 
Ook wordt het als een gemis ervaren dat landelijk of sectoraal gestandaardiseerde werkmethoden en methoden om de effectiviteit en efficiēntie vast te stellen ontbreken. BGD'en zouden deskundigheid op een aantal gebieden missen en zouden getalsmatig en cultureel gedomineerd worden door artsen, waardoor interdisciplinaire samenwerking geblokkeerd wordt. Tot slot is er de kritiek dat BGD'en zich onvoldoende bedrijfsgericht opstellen en beschikken over een zwak management.

Tot besluit de kritiek op de landelijke organisatie. Er zou geen slagvaardige landelijke BGZ-organisatie bestaan, en er zou een grote behoefte bestaan aan een Nederlands Instituut voor de BGZ.

Van Dijk (1989) vindt het niet zinvol om de BGZ een crisis aan te praten. Op vele plaatsen is de BGZ actiever en veelzijdiger dan ooit aan de slag. Dat neemt niet weg dat er, ook naar zijn mening, over het geheel genomen sprake is van een situatie van grote onzekerheid omtrent waar het met de BGZ naar toe moet. BGD'en gaan hier niet altijd adequaat mee om, zo is ook de mening van Van Griensven (1987). Te zeer defensief, te weinig actief en vernieuwend bezig zijn, zo karakteriseert hij de houding van veel BGD'en, en dit terwijl de geschiedenis genoeg voorbeelden heeft aangedragen hoe een "crisis" het hoofd geboden kan worden (Van Wely 1980).

Gevraagd naar het persoonlijk functioneren, blijkt uit een onderzoek van De Winter en Dijkstra (1985) dat, met uitzondering van de bedrijfsartsen bij de gemeente, bedrijfsartsen in het algemeen tevreden zijn met hun werk. Als gunstige kanten van het werk worden beschouwd de zelfstandigheid, de afwisseling en interessante factoren van het werk. Als ongunstig worden aangemerkt de overbelasting en de gebrekkige organisatie van de dienst.

De beleidsadviezen aan directie of ondernemingsraad geven de bedrijfsarts weinig voldoening; oorzaken van gebrek aan succes zoekt hij niet bij zichzelf. De onderzoekers pleiten ervoor dat in de (na)scholing een plaats wordt ingeruimd voor het opdoen van kennis en vaardigheden met betrekking tot beleidsadvisering en het opbouwen van structurele relaties met directie en ondernemingsraad. Geconcludeerd wordt dat bedrijfsartsen nog steeds (een onderzoek uit 1968 van Kuiper kwam namelijk ook tot deze conclusie) voornamelijk met individu-gerichte keurings- en spreekuuractiviteiten bezig zijn. Als oorzaken hiervoor noemen de auteurs de volgende factoren.

a. Tijdgebrek: vooral bedrijfsartsen met een verzekeringsgeneeskundige taak komen tijd tekort voor het op systematische wijze ter hand nemen van preventieve, werkplek-gerichte onderzoekstaken.

b. De professionele identiteit en expertise: de bedrijfsarts is een medicus. Het diagnose-recept-model wordt hem bij de opleiding met de paplepel ingegoten. Dit model schiet in de BGZ echter tekort. Op de werkplek realiseert hij zich dat zijn geneeskundige achtergrond ontoereikend is, en voelt hij zich ook het meest bedreigd door andere disciplines. De van oudsher aan de bedrijfsarts voorbehouden coördinerende rol komt hierdoor voor velen steeds meer onder 
druk te staan. Het risico dat de bedrijfsarts zich terugtrekt in de spreekkamer wordt dan ook niet denkbeeldig.

c. Positie en rol: Vanuit zijn professionele codes en wettelijke taakstelling zal de bedrijfsarts zijn positie als onafhankelijke hulpverlener en adviseur zo objectief mogelijk trachten te verwerkelijken. Dit wordt ook van hem verwacht door de partijen waarmee hij in het bedrijf te maken heeft. Het valt evenwel niet te ontkennen dat dit dualistische karakter in de positie van de bedrijfsarts in de praktijk kan leiden tot rolspanningen.

d. Economische ontwikkelingen: De weerslag van de crisisgedachte in meerdere bedrijven op de prioriteitsstelling ten aanzien van de taakuitoefening is, dat de bedrijfsarts zich meer gaat richten op taken die kwantificeerbaar rendement op kunnen leveren. Vooral individu-gerichte taken, die toch al hoog scoren bij bedrijfsleidingen, zoals bijv. verzuimbegeleiding, krijgen dan al gauw de overhand.

Op basis van een analyse van praktijk en wens ten aanzien van de diverse taakelementen van het BGZ-pakket komen De Winter en Dijkstra (1985) tot de conclusie dat de bedrijfsarts dreigt te worden tot "geen vlees en geen vis, en zeker geen deskundige", als hij er niet in slaagt zijn eigen inbreng herkenbaar te maken. Meer inbreng buiten het direct-individu-gebondene om, meer beleidsmatig en werkplekactief zijn, is vereist. Dit mistige beeld van de bedrijfsarts bij de diverse bedrijfsparticipanten (personeelszaken, ondernemingsraad, werknemers) wordt ook in ander onderzoek bevestigd (Tanke 1985, De Haas 1980, Ruinen 1985b, Kotek 1981, Weyenberg 1985). Vastgesteld dient te worden dat de percepties van bedrijfsparticipanten over de BGD sterk afhankelijk zijn van de positie die zij bekleden binnen de organisatie (Tanke 1985).

Uit het voorgaande komt al met al een weinig rooskleurig, maar vooral een niet duidelijk geprofileerd beeld naar voren van de bedrijfsarts c.q. de BGZ. Diverse auteurs dragen taakelementen aan die als speerpunt van het bedrijfsgezondheidkundig handelen kunnen dienen (Tanke 1985, Willems 1987, Lindeboom 1987). Hierbij staat centraal dat de artsenprofessie de enige is die medische klachten kan duiden, interpreteren en ook kan legitimeren.

Wat deed nu de NVAB met het crisisgevoel binnen de BGZ?

Allereerst stak zij de hand in eigen boezem (NVAB 1984c, NVAB 1983b, NVAB 1987a en NVAB 1988b). Algemeen beschouwd werd de alom geuite kritiek gegrond geacht. Een gemeenschappelijke inspanning werd nodig geacht om over dit dode punt in de BGZ heen te komen. Een eerste stap hiertoe zette zij zelf, door opzet, structuur en werkwijze van de NVAB aan te passen aan de eisen van de tijd (NVAB 1988c). De bestuurlijke consequenties van de reeds eerder gemaakte keuze dat de NVAB primair een bedrijfsartsenvereniging is, werden doorgevoerd. Middels een periodiek te actualiseren Beleidsnota, tracht de NVAB vortn te geven aan communicatie en informatie tussen haar en de leden. Als therna's die de komende jaren de aandacht van de BGZ-professie zullen vragen noemt de NVAB: verbete- 
ring van de opleiding, bevordering van de kwaliteit van de bedrijfsarts en zijn kwaliteitsbewustzijn, oprichting van een vereniging voor BGZ, formulering van het takenpakket voor de bedrijfsarts, bevordering van klantgericht en interdisciplinair werken. Het belangrijkste thema moet echter zijn de social-medische begeleiding en de meer nadrukkelijke rol die de bedrijfsarts hierin moet gaan spelen. Dit, zo stelt de NVAB, is cen essentiēle taak van de bedrijfsarts! (NVAB 1981b, NVAB 1987b, NVAB 1989a, NVAB 1990a en 1990d).

Daarnaast werden aan de uitvoering van BGZ-taken door vaststelling van een $B e-$ roepscode "minimum-eisen" gesteld. Tevens werd een eerste aanzet gegeven om tot consensus te komen over enige belangrijke taken van de BGZ, startend met het aanstellingsonderzoek. Vanuit de Stichting Kwaliteitsbevordering BGZ (SKB) is men, in opdracht van de BGZ voor het wegtransport, gestart met de ontwikkeling van modules voor periodiek onderzoek. Ook vanuit de wetenschappelijke instituten zal verhoogde aandacht gegeven worden aan instrument- en kwaliteitsontwikkeling binnen de BGZ (NVAB 1990a).

\subsubsection{Overheid en BGZ: roll en verwachtingen}

In hoofdstuk 5 wordt uitvoerig ingegaan op de rol van de overheid en wettelijke regelingen. In deze paragraaf wordt een aantal punten belicht dat aangeeft in welke richting de overheid denkt bij de invulling van BGZ. Er wordt beschreven welk standpunt de overheid inneemt ten opzichte van een algemene verplichtstelling van $B G Z$, welke taken de overheid tot BGZ rekent, en welke disciplines binnen de BGD volgens de overheid hiervoor nodig zijn.

\subsubsection{Verplichting}

Het laatste decennium wordt gekenmerkt door een terugtredende overheid. Binnen de gezondheidszorg betekent dit dat de overheid zich beperkt tot het scheppen van voorwaarden voor het goed functioneren van het gezondheidszorgbestel, en het inhoudelijk slechts sturen op hoofdlijnen. De (filosofie van de) Arbowet demonstreert de positie die de overheid wil innemen. De zorg voor gezonde, goede en veilige arbeidsomstandigheden wordt aan het samenspel tussen werkgevers en werknemers overgelaten, die zich hierin kunnen laten ondersteunen door deskundigen, waaronder BGD'en. De invloed van internationale en supranationale organen op het arbobeleid neemt toe.

Expliciet pleit de overheid in het door haar voorgestane beleid (bijv. Nota 2000) ervoor, dat bij beperkte middelen meer aandacht gegeven zal moeten worden aan onderzoek naar de beïnvloeding van omgevingsfactoren en naar de bevordering van gezonde leefwijzen. Daarom lijkt het leggen van nadruk op preventieve gezondheidszorg-activiteiten, waartoe dus ook BGZ behoort, een logische zaak.

Steeds meer richt de aandacht van de overheid zich daarbij op het hanteren van risicocriteria, waarbij aangetekend kan worden dat het risicocriterium meer aansluit bij een gezondheidkundige benadering. Het risicocriterium heeft betrekking op de 
aanwezigheid, de ernst en de omvang van gezondheidsrisico's van arbeid en arbeidsomstandigheden, en is van belang voor het bepalen van prioriteiten bij de uitbreiding van de verplichte zorg (Arboraad 1984. Rantanen 1981, De Roos 1987. DGA 1989b). Specifiek voor het onderwijs is er een experiment gestart met de gewenste inhoud en vormgeving van BGZ (Kamphuis et al. 1988, 1989 en 1990).

$\mathrm{Nu}$ het argument van een tekort aan deskundigheid/menskracht om BGZ, conform de situatie in het buitenland, uit te breiden tot de gehele werkende bevolking, minder valide is, ziet de overheid als belangrijkste bezwaren om BGZ verplicht te stellen acceptatieproblemen bij de sociale partners (wat is voor het bedrijfsleven de toegevoegde waarde van BGZ), onduidelijkheid over de gewenste vorm en inhoud van BGZ, en onvoldoende inzicht in effectiviteit en kwaliteit van tot dusver geleverde BGZ.

Tot slot is de recent voorgestelde wijziging van de toetsings- en erkenningsprocedure van BGD'en, een voorlopig eindpunt van de terugtredende overheid (DGA 1989b).

\subsubsection{Taken voor BGD'en}

De Arbeidsomstandighedenwet (Arbowet) geeft aan welke taken de overheid toekent aan de deskundige diensten, waaronder de BGD. Alvorens enige artikelen van de Arbowet toe te lichten, wordt eerst stil gestaan bij de sterk toegenomen aandacht voor de zieke en arbeidsongeschikte werknemer, en de mogelijke rol hierbij van de BGD.

Gegeven het immense probleem van de omvang en inhoud van het arbeidsongeschiktheidsprobleem voor onze samenleving (Knepper 1990d), wordt door de overheid een gezamenlijke inspanning van alle hierbij betrokken partijen (werkgevers, werknemers en deskundigen) noodzakelijk geacht (Najaarsoverleg 1990). Oplossingen worden gezocht in betere samenwerking tussen allen die betrokken zijn bij de begeleiding van de zieke c.q. arbeidsongeschikte (Lamers 1983), aanpassing, van regelgeving, bijvoorbeeld in de vorm van bonus-malus systemen die een meer preventie-gericht verzekeren van arbeidsongeschiktheid tot doel hebben (Bruins Slot 1989), het beter zichtbaar en toegarikelijk maken van de verzuim- en arbeidsongeschiktheidproblematiek (Lunshof 1988).

De rol van BGD'en hierbij is vanouds omstreden. De ILO acht een tak van BGD'en bij begeleiding in het kader van de Ziektewet schadelijk voor de vertrouwenspositie van de bedrijfsarts, en wijst deze taak voor BGD'en dan ook van de hand. De aanvankelijk afstandelijke houding van de NVAB ten opzichte van het uitvoeren van verzekeringsgeneeskundige taken door bedrijfsartsen, verandert in 1990 in een duidelijk actieve opstelling: zij komt met een voorstel sociaal medische begeleiding, waarin én arts centraal aanspreekpunt is voor primaire, secundaire en tertiaire preventie. Voor "claimbeoordeling" kan gebruik worden gemaakt van tweedelijnsvoorzieningen, zoals sociale zekerheidsdeskundigen (NVAB 1990d). Feit is dat in Nederland, met zijn unieke scheiding tussen het behandelings- en controlesysteem, de helft van de bedrijfsartsen begeleiding in het kader van de Ziektewet of 
verwante regelingen bij ambtenaren uitvoert. Diverse case-studies (Ekker 1976, Van Wijngaarden 1979) zouden aangeven dat dit zonder schade voor de vertrouwensrelatie arts-patient plaatsvindt. Voor Buys (1990) en Van Dijk (1990b) geeft sociaal-medische begeleiding extra informatie, die benut kan worden bij preventieve activiteiten.

Werkgevers en werknemers pleiten voor een actieve rol van BGD'en in de eerste fase van de arbeidsongeschiktheid (Najaarsoverleg 1990). Een samenhangend pakket van maatregelen wordt voorgesteld, waaronder intensivering van (verzuim)gevalsbehandeling, uitbreiding BGZ tot de hele werkende bevolking, optimalisering van de structuur en regelgeving van de sociale verzekeringen.

De "strijd" om de markt van de zieke werknemer lijkt ontbrand. Orationes pro domo van resp. bedrijfsverenigingen (verzekeringsgeneeskundigen) en BGD'en (bedrijfsartsen) zijn hierbij niet van de lucht (Tijhuis 1984, Lunshof 1988, NVAB 1989a, Bruins Slot 1989, Willems 1989, Streng 1989, Streng en Vermeu 1989, Den Bieman 1989, NVVG 1989, Bedrijfsgeneeskundige Dagen 1990). Al vaker is de suggestie gedaan van integratie van BGZ en verzekeringsgeneeskunde in een organisatorische eenheid (Muntendam 1959, Van Londen 1982, Willems 1990a, 1990b, NVAB/NVVG 1989, Lunshof 1990).

Hoe het ook zij, doeltreffende sociaal-medische begeleiding vereist samenwerking van sociaal-geneeskundige disciplines binnen en buiten het bedrijfsleven (Knepper 1990a, Buys 1988). Sociaal-medische begeleiding dient zich sterker te gaan richten op het voorkómen van medicaliseringsprocessen en het bevorderen van gedragsverandering (Knepper 1989). Vanwege de organisatorische context appelleert de huidige verzuimbegeleiding nauwelijks aan verantwoordelijkheidsgevoel bij werkgevers en werknemers. Dit vergemakkelijkt de uitstoot van mensen uit het arbeidsproces aanmerkelijk (Knepper 1990a, Bruins Slot 1988 en 1989).

Ook is institutionalisering van de samenwerking bij sociaal-medische begeleiding tussen bedrijf en BGD in de vorm van een sociaal-medisch team een positieve bijdrage aan de beheersing van de sociaal-medische begeleidingsproblematiek (Van Oosterom 1980, Plomp 1987c).

In de Arbowet wordt door de overheid de richting aangegeven waarin de zorg voor de werkende mens zich moet ontwikkelen, namelijk een planmatige, multidisciplinaire en samenhangende zorg voor de gezondheid, veiligheid en welzijn van de werkende mens.

Naast artikel 18 van de Arbowet, waarin een opsomming van BGZ-taken wordt gegeven, wijzen ook andere artikelen in de Arbowet in deze richting. Allereerst zijn dit artikel 3 en 4, waarin aan de werkgever de verplichting wordt opgelegd om "een zo groot mogelijke veiligheid, en een zo goed mogelijke: bescherming van gezondheid" na te streven. De werkgever kan zich hierbij laten ondersteunen door deskundige diensten, waaronder BGD'en. Het is de verantwoordelijkheid van de werkgever om, in overleg met de werknemersvertegenwoordiging, te bepalen in hoeverre dit streven "redelijkerwijs niet kan worden gevergd". Een kwestie van afweging van belangen. Artikel 4 van de Arbowet schrijft behalve een beleidsinten- 
tie-verklaring op Arbogebied ook nog voor dat de werkgever zijn beleid dienaangaande regelmatig evalueert, toetst en zo nodig aanpast aan "de stand van de BGZ dan wel de stand van de ergonomie en die van de arbeids- of bedrijfskunde". Een en ander dient de werkgever vast te leggen in een jaarplan. Artikel 6 van de Arbowet heeft betrekking op voorlichting en onderricht op het gebied van veiligheid en gezondheid. Niet alleen bij indiensttreding dient de werkgever de werknemer dienaangaande te informeren, hij dient dit te herhalen zo vaak als gewijzigde omstandigheden zulks nodig maken. BGD'en kunnen hierbij een adviserende en ondersteunende rol spelen. Artikel 9 van de Arbowet gaat over de melding en registratie van ongevallen en beroepsziekten. Hoewel er zeker nog wel vragen zijn over de thans voorgestelde methodiek van registratie, is het duidelijk dat op basis van een adequate registratie BGD'en beleidsstrategische plannen, specifiek op hun terrein, kunnen opstellen met betrekking tot het te voeren gezondheidsbeleid binnen de onderneming. (Willems en Buma 1988). Artikel 10 van de Arbowet verplicht, in samenhang met artikel 4, de werkgever cen jaarverslag op te maken met betrekking tot de veiligheid, de bescherming van de gezondheid en de maatregelen ter bevordering van het welzijn van de werknemers. Het jaarverslag dient ten minste te bevatten:

a. Een beschrijving van het gevoerde beleid.

b. Informatie over de wijze waarop uitvoering is gegeven aan de samenwerking en het overleg tussen werkgever en werknemers in het behartigen van de zorg voor de veiligheid, de gezondheid en het welzijn, en het overleg danrover met de deskundige diensten.

c. Een overzicht van beroepsgebonden problematiek en in dit kader uitgevoerde maatregelen.

Ook hier is de rol van de BGD evident. Artikel 12 van de Arbowet legt de werknemers een aantal algemene verplichtingen op, onder meer om de hun ter beschikking gestelde persoonlijke beschermingsmiddelen op de juiste wijze te gebruiken. Ook hier ligt een rol voor de BGD. In artikel 24 Arbowet wordt een opsomming gegeven van facetten, die een invloed kunnen hebben op de veiligheid, de gezondheid of het welzijn. Middels Algemene Maatregel van Bestuur (A.M.v.B.) kunnen regelen gesteld worden. Artikel 25 Arbowet biedt de mogelijkheid om bij A.M.v.B. geneeskundig onderzoek vooraf of periodiek verplicht te stellen, respectievelijk afhankelijk van de leeftijd van de werknemer, en van de eventuele gezondheidsrisico's. Artikel 43 tenslotte betreft de Arboraad, cen adviescollege werkzaam op het gebied van de veiligheid, de gezondheid en het welzijn in verband met de arbeid. De Raad heeft tot taak de minister voorstellen te doen en adviezen uit te brengen welke kunnen strekken tot bevordering van de veiligheid, de gezondheid en het welzijn in verband met de arbeid. De Raad kan ter behandeling van bijzondere onderwerpen commissies en werkgroepen instellen. Het College van Bijstand en Advies voor de Bedrijfsgezondheidszorg (was Bedrijfsgeneeskunde) wordt geacht te: zijn ingesteld als een commissie krachtens artikel 43 . Onder andere de NVAB is deelnemer aan deze commissie. Via deze commissie is er op centraal niveau cen ingang tot beinvloeding van arbo-ontwikkelingen. 
In 1993 zal een aantal ingrijpende wijzigingen in de Arbowet plaatsvinden. De redenen hiervoor zijn tweeledig: enerzijds om de EG-richtlijn 89/391 (de "Kaderrichtlijn") te implementeren in Nederlandse wetgeving, anderzijds om afstemming te krijgen tussen Arbowet en wetgeving om verzuim en arbeidsongeschiktheid terug te dringen (TAV, TZ, TBA). In hoofdstuk 5 wordt hier kort op ingegaan.

In opdracht van het DGA is onderzoek gedaan naar de effecten van invoering van de Arbowet op de arbeidsomstandigheden, de aandacht hiervoor en het hierop gerichte beleid van BGD'en, zowel in de particuliere als de overheidssector (Reubsaet et al. 1988, DGA 1989a). Het officiële moment van invoering van de Arowet is eigenlijk een fase in een proces, waarin we toch al een toenemende aandacht voor arbeidsomstandigheden zien. Sommige bedrijven hebben al op de wet geanticipeerd, andere hebben nog nauwelijks een arbobeleid ontwikkeld.

Uit het onderzoek naar de implicaties van invoering van de Arbowet in het particuliere bedrijfsleven blijkt vooral dat aanstelling van een veiligheidsfunctionaris, die zich beroepshalve bezig houdt met de arbeidsomstandigheden, een belangrijk middel is om de aandacht voor arbeidsomstandigheden te structureren en te stimuleren. BGD'en spelen in dit kader een geringere en soms ook onduidelijke rol. Met name wordt gepleit voor meer aandacht voor de rol van het middenkader in de bedrijven. Directies, ondernemingsraden, veiligheidsfunctionarissen en in mindere mate BGD'en hebben over het algemeen een redelijk positief oordeel over de Arbowet (al wil dit niets zeggen over de effectiviteit en uitvoering van deze wet). In kringen van ondernemingsraden en werknemers zijn er klachten over vaagheid en ingewikkeldheid van de wettekst.

Bij de overheidsinstellingen (DGA 1989a), zo is de conclusie, zijn de belangrijkste effecten van de invoering van de Arbowet gelegen in de (tijdelijke) activering van het arbo-bewustzijn, in de verdere structurering van de arbozorg, in de verdere systematisering van het arbobeleid en in de concrete verbetering van een aantal specifieke arbeidsomstandigheden. De effecten van de wet op de samenwerkingsrelatie tussen de werkgever en de werknemers, op de samenwerkingsrelaties met de deskundige diensten, op de inhoudelijke reikwijdte van het arbobeleid en op de integratie van arbo-overwegingen in het algemene bedrijfsbeleid zijn vooralsnog van geringe betekenis. Dit betekent dat de specifieke elementen die de Arbowet toevoegt aan de traditionele veiligheidswetgeving, namelijk de gedachte van samenwerking en overleg, de nieuwe taken van de deskundige diensten, de verruiming van het veiligheidsbegrip en de gedachte van geintegreerde beleidsvoering, pas in betrekkelijk geringe mate tot ontwikkeling zijn gebracht.

\subsubsection{De disciplines in het BGZ-team}

De noodzaak tot inter- en intradisciplinaire samenwerking binnen BGD'en lijkt gezien de brede problematiek op het gebied van gezondheid en arbeidsomstandigheden noodzakelijk (Leuftink 1980, Wink 1982, Thunissen en Lebbink 1990). Deze ontwikkeling van BGD'en naar multidisciplinaire diensten met een grotere diversi- 
teit aan organisatievormen is ook terug te vinden in het Advies inzake arbeidsgeneeskunde,(september 1984) uitgebracht door het Economisch en Sociaal Comité van de EG, alsook in het Verdrag en de Aanbeveling inzake BGD'en van de ILO (1985). Aan de bedrijfsarts wordt overigens wel een centrale positie toegekend.

De deskundige inbreng van de BGD op de werkplek dient verder ontwikkeld te worden, bijvoorbeeld door inbreng van arteidshygiënisten en veiligheidskundigen (NVAB 1985a). Er zijn discussies gaande over de vragen of er een functionaris moet zijn die als "eerstelijns werker" binnen de bedrijven de vinger aan de pols houdt, en wie deze taak zou moeten vervullen. Verschillende arbo-deskundigen kunnen hierbij cen rol spelen (NVAB 1983, Berk 1988, Selbach 1989, DGA 1990). Dat het gaan werken in multidisciplinaire verbanden niet zonder de nodige problemen verloopt, bewijst het door de overheid ondersteunde onderzoek naar de omvorming van een GD naar cen Arbodienst (SOZAWE 1989). Belangrijk is dat de BGD herkenbaar, duidelijk en eenduidig naar buiten treedt.

\subsection{Suggesties voor BGD'en om in te spelen op de veranderingen in de door de klanten en haarzelf geformuleerde wensen}

In de vorige paragrafen is een overzicht gegeven van de kritiek die vanuit de diverse geledingen, die betrokken zijn bij BGZ (werkgevers, werknemers, overheid en beroepsgroep), werd geuit met betrekking tot de organisatie en inhoud van BGZ. Of de BGD'en erin slagen een adequaat antwoord te geven op de geuite kritiek en wensen is onderwerp van onderzoek. In deze paragraaf wordt een aantal in de literatuur gegeven suggesties besproken, dat aangeeft hoe BGD'en BGZ kunnen leveren die meer op de wensen en behoeften van de klanten geënt is en bij eigen inzichten past.

Het is voor BGD'en belangrijk dat zij onderkennen dat zij met verschillende "omgevingen" te maken hebben, en hun doelen en hun strategie op wat langere termijn hierop afstemmen. Naast de omgeving van het bedrijf met al zijn functionarissen, zijn er voor de BGZ op nationaal niveau meerdere "omgevingen" aanwijsbaar: de politieke omgeving waartoe de overheid en de organisaties van werkgevers en werknemers op centraal en bedrijfstakniveau gerekend kunnen worden, en de omgeving van de gezondheidszorg en onderzoeksinstituten. Voor de BGZ zijn ze allemaal van belang in verband met haar "positie".

\subsubsection{Marktgerichtheid}

Als visie is marketing te omschrijven als de oriëntatie in een organisatie die het uitgangspunt vormt voor het nemen van beslissingen. Het betreft dan met name de beslissingen waarin het realiseren van c.q. inspelen op wensen van de afnemers centraal staat (zie verder ook hoofdstuk 4). Kasper (1990) omschrijft marktgerichtheid als volgt: de mate waarin een organisatie zich in haar totale denken en hande- 
len (zowel intern als extern) laat leiden door en -in positieve zin- gebonden weet aan de factoren die het marktgedrag van de organisatie en haar klanten/afnemers bepalen. In deze definitie zit een normatief element: marktgerichtheid geldt als richtsnoer voor het denken en het handelen.

Belangrijke elementen in dit kader zijn: kennis van de omgeving (concurrentie), kennis van de wensen en behoeften van de klant, kennis van de eigen mogelijkheden (Sytsma 1985). Het middels een kosten-baten analyse minimaal ten dele kunnen onderbouwen van de BGZ-activiteiten lijkt van belang (Van der Bruggen 1975, Jacques 1988, Boden 1986, Jacobs en Chovil 1983, Fielding 1991, Magnus 1985).

Belangrijk voor het tot stand brengen van een succesvol strategisch en "marktgericht" beleid is dat men zich realiseert dat dit eisen stelt aan de wijze waarop de BGZ haar werk organiseert, alsook aan de wijze waarop de BGZ haar externe betrekkingen aangaat, contacten onderhoudt en contracten aangaat (zie o.a. Scott 1982, Andriessen et al. 1985, Chapman 1988, COB/SER 1989).

\subsubsection{Multidisciplinaire samenwerking}

Om te kunnen voldoen aan de behoefte van de zeer gevarieerde cliëntenschaar en om in te kunnen spelen op de vaak zeer sterk uiteenlopende gezondheidsproblemen, zal een BGD een voldoende breed spectrum van deskundigheid in huis moeten hebben, en nieuwe deskundigheid zonodig moeten kunnen aantrekken of ontwikkelen. Een BGD moet dus multidisciplinair zijn, maar ook weer niet uiteenvallen in groepen van opzichzelfstaande, rivaliserende disciplines (NVAB 1984d, 1985a en 1988c, NVAB/NVVK/NVvA 1988, Thunissen en Lebbink 1990). Het werk in een BGD dient derhalve gestructureerd (georganiseerd) te worden naar afnemers-segmenten; dat wil zeggen dat de verantwoordelijkheid voor de BGZ in een bedrijf, cen aantal bedrijven of bedrijfsonderdelen, wordt opgedragen aan een (multidisciplinair) team. Op basis van een met het bedrijf overeengekomen plan, verricht dit team activiteiten binnen het bedrijf, overlegt en verantwoordt zich over gedane werkzaamheden, resultaten en eventueel gesignaleerde knelpunten. Een dergelijke manier van werken vraagt een klantgerichte cultuur die, veelal nog ontbreekt, alsook cen duidelijke (in- en externe) doelstelling. (Van Hees 1987, Plomp 1987c, Koch 1986).

Samenwerking op "macro-niveau" met andere organisaties die zich op het arbo-terrein bewegen is wenselijk (Kortsjens 1988, NVAB 1988b, Jakobs 1989).

\subsubsection{Professionaliteit en identiteit}

Regelmatig wordt ervoor gewaarschuwd dat klantgerichtheid (het centraal stellen van wensen en behoeften van de klant) niet kan en mag betekenen dat de eigen professionele verantwoordelijkheid en taakinvulling kan vervallen. Voor onkritisch conformisme jegens de wensen van de afnemers is geen plaats. Wanneer de BGZ haar bestaansrecht uitsluitend zou legitimeren met bedrijfseconomische waarden, dan wint zij mogelijk de gunst van werkgevers op korte termijn, maar verliest zij 
haar geloofwaardigheid op de lange termijn in de ogen van werknemers. De BGZ atrofiëert dan tot een ongericht en sterk uiteenlopend bemoeien van artsen met de gang van zaken in bedrijven (Metz 1985). Regulering van bovenaf zal in de plaats komen van een tekort schietend professioneel elan (Plomp 1987c). Van Wely (1984) spreekt in dit kader van de "dekmantelproblematiek", hetgeen er op neerkomt dat de "deskundige" zich taken aanmeet die hij niet aan kan of mag gaan. De verantwoordelijke dekt zich in, de deskundige toont zich zeker en dekt het probleem toe (zie ook Zuidema 1983).

Ook De Boorder (1986) waarschuwt ervoor dat door de BGZ op vragen van de klant weliswaar moet worden ingespeeld met een klantgerichte opstelling, doch dat moet worden voorkomen dat het bedrijfsleven zelf en uitsluitend zou besluiten welke diensten zij van de BGD betrekt en zich daarbij ook beslissend zou uitspreken over de kwaliteit van deze diensten. BGZ is zorg, dat wil zeggen dat het een longitudinaal en begeleidend karakter heeft, dat zich niet leent voor een contract dat vitsluitend op een basis van vergoeding van verrichtingen wordt gesloten. Deze zorg krijgt het meeste effect als zij opgenomen is als element in het sociaal beleid van de onderneming (NVAB 1985c).

Concluderend: de BGD'en moeten vanuit hun eigen professionaliteit door de klant aangedragen problematiek vertalen in een op maat gesneden takenpakket en advisering (Peters en Senden 1988), en zich als zodanig profileren.

\subsubsection{Beroepscode}

Naast het belang van profilering door de individuele bedrijfsarts, is het voor de professie BGZ een absolute must zich als geheel duidelijk te profileren en te manifesteren.

De beroepsgroep moet en kan de normen van het beroepsmatig handelen vaststellen die als richtlijn gelden voor de praktijk. De organisatie representeert het beroep op maatschappelijk niveau. De organisatie treedt op als pleitbezorger of lobbyist als het gaat om bevorderingen en vooral ook om richting te geven aan opleiding in het beroep en kennisontwikkeling (onderzoek), als vertegenwoordiger van het beroep naar overheid en verenigingen van afnemers en als deelnemer vanuit het beroep in algemeen maatschappelijke discussies. Intern, naar de eigen leden, zijn de taken van een beroepsvereniging, behalve normontwikkeling, ontwikkeling van het vak door methodiekontwikkeling, evaluatie en kwaliteitsbewaking.

Ook andere gremia, zoals overkoepelende organisaties van BGD'en, zijn actief hiermee bezig.

In 1989 brengt de NVAB een Beroepscode voor bedrijfsartsen (NVAB 1989d) uit, dat als richtsnoer voor bedrijfsartsen, als aanvulling op de gedragsregels van de KNMG, kan dienen, waaraan zij, opererend binnen spanningsvelden en belangentegenstellingen, hun gedrag kunnen toetsen. In 1992 (NVAB 1992/c) brengt de NVAB een eerste concept Beroepsprofiel van de bedrijfsarts uit. Beroepscode en gedragsregels kunnen een ruggesteun of leidraad bieden, maar natuurlijk nooit de bedrijfsarts ontslaan van de eigen verantwoordelijkheid. 
Van Gils (1988) attendeert erop dat een sterkere binding met de beropsgroep gepaard gaat met een groter spanningsveld met de organisatie.

\subsection{5. (Na)scholing en wetenschap}

Scholing en het uitdragen van een wetenschappelijk verantwoorde en onderbouwde deskundigheid zijn essentiële zaken voor het bestaansrecht en de overlevingskans van BGZ. Gezien het veelvuldig voorkomen van arbeidgebonden-gezondheidsproblematiek (Zielhuis 1987a en 1987b, NVAB 1990a, De Jong 1985), en de enorme omvang van de arbeidsongeschiktheidsproblematiek, zou onderzoek op dit gebied relevant en kostenbesparend zijn. Schrijnend is het dan te moeten constateren dat het resultaat van de vele inspanningen, om BGZ academisch vorm en inhoud te geven door het creëren van onder andere leerstoelen arbeidsgeneeskunde, zo pover is (SBOB 1985). Voor de oprichting van een nationaal wetenschappelijk overkoepelend instituut voor de BGZ wordt reeds vele jaren gepleit (Van Dijk 1990b, Willems 1990c). BGZ dient slechts door terzake deskundigen, in casu bedrijfsartsen, uitgeoefend te worden (BGZ is een specialisme). Dit neemt ernstige kritiek op de huidige opleidingen tot bedrijfsarts niet weg. (Heutink 1988, KNMG 1990a/1990b). Met name wordt meer kennis verwacht en geëist met betrekking tot kennis van organisatie(processen) (Baas 1987, Wolvetang 1989, Spijkerboer-Mons 1990) en epidemiologie (Sturmans et al. 1982). Bouter et al. (1989) waarschuwen overigens voor wat zij noemen epimatica: de indruk dat door allerlei gegevens te registreren, te beschrijven altijd etiologische vragen kunnen worden beantwoord en interventies worden geëvalueerd. De sociaal-geneeskundige elementen in het algemeen, en de BGZ-elementen in het bijzonder krijgen in de medische opleiding slechts geringe aandacht (SBOB 1985).

Een "Éducation permanente" is binnen de BGZ absoluut noodzakelijk: voor een belangrijk deel verkoopt de BGZ kennis (De Roo en Moll 1988). Schriftelijk onderwijs is hierbij onvoldoende (Evans 1987). Als ideaal wordt door Zielhuis (1987a) de bedrijfsarts gezien die zelf (mee) onderzoek initieert en al dan niet in samenwerking met een onderzoeksinstituut tot uitvoering brengt. Recent bood het NIA in dit kader het "senior research" plan aan. Naast meer wetenschappelijke activiteiten spreekt een aantal mensen zich ook uit voor een meer gestructureerde, beleidsmatige aanpak van BGZ-problemen in de praktijk van alledag (Bayens 1988a/1988b, Zielhuis et al. 1984, Spijkerboer-Mons 1990, Bruins Slot 1988, Van der Gulden et al. 1990, KNMG 1990a). Kennis van informele informatiecircuits vormt hierbij een cruciaal onderdeel (Willems 1990c, Tijssen en Senden 1989). Kennis is macht, maar macht is meer dan kennis (De Jong 1985), of zoals Pool (1986) het uitdrukt: "know how en know who".

Met name voor het management van de BGD'en zal de komende tijd een turbulente zijn, die stuurmanskunst vraagt die normaliter niet in de bagage van de artsenopleiding meegegeven wordt. Aanvullende opleiding is dan ook gewenst (Van Dijk 1989). 


\subsubsection{Het takenpakket BGZ en sociasl-medische begeleiding}

Een van de taakelementen van de BGZ die op korte termijn nadrukkelijk een vitwerking en standpuntbepaling behoeft is de rol van de bedrijfsarts bij de sociaalmedische begeleiding. Eind 1990 heeft de NVAB, naar aanleiding van het Najaarsoverleg van de regering, een voorstel met verstrekkende gevolgen hiertoe gedaan (zie eerder). Werkgevers- en werknemersorganisaties pleiten voor uitbreiding van BGZ voor de gehele werkende bevolking. Aan BGZ wordt een intensieve(re) begeleiding van werknemers in de eerste zes weken van het verzuimtraject, en een verdere follow-up en begeleiding bij reintegratie toegedacht (Najaarsoverleg 1990 , NVAB 1992b).

Zoals uit het voorgaande is gebleken is de "nood" hoog, dat wil zeggen er ligt een enorm probleem aangaande verzuim- en arbeidsongeschiktheidsproblematiek. Dit schept mogelijkheden voor de BGZ, die hier inhoudelijk en kwalitatief verantwoord op kan en moet inspelen. Preventie van beroepsziekten, met een verhoogde aandacht voor psychische problematiek samenhangend met het werk dient daarnaast voor de BGZ een centraal aandachtsveld te zijn/worden. Meer aandacht dient te worden gegeven aan specifieke groepen: adolescenten, vrouwen, ouderen, allochtonen. Naast aandacht voor de zieke mens is ook aandacht voor optimalisering van de gezondheidstoestand van de gezonde werkende mens nuttig, bijv. in de vorm van stress-interventieprogramma's, bedrijfsfitness. Meewerken aan optimalisering van prestaties van mensen (Van Dijk 1989, Van Griensven 1987).

Deelpakketten moeten niet het primaire streven van de BGZ zijn of worden, maar wel is differentiatie van het takenpakket naar bedrijfstak of beroepsgroep gewenst. In dit kader zijn reeds diverse experimenten gestart, bijvoorbeeld ten aanzien van BGZ voor het onderwijs (Kamphuis et al. 1988, 1989 en 1990).

\subsection{Samenvatting}

Een tweetal crises hebben de noodzaak voor BGD'en om zich te bezinnen op haar activiteiten versterkt. Enerzijds was dit de "crisis" in het bedrijfsleven, de veranderingen in arbeid en de organisatie van arbeid.

Anderzijds was dit de "crisis" in de gezondheidszorg, waarin grenzen aan de zorg werden gesteld, en vrạagtekens werden geplaatst bij het fundament van de gezondheidszorg.

Bezinning op het takenpakket door BGD'en is echter een permanent en aan BGZ eigen gebeuren. Immers, BGZ beweegt zich op het snijvlak van gezondheidszorg en maatschappij. Veranderingen hierin hebben repercussies op bedrijfsgezondheidkundige activiteiten.

De kritiek die geuit werd heeft als gemeenschappelijk kenmerk dat BGD'en onvoldoende toegankelijk waren voor wensen en behoeften van klanten. Onvoldoende traden BGD'en in overleg met de klant, onvoldoende hadden zij oog en oor voor 
wensen van de klant, en onvoldoende slaagden zij erin wensen van klanten in concrete BGZ-activiteiten te vertalen.

Werkgevers drongen aan op levering van BGZ op maat en met mate, op toetsbare dienstverlening. Werknemers achtten cen grotere aandacht van BGD'en voor wat er op de werkplek gebeurt noodzakelijk. BGD'en zelf onderkenden een gebrek aan marktgerichtheid en professionele profilering. De overheid vroeg om een meer beleidsmatige, op werkgebonden risico's gerichte BGZ.

Er werd in dit hoofdstuk een aantal suggesties gegeven, waarmee BGD'en beter zouden kunnen inspelen op de veranderde wensen van de klant. Duidelijk zal zijn dat naarmate BGD'en hier beter in slagen, dit een positief effect zal hebben op de ervaren kwaliteit van BGZ.

Met dit hoofdstuk is de noodzaak aangegeven dat BGD'en zich bezinnen op de door hun geleverde diensten en dienstverlening. Onderwerp van dit onderzoek is nu hoe BGD'en dit vertalen in hun kwaliteitsbeleid. Wat is het resultaat van deze zelfreflectie? De vraagstelling wordt benaderd vanuit twee perspectieven. Enerzijds wordt onderzocht welke aspecten van professionele kwaliteit vastgesteld kunnen worden. Anderzijds wordt geïnventariseerd welke aspecten van klantgerichte kwaliteit binnen BGD'en aanwezig zijn. Met andere woorden, kwaliteit wordt hier opgevat als rustend op twee pijlers: professionaliteit en marktgerichtheid. Om zicht te krijgen op deze aspecten van kwaliteit van zorg, wordt middels literatuuronderzoek in hoofdstuk 3 beschreven welke mogelijkheden de gezondheidszorgprofessie aanwendt om vorm en inhoud te geven aan professionele kwaliteit. In hoofdstuk 4 worden de mogelijkheden beschreven die BGD'en hebben om zicht te krijgen op wensen en behoeften van de klant, hoe vorm, structuur en inhoud gegeven kan worden aan een klant-en marktgericht denken. Hierbij wordt gebruik gemaakt van de mogelijkheden die de marketing biedt. Tot slot wordt in hoofdstuk 5 de rol van de overheid inzake BGZ beschreven. 


\section{Hoofdstuk 3}

\section{Aspecten van kwaliteit van BGZ, de visie van de professional. Kwaliteitszorg bij BGD'en.}

\subsection{Inleiding}

De afgelopen jaren wordt binnen de gezondheidszorg, regelmatig gediscussieerd over de kwaliteit van gezondheidszorg. Aan de ene kant acht de beroepsgroep zichzelf primair verantwoordelijk voor de kwaliteit van zorg. Aan de andere kant wordt de noodzaak van externe toetsing (door patient, overheid, verzekeraar) als integraal element in een kwaliteitsbeleid erkend. In 1990 werden landelijk afspraken gemaakt over een te ontwikkelen kwaliteitsbeleid binnen de gezondheidszorg (Frissen 1990). Hierin wordt aan patiënten een even belangrijke plaats gegeven als aan beroepsgroep en verzekeraars. Uit de literatuur blijkt echter dat de patiënt nog zelden betrokken wordt bij het formuleren van een kwaliteitsbeleid (Brandsma-van der Laan 1985, Janssen en Rutten 1986, Cense 1989).

Zeker binnen BGD'en dient de afnemer (werkgever en individuele werknemers) expliciet betrokken te worden bij de vaststelling van de gewenste kwaliteit van dienstverlening. Uiteindelijk immers bepaalt de mate waarin de dienstverlening van BGD'en voldoet aan de eisen en wensen van de afnemers, alsmede de mate waarin de dienstverlening leidt tot de oplossing van voor het bedrijf relevante problemen, de kwaliteit van dienstverlening van de BGD. Haar bestaansrecht is hier onlosmakelijk mee verbonden.

In dit hoofdstuk worden aspecten van kwaliteit van zorg beschreven vanuit het perspectief van de beroepsgroep. Welke aspecten worden door de beroepsgroep (de professie) van belang geacht om een bijdrage aan de kwaliteit van (bedrijfs)gezondheidszorg te leveren?

Dit hoofdstuk start met het aangeven van een conceptueel kader van het begrip kwaliteit (paragraaf 3.2). Paragraaf 3.3 belicht een aantal aspecten van kwaliteit van zorgverlening binnen de gezondheidszorg. Tevens wordt geprobeerd hierin enige lijn en samenhang te brengen.

Om als BGD kwaliteit te kunnen (blijven) leveren dient an een aantal organisatieaspecten te worden voldaan. Er moet sprake zijn van kwaliteitszorg (quality management). Dit wil zeggen dat de managementfunctie van de BGD mede gericht moet 
zijn op het bepalen en ten uitvoer brengen van een kwaliteitsbeleid. Dit betekent dat niet alleen de doelstellingen ten aanzien van kwaliteit vastgesteld en geëxpliciteerd dienen te worden, maar ook dat de BGD activiteiten ontplooit en vastlegt (bijvoorbeeld in de vorm van een kwaliteitsplan) om aan kwaliteitseisen te voldoen (kwaliteitsbeheersing), en regelmatig evalueert of de BGD nog voldoet aan de gestelde kwaliteitseisen (kwaliteitsborging).

Omdat kwaliteitszorg binnen BGD'en nog weinig ontwikkeld is, wordt in paragraaf 3.4 onderzocht welke activiteiten op dit terrein binnen de gezondheidszorg reeds ondernomen zijn. Er zal met name worden gekeken welke voor BGD'en relevante kwaliteitbevorderende activiteiten kunnen worden vastgesteld.

De betekenis van de professionalisering op vorm en inhoud van kwaliteitszorg wordt in paragraaf 3.5 aan de orde gesteld. Als belangrijke instrumenten voor de professional komen naar voren intercollegiale toetsing en de protocollering van diensten. Paragraaf 6 werkt deze aspecten verder uit. Tenslotte wordt het hoofdstuk samengevat.

\subsection{Wat is kwaliteit?}

Het begrip kwaliteit blijkt moeilijk te definiëren. Immers, een eenduidige opvatting over wat kwaliteit is, bestaat niet. Opvattingen over wat kwaliteit is hangen samen met en zijn gerelateerd aan een bepaald object (kwaliteit van..), zijn gericht op het bereiken van een bepaald doel, en worden door subjecten, mensen (arts, patient, overheid) verschillend gewaardeerd en geëvalueerd.

Kwaliteit kan worden gedefinieerd als eigenschap van het voorwerp van beschouwing (dit heet een descriptieve benadering) of als een subjectgebonden gebruik van het begrip kwaliteit (dit is een prescriptieve benadering). Een descriptieve definitie is een bewering die aangeeft wat de betekenis van een verschijnsel is. Een prescriptieve definitie is een bewering die een soort handeling aanbeveelt, suggereert of voorschrijft (Harteloh en Casparie 1991). Harteloh en Casparie (1991) geeft dit fundamentele onderscheid aanleiding tot het maken van een tweedeling in het begrippenkader van kwaliteitsbewaking en -bevordering. Aan de ene kant staat de zgn. aspectbenadering, kenmerken van zorg waarbij nog (wetenschappelijk) onderzocht moet worden welke de precieze samenhang met de kwaliteit van zorg is. Aan de andere kant een prescriptieve of zo men wil normatieve benadering, waarin kwaliteit van zorg wordt opgevat als het uitvoeren van activiteiten volgens een vast patroon, de zgn Deming-cyclus: plan-do-check-act.

Vuori, geciteerd in Harteloh en Casparie (1991), onderscheidt op formele gronden drie soorten definities van kwaliteit:

a. nominale definities: het gaat om formuleringen die in principe in wiskundige symbolen zijn uit te drukken, net zoals bijvoorbeeld "de mate van..." een verhouding uitdrukt die door een quotiënt kan worden weergegeven. Het SERVQUAL-model heeft een dergelijke definitie als basis (zie hoofdstuk 4). 
b. inhoudsanalyse: en rationele benadering van het begrip kwaliteit. Het begrip kwaliteit wordt geoperationaliseerd door ontleding in samenstellende delen. Er worden factoren aangegeven die samenhangen met het gebruik van de term kwaliteit. Het is in essentie een opsomming. De zgn. aspectbenadering is hiervan cen voorbeeld.

c. operationele definities: dit zijn definities van kwaliteit die een direct verband leggen tussen een verbetering van het geneeskundig handelen en een toename van de kwaliteit van de zorg.

Om de kwaliteit van een dienst te kunnen beïnvloeden is het de kunst te weten welke kenmerken van een dienst door de klant in verband worden gebracht met de kwaliteit van die dienst ("determinanten van kwaliteit"). In plaats van determinanten wordt in de gezondheidszorg vooralsnog van aspecten van zorg gesproken, die een samenhang met het oordeel kwaliteit vertonen. Hiermee wordt aangegeven dat binnen de gezondheidszorg (nog) onvoldoende bekend is over welke kenmerken in de ogen van de ontvanger van zorg van belang zijn voor de kwaliteit.

De eerste aanzet voor de zgn. aspectbenadering is door Caper in 1974 gegeven. Hij formuleert het principe dat aan de aspectbenadering ten grondslag ligt als volgt: "It seems useful to me to think of the quality of medical care as being seperable into a number of components. Some are measurable, and others are not" (geciteerd in Harteloh en Casparie 1991). Het is dus in beginsel een kwalitatieve analyse-methode.

De grote winst van de aspectbenadering is dat factoren naar voren kunnen worden gebracht vanuit verschillende invalshoek en door verschillende participanten, die betrokken zijn bij de totstandkoming van de dienst. In het geval van BGZ gaat het dan om werkgever, werknemers, overheid en professional. Soms is er overeenstemming over het belang van een aspect voor de kwaliteit, soms bestaat er (een groot) verschil van mening.

De aspectbenadering is een operationalisering van het abstracte concept "kwaliteit van zorg". Het gaat erom dat:

- bepaalde aspecten van het zorgproces worden aangewezen die van invloed worden geacht op de kwaliteit;

- de aard van de invloed van een aspect van zorg op de kwaliteit wordt vastgesteld (de "hoe-vraag");

- de geformuleerde aspecten in een zinvol verband worden gebracht door middel van ordening;

- de zorgverlening aan de hand van kennis van de geformuleerde aspecten beter kan worden afgestemd op de wensen en behoeften van de gebruiker om op deze manier een verbetering van de kwaliteit van zorg te realiseren; ofwel de geformuleerde aspecten zijn object van kwaliteitszorg.

Op basis van de aspectbenadering wordt de ervaren kwaliteit van BGZ in het onderzoek als volgt gedefinieerd: er is sprake van kwaliteit van BGZ, als de BGD op professioneel verantwoorde en klantgerichte wijze diensten verleent die afnemers 
wensen en nodig hebben. Een kwaliteit-gerichte cultuur binnen de BGD is hierbij van groot belang. Het durven afleggen van verantwoording, maar vandaaruit ook het durven vragen van verantwoording (Buiting 1991).

In paragraaf 3.3 worden enige professionele aspecten besproken, die samenhangen met kwaliteit van zorg. In diverse omschrijvingen van de kwaliteit van zorg worden deze aspecten benoemd (Stolte 1977, Van Wijmen 1983, Draaisma et al. 1986, Casparie 1989, NRV 1986, Vuori 1980, CBO 1988 en 1989, Federatie 1990b, Juran et al. 1974).

\subsection{Aspectbenadering van kwaliteit van zorg}

In deze paragraaf wordt een aantal professionele aspecten beschreven dat samenhangt met de kwaliteit van zorg (paragraaf 3.3.1). De klantgerichte aspecten van kwaliteit van BGZ komen in hoofdstuk 4 aan de orde. In paragraaf 3.3.2. wordt getracht een mogelijke samenhang tussen deze aspecten aan te brengen. Deze paragraaf heeft vooral tot doel een theoretisch kader aan te bieden, waarbinnen kwaliteitszorg van BGD'en geplaatst kan worden.

\subsubsection{Aspecten van kwaliteit van zorg}

Binnen de gezondheidszorg wordt een aantal aspecten genoemd dat een bijdrage levert aan de kwaliteit van zorg (CBO 1988, NRV 1986, Harteloh et al. 1991, Harteloh en Casparie 1991, Draaisma et al. 1986, Van Wijmen 1983, KNMG 1980, Tielens 1989). Deze aspecten leveren in concreto echter pas een bijdrage aan de kwaliteit van zorg na operationalisering. Tevens is van belang in het oog te houden dat de zwaarte die toegekend wordt aan de diverse aspecten van kwaliteit voor de verschillende bij BGZ betrokken partijen anders zal zijn.

De volgende aspecten worden geacht van belang te zijn voor de kwaliteit van gezondheidszorg:

* effectiviteit of doeltreffendheid: hieronder wordt verstaan de mate waarin een resultaat, welke onder optimale ("laboratorium-") condities bereikbaar is gebleken, ook inderdaad onder dagelijkse omstandigheden wordt bereikt.

- efficiency of doelmatigheid: hieronder verstaat men een vergelijking van de gebruikte middelen (geld, menskracht en tijd) met het bereikte resultaat. Met name het kosten(beheersings-) aspect staat de laatste jaren sterk in de belangstelling (rapport van de Commissie Dekker 1987, de Nota "Veranderingen verzekerd"), en wordt veelal (ten onrechte) geheel gelijk gesteld met efficiency.

* "efficacy" of werkzaamheid: dit is de mate waarin een middel of interventie resultaat oplevert voor de patient zoals deze onder optimale omstandigheden behaald kan worden. Het is als het ware "de" notie van de waarheid, de gouden standaard. 
deskundigheid en geschiktheid: dit zijn de traditionele aandachtspunten van de beroepsgroep (en de overheid) in het verband met kwaliteit van zorg. Deze komt tot uiting in zaken als (na)scholing en opleiding. (intercollegiale) toetsing, het ontwikkelen en bijhouden van kennis, vaardigheden en cen cliezntgerichte attitude. Een expliciete taakomschrijving en opvatting per beroepsgroep (Beroepscode bedrijfsartsen, artikelenreeks in Medisch Contact in 1989, waarin de diverse specialistenverenigingen hun visie op kwaliteit beschrijven bijvoorbeeld) draagt bij aan de duidelijkheid over hoe de beroepsgroep deze elementen in relatie met de kwaliteit van zorg beschouwt.

\subsubsection{De samenhang tussen aspecten van $k$ waliteit van zorg}

Naast de kwaliteit van zorg in de individuele arts-patient relatie bepalen organisatie van en procesvoering binnen de BGD mede de (mogelijke) kwaliteit van dienstverlening (Bersee 1990). Casparie (1991) hanteert de term "integrale kwaliteitszorg". Donabedian geeft een mogelijk ordeningsprincipe aan. Hij onderscheidt drie ingangen om kwaliteit te beoordelen: de structuur, het proces en het resultaat van de zorgverlening.

* structuur: dit zijn de min of meer constante karakteristieken van de zorgverlener, van middelen en menskracht, beschikbaarheid hiervan en de omgeving waarin de zorg verleend wordt. "Structure is relevant to quality by increasing or decreasing the probability of good performance", zoals hij het noemt.

* proces: Dit betreft de manier waarop de zorgverlening plaatsvindt. Er vindt toetsing aan of vergelijking met "normatieve procesvoering" plaats bij de beoordeling van kwaliteit. De normen worden ontleend aan de wetenschap, aan de ethiek of aan de "maatschappelijke context".

* het resultaat: het zich beperken tot bestuderen van het resultaat van zorgverlening heeft als nadeel dat, zelfs als men al in staat is een resultaat ten dele toe te schrijven aan de zorg(verlening)- hetgeen vaak al moeilijk zal zijn -dan nog is het moeilijk vast te stellen welke elementen in het proces verantwoordelijk zijn voor het bereikte resultaat.

Donabedian concludeert dat een integrale benadering gewenst is. (zie ook Casparie 1977, Herschel en Peters 1978, Vuori 1982, Selbmann 1982, Laane en Vuister 1990).

De medische professie kent een tweetal ingangen om de kwaliteit van zorg te "bewaken". Men doet dit door vooraf bepaalde (kwaliteits-)eisen te stellen aan een zorgverlener of zorginstelling, de zogenaamde inductieve weg. De veronderstelling is dat als aan betrokken criteria of eisen voldaan wordt de kwaliteit van zorg goed zal zijn. Voorbeelden van deze methodiek zijn examens en certificatie.

Men kan echter ook achteraf of continu de zorg en het zorguerleningsproces evalueren, de zogenaande deductieve weg. Dit kan men doen aan de hand van zgn. "indicatoren". In de klassieke benadering van kwaliteitsbewaking en -bevordering wordt een indicator opgevat als een (indirecte) maat voor de kwaliteit van zorg. In 
een meer bedrijfskundige benadering (Harteloh en Casparie 1991) wordt een indicator gebruikt als een zgn. screenende grootheid, die de aandacht vestigt op onderdelen van zorg die nader zouden moeten worden geẽvalueerd. Dat wil zeggen dat een indicator bij overschrijding van een zekere drempelwaarde een "probleemoplossend proces" op gang moet kunnen brengen. Een indicator kan hierbij informatie uitdrukken van een enkelvoudige (meestal sterk opvallende) gebeurtenis. We spreken dan wel van de Sentinel-events methode. Een indicator kan echter ook gebaseerd zijn op een verhouding of een ratio van plaatselijk voorkomende gebeurtenissen ten opzichte van het totaal van dat soort gebeurtenissen of als trend in de tijd (Van Wijmen 1983, Kessner en Kalb 1973, Fontus en Levy 1989, Hoekstra en Verzellenberg 1982, Reerink en Schweizer 1980, De Vries et al. 1990, Offerhaus 1990).

Aan het einde van deze paragraaf is een relativerende opmerking nog op zijn plaats, waar door Grünwald Schindl en Kraan Jetten (1985) op gewezen wordt. Vaak wordt impliciet verondersteld dat het voeren van beleid uitsluitend het resultaat is van rationele afwegingsprocessen. De praktijk echter, en dit geldt zeker ook voor de BGZ, is anders. Uitvoering van beleid in de praktijk is meer een resultante van onderhandelingen, compromissen, conflicten en misverstanden tussen "spelers" met verschillende positionele belangen en beïnvloedingsmogelijkheden. Een eclectische toepassing van evaluatiemodellen, aangepast aan doel en soort organisatie, wordt aanbevolen.

\subsection{Kwaliteitszorg in de gezondheidszorg}

\subsubsection{Inleiding}

Alvorens de ontwikkeling te schetsen van de kwaliteitszorg in de gezondheidszorg, is het misschien interessant op deze plaats een aantal door Lee en Jones in 1933 geformuleerde richtlijnen voor goede medische zorg nog eens de revue te laten passeren, omdat zij aan actualiteit nauwelijks hebben ingeboet en ook betrekking (kunnen) hebben op BGZ:

- Good medical care emphasizes prevention;

- Good medical care requires intelligent cooperation between the lay public and the practitioners of scientific medicine;

- Good medical care treats the individual as a whole;

- Good medical care maintains a close and continuing personal relation between physicians and patient;

(overgenomen uit Harteloh en Casparie 1991).

In Nederland is sedert 1974 een beweging te constateren naar meer systematische en gestructureerde bewaking van de kwaliteit van het medisch handelen (kwaliteitszorg). Hierbij is aanvankelijk sterk gekeken naar ontwikkelingen in de VS (Professional Standard Review Organizations= PSRO's). Ondersteund door een daartoe in 
het leven geroepen stichting, het Centraal Begeleidingsorgaan voor de Intercollegiale Toetsing (CBO), werd begonnen bij de specialisten, na enige jaren gevolgd door vergelijkbare activiteiten bij huisartsen (Grol 1987, Van den Bogaard 1988). Binnen de sociale geneeskunde ontbreekt een dergelijke gestructureerde bewaking van het zorgverleningsproces nog grotendeels, al worden hiertoe wel initiatieven ontplooid. (Brandsma- van der Laan 1985, Anderson 1982, Verzuu 1988, NVVG 1990, Van Lingen et al. 1990, LVSG 1989).

Kwaliteitszorg is een continue proces. Als cen bepaald niveau van kwaliteit van dienstverlening bereikt is, zullen doelen bijgesteld worden. Dit permanente streven naar verhoging van de kwaliteit kan men kwaliteitbevordering noemen. De volgende paragraaf werkt dit begrip verder uit. Tevens wordt aangegeven welke redenen de medische professie heeft om kwaliteitbevordering van haar diensten na te streven.

\subsubsection{Kwaliteitbevordering en medische professie}

Kwaliteitbevordering (quality assurance) is het complex van wetenschappelijke en maatschappelijke activiteiten gericht op het verbeteren van de kwaliteit van de gezondheidszorg (CBO 1988 en 1989). We kunnen hierin twee fasen en/of complexen van activiteiten onderscheiden:

* kwaliteitsbeoordeling (quality assessment): het diagnostische deel. Dat wil zeggen die activiteiten die gericht zijn op het documenteren en beoordelen van het niveau van kwaliteit van het segment van de zorgverlening dat men wil bestuderen. Het gaat hier om het vergelijken van de werkelijk geleverde zorg met van tevoren opgestelde en geaccordeerde criteria met standaards, en een nadere analyse van de aangetoonde gebreken.

* kwaliteitsverbetering (quality improvement): het therapeutische deel. Dat wil zeggen die activiteiten die ertoe leiden dat aangetoonde gebreken in het zorgverleningsproces worden opgeheven.

Er bestaan diverse redenen voor de medische professie om enige vorm van kwaliteitbevordering toe te passen. In de eerste plaats is er het professionele "belang", dat wil zeggen dat men streeft naar de beste zorg voor de patient. Daarnaast bestaat er een maatschappelijk belang, dat wil zeggen dat door de maatschappij aan de medische professie het mandaat gegeven en het vertrouwen geschonken is tot het zelf beoordelen van de vraag naar medische hulp en het verlenen van daarbij nodig geachte zorg (Leenen 1979 en 1981, Reerink 1985). Tot slot zijn er pragmatische belangen: de toenemende medisch-technische mogelijkheden, de risico's die verbonden zijn aan de toepassing van moderne diagnostische en therapeutische modaliteiten en de informatie-explosie in de geneeskunde en de gezondheidszorg maken bewuste keuzen noodzakelijk (Casparie en Van Everdingen 1989). Hierbij kan evaluatie van het eigen handelen niet gemist worden waardoor schade voor de patient en onnodig gebruik van schaarse middelen voorkomen kan worden. Bovendien opereert de gezondheidszorg steeds meer in een competitief krachtenspel, waarbij men te maken krijgt met een toenemende mondigheid van de patient, die 
verantwoording van het (medisch) handelen vraagt (Berkel et al. 1987, Stolte 1977, Leenen 1979, Kessener 1989, KNMG 1989b, Frissen 1990).

Deze redenen gelden in meer of mindere mate ook voor de BGZ.

De overheid speelt bij het proces van kwaliteitsbewaking in de gezondheidszorg op verschillende manieren een rol. Hoewel de overheid gekozen heeft voor een terughoudende opstelling, is zij de laatste jaren bezig wetgeving te ontwikkelen die tot doel heeft de positie van de patient te versterken (Wet Persoonsregistraties, Wet op de behandelingsovereenkomst). Daarnaast treffen we in de Wet Beroepen Individuele Gezondheidszorg (BIG) en het ontwerp Kwaliteitswet elementen aan die de overheid wenst te hanteren als aspecten van kwaliteit van medisch handelen. Tot slot heeft de overheid invloed op het zorgniveau, binnen de BGZ in het bijzonder, door erkenning van BGD'en ex Arbowet en het toezicht door de Arbeidsinspectie (Doppegieter 1989 en 1990, Roscam Abbing 1990, Van Rijen en Van Veen 1990, Sanders 1990).

Conform de wens van de beroepsgroep en passend bij een terughoudende overheid, laat de overheid het bewaken van de kwaliteit van zorg over aan de beroepsgroep zelf. $\mathrm{Zij}$ vraagt echter wel inzicht in en toezicht op het systeem dat de betrokken gezondheidszorgorganisaties hanteren om aan deze verantwoordelijkheid op toetsbare wijze gestalte te geven. Wetenschappelijke verenigingen kunnen in dit proces cen sturende en ondersteunende rol spelen (Casparie et al. 1989, KNMG 1990c, Hagendoorn 1989, Bouwman 1989).

Voor gezondheidsorganisaties, zoals BGD'en, geldt daarbij dat de organisaties zelf in de voorwaardenscheppende zin ruimte moeten bieden aan de individuele beroepsbeoefenaren om cen bijdrage aan een kwaliteitsbeleid te kunnen leveren (Van Leeuwen 1988).

\subsubsection{Kwaliteitszorg binnen de BGZ}

Zoals reeds aangegeven in paragraaf 3.4.1 is er binnen de BGZ in vergelijking met de curatieve zorg nog betrekkelijk weinig sprake van een systematische en gestructureerde kwaliteitszorg. Wel wordt door LVSG (LVSG 1989), NVAB en BGDorganisaties zelf hoge prioriteit toegekend aan het ontwikkelen van een kwaliteitszorg binnen de BGZ. Oprichting van een Stichting Kwaliteit binnen de BGZ past in dit streven. Ook de ontwikkeling van een concept "total quality management" in opdracht van de Federatie (Federatie 1990a/1990b) past hierin. De benaderingswijze is echter verschillend: de SKB richt zich met name op de produktkwaliteit ("technische" kwaliteit), terwijl de Federatie de proceskwaliteit ("functionele" kwaliteit) centraal stelt.

Het bewaken van de kwaliteit van BGZ wordt enerzijds vergemakkelijkt binnen de BGZ omdat de organisatorische structuur hiervoor binnen BGD'en gegeven is (De Boer 1981). De terugkoppeling van de client op mesoniveau is directer en explicieter (bijvoorbeeld via vastgelegde rechten van de ondernemingsraad met betrekking tot inzicht en inspraak in BGD-activiteiten). Anderzijds wordt controle van de 
kwaliteit van BGZ bemoeilijkt omdat het resultaat van haar inspanningen moeilijker meetbaar is. BGZ beweegt zich immers op het preventief terrein in een direct krachtveld van veelal tegengestelde belangen (Metz 1985, Bult 1987).

In toenemende mate wordt de gewenste werkwijze van BGZ beschreven en aan de orde gesteld, 0.a. door het opstellen van een Beroepscode voor bedrijfsartsen, het protocolleren van BGZ-taakelementen en het in kaart brengen van "kwaliteitscriteria" vanuit perspectief van de beroepsgroep en afnemers (Draaisma et al. 1991, Smulders 1980, Plomp 1987a, De Winter en Dijkstra 1984, Jenniskens 1982, NVAB 1989d).

De toenemende belangstelling voor kwaliteitszorg binnen BGD'en moet gezien worden tegen de achtergrond van een aantal, o.a. in hoofdstuk 2 aangegeven, maatschappelijke ontwikkelingen, zoals de toegenomen aandacht voor de kwaliteit van dienstverlening, de ontwikkelingen op het gebied van wettelijke toetsing van BGD'en (DGA 1989b), de toenemende concurrentie.

Kwaliteitszorg is een vorm van strategisch management. Het moet ertoe leiden dat het streven naar verbetering en beheersing van de kwaliteit van diensten en dienstverlening vorm en inhoud krijgt. De centrale gedachten van integrale kwaliteitszorg zijn:

- het is een taak van cen ieder die bij het dienstverleningsproces is betrokken;

- $\quad$ kwaliteitszorg vindt plaats waar het werk gebeurt (op de werkvloer);

- $\quad$ kwaliteitszorg is een systematisch bezigheid waar continu aan moet worden gewerkt (zgn. Deming-cyclus); De Deming-cyclus houdt in: het expliciteren van een doel ("plan"), het uitvoeren van een plan ("do"), het vergelijken van het gerealiseerde met het oorspronkelijke plan ("check"), en zonodig bijsturen ("act").

Het gaat bij kwaliteitszorg enerzijds om het op gang brengen van een verandering, anderzijds om het aanbrengen van een nieuwe structuur in al bestaande activiteiten. Een kwaliteitszorgsysteem dient de volgende elementen te bevatten (Federatie 1990a/1990b):

1. Kwaliteitsbeleid: explicitatie van de uitgangspunten met betrekking tot de kwaliteit van de dienstverlening zoals betrokken BGD deze nastreeft.

2. Beheersingsmaatregelen: het complex van activiteiten op materieel, organisatorisch en personeel gebied om het kwaliteitsbeleid te kunnen realiseren.

Kwaliteitsaspecten die hieruit voortvloeien zijn: doelmatigheid, continuiteit, beschikbaarheid.

3. Uitvoeringstechnieken: de richtlijnen, de procedures, protocollen en documenten op basis waarvan de centrale functies en de kerntaken van de BGD uitgevoerd moeten worden. Deze moeten passen in het vastgestelde kwaliteitsbeleid en uitvoerbaar zijn in bestaande beheersingsmaatregelen.

Hiermee samenhangende kwaliteitsaspecten zijn: doeltreffendheid, deskundigheid, zorgvuldigheid.

De afnemers van BGZ-diensten moeten de richting aangeven bij vaststelling van een kwaliteitsbeleid. Tussen BGD en afnemers (werkgever en individuele werkne- 
mers) dient een interactieproces tot stand te komen gericht op het opbouwen c.q. onderhouden van een duurzame relatie tussen BGD en klant. Belangrijke kwaliteitsaspecten in dit kader zijn betrouwbaarheid, respectvolle bejegening, omgangsvormen, verantwoordings-bereidheid, presentatie. Deze aspecten komen in het volgende hoofdstuk verder aan de orde (de klantgerichte aspecten van kwaliteit van BGZ). Zie 0.a. ook Makens en McEachern 1990.

Naast de invloed op de kwaliteit van dienstverlening van dit clientsysteem in strikte zin, spelen in dit kader echter ook andere partijen in de omgeving van de BGD een rol. Genoemd kunnen worden de overheid (DGA, Arbeidsinspectie, Arbowet), overkoepelende BGD-organisaties, beroepsverenigingen (NVAB, KNMG, LVSG), en anderen werkzaam binnen de gezondheidszorg (GAK, GMD, curatieve sector).

Een aantal pogingen om vorm te geven aan en instrumenten aan te reiken voor kwaliteitszorg binnen de sociale geneeskunde kan genoemd worden. Verburg (1981) werkt op bedrijfskundige wijze het model van Donabedian voor de BGZ verder uit. Timmer en Koten (1984) doen een poging kwaliteitseisen en kwaliteitsbewaking ten aanzien van de verzekeringsgeneeskundige te formuleren (zie ook NVVG 1990). Binnen de verpleeghuiszorg is door Van Lingen et al. (1990) een kwaliteitszorgmodel ontwikkeld. Tot slot kan worden gewezen op uitwerking van enige deelaspecten van kwaliteitszorg, bijvoorbeeld intercollegiale toetsing (Reinalda 1989). Zie ook Bult 1987, Docter 1987, Stille 1987, NVAB 1984b, Webb 1975, LVSG 1990.

BGD'en zijn op verschillende wijze bezig met kwaliteitszorg. EVD'en nemen vaak deel aan "total quality" programma's zoals die binnen hun bedrijf lopen. Bij GD'en zien we onder invloed van de Federatie een sterke tendens om tot uniformering van kwaliteitszorg te komen. Mogelijkheden voor een kwaliteitscertificatie worden hiermee in de toekomst vergemakkelijkt.

\subsection{Professionalisering en BGZ}

\subsubsection{Inleiding}

Kenmerkend voor een professie is dat zij haar eigen standaard en kwaliteit bepaalt en bewaakt. Een tweetal wegen kan hierbij bewandeld worden.

Enerzijds is er de weg waarbij ten aanzien van de BGZ-taken de "standaard" ontwikkeld wordt. Deze geeft aan hoe de betrokken taak idealiter uitgevoerd zou moeten worden. Getracht wordt vorm en inhoud te geven aan het professioneel handelen zelf. Instrumenten hiervoor zijn standaardisatie en het vaststellen van referentiekaders van BGZ-taken. In dit kader kunnen activiteiten genoemd worden als de discussies over het aanstellingsonderzoek en sociaal-medische begeleiding, de diverse vormen van periodiek onderzoek. In paragraaf 3.6 wordt getracht de standaard voor een viertal BGZ-taken te formuleren. Deze weg kan de weg van protocollering worden genoemd. 
Daarnaast is ontwikkeling van kwaliteitbevorderende activiteiten in algemene zin mogelijk. Hieronder valt bijv. een activiteit als intercollegiale toetsing. Binnen de BGZ heeft deze vorm van kwaliteithevordering nog een sterk rudimentair karakter, al kan gewezen worden op het experimenteren onder begeleiding van het CBO met een gestructureerde vorm van intercollegiale toetsing. Daarnaast kunnen genoemd worden het ontwikkelen van een Beroepscode (NVAB 1989d) en functieprofielen. De tendens naar de ontwikkeling van een kwaliteitskeurmerk (volgens bepaalde ISO-normen) kan eveneens hieronder gerekend worden. Belangrijk element hierin is de klachtenprocedure.

\subsubsection{Professionalisering}

De BGD, volgens Plomp (1987c), als professionele, dienstverlenende organisatie stelt niet alleen haar eigen normen, zij dient ook zorg te dragen voor een vorm van kwaliteitsbewaking. Een professionele opstelling kan echter strijdig zijn met een klantgerichte dienstverlening. Tevens kan een dergelijke cultuur "botsen" met anders georiënteerde organisatieculturen. Het vinden van een evenwicht tussen deze twee "polen" is voor BGD'en essenticel voor het bereiken van een door leverancier en ontvanger van zorg ervaren kwaliteitsniveau. Professionalisering definieert Plomp als een interactieproces tussen aanbieders, afnemers en sponsors van professionele diensten, waarbij aan leden van een professie handelings- en beoordelingsbevoegdheid wordt toegekend op een domein, vanwege het vermogen en de bijzondere deskundigheid die aan hen wordt toegeschreven om met delicate problemen op dat domein om te gaan. Hij benadrukt dat professionele autonomie geen vanzelfsprekendheid is, maar een mandaat dat door sponsors/klanten aan professionals wordt toegekend, en dat bijstelling behoeft als omstandigheden zich wijzigen (bijvoorbeeld als het probleem waarvoor de professional is ingehuurd, opgelost of beheersbaar is geworden). Als legitimatiegronden worden genoemd: kennis/deskundigheid; macht, dat wil zeggen de mogelijkheden om met de beroepsuitoefening beoogde doelen te bereiken; agogische actie, dat wil zeggen een dusdanige opstelling van de beroepsgroep dat bij de uitoefening in de eerste plaats rekening wordt gehouden met de noden en behoeften van de directe afnemers van de diensten (probleem- en cliēntgericht handelen).

Hoewel BGZ een duidelijk wettelijk kader kent (Arbowet), kan zij bij het nastreven van haar doelen hieraan maar betrekkelijk weinig voor bedrijven dwingende ondersteuning ontlenen. Binnen een bedrijf zullen gezondheidkundige doelen van de BGD altijd moeten concurreren met andere financiële, economische en technologische waarden en belangen.

Daarnaast kunnen de culturen tussen een professioneel georiënteerde organisatie als de BGD en "anders-georiënteerde" organisaties aanleiding zijn tot tegenstellingen. Er kunnen verschillen optreden in legitimatiebron van gezag en beveegdheden (hiërarchie versus beroepsgroep), wijze van controle en verantwoording van hande- 
len, en de oriëntatie op het werk (gericht op doel en nut organisatie versus normen en standaarden beroepsgroep).

Organisaties kunnen nogal verschillen in hun vermogen om professionalistische waarden te incorporeren. Daardoor loopt de plaats en de functie van professionals in organisaties nogal uiteen. Vooral in zogenaamde "ontwikkelingsgerichte" organisaties treft de professional een gunstige voedingsbodem.

Er zijn diverse factoren van invloed op de waardering van de BGD en haar dienstverlening. Naast een klantgerichte opstelling, waar in hoofdstuk 4 verder op wordt ingegaan, onderscheidt Plomp (1987c) een aantal structurele en taakinhoudelijke aspecten.

Als specifieke factoren noemt hij:

* de aard van de problemen en activiteiten die op cen bepaald terrein voorkomen; in principe wordt de BGD betrokken bij problemen en activiteiten waaran medische aspecten zitten (keuringen, reïntegratie).

- de taak en verantwoordelijkheid van de rolpartners van de BGD op cen deelterrein binnen het bedrijf; "deze kunnen tegengesteld zijn, en veelal zijn ze dat." De oplossing is gelegen in het concreet vastleggen van gewenste activiteiten en informatiestromen in een contract of overeenkomst.

* vorm en structuur van het overleg tussen bedrijf en BGD.

Als algemene factoren die van invloed zijn op de betrokkenheid van de BGD noemt Plomp:

* een probleem- en bedrijfsgerichte BGD-opstelling die als zodanig wordt herkend in het bedrijf en een actieve anticiperende handelwijze van de BGD, waarbij op centrale beleidsterreinen informatie wordt verzameld en adviezen worden verstrekt.

Het zoeken van steunpunten en het aangaan van coalities in een bedrijf, een kenmerk van een probleem- en bedrijfsgerichte strategische manier van handelen, lijken de meest bepalende BGD-determinanten voor het ontplooien van specifieke BGD-activiteiten. De aanwezigheid van speciale BGD-deskundigheid op arbeidshygiênisch terrein is daarbij geen noodzakelijke maar wel een begunstigende voorwaande.

* de mogelijkheden van en principiële bereidheid binnen het bedrijf voor BGZ. Het bleek dat BGZ het best gedijt in bedrijven met weinig manifeste gezondheidkundige problemen en een goed sociaal beleid, en het minst tot zijn recht komt in bedrijven met veel routinematige ongeschoolde arbeid en een relatief grote sociale problematiek.

Zijn conclusie luidt dan ook dat activiteiten en vragen rond individuele personeelsleden, waaraan duidelijk medische aspecten zitten, beschouwd kunnen worden als de feitelijke kern van het domein van de BGZ waarover tussen BGD, werkgevers en werknemers algemeen overeenstemming bestaat.

Door het dualistische karakter van de professional, als een technisch expert enerzijds, en cen pleitbezorger en hoeder van centrale maatschappelijke waarden anderzijds, komt de bedrijfsarts in een situatie te verkeren waarin hij verschillende rollen 
moet (kunnen) spelen: de rol van expert, de rol van begeleider en adviseur, en de rol van organisatiegenoot. In het kunnen onderscheiden en kunnen combineren van deze drie rollen ligt de sleutel voor het adequaat opereren van professionals in relatie tot hun sponsors en cliênten. Hierdoor wordt een uitweg geboden uit het dilemma van betrokkenheid en autonomie dat veel professionals ervaren. In de praktijk houdt dit in dat van een professional verwacht mag worden dat hij per situatie en probleem zo concreet mogelijk aangeeft wat zijn rol en inbreng is of kan zijn, en dat hij zijn overwegingen en professionele waarden en normen expliciteert. Dit schept de duidelijkheid die noodzakelijk is voor een adequaat verloop van het interactieproces met cliënten.

Kwaliteitskringen, intercollegiale toetsing, consensus-protocollen kunnen het BGZhandelen hierbij, al dan niet met als resultante een "kwaliteitskeurmerk", dienen als toetsbare explicitering. De ervaringen binnen de BGZ met genoemde elernenten is nog sterk beperkt, aldus Plomp (1987a/1987b, 1988).

\subsubsection{De plaats in het relatienetwerk en de beoordeling van de kwaliteit van BGZ}

De positie van waaruit gekeken wordt naar de BGD bepaalt de waardering van haar dienstverlening (Plomp 1987a/1987c, Tanke 1985).

Plomp beschrijft hoe de belangrijkste partijen die betrokken zijn bij BGZ (personeelszaken, veiligheidsdienst, afdelingsleiding, ondernemingsraad en directie) de BGD en haar dienstverlening evalueren.

Voor personeelszaken is vooral een actieve rol van de BGD bij verzuimbegeleiding, waarbij samenwerking bij voorkeur in een zogenaamd sociaal medisch team geinstitutionaliseerd wordt, van belang. Tussen de BGD en de veiligheidsdienst doen zich vaak competentieproblemen voor: het terrein van werkomstandigheden wordt door beide geclaimd. Afdelingschefs beoordelen de bijdrage van de BGD vooral op haar praktische bruikbaarheid en relevantie van problemen waar zij zelf mee zitten. Meestal betreft dit individuele casuistiek, waarbij informeel overleg op prijs wordt gesteld. Ondernemingsraden zijn de beste supporters van de BGD. Zij wensen op een breed terrein inbreng van de BGD. Ondanks dat ondernemingsraadsleden weinig contact hebben met de BGD, en ondanks dat ze niet of slechts gebrekkig geinformeerd worden door de BGD, oordelen de meeste ondernemingsraadsleden positief over de BGD ("natuurlijke bondgenoot"). Echter, naarmate ondernemingsraden zelf meer activiteiten ontplooien op het terrein van veiligheid en gezondheid en eigen standpunten innemen, is hun opstelling minder welwillend en wordt vaker negatief geoordeeld over de BGD-inbreng. In het algemeen wensen ondernemingsraden ook meer contact met de BGD, in tegenstelling tot de BGD zelf.

Voor directies tenslotte vormde een concreet probleem of de behoefte aan een bepaald soort BGD-activiteit meestal de reden om de diensten van een BGD aan te trekken. De contacten zijn over het algemeen gering. Men heeft er begrip voor dat de BGD vanuit een andere invalshoek gezondheidsproblemen in het bedrijf bena- 
dert. Men zet zich echter af tegen een a priori innemen van een "professioneel onafhankelijke houding" door de BGD.

Ook uit onderzoek van Tanke (1985) blijkt het belang van de positie van de beoordelaar voor de waardering van BGZ. Hij deed onderzoek in een zevental arbeidsorganisaties naar het beeld van de BGZ. In zijn onderzoek trok hij de conclusie dat de afdeling personeelszaken nog het meeste zicht heeft op de mogelijkheden van de BGD. Werknemers daarentegen zien de bedrijfsarts meestal vooral als de huisarts van het bedrijf, de eerste-hulp verlener. Wanneer er andere verwachtingen zijn, blijkt de BGD hieraan vaak niet te kunnen voldoen. Dit geldt bijvoorbeeld ten aanzien van het adviseren van de BGD voor wat betreft investeringen en nieuwe werkmethoden. De "arbitragerol" van de bedrijfsarts leek op meerdere plaatsen ingeburgerd. Vanuit zijn afgeleide status accepteert men de uitspraak van de bedrijfsarts, cok ten aanzien van niet strikt medische problemen. Ook wensen werknemers veel meer voorlichting van de BGD (welke rol kan en wil de BGD spelen); interesse in het bedrijf en de werknemers, zich uitend in regelmatig werkvloerbezoek; vaker periodiek onderzoek. Alleen door het hoger kader worden wat kanttekeningen gezet bij de combinatiefunctie bedrijfsarts-verzekeringsgeneeskundige (zie ook Hulshof et al. 1990).

\subsection{Protocollering in de BGZ}

\subsubsection{Inleiding}

Dienstverlening in de BGZ wordt gekenmerkt door een duidelijk spanningsveld tussen enerzijds de wensen en behoeften van de klant, en anderzijds de professionele normen en mogelijkheden. Protocollering van een aantal veel voorkomende BGZ-taken kan hierbij de functie hebben van houvast, van richtsnoer voor de BGD'en. Tevens biedt protocollering het voordeel dat een referentiekader wordt aangereikt waaraan de kwaliteit van zorg kan worden getoetst. Bovendien maakt het het ontastbare van een dienst meer tastbaar voor de klant. Een van de wegen waarlangs deze toetsing kan plaatsvinden is intercollegiale toetsing. Bovendien is protocollering van BGZ nodig om longitudinale gezondheidsbewaking van de werkende mens epidemiologisch verantwoord te maken. Een uniforme en in de tijd gezien constante wijze van gegevensverzameling en gezondheidsbewaking vormen de basis voor een preventief beleid met betrekking tot arbeidgerelateerde gezondheidsproblematiek.

In deze paragraaf wordt van de BGZ-kerntaken (aanstellingsonderzoek, periodiek onderzoek, spreekuur en werkplekonderzoek) een aantal aspecten beschreven, dat als bouwstenen zou kunnen dienst doen voor een aanzet tot protocollering. Ook wordt intercollegiale toetsing als instrument om kwaliteit te evalueren en te verbeteren belicht. 
Protocollering is dan op te vatten als het rationaliseren van de besluitvorming in de gezondheidszorg. Hierbij kunnen bepaalde technieken gebruikt worden, zoals besliskunde, "technology assessment", consensus-bijeenkomsten. Intercollegiale toetsing vormt als het ware de beroepsmatige plicht de kwaliteit van geleverde zorg regelmatig te evalueren en zonodig bij te stellen. Protocollering gaat dus vooraf aan intercollegiale toetsing.

$\mathrm{Na}$ in paragraaf 3.6.2 het theoretisch kader van protocollering en intercollegiale toetsing beschreven te hebben, wordt in paragraaf 3.6 .3 een poging gedaan om van een viertal BGZ-taken de kern-elementen te beschrijven.

\subsubsection{Begripsbepaling}

Vooraf aan het protocolleren van BGZ gaat het vaststellen van de doelstellingen van BGZ. Waarop richt de BGZ zich, welke doelen worden nagestreefd, welke resultaten willen BGD'en bereiken? Protocollen kunnen hierbij een functie hebben als wegwijzer.

Het woord protocol heeft betrekking op een zorgvuldige verslaglegging van bepaalde gebeurtenissen en activiteiten volgens vaste regels. Binnen de gezondheidszorg zou men onder een protocol kunnen verstaan het op papier vastleggen van de weg die leidt tot een optimaal zorgverleningsresultaat. Er wordt gebruik gemaakt van bepaalde methodieken (bijvoorbeeld beslisbomen), de criteria binnen het protocol komen tot stand op basis van (wetenschappelijk) onderzoek en hebben consensus binnen de beroepsgroep (Van der Heyde et al. 1983, Van Everdingen 1985, Van Everdingen et al. 1987, Roos 1983, Van der Meer 1988, Casparie en Van Everdingen 1989, Grol et al. 1990).

Protocollaire geneeskunde biedt perspectief ten aanzien van het bevorderen van de kwaliteit van zorg, omdat evaluatie van en communicatie over het zorgverleningsproces mogelijk wordt (Dunning 1984, Habbema 1988, Warndorff et al. 1988). Daarentegen bestaat echter ook de angst dat protocollering leidt tot verstarring van de zorgverlening ("kookboekgeneeskunde") (Vandenbroucke 1989).

Tot slot nog een kanttekening. Protocollaire geneeskunde gaat uit van de rationeel beslissende en opererende arts. Noch binnen de arts-patient relatie, noch binnen het krachtveld waarin de gezondheidszorg in het algemeen en de BGZ in het bijzonder zich bevindt, kan de arts hiermee uitsluitend uit de voeten. Philipsen (1979) is van mening dat het beoordelen door artsen beter verklaard kan worden met behulp van de speltheorie. Met wensen en strevingen van de patient, van de organisatie die zorg levert, dient bij het medisch handelen evenzeer rekening te worden gehouden. Pas als duidelijk is welk referentiepunt men als beroepsgroep kan en wil hanteren, is er plaats voor toetsing. Vanuit de professie gezien komt intercollegiale toetsing dan als belangrijk instrument naar voren, al zijn andere vormen van (externe) toetsing aanwezig (en noodzakelijk) binnen de BGZ, bijvoorbeeld door de Arbeidsinspectie en via de aangesloten bedrijven. De LVSG maakt intercollegiale toetsing in haar kwaliteitsplan tot een van de kempunten (LVSG 1989). 
Toetsing impliceert het bestaan van een referentiekader, vergelijkingsmateriaal. Binnen de gezondheidszorg komt men meestal nog niet verder dan het opstellen van richtlijnen, die in algemene termen aangeven hoe de zorgverlening er uit moet zien. Een criterium kan worden gedefinieerd als de operationele formulering van dat aspect van zorg (bijv. sterftecijfers) waarover een uitspraak ten aanzien van kwaliteit wenselijk wordt geacht (Casparie et al. 1989). Het begrip standaard heeft betrekking op de toelaatbare afwijking van een criterium (aan te duiden als een bereik met cen minimum en een maximum waarde). Het begrip "norm" kent een dubbele duiding, enerzijds als normatief begrip, anderzijds als beschrijvend begrip. In het woord norm zit zowel besloten "dat wat gebruikelijk is" als "dat waarnaar gestreefd zou moeten worden".

In de praktijk blijkt het vaststellen van criteria geen eenvoudige zaak. Technieken als protocollering, besliskunde en consensusbijeenkomsten worden hiervoor gebruikt.

Het Centraal Begeleidingsorgaan voor de Intercollegiale Toetsing (CBO) speelde en speelt nog steeds een belangrijke rol in dit kader, waarbij dit orgaan zijn ondersteuning langzamerhand ook ter beschikking stelt van de BGZ. Dit orgaan heeft een belangrijke bijdrage geleverd aan de zogenaamde consensusontwikkeling onder bercepsbeoefenaren. Doel hiervan is het naar elkaar toebrengen van diverse meningen binnen de medische professie, of, indien geen overeenstemming bereikt kan worden, het verduidelijken van die gebieden waarop de meningen uiteenlopen. Voor de individuele arts wordt dan (hopelijk) duidelijk aan welke criteria zijn werk zou moeten voldoen (Van Everdingen et al. 1985).

Specifiek probleem binnen de BGZ is dat het vaststellen van een referentiekader zich langs meerdere assen beweegt. Heeft men binnen de gezondheidszorg bij het primaire zorgverleningsproces in essentie uitsluitend met de patient te maken, binnen de BGZ komt hierbij nog de interactie met verschillende doelgroepen. Dit heeft als consequentie dat niet alleen het gewenste niveau met betrekking tot kennis en vaardigheden vastgesteld moet worden, maar dat dit kan variëren, afhankelijk van de doelgroep, het object waar men zich op richt.

Het evalueren van het eigen handelen is ook bedreigend. Evaluatie kan worden beschouwd als het zich bevinden op het kruispunt van kritisch terugblikken en planmatig vooruitzien. Dit vraagt om verandering en brengt spanning met zich mee (Brand 1974).

Onder intercollegiale toetsing kan men verstaan die activiteit waarbij de professie aan de hand van door haar zelf opgestelde en aanvaarde criteria de door haar geleverde zorg onderzoekt en beoordeelt, met als oogmerk het kwaliteitsniveau van de zorgverlening te verhogen. Het is een uitwisselingsproces van kennis en ervaringen tussen prefessionals, met het doel hiervan te leren en voor de kwaliteit van zorg ongunstig gedrag te veranderen. Het CBO hanteert hiervoor de zogenaamde nominaie groepsmethode. De professional wordt aangesproken op zijn professionele verantwoondelijkheid kwaliteit van zorg te leveren, en niet omdat dit vanuit de hiërarchische lijn opgelegd wordt. Dit heeft repercussies op de wijze waarop men vorm geeft aan intercollegiale toetsing binnen de organisatie. Om het toetsingspro- 
ces vorm en inhoud te kunnen geven, dient aan een aantal voorwaarden voldaan te worden. De zorg moet allereerst adequat geregistreerd worden (Kasdorp 1989, NRV 1986). Vervolgens dient een referentiekader ("norm") vastgesteld te worden (Grol en Mesker 1984, Meuwissen 1985). Eveneens moet er voldoende tijd en deskundigheid beschikbaar zijn. Tot slot is een toetsingsklimaat ("kaizen") van belang (Harteloh 1990b).

Het toetsingsproces is een circulair gebeuren: vaststellen van "normen" (wat wil ik bereiken?), het verzamelen van informatie over het eigen handelen (hoe doc ik het precies in de praktijk?), het vergelijken van het eigen handelen met de "norm", het bijstellen van het eigen handelen of eventueel van de norm etc.

(Na)scholing dient een integraal onderdeel van het toetsingsproces uit te maken. De meest doeltreffende methodiek hierbij, zowel met betrekking tot de inhoud als de te bereiken doelgroep, is nog niet uitgekristalliseerd (Grol en Schellevis 1986, Brandsma-Van der Laan 1985, Meuwissen 1985). Toepassing van intercollegiale toetsing in de geneeskunde vraagt vooraf een goede afweging van voor- en nadelen hiervan: wegen de kosten en de geïnvesteerde tijd op tegen (nog niet bewezen) baten voor de patient, verandert gedrag van de arts daadwerkelijk door deze "vrijwillige" kwaliteitsbewaking of zijn controle en sancties aangewezen middelen lacu. nes op te sporen en te verbeteren? (Grol 1987). Het onderzoek van Grol (1987) toont alvast aan dat wil onderlinge, groepsgewijze toetsing effect hebben ook methodologisch aan de nodige voorwaarden voldaan moet worden. Als belangrijkste winst van onderlinge toetsing zag hij dat artsen (weer) leren te leren.

\subsubsection{Kernelementen van enige BGZ-taken}

In deze subparagraaf worden van een viertal BGZ-taken kern-elementen beschreven, die de bouwstenen kunnen vormen voor de beschrijving van het ideaalbeeld (de "norm"). De beschrijving wordt beperkt tot de zogenaamde kerntaken: aanstellingsonderzoek (3.6.3.1.), spreekuur (3.6.3.2), periodiek onderzoek (3.6.3.3) en werkplekonderzoek (3.6.3.4).

De opbouw van deze subparagrafen is als volgt: eerst wordt in het kort de ontwikkeling geschetst in het denken over betrokken BGZ-taak. Dit illustreert de relativiteit en gebondenheid van "normen" aan de tijd(sgeest). Hierna vindt een begripsafbakening plaats. Vervolgens wordt vastgesteld welk(e) doel(en) men met de uitvoering van betrokken taak beoogt. Hiema komt de confrontatie met de praktijk: wat gebeurt er in de praktijk. Elke subparagraaf wordt afgesloten met enige concluderende opmerkingen.

Benadrukt moet worden dat ook het geheel conform de professionele standaard werken nog niet betekent dat de verleende zorg als kwaliteit ervaren wordt. Een professioneel verantwoorde taakuitvoering is slechts én instrument om antwoord te kunnen geven op een door klanten gevite vraag. Het is hiermee nog niet vanzelfsprekend dat dit een oplossing betekent voor de achter de vraag van de klant liggende problematiek. 


\subsubsection{Het aanstellingsonderzoek}

\section{Inleiding: een stukje geschiedenis}

De prijs voor eenvoud wat betreft aanstellingskeuringen gaat ongetwijfeld naar de manier waarop ooit in de Oost Chinese zeelui werden aangenomen. $\mathrm{Zij}$ moesten ten overstaan van een dokter over een touw springen. Ging dat goed dan konden ze worden aangemonsterd. $\mathrm{Ze}$ hadden dan namelijk bewezen dat ze een commando konden horen, het touw konden zien, en kracht genoeg hadden om te springen (Kuitenbrouwer 1988).

Men moet tot de negentiende eeuw wachten vooraleer met het oog op preventie meer nadrukkelijk aandacht wordt gevraagd voor de gezondheidstoestand van personen, voordat zij bepaald werk gaan verrichten. De industriēle revolutie met de vergrote vraag naar personeel dat enige tijd meekon en vrij van ziektekiemen was, heeft daarbij vermoedelijk een rol gespeeld (De Kort 1988b).

\section{Wat mag en moet bij een aanstellingsonderzoek?}

De huidige kritiek op de (on)mogelijkheden van het aanstellingsonderzoek is bepaald niet nieuw (zie Hulst 1953, Van Urk 1969, Sengers 1975, commissie Hessel 1972, Kamphuis 1982). Het aanstellingsonderzoek als selectiemiddel wordt niet mogelijk, maar ook maatschappelijk niet aanvaardbaar geacht (Van Wely 1972, Lappe 1983, De Wachter 1989).

Recent heeft de overheid haar standpunt bekend gemaakt, nadat een interdepartementale commissie hierover gerapporteerd had (NVAB 1989). We zijn hiermee weer terug op het moment dat in 1971 door Vellinga middels een motie aandacht wordt gevraagd voor de (zwakke) positie van de keurling bij het aanstellingsonderzoek, zij het dat de discussie nu op gang kwam naar aanleiding van het "verplicht stellen" van een Aids-test bij keuringen. Ook nu weer laat de overheid het aan het veld over een en ander zelf te regelen. Pas als het veld er niet uitkomt zal de overheid middels wettelijke maatregelen ingrijpen. Volgens Kuitenbrouwer (1988) wordt aan de in de Aanbeveling van de Stichting van de Arbeid (1982) vastgelegde rechten en plichten bij het aanstellingsonderzoek nog nauwelijks voldaan. In haar huidige advies pleit de overheid voor een terughoudend gebruik van het aanstellingsonderzoek, wijst zij op de relativiteit van dit onderzoek als selectie-instrument (zie ook Altink et al. 1989. De Kort 1988a, NVAB 1990b), dringt zij an op een versterking van de positie van de keurling, stelt zij dat informatie die verzameld wordt relevant dient te zijn voor de doelstelling, en stelt zij dat een eventuele pensioenkeuring niet van invloed dient te zijn op aanstelling in een nieuwe functie (NVAB 1989e, Hefting et al. 1987). Kortom de medische keuring mag geen routine zijn, maar moet maatwerk zijn. Zij sluit hier grotendeels aan bij adviezen dienaangaande, in 1978 uitgebracht door de Jong en Leuftink, en in 1980 overgenomen door de KNMG (KNMG 1980), recent nog geactualiseerd (KNMG 1989c), en conform het standpunt van de NVAB (NVAB 1989e, LOD 1990. Gevers 1988a/ 1988b). 


\section{Doel en nut van het aanstellingsonderzoek}

Het doel van het aanstellingsonderzoek moet zijn een medische beoordeling van de geschiktheid voor een gegeven functie zonder risico's voor de eigen gezondheid of die van anderen.

Door verschillende auteurs wordt gewezen op de beperkte waarde van de aanstellingskeuring als selectie-instrument (Lowenthal 1986, Bigos 1987, De Kort 1988b, Van Wely 1972). Het beperkte aantal mensen dat in de praktijk wordt afgekeurd of zich terugtrekt uit de procedure zou hiervan een uiting kunnen zijn. Van Wely (1972) acht keuren in zekere zin een testimonium paupertatis voor arbeidsomstandigheden: als deze goed zijn hoeven "normaal gezonden" niet te worden gekeurd.

De aanstellingskeuring kan binnen de BGZ echter andere dan selectie-functies hebben. Het wordt dan vaak het aanstellingsonderzoek genoemd. Het aanstellingsonderzoek kan een nuttig GVO-instrument zijn, of als startpunt van een longitudinale BGZ-begeleiding fungeren, waarbij uitgangswaarden c.q. vroegdiagnostiek een betekenis kunnen hebben in het kader van secundaire preventie (De Kort 1988b, Snook 1987, Schreurs 1989, LOD 1990).

\section{Het aanstellingsonderzoek in de praktijk}

De vorm en inhoud van het aanstellingsonderzock dienen afgestemd te zijn op de specifieke gezondheidseisen in de gevraagde functie. Er wordt maatwerk verwacht en gevraagd. Door de professie opgestelde richtlijnen kunnen hierbij een functic hebben.

Van Wely (1972) is van mening dat de klassieke aanstellingskeuring (vragenlijst, biometrie en lichamelijk onderzoek) vervangen kan worden door een screeningsmethode waarbij de arts aan de hand van door het paramedisch personeel verzamelde gegevens en door de sollicitant geleverde anamnestische gegevens beslist of hij de kandidaat wil onderzoeken of niet. De echte start van BGZ-begeleiding laat hij liever enige weken na indiensttreding beginnen: er zal dan meer vertrouwen zijn tussen werknemer en arts, en wederzijdse informatie zal beter mogelijk zijn.

Is er discussie over de vorm en inhoud van het aanstellingsonderzoek, door vrijwel alle bedrijfsartsen wordt het verrichten van een keuring voor vrijwel alle functies nuttig geacht, zij het als sluitstuk van de selectieprocedure (Kamphuis 1982). De overgrote meerderheid van de bedrijfsartsen acht zich hierbij in staat een redelijk betrouwbaar oordeel over de fysieke belastbaarheid te geven, zo'n $40 \%$ acht inschatting van de psychische belastbaarheid ook mogelijk. Bijna alle bedrijfsartsen vinden dat het belang van zowel bedrijf als sollicitant gediend moet worden; voor $90 \%$ echter lopen deze belangen niet parallel; voor ongeveer $20 \%$ stond het bedrijfsbelang voorop, vooral bij bedrijfsartsen met een verzekeringsgeneeskundige taak.

Bleek uit het onderzoek van Van Wely (1972) al dat artsen dezelfde keuringsgegevens sterk wisselend interpreteren, Blesgraaf et al. (1984) gingen in 1984 nog eens na in welke mate de bedrijfsarts uniform beslist bij aanstellingskeuringen die in de praktijk tot de uitslag beperkt geschikt, voorwaardelijk geschikt en niet geschikt 
leiden. Tevens werd onderzocht welke factoren van invloed zijn op het ontbreken van een uniforme beoordeling van keuringen. Hun conclusie was dat er duidelijk sprake is van een gebrek aan uniformiteit in keuringsbeslissingen. Welke factoren dit gebrek aan uniformiteit kunnen verklaren konden zij niet vaststellen. Gedacht kan worden aan verschil in doelstelling, keuringsrichtlijn, attitude van de keurend arts.

Onderzoek van Lourijsen et al. (1989 en 1991) bevestigen dit gebrek aan uniformiteit. $\mathrm{Zij}$ stuitten echter ook nog op cen verschillend omgaan met medische gegevens door de keurende artsen. Zo blijkt eenderde van de bedrijven bij de uitslag soms aanvullende informatie te krijgen waarin een oordeel wordt gegeven over de psychische gesteldheid van de keurling; 7\% van de bedrijven zegt af en toe zelfs inzage te krijgen in het keuringsrapport, 3\% zegt dit altijd te krijgen. Ruim een kwart van de artsen zegt zelf in de keuringsuitslag wel eens een uitspraak te doen over de psychische gesteldheid van een kandidaat.

Gegeven deze "willekeur" bij de beoordeling van en het omgaan met keuringsgegevens wordt het belang van een adequate "herkeuringsprocedure" des te belangrijker (Van der Leun 1981). Vrijwel alle bedrijfsartsen stemmen in met het aanbieden van een herkeuringsmogelijkheid (Kamphuis 1982).

\section{Concluderende opmerlingen}

De aanstellingskeuring als instrument om medische selectie toe te passen wordt op inhoudelijke en maatschappelijke gronden steeds meer ter discussie gesteld. De beoordeling in de praktijk blijkt weinig uniform. De roep om bescherming van de keurling wordt groter. De aanstellingskeuring benutten als startpunt van bedrijfsgezondheidkundige begeleiding biedt meer perspectief.

De naam aanstellingskeuring wordt in dat geval vaak vervangen door de term aanstellingsonderzoek.

\subsubsection{Het spreekuur}

\section{Inleiding}

Het bedrijfsgezondheidkundig spreekuur wordt beschouwd als de motor van het BGZ-handelen. Leyssen (1972) stelt dat het bedrijfsgezondheidkundig spreekuur mede als stethoscoop op het totale bedrijfsgebeuren dient. Het is hét moment bij uitstek om klachten, ziekten die een (vermoed) verband hebben met het werk of de werkomstandigheden te signaleren en dienaangaande te adviseren. Enigszins gekunsteld wordt wel eens onderscheid gemaakt tussen het bedrijfsgezondheidkundig spreekuur in engere zin, en het verzuimspreekuur. Doeltreffender is de suggestie van de LOD (LOD 1990) in dezen, die verschillende doelgroepen voor spreekuurbegeleiding onderscheidt.

Welke activiteiten vallen onder het begrip "spreekuur"?

De LOD (1990) formuleert, op voorstel van een daartoe ingestelde werkgroep, het bedrijfsgezondheidkundig spreekuur ruim. De scheiding tussen bedrijfsgezondheid- 
kundige activiteiten in engere zin en verzuimbegeleiding is vaak gekunsteld en wordt door de klant veelal niet onderkend. Men komt tot de term "begeleiding van ziekte"; waarbij onderscheid wordt gemaakt in cen vijftal doelgroepen (zie verder). Recente ontwikkelingen ten aanzien van de sociaal-medische begeleiding (Najaarsoverleg 1990) geven aan de BGZ een meer indringende taak bij de begeleiding van zieke werknemers ook al gedurende de eerste zes weken van het verzuim.

Bedrijfsartsen houden zich, in tegenstelling tot de curatieve collegae, meer bezig met de "niet zieke", althans de niet-arbeidsongeschikte mensen. Bedrijfsartsen worden hierdoor meer gestuurd vanuit het gezondheidkundig denken dan vanuit het ziektekundig denken. Leyssen (1972) acht de term bedrijfsgezondheidkundig spreekuur dan ook passender dan bedrijfsgeneeskundig spreekuur.

In hoofdstuk 2 werd reeds gesproken over de strijd die om "de zieke" ontbrand is. Zowel vanuit de hoek van de bedrijfsverenigingen (verzekeringsgeneeskundigen), als uit de hoek van de BGD'en (bedrijfsartsen) wordt een claim gelegd op de begeleiding van de zieke werknemer, op de zgn. sociaal-medische begeleiding. Maar wat wordt nu eigenlijk onder sociaal-medische begeleiding verstaan?

Maasen (1985) onderscheidt de volgende betekenissen van sociaal-medische begeleiding (SMB):

a. legitimatie van arbeids(on)geschiktheid en vaststelling van de vermoedelijke verzuimduur;

b. controle op het bestaan van arbeids(on)geschiktheid;

c. behandeling, doorgaans door de curatieve sector;

d. begeleiding tijdens de ziekteperiode, vooral gericht op werkhervatting;

e. revalidatie (rehabilitatie, reintegratie in het arbeidsproces) waarin behandeling, begeleiding, omscholing, arbeidsbemiddeling e.d. allemaal een rol spelen;

f. vaststelling van de mate van blijvende arbeids(on)geschiktheid ten behoeve van de verzekeringsorganen.

In het onderzoek is gekozen voor de definitie van de NVAB (NVAB 1989f), die luidt: "SMB is het geheel van activiteiten van medici of andere hulpverleners die door de werknemer gevraagd of voor hem nodig geacht worden en die gericht zijn op herstel, behoud of bevorderen van gezondheid en maatschappelijk evenwicht en die in beginsel gericht zijn op werkhervatting".

Kortom, sociaal medische begeleiding dient zich te richten op het behoud van functioneren en het bieden van een zo goed mogelijke compensatie w/aar dat niet langer haalbaar blijkt (Knepper 1990a/1990b/1990c). Sociaal-medische begeleiding dient zich sterker te gaan richten op het voorkómen van medicaliseringsprocessen en het bevorderen van gedragsverandering (Kuiper 1982). Veelvuldig blijkt er sprake van definiēringsproblemen: wat is ziekte, wat is arbeidsongeschiktheid (GMD 1984, Hunfeld 1984)? Vanuit verschillende invalshoeken wordt het belang van een meersporenbeleid (gericht op de verzuimer, de bedrijven en de organisatie van de sociale zekerheid) onderstreept, al is het effect van de diverse gesuggereerde oplossingen veelal nog niet bewezen (Prins 1990). 
Door meerdere bedrijfsartsen wordt gepleit voor een institutionalisering van de samenwerkingsverbanden binnen het bedrijf tussen BGD, personeelszaken en eventucel anderen in een zogenaamd sociaal medisch team (Van Oosterom 1980, Plomp 1987c).

Welke voor- en nadelen zijn er nu verbonden aan het uitvoeren van Ziektewetcontroles door de bedrijfsarts? Als belangrijkste nadeel wordt gezien dat de vertrouwensrelatie tussen bedrijfsarts en patient hierdoor wordt geschaad (Wolvetang 1978, NVAB 1981, Bedrijfsgeneeskundige dagen 1990, Tijhuis 1984). Case-studies bevestigen dit niet (Bleeksma 1986, Van Wijngaarden 1979, Ekker 1976, Ruinen 1985a). Als belangrijkste voordeel wordt gezien een vereenvoudiging in de verzuimbegeleiding en door het snellere contact betere mogelijkheden voor reīntegratie en informatievoorziening (Buijs 1990, Van Dijk 1990). Werkgeversorganisaties pleiten voor een actieve verzuimbegeleiding door BGD'en in het eerste Ziektewettraject (Najaarsoverleg 1990).

Ekker (1976) wijst erop dat bij de discussie over verzuimbegeleiding versus ziektecontrole, de patient zelf, de verzuimer zelf zelden gevraagd wordt wat hij ervan vindt. In zijn onderzoek geeft bijna de helft aan dat bij verzuimbegeleiding, welke uitgaat van algemeen vertrouwen, hiervan misbruik zal worden gemaakt. Het gecombineerd uitvoeren van een bedrijfsarts/verzekeringsgeneeskundige taak door de BGD maakt voor tweederde niets uit, voor een kwart geeft dit zelfs meer vertrouwen! Bij het door de onderzoeker onderzochte bedrijf betekende het overgaan van een ziektecontrole systeem naar verzuimbegeleiding voor bijna de helft een verbetering, iets meer dan $20 \%$ vond het een achteruitgang.

\section{Doelstellingen van het spreekuur}

Kuiper (1983) onderscheidt vier kernfuncties van het spreekuur:

1. gezondheidseducatieve interventie (het bevorderen van protoprofessionalisering van het begeleide individu);

2. situationele interventie, bijv, arbeidshygiënische adviezen;

3. relationele interventie, gericht op het trachten te herstellen van de relatie mens-arbeid;

4. structurele interventie, vrijwel gelijk aan behandelen (zoals in de curatieve sector).

Deze zogenaamde professionele zorg dient complementair te zijn aan zelfzorg en mantelzorg van de cliënt (Maassen 1986).

Hier wordt vaak als aparte activiteit nog aan toegevoegd het door middel van systematische registratie van spreekuurgegevens inzicht verkrijgen in de gezondheid van populaties werknemers en in factoren en omstandigheden in de werksituatie die daarop van invloed zijn.

Leyssen (1972) onderscheidt doelen van het spreekuur op microniveau (individuele begeleiding), meso- (groep/afdeling) en macroniveau (regionaal of bedrijfstakniveau). 
De LOD (1990) onderscheidt de volgende vijf doelgroepen voor "spreekuur-begeleiding":
a. De op het werk acuut zieken of gewonden. Deze groep vergt beheersing van periodieke instructie in levensreddend handelen.
b. De langdurig zieke of gehandicapt werkenden. Deze groep vraagt om perma- nente belastbaarheidsbewaking. se en advisering met betrekking tot de validiteit van aangegeven oorzaken en gevolgen.
c. De frequent kort verzuimenden met ziekte als reden. Deze groep vergt analy-

d. De langdurig zieke, niet-werkenden. Deze groep vergt begeleiding op weg naar reintegratie (WAGW) resp. WAO/AAW/IP (=invaliditeitspensioen).

c. Personen met (vermoede) beroepsziekten.

Als de plannen van de overheid (Najaarsoverleg 1990) doorgaan, zal hierbij een sociaal-medische begeleiding-rol komen ook voor BGD'en die tot dusver geen taak hebben in het vaststellen van de arbeidsongeschiktheid. BGD'en zullen hierbij gedurende het eerste traject van de arbeidsongeschiktheid (zes weken) een cerstelijnsfunctie vervullen inzake "verzekeringsgeneeskundige" begeleiding. De beroepsgroep, bij monde van de NVAB (1990d) gaat dit appell van overheid/werkgevers en werknemers niet uit de weg. $\mathrm{Zij} \mathrm{komt} \mathrm{met} \mathrm{een} \mathrm{voorstel} \mathrm{hoe} \mathrm{betrokken} \mathrm{plannen} \mathrm{ade-}$ quaat georganiseerd en gestructureerd zouden kunnen worden.

Naast de begeleiding van (zieke) werknemers, kan middels het spreekuur informatie verkregen worden over mogelijk arbeid-gebonden problematiek. Van Bemmel en Van der Lei (1988) duiden erop dat naast deze "wetenschappelijke kennis" (zij noemen dit "know-why") empirische kennis, dat wil zeggen ervaring die opgedaan wordt in de praktijk (zij noemen dit "know-how") een belangrijke kennisbron vormt.

Van belang is niet alleen hoe, maar vooral ook wat men registreert. Pas als men het doel van registratie heeft vastgesteld (Gelderman 1990), is een uitwerking van de wijze van registratie zinvol (Grootendorst 1980, Ten Hoopen 1979).

Het nut van adequate registratie van spreekuurgegevens als signaleringssysteem en voorspeller van eventuele arbeidsongeschiktheid op termijn, wordt aangegeven door van Til (1982) en de Winter (1983). Van Til deed een analyse van systematisch geregistreerde gegevens van het bedrijfsgezondheidkundig spreekuur. De variatie aan problemen is groot. Leyssen (1972) werkt in zijn proefschrift een registratiesysteem uit, getoetst in de praktijk. Bruins-Slot (1984), Dijkstra et al. (1978) houden een pleidooi voor de toepassing van de ICHPPC-2 codering, omdat deze codering betere registratie-mogelijkheden geeft voor klachten.

Aan een adequate registratie gaat nogal wat vooraf (Dijkstra et al. 1978, Putten en Oversloot 1984). Inhoudelijk moet worden vastgesteld welke gegevens voor registratie in aanmerking komen, er moeten voorschriften gegeven worden over de wijze waarop die gegevens worden verzameld, opgeslagen en verwerkt; en er dient aantekening te worden gehouden van het registratieproces zelf in verband met het 
longitudinale karakter van het te vormen gegevensbestand. Bovendien moet koppeling tussen gezondheidsgegevens en gegevens over de (werk)belasting mogelijk zijn. Automatisering van de gegevensverwerking wordt hierbij vrijwel onvermijdelijk (Gelderman 1990, Petit en Van den Heuvel 1990). Uitdrukkelijk zal rekening gehouden moeten worden met inzagerecht, de Wet op de behandelingsovereenkomst en de Wet persoonsregistraties (Doppegieter 1989 en 1990, Kastelein 1989).

\section{Het spreekuur in de praktijk}

ledere werknemer moet vrij zijn het spreekuur te bezoeken. Overigens, zo blijkt uit het onderzoek van Plomp (1987a), leidt een ruime en laagdrempelige mogelijkheid om de bedrijfsarts te consulteren niet tot een toename in het consulteren van de BGD in verband met werkgerelateerde problemen. Werknemers die spontaan het spreekuur bezoeken blijken dit in de meerderheid van de gevallen te doen vanwege een ongeval of licht somatische aandoeningen. Volgens onderzoek van Van den Heuvel en Jenniskens (1974) en Leyssen (1972) zou zo'n 12\% van de werknemers het spreekuur bezoeken met werk-gerelateerde problemen. Werknemers daarentegen zien zelf veel vaker een verband tussen hun klachten en het werk! Vaak zal de client zijn klacht in eerste instantie "medisch" op tafel leggen. Aan de bedrijfsarts de taak te trachten de feitelijke problematiek boven water te krijgen, die in meer of mindere mate bedreigend kan zijn voor het bedrijf enerzijds, en de betrokken werknemer ook zelf anderzijds.

Door verschillende onderzoekers is getracht een evaluatie te maken van het spreekuur: welke mensen bezoeken het spreekuur, hoe ervaren ze dit BGZ-element, welke zaken worden aan de orde gesteld (De Haas 1980, Plomp 1987a, Baars 1984, Leyssen 1972)? Leyssen (1972) hield een onderzoek in een spreekuur-configuratie, waarin een zeer forse preselectie plaatsvond door de bedrijfsverpleegkundige. Aan de $15 \%$ mensen die het spreekuur van de bedrijfsarts bezoeken, besteedt de bedrijfsarts 1/8 direct en 1/8 indirect van zijn totaal beschikbare tijd. Afhankelijk van de definities komt hij tot de bevinding dat van nieuwe consulten $1 / 4$ tot $1 / 3$ een specifiek bedrijfsgeneeskundige stimulus aandraagt. Plomp (1987a) komt tot vergelijkbare, lage, aantallen werkgerelateerde klachten. Vooral spontaan spreekuurbezoek vindt bijna altijd plaats vanwege een ongeval of licht somatische aandoeningen. De tevredenheid over het spreekuur bij werknemers is aldus Plomp meer gerelateerd aan de verwachtingen die de werknemers hebben bij het consulteren dan aan het handelen van of de persoon van de bedrijfsarts zelf. Gemalkkelijker doet de bedrijfsarts het goed bij de behandeling van "minor ailments", dan bij de begeleiding van patienten met chronische aandoeningen, of het plegen van bedrijfsgeneeskundige interventies. Ronduit ontevreden zijn de mensen die worden opgeroepen met als reden "verzuim".

Uit onderzoek van Ruinen (1985a) en De Haas (1980) in een "gemeentelijke setting" blijkt het grootste deel van het spreekuurbezoek te bestaan uit "verzuimers". Driekwart van de ondervraagden (Ruinen 1985a) achtte de bedrijfsarts voldoende op de hoogte van de arbeidsomstandigheden, al geeft tweederde aan de bedrijfsarts 
de voorafgaande twee jaren nooit op de werkplek gezien te hebten. Er bleek vooral een behoefte te bestaan aan GVO, niet zozeer bedrijfsgezondheidkundig gericht, maar veel meer in algemene gezondheidkundige zin.

Baars (1984) deed onderzoek bij een verzekeringsmaatschappij. Uit dit onderzoek komt naar voren dat mensen die daadwerkelijk "spreekuur-ervaring" hebben positiever cordelen over de BGD. Ook uit dit onderzoek komt naar voren dat de BGD voor werknemers niet het eerste aanspreekpunt is voor werkgerelateerde problemen. Afdelingschef en huisarts gaan de bedrijfsarts voor, ondanks dat men in meerderheid best vertrouwen heeft in (de invloed van) de bedrijfsarts. Al met al toonde $80 \%$ zich tevreden over het spreekuur.

Volgens Thunisse (1991) is meer training in consultvoering vereist.

\section{Concluderende opmerkingen}

Onder de BGZ-taak "spreekuur" kunnen vele BGZ-activiteiten gecategoriseerd worden. Een meer geprononceerde rol van de BGD bij de begeleiding van de zieke werknemer wordt door verschillende redenen ingegeven. Een meer systematische aanpak van het spreekuur en een gestandaardiseerde registratie van gegevens kunnen mogelijk een betere basis vormen voor informatie over werkgebonden (ziekte). problemen.

\subsubsection{Het periodiek onderzoek}

\section{Inleiding}

Periodiek gezondheidsonderzoek van mensen is geen nieuw verschijnsel. Reeds in 1861 uit Dobell de veronderstelling dat periodiek gezondheidsonderzoek van mensen die op het eerste gezicht gezond zijn, de morbiditeit en mortaliteit van die groep gunstig zou kunnen beïnloeden door het opsporen van ziekten in een preklinisch stadium (Broersen et al. 1989, Koopman 1982). Onderzoek in de BGZ betreffende TBC (Burger) en ischemische hartziekten (COPIH) speelt in op een preventieve taak ten aanzien van veel, ook en vooral onder de beroepsbevolking, voorkomende ziekten. Dergelijke onderzoeken blijken zeker vruchten af te werpen, maar uiteindelijk betreft het een vorm van secundaire preventie, het voorkómen van erger (Van der Hoeven 1971). Ook is dergelijk onderzoek niet primair gericht op de relatie werk-gezondheid. Echter, het COPIH-onderzoek bewijst dat het mogelijk is een zeer gevarieerde beroepspopulatie op gestandaardiseerde wijze periodiek te onderzoeken, in dit geval op de aanwezigheid van risicofactoren voor hart- en vaatziekten (Broersen et al. 1989), en interventie te plegen. Deze ervaring heeft de weg geplaveid voor de ontwikkeling en toepassing van andere gestandaardiseerde methodieken, ook die van typisch bedrijfsgezondheidkundige aard.

Jongh werpt in 1957 al een kritisch licht op het fenomeen periodieke keuring als hij stelt: "Reeds het feit dat men bij een keuring zich begeeft zonder verzoek van de keurling in de lichamelijke, maar ook zelfs de geestelijke problemen waarmede elk mens te worstelen heeft, schept een problematiek, die waard is om overdacht te worden". Een andere belangrijke vraag voor hem is tevens wat er met de bevindin- 
gen van het periodiek onderzoek gedaan moet worden, op individueel niveau en groepsniveau. Vraagtekens dus ten aanzien van de ethiek van het periodiek gezondheidsonderzoek en de consequenties voor de onderzochte.

\section{Het perlodiek onderzoek: begrippen}

De afgelopen decennia worden gekenmerkt door de nodige begripsverwarting op dit gebied. Aanvankelijk ontbreekt zelfs die vorm van periodiek onderzoek die, op groepsniveau, een duidelijke relatie met werk(omstandigheden) legt (NVAB 1979), en die door meerdere bedrijfsartsen als essentieel wordt beschouwd (Wolvetang 1980, Wulms 1982, Koopman 1982, Parkinson en Grennan 1986, Hulshof et al. 1990).

Grosso modo worden de volgende vormen van periodiek onderzoek, die binnen de BGZ uitgevoerd (kunnen) worden, onderscheiden: onderzoek gericht op:

1. blootstellingen in arbeidssituaties ("medical surveillance" resp. "biological monitoring");

2. veiligheidsaspecten samenhangend met de functie (o.a. chauffeurs);

3. de leeftijd (o.a. ouderen of jeugdigen);

4. "volksziekten" (algemeen periodiek onderzoek=APO);

5. de "algemene gezondheidstoestand" (bevolkingsonderzoek in arbeidspopulaties);

6. de gezondheid en werk(omstandigheden) van een groep werknemers (periodiek bedrijfsgezondheidkundig onderzoek).

Onderzoeken, genoemd onder 1 en 2 , zijn vormen van gericht periodiek onderzoek).

\section{Doelstellingen periodiek onderzoek}

Met name in het buitenland (V.S.) zijn meerdere pogingen gedaan de baten van het periodiek onderzoek in kaart te brengen. Naast het nut in termen van het voorkomen van gezondheidsschade, worden economische voordelen berekend. De VSspecifieke situatie (bijvoorbeeld de organisatie van de BGZ en de sociale verzekeringswetgeving) maakt een vergelijking met ons land moeilijk (Millar 1986, Halperin et al. 1986, Wittgens 1986, Hessel en Zeiss 1988, Jacobs 1980). Op eventuele medicaliseringseffecten van het periodiek onderzoek kan gewezen worden. Theoretisch lijkt de werkplek wel een gunstige plek om gezondheidsinterventie te plegen. Immers, men heeft de beschikking over een laagdrempelige voorziening, gericht op een wel omschreven en goed bereikbare groep mensen met een zeker risico, en goede "voorzieningen" en support (Warner et al. 1988).

Het geven van GVO tijdens en naar aanleiding van het periodiek onderzock lijkt een gunstig moment (Fielding 1988, Van der Slikke 1982), doch wil dit doeltreffend zijn, dan zitten er heel wat haken en ogen aan (Dickerson 1983).

Los van de discussie of en hoe periodiek onderzoek effectief en efficiēnt uitgevoerd kan worden, blijft de vraag of niet andere BGZ-taken meer geschikt zijn om de doelen van de BGZ te bereiken (Broersen et al. 1989, Docter 1988, Van Hees 1988 en 1989). 
Door de LOD wordt de volgende begripsbepaling van de doelstellingen van periodiek onderzoek voorgesteld (LOD 1990):

A. doelen gericht op het individu: individueel advies ten aanzien van gezondheid en werk;

B. doelen gericht op groep c.q. organisatie: informatie verzamelen c.q. adviseren ten aanzien van functic- en afdelingsgerichte problematiek in het belastingbelastbaarheidsevenwicht;

C. doelen gericht op wetenschap: het vormen van groepsgegevens i.v.m. epidemiologisch onderzoek. Gepleit wordt om periodiek onderzoek cok te richten op onderzoek naar leefgewoonten; dit zou ook meer bij de praktijk aansluiten.

Mede afhankelijk van de doelstelling(en) die men tracht te bereiken door periodiek onderzoek, wordt aan de uitvoering van het periodiek onderzoek een aantal randvoorwaarden gesteld. Allereerst kan een aantal voorwaarden geformuleerd worden die met name procedureel en organisatorisch van aard zijn (NVAB 1979). Het betreft zaken als de samenhang van het periodiek onderzoek met de doelstelling van BGZ, met overige BGZ-activiteiten, met het totale bedrijfsbeleid en met het gezondheidszorgsysteem. Daarnaast zijn er echter voorwaarden die meer inhoudelijk van aard zijn. Een groot probleem is immers dat werkgebonden ziekten het resultaat zijn van een samenspel van factoren waaronder individuele gevoeligheid, omgevingsfactoren en individueel gedrag. Onderzoek ter bewaking van werkgebonden ziekten dient dan ook gericht te zijn op zowel het identificeren van "gevoelige" personen ("screening") als schadelijke expositieniveaus ("monitoring"), als het stimuleren van veilig en gezond werken, en het evalueren van maatregelen. (Schilling 1986, Miller 1986).

Referentiegegevens zijn nodig om te kunnen signaleren of testresultaten "afwijkend" zijn. Broersen et al. (1989) stellen in dit kader voor twee referentiegroepen te hanteren: de eerste referentiegroep wordt gevormd door de eigen bedrijfstak (hiermee komt men vooral voor het onderzochte bedrijf specifieke signalen op het spoor), een tweede referentiegroep wordt gevormd door de totale populatie van alle werknemers zoals die uit andere onderzoeken bij andere bedrijven verzameld is (hiermee komt men vooral bedrijfstakgebonden signalen op het spoor). Vervolgens is er een aantal voorwaarden dat methodologisch van aard is (Durinck en Munnik 1978). Ook voor periodiek onderzoek gelden de aanbevelingen zoals die gesteld worden aan "screening", zoals die door Junger en Wilson al in 1968 voor "screening" in het algemeen werden geformuleerd, zoals sensitiviteit, specificiteit, validiteit van de test (Halperin et al. 1986, Griner en Glaser 1982, Van Geen 1983).

Tot slot kunnen wettelijke bepalingen als voorwaarden gelden om een periodiek onderzoek in te stellen (bijvoorbeeld in artikel 25 Arbowet, bepalingen in bijzonde$\mathrm{re}$ arbeidswetten, zoals de Kernenergiewet, of bepalingen in andere wetten zoals Wet autovervoer personen. 


\section{Het periodiek onderzoek in de praktijk}

De vraag of bedrijfsartsen het verrichten van periodieke onderzoeken een nuttig en prettig onderdeel van hun takenpakket vinden, is reeds lang onderwerp van discussie. Reeds de nestor van de BGZ, Burger, vraagt zich af of periodiek gezondheidsonderzoek voldoende interessant onderzoek is om een bedrijfsarts te boeien. Gericht periodiek onderzoek wordt door de meeste bedrijfsartsen wel als nuttig en zinvol ervaren (Koopman 1982).

Aan het periodiek onderzoek wordt, volgens een onderzoek van Verhoef (1978), door de bedrijfsarts gemiddeld bijna 7 uur per week besteed, waarbij de modus ligt bij 4 uur en een grote spreiding opvalt. Voor- en nadelen werden in dit onderzoek ook op een rijtje gezet. Als belangrijkste nadelen onderkent men het geven van een vals gevoel van veiligheid aan de onderzochten en de tijdrovendheid van het onderzoek. Het belangrijkste voordeel zou gelegen zijn in het opsporen van en kunnen adviseren aangaande belastings- en belastbaarheidsaspecten. Ruim de helft van de BGD'en maakt geen afspraken met de ondernemingen aangaande het periodiek onderzoek. Als dit wel het geval is betreft het afspraken over de frequentie van onderzoek en de leeftijd van de te onderzoeken populatie.

Bij een onderzoek onder 512 bedrijfsartsen blijkt dat $90 \%$ met hun periodiek onderzoek voldoende inzicht verkrijgt over de fysieke belastbaarheid van de onderzochte (Koopman 1982). Met betrekking tot de mentale draagkracht is $44 \%$ deze mening toegedaan, met name jongere bedrijfsartsen zetten hier vraagtekens. Bijna tweederde van de bedrijfsartsen blijkt het periodiek gezondheidsonderzoek te evalueren, al wordt niet aangegeven hoe dit eruit ziet. Al met al ziet driekwart van de onderzochten wel nut in het periodiek gezondheidsonderzoek.

De uitvoering van het periodiek gezondheidsonderzoek in de BGZ vindt niet gestandaardiseerd plaats (Van Putten en Oversloot 1986, Van Putten et al. 1988, Winter et al. 1988, Marcelissen et al. 1988). Uit hun onderzoek blijken er grote verschillen in de opzet van het periodiek gezondheidsonderzoek tussen diensten. Zo zijn er diensten die alle werknemers oproepen en diensten die alleen oudere werknemers oproepen. Het gebruik van standaard-formulieren zegt daarbij niet zoveel: het kan betekenen dat er een individu-gericht APO, dan wel een meer groepsgericht periodiek bedrijfsgezondheidkundig onderzoek, dan wel een tussenvorm wordt vitgevoerd. De auteurs adviseren om de term periodiek bedrijfsgezondheidkundig onderzoek te reserveren voor díe vormen van periodiek gezondheidsonderzoek waarvoor alle werknemers bedrijfs- of afdelingsgewijs worden opgeroepen, en waarbij de gegevens van individuele werknemers tot groepsniveau worden geaggregeerd, en waarbij deze gegevens vervolgens worden beoordeeld in samenhang met de eveneens verzamelde gegevens over werk en werkomstandigheden van dezelfde groep. Van de Gulden en Senden (1990) pleiten voor de ontwikkeling van "submodulen", vragenlijsten specifiek gericht op en ontwikkeld binnen bepaalde branches.

Veelvuldig wordt door de beroepsgroep opgemerkt dat het algemeen periodiek onderzoek (APO) niet thuis hoort binnen de BGZ. Werknemers blijken deze me- 
ning echter niet altijd te delen (Krijgsman 1980): bijna een ieder beschouwt het periodiek gezondheidsonderzoek, ook als dat alleen gericht is op het onderzoeken van de algemene gezondheidstoestand, als een regelmatige "controle", ruim de helft beschouwt een gunstige uitslag een garantie voor een goede gezondheid, en mocht de BGD eventueel besluiten het ECG weg te laten, dan zou de helft van de deelnemers afhaken! (zie ook Griffioen en Van Oosten 1991). Door krap de helft wordt het periodiek onderzoek als een goede gelegenheid beschouwd om bepaalde problemen in het werk te bespreken. De tevredenheid over het periodiek onderzoek bij werknemers blijkt uit de verslagen van de BgBouw. $85 \%$ van de werknemers boven de 35 jaar geeft gehoor aan een uitnodiging voor periodiek onderzoek, en $90 \%$ is de mening toegedaan dat periodiek onderzoek een zinvolle zaak is jaarverslag Arbouw 1989).

Ook Hulshof et al. (1990) onderzochten de ervaringen van deelnemers aan het periodiek bedrijfsgezondheidkundig onderzoek. Van de deelnemers is $77 \%$ tevreden met het periodiek bedrijfsgezondheidkundig onderzoek als geheel, en vindt $94 \%$ herhaling zinvol. De voorlichting over het periodiek bedrijfsgezondheidkundig onderzoek wordt als onvoldoende ervaren. Vooral de werknemers zijn onvoldoende geïnformeerd over de inhoud van het opgestelde verslag naar aanleiding van de periodieke bedrijfsgezondheidkundige onderzoeken. Slechts $20 \%$ bespeurt een daadwerkelijke verbetering van de arbeidssituatie naar aanleiding van het periodiek bedrijfsgezondheidkundig onderzoek. De auteurs doen de aanbeveling conclusies en aanbevelingen van het periodiek bedrijfsgezondheidkundig onderzoek beter te vertalen in beleidssuggesties voor het bedrijf, en zorg te dragen voor een adequate follow-up.

Ook werd door genoemde auteurs de prioriteitsscore bij de ontvangers van zorg betreffende BGD-activiteiten onderzocht. Het individu-gerichte periodiek gezondheidsonderzoek voor werknemers ouder dan 50 jaar wordt door alle functiegroepen als het meest belangrijke gezien.

\section{Concluderende opmerkingen}

Het periodiek onderzoek wordt door werknemers als een waardevolle zaak gezien. Binnen de BGZ heeft men nog geen opinio communis bereikt over de meest wenselijke vorm en inhoud van het periodiek onderzoek.

\subsubsection{Het werkplekonderzoek}

\section{Inleiding}

Bij een beschrijving van de geschiedenis van de ontwikkelingen binnen de BGZ over het werkplekonderzoek, hoort een toelichting op het zogenaamde Model Bedrijfsgezondheidszorg. Het Model BGZ (Jenniskens 1982), een initiatief van de werkgroep directeuren van gezamenlijke BGD'en, had een drieledig doel c.q. faseopbouw:

a. Het ontwikkelen van gestandaardiseerde instrumenten om werkzaamheden binnen de BGZ te kunnen meten en evalueren. 
b. Het onderzoeken van transversale relaties tussen de verschillende elementen uit het model.

c. Het bestuderen van longitudinale relaties met behulp van het model.

De eerste fase resulteerde o.a. in de ontwikkeling van een aantal instrumenten ten behoeve van bijvoorbeeld een zogenaamd groepsergogram (een gestructureerde, gestandaardiseerde registratie van een aantal belastende factoren in de taak en taakomgeving van een functionele groep). De ervaringen uit de eerste fase van het Model BGZ zijn nimmer samengevoegd in een eindrapport. Door het NIPG is wel een evaluatieonderzoek ingesteld, getiteld "Naar een signaleringssysteem in de BGZ", welk concludeerde dat de ontwikkelde instrumenten voor het merendeel de toets der kritiek (nog) niet konden doorstaan. De aanpak werd als te ambitieus geschetst. Mogelijk dat bij voortschrijdende automatisering de mogelijkheid om grote databestanden op toegankelijke wijze op te bouwen binnen handbereik van meer BGD'en komen (Baidjoe 1983).

\section{Doelstellingen werkplekonderzoek}

In globale termen omschreven is het doel van werkplekonderzoek het in kaart brengen, objectiveren en registreren van belastende factoren in de werkomgeving. Op basis van deze gegevens kan individueel en groepsgericht, curatief en preventief advisering plaatsvinden over werkgerelateerde gezondheidsproblematiek.

Geattendeerd kan worden op artikel 9 van de Arbowet, waarin het melden van (vermoede) beroepsziekten verplicht is gesteld (Willems 1985, 1988). Veel meer dan tot dusver het geval is zouden BGD'en middels registratie hiervan een instrument in handen hebben om tot een planmatige en beleidsmatige aanpak van voor het bedrijf relevante BGZ-problemen te komen. Naast kennis van ziektebeelden, is een optimale kennis van de werkplek in dezen natuurlijk onontbeerlijk.

Slechts $18 \%$ van de bedrijfsartsen gaf aan in een enquête van Willems (1988), dat binnen hun dienst geconstateerde beroepsziekten zodanig worden opgeslagen dat zij "groepsgewijs" samengesteld kunnen worden, terwijl bijna 75\% aangeeft regelmatig met beroepsziekten te worden geconfronteerd.

Uit de literatuur blijkt een toenemende behoefte te bestaan aan een systematische en meer betrouwbare aanpak van het onderzoek naar de gezondheidsbedreigende factoren in de werkomgeving (Oostendorp et al. 1987, Zielhuis et al. 1984, Sturmans et al. 1982). Hierbij is in veel gevallen de nevendoelstelling te komen tot een betere registratie van valide blootstellingsgegevens, zodat de mogelijkheden voor epidemiologisch onderzoek vergroot en verbeterd worden. Veelal ligt hierbij overigens de nadruk op registratie van gegevens over de blootstelling aan chemische stoffen. Sturnnans et al. (1982) pleiten ervoor beleidsonderbouwend epidemiologisch onderzoek van (onbekende) gezondheidsbedreigende factoren in het arbeidsmilieu in te passen binnen de BGZ. Door het periodiek verrichten van metingen in de arbeidsomgeving richt de BGZ zich op primaire preventie, in tegenstelling tot het periodiek onderzoeken en screenen van mensen, met als enig effect het verdelen van groepen werknemers in een groep die al ziek is en een groep die dit (nog) niet is. Het gezondheidkundig onderzoek kan zich beperken tot het steekproefsgewijs "bio- 
logisch monitoren" van bepaalde beroepen/functies. Dergelijk onderzoek vereist echter wel het een en ander, zoals een systematische verzameling en registratie van gegevens die, enerzijds betrekking hebben op expositiefactoren gelegen in het werk, de werkomgeving en de werkomstandigheden, en anderzijds van gegevens die betrekking hebben op indicatoren van de gezondheidstoestand. Daarnaast is verzameling van gegevens nodig over de arbeidshistorie, "verstorende" variabelen als leefmilieu en personalia. Last but not least is verzameling van "data-linkage"gegevens vereist, dat wil zeggen gegevens die de koppeling leggen tussen de diverse gegevensstromen.

Behalve de bronnen van gegevens zijn ook de instrumenten waarmee deze gegevens verzameld kunnen worden van belang. Dit besef was 0.8 . aanleiding tot het $\mathrm{zgn}$. Model BGZ.

Een uit bedrijfsgezondheidkundig oogpunt relevant classificatiesysteem van ziekten, klachten en problemen - een onmisbare voorwaarde voor verwezenlijking van epidemiologisch onderzoek - moet probleemgeoriënteerd zijn. De ICHPPC - in de laatste jaren ook voorkomend in een voor de BGZ aangepaste versie - voldoet hieraan veel beter dan de klassieke coderingen als de ICD (Oostendorp en Kromhout 1985).

Samenwerking met betrekking tot de gegevensverzameling met andere BGD'en, met instanties die morbiditeits- en mortaliteitsgegevens verzamelen (zoals CBS, pensioenfondsen), en het curatieve circuit is onmisbaar voor een voldoende verantwoorde omvang en kwaliteit van een databestand.

Dijkstra (1981) gaat in op de vraag of onderzoek naar ongunstige arbeidsomstandigheden met behulp van vragenlijsten mogelijk is en betrouwbare informatie kan opleveren. Onder een aantal voorwaarden, zo concludeert hij, waaronder het vertrouwen dat de onderzoekende instantie moet zien te bewerkstelligen bij de werknemers een van de voornaamste is, kan met behulp van goed gestructureerde vragenlijsten, met een duidelijke doelstelling, adequaat materiaal verkregen worden. Hij pleit er ook nog voor om het bij uitstek multidisciplinaire onderwerp van arbeidsomstandigheden ook als zodanig te benaderen, met andere woorden een gezamenlijke inzet van BGD, personeelszaken, veiligheidsdienst (zie ook Hall 1975).

In 1990 werd door het LOD een voorstel "standaardisatie van werkplekactiviteiten" gedaan (LOD 1990). Men onderscheidt naast werkplekbezoek ook oriënterend werkplekonderzoek (owpo), oriënterende werkplekmetingen (owpm) en uitgebreide werkplekmetingen. Owpo en owpm lenen zich wel voor standaardisatie en het voorstel is daarover uitgewerkt.

\section{Het werkplekonderzoek in de praktijk}

Of de indruk juist is dat bedrijfsartsen weinig aan werkplekbezoek doen, is nagegaan door middel van een enquête onder de leden van de NVAB door Baidjoe (1983). Van de populatie geeft $46,3 \%$ aan op systematisch zijn werkplekbezoek te doen. De belangrijkste reden voor werkplekbezoek is om beter op de hoogte te zijn van de arbeidsomstandigheden. Het overgrote deel is tevreden over het resultaat 
van werkplekbezoek. De helft van de totale populatie heeft niet voldoende tijd voor werkplekbezoek. Diensten met een verzekeringsgeneeskundige taak in het pakket, hebben minder tijd voor werkplekbezoek en doen dat ook minder dan andere diensten. Vooral de GG\&GD'en en de DGD'en komen ongunstig uit de bus. Naast de factor tijd speelt ook mee dat men geen verkeerde verwachtingen wil wekken en dat het soort bedrijf niet noodzaakt tot werkplekbezoek.

Dijkstra (1985) ziet uit zijn onderzoek onder bedrijfsartsen het beeld bevestigd dat de bedrijfsarts, doordat hij erg veel tijd kwijt is aan het houden van (verzuim)spreekuren en keuringen, niet of nauwelijks toekomt aan het bezoeken van de werkvloer. Vooral een verzekeringsgeneeskundige taak "dwingt" de bedrijfsarts vrijwel constant in zijn spreekkamer te blijven. Als oorzaken waarom de bedrijfsarts toch vasthoudt aan spreekuuractiviteiten, resp. weerhouden wordt van de minder-individu gerichte en meer preventieve taken, noemt Dijkstra de professionele identiteit en expertise van de bedrijfsarts (hij is vooreerst medicus, vertrouwd met het diagnose-recept-model), de dualistische positie (het ingeklemd zitten tussen wensen en verwachtingen van resp. management en werknemers), de (tijd)druk op het uitvoeren van de sociaal-medische begeleidingstaak, en tot slot economische ontwikkelingen (men gaat zich meer richten naar taken die voor het management van het bedrijf meer kwantificeerbaar rendement opleveren, zoals de individugerichte taken). Zie ook Van Rijssen-Moll 1982, Baas 1989, Veeneklaas en Lodewijks 1988).

De behoefte aan standaardisatie van het verrichten van werkplekonderzoek wordt in een enquête in 1983 (Giessen et al. 1983) geïnventariseerd. Behoefte aan protocollen voor groepsgericht werkplekonderzoek blijkt bij ruim $80 \%$ aanwezig. De ontwikkeling van een protocol gericht op groepsgericht werkplekonderzoek wordt realiseerbaar geacht. Aan protocollering van individueel gericht werkplekonderzoek is minder behoefte. Dit zal ook moeilijker realiseerbaar zijn.

Ook Oostendorp et al. (Oostendorp et al. 1987, Oostendorp en Kromhout 1985) inventariseerden de houding van BGD'en ten aanzien van standaardisatie van algemeen werkplekonderzoek. Daarnaast probeerden zij een overzicht te krijgen van de verschillende methoden die in Nederland voor dergelijk onderzoek worden gebruikt. Door de meerderheid van de respondenten werd aangegeven dat er regelmatig algemeen werkplekonderzoek werd gedaan, echter niet altijd aan de hand van een bepaald protocol. Veruit het merendeel van de respondenten bleek behoefte te hebben aan een standaardmethode voor algemeen werkplekonderzoek. Er werden 39 momenteel gebruikte protocollen voor algemeen werkplekonderzoek vergeleken, waarbij bleek dat er niet eén bruikbaar is in verschillende typen bedrijven. Er wordt dan ook gepleit voor een beperkte methode, waarop in specifieke situaties of - en dit heeft de voorkeur - per bedrijfstak aanvullingen mogelijk zouden zijn.

Naast algemeen werkplekonderzoek onderscheidden de auteurs een gericht werkplekonderzoek, dat met name in EVD'en vaker plaatsvindt dan algemeen onderzoek. Vooral bij de GD blijkt in het overgrote deel bij het algemeen werkplekonderzoek gebruik gemaakt te worden van een standaardformulier of checklist. De diepgang van protocollen is verschillend. De auteurs maken een onderverdeling in 
6 groepen, waarbij op niveau 1 de arbeidsomstandigheden worden beschreven aan de hand van een lijst met belastende factoren, en niveau 6 de arbeidsomstandigheden worden omschreven aan de hand van een lijst van gedetailleerd omschreven aandachtspunten, waarbij aangekruist moet worden of ze al dan niet aanwezig zijn. Bovendien wordt steeds een beoordeling gegeven met behulp van gedetailleerd omschreven waarderingscodes. De eerste 3 niveaus beperken zich tot een beschrijving van de situatie, de 3 "hoogste" niveaus proberen een beoordeling van de arbeidsomstandigheden te geven. Zie ook Senden/Kolk 1989.

\section{Conclusie}

Het belang van werkplekonderzoek voor de BGZ wordt alom onderkend. Het blijkt in de praktijk moeilijk hieraan gestalte te geven in een zodanige vorm dat epidemiologisch verantwoord onderzoek op basis hiervan mogelijk is.

\subsection{Samenvatting}

In dit hoofdstuk werd de kwaliteit van BGZ beschreven vanuit het perspectief van de beroepsgroep, de professional zelf. Onderzocht werd welke aspecten van zorg de professional in de gezondheidszorg in het algemeen en de BGZ in het bijzonder rangschikt onder "kwaliteitszorg". Genoemd kunnen worden: de werkwijze en taakuitvoering van de bedrijfsarts, het rendement van zijn handelen, de bruikbaarheid van zijn advisering.

Er werden enige suggesties gegeven hoe een samenhang aangebracht kan worden tussen deze verschillende aspecten van zorg.

Als belangrijke instrumenten voor kwaliteitszorg in de BGZ kwamen naar voren intercollegiale toetsing en protocollering. Tegen de achtergrond van professionaliseringsprocessen in de BGZ werden elementen van de BGZ-kerntaken, die de bouwstenen kunnen vormen voor protocollering, besproken.

Uit dit hoofdstuk kan geconcludeerd worden dat de professie de bewaking van de kwaliteit van (medische) zorg tot haar taak rekent. Met betrekking tot de BGD'en kan dan vastgesteld worden dat nog weinig sprake is van een vastleggen van deze verantwoording in toetsbaar kwaliteitszorg. Wel kan op diverse initiatieven tot protocollering geduid worden.

Protocollering van BGZ-activiteiten kan een meerledige functie hebben: in het optredende spanningsveld tussen de wensen van de klant en binnen de beroepsgroep aanvaarde mogelijkheden kan protocollering fungeren als richtsnoer. Daarnaast kan protocollering binnen kwaliteitszorg dienen als referentiekader. Tot slot heeft protocollering een functie bij een longitudinale en epidemiologisch verantwoorde gezondheidsbewaking van mens en werk.

Ook kan worden opgemerkt dat het oordeel over de kwaliteit van BGZ afhankelijk is van de positie van de beoordelaar in de onderneming.

Kwaliteit van BGZ wordt echter niet alleen bepaald door professionele aspecten. De klant van BGZ dient aan te geven aan welke diensten behoefte is. Tevens zal de 
klant de wijze van dienstverlening door de BGD als belangrijke factor meenemen in zijn beoordeling van de kwaliteit van de BGD en haar diensten. 


\section{Hoofdstuk 4}

\section{Aspecten van kwaliteit van BGZ, de visie van de klant. Marketing en BGZ}

\subsection{Inleiding}

In het vorige hoofdstuk kwamen aspecten aan de orde die vanuit het perspectief van de professional van belang worden geacht voor de kwaliteit van BGZ. In dit hoofdstuk wordt ingegaan op aspecten die de afnemer van diensten belangrijk vindt in verband met de kwaliteit van $B G Z$.

Diverse malen is reeds gewezen op de centrale positie van de klant bij de bepaling van de kwaliteit van BGZ. De klant draagt primair wensen en problemen aan. BGD'en moeten trachten hier op professioneel verantwoorde en klantgerichte wijze op in te spelen. Het gaat dan om afstemming van vraag en aanbod, om klantgerichte dienstverlening, om een marktgerichte opstelling. Het gaat dan om het toepassen van marketing-principes.

Het begrip marketing moet hierbij ruim opgevat worden. Het betreft in de eerste plaats een bepaalde manier van denken. Maar marketing is ook het toepassen van marketing-instrumenten. Paragraaf 4.2 werkt dit verder uit.

$\mathrm{Na}$ in die paragraaf het conceptuele kader van het begrip marketing geschetst te hebben, worden in paragraaf 4.3 enige specifieke kenmerken van marketing in dienstverlenende organisaties beschreven.

Op basis van literatuuronderzoek wordt een aantal knelpunten onderkend, dat kan optreden bij de toepassing van marketing in de BGZ. Paragraaf 4.4 geeft hiervan een overzicht.

Alvorens het hoofdstuk met een samenvatting wordt afgesloten, wordt in paragraaf 4.5 aangegeven hoe marketing binnen BGD'en kan worden toegepast. 


\subsection{Het begrip marketing}

\subsubsection{Inleiding}

Het toepassen van een, overigens meestal maar beperkt, aantal marketing-principes binnen de gezondheidszorg mag zich de laatste jaren in een grote populariteit verheugen. Reorganisatie van de gezondheidszorg (plannen van de "Commissie Dekker", van Simons) zullen hier mede debet aan zijn (Van Dijk en Jaspers 1988, Rutten 1987, Elsinga 1987, Kroonen en Boot 1987, Verbrugge en Broere 1988).

In het algemeen is de belangstelling voor het "marketing-denken" in de dienstverlenende sector groeiend. Dit geldt zowel ten aanzien van externe dienstverlening, alsook ten aanzien van "interne" dienstverlening, d.w.z. de wijze waarop afdelingen binnen een bedrijf zich naar elkaar opstellen en met elkaar omgaan (Geval 1990).

Toepassing van marketing-beginselen kan leiden tot een grotere tevredenheid van bestaande clienten, een efficiëntere benadering van de markt, en meer duidelijkheid bij alle medewerkers binnen de dienstverlenende instelling ten aanzien van de opstelling tegenover de markt (interne communicatie) en het elkaar binnen de organisatie zelf zien als "klant" (interne marketing). (Van der Hart 1986).

Een synthese van "externe marketing", gericht op de klanten buiten de eigen organisatie, en "interne marketing", gericht op een klantgerichte opstelling binnen de eigen organisatie, wordt door diverse auteurs bepleit (Mindak en Folger 1990, Grönroos 1990a, Jones 1990, Flipo 1986). In wezen wordt hier gesproken over twee denkmodellen, het marketing-model en het organisatie-model (Kasper 1990). Het gaat om het creëren van een marktgerichte organisatie(cultuur). Marktgerichtheid moet richtsnoer zijn voor denken en handelen van de organisatie (Kasper 1990).

\subsubsection{Definitie marketing}

Conceptualisatie van het begrip marketing is mogelijk vanuit diverse invalshoeken. In zijn oorspronkelijke betekenis gaat het bij marketing om het tot stand brengen van een ruiltransactie: de organisatie biedt een bepaalde klantenkring iets aan, die bereid is hiervoor een bepaalde inspanning of betaling te leveren (Kotler en Clarke 1987, Blanken en Van der Meulen 1987, Leeflang en Beukenkamp 1987).

$\mathrm{Er}$ is cen duidelijke tendens waarneembaar waarbij marketing zich niet beperkt tot de totstandkoming van een eenmalige ruiltransactie, maar waarbij marketing zich richt op het behouden van klanten, op de relatie met klanten.

Het begrip marketing kent een aantal dimensies: (Kotler en Clarke 1987, Leeflang en Beukenkamp 1987, Verhage en Cunningham 1984):

a. marketing als een mentaliteit, een manier van denken (de "think-consumer" gedachte (Grönroos 1982);

b. marketing als een verzameling van activiteiten;

c. marketing als (organisatorische) functie in een bedrijf, de infrastructuur. 
Naast deze drie dimensies, die in de volgende subparagrafen worden uitgewerkt omdat zij van betekenis kunnen zijn voor BGD'en kan marketing worden beschouwd als een veld van wetenschappelijk onderzoek, en als probleemgebied.

\subsubsection{Marketing als mentaliteit}

Marketing betekent dat men als BGD bereid is de organisatie waaraan men diensten verleent te zien door de ogen van de afnemer (Van der Hart 1991). Wat ervaart de klant als relevante problemen, welke bijdrage kunnen BGD'en leveren aan de oplossing van deze problemen, wat is de meerwaarde van de dienstverlening van BGD'en hierbij in vergelijking met eventuele concurrenten? Dit impliceert niét een geheel wegcijferen van wensen en doelen van de organisatie zelf, integendeel. Het gaat er juist om die activiteiten te gaan doen, waar cen organisatie voor staat en wil staan, maar die wel passen bij de behoeften van een bepaalde klantengroep.

Er zijn attitudes denkbaar die strijdig zijn met de marketing-mentaliteit, en daarmee een negatief effect kunnen hebben op de afstemming van vraag en aanbod, en daarmee op de kwaliteit van de BGZ (Geval 1990).

Allereerst bestaat er het risico van een te sterke professie-gerichtheid. Diensten worden vanuit een professionele deskundigheid ontwikkeld, en men neemt als vanzelfsprekend aan dat "de" klant of "een" klant er wel behoefte aan zal hebben. Technische vakkennis of professionele cultuur domineren, en men is geneigd om produktkwaliteit en beroepscultuur te laten prevaleren boven de feitelijke marktbehoefte. In hoofdstuk 2 kon een aantal negatieve effecten worden vastgesteld van een dergelijke houding binnen BGZ.

Een ander risico is een te sterke verkoopgerichtheid. Dienstverlening wordt opgedrongen, vaak in een agressieve vorm. Er worden dingen beloofd die de organisatie op termijn niet kan waarmaken.

Ook een te sterke gerichtheid op de eigen organisatie kan een ongunstig effect hebben. De organisatie is (te) sterk gericht op het eigen interne gebeuren. Van de client wordt verwacht dat hij zich geheel schikt naar de wensen en regels van de leverancier van de dienst.

Ook een te sterke gerichtheid op persoonlijk gewin, waarbij de doelgroep in dienst wordt gesteld van realisering van persoonlijke ambities en inkomstenverwerving, wordt als ongunstig gezien. De uitvoerders van BGZ binnen de BGD kunnen redelijk autonoom vorm en inhoud geven aan hun dienstverlening. Primair worden zij aangesproken op professionele verantwoordelijkheid, in veel mindere mate op klantgerichtheid.

Effectieve marketing is slechts mogelijk als de gehele organisatie van de noodzaak hiertoe doordrongen is, zowel de top van de dienstverlenende instelling, als de uitvoerders in het veld (Van der Hart 1983, Van Sprundel 1982, Van der Steeg en Jaspers 1986). 


\subsubsection{Marketing als een verzameling van activiteilen}

Marketing omvat eveneens een aantal gestructureerde en planmatig verlopende activiteiten, dat er op gericht is "het ruilproces" adequaat te laten verlopen (Baart et al. 1982, Mackenbach 1982, Van der Hart 1991).

De marketing-activiteiten kunnen in een marketingplan opgenomen worden. Een dergelijk plan bevat een aantal elementen:

a. Een situatieanalyse, zowel intern als extern: dit wil zeggen dat men onderzoek doet naar hoe de BGD ervoor staat, welke activiteiten de BGD kan ondernemen. Ook de omgeving van de BGD (de markt) dient te worden geanalyseerd: met welke klanten heeft de BGD te maken, welke behoeften kunnen vastgesteld worden? Er dient een strategische marktvisie voor een planperiode van zo'n 2-5 jaar ontwikkeld te worden: welke diensten wil de BGD in de komende jaren leveren?

b. Op basis van deze situatieanalyse kan de BGD een overzicht opstellen met sterke en zwakke punten, en verder een overzicht van kansen en bedreigingen.

c. De volgende stap in het marketingplan is het concreet vaststellen van marketingdoelen: welke doelgroepen wil de BGD bereiken, welke diensten wil zij gaan verlenen? Een BGD kan immers niet de hele markt bedienen. De BGD kan zich het beste concentreren op gebieden waar zij zelf sterk in is, of tenminste sterker dan de concurrent. In dit kader kan het begrip segmentatie worden genoemd. Segmentatie kan worden omschreven als (Leeflang en Beukenkamp 1987): het verdelen van een (nauwkeurig afgebakende) markt in kopersgroepen (segmenten), op een zodanige wijze dat consumenten binnen een kopersgroep een zoveel mogelijk homogene respons op marketing-stimuli bezitten, dat de respons tussen kopersgroepen onderling zoveel mogelijk verschilt, en dat het mogelijk is om de kopersgroepen te identificeren door middel van bepaalde kenmerken en wel op een wijze dat men hier met marktinstrumenten op kan inspelen.

d. Na de vraag van het "aan wie wil de BGD diensten verlenen", komt de vraag aan de orde hoe een BGD de diensten aan de klant aanbiedt. Er moet een keuze gemaakt worden welke mix van stuurvariabelen het beste aansluit op enerzijds wensen van de klant, en anderzijds de mogelijkheden van de BGD. Dit complex van stuurvariabelen wordt de marketing-mix genoemd (zie verder paragraaf 4.2.3). Deze marketing-mix vormt de kern van marketing-activiteiten op tactisch niveau. Activiteiten dienen wel te passen in de globaal vastgestelde strategie van de BGD (de "mission" van de BGD).

C. De volgende stap is de concretisering van alle plannen, hoe implementeert de BGD haar plannen, hoe gaat de BGD in de dagelijkse praktijk om met de afnemers van diensten (operationele marketing). Belangrijke activiteiten in dit kader zijn: hoe onderhoudt de BGD de communicatie met haar klanten, hoe is de klachtenbehandeling geregeld, hoe onderhoudt de BGD haar relatienetwerk, hoe is haar functionele dienstverlening (verstrekken van informatie, het maken van afspraken, de planning van activiteiten)? Binnen de BGD moet 
duidelijk vastgesteld worden welke acties genomen dienen te worden, gekoppeld aan een tijdpad, personen en voorwaanden. Dit alles betreft de (klantgerichte) kwaliteit van de dienstverlening. Door Parasuraman et al. (1986) is een model ontwikkeld waarmee deze kwaliteitsaspecten in kaart gebracht kunnen worden (zie 4.2.4).

f. Tot slot dient de BGD periodiek te evalueren of de door haar gestelde doelen bereikt zijn, op welke plaatsen bijstelling nodig is, of nieuwe diensten ontwikkeld kunnen worden. Stemmen de bereikte resultaten overeen met de vooraf geformuleerde doelstellingen, en zo dit niet het geval is welke verklaringen kunnen voor deze discongruentie gevonden worden. Op dit punt gekomen start cen nieuw marketingplan.

\subsubsection{Marketing als functie}

Als er gesproken wordt over marketing als functie wordt bedoeld de wijze waarop marketing-activiteiten binnen de organisatie een (infra)structuur krijgen in een organisatorische eenheid. Grönroos (Grönroos 1990) wijst op het risico dat bij het bestaan van een aparte "marketing-afdeling" de marketing niet als een aandachtspunt voor de rest van de organisatie wordt gezien. Vooral in het dienstverleningsproces, waar een intensief contact is tussen personeel van de organisatie en de klant, is betrokkenheid van het personeel van belang. Grönroos noemt het dienstverlenend personeel in dit kader "parttime-marketers".

Een adequate informatievoorziening over de feitelijke situatie over de markt (de doelgroepen die de organisatie wenst te bereiken), kennis over marketinginstrumentarium, vormen naast een marktgerichte mentaliteit in alle geledingen, de basis om marketingactiviteiten doeltreffend te doen zijn. Ook binnen BGD'en zou een infrastructuur voor marketingactiviteiten van belang kunnen zijn.

\subsubsection{De marketing-mix}

In het voorafgaande is het begrip "marketing-mix" geîntroduceerd. Het is de verzameling van stuurvariabelen in de ruiltransactie tussen de leverancier en klant. Kotler en Clarke (1987) definiëren dit begrip als volgt: "the meaningfull organization of the controllable variables which directly influence customer and consumer transactions".

Onderstaand worden de elementen van de marketing-mix verder uitgewerkt. Deze elementen worden toegespitst op de toepasbaarheid in de dienstverlenende sector (zie cok Faes en Van Tilborgh 1984).

\subsubsection{Het personeel}

Het personeel vormt de kern in het dienstverlenende proces.

De medewerkers van de BGD, die de zorg in de praktijk leveren, moeten in staat zijn om een door de klant gevraagde dienst volgens (beroeps)normen te leveren 
("technische kwaliteit"). Daarnaast moeten zij de dienst op een zodanige manier leveren, dat de klant tevreden is en blijft over de dienst. Dit stelt eisen aan communicatievaardigheden, deskundigheid, gedrag. (Na)scholing dient hier een belangrijke plaats in te nemen (Van der Hart 1986 en 1988, Grönroos 1982). Het uitvoerend personeel bepaalt uiteindelijk de kwaliteit van de "performance", de dienstverlening. Vaak kunnen concurrenten dezelfde diensten leveren, en is kwaliteitsverschil vooral te behalen in een (positief) verschil in dienstverlening, de manier waarop ("functionele kwaliteit") men diensten verleent (Zeithaml et al. 1990).

\subsubsection{De dienst (het "produkt")}

Het betreft hier de diensten die de BGD kan leveren. Welke activiteiten kan zij ondernemen, hoe kan de BGD een bijdrage leveren aan het oplossen van problemen? Omdat diensten niet tastbaar zijn, omdat diensten in tegenstelling tot produkten geen direct zichtbare produktkenmerken hebben, is de wijze waarop de diensten geleverd worden (de dienstverlening) van groot belang. We zien hier naast elkaar het belang van de professionele kwaliteit van de dienst ("technische" kwaliteit) en de klantgerichte kwaliteit ("functionele" kwaliteit). Van der Hart (1991) noemt dit resp. de medische en functionele dienstverlening. Algemeen gesteld betekent dit dat de BGD diensten levert die actueel zijn en blijven, dat de BGD diensten en dienstverlening bijstelt in interactie met haar relatie met de klant, dat zij nieuwe activiteiten entameert. Geleverde diensten moeten bruikbaar en begrijpelijk zijn, diensten moeten worden geleverd op momenten dat de klant er behoefte aan heeft.

De BGD kan proberen met een bepaalde dienst in een bestaande markt te penetreren, of zij kan proberen een nieuwe markt te veroveren. Daarnaast kan de BGD met een nieuwe dienst zijn positie verstevigen op de bestaande markt of op nieuwe markten. Belangrijk is dat een uitbreiden van het dienstenpakket evenwichtig plaatsvindt, en dat nieuwe diensten (blijven) aansluiten bij de kernactiviteiten van de organisatie (Lovelock 1984).

\subsubsection{De plaats}

De klant van de BGD is vaak aanwezig op de plaats waar de dienst geleverd wordt. Produktie en consumptie vinden op dezelfde plek plaats. Dit stelt in vergelijking met de situatie in de industrie eisen aan de plaats waar de produktie (lees dienstverlening) plaatsvindt. Elementen die in dit kader de aandacht vragen zijn de huisvesting, de bereikbaarheid, de toegankelijkheid, de inrichting van werkruimten, het gehanteerde instrumentarium. Bereikbaarheid heeft hier een brede betekenis: het betreft geografische bereikbaarheid, bereikbaarheid in de tijd (openingsuren, wachttijden, de tijd waarbinnen afspraken gemaakt kunnen worden), en "psychologische" bereikbaarheid (Kotler 1987). 


\subsubsection{Communicatie}

De BGD dient met meerdere doelgroepen te communiceren, binnen het bedrijf (werkgever, werknemers, overlegkaders) en buiten het bedrijf (GAK, ABP, GMD, huisartsen, specialisten, overheid). De communicatie moet gericht zijn op het beinvloeden van de kennis, de attitude en/of het gedrag van een of meer van deze doelgroepen. Men maakt hierbij wel onderscheid tussen "corporate communication" (de communicatie van de BGD als zodanig) en marketing-communicatie (welke diensten levert de BGD, wat kan hiervan de meerwaarde zijn voor de doelgroepen) (Floor en Van Raay 1989). Marketing-communicatie kent daarbij twee sporen: thema-communicatie, gericht op beinnvloeding van kennis en/of attitude en gericht op het opbouwen en onderhouden van relaties met klanten, en daarnaast actiecommunicatie, gericht op (directe) beïnvloeding van het (koop)gedrag van de klant.

Bij het overdragen van het beeld van een dienst moet geprobeerd worden om de dienstverlening in min of meer tastbare vorm weer te geven. Mogelijkheden hiervoor liggen in de inrichting van de omgeving, waarin de dienstverlening plantsvindt (het gebouw, de sfeer), of in een standaardisatie en uniformering van de dienstverlening (huisstijl). Het doel hiervan is dat de afnemer een concreter beeld van de dienst krijgt. Er bestaan meerdere mogelijkheden om klanten te informeren over de diensten die de BGD kan leveren. Dit kan variëren van een geheel onpersoonlijke wijze (bijv. via reclame in dagbladen) tot een sterk persoonlijke wijze (bijv. via mond-tot-mond reclame). Via "direct" marketing activiteiten probeert de organisatie rechtstreeks in contact te treden met de klant, en een relatie met deze op te bouwen.

Bij promoting van een produkt of dienst, of bij profilering van de organisatie, wordt Public Relations wel eens ten onrechte vereenzelvigd met marketing (Kotler en Clarke 1987). Onder Public Relations dient te worden verstaan het stelselmatig bevorderen van wederzijds begrip tussen een organisatie en haar doelgroepen (Nederlands Genootschap voor Public Relations, Leeflang en Beukenkamp 1987).

Als mogelijkheden voor profilering en promoting, zou de BGD haar dienst en haar medewerkers kunnen presenteren in een folder voor de klanten. $\mathrm{Zij}_{\mathrm{ij}}$ zou ook in de uitnodigingsbrief voor deelname aan BGZ-activiteiten kunnen beschrijven wat de BGD verstaat onder betrokken BGZ-activiteit, wat de klant kan verwachten.

Tot slot moet er op worden gewezen dat een goede afstemming van de verschillende marketing-communicatie-instrumenten vereist is: het beeld dat de organisatie van zichzelf en haar diensten geeft moet consistent zijn. Personeel van de organisatie moet daar naar handelen.

Het door de klant afnemen van een professionele dienst verschilt van het kopen van een produkt (Booms en Bitner 1981). Voor klanten van professionele dienstverlening gaat het vaak om problemen die een grote onzekerheidsmarge in zich hebben, waar zij zelf weinig inhoudsdeskundig zijn. Het betreft problemen, waarbij de klant van tevoren moeilijk kan onderzoeken of de dienstverlener dit probleem, deze onzekerheid, kan wegnemen. Binnen de BGZ gaat het bijvoorbeeld om fundamen- 
tele bedrijfsproblemen of delicate individuele "kwesties". Het gaat bij (professionele) dienstverlening dan ook als het ware om "het communiceren van vertrouwen" (Van der Hart 1983). Daarom is het dan ook van belang dat de BGD ook buiten de directe werksfeer om, bekendheid geniet en een goede naam ("corporate image") heeft. Het opbouwen van een relatie- en referentienetwerk vormen belangrijke mogelijkheden het afnemen van diensten te stimuleren, daar betrokken netwerken als promotoren voor de BGD kunnen gaan fungeren. Zich laten zien op presentaties op bedrijven, bij gelegenheid bedrijven uitnodigen op de dienst, zijn goede mogelijkheden hierbij, evenals het verrichten van "in aanzien staande" nevenfuncties, en het publiceren in vaktijdschriften.

\subsubsection{De prijs (tariefstelling)}

In de industrie vormt de prijs een belangrijk element in de marketing-mix. Natuurlijk geldt dit ook voor de dienstverlenende sector (BGD'en), maar binnen de dienstverlenende sector (BGD'en) komen hier nog non-monetaire prijs-elementen bij. Het gaat vaak om delicate kwesties, het is tevoren niet precies bekend wat de organisatie/dienst in dezen kan bieden en welke consequenties dit voor de gebruiker zelf heeft. Dit kan leiden tot een zekere psychologische drempel in de professionele dienstverlening.

Bij de gebruikers van BGZ lijkt er een toenemende behoefte aan differentiatie in pakket en prijsstelling. Er wordt de mogelijkheid gewenst van afname van specifieke diensten, met een daarbij passende prijs, in plaats van de verplichting van afname van een totaal pakket van diensten met een vaste (abonnements)prijs. Uitgaven voor BGZ moeten concurreren met andere uitgaven van het bedrijf. Het afnemen van BGD-diensten brengt additionele kosten met zich mee, daar de afname van diensten door werknemers gepaard gaat met tijd- en produktieverlies.

Samenvattend bevat de marketing-mix in de BGZ de volgende elementen: de BGDmedewerkers, de professionele diensten (het takenpakket), de klantgerichte dienstverlening, een bepaalde tariefstelling, het zichtbaar maken van de diensten van de BGD en de communicatie met de klant, en de plek waar de diensten worden geleverd. Door deze elementen op de juiste wijze in te zetten kan de BGD de, binnen haar strategisch beleid vastgestelde doelen, namelijk het afnemen van bepaalde diensten bij diverse doelgroepen, realiseren.

Voorwaarde is wel dat de BGD-medewerkers op een marktgerichte wijze met de afnemers omgaan. De wijze waarop de BGD in de dagelijkse praktijk omgaat met haar klanten bepaalt voor de klant in belangrijke mate de (ervaren) kwaliteit van de dienst. In de volgende paragraaf wordt een model uitgewerkt, waarmee aspecten van klantgerichte kwaliteit geëvalueerd kunnen worden (Parasuraman et al. 1986, Zeithaml et al. 1987 en 1990). 


\subsubsection{Kwaliteit van dienstverlening}

Het perspectief van de klant aan de hand van het SERVQUALmodel

\subsubsection{Inleiding}

De kwaliteit van dienstverlening is momenteel een populair onderwerp. Vooral "pure" dienstverleners als banken en verzekeringsinstellingen hebben er belangstelling voor. Er bestaat een tendens naar certificatie van dienstverlening volgens ISOnormen. Er kan op het gevaar worden gewezen dat certificatie verleidt tot het opstellen van handboeken, zonder dat de mensen binnen de organisatie zich een klantgerichte filosofie eigen willen maken.

Als in dit onderzoek wordt gesproken over aspecten van kwaliteit vanuit het perspectief van de klant, gaat het om zaken als: in hoeverre staat de BGD open voor wensen van de klant, in hoeverre vertaalt de BGD wensen van de klant in de door haar geleverde diensten? Welke houding van de BGD is gunstig om een positief kwaliteitsoordeel van de klant te krijgen? Is de afstemming van zorg een belangrijk element bij de beoordeling van de kwaliteit?

BGD'en bewegen zich als professionele, dienstverlenende organisaties in een sterk krachtveld van tegengestelde doelen en belangen. Explicitatie hiervan is nodig om als BGD maatwerk te kunnen leveren. Beoordeling van de kwaliteit van een dienst door de klant zal zowel afhankelijk zijn van zijn verwachtingen ten aanzien van de af te nemen dienst, als van de concrete interactie tussen klant en de personen in de dienstverlenende instelling. Zoals reeds werd aangegeven, is daarmee een hoofdrol weggelegd voor het uitvoerend personeel. Daarnaast kan met name het uitvoerend personeel lacunes in de kwaliteit van de geleverde zorg signaleren. Bij het verlenen van diensten gaat de klant vaak impliciet er van uit dat de technische of professionele kwaliteit in orde is; hij kan hier immers weinig of niet over oordelen. De klant gaat veel meer af op de zgn. functionele kwaliteit, de manier waarop hij benaderd en bejegend wordt. Dat kan hij immers ook beoordelen.

Zoals reeds vermeld noemt Grönroos (1982) deze twee aspecten van kwaliteit resp. "technical quality" en "functional quality". Technische kwaliteit kan als een voorwaarde voor een succesvolle functionele kwaliteit gezien worden. In 1984 wordt er door Grönroos een derde dimensie aan toegevoegd, namelijk het "corporate image" (Kunst en Lemmink 1992). Deze indeling vertoont grote gelijkenis met de drie dimensies van Lehtinen: physical quality, enterprise quality en interactive quality (Kunst en Lemmink 1992). Tijdelijke technische "storingen" kunnen gecompenseerd worden door een goede functionele kwaliteit (Baart et al. 1982).

Directe maatstaven om de kwaliteit van diensten te meten in termen van winstbijdrage, omzet en marktaandeel ontbreken binnen BGD'en.

In dit onderzoek wordt bij de beschrijving van klantgerichte aspecten van kwaliteit een gedeeltelijke parallel getrokken met het zogenaamde SERVQUAL-model (Parasuraman et al. 1986). Dit model beschrijft in zijn oorspronkelijke versie 10 dimen- 
sies die vanuit het perspectief van de klant als aspecten van kwaliteit kunnen gelden.

\subsubsection{Het SERVQUAL-model}

Door Parasuraman et al. (1986) is een model ontwikkeld om de kwaliteit van dienstverlening te kunnen beoordelen (SERVQUAL). In figuur 4.1. is hun onderzoeksmodel weergegeven.

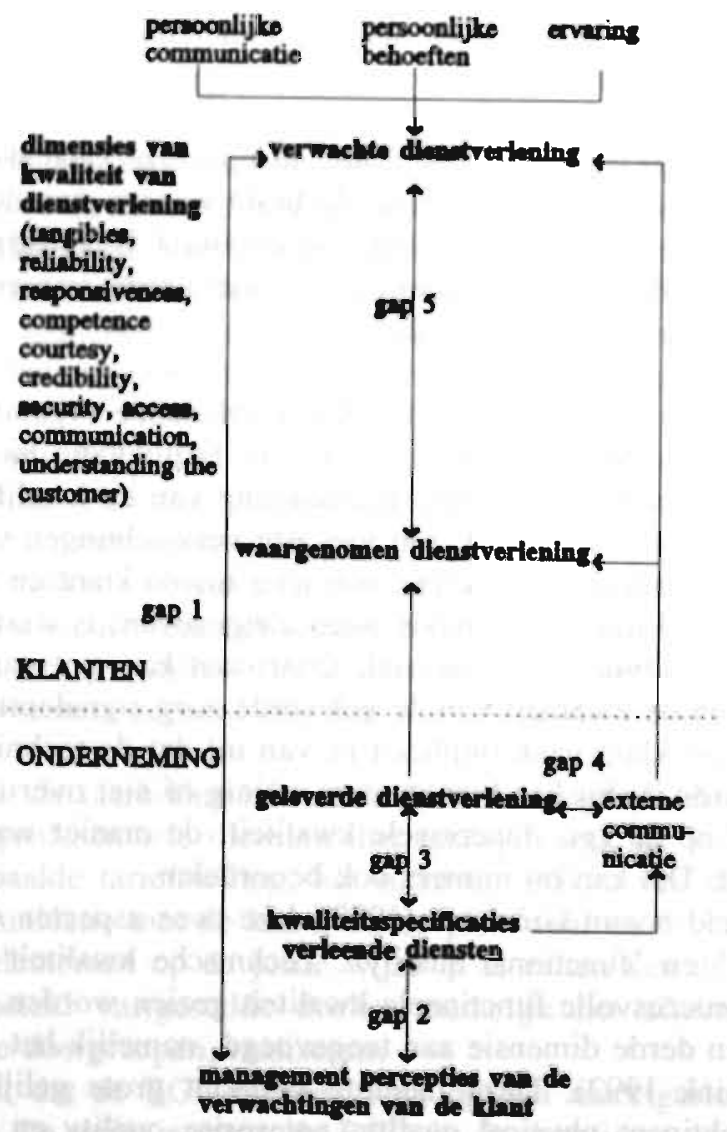

Figuur 4.1. Het SERVQUAL-model

Parasuraman et al. onderscheiden cen viertal "gaps" in de communicatie tussen organisatie en klant, die de kwaliteitservaring kunnen beïnvloeden (Parasuraman et al. 1986, Zeithaml et al. 1987 en 1990). 
1. De "gap" tussen verwachtingen van de klant en de beoordeling door management wat de klant volgens hem verwacht. Vertaalt het management op juiste wijze de behoeften van de klanten? Het gaat hier om de mate waarin de organisatie markt-en klantgericht is. Een voorbeeld is de aandacht die aan bescherming van de privacy wordt gegeven. Deze "gap" is o.a. afhankelijk van de mate van klantgerichtheid van het management, de communicatie tussen werkvloer en management (komen de signalen van de klant naar boven?).

2. De "gap" tussen de beoordeling door het management van de verwachtingen van de klant en het vertalen in kwaliteits-normen of -specificaties. Deze "gap" is o.a. afhankelijk van het commitment van het management bij het willen leveren van kwaliteit, het stellen van kwaliteitsdoelen (zijn deze conform wens van de klant), het daar waar mogelijk standaardiseren van taakelementen , en de mate van "feasibility", dat wil zeggen de mate waarin de leiding bereid is aan wensen van klanten tegemoet te komen.

3. De "gap" tussen kwaliteitsnormen en dienstverlening in de praktijk. In feite is dit het verschil tussen efficacy (het haalbare onder ideale, theoretische omstandigheden) en effectiviteit ("de praktijk"). Deze "gap" is o.a. afhankelijk van de teamgeest, het wij-gevoel, de geschiktheid voor de functie, de beschikbare middelen, duidelijkheid voor het personeel wat van hun verwacht wordt.

4. De "gap" tussen dienstverlening in de praktijk en het geven van informatie hierover, de communicatie met de klant. Maakt de organisatie waar wat beloofd en uitgedragen wordt in haar communicatie met de klant? Het gaat hier om het "imago" van de organisatie. Deze "gap" is o.a. afhankelijk van de mate van horizontale communicatie, dat wil zeggen de interne afstemming van activiteiten, en ook van het uitsluitend toezeggen van diensten die kunnen worden waargemaakt.

Hun veronderstelling is dat de "gap" tussen wat een klant verwacht van een dienst en wat de klant in de praktijk ervaart ("gap" 5 in schema 1) een functie is van de hierboven genoemde "gaps". Globaal zouden deze "gaps" kunnen worden samengevat in de termen communicatie en procescontrole (Parasuraman et al. 1986, Zeithaml et al. 1990).

Uit hun onderzoekingen bleek dat, ongeacht het soort dienstverlening, door klanten 10 dimensies in meer of mindere mate worden gehanteerd bij het beoordelen van de kwaliteit van dienstverlening. Het zijn de volgende criteria:

1. "Reliability" (dit betreft de consistentie en betrouwbaarheid van de dienstverlening, de geleverde prestatie. Het betekent ook dat de organisatie levert wat zij toezegt);

2. "Responsiveness" (de bereidheid van de mensen binnen de organisatie zich dienstverlenend en klantvriendelijk op te stellen);

3. "Competence" (dit is de professionele kwaliteit, de vereiste deskundigheid);

4. "Access" (de in brede zin opgevatte toegankelijkheid van de dienst);

5. "Courtesy" (dit is de beleefdheid, de respectvolle bejegening van de klant); 
6. "Communication" (het gaat hier om het verschaffen van duidelijke en begrijpelijke informatie over de dienstverlening);

7. "Credibility" (dat wil zeggen dat de organisatie het beste voorheeft met de klant, het gaat ook om het "corporate image");

8. "Security" (dit houdt in dat de klant niet wordt blootgesteld aan onnodige risico's);

9. "Understanding/knowing the customer" (dit houdt in de levering van een dienst, die op de wensen van de klant is afgestemd);

10. "Tangibles" (dit betreft de plaats waar de diensten worden verleend. Over welke faciliteiten wordt beschikt, hoe zijn ruimten ingericht, welke middelen en instrumentarium worden gebruikt).

In vervolgonderzoeken werden de oorspronkelijk 10 dimensies teruggebracht tot 5 , namelijk "reliability" (betrouwbaarheid), "tangibles" (fysieke omgeving, apparatuur), "responsiveness" (bereidheid om (snel) te helpen), "assurance" (een samenvoeging van dimensie $3,5,6,7,8$, vertrouwelijke en adequate behandeling) en "empathy" (een samenvoeging van dimensie 4 en 9, persoonlijke zorg en aandacht) (Zeithaml et al. 1990).

De door de klant waargenomen kwaliteit van de geleverde dienst is de vergelijking die hij maakt tussen wat hij verwacht had en wat hij ervaart in de praktijk. Het beoordelen van de kwaliteit van produkten is gemakkelijker omdat produkten vaak voorafgaand aan de koop "bekeken" en onderzocht kunnen worden (dit worden genoemd "search" en "experience properties"). Bij het afnemen van diensten, van $B G Z$, geldt dat, zelfs nadat een klant een dienst heeft ervaren, het moeilijk blijft voor hem de kwaliteit te beoordelen. Er wordt vertrouwd op de professional (Darby en Karni (1973), noemen dit "credence properties"). Bij het beoordelen van de kwaliteit van BGZ-dienstverlening staan de klant slechts twee "search-properties" ter beschikking, namelijk "tangibles" en "credibility". De meeste dimensies (of aspecten) vallen echter in de categorie "experience properties", zoals "access", "courtesy", "reliability", "responsiveness", "understanding/knowing the customer", en "communication". Met andere woorden, een oordeel over de dienstverlening is vaak pas mogelijk nadat de dienst afgenomen is. En omdat diensten zo kunnen verschillen (zowel qua inhoud, als persoon die ze levert als de omstandigheden waaronder dit plaatsvindt) zal iedere keer weer opnieuw deze beoordeling plaatsvinden. Steeds dus zal de aandacht gericht moeten zijn op het leveren van kwaliteit (nogmaals wordt geattendeerd op de centrale betekenis van de concrete leverancier van diensten). De twee resterende criteria, "competence" en "security" zijn zelfs na het ervaren van een dienst, niet of nauwelijks te beoordelen!

Het aspect betrouwbaarheid blijkt eén van de belangrijkste dimensies (Zeithaml et al. 1990). De verwachtingen van de klant zijn bovendien niet constant en statisch. Daarnaast is er sprake van een bepaalde tolerantiebreedte. Dit is het gebied tussen het dienstverlenings-niveau wat een klant (idealiter) zou hopen te krijgen en het niveau dat hij acceptabel, adequaat vindt. Het is als het ware een mengeling tussen wat zou kunnen en wat zou moeten. Omdat betrouwbaarheid in de ogen van de 
klant de kern vormt van het dienstverleningsgebeuren, is de tolerantiebreedte hier gering. Een beleidsmatig relevante bevinding is dat de tolerantiebreedte stringenter en beperkter wordt, als de dienstverlening de eerste maal niet aan de verwachtingen van de klant heeft voldaan.

Om de betrouwbaarheid van dienstverlening te meten staan twee wegen open: de zgn. attribute-based methode, dat wil zeggen dat de dienstverlening wordt onderscheiden in een aantal kenmerken, die relevant zijn voor de door de klant ervaren kwaliteit (vooral toepasbaar voor routinematige dienstverlening) en de zgn. incident-based methode, dat wil zeggen dat wordt nagegaan door welke activiteiten de dienstverlening als extreem goed c.q. slecht werd ervaren. In feite vullen deze twee methoden elkaar aan. Gebleken is (Kunst en Lemmink 1992) dat beter voldoen dan de klant verwacht positieve effecten heeft op de door de klant ervaren kwaliteit. Het gaat niet alleen om het vermijden of voorkómen van fouten.

Toepassing van de SERVQUAL is niet zozeer gelegen in het verkrijgen van een bepaalde kwaliteitsscore, immers criteria of referentienormen ontbreken. Het is geen meetinstrument in de strikte zin, maar een denkmodel, dat een vertaling mogelijk maakt van lacunes in de door de klant ervaren kwaliteit van dienstverlening naar corzaken in de organisatie.

De toepassing is vooral gelegen in het onderzoeken van tijdtrends in het verwachtings- en ervaringspatroon van diensten bij klanten, in het zich kunnen vergelijken met concurrenten, en tot slot in het segmenteren van de markt.

Anderson (Kunst en Lemmink 1992) is van mening dat het SERVQUAL-model onvoldoende theoretisch is verankerd.

\subsection{Marketing in de dienstverlenende sector}

\section{Inleiding}

Het onderscheid tussen de dienstverlenende sector en produktiesector wat betreft de plaats van marketing als vertaler tussen produktie en consumptie vervaagt (Grönroos 1990). Marketing heeft niet alleen een functie bij het onderzoeken of en welke diensten/produkten aansluiten bij de behoeften van de klant, maar ook is het een functie van de marketing om de dienstverleners "marketing-bewust" te maken, om de relatie tussen leverancier en klant positief te beīnvloeden.

Met andere woorden, marketing heeft binnen het dienstverlenende proces zowel op de consumptie als op de produktie effecten en vice versa (Desouza 1989, Zeithaml 1990, Hensel 1990).

Het specifieke van professionele dienstverlening is dat de professional zelf de behoeften van de klant vertaalt in een dienst of produkt. Met andere woorden, de professional definieert zelf zijn produkt(en) en zijn dienstverlening.

Marketing van produkten is niet zonder meer en ongewijzigd toepasbaar binnen de dienstverlenende sector (Booms en Bitner 1981, Baart et al. 1982, Grönroos 1982, 
Van der Hart 1983, Grinwis en Keuning 1985, Lysonski en Lombardo 1985, Van Delden 1988, Babakus en Mangold 1992).

Ook Kasper (1990) onderkent verschil tussen de marketing van produkten en de marketing van diensten. In tegenstelling tot de hierboven genoemde auteurs, stelt hij dat de marketing van produkten een aantal specifieke kenmerken kent ten opzichte van marketing van diensten, welke meer algemeen van aard is.

Hoe het ook zij, het is duidelijk dat er relevante verschilpunten aanwezig zijn in de marketing van diensten en produkten. De volgende verschilpunten kunnen worden genoemd (Rathmell 1974, Shostack 1977):

Geen eigendomsoverdracht.

Bij het verlenen van diensten vindt geen eigendomsoverdracht plaats. Er wordt service verleend, een onderzoek gedaan, een advies gegeven. De dienst kan niet meegenomen worden. De afnemer bevindt zich in een meer afhankelijke positie, want hij kan het aanbod alleen maar beoordelen in relatie tot de producent op het moment van de dienstverlening en vaak zelfs pas erna.

Niet op voorraad.

Diensten zijn niet op voorraad te maken of te leveren. Dit maakt planning moeilijker. De produktiecapaciteit moet zijn afgestemd op de vraagpieken; een flexibele capaciteit, waardoor het aanbod kan worden aangepast aan de vraag, is niet altijd mogelijk. Vooral in de dienstverlening, waar specialisme vereist is, vormt de aanwezige personele capaciteit een investering, die leidt tot vaste kosten in plaats van variabele kosten. Nieuw personeel vereist vaak aanzienlijke investeringen in training, opleiding en motivatie.

\section{- Geen uniforme kwaliteitsnormen.}

Bij het verlenen van diensten gaat de klant impliciet er meestal van uit dat de technische of professionele kwaliteit in orde is. Hij kan hier immers weinig of niet over oordelen. Daarentegen gaat de klant veel meer af op de zogenaamde functionele kwaliteit, de manier waarop men benaderd en bejegend wordt (Kruyt 1985).

De prestatie per situatie zal verschillen. Hierin spelen mee de persoon van de dienstverlener, de afnemer van diensten en het soort dienst.

Produktie en verkoop lopen vaak simultaan.

$\mathrm{Er}$ is een interactie tussen produktie en verkoop, en beide functies zijn niet altijd te scheiden, zoals in een industrieel bedrijf. Dienstverlenend personeel participeert in veel gevallen in de produktie. Langeard et al. (1981) stellen in dit kader een nieuw woord voor, namelijk servuctiesysteem. Dit betreft alle voor de client zichtbare elementen van het dienstensysteem. 
De client participeen in het productieproces.

Dit impliceert, dat de afnemer naast de producent, de dienstverlening en het resultaat hiervan mede beïnvloedt.

Baart et al. (1982) spreken in dit kader van een fundamentele en delicate positie. Fundamenteel omdat de persoon de dienst verleent en daarmee gelijk gesteld wordt met de organisatie. Delicast omdat hij de onderneming vertegenwoordigt en dus haar doelstellingen tegenover de client tracht te verdedigen, waarbij tegenstrijdige belangen een rol kunnen spelen. Des te groter de contactijd wordt, des te delicater is de taak van de contactpersoon in het dienstverlenend interactief proces.

\section{Diensten zijn niet tastbaar.}

In het algemeen bestaan diensten uit een aantal elementen waarvan sommige cen tastbaar karakter hebben (bijv. een rapportage over een werkplekonderzoek), en niet tastbare elementen (de adviesverlening op zich, dus het werk dat vooraf gaat aan het aanbieden van een rapport en de follow-up).

Een tastbaar produkt heeft normaliter een aantal karakteristieken die de herkenbaarheid vergroten, zoals bijvoorteeld de verpakking of cen merknaam. Hiermee kan door de leverancier van produkten worden gekozen voor een bepaalde "stijl" of presentatie. Ook een dienstverlenende organisatie (bijvoorbeeld een BGD) kan een keuze maken voor een bepaalde stijl: een luxueus gebouw, de eigen werkplekken zodanig inrichten dat zij een voorbeeldfunctie hebben voor de te verzorgen bedrijven, een uitbreiding van de openingsuren of een vergoeding van door klanten gemaakte reiskosten ("features"), een fraaie opmaak en lay-out van rapporten, of het hanteren van een logo.

Omdat, ook binnen de BGZ, de afname van diensten door de klant gepaard gaat met het nemen van risico's - het is op voorhand moeilijk in te schatten wat de klant precies zal krijgen en hoe de kwaliteit zal zijn -, is het mogelijk dat bij de klant op basis van positieve ervaringen "merkentrouw" ontstaat: de klant probeert niet gauw te dienst van de concurrent af te nemen, omdat dan het proces van risico-nemen opnieuw optreedt (Lovelock 1984).

Persoonlijke verklaringen ("testimonials"), mond-tot-mond reclame zijn in het kader van het tastbaar maken van diensten waardevol, vooral als dit gebeurt door "belangrijke" personen.

Een direct prijssignaal ontbreek.

Als in het bedrijfsleven een slecht produkt wordt geleverd, wordt dit snel opgemerkt. Het produkt wordt niet meer verkocht, de winst slinkt. In de nonprofit sector ontbreekt dit directe signaal.

- Verschillende doelgroepen.

De dienstverlenende sector kent vaak meerdere doelgroepen. Naast de directe klantenkring, dat wil zeggen de doelgroep waaraan de dienst geleverd wordt (in de BGZ zijn dat primair de werknemers), kan de dienstverlener ook te 
maken hebben met de groep die de dienstverlening mogelijk maakt, door deze ter beschikking te stellen en te betalen (in de BGZ zijn dit de werkgevers).

Daarnaast geldt dat professionele dienstverleners (zoals bedrijfsartsen) ook verantwoording willen afleggen naar de eigen beroepsgroep. Primair legt de professional normen en standaarden van de beroepsgroep aan bij de uitvoering van zijn werk (Mok 1973, geciteerd in Plomp 1987c). De beroepspraktijk van professionals kenmerkt zich in díe zin, dat overdraagbare kennis en regels een beperkte rol spelen, en dat vaak problemen spelen die een hoge mate van onvoorspelbaarheid bezitten. Dergelijke complexe en/of delicate problemen, zoals die binnen de BGZ frequent kunnen voorkomen (bijv. werkgever-werknemer relatie), en de verwachting dat een professional de exclusieve kennis en deskundigheid bezit deze problemen te behandelen, bepalen zijn positie (zie Plomp 1987c, Kotler en Clarke 1987, Verhage en Cunningham 1984).

In de volgende paragraaf wordt op enige knelpunten bij de toepassing van marketing in de BGZ ingegaan.

\subsection{Knelpunten bij de toepassing van marketing in de BGZ}

\subsubsection{Inleiding}

In hoofdstuk 2 werd beschreven dat de klant van BGZ kritischer is geworden. Bedrijven vragen zich af of zij een op hun wensen en problemen afgestemde BGZ krijgen. Vaker wordt de vraag naar de meerwaarde van BGZ gesteld.

Een groeiend aantal ondernemingen gaat selectiever met dienstverleners om, en een duurzame relatie tussen de dienstverlener en zijn klanten is niet meer zo vanzelfsprekend als voorheen. De klant is kritischer bij de keuze van zijn adviseurs (Van der Hart 1986). De klant vraagt om kwaliteit, om het zichtbaar maken van de kwaliteit van diensten (Cottaar 1989, Van Reekum 1989, Levie 1989).

In de collectieve contracten die tussen BGD'en en bedrijfstakken gesloten worden, worden in toenemende mate kwaliteitseisen gesteld. Er ontstaat tussen de diverse BGD-organisatievormen toenemende concurrentie. De voorheen vanzelfsprekende verdeling van de markt is aan het verdwijnen. Geprivatiseerde overheidsdiensten gaan zich op het terrein van het particuliere bedrijfsleven begeven, en vice versa. Bedrijfsverenigingen, commerciële Arbo-adviesdiensten gaan ook op de BGZ-markt opereren. Tot slot spelen ontwikkelingen op het gebied van de Arbo-wetgeving ook een rol. De overheid treedt terug, zij verwacht zelfwerkzaamheid van BGD'en op het gebied van kwaliteitszorg, maar stelt tegelijkertijd wel de eis dat de BGD'en een dergelijk kwaliteitssysteem extern laten toetsen.

Kortom, de noodzaak voor BGD'en om zich te profileren neemt toe. BGD'en zullen de klant duidelijk moeten maken welke meerwaarde zij voor bedrijven hebben, BGD'en zullen moeten kunnen inspelen op de wensen van de klant, de kwaliteit 
van de dienstverlening van BGD'en zal ook in de ogen van de klant, goed meeten zijn.

Toepassing binnen BGD'en van marketing in de ruime betekenis van het woord, zou hiertoe een substantiële bijdrage kunnen leveren. De inbreng van marketing is gelegen in enerzijds versterking van een klantgerichte cultuur binnen BGD'en, en in anderzijds verschaffing van marketinginstrumenten in strikte zin.

\subsubsection{Knelpunten}

In deze paragraaf wordt stilgestaan bij obstakels die toepassing van marketing in de BGZ bemoilijken.

Het gaat dan om een confrontatie van theorie (Van der Hart 1983 en 1986) en praktijk van BGZ (zoals deze is gebleken uit hoofdstuk 2).

\subsubsection{Het produkt BGZ}

Marketing heeft tot doel een ruiltransactie tot stand te brengen tussen leverancier en ontvanger. De vraag die gesteld kan worden is, of de BGD'en in stat zijn diensten te leveren waar klanten behoefte aan hebben. Hierbij doet zich een aantal problemen voor. Allereerst moet worden vastgesteld wie door de BGD als klant wordt beschouwd. BGD'en hebben te maken met meer klanten: werkgever en werknemers. Een complicerende factor hierbij is, dat BGD'en moeten opereren in een veld met ten dele tegengestelde belangen, waarbij het onderwerp van zorg en aandacht, gegeven de bedrijfsgezondheidkundige problematiek, vooral de werknemers zullen zijn en in mindere mate degene die het produkt BGZ betaalt, de werkgever. Deze heeft er natuurlijk wel belang bij dat zijn werknemers gezond en gemotiveerd aan het werk kunnen blijven. Dit spanningsveld maakt een expliciete profilering van en doelgroep-bepaling voor de BGD noodzakelijk. Het aantonen van de (meer)waarde van BGZ kan in conflict komen met de medische ethiek, en met de door de bedrijven aangereikte problematiek (Plomp 1987c). BGD'en bewegen zich namelijk voor een belangrijk deel op het gebied van "delicate" en gezondheidkundige problemen met een grote onzekerheidsfactor. Zonder schending van professionele codes, zoals het medisch beroepsgeheim, moeten BGD'en toch proberen aan te geven dát, en hoe zij een bijdrage kunnen leveren aan oplossing van problemen van individuele werknemers en het bedrijf.

Vanuit marketing oogpunt gezien dienen BGD'en te starten met de vaststelling van behoeften bij de gekozen doelgroep. Deze keuze moet passen bij de mogelijkheden van de BGD. In hoofdstuk 2 is gebleken dat BGD'en de BGZ-diensten (nog) onvoldoende hebben omschreven en geprofileerd in de egen van zowel de ontvangers van zorg, als de leveranciers zelf. Ook is in hoofdstuk 2 gewezen op de belangrijke verschillen tussen GD en EVD. GD en EVD hebben een verschillende klantenstructuur, zij hebben een verschillende positie in en ten opzichte van het bedrijf, en er bestaat een verschillend verwachtingspatroon. Dit zou moeten leiden tot een 
andere inzet van marketing(instrumenten) door de respectieve BGD-organisatievormen.

\subsubsection{Opstelling BGD}

Vaak verschilt de cultuur van een BGD van de cultuur van het bedrijf, waaraan BGZ wordt geleverd (Plomp 1987c).

Door de afnemers van BGZ wordt aan BGD'en (de professional) handelings- en beoordelingsbevoegdheid toegekend op het domein van arbeid-gezondheid. Deze professionele autonomie is echter geen vanzelfsprekendheid, maar een mandaat, dat wordt toegekend aan professionals door financiers en clienten. Dat mandaat wordt niet voor altijd verschaft, maar zal regelmatig moeten worden bijgesteld wanneer de omstandigheden (de bedrijfsproblematiek) zich wijzigen. Ook is denkbaar dat het probleem dat de aanleiding vormde een professional in te schakelen is opgelost of voor de organisatie voldoende beheersbaar is geworden, of dat er voor de organisatie meer asntrekkelijke alternatieve oplossingen zijn, hetzij in de probleemoplossende zin, hetzij in de leverancier van zorg (concurrentie). Mok (1973, geciteerd in Plomp 1987c) noemt als legitimeringsgronden voor het tot stand komen van professionaliseringsprocessen kennis, macht en probleem - en clientgericht denken.

Vanuit marketing oogpunt gezien is voor de BGD een markt- en klantgerichte opstelling van belang. De vraag is, gegeven de in hoofdstuk 2 geuite kritiek, of BGD'en er voldoende in geslaagd zijn zich marktgericht op te stellen. Professionaliteit krijgt binnen BGD'en de nadruk. De klant wordt nog weinig betrokken bij het formuleren van behoeften, en bij de evaluatie van de dienstverlening.

\subsubsection{Kwaliteit van $B G Z$}

In de kwaliteit van de geleverde dienst kan een BGD zich van zijn concurrenten onderscheiden. De vraag die in dit kader gesteld kan worden is wie de kwaliteit bepaalt c.q. beoordeelt. Is dit uitsluitend de leverancier van zorg, uitsluitend de klant, de overheid, of een combinatie? In de BGZ profiteert de werkgever, dat wil zeggen de klant die betaalt, meestal slechts indirect. Het grootste deel van haar activiteiten richt de BGD namelijk op een andere klantengroep, de werknemers. Onvoldoende kwaliteit wordt vaak via omwegen teruggekoppeld. Dit levert het gevaar op van vervreemding van de doelgroep en verlies van effectiviteit van dienstverlening (Van der Hart 1983). Tevens kan de vraag gesteld worden, welke criteria moeten worden gehanteerd bij het beoordelen van de kwaliteit van een dienst. Gaat het uitsluitend om professionele aspecten van kwaliteit ("technische kwaliteit"), of spelen klantgerichte aspecten ("functionele kwaliteit"), rendement en effectiviteit ook een rol? Gezien de verwevenheid van de BGZ met het bedrijfsgebeuren kain het niet anders dan dat naast de BGD zelf, ook de klanten een oordeel moeten kunnen geven over de geleverde dienst. Op de achtergrond spelen in de voorwaardenscheppende zin beroepsgroep en overheid mede een rol. 
Marketing zal met name hierbij de aandacht vragen voor inbreng van de klant. Voor de BGD brengt dit bijvoorbeeld met zich mee dat adequaat wordt omgegaan met klachten over de BGD of de BGZ (Booms en Bitner 1981), en dat de BGZ regelmatig wordt geëvalueerd.

Vanuit marketing oogpunt gezien is ook het oordeel van de klant over de kwaliteit van dienstverlening van belang. BGD'en lijken tot dusver te zeer de nadruk te leggen op "professionele" of "technische" aspecten van de kwaliteit van zorg. Er lijkt nog onvoldoende aandacht bij BGD'en om de klant te betrekken bij de beoordeling van de kwaliteit van BGZ. De afstemming tussen de door de klant gevraggde zorg en de door de BGD geleverde dienst, kan worden verbeterd.

\subsubsection{Scholing}

Het bedrijfsleven werd, zo werd in hoofdstuk 2 beschreven, geconfronteerd met een scala aan nieuwe problemen. De veranderde vraagstelling die hieruit voort. vloeit, zal repercussies hebben op de organisatie van de BGD. Er worden andere eisen gesteld aan mensen en middelen binnen de BGD. Naast vakinhoudelijke scho. ling. zal de bedrijfsarts bijvoorbeeld ook (meer) scholing dienen te krijgen in probleemoplossend en kJantgericht werken. Ook van de leiding van BGD'en wordt het nodige gevergd. Zij moet in staat zijn een organisatie te leiden, die flexibel in kan spelen op wensen van een breed pallet aan bedrijven, met behoud van een eigen identiteit en professionaliteit. Het sturen van professionele organisaties vraagt een specifieke aanpak (Weggeman et al. 1987, Heskett 1987).

Vanuit marketing oogpunt gezien is het omgaan met klanten, ook in professionele dienstverlenende organisaties, van belang.

De opleiding tot (bedrijfs)arts is nog onvoldoende gericht op het omgaan met klanten en organisaties. Wel wordt getracht in de huidige opleiding hierin meer te voorzien.

\subsubsection{Marketing-mix}

In hoofdstuk 2 is gebleken dat werkgevers en werknemers duidelijk wensen hebben ten aanzien van een andere tarief-opbouw van BGZ. Er worden door de klant wensen geuit over prijsdifferentiatie, taakdifferentiatie, bereikbaarheid en beschikbaarheid, profilering van de BGD en haar diensten. Ook BGD'en zelf geven aan dat wijziging van deze punten wenselijk is. De professionele cultuur van de BGD kan er de oorzaak van zijn dat tot dusver door BGD'en onvoldoende gebruik wordt gemaakt van marketinginstrumenten. Profilering en zichtbaar maken van de "produkten" van de eigen professie wordt in de professionele dienstverlening vaak als niet nodig of als niet-ethisch beschouwd (Lovelock 1984).

Grōnroos (1990b) wijst erop, dat bij de professionele dienstverlener, marketinginstrumenten met name moeten worden ingezet om met de klant duurzame relaties op te bouwen. Er kan niet worden volstaan met het cenmalig aan de man brengen van 
een dienst. Hij hanteert hiervoor resp. de termen "relationship marketing", en "transaction-marketing".

Vanuit marketing oogpunt gezien is het hanteren van marketing-mix instrumenten van belang. Binnen de gezondheidszorg in het algemeen en ook binnen de BGD'en, bestaat tot dusver een afwerende houding ten aanzien van toepassing van marketing-mix instrumenten bij het benaderen van het veld.

\subsection{Marketing en BGD}

Van der Hart (1986) gaat als een van de weinigen specifiek in op de toepassing van marketing in BGD'en. Wel wordt er door verschillende mensen en organisaties op gewezen dat marketing een kwaliteitsbijdrage kan leveren aan het produkt BGZ (Federatic 1990a, Van Reekum 1989, Van Hees 1987 en 1989, Levie 1989, Baas 1989, Jakobs 1989).

In paragraaf 4.2.2.2. kwamen de elementen van een marketingplan reeds aan de orde. Conform Van der Hart (1986) kan een drietal niveaus worden onderscheiden:

a. Het strategisch niveau: Hiermee wordt bedoeld dat de BGD'en een marktvisie ontwikkelen: welke produkten wil de BGD op de markt brengen, welke doelgroepen wil de BGD hiermee bereiken.

Bij toenemende concurrentie van leveranciers van BGZ (-elementen), zullen hierbij keuzen moeten worden gemaakt: hoe en waarin kan de BGD zich onderscheiden, hoe wil zij zich positioneren in de markt, hoe worden kwaliteitseisen, mede in overleg met de doelgroepen, geformuleerd?

De BGD'en zullen hierbij moeten inspelen op zich binnen ondernemingen afspelende veranderingen, zowel in het soort BGZ-problemen (vergrijzing beroepsbevolking, versterkte instroom van mensen met een handicap, een toename van de deelname van vrouwen aan het arbeidsproces, verschuiving van fysiek belastende arbeid naar psycho-mentale belasting), als in de wijze waarop ondernemingen zich organiseren (human resources management, business-unit structuur, privatiseren en afstoten van die activiteiten die niet meteen tot de kernactiviteiten van de onderneming behoren). BGD'en kunnen hierbij een weg kiezen die meer of minder dicht blijft bij de traditionele BGZprodukten. Wettelijke kaders laten voldoende ruimte voor eigen invulling. Sterker nog, bij een terugtredende overheid zal de totstandkoming van een BGZ-pakket steeds meer het resultaat zijn van "onderhandeling" en overleg tussen de direct betrokkenen, te weten werkgevers en werknemers.

Conclusie: de rode draad, de koers waarlangs wordt gevaren, moet duidelijk worden aangegeven en gemarkeerd. Dit is, zowel voor het functioneren van de BGD zelf, als voor het profileren naar de markt toe, een noodzakelijke voorwaarde.

b. Het tactische niveau: Nadat de grote lijnen zijn aangegeven waarlangs de BGD zich de komende jaren zou willen bewegen, dient te worden uitgewerkt hoe deze doelstelling(en) bereikt kan (kunnen) worden: hoe moet de marke- 
ting-mix worden gebruikt om het proces in de gewenste richting te sturen; welke eisen moeten worden gesteld aan de organisatie, aan de manier waarop de BGD haar werk moet organiseren; welke mensen en middelen moeten worden ingezet; hoe dient de tariefstelling te zijn? De activiteiten van de BGD moeten daarbij afgestemd worden op de vraag en de vraagsteller: een bouwbedrijf vraagt andere produkten en een andere benaderingswijze dan een ziekenhuis (zie ook Weggeman et al. (1987)). Daarnaast is een rol weggelegd voor interne marketing (binnen de BGD) om dit beleid te kunnen laten uitdragen door de uitvoerders van BGZ, en om een kwaliteits- en marketingcultuur te vormen c.q. te stimuleren.

c. Het operationele niveau: Tot slot moet worden aangegeven hoe de uitvoering in de praktijk moet plaatsvinden. Dit vereist training, scholing en deskundigheid van het personeel. Binnen een BGD gaat het dan om scholing van de professionele deskundigheid en van klantgericht werken. Hoe gaan medewerkers van de BGD met elkaar en met de klanten om, hoe dienen de communicatielijnen te verlopen, hoe is de bereikbaarheid geregeld? Een en ander kan concreet onder andere worden vertaald in voorbeeldfunctie directie, gedragsregels, huisstijl, reglement, en concrete dienstverlenings- of activiteitenplannen etc.

Aan de implementatie van een marketingplan, is een aantal voorwaarden verbonden. Allereerst dient er binnen de BGD in alle geledingen sprake te zijn van een markt- en klantgerichte mentaliteit. De klant dient bij alle activiteiten centraal te staan. Het streven van de BGD dient primair gericht te zijn op het oplossen van voor de klant relevante problemen. De klant dient ook een belangrijke plaats te hebben bij de evaluatie van geleverde diensten. Het SERVQUAL-model zou hierbij een nuttig instrument kunnen zijn. Deze klantgerichte houding dient tot uiting te komen in de communicatie met de klant, in het opbouwen van een relatie met de klant, in het geven van informatie over de mogelijkheden van de BGD, en in het omgaan met klachten van de klant. Een dergelijke klantgerichte houding dient echter niet uitsluitend extern gericht te zijn, dat wil zeggen naar de afnemers van BGZ. Ook intern, dat wil zeggen gericht op de medewerkers van de BGD onderling, dient sprake te zijn van een klantgerichte houding (interne marketing). In de tweede plaats dient er binnen de BGD een infrastructuur te zijn voor marketingactiviteiten. Systematisch en structureel moet informatie verzameld worden over de markt, maar ook over de eigen sterkten en zwakten, over de positie van de BGD ten opzichte van de concurrent. Nieuwe diensten moeten ontwikkeld worden. Tot slot dient een periodieke evaluatie van het dienstenpakket en de dienstverlening plaats te vinden. Onderzocht moet worden of doelen en doelgroepen bereikt zijn. Een dergelijke evaluatie dient integraal onderdeel uit te maken van de kwaliteitszorg van de BGD. 


\subsection{Samenvatting en conclusies}

In dit hoofdstuk werd het conceptuele kader van het begrip marketing besproken. Marketing werd hierbij breed opgevat. Aan de ene kant werd marketing beschreven als een klantgerichte manier van denken. Aan de andere kant werd marketing uitgewerkt als een complex van activiteiten. De elementen van een marketingplan werden geschetst. In paragraaf 4.3 werden de specifieke kenmerken van marketing in de dienstverlenende organisaties besproken. De knelpunten bij toepassing van marketing in BGD'en kwamen in paragraaf 4.4 aan de orde. Tot slot werden de elementen voor een marketingplan binnen BGD'en aangereikt.

Geconcludeerd kan worden dat toepassing van marketing een bijdrage kan leveren aan het verhogen van de kwaliteit van BGZ. Enerzijds ligt deze bijdrage in het expliciteren van een klantgericht dienstenpakket. Anderzijds ligt deze bijdrage in het benadrukken van het belang van klantgerichte aspecten van kwaliteit voor een "totaal" kwaliteitsoordeel. Het SERVQUAL-model biedt een mogelijkheid een aantal essentiële klantgerichte kwaliteitsaspecten te inventariseren, met name op het operationele niveau van BGD-activiteiten. Met dit model is een koppeling mogelijk tussen een eventueel tekort schieten van de klantgerichte kwaliteit, en de oorzaken hiervan in de organisatie. 


\section{Hoofdstuk 5}

\section{Wettelijk kader BGZ}

\subsection{Inleiding}

De overheid speelt mede een rol bij de totstandkoming van BGZ. In het onderzoek is deze rol verder niet onderzocht. De belangrijkste reden is dat verwacht mag worden dat er sprake zal zijn van een uniform effect van de rol van de overheid (wetgeving) ten aanzien van de door verschillende BGD(-organisatievormen) geleverde BGZ. Het door de overheid gehanteerde kwaliteitsinstrumentarium is in feite van toepassing voor de gehele BGZ. Tevens kan als reden worden opgevoerd dat de overheid wel een invloed kent op overkoepelend en globaal niveau, maar niet direct op bedrijfsniveau. Het onderzoek gaat echter juist in op de ervaren kwaliteit en de totstandkoming hiervan op (concreet) bedrijfsniveau.

Toch wordt in dit hoofdstuk wel de rol beschreven die de overheid c.q. wetgeving speelt en vooral heeft gespeeld bij de zorg voor arbeidsomstandigheden en de kwaliteit van zorgverlening door de BGZ. Hiermee wordt inzicht verkregen in de (mogelijke) bijdrage van de overheid en haar instrumentarium aan de totstandkoming van BGZ.

Paragraaf 5.2 bespreekt relevante arbeidswetgeving. Het ontstaan hiervan, alsook de achtergronden die tot betrokken wetgeving hebben geleid, worden aangeduid omdat hiermee inzicht kan worden verkregen in de rol die de overheid heeft gespeeld. Er zal nader worden ingegaan op de Arbowet, waarmee het kader van de BGZ wordt aangegeven. Paragraaf 5.3 beschrijft de ontwikkeling van BGZ en voor deze ontwikkeling relevante wetgeving. Het hoofdstuk wordt afgesloten met een korte beschrijving van de organisatie en het wettelijk kader van BGZ in het buitenland. Er kan immers worden verwacht dat voortschrijdende internationalisering van wetgeving en ervaringen met de organisatie van BGZ in het buitenland, in toenemende mate invloed zullen uitoefenen op de Nederlandse situatie.

\subsection{Relevante arbeids(omstandigheden)-wetgeving}

\subsubsection{Inleiding}

Uit bestudering van het ontstaan en de inhoud van relevante arbeids(omstandigheden)-wetgeving kunnen de effecten van de rol van de overheid en wetgeving op 
omvang en inhoud van BGZ naar voren komen. Beschermende wetgeving op dit gebied komt, in vergelijking met de ons omringende landen, pas laat (eind vorige eeuw) op gang. Vertaling van dergelijke wetgeving naar een organisatie van BGZ neemt de nodige tijd in beslag, zodat $B G Z$ als een relatief nieuw vak moet worden beschouwd. Deze constatering is van belang omdat het huidige kwaliteitsniveau van BGZ tegen deze achtergrond moet worden beoordeeld, tegen de achtergrond dat de BGZ nog niet kan bogen op cen lange staat van dienst, omdat zij pas haar intrede doet na de Eerste Wereldoorlog. Voor een meer uitvoerige (historische) beschrijving kan worden verwezen naar wetteksten, en naar Van Rijssen-Moll 1983 en 1987, Van Zwam 1986, 1987 en 1991, Geers 1988, Spreeuwers 1988, NIA 1989, Klaver en Vusse 1988.

\subsubsection{De geschiedenis van de arbeidswetgeving}

De eind vorige eeuw in Nederland intredende industrialisatie leidde tot een toenemende belangstelling voor de positie en het lot van arbeiders. $\mathrm{Z}_{\mathrm{ij}}$ vormden als het ware een nieuwe "klasse" met specifieke problematiek. De veelal erbarmelijke arbeidsomstandigheden, en de reacties hierop van zowel arbeiders zelf als "liberale" politici en fabrikanten vormden, de aanleiding voor de overheid om voor het eerst in de geschiedenis in te grijpen in de "vrije" relatie werkgever-werknemer. Aanvankelijk beperkt dit ingrijpen zich tot bescherming van kinderen (het beroemde Kinderwetje van Van Houten uit 1874). Door onderzoek naar de arbeidsomstandigheden in de industrie (bijvoorbeeld door parlementaire enquêtes) werd duidelijk dat ook voor andere groepen beschermende wetgeving gerechtvaardigd was. De Veiligheidswet 1895 en de Arbeidswet 1919 waren het resultaat. Daarnaast werd bescherming van de arbeidende mens vastgelegd in het Burgerlijk Wetboek (artikel 1638x, dat spreekt over de verplichting van de werkgever om de werknemer tegen gevaar voor lijf, eerbaarheid en goed te beschermen), en werd wetgeving voor specifieke arbeid verder uitgewerkt (Mijnwet, Caissonwet, Steenhouwerswet, Phosphorluciferwet, Stuwadoorswet). De Ongevallenwet van 1901 tot slot erkende het recht op compensatie van de financiële gevolgen van (bedrijfs)ongevallen.

Door de Veiligheidswet 1934 (en de hieruit voortvloeiende Veiligheidsbesluiten) wordt de werkingssfeer sterk uitgebreid.

In het begin van de zeventiger jaren bleek de vigerende Arbowetgeving niet meer adequaat. De veranderde ideeën over de rol van de arbeid, de bedrijfsgenoten en de overheid werden in de memorie van toelichting (TK 1976-1977, 14497, nr.3) als volgt verwoord: "Het gaat om een benadering, zo men wil een filosofie, die niet alleen op de veiligheidswetgeving van toepassing is, doch evenzeer op andere delen van het terrein van arbeidsbescherming. Deze kan zo worden verstaan dat naast de sterke motieven voortvloeiende uit de wens tot het voortdurend verhogen van de normen van bescherming, die op zichzelf al tot vernieuwing van de wetgeving dwingen, vooral geldt dat behalve aan economische welvaart in toenemende mate belang wordt gehecht aan het zich welbevinden van de werkende mens met betrek- 
king tot zijn werk. Het zich welbevinden bij het werk moet geplaatst worden binnen het kader van het tijdsbestek en zal dan ook in overeenstemming moeten zijn met de heersende opvattingen onder de werknemers over de beleving van hun arbeid". Humanisering van de arbeid wordt een wettelijk vastgelegde doelstelling. De considerans:" ... zulks ter bevordering van menswaardige arbeid".

Voor het eerst geeft de wet aan, welke beginselen zij bij de bescherming van het arbeidsmilieu wenst te hanteren, niet met de bedoeling concrete voorschriften op te leggen, maar als leidraad voor binnen bedrijven te ontwikkelen Arbobeleid. Andere wetgeving paste ook beter in het veranderde denken in de samenleving en bij de overheid, cen denken waarbij vrijwillige samenwerking tussen de sociale partners een plaats krijgt naast of in plaats van dwingende wetgeving. De taak van de wetgever ligt dan bij het scheppen van juridische garanties en institutionele kaders om deze zelfwerkzaamheid van het bedrijfsleven te kunnen concretiseren (de "terugtredende" overheid).

Hoewel de "filosofie die uit het wetsontwerp sprak" door alle politieke fracties met instemming werd ontvangen, stuitte met name de introductie van het begrip welzijn, en het onvoldoende (kunnen) concretiseren en limiteren van de consequenties hiervan, op weerstand, of het gaf althans aanleiding tot frequente discussies. Uiteindelijk is hierop in die zin ingespeeld dat het begrip welzijn is gelimiteerd en geconcretiseerd tot een viertal clusters (Vaas 1988, Arboraad 1989, Peeters 1990, Voskamp 1987 en 1988b). Het ontwerp Arbowet werd na 5 jaar politieke discussie, zonder dat in essentie de doelstelling en de uitwerking van de wet werd aangetast, kamerbreed aangenomen en in Staatsblad 664 gepubliceerd als Wet van 8/11/80, houdende de bepalingen in het belang van de veiligheid, de gezondheid en het welzijn in verband met de arbeid (Arbowet). Hiermee kwam wetgeving tot stand die duidelijk afwijkend was van vroegere wetgeving in die zin dat:

- humanisering van (of welzijn bij) de arbeid een wettelijk vastgelegde doelstelling werd;

- de overheid zich terughoudend(er) opstelt: de zorg voor arbeidsomstandigheden laat de overheid over aan werkgever en werknemer (artikel 4), maar wel binnen indicatieve normen (artikel 3);

- de ontwikkeling van deskundigheid binnen de onderneming op het gebied van arbeidsomstandigheden werd gestimuleerd.

Ook de Arbowet werd onderworpen aan de "toets" van de overheid om haar regelgeving te dereguleren en te vereenvoudigen (Voskamp 1988a).

Een stortvloed van amendementen ten spijt werd de "gedereguleerde" Arbowet aangenomen en verscheen de wijziging van de Arbowet in 1987 (staatsblad 535). De minister toonde zich tevreden over de sterkte van de Arbowet. Immers, ondanks de toetsing van twee zware commissies was de in de wet verankerde systematiek van globale normen met daaraan gekoppeld een grote eigen verantwoordelijkheid voor werkgevers en werknemers, ondersteund door terzake deskundigen, overeind gebleven en als goed beoordeeld. 


\subsubsection{Invoering van de Arbowet: fasen en consequenties}

Over het tijdpad van invoering van de Arbowet, alsmede de uitbreiding hiervan in de diverse sectoren, is uitvoerig gedelibereerd, met als resultaat een uiterst onoverzichtelijke invoering van de Arbowet. De gestelde fasering werd meestal niet gehaald, met name bleef de invoering bij de sectoren als onderwijs, overheid en justitie sterk achter. Eind 1991 kan er worden vastgesteld dat de Arbowet in al zijn fasen is ingevoerd (Kuin 1987, Reubsaet et al. 1988, VBR 1990, DGA 1989a, Arboraad 1990b). Door Van Zwam (Van Zwam 1991) wordt gepleit voor een thematische vitwerking van "veiligheidsbesluiten" in plaats van sectorale veiligheidsbesluiten. Dit is overzichtelijker en sneller.

De deregulering had ook consequenties voor de Arbeidsinspectie en de Arboraad, een belangrijk advies- en overlegorgaan met de sociale partners voor de overheid op het gebied van arbeidsomstandigheden (Zoest 1988).

Aan de Arbeidsinspectie werden bij krimpende middelen meer taken toegedacht (bijvoorbeeld het voeren van introductiegesprekken bij de bedrijven ter voorbereiding van de invoering van de Arbowet). Naar aanleiding van een weinig positief rapport van de Rekenkamer, verschenen in 1989, over het functioneren van het DGA en de Arbeidsinspectie, kwamen nogal wat reacties los. De vakvereniging, FNV, herkende het door de Rekenkamer geschetste beeld, en pleitte ondermeer voor capaciteitsuitbreiding en versterking van het management. Staatssecretaris de Graaf van Sozawe acht daarentegen de Arbeidsinspectie anno 1989 wel voor haar taken berekend, en stelt dat zij middels een actieve en projectmatige werkwijze (bijv. project Arbo '91) de effectiviteit van handelen reeds aanmerkelijk had opgevoerd. Een personeelsuitbreiding werd voorzien. Ook binnen het Directoraat Generaal van de Arbeid (DGA) vond eind tachtiger jaren een interne reorganisatie plaats, die een meer geïntegreerde, multidisciplinaire en gerichte beleidsvoering mogelijk moest maken (Willems et al. 1988, Smid 1988).

Het meest indringende effect van deregulering van de Arbowet op de taken van de Arboraad was dat met ingang van 1/1/88 de betrokkenheid van de Raad (en dan met name het college van bijstand en advies voor de BGZ) bij individuele gevallen beëindigd werd. Dat wil zeggen dat zij zich sinds die tijd niet meer bezighoudt met de goedkeuring van de aanstelling van artsen als bedrijfsarts, of de advisering over de erkenning van BGD'en. Wel vindt de beleidsmatige advisering over de BGZ op de normale wijze voortgang, zij het dat in beleidsvoorbereidende zin meer aan het DGA wordt gedelegeend (NVAB 1989b). Ook de samenstelling van de Raad veranderde: meer participanten van werkgevers en werknemers ten koste van beroepsgroepen. Krachtens kabinetsbesluit zal na realisatie van de invoering van de Arbowet gežvalueerd worden of de Arboraad blijft bestaan, mede in relatie tot de activiteiten van de SER (Zoest 1988). Het zwaartepunt, aldus de secretaris van de Arboraad bij gelegenheid van het eerste lustrumsymposium, zal gaan verschuiven naar de uitvoeringsproblematiek en de verdere uitwerking van de wet, bijv. de uitbrei- 
ding van de BGZ. De samenstelling van de Arboraad sluit het beste aan bij internationale regelingen, die de betrokkenheid van de sociale partners bij regelgeving op Arbobeleid essentieel achten (NVAB 1990c).

\subsection{Ontwikkeling BGZ \\ Relevante wetgeving}

\subsubsection{Inleiding}

De geschiedenis van de sociale geneeskunde in ons land begint met het optreden van de hygiënisten omstreeks het midden van de vorige eeuw. Door de vanaf die tijd langzaam toenemende industrialisatic ontstonden nieuwe problemen ten aanzien van de volksgezondheid. Door genoemde hygiënisten (stadsgeneesheren of armendokters) werd een samenhang vastgesteld tussen leef-, woon- en werkomstandigheden en het voórkomen van ziekten. $\mathrm{Z}_{\mathrm{ij}}$ trokken uit hun bevindingen cok politieke conclusies. $\mathrm{Zij}$ bepleitten sociaal-maatschappelijke hervormingen teneinde de volksgezondheid te bevorderen. Mensen als Coronel, Heyermans hebben op het gebied van de "arbeidsgeneeskunde" baanbrekend en initiërend werk geleverd (Van Rijssen-Moll 1983, Spreeuwers 1988, Houwaart 1983, Ten Have 1983).

Maar ook de rol van de Arbeidsinspectic is van groot belang geweest voor het vergroten van onze kennis op het gebied van de arbeidsomstandigheden, en het vertalen hiervan in concrete (wettelijke) maatregelen. Werd in het begin de zorg voor gezonde en veilige arbeidsomstandigheden gezien als een louter "technische aangelegenheid", langzaam maar zeker werd onderkend dat ook (preventieve) medische advisering op dit gebied wenselijk was. De aanstelling van een medicus (in 1903) bij de Arbeidsinspectie was dan ook een logische stap.

Al na het inwerking treden van de Veiligheidswet $1895 \mathrm{kwam}$ de vraagstelling aan de orde of de zorg voor de hygiëne bij de arbeid niet in de bedrijven zelf georganiseerd diende te worden in plaats dat deze door de overheid van buitenaf werd opgelegd. Het duurde tot 1928 voor dit onderwerp weer ter sprake kwam. De toenmalige medisch adviseur van de Arbeidsinspectie pleitte toen voor de aanstelling van speciale artsen voor het bedrijfsleven, al was het maar omdat de Arbeidsinspectie gezien haar doelstelling en personele middelen nooit een werkelijk passende zorg zou kunnen leveren (van Rijssen-Moll 1983).

In enkele grote Nederlandse bedrijven ontstonden na de eerste wereldoorlog Geneeskundige Diensten, die als hoofdtaak de ongevallen behandeling hadden, doch die tevens aandacht schonken aan de preventie van ongevallen, beroepsziekten en ziekteverzuim. Uit de geschiedenis van de BGZ blijkt dat de gebieden waarop BGZ zich concentreert, in de tijd variëren. Zo stond bijvoorbeeld de opsporing van tuberculose in de BGZ centraal ná de crisis in de jaren dertig, en vormde in die tijd tuberculoseopsporing als het ware de kurk waarop de BGZ dreef.

In 1946 werd binnen het raam van de Nederlandse Vereniging voor Sociale Geneeskunde de sectie (later Nederlandse Vereniging) voor Arbeids- en Bedrijfsge- 
neeskunde opgericht. De NVAB heeft aanzienlijk bijgedragen aan de omschrijving van de taken en de werkwijze van BGD'en, ondermeer door het samenstellen van een rapport (NVAB 1948) waarin werd aangedrongen op een wettelijke regeling van de BGZ. Een daarna door de Minister van Sociale Zaken en Volksgezondheid ingestelde Commissie Wettelijke Regeling van de Bedrijfsgeneeskunde in Nederland onder voorzitterschap van de Directeur Generaal van de Arbeid, Ir. Z. Th. Fetter, werkte deze plannen verder uit (1952). Een afsluiting van deze trend naar erkenning van BGZ is de totstandkoming van de Wet op de Bedrijfsgeneeskundige Diensten (Wet van 19 februari 1959 tot aanvulling van de Veiligheidswet en de Stuwadoorswet, Staatsblad 56), waarin worden omschreven "Maatregelen met betrekking tot de preventieve gezondheidszorg in fabrieken en werkplaatsen" (Burger 1974).

\subsubsection{Wet op de Bedrijfsgeneeskunde 1959}

\section{Aanvulling Veillgheidswet 1934}

In 1959 werd aan de Veiligheidswet 1934 een nieuwe paragraaf toegevoegd betreffende de bedrijfsgeneeskundige diensten. De overheid beoogde hiermee de BGZ in Nederland een wenselijk geachte stimulans te geven (Geers 1988). Tevens zou het verzorgingsveld van de BGZ beter omgrensd kunnen worden, en zouden er richtlijnen gegeven kunnen worden voor de opzet van BGD'en en waarborgen voor de onafhankelijkheid van de bedrijfsarts in de onderneming. Hoewel de materie mede betrekking heeft op het algemene terrein van de gezondheidszorg en tegelijkertijd kan worden beschouwd als een medische beroepsregeling, is geen aansluiting gezocht bij gezondheidszorgwetgeving. Dit werd gemotiveerd met de overweging, dat het bedrijfsgeneeskundig werk zijn primaire taak vindt in de onderneming en dat een regeling terzake derhalve aan moet sluiten bij andere, het interne ondernemingsgebeuren rakende regels. Bovendien zou het toezicht op de BGD'en toevallen aan de Arbeidsinspectie (Geers 1988).

In deze wet werd voor bedrijven bedrijfsgeneeskundige verzorging verplicht gesteld bij een bepaalde grootte (meer dan 750 werknemers) of bij bepaalde risico's voor de gezondheid van de werknemers. De wet geeft aan welke taakelementen een BGD moet kunnen verrichten. De opgesomde taken zijn die welke integraal zijn overgenomen in artikel 18 van de Arbowet.

Voorts worden er erkenningseisen gesteld aan het personeel, de medische zelfstandigheid en de outillage (later o.a. uitgewerkt in Besluiten eisen BGD'en).

Daarnaast achtte de overheid afbakening met de overige sectoren van de gezondheidszorg indertijd wenselijk. Er werd gesteld (artikel 8d) dat een BGD bij het uitoefenen van haar taken geen adviezen geeft of behandelingen toepast, welke in de verhouding van de patient tot zijn huisarts treden, en dat de BGD zich, na het constateren van een ziekte of afwijking, onthoudt van verrichtingen welke behoren tot het terrein, waarop consultatiebureaus en soortgelijke instellingen van gezondheidszorg werkzaam plegen te zijn. Met instemming van patient en huisarts/instelling mag overigens wel tot behandeling overgegaan worden.

(Opgenorkt tan nog worden dat in de Bijlago bij de Handelingen Tweode Kamer 1954-1955,3834,nr.3 (M.v.T.) wordt voorgesteld om de grens van verplichtstelling voor BGZ voor een bedrijf bij 250 wertanemers 
to beggea, mot de optie dat dit gotal geleidelijk vorlaagd zou kunnen worden naar gelang meer bedrijfsartsen beschikbas zoculen komen).

\subsubsection{Wijziging Veiligheidswet 1971}

Het werkingsgebied van de Veiligheidswet werd aanzienlijk uitgebreid door de Wet van 25 maart 1971 tot wijziging van de Veiligheidswet 1934 en de Stuwadoorswet (Staatsblad 225). De verplichtstelling tot het hebben van een BGD wordt niet meer gerelateerd aan een fabriek of werkplaats, maar aan een inrichting van een onderneming vallende onder een bij AMVB aangewezen categorie van inrichtingen. Bij het bepalen van het getalscriterium telt ook het kantoorpersoneel mee. De verplichtstelling geldt ook als bedrijven of bedrijfsonderdelen in elkaars nabijheid liggen. Door deze wijziging van de Veiligheidswet werd ook wijziging noodzakelijk van respectievelijk het Besluit eisen BGD'en (13/11/1974, staatsblad 741) en het Besluit verplichtstelling van BGD'en (13/11/1974, staatsblad 740). In 1982 (Staatsblad 408) werd het Besluit verplichtstelling BGD'en weer gewijzigd, in die zin dat het getalscriterium werd teruggebracht naar 500. Daarnaast werden de werkverbanden als bedoeld in artikel 10, lid 1, van de Wet sociale werkvoorziening, aangewezen tot verplichtstelling van BGZ. In 1990 wordt het verplichtstellingscriterium bijgesteld in die zin dat een bedrijf, onafhankelijk van zijn totale grootte, verplicht is tot aansluiting bij een BGD of veiligheidsdienst als er 330 werknemers arbeid in een fabriek of werkplaats of stuwadoorsarbeid verrichten (dus niet meer het criterium "uitsluitend of in hoofdzaak").

\subsubsection{Wijzigingen Arbowet en andere relevante wetgeving}

De laatste jaren zijn de ontwikkelingen op arboterrein in een stroomversnelling geraakt. Door de overheid is een duidelijke koppeling gelegd tussen enerzijds Arbozorg, en anderzijds verzuimbegeleiding. De klassieke taakverdeling tussen BGD'en en bedrijfsverenigingen vervaagt door nieuwe wetgeving, zoals de gewijzigde Arbowet en de Wet Terugdringing Ziekteverzuim (TZ). Concurrentie wordt bevorderd. Aan marktaanbieders zullen dezelfde eisen worden gesteld. De term "BGD" verdwijnt, er wordt voortaan gesproken over arbodiensten. De nieuwe ontwikkelingen laten zich als volgt samenvatten:

(Opgemerkt kan worden dat bij het ter perse gaan van het onderzoek over onderstaande voorstellen nog definitieve besluitvorming moest plaatsvinden).

\section{Wijziging Arbowet}

Aan het huidige artikel 4 wordt toegevoegd dat het (VGW-)beleid gebaseerd moet zijn op een deugdelijke en op schrift gestelde inventarisatie en evaluatie van alle gevaren op het terrein van de gezondheid, de veiligheid en het welzijn. Deze arbobrede inventarisatie en -evaluatie van risico's is voortaan de basis voor beleidsvoering door de werkgever. 
- In cen nieuw artikel 4a wordt bepaald dat het ondememingsbeleid zich ook moet richten op het zoveel mogelijk beperken van het ziekteverzuim. Onderdeel daarvan is in ieder geval de begeleiding tijdens ziekte.

- Artikel 17 en 18 veranderen ingrijpend. Aan de ene kant komt er voor iedere werkgever de verplichting zich voor een aantal benoemde taken te laten ondersteunen door deskundigen, aan de andere kant ontstaat er een grote organisatievrijheid voor de werkgever hoe hij, in samenspraak met de ondememingsraad, hieraan invulling wil geven. Er is echter eén maar, de organisatievrijheid wordt ingeperkt voor de eerste drie van de hieronder genoemde taken, waarvoor de werkgever een gecertificeerde arbodienst moet inschakelen.

1. bijstand bij het verrichten en opstellen van de risico-inventarisatie en evaluatie en advisering daarover;

2. bijstand bij verzuimbegeleiding;

3. arbeidsgezondheidkundig onderzoek (lees: vrijwillig en risicogericht periodiek onderzoek). Voor deze taak wordt een nieuw artikel 24a geintroduceerd;

4. adviseren en samenwerken met werkgever, werknemers en de ondernemingsraad;

5. ondersteuning bij de uitvoering.

De verplichting zich te laten ondersteunen bij de risicoinventarisatie en evaluatie en bij de verzuimbegeleiding door een gecertificeerde arbodienst zal gefaseerd worden ingevoerd. Op basis van verzuimhoogte en arborisico's worden twee klassen onderscheiden. Bedrijven uit de eerste klasse, waaronder bouwnijverheid en vervoer, zullen uiterlijk 1/1/95 in het bezit moeten zijn van een door een arbodienst goedgekeurde risicoinventarisatie en -evaluatie, en zij zullen zich uiterlijk vanaf $1 / 1 / 95$ voor de verzuimbegeleiding moeten laten bijstaan door een gecertificeerde dienst. Voor werkgevers uit klasse twee geldt als datum 1/1/97.

- In het nieuwe artikel 31 a wordt het begrip certificatie geintroduceerd. Het is niet meer en minder dan dat de overheid toetst of aan (minimale) wettelijke eisen wordt voldaan. Specifiek zal daarbij worden gelet op de arbobrede deskundigheid. Het toezicht door de Arbeidsinspectie en de handhavingsmogelijkheden zullen uitgebreider worden (aanwijzing, intrekking certificaat). De geldigheidsduur van een certificaat is steeds beperkt tot maximaal 4 jaar. Een te verwachten ontwikkeling is dat de overheid t.z.t. zal besluiten om de certificatie uit te besteden.

\section{Besluit Arbodiensten}

Het begrip "erkenning" verdwijnt, en wordt vervangen door "certificatie". Hiermee wordt aangegeven dat arbodiensten niet meer worden erkend per bedrijf, maar als arbobrede deskundige dienst op zich zelf. De huidige BGD'en komen als zodanig niet voor een certificaat in aanmerking en kunnen derhalve geen kerntaken verrichten voor de werkgever. 
Van een arbodienst is allleen sprake als er binnen de dienst tenminste én (in verband met de continuitteit) deskundige aanwezig is op de volgende vier vakgebieden: arbeids- en bedrijfsgeneeskunde, arbeidshygiëne, veiligheidskunde en de arbeids- en organisatiekunde. (N.B. het is nog de vraag of alle genoemde deskundigen in het definitieve besluit een plaats houden). Voor de toets op de deskundigheid van kerndisciplines zal zoveel mogelijk gebruik worden gemaakt van registers van beroepsbeoefenaren of het bezit van cen certificaat van vakbekwaamheid, die door de minister wordt aangewezen. Dit laatste zal nog moeten plaatsvinden voor wat betreft de arbeids- en organisatiekunde.

Een groot aantal organisatie-eisen gaat vervallen, zoals het afstandsheginsel ten opzichte van de te verzorgen bedrijven, de eis van tenminste ten werknemer in het bestuur, het non-profit-beginsel, het jaarverslag en de eis dat de arts of veiligheidskundige hoofd van dienst moet zijn. De dienst moet wel in hoofdzaak arbo-ondersteuning als bedoeld in de wet tot doel hebben.

De uitrustingseisen zijn globaal geformuleerd en wijken nauwelijks af van het verleden. Gesteld wordt dat in elk geval ter beschikking staan de benodigde apparatuur en hulpmiddelen, alsmede, voorzover de uitoefening van de taken dit vereist, een spreekkamer, een wachtkamer, een behandelruimte en een kleedruimte die zodanig zijn ingericht, dat de privacy van de werknemers is gewaarborgd. Op basis van de Wet Persoonsregistraties worden ook eisen gesteld aan de opslag en toegankelijkheid van (medische) gegevens. Nieuw is de bepaling dat arbodiensten als onderdeel van het certificaat verplicht zijn desgevraagd de nodige statistische gegevens aan de minister te verstrekken. De diensten zullen worden getoetst op het in staat zijn tot het verlenen van diensten aan in principe elk bedrijf. Er zal een zgn. audit worden ontwikkeld, waarin wordt opgenomen een steekproef in bedrijven naar het effect van de dienstverlening. Belangrijke functie-eisen zijn: het op een upto-date wijze vervullen van taken, gestructureerde en systematische arbozorg en verzuimbeleid (met speciale aandacht voor risicogroepen, ongevallen en beroepsziekten), de evaluatie van de dienstverlening, en de continuîteit van dienstverlening.

\section{Wet Terugdringing Ziekteverzuim}

Op basis van deze wet komen de kosten van ziekte gedurende de eerste 6 weken (voor bedrijven met minder dan 15 werknemers wordt dit waarschijnlijk 2 weken) voor eigen rekening van de werkgever. Gedurende deze eigen-risicoperiode is de werkgever ook verantwoordelijk voor de controle en begeleiding van de zieke werknemer. Hij moet daarbij gebruik maken van een gecertificeerde deskundige. De wet bouwt verder nog andere prikkels in die ertoe moeten leiden dat werkgevers een actief verzuimbeleid voeren en dat verzuim en arbeidsongeschiktheid worden teruggedrongen.

\section{Arbobesluiten}

Om uitvoering te geven aan een aantal internationale verplichtingen zag een woud aan Besluiten en arbovoorschriften het licht in de afgelopen jaren. Voor BGZ relevante besluiten zijn o.a. het Besluit Beeldschermwerk, Bedrijfshulpverlening, Per- 
soonlijke Beschermingsmiddelen, Toxische stoffen, Fysieke belasting en de Lawaairichtlijn.

\subsubsection{Kwaliteitsinstrumenten in de Arbowet}

In paragraaf 2 werd de betekenis besproken van de invoering van de Arbowet op het Arbobeleid. In deze paragraaf wordt besproken welke instrumenten de overheid kan hanteren om de kwaliteit van BGD'en te toetsen. Er kan overigens worden geconstateerd dat de overheid in het laatste decennium ernaar streeft, toetsing van de BGZ aan het veld zelf over te laten (bedrijven en BGD'en) (DGA 1989b, NRV 1987).

Omdat mag worden verwacht dat in het vigerende systeem van kwaliteitsbewaking op korte termijn de nodige wijzigingen zullen optreden, wordt volstaan met het kort memoreren van door de overheid te hanteren instrumentarium bij de bewaking van de kwaliteit van BGZ tot dusverre. Het gaat dan om zaken als (Arboraad 1984): de aanwijzing (de mogelijkheid van de overheid een bedrijf te verplichten BGZ aan te trekken), de ontheffing en de erkenning. Ingevolge artikel 18 Arbowet moeten er bij AMVB of bij ministeriële beschikking nadere regels worden gesteld met betrekking tot BGD'en. Het gaat dan om eisen die worden gesteld aan het takenpakket van de BGD, aan de uitrusting en de personeelsbezelting van een BGD, aan het personeel en aan de samenwerking met andere deskundigen.

De Arboraad constateert (Arboraad 1984) dat de Arbowet slechts voorziet in een erkenning van diensten, die werkzaam zijn voor verplicht aangesloten bedrijven, en geen regeling kent op grond waarvan een werkgever zijn vrijwillige dienst of de GD waarbij hij op basis van vrijwilligheid is aangesloten, op eigen verzoek ten behoeve van zijn bedrijf kan laten erkennen. Weliswaar bestond in het kader van de Veiligheidswet de mogelijkheid van vrijwillige toetsing, maar deze kon niet leiden tot erkenning. Van diverse zijden werd de wens geuit naar een andere regelgeving (Willems 1988, NVAB 1984b).

Dit heeft geleid tot een voorstel Stelselwijziging bedrijfsgezondheids- en -veiligheidszorg (DGA 1989b). Er wordt een aantal redenen genoemd waarom wijziging noodzakelijk is: een effectief en efficiënt kunnen bevorderen van zowel de kwaliteit als de uitbreiding van BGZ, en internationale ontwikkelingen (bijvoorbeeld de EEG kaderrichtlijn "betreffende de tenuitvoerlegging van maatregelen ter bevordering van de verbetering van de veiligheid en de gezondheid van de werknemers op het werk", EEG 89/391).

De kern van het voorstel is het aanspreken van het veld van de gezondheidszorg en maatschappelijke dienstverlening op zijn verantwoordelijkheid voor de kwaliteit. Certificatie (door een privaatrechtelijke instantie) kan daarbij een nuttige functie vervullen. Het is denkbaar dat de overheid het veld bepaalde procedures oplegt welke moeten leiden tot door het veld zelf te ontwikkelen kwaliteitseisen. Waar nodig zal ook de overheid een actieve rol spelen ten aanzien van kwaliteitsnormering. De overheid zal tenminste de minimum-eisen moeten bepalen en moeten toe- 
zien op de naleving. Toezicht moet zich in de toekomst richten op het zorgsysteem als zodanig (en niet op het tot aansluiting bij een BGD verplichte bedrijf), waarbij niet langer onderscheid wordt gemaakt tussen verplichte en vrijwillige zorg. Deze laatste zal in de nieuwe opzet evenzeer moeten worden beoordeeld op kwaliteit. Het wettelijk handhavingsinstrumentarium zal zich rechtstreeks moeten richten op de dienstverlening door de deskundige dienst wat betreft die aspecten van zorg, die tot de eigen beïnvloedingssfeer van de dienst behoren en die voorwaarde zijn voor goed kwalitatief functioneren. De sanctiemogelijkheden moeten worden uitgebreid in die zin, dat langs een korte weg de dienst op onderdelen van de kwaliteit van zijn dienstverlening kan worden aangesproken door middel van een aanwijzing en/of eis wasabij de weigering/intrekking van de erkenning meer als laatste en zwaarste sanctie wordt gehanteerd. Daarnaast moet de werkgever worden aangesproken op die aspecten die betrekking hebben op diens directe invloedssfeer en verplichtingen. Het accent bij toetsing door de Arbeidsinspectie zal meer dan voorheen moeten liggen op regeimatig toezicht (audit) op beleids-en taakstellingsniveau in tegenstelling tot de thans gebruikelijke toetsing op taakverrichtingsniveau (DGA 1989b). De Arbeidsinspectie krijgt dus zowel een rol bij toetsing van de deskundige dienst, als ook bij de toetsing van de Arbozorg in en door de bedrijven.

Met betrekking tot het stellen van wettelijke minimumnormen door de overheid zal er vooral een zwaardere eis worden gesteld ten aanzien van de multidisciplinaire (ook niet-medische) professionaliteit van diensten die Arbozorg leveren. Dit wordt noodzakelijk geacht om invulling te kunnen geven aan effectuering van het in de nieuwe regelgeving sterk gestimuleerde bronbeleid in bedrijven. Aan de verschillende deskundigen zullen eisen van professionele deskundigheid (bijvoorbeeld voor bedrijfsartsen inschrijving in het register van de KNMG) en eisen m.b.t. het functioneren (in relatie tot het bedrijf) worden gesteld.

De EG-richtlijn 89/391 bepaalt dat het bereikte preventieniveau in de Lid-staten niet mag worden verlaagd. Daarom blijven de vroeger "verplichte" bedrijven verplicht om hun zorg voor het gezondheidsdeel volledig te betrekken bij de BGD'en. Voortaan wordt echter (in de wet) niet meer gesproken over BGD'en, maar over deskundige diensten van het hoogste deskundigheidsniveau. Bovendien zullen overige bedrijven het zogenaamde kerntakenpakket altijd moeten betrekken van een dienst van het hoogste deskundigheidsniveau. Dit kerntakenpakket bestaat uit drie onderdelen, namelijk de op schrift gestelde risicoinventarisatie en -evaluatie met advies, de verzuimbegeleiding en het periodiek onderzoek. De overige taken, voor zover nodig gebleken uit de risicobepaling of rechtstreeks voortvloeiend uit de wet kan de werkgever ook bij andere deskundigen onderbrengen (Mulock 1992, Kwantes 1992).

De overheid geeft hiermee aan welke doelen zij voor ogen heeft: deskundige ondersteuning voor alle werknemers/werkgevers bij het Arbobeleid en het verzuimbeleid. De belangrijkste verschillen met het huidige stelsell zijn dat de verplichtstelling voor preventiezorg wordt uitgebreid naar alle arbeidsorganisaties, dat de wet een doelvoorschrift geeft door te stellen dat preventietaken gerelateerd moeten zijn aan de 
omvang van de arborisico's in de arbeidsorganisaties, en dat het nieuwe systeem impliciet uitgaat van geĩntegreerde zorg in plaats van de huidige kolomsgewijze deskundige zorg (Feringa et al. 1992).

\subsubsection{Uitbouw BGZ}

Het aantal werknemers dat in ons land BGZ ontvangt wordt geschat op ruim 1,7 miljoen, zijnde ruim een derde van de werkende bevolking (NIPG/TNO, stand op 1/8/88). Het aantal verzorgde werknemers bleef sinds 1982 ongeveer gelijk, nadat dit vanaf 1970 tot 1982 zij het in afnemende mate nog toenam! Al jaren wordt door diverse gremia (overheid, beroepsgroep, adviescommissies) gepleit voor een uitbreiding van BGZ ten behoeve van iedereen die beroepsmatig arbeid verricht (NRV 1987. TK 13/9/79, 14497.9, werkgroep directeuren GD'en 1984, TK 1978-1979, 15300 hoofdstuk XV, nr. 30).

Er wordt gesteld dat BGZ cen bijdrage kan leveren aan het terugdringen van gezondheidsrisico's in en door het werk, en aan een optimalisering van condities, welke de mens in staat stellen tot een verdere ontplooiing en bevrediging in de arbeidssituatie. De vraag is dan ook gewettigd of het capaciteitsprobleem aangaande de bedrijfsartsen cen voldoende valide argument is om, in tegenstelling met de situatie in het buitenland, BGZ (nog) niet voor iedereen die beroepsmatig arbeid verricht, verplicht te stellen.

Bij de uitbreiding van BGZ naar de gehele beroepsbevolking, dient rekening te worden gehouden met de ontwikkeling van richtlijnen en criteria teneinde tot een rationele, sluitende en efficiënte gebiedsindeling te komen (NVAB 1985b). Een daartoe door de NVAB ingestelde commissie stelde voor de volgende criteria te hanteren: historische (situatie is zo gegroeid), efficiëntie-, adherentie-, en geografische criteria. Een en ander laat specifieke wensen van de klant (bedrijven) onverlet. De NRV (NRV 1987) spreekt over het instellen van een zogenaamd regionaal overleg, waarin zouden moeten participeren de beroepsbeoefenaren, de besturen van GD'en c.q. de Federatie, de Arbeidsinspectie, de regionale geneeskundige inspectie, de provinciale raad volksgezondheid, gemeenten en provincie, de bedrijfsverenigingen en de GMD. Ook met andere sectoren uit de gezondheidszorg moeten contacten worden onderhouden (NRV 1987).

Uitbreiding van BGZ heeft plaatsgevonden langs twee lijnen. Aan de ene kant was er sprake van een getalscriterium, dat in de loop der jaren werd verlaagd. Daarnaast ging het risicocriterium een steeds belangrijker rol spelen (Arboraad 1986, NRV 1987). Zo noemt de Arboraad de gezondheidszorg, de chemische industrie, land- en tuinbouw en de bouw als sectoren waarvoor op korte termijn een uitbreiding van de verplichting noodzakelijk geacht zou kunnen worden (zie ook DGA 1988a, DGA 1988b, DGA 1988c). De uitbreiding van BGZ wordt steeds meer gekoppeld aan de vraag van de meerwaarde van BGZ. Een aanpak, waarbij gezondheidsproblemen c.q. - risico's in cen bepaalde bedrijfstak worden geïnventariseerd en op basis hiervan een BGZ-pakket op maat wordt geleverd, vindt steeds 
meer gehoor. Met het van kracht worden van de Arbowet komt de zorg voor uitbreiding van BGZ steeds meer te liggen bij de sociale partners. In het voorstel van het DGA betreffende modemisering van de wettelijke regeling van de BGZ en het te voeren beleid (DGA 1989b) wordt de gewijzigde rol van overheid belicht. Naast haar taak als "wettelijk zorguitbreider" zal de overheid de eigen verantwoordelijkheid van de sociale partners moeten benadrukken, stimuleren en ondersteunen en aldus tevens co-actor worden op het terrein van de vrijwillige zorguitbreiding. Op deze wijze zou ook kunnen worden ingespeeld op het ervaringsfeit dat de vrijwillige zorg als wegbereider kan fungeren voor verplichte zorg van kwalitatief goed niveau. In concreto betekent deze stellingname van de overheid het volgende:

- $\quad$ Als uitgangspunt wordt gekozen dat het invoeren van BGZ primair een verantwoordelijkheid is van de sociale partners, zowel op bedrijfstak- en brancheniveau als op het niveau van het individuele bedrijf.

- De overheid draagt een eindverantwoordelijkheid voor de realisering van het recht op zorg voor de gezondheid in verband met de arbeid en de kwaliteit ervan (cf. EEG-richtlijn 89/391). Het bewaken van de prioriteitsstelling bij de bevordering van BGZ in (deel)sectoren van het arbeidsbestel is dan ook een belangrijke overheidstaak. Daarbij zullen jaarlijks prioriteiten afgesproken moeten worden en invoeringsplannen moeten worden opgesteld. Het afspreken van termijnen en het evalueren van de realisering zullen daarvan deel uit maken.

Modelontwikkeling voor een bedrijfstak- en risicogerichte zorg is een noodzakelijke voorwaarde voor de uitbreiding van de BGZ in niet-industriële sectoren en in kleine bedrijven. Deze dient bij voorkeur tot stand te komen in goed overleg tussen sociale partners, overheid, deskundige diensten en onderzoeksinstituten.

- Bij de implementatie van de noodzakelijk geachte prioriteiten behoeft wettelijke verplichting niet steeds het eerst aangewezen instrument te zijn. De overheid kan ook stimulerend en voorwaardenscheppend actief zijn. Het instrument van verplichtstelling kan gereserveerd worden voor die situaties waarin vrijwillige initiatieven niet (binnen redelijke termijn) tot ontwikkeling komen of tot onvoldoende kwalitatief resultaat leiden, of als vrijwillige initiatieven leiden tot partiële zorg danwel onvolledige doorvoering naar de doelgroepen in kwestie, of als de aard van de te bereiken doelgroepen van dien aard is (niet bedrijfstakgewijs georganiseerd of verspreid over diverse bedrijfstakken) dat verplichtstelling van afzonderlijke bedrijven het aangewezen instrument is. Tot slot kan de overheid overgaan tot verplichtstelling bij (categorieën van) bedrijven als er sprake is van (ernstig vermoeden van) een verhoogd gezondheidsrisico voor de werknemers.

- De mogelijkheid moet worden geschapen om de verplichtstelling naar zijn inhoud te beperken tot onderdelen van het thans in de wet opgenomen takenpakket, waardoor een flexibele taakverrichting mogelijk wordt, welke rekening houdt met de specifieke kenmerken van het bedrijf/de inrichting. Dit maakt tevens mogelijk dat de wettelijk voor te schrijven zorgplicht ook par- 
tieel kan zijn (aanvullende zorgplicht). Dit mede in verband met de doorvoering van zorg naar bepaalde kleine bedrijven waar een aantal taken van artikel 18 Arbowet als minder relevant kunnen worden beschouwd. Met andere woorden, behalve categorieēn van bedrijven (artikel 18, lid 1) en individuele bedrijven (artikel 18, lid 2) moeten ook onderdelen van bedrijven, dan wel tijdelijke arbeidssituaties en groepen van personen verplicht gesteld kunnen worden.

- Het stimulerend en voorwaardenscheppend beleid zal zich op een aantal kemzaken moeten richten. Als prioriteiten worden genoemd de optimalisering van de organisatievorm (professionaliteit, samenhang BGZ-veiligheidszorg), de ontwikkeling van protocollen voor BGZ-activiteiten, model- en protocolontwikkeling voor met name kleine bedrijven.

- Om de realisering van de gestelde prioriteiten en doelen te kunnen bewaken en evalueren is een signaleringsinstrument noodzakelijk. Te overwegen is een gestandaardiseerde rapportage van deskundige diensten.

De laatste jaren krijgt BGZ in versneld tempo een brede maatschappelijke en politieke inbedding en aanvaarding (Mulock 1992, NVAB 1992). Om aansluiting te houden bij internationale ontwikkelingen moest de Arbowet worden gewijzigd. Van deze gelegenheid wordt gebruik gemaakt om een aantal wijzigingen door te voeren, zoals moderniseringsvoorstellen BGZ ("certificatie"), sociaal-medische begeleiding en de rol van de BGD, afstemming van Arbowet met wetgeving ter beperking en vermindering van verzuim en arbeidsongeschiktheid (TAV, TZ, TBA).

Wijziging was eveneens noodzakelijk om uitvoering te geven aan de motie van het kamerlid Beijlen-Geerts, waarin werd uitgesproken dat een vorm van BGZ voor alle werknemers verplicht gesteld moet worden (1991). Deze motie luidt als volgt: "De Kamer, gehoord de beraadslaging, overwegende dat het belang van bedrijfsgerichte controle en begeleiding voor het bestrijden en voorkomen van ziekteverzuim onomstotelijk vaststaat; overwegende dat in dit verband gedurende de eerste zes weken van ziekte de BGZ een belangrijke taak heeft; voorts overwegende dat door een voorgenomen wijziging van de Ziektewet de eerste zes weken van het ziekteverzuim voor rekening van de werkgever zullen komen, waardoor de bemoeienis van de verzekeringsgeneeskundige zorg vermindert, spreekt uit dat een vorm van BGZ op afzienbare termijn alle werknemers in Nederland dient te omvatten; verzoekt de Regering in het kader van de implementatie van de EG-richtlijn 89/391 inzake de preventiediensten en in samenhang met het voor rekening van de werkgever brengen van de eerste zes weken ziekteverzuim, te komen tot een verplichtstelling voor de werkgever vanaf 1/1/93 een vorm van BGZ beschikbaar te stellen aan alle werknemers, en gaat over tot de orde van de dag". 


\subsection{BGZ in het buitenland}

\subsubsection{Inleiding}

De situatie in Nederland is in een drietal opzichten duidelijk afwijkend van de ons omringende landen: allereerst valt op dat in de ons omringende landen wel al iedereen die beroepsmatig arbeid verricht (formeel) onder de BGZ valt. In de tweede plaats bestaat in het buitenland de strikte scheiding tussen behandeling en controle niet. Als derde verschilpunt kan gewezen worden op het in Nederland op grote schasl voorkomen van de combinatietask BGZ en verzekeringsgeneeskunde.

Toch is bestudering van de organisatie van BGZ in het buitenland nuttig, omdat enerzijds kan worden verwacht dat internationale wetgeving in toenemende mate van invloed zal zijn op nationale wetgeving, en omdat anderzijds in het buitenland ervaringen zijn opgedaan met BGZ voor de gehele beroepsbevolking. Zowel in Nederland als in vele andere Westeuropese landen, heeft er in de afgelopen 15 jaar een grondige herziening plaatsgevonden van de wetgeving betreffende de veiligheid en gezondheid bij het werk. Gemeenschappelijk kenmerk van die hervormingen is de verschuiving van regelgeving en toezicht door de overheid in de richting van vorming en uitvoering van een Arbobeleid op het niveau van het bedrijf. Bijstand en advies van deskundigen vormen een belangrijke voorwaarde wil de zorg succesvol zijn (Gevers 1986).

\subsubsection{Internationale bepalingen}

De ontwikkeling van BGZ is in West-Europa beinvloed door twee internationale (algemene) aanbevelingen: een aanbeveling uit 1959 van de ILO, en een uit 1962 van de EEG. BGZ heeft in beide aanbevelingen een uitgesproken medisch karakter: BGZ zou voornamelijk artsenwerk zijn. De ontwikkeling naar multidisciplinaire diensten met een grotere diversiteit aan organisatievormen is terug te vinden in enkele meer recente internationale documenten, te weten het Advies inzake Arbeidsgeneeskunde, uitgebracht in september 1984 door het Economisch en Sociaal Comité van de EG en het Verdrag en de Aanbeveling inzake BGD'en van de ILO uit 1985. Er wordt geen voorkeur uitgesproken voor een bepaalde wijze van organisatie van BGZ (zie ook Charta voor de BGZ (NVAB 1981a)). Gevers (1986) concludeert dat afgezien van het doen van verzuimcontroles door bedrijfsartsen, afgewezen in het ILO-verdrag, de Nederlandse wetgeving goeddeels in overeenstemming is met ILO-bepalingen.

Daarnaast brengt de ILO ook meer gerichte aanbevelingen uit, bijvoorbeeld Verdrag nr. 136 uit 1971 over benzeen, en nr. 139 uit 1974 over kankerverwekkende stoffen.

Elk van de drie gemeenschappen die tezamen de Europese Gemeenschappen vormen heeft mede ten doel de verbetering van arbeidsonstandigheden van werknemers. Euratom richt zich daarbij op bescherming tegen straling, de Europese $\mathrm{Ge}$ - 
meenschap voor Kolen en Staal (EGKS) richt zich tot de onder haar ressorterende industriezn en beperkt haar activiteiten tot informatie-uitwisseling, onderzoek en overleg. De derde en verreweg belangrijkste component van de EG is de Europese Economische Gemeenschap (EEG). Sinds de oprichting in 1957 is er sprake van een geleidelijke uitbouw van beleid en regelgeving betreffende arbeidsomstandigheden. Het EEG-verdrag draagt de Europese Commissie op, om samenwerking tussen de lidstaten op dit gebied te bevorderen. In 1974 is, met het oog op de verdere ontwikkeling van het EEG-beleid, een uit deelnemers van alle lidstaten samengesteld Raadgevend Comité voor veiligheid, hygiēne en gezondheidsbescherming bij het werk opgericht (NIA 1990).

Door de EEG is een aantal richtlijnen tot stand gebracht op het gebied van veiligheid en gezondheid. Richtlijnen hebben de status van verplichte opname hiervan in nationale wetgeving. Ze zijn bindend met betrekking tot het afgesproken resultaat, de wijze waarop dit resultaat moet worden bereikt wordt echter overgelaten aan de nationale wetgever. Aanbevelingen zijn daarentegen vrijblijvend. Verder stelt de EEG actieprogramma's op, bijvoorbeeld inzake veiligheid en gezondheid bij het werk (Gevers 1986).

De richtlijnen die betrekking hebben op veiligheid en gezondheid zijn gebaseerd op artikel 100a (de zogenaamde harmonisatierichtlijn), 117 en 118 van het EEG-verdrag (Kaderrichtlijn 89/391, Geers 1988, Gevers 1986, NIA 1990, Allegro en Verschuren 1990).

In artikel 117 gaat het om de noodzaak van de "verbetering van de levensstandaard en van de arbeidsvoorwaarden van de werknemers". Artikel 118 heeft tot doel een nauwe samenwerking op sociaal gebied tussen de lidstaten te bevorderen, zoals bescherming tegen arbeidsongevallen, beroepsziekten en hygiëne. Aanbevelingen die hieruit voortvloeien gaan onder andere over BGD'en, over de vaststelling van een lijst van beroepsziekten, over medische controle van werknemers die aan bijzondere risico's blootstaan. De gevolgen voor de Arbowet van de in 1989 uitgebrachte richtlijn, betreffende de tenuitvoerlegging van maatregelen ter bevordering van de verbetering van de veiligheid en de gezondheid van de werknemers op het werk (EEG 89/391), die ingaande 1/1/93 opgenomen dient te zijn in nationale wetgeving, hebben betrekking op de volgende terreinen: een schriftelijk vast te leggen integrale risico-inventarisatie en - evaluatie van arborisico's, het verplicht voeren (en vastlegen) van een verzuimbeleid, deskundige bijstand $m$.b.t. preventie en bescherming van bercepsrisco's, deskundige bijstand m.b.t. bedrijfshulpverlening, en het bieden van de mogelijkheid van periodiek onderzoek aan elke werknemer. De preventiezorg kent een drietal niveaus, dat afhankelijk zal zijn van de grootte van het bedrijf en/of de arborisico's. Alle werkgevers moeten eén of meer werknemers aanwijzen die taken gaa(t)n verrichten op "preventiegebied". De werkgever kan deze taken ook vitbesteden aan externe personen of diensten.

Als uitwerking van deze algemene richtlijnen zijn of worden drie bijzondere richtlijnen vastgesteld, namelijk cen over werkplaatsen, machines en persoonlijke beschermingsmiddelen, over beeldschermen en over het tillen van zware lasten. Ook 
is door de EG een richtlijn vastgesteld die tot doel heeft uniformering van de opleiding tot bedrijfsarts (EEG 85/594).

Tot slot kan bij de opsomming van internationale bepalingen worden genoemd het in 1961 in Turijn tot stand gekomen Europees Sociaal Handvest, waartoe Nederland pas in 1978 is toegetreden. Artikel 3 van dit handvest heeft betrekking op de arbeidssituatie. Het verplicht aangesloten landen om voorschriften uit te vaardigen teneinde het recht op een veilige arbeidsplaats te waarborgen, de naleving van de voorschriften te controleren en zo nodig overleg te plegen met de sociale partners omtrent maatregelen die de bedrijfsveiligheid en hygiëne kunnen verhogen.

\subsubsection{BGZ in andere Europese landen}

In de ons omringende landen valt iedereen die beroepsarbeid verricht onder de BGZ. In de meeste landen is de werkwijze van de bedrijfsarts meer indringend geregeld (onder andere de inzettijd). Elementen die in de buitenlandse wetgeving zijn opgenomen hebben betrekking op de uitwerking van de verplichting van de werkgevers in BGZ te voorzien, op de mate waarin de inhoud van de zorg wordt geregeld, op de organisatievormen van BGZ, op de wijze waarop de onafhankelijkheid van de bedrijfsarts gewaarborgd kan worden, en op het beheer en bestuur (inspraak) van BGD'en. In de meeste landen wordt BGZ op dezelfde wijze als in Nederland georganiseerd met EVD'en en GD'en. In Duitsland is een branchegerichte BGZ-organisatie verder ontwikkeld. De organisatie van BGZ in Italië en Groot Britannie is duidelijk afwijkend, in die zin dat BGZ in deze landen een onderdeel vormt van de openbare gezondheidszorg. Het zou hier te ver voeren om de organisatie van BGZ in de ons omringende landen verder in details te bespreken. De geïnteresseerde lezer wordt verwezen naar Gevers 1982 en 1986, Kwantes 1989, Budde en Witting 1984, Tijsse Klasen 1988, Mehl 1989.

\subsection{Samenvatting}

Dit hoofdstuk heeft een beschrijving gegeven van het wettelijk kader waarbinnen BGZ is ontstaan en opereert. De (gewenste) rol van de overheid vroeger en nu kwam ter sprake. Er werd stilgestaan bij de totstandkoming en de inhoud van de Arbowet. Het hoofdstuk werd afgerond met een beschrijving van internationale ontwikkelingen.

Uit dit hoofdstuk wordt een (inter)nationale trend zichtbaar, waarbij de overheid op het gebied van arbeidsomstandigheden terugtreedt, en zij de verantwoordelijkheid voor een goed Arbobeleid legt op bedrijfsniveau, in plaats van het uitbrengen van regelgeving en het houden van toezicht. Bijstand en advies van deskundigen wordt van belang geacht, maar de deskundigen moeten wel zelf hun meerwaarde bewijzen. 


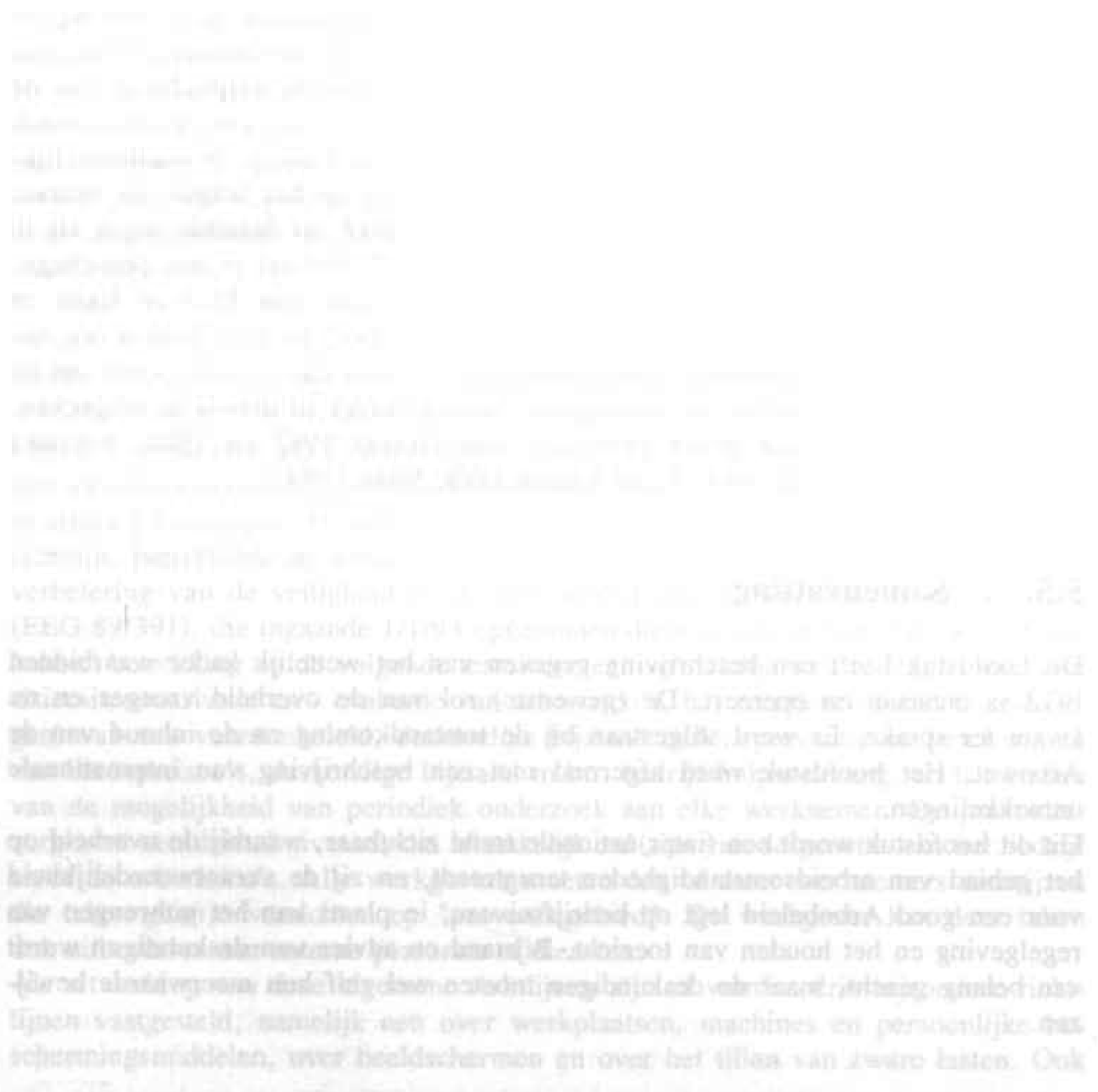




\section{Hoofdstuk 6}

\section{Het onderzoeksmodel}

\subsection{Inleiding}

Op basis van de vorige hoofdstukken kan worden geconcludeerd dat de kwaliteit van BGZ de resultante is van de invloed van diverse partijen: de overheid die kaders stelt; de werkgever, die de (financiēle) speelruimte vaststelt; de werknemers die de belangrijkste doelgroep vormen voor de BGZ-praktijk van alledag; en tot slot de BGD'en zelf, die op professioneel verantwoorde wijze BGZ willen leveren, dat wil zeggen getoetst aan normen zoals die binnen de beroepsgroep bestaan.

Kwaliteit van BGZ wordt op basis van de voorgaande hoofdstukken dan ook als volgt gedefinieerd: onder kwaliteit van BGZ wordt verstaan dat BGD'en op professioneel verantwoorde wijze BGZ leveren, dat wil zeggen passend binnen de mogelijkheden van de BGD en getoetst aan de normen binnen de beroepsgroep (professionaliteit), en dat wordt ingespeeld op vastgelegde en zich veranderende behoeften en wensen bij de klant, en dat de dienstverlening plaatsvindt op een klantgerichte wijze (klantgerichtheid). In het onderzoek wordt verder gesproken over de termen professionaliteit en klantgerichtheid.

\subsection{Probleemstelling}

Om de kwaliteit van BGZ te beschrijven wordt gekozen voor een aspectbenadering, dat wil zeggen dat een aantal aspecten dat een (mogelijk) verband heeft met kwaliteit van BGZ, wordt onderzocht. Dit vindt plaats vanuit twee optieken ("dyadic view" (Brown en Swartz 1989, Swartz en Brown en 1989, Harteloh en Casparie 1991)): vanuit het perspectief van de klant, en vanuit het perspectief van de professional.

Het onderzoek valt uiteen in twee centrale onderzoeksvragen:

1. Hoe ervaren leveranciers en ontvangers van BGZ een aantal aspecten van de kwaliteit van BGZ. Met andere woorden, hoe wordt kwaliteit van BGZ ervaren op de respectieve dimensies professionaliteit en klantgerichtheid?

Dit wordt beschreven in hoofdstuk 8 .

2. Welke bedrijfs- of bedrijfsartsgebonden variabelen hangen samen met de onderzochte aspecten van kwaliteit? Dit wordt beschreven in hoofdstuk 9. 
Het onderzoek heeft een exploratief karakter. Behalve dat bovenstaande vraagstellingen worden onderzocht voor de gehele onderzoekspopulatie, wordt ook ingegaan op verschillen tussen GD'en en EVD'en met betrekking tot de genoemde vraagstellingen.

GD'en en EVD'en verschillen in organisatie, in positie in en ten opzichte van het bedrijf. EVD'en vervullen in vergelijking met GD'en binnen het bedrijf een andere rol (vergelijkbaar met het verschil tussen een interne en externe organisatie-adviseur); er is dan ook sprake van een ander verwachtingspatroon, hetgeen tot uiting komt in werkwijze en takenpakket van de BGD.

De (beperkte) omvang van de respons en het aantal variabelen maken het noodzakelijk dat kritisch wordt gekeken naar de betrouwbaarheid van eventuele verschillen tussen GD en EVD in samenhang tussen de verschillende variabelen.

\subsection{Relatienetwerk BGD}

Kwaliteitsbeoordeling kan niet los gezien worden van de brede context waarbinnen het BGZ-systeem zich bevindt, waarin relaties onderhouden worden tussen bedrijf en BGD, maar ook tussen BGD en andere zorginstanties, de beroepsgroep, en de overheid. Al deze partijen kunnen het ervaren kwaliteitsniveau beinvloeden (Oirbons 1984, Felser 1985, NVAB 1989a, Draaisma 1986, FNV 1985).

In eerdere hoofdstukken werd geconstateerd dat de positie van waaruit naar BGZ gekeken wordt, mede bepalend is voor een kwaliteitsoordeel. Deze complexiteit van het BGD-relatienetwerk (klantensysteem) onderstreept de noodzaak van een afstemming tussen de aanbieder van BGZ en de ontvangers hiervan.

Als elementen die een rol spelen bij het bepalen van de kwaliteit van BGZ kunnen aan de kant van de aanbieder van BGZ genoemd worden: worden door de BGD de juiste taken uitgevoerd, beschikt de BGD over voldoende en adequate menskracht en middelen, is de BGD in staat de gezondheid van mensen in kaart te brengen en de belasting vanuit het werk, slaagt de BGD erin deze informatie te vertalen in relevante aanbevelingen ter bescherming van de gezondheid van de werkende mens?

Aan de kant van de ontvangers van BGZ kunnen als elementen genoemd worden: houdt de BGD voldoende rekening met verhoudingen tussen de partijen in het klantsysteem, maakt de BGD duidelijk dat zij weet wat het klantsysteem verwacht en wenst, komt de BGD tegemoet aan de wensen van het klantsysteem, maakt de BGD duidelijk wat zij wel en wat zij niet kan, hoe operationaliseert de BGD haar doelstelling(en), is er overeenstemming tussen BGD en klant over de gewenste aanpak?

Over de faciliterende en voorwaardenscheppende rol van de overheid bij de totstandkoming van het niveau van kwaliteit van BGZ, werd gesproken in hoofdstuk 5. In dit onderzoek is deze invloed verder niet expliciet meegenomen. 
Behalve de complexiteit van het relatienetwerk spelen ook andere factoren mee die een becordeling van de kwaliteit van BGZ bemoeilijken.

Allereerst is dat het preventieve karakter van bedrijfsgezondheidszorg. Effecten van BGZ-interventie, met als doel een preventie van arbeidgerelateerde-ziekten, zijn moeilijk, en vaak pas op lange termijn, meetbarar.

Daamaast is het ontstaan van ziekte meestal het gevolg van een multicausaal corzakencomplex. Het vaak in de BGZ gehanteerde belasting-belastbaarheidsmodel tracht deze complexiteit te visualiseren en objectiveren.

Ook moet, als algemeen probleem binnen de gezondheidszorg, worden geconstateerd dat van veel ziektes het natuurlijk beloop onbekend is. Dit maakt het kunnen meten van resultaten van eventuele interventie moeilijk. Onbekend is immers wat er gebeurd zou zijn als er niet geintervenieerd was.

Tot slot kan worden opgemerkt dat het instrumentarium om belasting enerzijds en belastbaarheid anderzijds te meten vaak nog ontbreekt (Draaisma 1986, Sturmans 1982, Holland 1983).

\subsection{Vooronderzoek}

Omdat medio 1987 het veld van BGZ behoorlijk in beroering en beweging was, vond een sondering naar eventuele medewerking van de diverse participanten plaats. Hiertoe werden gesprekken gevoerd met vertegenwoordigers van werkgevers- en werknemersorganisaties, met het Directoraat Generaal van de Arbeid (DGA), met de diverse organisaties van deskundige diensten, met de voorzitter van de NVAB en met enige deskundigen op het terrein van BGZ.

Uit dit vooronderzoek bleek dat het veld afwachtend en kritisch stond tegenover onderzoek naar de kwaliteit van BGZ.

\subsection{Verloop van het onderzoek}

$\mathrm{Na}$ (vereiste) instemming met het onderzoek door de NVAB, de werkgroep directeuren van GD'en en de Vereniging Directeuren Basisgezondheidsdiensten, kon met enquêtering worden gestart in het tweede kwartaal van 1988. Eind 1988 werd het veldwerk afgesloten. Er is gebruik gemaakt van schriftelijke, gestructureerde enquêtering.

Omdat een grote non-respons werd verwacht, werd het BGZ-veld breed benaderd, dat wil zeggen dat alle GD'en werden benaderd $(\mathrm{N}=44), 44$ EVD'en, 15 afdelingen BGZ van een GG\&DD, en de 5 regiohoofden van de Rijks Bedrijfsgezondheids- en Bedrijfsveiligheidsdienst (RBB). De deelnemers werden random getrokken uit de door het DGA uitgegeven Landelijke Adreslijst Bedrijfsgezondheidsdiensten van 1 mei 1987 (met uitzondering van de GD'en, die allemaal werden benaderd). 
Gegeven de lage respons van respectievelijk de afdelingen BGZ van een GG\&GD en van de RBB, is afgezien van een separate beschrijving van kenmerken van deze BGD-organisatievormen en van de ervaren kwaliteit van BGZ. In de volgende hoofdstukken worden dus uitsluitend de resultaten beschreven van het onderzoek bij bedrijven met GD en (particuliere) EVD.

Het onderzoek doorliep de volgende stappen:

1. Enquetering van de directies van de BGD.

2. Selectie van een bedrijf met tenminste 35 medewerkers en een technische dienst met tenminste drie medewerkers.

Dit vond plaats bij GD'en door een random steekproef uit de BGD-jaarverslagen, bij EVD'en kan deze steekproef natuurlijk niet random zijn. 3. Enquattering hoofd personeelszaken en bedrijfsarts van het geselecteerde be-
drijf.

4. Enquêtering van de voorzitter van de werknemersvertegenwoordiging en van random drie werknemers van de technische dienst uit een opgave door het bedrijf van maximaal 10 medewerkers.

$\mathrm{Er}$ is een keuze gemaakt om specifiek een afdeling van een bedrijf te benaderen. Hiermee wordt bestudering mogelijk van het concrete afstemmingsvraagstuk tussen leverancier en ontvanger van BGZ. De keuze van de technische dienst werd ingegeven omdat een dergelijke afdeling in vrijwel alle bedrijven voorkomt, onafhankelijk van de BGD-organisatievorm. Bovendien mag worden verondersteld dat binnen de technische dienst concrete BGZ-problemen (kunnen) voorkomen.

Figuur 6.1 vat de partijen, die in het onderzoek werden betrokken, en die de belangrijkste rol spelen bij de totstandkoming van (de kwaliteit van) BGZ, nog eens samen.

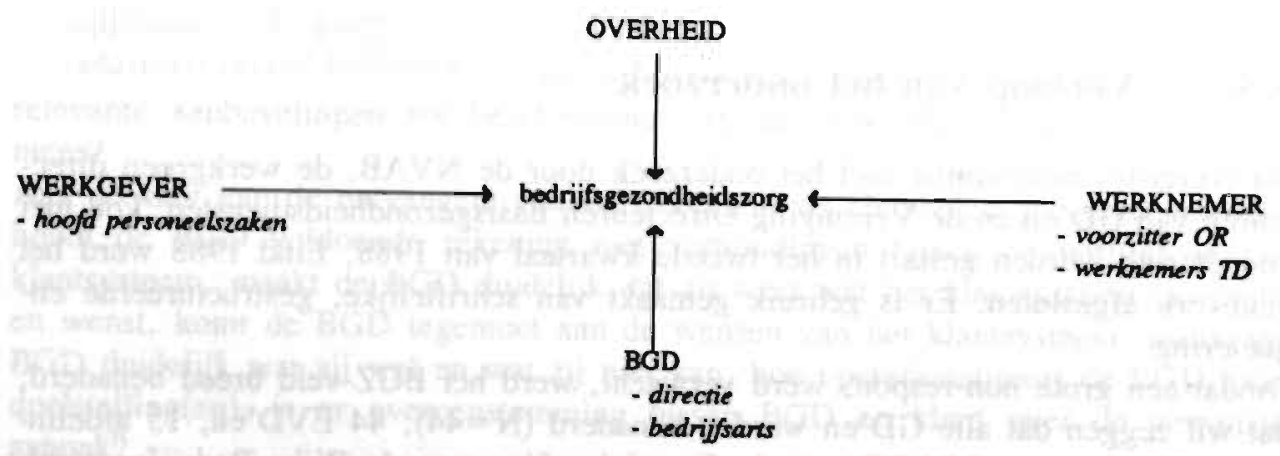
Figuur 6.1. Partijen die betrokken zijn bj de totstandkoming van BGZ en die in het onderzoek zije
getinqueteerd (cursief) 


\subsection{Respons}

De uiteindelijke respons wordt sterk beinnvloed door de wijze waarop in dit onderzoek het veld werd benaderd. Omdat het onderzoek was gericht op de bestudering van het concrete afstemmingsvraagstuk, werd er getracht om per bedrijf de medewerking te verkrijgen van het gehele BGD-relatienetwerk.

Dit heeft ertoe geleid dat respectievelijk bedrijfsartsen, voorzitter ondernemingsrasd, en werknemers slechts werden benaderd, wanneer toestemming en deelname werd verkregen van de directie van de BGD en de directie van het bedrijf. Dit verklaart een afname van het absolute aantal respondenten bij respectievelijk bedrijfsartsen, werknemers en voorzitters van werknemersvertegenwoordigingen.

Het veldwerk werd binnen driekwart jaar (eind 1988) afgesloten om de invloed van te grote tijdverschillen op het onderzoek te voorkómen. Na telefonische en schriftelijke rappelering resulteerde de volgende respons (tabel 6.1 en 6.2):

Tabed 6.1. Respons GD

\begin{tabular}{|c|c|c|}
\hline & verstumend & respons \\
\hline directio BGD & 44 & 32 (73)\%) \\
\hline bedrijfsarts & 20 & $17(85 \%)$ \\
\hline hoofd peraoneelszakion & 32 & $20(63 \%)$ \\
\hline voorzitter ondernemingsneed & 20 & $16(80 \%)$ \\
\hline sddeling technieche dienst & 20 & 18 (90\%) \\
\hline
\end{tabular}

Tabel 6.2. Respons EVD

\begin{tabular}{lcc}
\hline & verstuurd & respons \\
\hline directio BGD & 44 & $20(45 \%)$ \\
bedrijfsarts & 12 & $15(100 \%)$ \\
boofd personeelszaken & 21 & $12(57 \%)$ \\
voorzitter ondernomingsraed & 12 & $10(83 \%)$ \\
afdeling technische dienst & 13 & $13(100 \%)$ \\
\hline
\end{tabular}

- dit zijn meer respondenten omdal bij kleinere EVD'en de directeur en do uitvoerend bedrijfents dezolfde persoon kunneo zijn.

\section{Redenen voor non-respons}

Door de gehanteerde onderzoeksopzet, kan er niet worden gesproken van een representatieve steekproef bij de leveranciers en de ontvangers van BGZ. Wel is een bestudering mogelijk van het door de leveranciers en ontvangers van BGZ ervaren kwaliteitsniveau tussen de BGD-organisatievormen onderling (te weten tussen GD en EVD), en van de invloed van bedrijfsarts- en bedrijfsvariabelen op de ervaren kwaliteit. Er kunnen met andere woorden geen uitspraken worden gedaan in algemene zin over het kwaliteitsniveau van BGD'en c.q. de BGZ. Opgemerkt kan nog worden dat de steekproef een landelijke spreiding heeft.

In hoofdstuk 7 wordt ingegaan op enige verschillen tussen de GD en EVD. Op een belangrijk verschil wordt nu reeds gewezen. Dit betreft het verschil in de grootte van de door de BGD te verzorgen bedrijven: $75 \%$ van de bedrijven die door 
GD'en worden verzorgd, heeft tussen 100 en 500 werknemers, terwijl $92 \%$ van de bedrijven die door EVD'en worden verzorgd meer dan 500 werknemers in dienst heeft.

Door de gekozen benadering van het onderzoeksveld varieert de (non)-respons per respondent (zie eerder). Hierdoor is er een afname van het absolute aantal respondenten, maar niet van het relatieve aantal respondenten.

De redenen van "non-respons" zijn als volgt verdeeld:

A. GD'en:

stap 1: aanschrijven directies $\mathrm{GD}(\mathrm{N}=44)$

* directies GD (respons $=73 \%$ )

- I maal cen expliciete weigering

- 2 maal vanwege fusie/reorganisatie

- 9 maal is de reden van de weigering onbekend

stap 2: aanschrijven hoofd personeelszaken $(\mathrm{N}=32)$

* hoofd personeelszaken GD-bedrijven (respons $=63 \%$ )

- I maal vanwege privacy-bezwaren

- 1 maal omdat het bedrijf te klein bleek

- 4 maal vanwege tijdgebrek

- 6 maal blijft de reden van de weigering onbekend

stap 3: benaderen bedrijfsarts, voorzitter Ondernemingsraad, werknemers $(\mathrm{N}=20)$

* voorzitter Ondernemingsraad (respons $=80 \%$ )

- 4 maal reden onbekend

* werknemers (respons $=90 \%$ )

- 2 maal reden onbekend

* bedrijfsarts (respons $85 \%$ )

- 3 maal reden onbekend

B. EVD'en:

stap 1: benaderen directies EVD $(\mathrm{N}=44)$

* directie EVD (respons $=45 \%$ )

- 4 maal reorganisatie (met name enkele grote EVD'en)

- $7 \mathrm{maal}$ vormde de BGD een onderdeel van een grotere EVD en/of was er slechts sprake van een parttime en beperkte BGD-functie

- 2 maal bleek het bedrijf failliet

- 2 maal werd tijdgebrek als reden opgegeven

- 9 maal blijft de reden van de weigering onbekend

stap 2: benaderen hoofd personeelszaken $(\mathrm{N}=21)$

* hoofd personeelszaken (respons $=57 \%$ )

- 3 maal vanwege tijdgebrek c.q. andere prioriteiten

- 6 maal blijft reden weigering onbekend

stap 3: benaderen bedrijfsarts $(\mathrm{N}=12)$, voorzitter ondernemingsraad $(\mathrm{N}=12)$, 


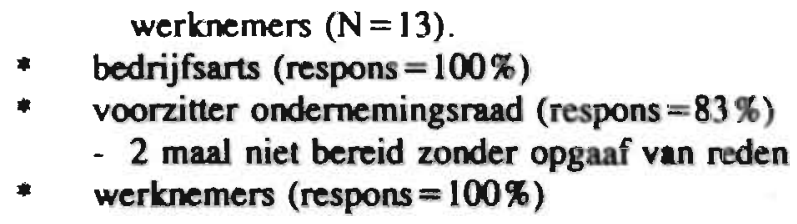

\subsection{Operationalisatie}

\subsubsection{Inleiding}

Bij de keuze van de vragen is sterk aangesloten bij de exacte taken en taakuitvoering van de bedrijfsarts, zoals deze worden genoemd in de Arbowet. Er is met andere woorden voor gekozen het werk van de bedrijfsarts op te splitsen in een aantal logische elementen: met welke zaken houdt de bedrijfsarts zich bezig, hoe gaat hij in de praktijk te werk, wat zijn zijn opvattingen over het werk, hoe vindt de takuitvoering in de praktijk plaats, welk effect heeft zijn handelen. De impliciete doelstelling van bedrijfsgezondheidszorg, namelijk groepsgerichte preventie van arbeidgebonden ziekten en arbeidsongeschiktheid, ligt ten grondslag aan de selectie van de vragen. De vragen zelf zijn rechtstreeks gericht op de hiervoor genoemde elementen.

\subsubsection{Operationalisatie van het begrip kwaliteit}

Zoals reeds werd beschreven in paragraaf 2 van dit hoofdstuk, wordt in het onderzoek de kwaliteit van BGZ beschreven door middel van de aspectbenadering. Er worden onderscheiden aspecten die betrekking hebben op de professionele kwaliteit van BGZ (paragraaf 6.7.2.1), en aspecten die betrekking hebben op de klantgerichte kwaliteit (paragraaf 6.7.2.2).

Bijlage 2 geeft een overzicht van de samenstelling van de verschillende kwaliteitsvariabelen.

\subsubsection{Aspecten van professionele kwaliteit}

In de relatie die de bedrijfsarts met het bedrijf onderhoudt kan een aantal aspecten van professionele kwaliteit worden onderscheiden: op welk terrein beweegt de bedrijfsarts zich, hoe gaat hij te werk, hoe is de kwaliteit en doeltreffendheid van zijn advisering. In het onderzoek zijn de volgende aspecten van professionele kwaliteit bestudeerd: de werkwijze van de bedrijfsarts, het werkterrein van de BGD, de bruikbaarheid van advisering van de BGD, de professionele uitvoering van BGZkerntaken, en het rendement van de BGZ-kerntaken. 


\section{De werkwijze van de bedriffsarts}

Hieronder wordt verstaan het op groepsniveau registreren van gegevens van de werkplek en het periodiek onderzoek, het rapporteren aan directie en ondernemingsraad, en het eventueel ongevraagd adviseren door de bedrijfsarts.

Bij de registratie van gegevens gaat het om de mate waarin en de wijze waarop BGD'en BGZ-activiteiten registreren. Het gaat dan vooral om de mogelijkheid gegevens zodanig te registreren dat analyse van geaggregeerde gegevens mogelijk is, tijd- en oorzaaktrends zijn op te sporen. Het gaat dus om registratie naast het medisch dossier of de status. Het onderzoek beperkt zich tot bestudering van deze registratieve activiteiten bij het periodiek onderzoek en het onderzoek van de werkplek. Deze activiteit kan als graadmeter dienen van mogelijkheden voor preventief beleid.

Bij de rapportage van de BGD aan het bedrijf werd onderzocht of de BGD in gelijke mate rapporteert aan directie en ondernemingsraad. Hiermee wordt een indruk verkregen van de opstelling van de BGD ten opzichte van respectievelijk werkgever en werknemer.

Als laatste element in de werkwijze van de bedrijfsarts werd onderzocht wanneer bedrijfsartsen ongevraagd advies uitbrengen aan het bedrijf. Hiermee wordt een indruk verkregen van de (mate van) professionele autonomie van de bedrijfsarts.

\section{Het werkterrein van de BGD}

Het werkterrein van de BGD wordt op twee elementen onderzocht: de inhoud en de omvang van BGZ-activiteiten.

Onder de inhoud van BGZ-activiteiten wordt verstaan of de BGD niet alleen wordt ingeschakeld bij individuele problematiek, maar ook bij beleidszaken, zoals automatisering, (re)organisatie, nieuwbouw en verbouwing. Dit is zowel uit het perspectief van personeelszaken als van de ondernemingsraad bekeken.

De omvang van BGZ-activiteiten betreft het door de BGD ondernemen van taken naast het uitvoeren van kerntaken. Hieronder vallen activiteiten als GVO, de melding van beroepsziekten, revalidatie, verbetering van arbeidsverhoudingen en EHBO.

\section{De bruikbaarheid van advisering}

Er wordt onderzocht of de advisering van de BGD door de klant, zowel personeelszaken als ondernemingsraad, als bruikbaar wordt ervaren. Als elementen die deze bruikbaarheid bepalen, gelden: het inspelen van de advisering op actuele problematiek, een begrijpelijke formulering van het advies, de snelheid waarmee een advies tot stand komt, het rekening houden met zowel werkgevers als werknemersbelangen, en het verzorgen van de follow-up van de advisering.

Advisering is cen zichtbaar (en toetsbaar) produkt van bedrijfsgezondheidkundige activiteiten. 


\section{De professionele uitvoering van BGZ-kerntaken}

Dit betreft de uitvoering in de praktijk door de bedrijfsarts van de volgende taken: aanstellingskeuring, spreekuur, periodiek onderzoek en werkplekonderzoek. Deze taken worden op operationeel niveau bestudeerd. Door een vergelijking te maken tussen de manier waarop deze taken in de praktijk worden uitgevoerd met de manier waarop bedrijfsartsen wensen dat deze taken zouden worden uitgevoerd, kan een beeld van de (gewenste) professionele kwaliteit verkregen worden. De hier genoemde kerntaken worden als zodanig in de literatuur genoemd (zie hoofdstuk 2).

\section{Het rendement van BGZ-kerntaken}

Het rendement van BGZ-kerntaken is bestudeerd vanuit de optiek van de ondernemingsraad. Elementen die hierbij een rol spelen zijn: is met de uitvoering van BGZ-taken een preventief effect ten aanzien van werkgebonden ziekte en arbeidsongeschiktheid mogelijk, is de kennis over werk en arbeidgerelateerde ziekten toegenomen, is de kennis over wat de BGD is en wat de BGD kan toegenomen? Deze variabele probeert inzicht te geven in de effectiviteit van het BGZ-handelen (in de ogen van de ondernemingsraad).

\subsubsection{Aspecten van Hautgerichte kwaliteit}

In het onderzoek worden de volgende klantgerichte aspecten onderzocht: de ondersteunende rol van de BGD, de houding van de BGD, de ervaring van de klant met de uitvoering van taken door de BGD, de samenwerking tussen BGD en bedrijf, en de afstemming met de klant van de taakuitvoering. Naar analogie van het SERVQUAL-model (zie hoofdstuk 4) zouden deze termen min of meer achtereenvolgens genoemd kunnen worden: "responsiveness", "access", "reliability", "communication" en "understanding the customer".

\section{De ondersteunende rol van de BGD}

Dit betreft een tweetal elementen. In de eerste plaats gaat het om een algemene indruk bij respectievelijk ondernemingsraad en personeelszaken over de ondersteuning door de BGD bij de vormgeving aan het sociaal beleid van de onderneming. In de tweede plaats gaat het om de positie en de stellingname die de BGD inneemt bij haar advisering aan de klant. Het is een waarneming van de klant van de BGD, de wijze waarop de klant naar de BGD kijkt, wat zij van de BGD verwacht.

\section{De houding van de $B G D$}

Hieronder wordt verstaan de mate waarin de BGD volgens personeelszaken ruimte biedt voor inbreng van de individuele werknemer en de werkgever, en of de opstelling van de BGD door personeelszaken als klantvriendelijk wordt ervaren.

\section{De ervaring met de taakuitvoering}

Het gaat hier om concrete taakuitvoering. Onderzocht wordt hoe de klant (werknemer en ondernemingsraad) de houding van de BGD ervaart bij het aanstellingson- 
derzoek, bij het periodiek onderzoek en de verzuimbegeleiding. Ook wordt onderzocht of de ondernemingsraad van mening is dat de BGD nast haar kerntaken voldoende activiteiten ontplooit.

De verschillen met de variabele "houding van de BGD" zijn enerzijds dat in dit geval wordt onderzocht hoe de houding van de BGD is bij concrete taakuitvoering, en anderzijds dat niet personeelszaken, maar werknemers en ondernemingsraad hun visie hierover geven.

\section{De samenwerking tussen BGD en bedrijf}

Dit betreft de inschatting door de ondernemingsraad van de consistentie van de samenwerking tussen BGD en achtereenvolgens de directie van het bedrijf, de ondernemingsraad en personeelszaken.

\section{De mase van afstemming tussen leverancier en ontvangers van $B G Z$}

Er wordt onderzocht of de uitvoering van BGZ-kerntaken in de praktijk overeenstemt met de wensen en verwachtingen van de ontvangers van zorg (ondermemingsraad en werknemers). Het gaat hierbij niet om de vraag of een bepaalde taak terecht wordt uitgevoerd, maar om de vraag of de taken op operationeel niveau worden uitgevoerd naar wens van de klant.

\subsubsection{Operationalisatie van de bedrijfsarts- en bedrijfsvariabelen}

\subsubsection{Verantwoording selectie bedrijfsarts- en bedrijfsvariabelen}

Van de geselecteerde bedrijfsarts- en bedrijfsvariabelen wordt verondersteld dat zij een algemeen effect hebben op de onderzochte aspecten van kwaliteit, waarbij echter de invloed per variabele en kwaliteitsaspect qua richting en intensiteit kan variëren.

\section{Bedriffsarts-variabelen}

Naarmate de bedrijfsarts langer BGZ levert aan het betrokken bedrijf, heeft hij meer kennis kunnen opdoen van de arbeidsomstandigheden en de cultuur van het bedrijf. Er wordt verondersteld dat hij hierdoor zijn adviezen beter kan onderbouwen, en hij beter de weg kent om adviezen om te zetten in concrete maatregelen door het bedrijf.

Op Arbogebied c.q. het sociaal beleid bewegen zich ook andere disciplines (door Plomp (1987) rolpartners genoemd). Voor het effectueren van de doelstellingen van BGZ is hun inbreng en ondersteuning essentieel. In het onderzoek is alleen de mate waarin de bedrijfsarts overleg voert met de directie van het bedrijf meegenomen, mede omdat GD en EVD hierin van elkaar verschillen.

Rapportage is éen van de activiteiten waaraan het werk van de BGD te toetsen is. Het maken van afspraken over rapportage betekent dat de BGD haar dienstverlening toetsbaar maakt. 
Naarmate de bedrijfsarts meer ruimte ervaart in de samenwerking met de rolpartners binnen het bedrijf, heeft dit positieve effecten op met name de klantgerichte kwaliteit.

Naarmate de bedrijfsarts de voor betrokken bedrijf beschikbare tijd als ruimer ervaart, kan worden verwacht dat het activiteitenniveau van de BGD toeneemt, en er een toename zal zijn in de waardering door de klant van de BGZ.

De individuele taakopvatting van de bedrijfsarts is van wezenlijk belang bij de concretisering van de BGZ in de praktijk. Hoe hij uiteindelijk aankijkt tegen (de invulling van) zijn vak, zijn referentie- en normenkader zullen in hoge mate bepalen hoe de dienstverlening tot stand komt, en welke diensten hij levert.

\section{Bedriffsuriabelen}

Naarmate een bedrijf groter is, kunnen enerzijds meer (gevarieerde) gezondheidsbelastende factoren een rol spelen, anderzijds zal de ondersteuning op Arbogebied binnen het bedrijf meestal groter zijn.

Naarmate meer (gezondheid) belastende aspecten in de arbeidsomstandigheden een rol spelen, zal de kans op (gewenste) inbreng van de BGD groter zijn. Echter, niet alle belastende aspecten maken een inbreng van de BGD mogelijk. Er wordt verondersteld dat vooral de aanwezigheid van veel fysiek belastende factoren in het bedrijf de beoordeling van de BGZ positief beïnvloedt.

De hoogte van het verzuim kan van betekenis zijn als parameter voor effectief handelen door de BGD.

Naarmate de BGD sneller contact heeft met de zieken heeft dit effect op de ervaring van de taakuitvoering bij de ontvangers van zorg.

De (professionele en klantgerichte) kwaliteit van BGZ wordt dus vanuit twee invalshoeken onderzocht. In de eerste plaats wordt de samenhang bestudeerd tussen bedrijfsarts-variabelen en de kwaliteit van BGZ. Daarnaast wordt de samenhang bestudeerd tussen bedrijfsvariabelen en de kwaliteit van BGZ.

Bijlage 2 geeft een overzicht van de samenstelling van de bedrijfsarts- en bedrijfsvariabelen.

\subsubsection{Operationalisatie bedrijfsarts-variabelen}

1. De ervaring van de bedrijfsarts. Dit betreft het aantal jaren dat de bedrijfsarts aan het betrokken bedrijf BGZ levert (ervaring bedrijfsarts).

2. Het overleg met de directie van het bedrijf. Dit is de mate waarin de bedrijfsarts overleg voert met de directie van het bedrijf. Dit kan variëren van nauwelijks tot regelmatig (overleg met directie).

3. Het maken van afspraken over rapportage. Dit betreft het al dan niet maken en vastleggen van de afspraak over rapportage aan het bedrijf (afspraak rapportage). 
4. De speelruimte in het bedrijf. Dit is het al dan niet ervaren van ruimte door de bedrijfsarts in de samenwerking met respectievelijk de directie, de ondernemingsraad en personeelszaken van het bedrijf (ervaren speelruimte).

5. De beschikbare tijd. Dit betreft de inschatting van de beschikbare tijd voor betrokken bedrijf door de bedrijfsarts. Dit kan variëren van onvoldoende tot ruim voldoende (beschikbare tijd).

6. De taakopvatting van de bedrijfsarts. Dit is de wijze waarop de individuele bedrijfsarts zijn taak, zijn werk opvat. Het is opgebouwd uit de mening van de bedrijfsarts over diverse relevante BGZ-onderwerpen (taakopvating).

\subsubsection{Operationalisatie van bedriffsgebonden variabelen}

1. De grootte van het bedrijf. Dit betreft het aantal werknemers, dat de bedrijfsarts verzorgt (grootte bedrijf).

2. Het voorkomen van belastende factoren in het bedrijf. Het gaat om de mate waarin fysiek belastende omstandigheden voorkomen in het bedrijf (fysieke Arbo).

3. De hoogte van het verzuim in betrokken bedrijf. Dit is het gemiddelde verzuimpercentage over 1985 en 1986 (verzuimhoogte).

4. De snelheid van contact met zieken. Dit is de tijd waarbinnen de BGD contact opneemt met zieke werknemers. Het kan variëren van 1 tot meer dan 20 dagen (snelheid contact met zieken).

\subsection{Het onderzoeksmodel}

In figuur 6.2 wordt het volledige onderzoeksmodel samengevat.

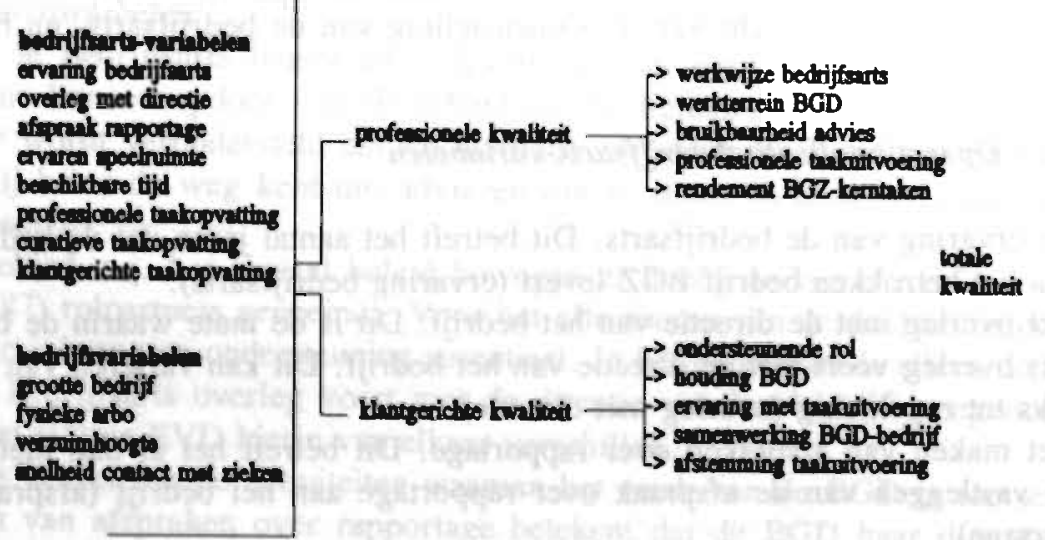

Figuur 6.2. Het onderzoeksmodel 


\subsection{Samenvatting}

In dit hoofdstuk werd het verloop van het onderzoek en het onderzoeksmodel beschreven. De kwaliteit van BGZ wordt beschreven door middel van de aspecthenadering. Er worden professionele en klantgerichte aspecten van kwaliteit van BGZ onderscheiden.

Er wordt een aantal bedrijfsarts- en bedrijfsvariabelen geselecteerd met een mogelijke samenhang met (professionele en klantgerichte) aspecten van kwaliteit van BGZ. 


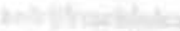

175.

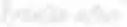

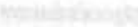

can

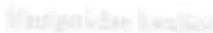

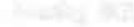

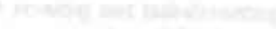

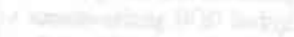

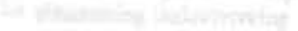

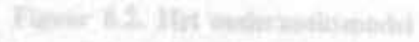




\section{Hoofdstuk 7}

\section{Beschrijving van het BGZ- relatienetwerk}

\subsection{Inleiding}

In dit hoofdstuk wordt een beschrijving gegeven van de bedrijven, de BGD'en en de bedrijfsartsen uit het onderzoek.

Samen vormen zij het BGZ-relatienetwerk. Dit hoofdstuk geeft hiermee het kader aan waarbinnen een kwaliteitsbeleid van een BGD gestalte krijgt.

Zoals eerder gesteld verschillen GD'en en EVD'en in organisatie, in positie in en ten opzichte van het bedrijf. Vandaar dat idealiter de beschrijving separaat zou plaatsvinden voor de respectieve BGD-organisatievorm (GD en EVD). De (beperkte) omvang van de respons maakt het echter noodzakelijk eventuele verschillen tussen GD en EVD voorzichtig te bekijken. Aan de hand van de Fisher's exact test is nagegaan of verschillen statistisch significant zijn.

Overigens kan nog worden opgemerkt dat het zoeken naar verschillen sec tussen GD en EVD niet het belangrijkste onderwerp van onderzoek was. De in dit hoofdstuk beschreven verschillen tussen GD en EVD hebben dan ook voornamelijk cen indicatief karakter.

Tevens kan worden opgemerkt dat in de tabellen de genoemde percentages betrekking hebben op het werkelijke aantal respondenten, dat wil zeggen de item-respons. $\mathrm{Bij}$ een eventuele non-respons van de vraag, waar betrokken item onderdeel van uit maakt, mag immers niet verondersteld worden dat het niet invullen van de vraag de betekenis van een "neen-antwoord" heeft.

De opbouw van de tabellen is als volgt. Per BGD-organisatievorm (GD en EVD) wordt per item het werkelijke aantal absolute respondenten aangegeven. In de totaal-tabel worden ook percentages weergegeven. Deze hebben uitsluitend betrekking op het aantal respondenten. Indien er sprake is van een groot verschil in respons tussen GD en EVD, of van een relevante non-respons, wordt dit vermeld. Indien een verschil volgens de Fisher's exact test een p-waarde kleiner of gelijk .05 heeft, wordt dit achter betrokken item aangegeven met een sterretje $(* ; p=<.05)$.

Eerst wordt ingegaan op de bedrijven. Welke arboproblemen vragen de aandacht, hoe hoog is het verzuim, is er sprake van een voedingsbodem voor Arbo- en so- 
ciaal beleid, en hoe zijn de afspraken of contracten tussen het bedrijf en de BGD tot stand gekomen (paragraaf 7.2).

Hierna, in paragraaf 7.3, wordt de organisatie van de BGD beschreven. Hoe is de interne sturing van de BGD, welke afspraken maakt de BGD met de bedrijven, welke mensen en middelen heeft de BGD ter beschikking.

In paragraaf 7.4 tenslotte wordt een profiel van de bedrijfsarts geschetst. Hoe gaat hij binnen en buiten het bedrijf te werk, welke opvattingen heeft hij over zijn vak.

\subsection{Beschrijving van de bedrijven}

Hoe de inbreng van de BGD wordt beoordeeld, kan sterk afhangen van het soort bedrijven waaraan BGZ geleverd wordt. Welke BGZ-relevante problemen spelen er, hoe is het arboklimaat, over welke arbodeskundigheid wordt beschikt? Daarnaast vormt de inhoud van de overeenkomst, het contract tussen BGD en bedrijf een belangrijk kader voor de dienstverlening. De rol van resp. bedrijf en BGD bij de totstandkoming van de inhoud van het contract wordt beschreven.

\subsubsection{Arbeidsomstandigheden}

Tweederde van de bedrijven bevindt zich wat betreft sociaal-economische situatie in een opgaande lijn. GD en EVD onderscheiden zich (overigens niet significant) wat betreft de sociaal-economische situatie in die zin dat in EVD-bedrijven de afgelopen jaren vaker kwantitatieve wijzigingen op personeelsgebied hadden plaatsgevonden $(G D=4 x ; E V D=5 x)($ tabel 7.1).

Tabel 7.1. Sociarteconomische situatie van de bedrijven

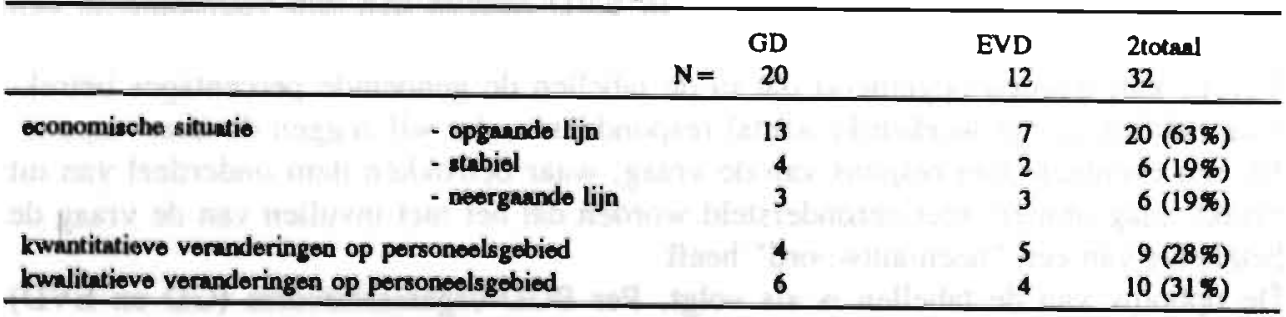

Volgens de hoofden personeelszaken spelen in de bedrijven vooral lichamelijke belasting en ploegendienst een belangrijke rol. Toxicologische belasting speelt in meer GD-bedrijven een rol dan in de onderzochte EVD-bedrijven (tabel 7.2). 


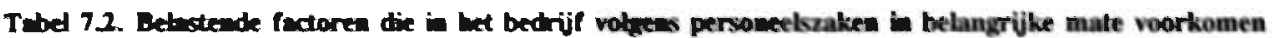

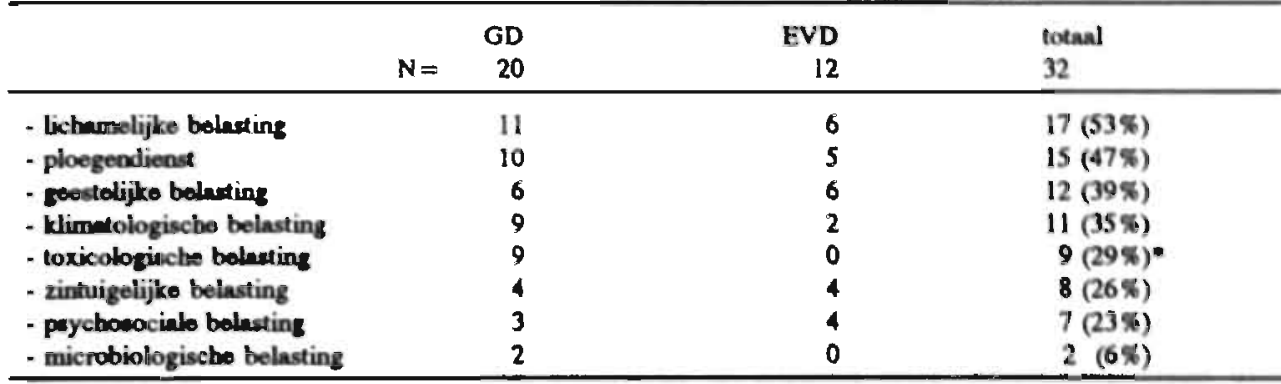

- Fisher's oxuct toet p $<.05$

\subsubsection{Verzuim en arbeidsongeschiktheid}

Bij de helft van de GD-bedrijven ligt het verzuimpercentage voor het totale bedrijf in 1985 en 1986 rond de 8\% (spreiding 4-16\%), terwijl dit bij de technische dienst gemiddeld lager ligt, namelijk rond de 6\%. De verzuimduur lag in 1985 en 1986 bij een kwart van de GD-bedrijven rond de 11 dagen, de helft van de bedrijven geeft dit niet aan.

Bij EVD-bedrijven zien de verzuimparameters er gunstiger uit. Het verzuimpercentage ligt gemiddeld lager (rond de 6,5\%), bij een met GD-bedrijven vergelijkbare gemiddelde verzuimduur, duidend op een lagere verzuimfrequentie bij EVD-bedrijven.

\subsubsection{Voedingsbodem Arbeidsomstandigheden}

In het kader van de Arbowet kent de overheid aan de werkgever de verantwoordelijkheid toe om op bedrijfsniveau in samenspraak met de werknemers(vertegenwoordiging) zijn zorg voor gezondheid, veiligheid en welzijn in concreet beleid te vertalen, waarbij de BGD als één van de deskundige diensten beide partijen met advisering terzijde kan staan.

De binnen het bedrijf op het arbogebied aanwezige disciplines laten tussen de GDen EVD-bedrijven een aantal duidelijke verschillen zijn, waaraan het verschil in bedrijfsgrootte mede debet zal zijn. Alle EVD-bedrijven en de helft van de GDbedrijven hebben een veiligheidsfunctionaris of -dienst; bij 11 EVD-bedrijven is een bedrijfsmaatschappelijk werker in dienst tegen 3 bij GD-bedrijven; een psycholoog wordt in 2 EVD-bedrijven aangetroffen; een commissie Veiligheid, Gezondheid en Welzijn, die door de werknemersvertegenwoordiging is ingesteld, is er bij 78\% van de bedrijven; cen zgn. Arbocommissie, d.w.z. een overleg en besluitvormend orgaan op directieniveau, is anwezig bij iets meer dan de helft van de bedrijuen (tabel 7.3). 
Tabel 7.3. De hinnen het bedriff werkene arbo-rolpertners

\begin{tabular}{|c|c|c|c|}
\hline & $\begin{array}{r}\text { GD } \\
20 \\
\end{array}$ & $\begin{array}{r}\text { EVD } \\
12\end{array}$ & $\begin{array}{l}\text { tocual } \\
32\end{array}$ \\
\hline - veilicheidefunctioneris/-dienat & 10 & 12 & $22(69 \%)$ \\
\hline - bedrijfsmantechappelijk werk & 3 & 11 & $14(44 \%)$ \\
\hline - bedrijfapeycholoog & 0 & 2 & $2(6 \%)$ \\
\hline - commissie VOW (werknemerscio) & 15 & 10 & $25(78 \%)$ \\
\hline - Arbocommissio (werkgoverscie) & 9 & 8 & $17(53 \%)$ \\
\hline
\end{tabular}

Van de rolpartners op arbogebied heeft de BGD het meest te maken met de afdeling personeelszaken. Hoe hebben de bedrijven de personeelszorg georganiseerd? Meer dan $90 \%$ van de bedrijven heeft de beschikking over cén of meer personeelsfunctionarissen, in ruim de helft betreft dit een fulltime functionaris. Qua opleiding valt de grootste groep in de HBO-groep. Lang niet altijd blijkt er op directieniveau directe inbreng van een personeelsfunctionaris. Inhuren van tijdelijke externe deskundigheid (adviesbureaus) komt regelmatig voor. De hoofdaandacht bij het personeelswerk gaat uit naar werving en selectie en personeelsplanning.

BGD en personeelszaken proberen aan hun gemeenschappelijke taak inzake het sociaal beleid meer vorm en inhoud te geven door veelal samen te werken in een zogenaamd sociaal medisch team. Naast personeelszaken en BGD kunnen andere participanten - maar dan vrijwel altijd ad-hoc - aan dit overleg deelnemen, zoals afdelingsleiding. Bij EVD-bedrijven completeert de bedrijfsmaatschappelijk werker vaak het sociaal medisch team, terwijl dit bij GD-bedrijven zelden het geval is. Passend binnen de filosofie van de Arbowet wordt de concrete uitvoering van het beleid op het gebied van veiligheid, gezondheid en welzijn in de praktijk meestal aan de respectieve participanten (veiligheid, gezondheid, welzijn) toegewezen, althans bij EVD-bedrijven; bij zo'n 20\% van de GD-bedrijven wordt hiertoe binnen de directic een speciaal aangestelde persoon verantwoordelijk gesteld.

\subsubsection{Contract BGZ}

In deze paragraaf wordt de totstandkoming van het contract tussen bedrijf en BGD beschreven. Zaken die hierbij aan de orde komen zijn: wie nam het initiatief tot aansluiting bij een BGD, wat waren de voornaamste redenen van aansluiting, waarover worden in het contract afspraken gemaakt, welke invloed had resp. de BGD en het bedrijf bij de totstandkoming van het contract, welke kosten zijn er gemoeid met BGZ, welke betalingswijze wordt door het bedrijf gewenst, welke mening heeft het bedrijf over het in eén functie combineren van de taak van de bedrijfsarts en verzekeringsgeneeskundige?

\subsubsection{Initiatief tot aansluiting bij een BGD}

Het initiatief tot aansluiting van een bedrijf bij de BGD kwam meestal van zijde van de directie van het bedrijf. Bij een derde van de GD-bedrijven vormde acquisitie van de BGD de aanleiding tot aansluiting. Voordat de bedrijven zich aansloten 
bij cen BGD of overgingen tot de oprichting van een eigen BGD, had tweederde al enige vorm van medische begeleiding, die zich beperkte tot het laten verrichten van aanstellingskeuringen. Slechts bij uitzondering werd een verzuimspreekuur gehouden of werd bij werknemers periodiek onderzoek verricht. Bij de overweging(en) zich aan te sluiten bij de huidige BGD speelden vooral een rol de verwachting van betere continuitteit in zorgverlening en van meer deskundigheid. De zorg werd niet goedkoper.

\subsubsection{Redenen tot aansluiting bij een $B G D$}

BGZ wordt primair gezien als een element van het te voeren social beleid van de onderneming. Daarnaast vormen gerichte vraagstellingen aanleiding tot het aantrekken van BGZ, zoals het laten verrichten van aanstellingskeuringen en (vooral bij GD-bedrijven) periodieke onderzoeken. De aanwezigheid van eventuele gezondheidsrisico's wordt door 9 bedrijven als reden aangevoerd om BGZ in te voeren (tabel 7.4).

Tubel 7.4. Redenea on BCZ in te voeres volgens opanve personeekzaken (meerdere Mems mogelib)

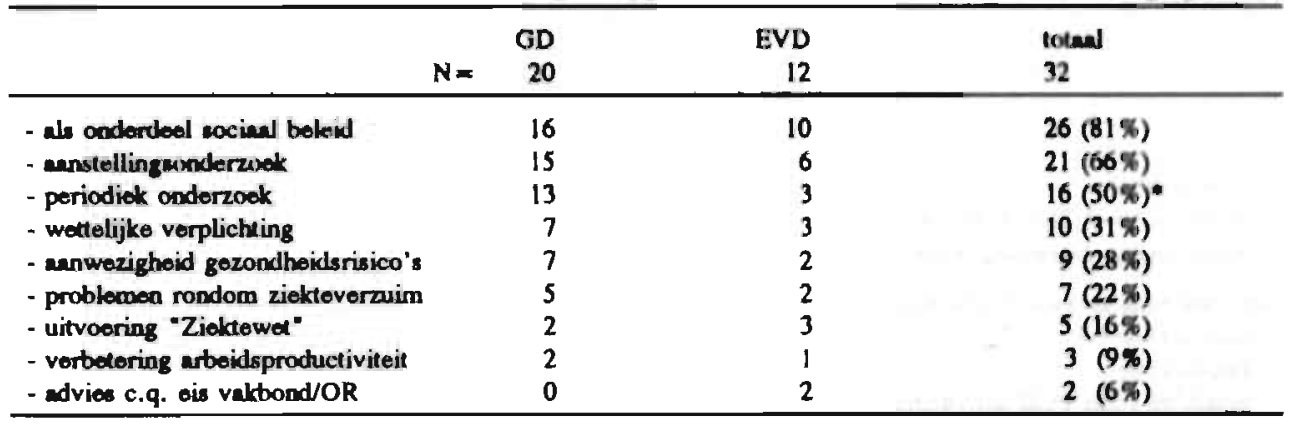

- Fisher' exact teet $\mathbf{p}<.05$

\subsubsection{De "onderhandelingen" over het contract}

In deze paragraaf komt aan de orde hoe de hiervoor genoemde redenen van aansluiting bij een BGD worden vertaald in een contract. De grote non-respons op deze vraag (met name in EVD-bedrijven) wijst er mogelijk op dat (met name in EVD-bedrijven) geen contract-onderhandeling heeft plaatsgevonden. Indien er wel contractonderhandelingen hebben plaatsgevonden, dan wordt de ondernemingsraad meestal vanaf het begin betrokken bij het besluitvormingsproces.

Hoe stelt de directie van de BGD zich op als een bedrijf slechts een beperkt aantal taken wenst? Wat weegt dan zwaarder: de eigen professionaliteit of de wens van de klant? Rond een derde van de BGD'en laat de wens van de klant hierbij prevaleren, dat wil zeggen dat het beperkte takenpakket als zodanig wordt geaccepteerd. De overige directies, voor zover deze vraag wordt beantwoord, oefenen "druk" uit 
deze taken toch in een groter geheel op te nemen of het karakter van tijdelijkheid
("groeipakket") te geven.

Over het takenpakket en de taakuitvoering van BGZ wordt bij GD-bedrijven regelmatig onderhandeld. De bedrijven hebben hierbij overigens niet het idee dat zij veel invloed hebben kunnen uitoefenen op omvang en prijs van het BGZ-pakket. Vooral ten aanzien van de taakuitvoering wordt door bijna tweederde van de GDbedrijven meer invloed gewenst (tabel 7.5).

Thel 7.5. De totetendkoming van bet contract (volgens personeclszaken)

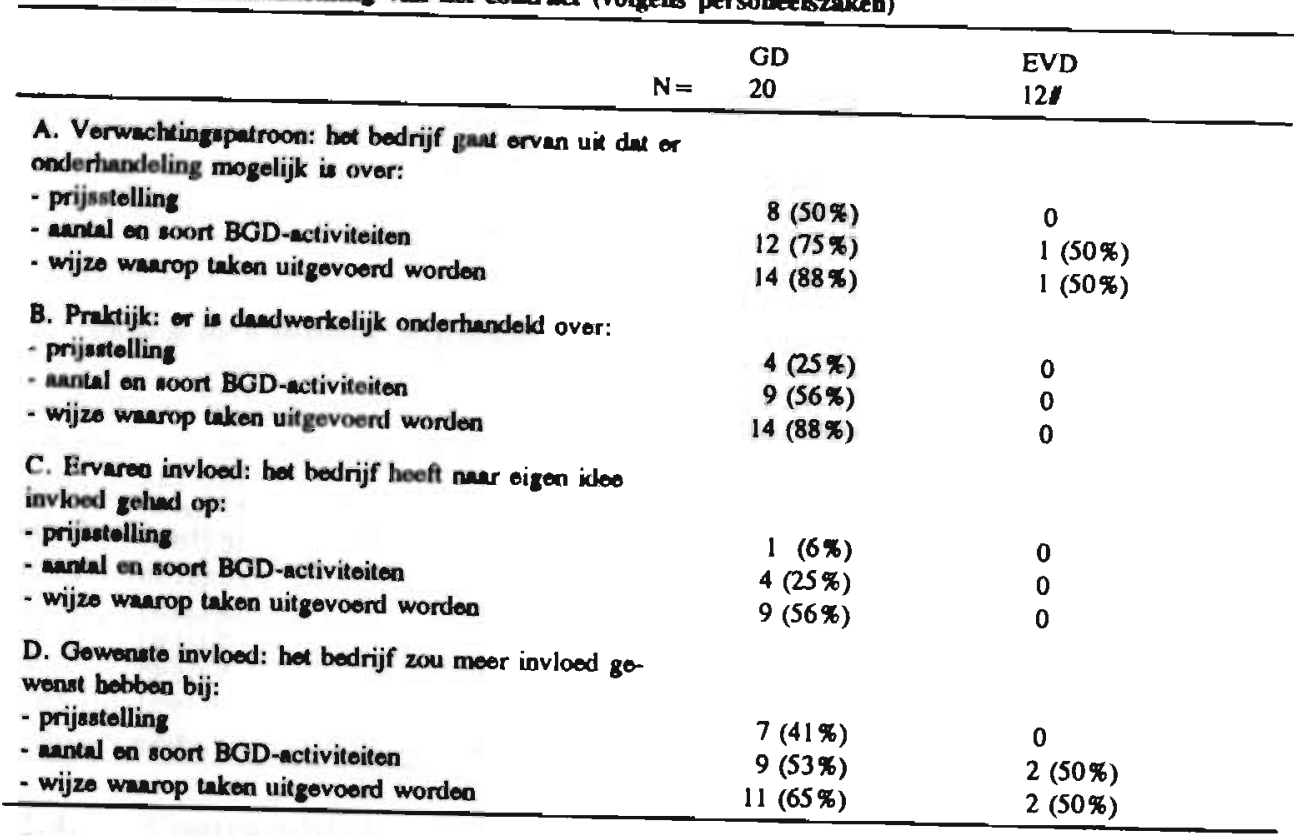

Grote non-respons EVD-bedrijven

\subsubsection{Kosten BGZ: praktijk en wensen}

De meest gebruikelijke betalingswijze bij GD'en is het abonnementstarief, dat in 1986 gemiddeld f. 157,00 bedroeg. Voor dit bedrag levert de overgrote meerderheid een "standaard-pakket", dat wil zeggen de taken zoals omschreven in artikel 18 van de Arbowet. Bij uitzondering worden aanstellingskeuringen (nog) apart in rekening gebracht, of wordt er intreegeld gevraagd. Verrekening op verrichtingenbasis is uitzonderlijk. Over de betalingssystematiek bij EVD'en kan op basis van dit onderzoek, vanwege non-respons, weinig worden gezegd. Het beperkt aantal (25\%) EVD'en dat opgave deed van de kosten per werknemer, levert een gemiddeld bedrag op van ruim $f 180,00$. 
Ook ten aanzien van de vraag naar gewenste financiering is er bij EVD-bedrijven sprake van een grote non-respons. Bij GD-bedrijven bestaan er verschillen in opvatting over de gewenste financiering tussen de directie van de BGD en personeelszaken. Personeelszaken wil per taak betalen, de directie van de BGD wil betaald worden op basis van een bepaald percentage van de loonsom of op basis van verhuur van tijd (tabel 7.6).

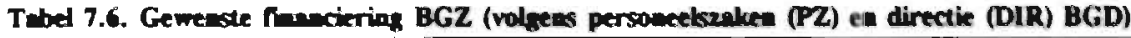

\begin{tabular}{|c|c|c|c|c|}
\hline $\mathbf{N}=$ & $\begin{array}{l}\text { PZ-GD } \\
20\end{array}$ & $\begin{array}{l}\text { PZ-EVD } \\
12 \theta^{\prime}\end{array}$ & $\begin{array}{l}\text { DIR-OD } \\
32\end{array}$ & $\begin{array}{l}\text { DIR-EVD } \\
20 \|\end{array}$ \\
\hline - sociale premios & $2(10 \%)$ & 0 & $18(58 \%)^{*}$ & $2(20 \%)$ \\
\hline - percentage van de verkoonde som & $1(5 x)$ & $2(67 \%)$ & $7(23 \%)^{*}$ & $6(67 \%)$ \\
\hline - bijdnge/tarief per tuak & $9(45 \%)$ & $2(67 \%)$ & - & - \\
\hline - prijsstelling per risicogroep & 1 (5\%) & $1(33 \%)$ & $15(52 \%)^{*}$ & $5(56 \%)$ \\
\hline - verhuar van tijd & $3(15 \%)$ & 0 & $23(77 \%)$ & $3(30 \%)$ \\
\hline - toesles bij specialo gobeurtenizsen & $5(25 \%)$ & 0 & $22(73 \%)^{*}$ & $5(56 \%)$ \\
\hline
\end{tabular}

- Fisher's oxact tout p $<.05$

trate non-respons EVD bedrijven

\subsubsection{Inhoud van het contract tussen BGD en bedriif}

Na beschreven te hebben hoe het contract of de overeenkomst tot stand komt, is het nu de vraag wat er uiteindelijk in concreto in het contract wordt afgesproken.

GD-bedrijven leggen hun dienstverlening voor $80 \%$ van de bedrijven vast in een contract of overeenkomst. In EVD-bedrijven opereert de BGD bijna altijd zonder expliciet dienstverleningscontract.

In het contract worden meestal opgenomen een financiële regeling en de taken die de BGD zal uitvoeren. Bij bijna $40 \%$ van de GD-bedrijven wordt in het contract opgenomen wie vanuit het bedrijf primair de contactpersoon is, en welke procedure moet worden gevolgd als er veranderingen worden gewenst in het contract. Zelden wordt in het contract afgesproken dat de dienstverlening wordt geëvalueerd (tabel 7.7).

Toch zijn de meeste bedrijven van mening dat, ondanks het globale karakter van de meeste contracten, de BGD weet van haar wordt verwacht.

In de CAO zijn maar bij $20 \%$ van de bedrijven afspraken gemaakt over de BGZdienstverlening. Doorgaans betreft dit afspraken over periodiek onderzoek. 


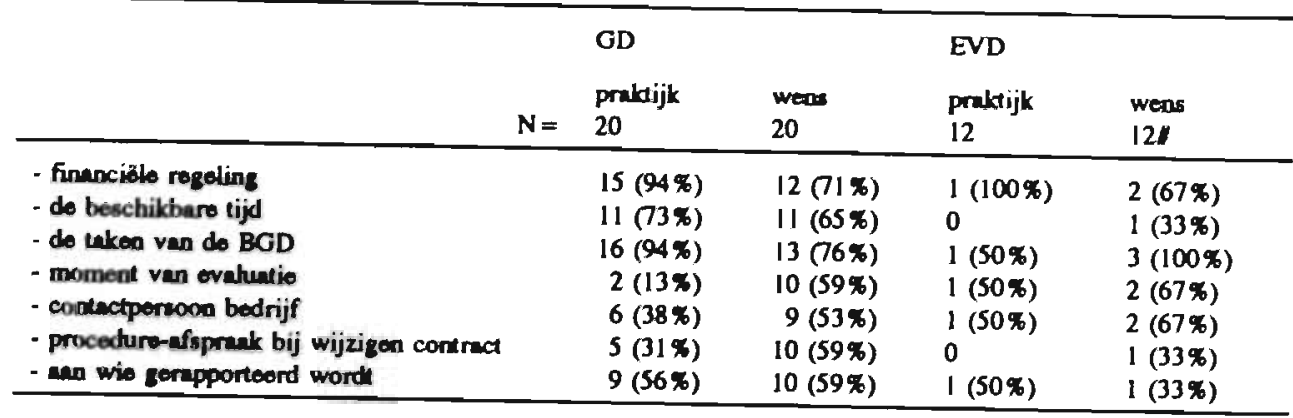

I grote non-reapons EVD-bedrijven

\subsubsection{Opinles m.b.t. de organisatie van de verzekeringsgeneeskundige taak}

Aan personeelszaken van de bedrijven en de directie van de BGD werd de mening gevraagd over het combineren van de taak van de bedrijfsarts en de verzekeringsgenceskundige in eén persoon. Dat de combinatiefunctie in de toekomst opgelegd zal worden, werd door een minderheid van de directies van BGD'en vermoed (tabel 7.8).

Thbel 7.8. De ormankatle ven de verzekeringsgeneeskundige enk. Wat is de mening van resp. de directie ven de BGD (DIR) en personeelszaken (PZ) over de comblnatiefunctie bedriffsarts-verzekeringsgenees-
kundlge?

\begin{tabular}{|c|c|c|c|c|c|}
\hline \multirow{2}{*}{ 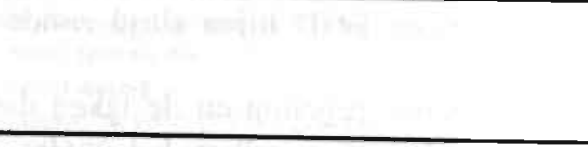 } & \multicolumn{3}{|c|}{ GD } & \multicolumn{2}{|l|}{ EVD } \\
\hline & $\mathbf{N}=$ & $\begin{array}{l}P Z \\
20\end{array}$ & $\begin{array}{l}\text { DIR } \\
32\end{array}$ & $\begin{array}{l}P Z \\
12\end{array}$ & $\begin{array}{l}\text { DIR } \\
20\end{array}$ \\
\hline - voorstender & & $7(35 \%)$ & $14(45 \%)$ & $4(57 \%)$ & $13(72 \%)$ \\
\hline - zal in toekomat wel opgelegd worden & & & $4(13 \%)$ & & $2(11 \%)$ \\
\hline - geef moer rolovanto informutio over een bedrijf & & $2(10 \%)$ & $19(61 \%)$ & $2(17 \%)$ & $12(67 \%)$ \\
\hline & & $11(55 \%)$ & $8(26 \%)$ & $4(57 \%)$ & $4(22 \%)$ \\
\hline - workt offectiover t.a.v. verzuimbeheersing & & $9(45 \%)$ & & $5(71 \%)$ & \\
\hline
\end{tabular}

\section{groto non-respons EVD-bedrijven}

Aan de bedrijfsarts (BA), directie BGD (DIR), personeelszaken (PZ) en ondernemingsraad (OR) werd gevraagd of naar hun mening de combinatiefunctie bedrijfsarts-verzekeringsgeneeskundige de vertrouwensrelatie tussen arts en patient schaadt. Onderstaand in tabelvorm hiervan het resultaat (tabel 7.9). 
Tabel 7.9. Invoed verzekeringsgemeeskuedige tauk op de arts-patient relatie. Dexe invloed wordt schadelijk geacly door.

\begin{tabular}{|c|c|c|c|c|c|}
\hline & $N=$ & $\begin{array}{l}\text { BA } \\
17\end{array}$ & $\begin{array}{l}\mathrm{PZ} \\
20\end{array}$ & $\begin{array}{l}\text { DIR } \\
32\end{array}$ & $\begin{array}{l}\text { OR } \\
16\end{array}$ \\
\hline GD & & $7(4 \mid \%)$ & $10(50 \%)$ & $5(16 \%)^{*}$ & $13(81 \%)$ \\
\hline & $\mathbf{N}=$ & 15 & 12 & 20 & 10 \\
\hline EVD & & 0 & $3(43 \%)$ & $3(17 \%)$ & $7(70 \%)^{\circ}$ \\
\hline
\end{tabular}

- Finbor's oxuct toet $\mathrm{p}<.05$

I non-respons EVD-bedrijven

De ondernemingsraad is meestal van mening dat deze combinatiefunctie schadelijk is, zowel bij GD- als EVD-bedrijven. Zeven bedrijfsartsen bij GD-bedrijven achten deze combinatie ook schadelijk, terwijl geen enkele EVD-bedrijfsarts deze combinatie schadelijk vindt. Maar weinig directies van BGD'en achten de combinatiefunctie schadelijk. Het lijkt erop dat functionarissen uit het bedrijf het combineren van de functie van bedrijfsarts en verzekeringsgeneeskundige in eén perscon schadelijker vinden voor de vertrouwensrelatie arts-patient dan BGD-medewerkers zelf. Het verschil tussen ondernemingsraad en de directie van de BGD is significant in GD- en EVD-bedrijven, en tussen ondernemingsraad en personeelszaken in EVDbedrijven.

\subsubsection{Samenvatting}

In paragraaf 2 werd een beschrijving gegeven van de bedrijven. Tegen de achtergrond van de beperkte respons kunnen indicatief als verschillen tussen GD- en EVD-bedrijven worden genoemd:

bij GD-bedrijven speelt toxicologische belasting een grotere rol dan bij EVDbedrijven;

in EVD-bedrijven ligt het verzuim gemiddeld lager;

- EVD-bedrijven beschikken vaker over veiligheidsfunctionaris, en bedrijfsmaatschappelijk werker. Dit komt bijvoorbeeld tot uiting in de samenstelling van het sociaal medisch team;

- bij EVD-bedrijven vindt in het algemeen geen contractonderhandeling plaats; personeelszaken in GD-bedrijven wenst meer invloed bij de totstandkoming van het contract met de BGD dan nu het geval is;

- meer GD- dan EVD-bedrijfsartsen achten de combinatiefunctie bedrijfsartsverzekeringsgeneeskundige schadelijk voor de vertrouwensrelatie arts-patient.

- functionarissen uit het bedrijf lijken de combinatiefunctie bedrijfsarts-verzekeringsgeneeskundige vaker schadelijk te achten voor de vertrouwensrelatie artspatient dan BGD-medewerkers zelf. 


\subsection{Organisatie BGD}

Deze paragraaf gaat in op de wijze waarop BGD'en zijn georganiseerd. Welke mensen en middelen zijn ter beschikking, hoe worden deze ingezet?

\subsubsection{Interne organisatie}

Bij GD'en wordt vaker een norm gehanteerd bij het inzetten van BGD-personeel in de te verzorgen bedrijven dan bij EVD'en ( $81 \%$ versus $50 \%$ ). Het aantal werknemers dat door de bedrijfsarts moet worden verzorgd, ligt bij GD-artsen gemiddeld hoger, zowel met als zonder de verzekeringsgeneeskundige taak (VG) (tabel 7.10). Aan de ene kant heeft de GD-bedrijfsarts de beschikking over meer eerstelijnswerkers (bijvoorbeeld bedrijfsverpleegkundige), aan de andere kant heeft de GD-bedrijfsarts minder specialisten (zoals psycholoog) ter beschikking dan de EVD-bedrijfsarts.

Tabel 7.10. Het anntal te verzorgen werknemens per bedrijsarts

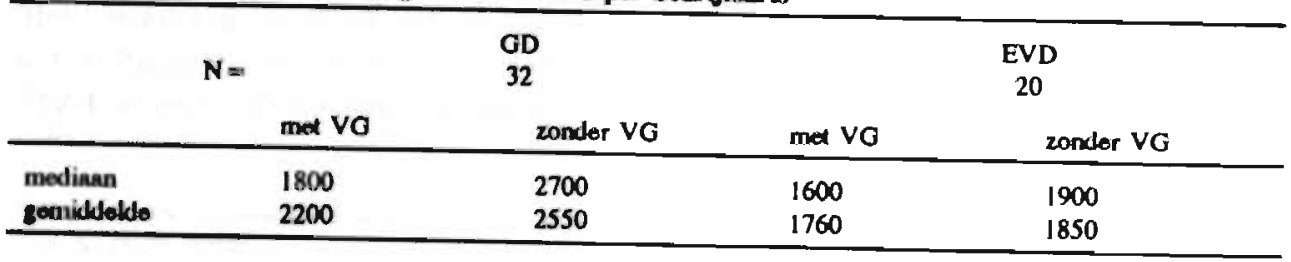

De bestuurlijke organisatie van GD en EVD verschilt wezenlijk. De GD kent als rechtsvorm de stichting of een vereniging. Meestal wordt door het bestuur gewerkt volgens het raad van commissarissenmodel. De invloed van werknemers via het bestuur komt in ruim de helft tot uiting in een paritaire bestuurssamenstelling werkgevers-werknemers, echter een werknemersoverwicht komt niet voor.

Bijna de helft van de EVD'en neemt een positie in rechtstreeks onder de (bedrijfs)leiding, en een derde onder het (hoofd) personeelszaken.

$\mathrm{Er}$ is sprake van een verschil in bevoegdheidsbreedte, niet bij aanschaf van medische apparatuur en het vormgeven aan nascholing, wel bij het uitbreiden van het personeelsbestand en de aanschaf van niet-medische apparatuur. GD'en hebben hier meer bevoegdheid (tabel 7.11).

Het voeren van acquisitie is (vooralsnog) een activiteit die uitsluitend wordt aangetroffen bij GD'en. De directie van de BGD heeft vrijheid van handelen bij het bepalen van de inhoud en omvang van dienstverlening, en in mindere mate bij het vaststellen van de prijs van dienstverlening. 


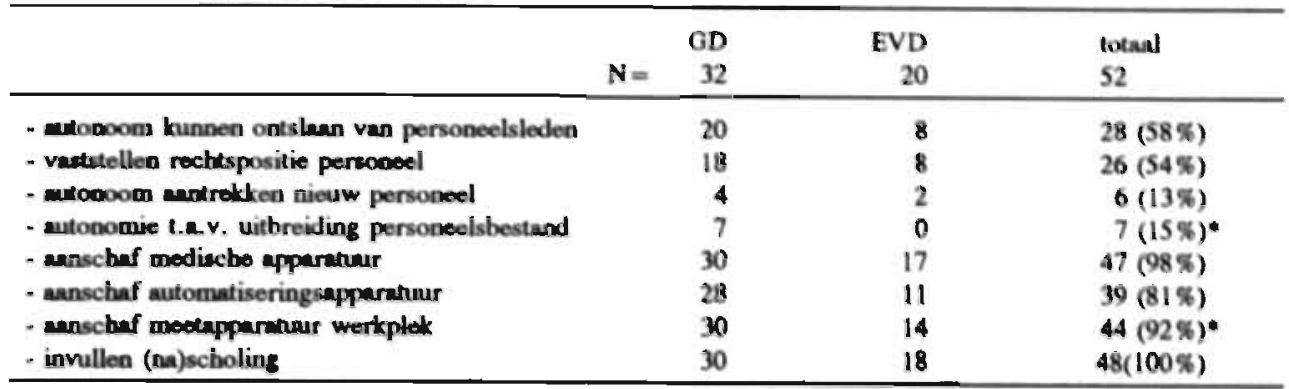

* Fisher's oxect ted $p<.05$

\subsubsection{Personeel en middelen}

\section{Personeel}

De grootte van de BGD varieert sterk. Bij GD'en staan vaker bedrijfsverpleegkundigen en arbeidshygiënisten ter beschikking, terwijl bij EVD'en vaker bedrijfsmaatschappelijk werkers en psycholoog ter beschikking staan. Er kan nog worden opgemerkt dat een kwart van de GD'en zelf een veiligheidsfunctionaris in dienst heeft.

\section{Apparatuur}

GD en EVD beschikken in gelijke mate over de standaard medische apparatuur (bijvoorbeeld audiometer en ECG-apparatuur). Daarentegen heeft de GD vaker de beschikking over een fietsergometer en/of telemetrieapparatuur, en beschikt de EVD vaker over apparatuur om bloed en urineonderzoek te doen (nier- en leverfuncties, cholesterol, metabolieten).

De meeste GD'en en EVD'en beschikken over computerfaciliteiten. Het gebruik hiervan is echter verschillend: bij EVD'en wordt de computer vaker ingezet voor het vastleggen van verzuimgegevens en spreekuur.

\subsubsection{Samenvatting}

Er bestaan verschillen tussen GD en EVD in aantal en functie van het BGD-personeel, alsook in beschikbare middelen. Het interactieproces tussen BGD en bedrijf zou dit verschil kunnen verklaren: bij een andere vraag c.q. ander bedrijf past ook een ander aanbod.

Bij GD'en bestaat een wat grotere bevoegdheid van de directie. 


\subsection{Bedrijfsarts, een profielschets}

In de vorige paragrafen werden de organisaties beschreven waarvoor en van waaruit de bedrijfsarts werkzaam is. In deze paragraaf wordt de bedrijfsarts zelf beschreven. Twee aspecten worden hierbij belicht:

- met wie onderhoudt de bedrijfsarts contacten (paragraaf 7.4.1.);

- welke opvattingen heeft de bedrijfsarts over zijn vak (paragraaf 7.4.2.).

De bedrijfsarts in het onderzoek blijkt vrijwel altijd van het mannelijke geslacht te zijn, bijna altijd (recent) de opleiding tot bedrijfsarts te hebben gevolgd, en zelden naast zijn werk nog nevenfuncties te vervullen. De gemiddelde leeftijd ligt rond de 40 jaar.

\subsubsection{Overlegpartners van de bedrijfsarts}

De concrete takuitvoering komt in het volgende hoofdstuk aan bod. In deze paragraaf wordt beschreven hoe de bedrijfsarts samenwerkt binnen en buiten het bedrijf. De bedrijfsarts voert binnen het bedrijf het meeste overleg met personeelszaken, in mindere mate met afdelingsleiding. Daarnaast wordt veelvuldig overleg gepleegd met collegae uit de verzekeringsgeneeskundige sector. Er kan nog worden opgemerkt dat EVD-bedrijfsartsen vaker dan hun GD-collegae overleggen met de directie van het bedrijf, en er kan worden opgemerkt dat iets minder dan $20 \%$ van de bedrijfsartsen regelmatig overleg heeft met de ondernemingsraad (tabel 7.12).

De helft van de bedrijfsartsen besteedt per jaar aan nascholing gemiddeld 6 kJinische avonden of voordrachten vanuit de beroepsgroep, verband houdend met het arts zijn, 5 dagen per jaar voor het bezoeken van symposia, en gemiddeld 4 uur per week aan bestudering van tijdschriften en literatuur.

Twbel 7.12. De bedrüfsarts voert regelmatig overleg met:

\begin{tabular}{|c|c|c|c|}
\hline & $\begin{array}{r}\text { GD } \\
N=\quad 17 \\
\end{array}$ & $\begin{array}{r}\text { EVD } \\
15 \\
\end{array}$ & $\begin{array}{l}\text { totaal } \\
32 \\
\end{array}$ \\
\hline - afdeling personeolszaken & 16 & 14 & $30(94 \%)$ \\
\hline - afdelingsloiding & 11 & 12 & $23(72 \%)$ \\
\hline - GAK/GMDIABP & 14 & 9 & $23(72 \%)$ \\
\hline - collegno curatiovo sector & 7 & 7 & $14(44 \%)$ \\
\hline - directis bedrijf & 3 & 9 & $12(38 \%)^{*}$ \\
\hline - worknemersvertegenwoordiging & 3 & 3 & $6(19 \%)$ \\
\hline - collegae bedrijfsartsen buiten de BGD & 2 & 4 & $6(19 \%)$ \\
\hline - wetenschappelijke instituten & 2 & 3 & $5(16 \%)$ \\
\hline
\end{tabular}

* Fishor's oxact lest $p<.05$ 


\subsubsection{De opvattingen van de bedrijfsarts over zijn vak}

De wijze waarop iemand aankijkt tegen zijn functie- gevoed door persoonlijke ervaringen en omgeving in de ruime zin van het woord - zullen een belangrijke rol spelen bij het concreet handelen in de praktijk ("taakopvattingen"). Aan de hand van 26 "statements" wordt een indruk hiervan verkregen. Deze "statements" hadden betrekking op de volgende aspecten:

- wat verstaat de bedrijfsarts onder kwalitatief goede BGZ;

- welke spanningsvelden ervaart de bedrijfsarts;

- hoe kan de werkwijze van de bedrijfsarts worden beschreven;

- hoe kijkt de bedrijfsarts aan tegen verzuim(ers);

- hoe ervaart de bedrijfsarts zijn positie in het bedrijf?

Op basis van de literatuur over taakopvattingen bij bedrijfsartsen (Draaisma et al. 1991, Kaiser 1992) zijn door ons drie clusters van taakopvattingen geconstrueerd, te weten: de bedrijfsarts, die gekenmerkt wordt doordat hij uit de curatieve sector komt, voor wie BGZ een secundaire keuze was, die pessimistisch is over kennis bij werkgever en werknemer over BGZ, en die vindt dat een bedrijfsarts ook curatief mag handelen (in het onderzoek wordt verder gesproken over een curatieve taakopvarting); daarnaast de bedrijfsarts die zijn handelen sterk laat bepalen door opvattingen van zijn professie, voor wie technische competentie voorop staat, die van mening is dat de BGD het beste in staat is om aan te geven welke bedrijfsgeneeskundige taken voor een gegeven bedrijf nodig zijn, en die grosso modo tevreden is over de effectiviteit van zijn handelen (verder genoemd een professionele taakopvarting); en tot slot de bedrijfsarts die zich klantgericht en actief opstelt, werknemers invloed toekent bij de te leveren BGZ, en die dienstverlening vast wil leggen in een overeengekomen dienstverleningsplan (verder genoemd een klantgerichte taakopvatting).

Vervolgens zijn deze clusters op inhoudelijke consistentie getoetst met behulp van een reliability-test (Cronbach's alpha). De drie geconstrueerde clusters bleken voldoende homogeen (alpha respectievelijk .62, .66 en .64). De onderlinge relatie tussen deze drie taakopvattingsvariabelen is weergegeven in tabel 7.13.

Tabel 7.13. Correlaties tussen tankopvartingsclusters

\begin{tabular}{llll}
\hline & professioned & curatief & klantgericht \\
\hline $\begin{array}{l}\text { professioned } \\
\text { curatiof }\end{array}$ & 1.000 & -.18 & .23 \\
klantgericht & & 1.000 & .02 \\
\hline
\end{tabular}

Dozo semenhangen zijn niet statistisch significant 


\subsubsection{Kenmerken van kwaliteif volgens de bedrijfsarts}

Kwalitatief goede BGZ kenmerkt zich naar de mening van vrijwel elke bedrijfsarts allereerst door technische competentie van de zorgverleners, waarbij opvallend is dat EVD-bedrijfsartsen deze mening minder vaak zijn toegedaan $(90 \%$ versus $50 \%)$. Het vastleggen van de dienstverlening in een tevoren besproken en afgesproken plan/contract is voor de grote meerderheid een vereiste. Het over de gesignaleerde problematiek gestructureerd overleg plegen in een sociaal medisch team levert voor velen een positieve bijdrage aan de kwaliteit van BGZ.

\subsubsection{Spanningsvelden van de bedriifsarts}

De bedrijfsarts staat bloot aan verschillende spanningsvelden. Enerzijds is er een spanningsveld tussen belangen werkgever-werknemer, anderzijds kan de bedrijfsarts klem zitten tussen de wensen van de directie van de BGD en van de directie van het bedrijf. Het gaat er immers om BGZ te leveren op maat, met kwaliteit en met behoud van de eigen professionaliteit, doch ook met oog voor financiële haalbaarheid, zowel intern als extern. Toch lijken de spanningen wel mee te vallen. Weliswaar ervaart een meerderheid inderdaad het spanningsveld in de belangen werkgever-werknemer, maar slechts een kleine groep bedrijfsartsen is somber over de toekomst van de BGZ, en slechts een kleine groep ervaart te weinig medewerking van de kant van het bedrijf bij het tot stand brengen van reïntegraties. De grote meerderheid heeft het idee dat uitgebrachte adviezen meestal wel worden opgevolgd, waarbij tweederde van mening is dat de BGD rekening moet houden met economische haalbaarheid van adviezen. Slechts een zeer beperkt aantal bedrijfsartsen voelt zich klem zitten tussen de eisen van de eigen directie en van het bedrijf. EVDbedrijfsartsen zijn vaker van mening dat de doelstellingen van het bedrijf parallel aan de doelstellingen van de BGD dienen te lopen.

\subsubsection{Beleid en werkwijze van de bedrijfsarts}

De BGZ heeft als kenmerken groepszorg, preventie en kennis van de werkplek. EVD-bedrijfsartsen richten zich meer op individu-gerichte taken. Ook achten zij een curatieve opstelling van de bedrijfsarts vaker acceptabel. Dit verschil wordt niet verklaard door een andere achtergrond, noch door een andere mening over het nut voor de bedrijfsarts te beschikken over een curatieve achtergrond c.q. ervaring.

GD- en EVD-bedrijfsartsen zijn in gelijke mate bereid bij arbeidsconflicten (actief) te bemiddelen, en ook kennen beide in gelijke mate waarde toe aan het doen van werkplekonderzoek.

De meerderheid van de bedrijfsartsen acht zichzelf het beste in staat om aan te geven welke bedrijfsgeneeskundige taken voor een gegeven bedrijf nodig zijn. De meeste bedrijfsartsen schatten de kennis bij werkgever en werknemer over de (on)mogelijkheden van de BGZ laag in. 


\subsubsection{De visie van de bedrijfsarts over verzuim}

De BGZ kan de nadruk leggen op de eigen professionaliteit, of meer op de wensen van de werknemer respectievelijk werkgever. Het beste komt dit tot uiting in opvattingen ten aanzien van verzuimbe(ge)leid(ing). De opvatting dat het hervatten na ziekte primair de verantwoordelijkheid van de zieke is, is de mening van ruim tweederde van de bedrijfsartsen (er is hier geen onderscheid zichtbaar tussen GD en EVD). Of de combinatiefunctie bedrijfsarts-verzekeringsgeneeskundige de vertrouwensrelatie arts-patient schaadt wordt wisselend ervaren (zie tabel 7.9). Frequent verzuim wordt door bedrijven als het meest storend voor het produktieproces gezien. Bijna de helft van de bedrijfsartsen is van mening dat een inefficiënte organisatie van het bedrijf mede een oorzaak is van frequent verzuim. Voor de helf van de GD-artsen, en voor een vijfde van EVD-bedrijfsartsen, hebben veel mensen tegenwoordig een lage verzuimdrempel.

\subsubsection{Samenvatting}

Bedrijfsartsen kijken verschillend aan tegen hun vak. Er kan een drietal clusters worden onderscheiden: de bedrijfsarts met een "curatieve" taakopvatting, met een "professionele" taakopvatting en met een "klantgerichte" taakopvatting. EVD-bedrijfsartsen plegen meer overleg met de directie van het bedrijf.

\subsection{Samenvatting}

In dit hoofdstuk werden verschillende structuur- en organisatiekenmerken van BGD en bedrijf besproken. Hiermee werd het kader van de BGZ aangegeven. Ook werd een profielschets van de bedrijfsarts gemaakt.

De verschillen die werden vastgesteld tussen GD en EVD, zijn in belangrijke mate de resultante van het interactieproces tussen BGD en bedrijf. Verschillen zijn als zodanig uiting van het gewenste maatwerk. Bij EVD-bedrijven verloopt het interactieproces mogelijk meer impliciet. Een expliciete discussie voorafgaand aan de totstandkoming van een contract tussen BGD en bedrijf lijkt binnen EVD-bedrijven niet plaats te vinden. 
Shat

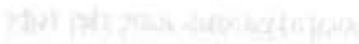

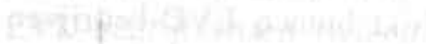

ant

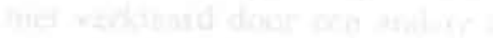

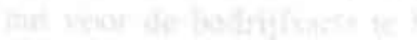

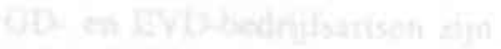

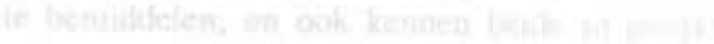

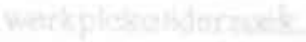

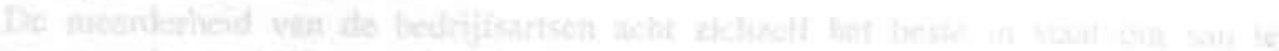

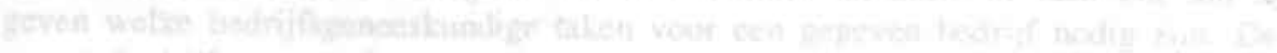

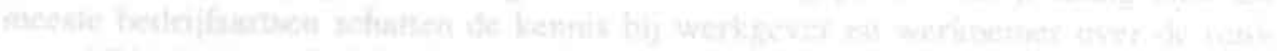

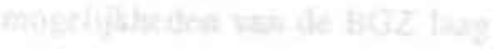

135 


\section{Aspecten van kwaliteit van BGZ.}

\section{De visie van de leverancier en de ontvanger van BGZ over professionaliteit en klantgerichtheid}

\subsection{Inleiding}

In hoofdstuk 7 werd het relatienetwerk van de BGZ beschreven. Aan de orde kwamen de structuur en de organisatie van bedrijf en BGD, en een profielschets van de bedrijfsarts.

In het onderzoek worden onderscheiden aspecten van professionele en aspecten van klantgerichte kwaliteit. Als professionele aspecten van kwaliteit worden beschouwd: de werkwijze van de bedrijfsarts, het werkterrein van de BGD, de bruikbaarheid van advisering, de taakuitvoering en het rendement van taken. Als klantgerichte aspecten van kwaliteit worden beschouwd: de ondersteunende rol van de BGD, de opstelling van de BGD richting klant, de ervaring van klanten met de uitvoering van de taken door de BGD, de samenwerking tussen BGD en bedrijf, en de afstemming van de uitvoering van zorg naar wens van de klant.

De ervaren kwaliteit van BGZ wordt beschreven vanuit het perspectief van de leverancier van BGZ en vanuit het perspectief van de klant. De bedrijfsarts en in beperkte mate de directeur van de BGD representeren hier de leverancier van BGZ. Aan de kant van de klant treden als representant op het hoofd personeelszaken, de voorzitter van de ondernemingsraad en een aantal werknemers. Om de eventuele invloed van de BGD-organisatievorm op de ervaren kwaliteit te onderzoeken, wordt bij de beschrijving steeds onderscheid gemaakt tussen GD en EVD. Ook in dit hoofdstuk is aan de hand van de Fisher's exact test nagegaan of verschillen statistisch significant zijn. Er moet nogmaals worden benadrukt dat de (beperkte) omvang van de respons het noodzakelijk maakt, voorzichtig te zijn met het trekken van conclusies met betrekking tot verschillen tussen GD en EVD.

De opbouw van de tabellen is conform die van hoofdstuk 7: per BGD-organisatievorm wordt per item het absolute aantal respondenten weergegeven. Indien de Fisher's exact test $<.05$ is, wordt dit achter betreffend item aangegeven met cen sterretje $(*)$. 
Er kan nog worden opgemerkt dat in de tabellen de genoemde percentages betrekking hebben op de item-respons.

De onderscheiden aspecten van ervaren kwaliteit van BGZ kunnen niet in gelijke mate worden beoordeeld door de respectieve respondenten. Van personeelszaken en ondernemingsraad wordt bijvoorbeeld een bredere kijk verwacht op de diverse aspecten van kwaliteit van BGZ dan van de werknemers. Het onderstaand schema (schema 8.1) geeft een overzicht per respondent van de onderzochte aspecten van kwaliteit van BGZ. Door middel van een + is aangegeven welke aspecten bij betreffende respondent zijn onderzocht.

Schem 8.1. Kwalketseospect en responden

\begin{tabular}{|c|c|c|c|c|}
\hline & Bedrijfsents & $\begin{array}{l}\text { Personesels- } \\
\text { zaken }\end{array}$ & $\begin{array}{l}\text { Ondernemings- } \\
\text { rand }\end{array}$ & Werknemers \\
\hline $\begin{array}{l}\text { profensionele kwaliteit } \\
\text { werkwijzo } \\
\text { werkterroin } \\
\text { bruikbnerhoid advie } \\
\text { tuakuitvooring kemtaken } \\
\text { rendement kemtaken }\end{array}$ & $\begin{array}{l}+ \\
+\end{array}$ & $\begin{array}{l}+ \\
+ \\
+\end{array}$ & $\begin{array}{l}+ \\
+ \\
+ \\
+\end{array}$ & \\
\hline $\begin{array}{l}\text { Klentgerichte kwaliteit } \\
\text { ondersteuning } \\
\text { houxting BOD } \\
\text { ervaring met takuitvoering } \\
\text { komtaken } \\
\text { samenwerking BGD bedrijf } \\
\text { afatemming kerntankuitvoering }\end{array}$ & + & $\begin{array}{l}+ \\
+\end{array}$ & $\begin{array}{l}+ \\
+ \\
+ \\
+\end{array}$ & + \\
\hline
\end{tabular}

De opbouw van dit hoofdstuk is als volgt. In paragraaf 8.2 worden de professionele aspecten van ervaren kwaliteit van BGZ beschreven (professionele kwaliteit). In paragraaf 8.3 worden de klantgerichte aspecten van ervaren kwaliteit van BGZ beschreven (klantgerichte kwaliteit).

\subsection{Professionele aspecten van kwaliteit van BGZ}

Professionele kwaliteit wordt beschreven aan de hand van de volgende aspecten: de werkwijze en het werkterrein van de bedrijfsarts/BGD, de bruikbaarheid van advisering door de BGD, de uitvoering van BGD-kerntaken en het rendement van BGZ-kernactiviteiten. Deze aspecten worden achtereenvolgens beschreven in paragraaf 8.2.1 tot en met 8.2.5. 


\subsubsection{Werkwijze van de BGD c.q. de bedrijfsarts}

Tweederde van de (GD- en EVD)-bedrijfsartsen ervaart de ter beschikking staande tijd als (ruim) voldoende. Vrijwel alle BGD'en kunnen een volledig pakket BGZ leveren in de zin van artikel 18 van de Arbowet. EVD'en rekenen EHBO-activiteiten vaker tot hun taak. Om prioriteiten te kunnen stellen in het brede takenpakket, gaat driekwart van de bedrijfsartsen planmatig te werk volgens een tevoren besproken en overeengekomen dienstverlenings- of activiteitenplan. $\mathrm{Om}$ deze prioriteitsstelling actueel te houden, evalueert tweederde van de bedrijfsartsen tenminste eenmaal per jaar de geleverde BGZ met de directie van het bedrijf.

De meeste GD-bedrijfsartsen (BA) en de helft van de EVD-bedrijfsartsen maken afspraken over de wijze waarop aan het bedrijf zal worden gerapporteerd (al wordt dit maar bij iets meer dan de helft van de GD-bedrijven in het contract opgenomen). Er wordt vaker gerapporteerd aan de directie van het hedrijf dan aan de ondernemingsraad (OR). In EVD-bedrijven is dit verschil statistisch significant (tabel 8.1).

Tabel 8.1. Afsprakem over rapportage

\begin{tabular}{|c|c|c|c|c|c|}
\hline$N=$ & $\begin{array}{l}\text { BA-OD } \\
17\end{array}$ & $\begin{array}{l}\text { BA-EVD } \\
15\end{array}$ & $\begin{array}{l}\text { lowed } \\
32\end{array}$ & $\begin{array}{l}\text { OR-GD } \\
16\end{array}$ & $\begin{array}{l}\text { OR-EVD } \\
10\end{array}$ \\
\hline - afspraken gomalat over rapportigo & 14 & 7 & $21(68 \%)$ & & \\
\hline - altijd rapportage an directie? & 14 & $10^{*}$ & $24(75 \%)$ & & \\
\hline - altijd rapportage an OR? & 10 & 5* & $15(47 \%)$ & & \\
\hline $\begin{array}{l}\text { - verplichte rapportago volgens artikel } \\
18 \text { Antowet? }\end{array}$ & 7 & 10 & $17(57 \%)$ & 10 & 5 \\
\hline
\end{tabular}

- Fisber's oxnct $\mathrm{p}<.05$

Volgens $40 \%$ van personeelszaken adviseert de BGD wel eens ongevraagd. Het bedrijf neemt vaker het initiatief en vraagt de BGD om gericht advies. Opgemerkt kan worden dat de bedrijfsarts het bedrijf een minder actieve rol toedicht dan personeelszaken zichzelf geeft (niet significant)(tabel 8.2).

Tabel 8.2. Adviesfunctie BGD: initiatiefnemer

\begin{tabular}{|c|c|c|c|c|c|c|}
\hline & \multicolumn{3}{|c|}{ bedrijfserts } & \multicolumn{3}{|c|}{ personeelszaken } \\
\hline$N=$ & $\begin{array}{l}\text { GD } \\
17\end{array}$ & $\begin{array}{l}\text { EVD } \\
15\end{array}$ & $\begin{array}{l}\text { toted } \\
32\end{array}$ & $\begin{array}{l}\text { GD } \\
20\end{array}$ & $\begin{array}{l}\text { EVD } \\
12\end{array}$ & $\begin{array}{l}\text { toteal } \\
32\end{array}$ \\
\hline $\begin{array}{l}\text { - bedrijf neemt zelf rogelmatig bet initiatiof } \\
\text { - BGD adviseort ongovrangd }\end{array}$ & 10 & 9 & $19(59 \%)$ & $\begin{array}{r}17 \\
7 \\
\end{array}$ & $\begin{array}{l}8 \\
5\end{array}$ & $\begin{array}{l}25(81 \%) \\
12(40 \%)\end{array}$ \\
\hline
\end{tabular}

Er is ook onderzocht hoe de verschillende bedrijfsgezondheidkundige gegevens worden geregistreerd. 
Registratie van spreekuuractiviteiten met andere dan uitsluitend individuele doeleinden (de status), vindt bij ruim de helft van de bedrijfsartsen plaats.

Driekwart van de GD-bedrijfsartsen geeft aan te beschikken over een registratiesysteem dat een analyse van de gegevens van periodiek onderzoek op groepsniveau mogelijk maakt. Bij EVD-bedrijven is sprake van een grote non-respons op deze vraag.

Tweederde van de GD-bedrijfsartsen (en een derde van de EVD-bedrijfsartsen) kan met de registratie van werkplekgegevens werkplekken in de tijd volgen, de helft van de GD-bedrijfsartsen en een derde van de EVD-bedrijfsartsen kan hiermee analyses op groepsniveau uitvoeren.

\subsubsection{Werkterrein van de BGD}

Waarover wordt aan de BGD advies gevraagd en waarover gaan de contacten tussen BGD en bedrijf?

De adviesfunctie van de BGD beperkt zich vooral tot individueel gerichte problematick (m.b.t. gezondheid of de individuele werkplek). De BGD wordt maar weinig geconsulteerd over meer beleidsmatige problemen zoals nieuwbouw. De EVD wordt vaker betrokken bij psychosociale problematiek (tabel 8.3).

Tabel 8.3. Consulatie BGD

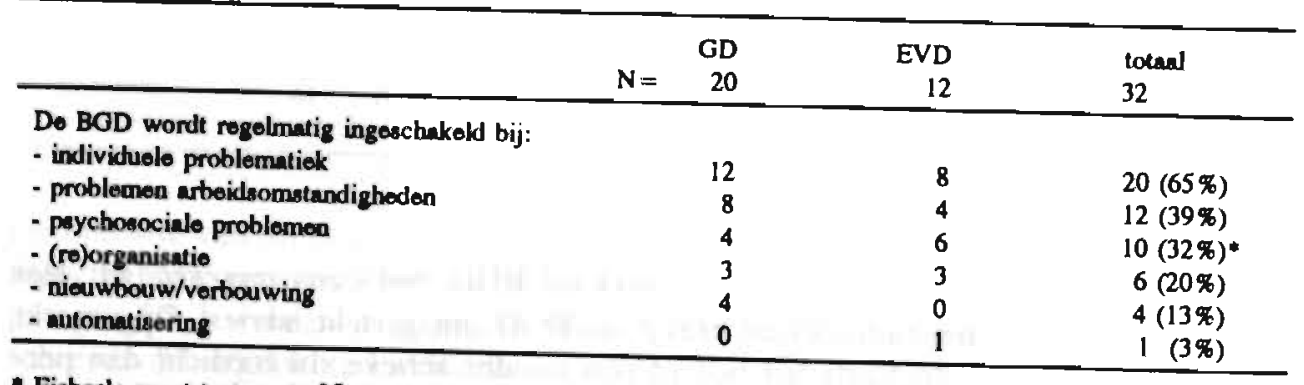

- Fisher's oxact tost $p<.05$

Naast de contacten die er optreden tussen BGD en bedrijf bij de kerntaken (aanstellingsonderzoek, spreekuur, periodiek onderzoek en werkplekonderzoek), heeft nog een derde deel van de werknemers op andere gebieden contact met de BGD. Deze contacten hebben meestal te maken met het klassieke medische terrein. Het gaat om advisering of informatie over een bepaalde klacht of ziekte, en (bij EVD-bedrijven) (ongewilde) contacten in het kader van een EHBO-behandeling. 


\subsubsection{De advisering van de BGD}

In deze paragraaf wordt de kwaliteit van advisering belicht. Beschreven wordt of deze goed bruikbaar is voor bedrijven, of zij actueel is, of zij snel wordt geleverd, of zij voldoende rekening houdt met de belangen van het bedrijf.

Personeelszaken vindt meestal de advisering van de BGD goed bruikbaar, inspelend op actuele problematiek, in begrijpelijke vorm opgesteld en voldoende rekening houdend met het bedrijf(sbelang). De ondernemingsraad is in het algemeen minder positief over de kwaliteit van advisering dan personeelszaken (tabel 8.4).

Tabel 8.4. Kwalike' advisering volgens personeelszaken en ondernemingsrasd

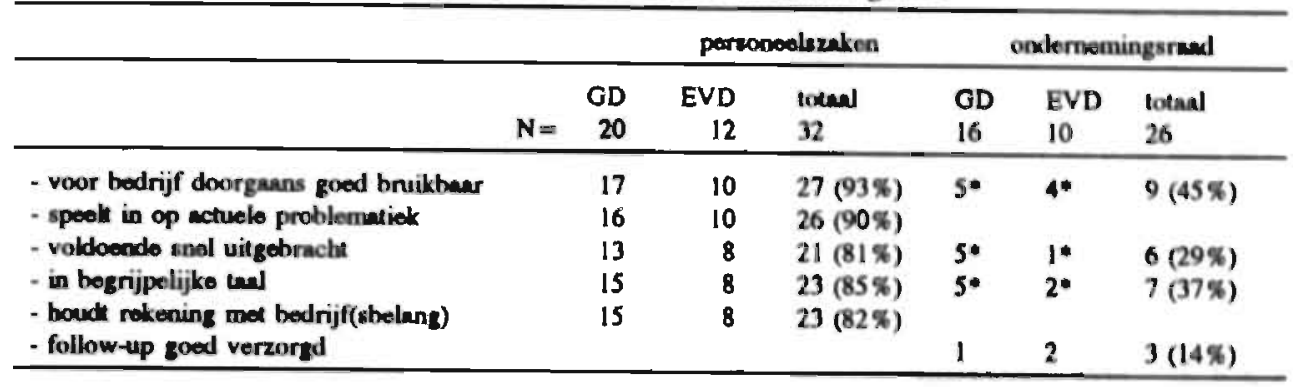

- Fisher's exact teat $p<.05$

\subsubsection{Uitvoering van de BGZ-kerntaken}

In deze paragraaf wordt de uitvoering van de volgende BGZ-kerntaken beschreven: het aanstellingsonderzoek, het spreekuur, het periodiek onderzoek en het onderzoek van de werkplek. Er wordt beschreven welke elementen door de bedrijfsarts van belang worden geacht voor de uitvoering van betrokken taak. Hieraan voorafgaand wordt een overzicht gegeven van kengetallen van betrokken taak.

\subsubsection{Het aanstellingsonderzoek}

\section{Kengetallen aanstellingsonderzoek}

In 1985 en 1986 werden door GD'en ongeveer 1850 aanstellingskeuringen uitgevoerd, door EVD'en ongeveer 700. Er vindt zelden een afkeuring plaats. Bij driekwart van de GD'en ligt het afkeuringspercentage rond de 1\%. Bij EVD'en is sprake van een grotere spreiding, het afkeuringspercentage kan oplopen tot $4 \%$. Ongeveer $1 \%$ zou zich gedurende de keuringsprocedure terugtrekken, en rond de $4 \%$ van de keurlingen wordt beperkt geschikt verklaard. 
Het aanstellingsonderzoek in de praktijk

Vrijwel alle bedrijfsartsen vinden dat een aanstellingsonderzoek altijd geĩndiceerd is. Vrijwel alle bedrijfsartsen keuren functiegericht, waarbij de beoordeling of de keurling het werk lichamelijk aankan, altijd onderdeel van de taakuitvoering is (tabel 8.5).

Tabel 8.5. Aanstellingsonderzoek in de praktijk (ba=bedrifsarts)

\begin{tabular}{|c|c|c|c|c|}
\hline & $\mathbf{N}=$ & $\begin{array}{l}\text { GD } \\
17\end{array}$ & $\begin{array}{l}\text { EVD } \\
15 \\
\end{array}$ & $\begin{array}{l}\text { totand } \\
32\end{array}$ \\
\hline - ba bekijkt altijd of keurling bet work lichamelijk asnkan & & 17 & 15 & $32(100 \%)$ \\
\hline - be beapreakt altijal eernt do uitslag mot de keurling & & 17 & 13 & $30(94 \%)$ \\
\hline - be keurt altijd functiogerich & & 14 & 14 & $28(88 \%)$ \\
\hline - ba wijst altijd op herkeuringsmogelijkheden & & 11 & 8 & $19(66 \%)$ \\
\hline - ba bokijkt altijd of keurling het werk geestelijk anken & & 8 & 10 & $18(56 \%)$ \\
\hline - ba kourt alijijl zolf allo mensen van zijn bedrijf & & 10 & 5 & $15(50 \%)$ \\
\hline - ba brengt werkgever altijd op de hoogte van medische beperkingen & & 4 & 9 & $13(42 \%)$ \\
\hline - ba geef altijd het voordeel van de twijfel an de keurling & & 6 & 3 & $9(28 \%)$ \\
\hline - ba beoordeelt altijd of keurling in do groep past & & 3 & 4 & $7(22 \%)$ \\
\hline - ba betrekt verzuimrisico ahijd bij de keuring & & 3 & 1 & $4(14 \%)$ \\
\hline - ba selecteert altijd mee & & 0 & 0 & 0 \\
\hline
\end{tabular}

\subsubsection{Het spreekuur}

In deze paragraaf wordt de uitvoering van het spreekuur beschreven.

\section{Kengetallen spreekuur}

Er is een verschil in het tijdstip waarop de bedrijfsarts een zieke ziet: de GD-bedrijfsarts heeft meestal pas na 20 werkdagen contact met een zieke, terwijl bijna de helft van de EVD-bedrijfsartsen een zieke ziet binnen twee weken.

Tabel 8.6. Inhoud spreekuurcontact volgens werknemers

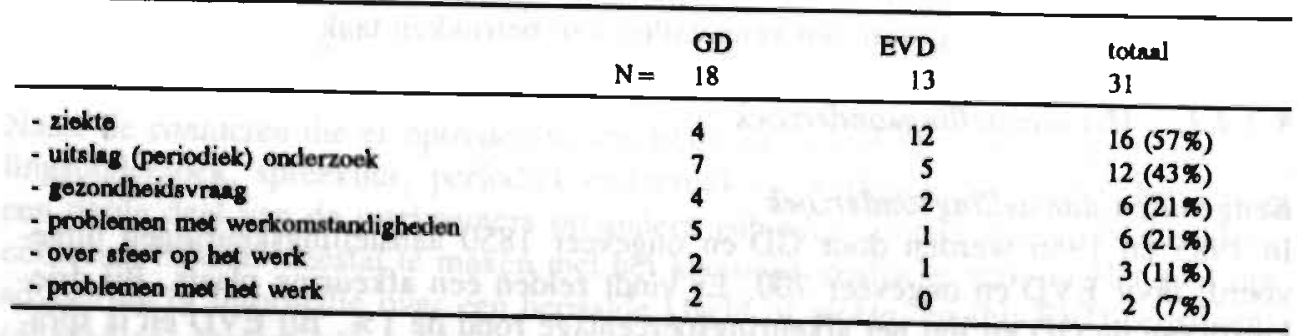

Ruim eenderde van de werknemers bij GD-bedrijven, en ruim driekwart van de werknemers van EVD-bedrijven is in de afgelopen 5 jaar wel eens op het spreekuur geweest. De reden voor spreekuurbezoek is in EVD-bedrijven bijna altijd een ziekte of het ziek zijn. Maar weinig werknemers geven aan dat er op het spreekuur wordt gepraat over problemen met het werk of de werksfeer. Het spreekuur wordt 
tevens gebruikt om de uitslag te geven van een bepaald (periodiek) onderzoek (tabel 8.6).

\section{Het spreekuur in de praktijk}

Een derde van de bedrijfsartsen zonder verzekeringsgeneeskundige taak (met name de GD-bedrijfsarts in dit onderzoek) doet altijd uitspraken over de arbeids(on)geschiktheid van zieken. De toegang tot het spreekuur is vrij. Een oproepbeleid van de BGD bestaat alleen voor zieke werknemers (bijvoorbeeld frequent verzuimers), maar niet voor specifieke groepen (zoals de oudere werknerner).

De bedrijfsarts gaat bijna altijd na of zijn advies wordt opgevolgd, of de oorzaak van een klacht mogelijk in het werk ligt. Er wordt binnen het bedrijf regelmatig over zieke werknemers gesproken, mits met toestemming van betrokken werknemer (tabel 8.7).

Tabel 8.7. Spreekuur in de praktijk (opgave bedriffserts)

\begin{tabular}{|c|c|c|c|}
\hline & $\begin{array}{r}\text { GD } \\
N=\quad 17 \\
\end{array}$ & $\begin{array}{r}\text { EVD } \\
15 \\
\end{array}$ & $\begin{array}{l}\text { totmal } \\
32\end{array}$ \\
\hline - controle of edviezen opgevolgd worden & 15 & 15 & $30(97 \%)$ \\
\hline - atijd reletie mat werk nagan & 15 & 15 & 30 (97\%) \\
\hline - rechtstroekse consultatie & is & 14 & $29(97 \%)$ \\
\hline - medische beperkingen doorgeven & 14 & 15 & $29(97 \%)$ \\
\hline - overleg mat personeelszaken alleen na toestemming & 15 & 13 & $28(90 \%)$ \\
\hline - meklt als ziekte oorzenk beeft in werk & 12 & 14 & $26(84 \%)$ \\
\hline - prognose over veraim & 12 & 14 & $26(84 \%)$ \\
\hline - altijd uitspraak over asbeids(on)geschiktheid & 6 & 3y & $9(47 \%)$ \\
\hline - olke zioko zien & 5 & $4 t$ & $9(47 \%)$ \\
\hline
\end{tabular}

groke non-respons bij EVD-bedrijven op deze items

\subsubsection{Het periodiek onderzoek}

De volgende vormen van periodiek onderzoek werden onderscheiden: algemeen periodiek onderzoek, d.w.z. een medisch onderzoek zonder directe relatie met het werk; gericht periodiek onderzoek, d.w.z. medisch onderzoek bij bepaalde functies of werkzaamheden met gezondheidsrisico's; periodiek bedrijfsgezondheidkundig onderzoek, d.w.z. onderzoek van een groep werknemers (bijv. afdeling) naar hun gezondheid en werk(omstandigheden).

\section{Kengetallen periodiek onderzoek}

$68 \%$ van de werknemers (GD $=55,6 \%$, EVD $=76,9 \%$ ) heeft ooit aan een periodiek onderzoek deelgenomen, gemiddeld zelfs 2 maal. Van de ondernemingsraad heeft bij bedrijven met GD $87,5 \%$, bij EVD-bedrijven $20 \%$ an een periodiek onderzoek deelgenomen. De werknemers die deelnemen aan periodiek onderzoek, komen uit alle mogelijke functies: van administratief tot produktiewerk. 


\section{Het periodiek onderzoek in de praktijk}

De vraag naar tijdsbesteding door de bedrijfsarts van de verschillende vormen van periodiek onderzoek, wordt voor het algemeen periodiek onderzoek en gericht periodiek onderzoek zelden beantwoord. Aan het periodiek bedrijfsgezondheidkundig onderzoek wordt gemiddeld 3 uur per week besteed.

De meerderheid van personeelszaken en ondernemingsraad geven de voorkeur aan het periodiek bedrijfsgezondheidkundig onderzoek, en in mindere mate aan het gericht periodiek onderzoek. Het algemeen periodiek onderzoek zou slechts voor een enkeling nuttig zijn. In de praktijk zou het algemeen periodiek onderzoek echter de meest voorkomende vorm van periodiek onderzoek zijn.

De gezondheidstcestand werd, aldus de werknemers, bijna altijd in zijn geheel bekeken. Slechts volgens een enkeling kijkt de BGD tijdens het periodiek onderzoek (ook) naar het werk.

Volgens ongeveer de helft van de bedrijfsartsen vindt periodiek onderzoek in de praktijk plaats naar aanleiding van leeftijd en gezondheidsrisico's. In EVD-bedrijven vormt bloedonderzoek vaker (niet significant) onderdeel van het periodiek onderzoek. De GD-bedrijfsarts brengt vaker een groepsrapportage uit (statistisch significant). De deelname aan het periodiek onderzoek is bij EVD-bedrijven niet altijd vrijwillig (tabel 8.8).

Tabel 8.8. Het perlodlek onderzoek in de pralatik (volgens bedrijfsarts)

\begin{tabular}{|c|c|c|c|}
\hline & $\begin{array}{r}\text { GD } \\
\mathrm{N}=\quad 17 \\
\end{array}$ & $\begin{array}{r}\text { EVD } \\
15 \\
\end{array}$ & $\begin{array}{l}\text { totan } \\
32 \\
\end{array}$ \\
\hline - deolname vrijwillig & 17 & 11 & $28(88 \%)$ \\
\hline - bij gezondheidsrisico's in werk & 10 & 10 & $20(65 \%)$ \\
\hline - altijd bloedonderzook & 7 & 12 & $19(63 \%)$ \\
\hline - groeperapportage & 14 & 5 & $19(59 \%)^{*}$ \\
\hline - boven bepaakde leefijd & 9 & 10 & $19(59 \%)$ \\
\hline - allijd lichumelijk onderzook & 4 & 5 & $9(28 \%)$ \\
\hline - rapportage over individuele resultaren & 1 & 0 & $1(3 \%)$ \\
\hline
\end{tabular}

- Fisher's oxact teat $\mathrm{p}<.05$

\subsubsection{Het werkplekonderzoek}

In deze paragraaf wordt een korte beschrijving gegeven van de uitvoering van het werkplekonderzoek.

\section{Rengetallen werkplekonderzoek}

In ongeveer tweederde van de bedrijven hebben werknemers van de technische dienst (N.B. dit was de doelgroep van het onderzoek) de BGD de afgelopen 5 jaar wel eens op de afdeling een werkplekonderzoek zien doen. Daarnaast zagen in de afgelopen $\mathbf{5}$ jaar in bijna de helft van de bedrijven betrokken werknemers wel eens een medewerker van de BGD op hun afdeling, gemiddeld zelfs driemaal. Onderne- 
mingsraadsleden, die uit alle geledingen van het bedrijf kwamen, hadden veel minder vaak de BGD een werkplekonderzoek zien doen c.q. op hun afdeling gezien.

\section{Het werkplekonderzoek in de praktijk}

Een scala aan werkaspecten was in de afgelopen 5 jaar onderzocht, variërend van de klimaatsituatie tot arbeidssfeer. Er is specifiek gevraagd of de BGD ooit een onderzoek had verricht naar blootstelling aan oplosmiddelen. Dit blijkt voor de helft van de bedrijven het geval. Van een uniforme en protocollaire aanpak was geen sprake.

De bedrijfsarts tracht een actieve rol te spelen op de werkplek. In de praktijk kunnen weinig bedrijfsartsen hier dagelijks veel tijd aan besteden. Klachten van werknemers vormen de belangrijkste reden cen werkplekonderzoek te doen. De bedrijfsarts wordt niet routinematig betrokken bij de ontwerpfase van een werkplek (tabel 8.9).

Tabel 8.9. Het werkplekonderzoek in de praktijk (rolgees bedrifiserts)

\begin{tabular}{|c|c|c|c|}
\hline & $\begin{array}{r}\text { GD } \\
\mathrm{N}=\quad 17 \\
\end{array}$ & $\begin{array}{r}\text { EVD } \\
15\end{array}$ & $\begin{array}{l}\text { toteal } \\
32\end{array}$ \\
\hline - ectiove opstelling BGD & 10 & 5 & 15 (48\%) \\
\hline - kout bedrijfarts degalijks voel tijd & 2 & 0 & $2(6 \%)$ \\
\hline - BGD a in ontwerpfiase betrokken & 0 & 1 & $10 \%)$ \\
\hline - bedrijfuerts gaet altijd in op klactiten werknemers & 14 & 12 & $26(81 \%)$ \\
\hline - rapportage uitshuitend an directio & 2 & 1 & $3(10 \%)$ \\
\hline
\end{tabular}

\subsubsection{Rendement van de kerntaken}

In deze paragraaf wordt het rendementsoordeel beschreven dat de ondernemingsraad en (eventueel) de bedrijfsarts en werknemers hebben over achtereenvolgens het aanstellingsonderzoek, het spreekuur, het periodiek onderzoek en het onderzoek van de werkplek.

\subsubsection{Rendement van het aanstellingsonderzoek}

Vrijwel elk ondernemingsraad-lid neemt aan dat de BGD bij het aanstellingsonderzoek kan beoordelen of de keurling het werk lichamelijk aankan. Slechts de helft denkt dat een beoordeling van de BGD mogelijk is of de keurling het werk ook geestelijk aankan.

Weinig ondernemingsraden kennen aan het aanstellingsonderzoek rendement toe als instrument om arbeidsongeschiktheid te voorkomen(tabel 8.10). 
Tabel 8.10. Rendement aanstellingsonderzoek (ondernemingsraad)

\begin{tabular}{|c|c|c|c|}
\hline & $\begin{array}{l}\text { GD } \\
16 \\
\end{array}$ & $\begin{array}{l}\text { EVD } \\
10 \\
\end{array}$ & $\begin{array}{l}\text { toten } \\
26\end{array}$ \\
\hline - minder overplentsingen om medischo redenen & 3 & 1 & $4(19 \%)$ \\
\hline - minder werknomons worden op termijn afgekeurd & 5 & 1 & $6(29 \%)$ \\
\hline - mindor ziekeno & 0 & 2 & $2(10 \%)$ \\
\hline
\end{tabular}

\subsubsection{Het rendement van het spreekuur}

De BGD slaagt er volgens de werknemers in de praktijk niet vaak in hun te helpen bij het realiseren van tijdelijk of blijvend aangepast of lichter werk. Rond een kwart van de werknemers denkt wel dat de BGD een bijdrage levert aan het verbeteren van de arbeidsomstandigheden.

Rond driekwart van de EVD-bedrijfsartsen heeft het idee dat door hun verzuimbegeleiding werknemers minder snel verzuimen (verhoging verzuimdrempel) en ook sneller aan het werk gaan (verlaging hervattingsdrempel). Nog geen $20 \%$ van de GD-bedrijfsartsen deelt de mening dat verzuimbegeleiding door de BGD een effect heeft op de verzuimdrempel, bijna tweederde ervaart wel een gunstig effect op de hervattingsdrempel.

Tabel 8.11. Rendement spreekuur (bedrifsarts, ondernemingsiagd en werknemers)

\begin{tabular}{|c|c|c|c|}
\hline & \multicolumn{3}{|l|}{ bedrijfsares } \\
\hline$N=$ & $\begin{array}{l}\text { GD } \\
17 \\
\end{array}$ & $\begin{array}{l}\text { EVD } \\
15 \\
\end{array}$ & $\begin{array}{l}\text { Totanal } \\
32\end{array}$ \\
\hline $\begin{array}{l}\text { - worknemers verzuimen mindor snol } \\
\text { - worknemers gaten snollor an bot werk } \\
\text { - goon offoct }\end{array}$ & $\begin{array}{r}3(19 \%) \\
11(65 \%) \\
5(36 \%) \\
\end{array}$ & $\begin{array}{r}10(71 \%) \\
12(80 \%) \\
3(25 \%) \\
\end{array}$ & $\begin{array}{r}13(43 \%) \\
23(72 \%) \\
8(31 \%)\end{array}$ \\
\hline \multirow[t]{2}{*}{ 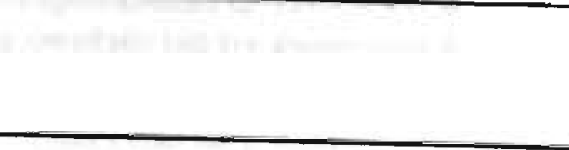 } & \multicolumn{3}{|c|}{ ondememingsrand } \\
\hline & $\begin{array}{l}\text { GD } \\
16 \\
\end{array}$ & $\begin{array}{l}\text { EVD } \\
10 \\
\end{array}$ & $\begin{array}{l}\text { totanal } \\
26 \\
\end{array}$ \\
\hline 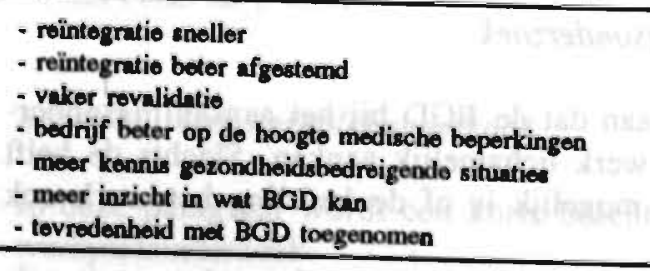 & $\begin{array}{l}0 \\
2(15 \%) \\
5(39 \%) \\
6(46 \%) \\
7(54 \%) \\
5(39 \%) \\
4(31 \%) \\
\end{array}$ & $\begin{array}{l}2(25 \%) \\
2(25 \%) \\
3(38 \%) \\
4(50 \%) \\
3(38 \%) \\
1(13 \%) \\
2(25 \%) \\
\end{array}$ & $\begin{array}{r}2(10 \%) \\
4(19 \%) \\
8(38 \%) \\
10(48 \%) \\
10(48 \%) \\
6(29 \%) \\
6(29 \%) \\
\end{array}$ \\
\hline 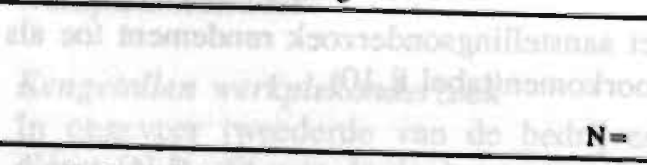 & $\begin{array}{l}\text { worknemere } \\
\text { GD } \\
18 \\
\end{array}$ & $\begin{array}{l}\text { EVD } \\
13 \\
\end{array}$ & 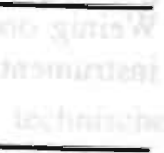 \\
\hline $\begin{array}{l}\text { - rodisatio tijdolijk angopast work } \\
\text { - roalieatio blijvend anngepast work } \\
\text { - verbetering arboidsomatundighodon }\end{array}$ & $\begin{array}{l}3(23 \%) \\
2(15 \%) \\
4(31 \%)\end{array}$ & $\begin{array}{l}1(8 \%) \\
0 \\
3(23 \%)\end{array}$ & . \\
\hline
\end{tabular}


Volgens ongeveer de helft van de ondernemingsraden blijt het bedrijf door het spreekuur beter op de hoogte van medische beperkingen, en wordt er meer kennis verkregen van gezondheidbedreigende situaties. Voor minder dan een vijfde van de ondernemingsraden draagt het spreekuur bij aan een snellere of beter afgestemde reìntegratie (tabel 8.11).

\subsubsection{Het rendement van het periodiek onderzoek}

Voor ongeveer de helf van de ondernemingsraden ligt het rendement van het periodiek onderzoek in het vergroten van de bekendheid van de BGD en het verkrijgen van een beter contact met de werknemer.

Volgens bedrijfsartsen wordt door het periodiek onderzoek een beter contact met werknemers verkregen, en wordt er meer werkgebonden problematiek opgespoord. De bedrijfsarts zelf is positiever over het rendement van het periodiek onderzock dan de ondernemingsraad. Ten aanzien van het item "meer werkgebonden problematiek opgespoord" is dit in GD-bedrijven significant (tabel 8.12).

Tabet 8.12. Rendement periodiek onderzoek volgens ondenwemingsrond/hedrifsarts. Perlodikk onderzock beeft in belnngrijke mate peleid tot:

\begin{tabular}{|c|c|c|c|c|c|c|}
\hline & \multicolumn{3}{|c|}{ bodrijfent: } & \multicolumn{3}{|c|}{ ondernemingsrand } \\
\hline $\mathbf{N}=$ & $\begin{array}{l}\text { GD } \\
17\end{array}$ & $\begin{array}{r}\text { EVD } \\
15\end{array}$ & $\begin{array}{l}\text { Iotenal } \\
32\end{array}$ & $\begin{array}{l}\text { GD } \\
16\end{array}$ & $\begin{array}{l}\text { EVD } \\
10\end{array}$ & $\begin{array}{l}\text { loted } \\
26\end{array}$ \\
\hline - meer bekendheid over BGD & & & & 7 & 3 & $10(40 \%)$ \\
\hline - beter contect mot werkgover & 6 & 4 & $10(31 \%)$ & 5 & 1 & $6(24 \%)$ \\
\hline - beter contect met worknemer & 14 & 15 & $29(91 \%)$ & 9 & 4 & $13(50 \%)$ \\
\hline - gezondheidsrisico's opgespoord & 10 & 6 & $16(50 \%)$ & 5 & 2 & $7(27 \%)$ \\
\hline - gezondheidsbedreigendo factoren opgespoord & & & & 5 & 2 & $7(27 \%)$ \\
\hline - minder zicken & & & & 1 & 2 & $3(12 \%)$ \\
\hline - meer workgebonden problematiek opgespoord & $14^{*}$ & 12 & $26(81 \%)$ & 2 & 2 & $4(16 \%)$ \\
\hline
\end{tabular}

- Fishor's oxact teet $\mathbf{p}<.05$

\subsubsection{Het rendement van het werkplekonderzoek}

Rond een derde van de ondernemingsraad heeft het idee dat door werkplekonderzoek meer kennis over gezondheidbedreigende situaties is verkregen, en dat er meer gedaan is aan arbeidsplaatsverbetering. Dat in belangrijke mate minder werkgebonden ziektes zouden voorkomen ("echte" preventie) wordt zelden aangenomen (tabel 8.13). 
Tabel 8.13. Rendement werkplekectiviteiten BGD volgens ondernemingsrand

\begin{tabular}{|c|c|c|c|}
\hline & $\begin{aligned} \mathrm{GD} \\
\mathrm{N}=16 \\
\end{aligned}$ & $\begin{array}{l}\text { EVD } \\
10\end{array}$ & $\begin{array}{l}\text { totsel } \\
10\end{array}$ \\
\hline - meer kennis over gezondheidbedreigende situatie & 4 & 4 & $8(36 \%)$ \\
\hline - meor gedanen an arboideplantsvorbocioring & 6 & 3 & $9(38 \%)$ \\
\hline - minder werkgobonden zielates & 2 & 0 & 2 (10\%) \\
\hline
\end{tabular}

\subsection{Klantgerichte aspecten van kwaliteit van BGZ}

De volgende klantgerichte aspecten van kwaliteit van $\mathrm{BGZ}$ worden achtereenvolgens beschreven: de ondersteunende rol, de houding van de BGD, de ervaring met de uitvoering van BGZ-taken, de samenwerking met andere rolpartners en de afstemming in taakuitvoering. Deze begrippen hebben verwantschap met de volgende dimensies uit het SERVQUAL-model (zie hoofdstuk 4): responsiveness, access, reliability, communication en "understanding the customer".

\subsubsection{De ondersteunende rol van de BGD}

Dit aspect bevat twee elementen. In de eerste plaats de ondersteuning door de BGD in algemene zin bij de totstandkoming van het sociaal beleid. Daarnaast de mate waarin de BGD erin slaagt een zelfstandige en onafhankelijke positie in te nemen, bijvoorbeeld bij omstreden kwesties. Wat is de mening hierover van resp. personeelszaken en ondernemingsraad?

Tussen eenderde (GD-bedrijven) en bijna de helft (EVD-bedrijven) van personeelszaken is van mening dat de BGD in belangrijke mate een ondersteunende rol speelt bij de totstandkoming van het sociaal beleid.

De ondernemingsraad is minder vaak (dan de bedrijfsarts en personeelszaken) van mening dat de BGD in belangrijke mate het sociaal beleid ondersteunt (niet significant) (tabel 8.14).

Tabel 8.14. Ondersteunende rol van de BGD. De BGD speelt in belangrijke mate een rol bij de totstandkoming van bet sociagl beleld

\begin{tabular}{lllll}
\hline & & bedrijfsarts & ondernemingsmad & personeelszaken \\
\hline GD & $\mathrm{N}=$ & 17 & 16 & 20 \\
& & 5 & 2 & $7(35 \%)$ \\
EVD & $\mathrm{N}=$ & 15 & 10 & 12 \\
& & 6 & 1 & $5(46 \%)$ \\
totanal & $\mathrm{N}=$ & 32 & 26 & 32 \\
& & $11(34 \%)$ & $3(21 \%)$ & $12(39 \%)$ \\
\hline
\end{tabular}

Voor ondernemingsraad en personeelszaken stelt de BGD zich voldoende objectief en onpartijdig op in kwesties die omstreden zijn. 
Volgens personeelszaken speelt de BGD goed in op gezondheidkundige problemen die zich in het bedrijf voordoen, een mening die door minder ondernemingsraden wordt onderschreven (in EVD-bedrijven significant verschil). Ondernemingsraden vinden in vergelijking met personeelszaken dat BGD'en zich minder vasthoudend opstellen (niet significant). Zowel voor personeelszaken als ondernemingsinad is de reactie van de BGD op vragen uit het bedrijf meestal adequaat (tabel 8.15).

Tubel 8.15. Pogitie BGD

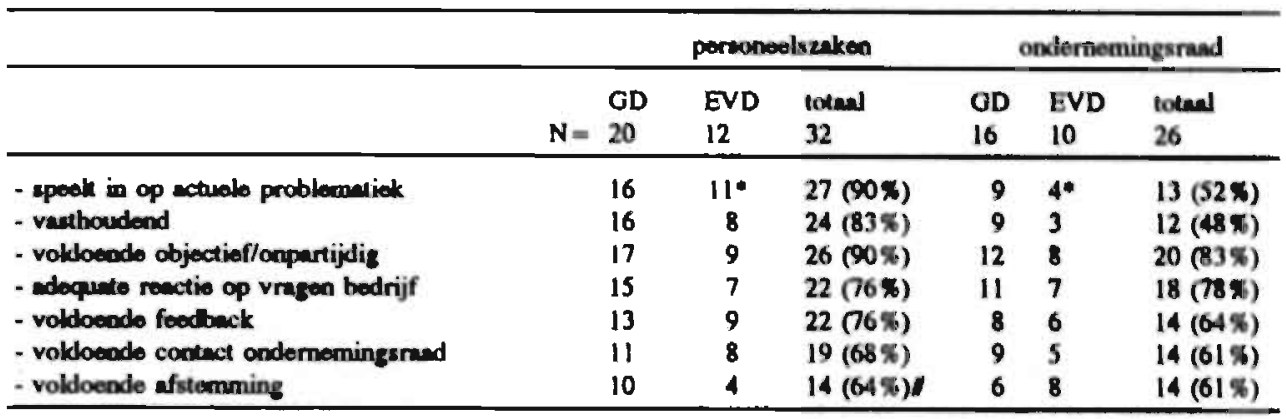

- Fisher's oxect tea p $<.05$

I jrote non-reapon:

\subsubsection{De houding van de BGD}

Dit aspect bevat elementen als: ervaart de klant (personeelszaken) de houding van de BGD als klantvriendelijk of als professionalistisch, is de BGD/bedrijfsarts goed toegankelijk, heeft de BGD een goede naam?

Ruim 60\% van de hoofden personeelszaken ervaart de houding van de BGD niet als klantvriendelijk. Rond 20\% ervaart de BGD als afstandelijk. In bijna de helft van de GD-bedrijven (en daarentegen nog geen $20 \%$ van de EVD-bedrijven) wordt de houding van de BGD gekenmerkt als professionalistisch, dat wil zeggen teveel nadruk op vakkennis en eigen beroepscultuur. De BGD-medewerker is overigens niet uit op persoonlijk gewin. De meeste BGD'en hebben volgens de bedrijven (die deze vraag invullen) een goede naam ("corporate image"). Tevens biedt de BGD volgens tweederde van de bedrijven regelmatig voldoende ruimte voor eigen inbreng van de klant. In EVD-bedrijven geeft personeelszaken vaker dan in GD-bedrijven (niet statistisch significant) aan dat de BGD meer ruimte biedt aan individuen (tabel 8.16). 


\begin{tabular}{|c|c|c|c|}
\hline & $\begin{array}{l}\text { GD } \\
20 \\
\end{array}$ & $\begin{array}{l}\text { EVD } \\
12 \\
\end{array}$ & $\begin{array}{l}\text { tocmal } \\
32\end{array}$ \\
\hline - houding biedt nuimte inbreng bedrijf & 13 & 7 & $20(65 \%)$ \\
\hline - bouding hiodt ruimte inbreng indivith & 10 & 9 & $19(61 \%)$ \\
\hline - klantvriendelijk & 8 & 4 & $12(39 \%)$ \\
\hline - de nedruk ligt op eigen vakkennis on beroepecultuar & 9 & 2 & II (35\%) \\
\hline - Afrtandelijk & 4 & 2 & $6(19 \%)$ \\
\hline - do nadruk liget op hat aigea interno BGD-gebeuren & 1 & 2 & 3 (10\%) \\
\hline - de nadruk ligt op het behaten van perroondijk nuccee van de & & & \\
\hline BGD-medewerken & 0 & 1 & $1(3 \%)$ \\
\hline - opdringeris & 0 & 1 & $1(3 \%)$ \\
\hline - BOD heeft con goedo naem ("corporate imngo") & 15 & $5 /$ & $20(80 \%)$ \\
\hline
\end{tabular}

groto non-reapons

Werknemers ervaren op voorhand geen hoge drempel naar de BGD. Driekwart meent op eigen initiatief problemen te kunnen aankaarten bij de BGD (GD en EVD). Wat betreft de fysieke bereikbaarheid speelt geografische afstand slechts bij een enkele GD een rol. Wel bestaat er bij bijna eenderde van de GD-bedrijven de behoefte aan een sneller reageren door de BGD op vragen van hun kant, en op meer op het bedrijf afgestemde openingstijden. Bij EVD-bedrijven bestaan deze wensen niet of nauwelijks.

\subsubsection{Ervaring met taakuitvoering}

In deze paragraaf komen aan de orde de ervaringen van ondernemingsraad en werknemers met uitvoering van activiteiten van de BGD buiten het directe kerntakenpakket, en de ervaring met de uitvoering van de kerntaken (aanstellingsonderzoek, spreekuur, periodiek onderzoek en werkplekonderzoek) (tabel 8.17).

In zijn algemeenheid lijkt de BGD betrekkelijk weinig extra activiteiten te ondernemen buiten de kemtaken en EHBO.

Welke ervaringen heeft de klant opgedaan met de uitvoering van de BGZ-kerntaken?

\section{Het aanstellingsonderzoek}

88\% van de werknemers heeft een aanstellingskeuring meegemaakt. De bedrijfsarts verrichtte bijna altijd een lichamelijk onderzoek. De uitslag werd volgens de werknemers bij een kwart van de GD-bedrijven, en bij minder dan 10\% van de EVDbedrijven met de keurling besproken. De keuring wordt volgens de meeste werknemers correct en snel uitgevoerd.

\section{Het spreekuur}

In paragraaf 8.2.4.2. werd vastgesteld dat de meeste spreekuurcontacten ziek(t)ebegeleiding betreffen. Bijna een kwart van de werknemers ervaart deze begeleiding 
als prettig, bij minder dan $10 \%$ van de GD-bedrijven en bijna eenderde van de EVD-bedrijven wordt de begeleiding ervaren als controle. De overigen beschrijven hun ervaringen als "neutraal". De ervaring van de ondernemingsraad stemt overeen met die van de werknemers.

\section{Het periadiek onderzoek}

Alle werknemers hebben het periodiek onderzoek als prettig ervaren. Opgemerkt kan worden dat bijna de helft naar aanleiding van het periodiek onderzoek ofwel geen advies kreeg ofwel een advies kreeg waar weinig mee kon worden gedaan.

\section{Het onderzoek van de werkplek}

Volgens de ondernemingsraad in GD-bedrijven neemt de afdelingsleiding meestal het initiatief om werkplekonderzoek te laten doen. Bij EVD-bedrijven zou de directie van het bedrijf of de BGD zelf vaker het initiatief nemen. De ondernemingsraad geeft in ongeveer eenderde van de bedrijven de aanzet tot werkplekonderzoek. Veel werknemers geven aan geen zicht te hebben wie het werkplekonderzoek entameert. Van het beperkt aantal werknemers dat wel een mening hierover heeft, denkt de helft dat het initiatief bij de ondernemingsraad ligt.

Werknemers vragen zelden zelf of de BGD de werkplek onderzoekt. Wel geven klachten van de werknemers de bedrijfsarts aanleiding om werkplekonderzoek te verrichten (zie tabel 8.9).

De meerderheid van de ondernemingsraden acht de BGD goed in staat werkplekonderzoek te doen, en is ook tevreden over de bereidheid van de BGD onderzoek op de werkplek te doen. De rapportage over werkplekonderzoek wordt door een ruime meerderheid van de werknemers en ondernemingsraad als goed bruikbaar ervaren, al geeft de helft van de ondernemingsraden aan dat de BGD het werkplekonderzoek niet snel verricht. Opmerkelijk is dat bij GD-bedrijven $90 \%$ van de ondernemingsraden (maar bij EVD-bedrijven slechts de helft van de ondernemingsraden) van mening is dat de BGD voldoende kennis heeft van de werkomstandigheden. De BGD wordt, volgens de ondernemingsraad, zelden om advies gevraagd bij wijzigingen in het produktieproces of de produktiemiddelen. Minder dan de helft van de werknemers en de ondernemingsraden vindt dat de BGD actief gezondheidschadelijke factoren in het werk opspoort (tabel 8.17). 


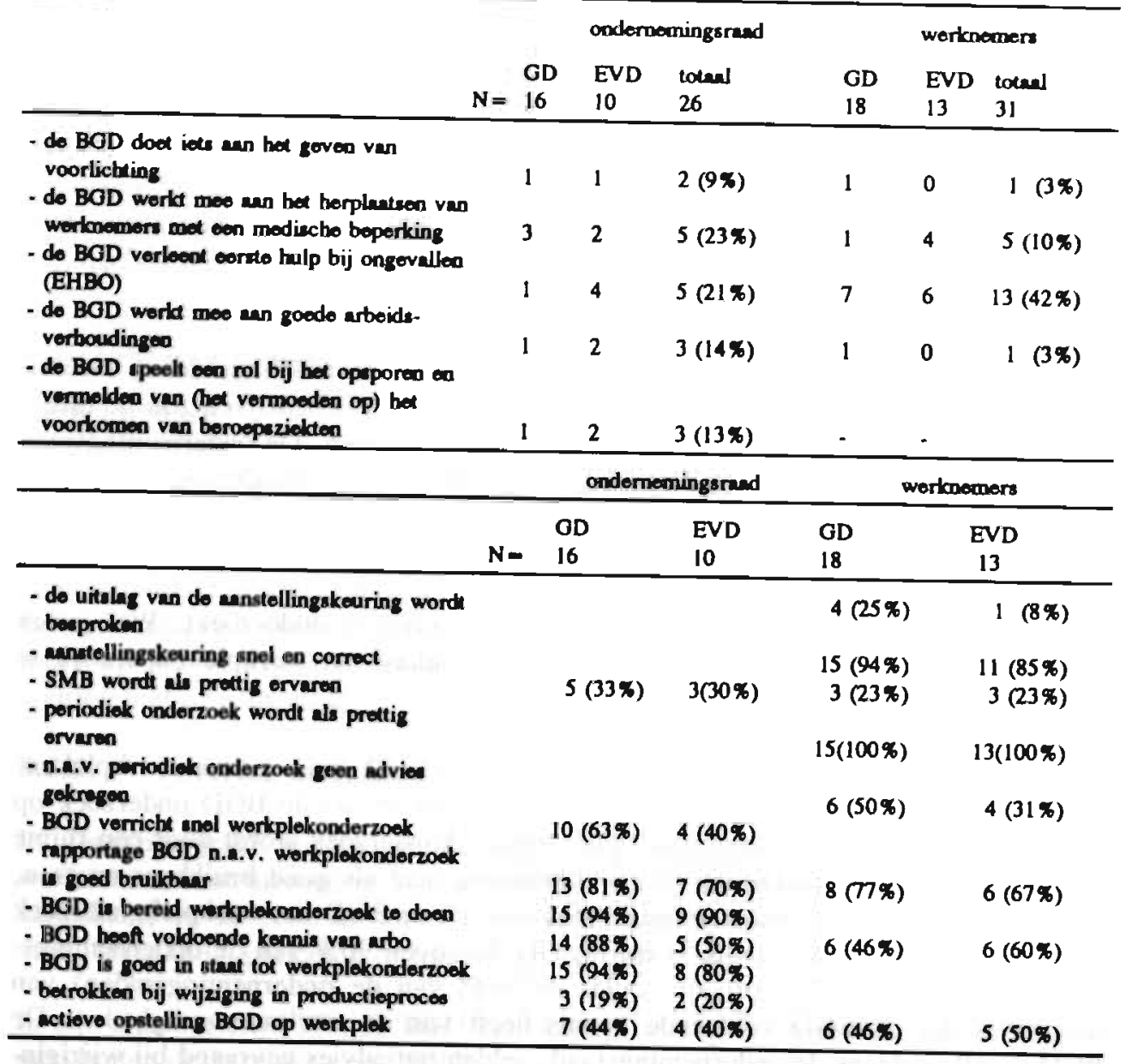

\subsubsection{De samenwerking tussen BGD en bedrijf}

De meeste bedrijven hebben het idee dat er een consistent samenwerkingsbeleid is tussen BGD en bedrijf (directie, ondernemingsraad, personeelszaken en veiligheidsdienst). Ook bedrijfsartsen ervaren een consistente samenwerking met het bedrijf, ook met de werknemers (tabel 8.18). 
Tabed 8.18. De anwezigheid van voldoende samenwerkingsruimte binnen tet bedrijf

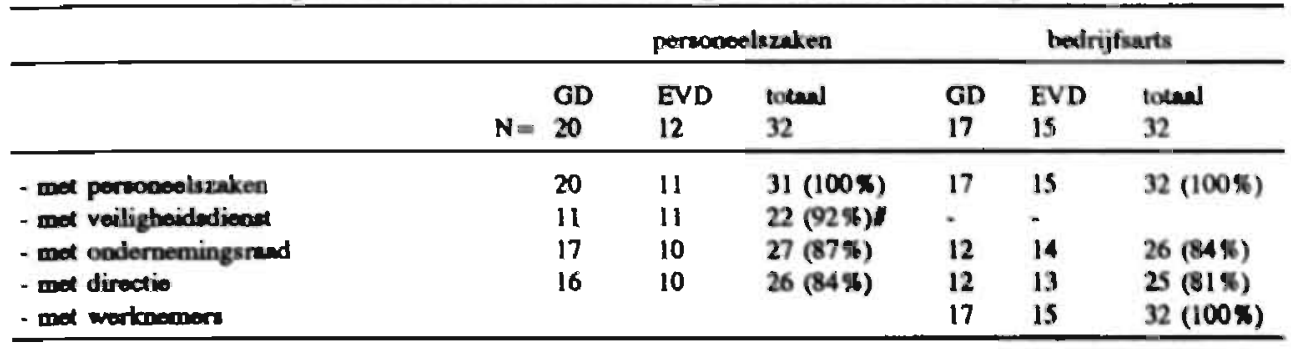

Irote non-respon

De samenwerking met personeelszaken wordt unaniem als positief ervaren. Mogelijk dat het institutionaliseren van dit overleg in een zogenaamd sociaal medisch team hieraan bijdraagt. De helft van de bedrijfsartsen toont zich erg tevreden over het functioneren van dit team, iets minder bedrijfsartsen (statistisch niet significant) zijn tevreden over de "output" van dit team (tabel 8.19). Mogelijk duidt deze "discrepantie" erop dat de bereidheid tot samenwerking er wel is, maar de mogelijkheden en ruimte om problemen op te lossen beperkt is.

Tabel 8.19. Het functioneren en de oxtput van Let sociad medisch tean

\begin{tabular}{|c|c|c|c|c|}
\hline & $\mathrm{N}=$ & $\begin{array}{l}G D \\
17\end{array}$ & $\begin{array}{l}\text { EVD } \\
15 \\
\end{array}$ & $\begin{array}{l}\text { totenal } \\
32 \\
\end{array}$ \\
\hline - functioneron & & 71 & 7 & $14(52 \%)$ \\
\hline - output & & sI & 5 & $10(37 x)$ \\
\hline
\end{tabular}

grole non-rospons bij GD-bedrijfuarteen

\subsubsection{De afstemming van de taakuitvoering}

In paragraaf 8.2.4 werd de uitvoering van BGZ-taken in de praktijk beschreven. In deze paragraaf wordt beschreven welke wensen er bestaan bij bedrijfsarts en klant over de taakuitvoering. De vraag hierbij is in hoeverre de praktijk overeenstemt met de gewenste taakuitvoering. Deze paragraaf start met een beschrijving van de globale prioriteitsstelling in het BGZ-pakket door leverancier van BGZ en de ontvanger van $B G Z$.

\subsubsection{Prioriteitsstelling BGZ-activiteiten}

Er kunnen meerdere criteria onderscheiden worden, die een rol kunnen spelen bij het stellen van prioriteiten ten aanzien van de omvang en inhoud van de BGZ, zoals: waaraan bestaat inhoudelijk de meeste behoefte, bij welke BGZ-activiteiten is de kosten-baten balans het meest gunstig, welke BGZ-activiteiten hebben al teveel of te weinig aandacht gekregen. De prioriteitsstelling kan tevens variëren afhanke- 
lijk van de verschillende partijen die betrokken zijn bij de BGZ (leveranciers en ontvangers van BGZ).

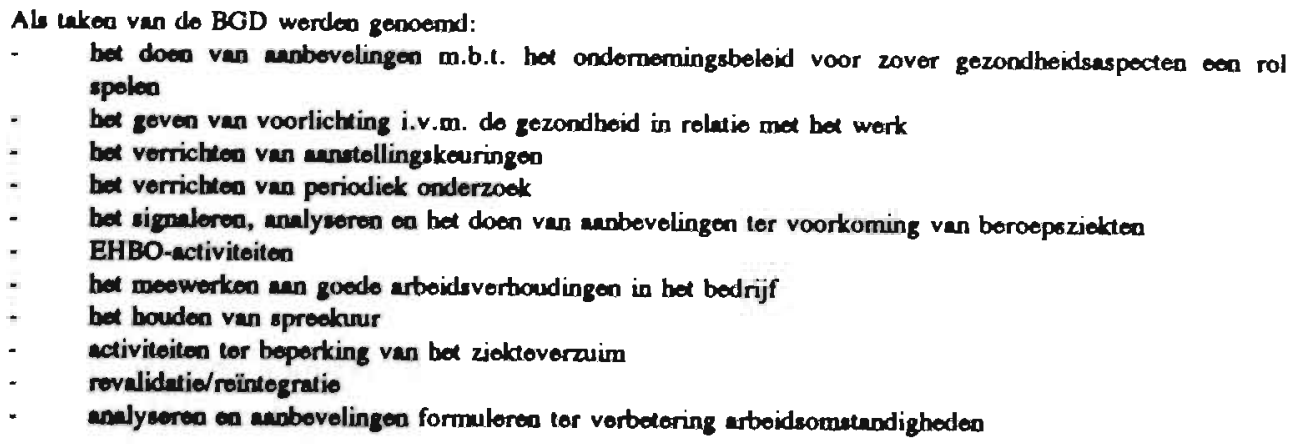

Er bestaat een redelijke mate van overeenstemming tussen leveranciers van BGZ (directie BGD en bedrijfsarts) en ontvangers van BGZ (personeelszaken, ondernemingsraad) in hun mening over welke taak het meeste bijdraagt aan het bereiken van de doelstellingen van BGZ. Het gaat dan om het doen van aanbevelingen met betrekking tot het ondernemingsbeleid voor zover gezondheidsaspecten een rol spelen. Dit hoeft weinig bevreemding te wekken, omdat deze taakomschrijving veel gelijkenis heeft met de definitie van de doelstelling van BGZ in het algemeen. Maar ook de uitwerking vertoont veel overeenkomsten: de nadruk wordt gelegd op analyse en onderzoek van de arbeidsomstandigheden, op gezondheidsvoorlichting en -opvoeding (GVO), en op het bedrijfsgezondheidkundig spreekuur. Alleen de ondernemingsraad in GD-bedrijven voegt hier nog een taak aan toe, namelijk het verrichten van periodiek onderzoek.

Als er wordt getracht een koppeling te leggen tussen enerzijds de kosten die het uitvoeren van een bepaalde taak met zich meebrengt en anderzijds zijn bijdrage aan het bereiken van de doelen van BGZ, met andere woorden hoe wordt gehandeld bij een beperkt budget, dan wordt een ander beeld verkregen. Bij voorkeur wordt het geld dan besteed aan het in kaart brengen van en het doen van aanbevelingen op het terrein van de arbeidsomstandigheden. De leveranciers van zorg leggen daarnaast de nadruk op het spreekuur, de ondernemingsraad op GVO en periodiek onderzoek (met name bij GD-bedrijven), en personeelszaken besteedt bij voorkeur het geld aan het laten verrichten van aanstellingskeuringen.

In de praktijk onderschrijven met uitzondering van de GD-directie de andere respondenten dat aanstellingskeuringen teveel aandacht krijgen. Over welke taken nog meer teveel aandacht krijgen, lopen de meningen sterk uiteen. De directie van de BGD vindt dat periodiek onderzoek teveel aandacht krijgt (in tegenstelling tot de ondernemingsraad); bedrijfsartsen, met name bij GD-bedrijven, vinden dat er teveel aandacht moet worden besteed aan activiteiten ter beperking van het ziekteverzuim. Er bestaat wel weer overeenstemming over waar het aan schort, waar te weinig aandacht aan wordt besteed, namelijk een beleidsmatige aanpak en meer werkplek- 
onderzoek c.q. -advisering. Daamaast krijgt volgens de ondernemingsraad GVO te weinig aandacht.

\subsubsection{De wensen ten aanzien van de uitvoering van het aanstellingsonderzoek}

De meeste bedrijfsartsen willen functiegericht keuren, en becordelen of betrokkene het werk lichamelijk ankan. Selectie-aspecten van het aanstellingsonderzoek (zoals "passen in de groep", "meewegen verzuimrisico", en "meeselecteren") worden door minder bedrijfsartsen wenselijk geacht. Toch zou bijna een kwart van de GD. bedrijfsartsen in de selectiefase van een sollicitatieprocedure willen keuren.

De ondernemingsraad en nog in sterkere mate werknemers wensen dat de positie van de individuele werknemer bij de aanstellingskeuring wordt versterkt. Het wordt niet wenselijk geacht om het aanstellingsonderzoek te hanteren als selectieinstrument. EVD-bedrijfsartsen wensen vaker (significant) de werkgever te informeren over medische beperkingen van werknemers. Werknemers vinden het minder vaak dan ondernemingsraad en bedrijfsarts van belang dat de vitslag, eerst met de keurling wordt besproken (tabel 8.20).

Er kan worden geconcludeerd dat de bedrijfsarts de nadruk legt op het functiegericht keuren, bedrijfsarts en klant zijn het eens over de wenselijkheid van de rechten van de keurling (eerst uitslag bespreken, herkeuringsmogelijkheden).

Tabel 8.20. Wensen van bedriffsarts, werknemers en ondermemlngarnad bi bet anntellingonderzoek

\begin{tabular}{|c|c|c|c|c|c|c|c|c|c|}
\hline & \multicolumn{3}{|c|}{ bodrijfsarts } & \multicolumn{3}{|c|}{ ondernemingsrand } & \multicolumn{3}{|c|}{ worknemern } \\
\hline$N=$ & $\begin{array}{l}\text { GD } \\
17\end{array}$ & $\begin{array}{l}\text { EVD } \\
15\end{array}$ & $\begin{array}{l}\text { total } \\
32\end{array}$ & $\begin{array}{r}G D \\
16\end{array}$ & $\begin{array}{l}\text { EVD } \\
10\end{array}$ & $\begin{array}{l}\text { totud } \\
26\end{array}$ & $\begin{array}{l}\text { OD } \\
18\end{array}$ & $\begin{array}{l}\text { EVD } \\
13\end{array}$ & $\begin{array}{l}\text { Iotwal } \\
31\end{array}$ \\
\hline - functiegerich & 16 & 14 & $30(94 \%)$ & 7 & 6 & $13(50 \%)$ & - & a & \\
\hline - pact in groep & 8 & 6 & $14(44 \%)$ & 1* & os & $1(4 \%)$ & $0^{*}$ & $0^{*}$ & \\
\hline $\begin{array}{l}\text { - lichamelijk bet werk } \\
\text { ennkenn }\end{array}$ & 16 & 15 & $31(97 \%)$ & 10 & 8 & $18(69 \%)$ & 6 & 3 & $9(29 \%)$ \\
\hline $\begin{array}{l}\text { - geectelijk bet wert } \\
\text { ankan } \\
\text { - werkgover informer }\end{array}$ & 10 & 11 & $21(66 \%)$ & 7 & 1 & $8(31 \%)$ & 1 & 0 & $1(3 \%)$ \\
\hline $\begin{array}{l}\text { over mediecho beper- } \\
\text { kingea } \\
\text { - verzuimrisico meewo- }\end{array}$ & 6 & 11 & $17(53 \%)$ & 4 & 1 & $5(19 \%)$ & 2 & 0 & $2(6 \%)$ \\
\hline $\begin{array}{l}\text { gea } \\
\text { - voordool twijfel werk- }\end{array}$ & 2 & 2 & $4(13 \%)$ & $\mathbf{0}$ & 0 & 0 & 2 & 0 & $2(6 \%)$ \\
\hline nemer & 9 & 4 & $13(42 \%)$ & 22 & 3 & $5(19 \%)$ & 3 & 0 & $3(10 \%)$ \\
\hline - uitsing eern besproken & 16 & 13 & $29(94 \%)$ & 13 & 10 & $23(92 \%)$ & 13 & 7 & $20(65 \%)$ \\
\hline $\begin{array}{l}\text { - herkeuringamogelijk- } \\
\text { beid }\end{array}$ & 12 & 8 & $20(63 \%)$ & 8 & 8 & $16(62 \%)$ & 8 & 5 & $13(42 \%)$ \\
\hline - meo relocterea & 4 & 1 & $5(16 \%)$ & ad & 0 & & & & \\
\hline
\end{tabular}

- Fisher's exect teat p<.05 (1.0.v. bedrijfurts)

\& Fisher's exact tout $.05<p<.10$ (t.o.v. bedrijfarts) 


\subsubsection{De wensen ten aanzien van de uitvoering van het spreekuur}

Bedrijfsartsen willen niet elke zieke zien op het spreekuur en altijd een uitspraak doen over arbeidsongeschiktheid. Het merendeel van de bedrijfsartsen wil aan het bedrijf doorgeven als werknemers een tijdelijke medische beperking hebben. In EVD-bedrijven onderschrijft de bedrijfsarts minder vaak (statistisch niet significant) de stelling dat pas met derden wordt overlegd als betrokkene hiertoe toestemming geeft. De bedrijfsarts wil zich bij zijn spreekuuractiviteiten laten leiden door het verband dat er eventueel bestaat tussen klacht/ziekte en werk.

Ook de ondernemingsraad en werknemers willen niet dat de bedrijfsarts elke zieke op het spreekuur ziet. De ondernemingsraad vindt vaker dan de werknemers dat de BGD de relatie tussen ziekte en werk moet nagaan (bij EVD-bedrijven significant). Werknemers vinden dit aspect, mogelijk uit angst voor persoonlijke consequenties, zelden wenselijk. De klant (ondernemingsraad en werknemer) vindt het niet altijd wenselijk dat de bedrijfsarts expliciet toestemming vraagt voordat hij met derden over een werknemer overlegt (tabel 8.21).

Er kan worden vastgesteld dat voor leverancier en afnemer van BGZ als voornaamste wens geldt dat de BGD rechtstreeks geconsulteerd kan worden. De bedrijfsarts wenst vaker dan de klant dat medische beperkingen worden doorgegeven aan de werkgever.

Tabel 8.21. Wensen ten arnzilen van bet spreekuur

\begin{tabular}{|c|c|c|c|c|c|c|c|c|c|}
\hline \multirow{2}{*}{ 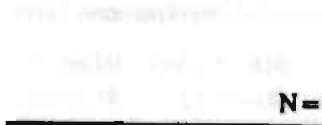 } & \multicolumn{3}{|c|}{ bedrijfourts } & \multicolumn{3}{|c|}{ ondemerningsrand } & \multicolumn{3}{|c|}{ werknemers } \\
\hline & $\begin{array}{l}\text { GD } \\
17\end{array}$ & $\begin{array}{l}\text { EVD } \\
15\end{array}$ & $\begin{array}{c}\text { tocal } \\
32\end{array}$ & $\begin{array}{l}G D \\
16 \\
\end{array}$ & $\begin{array}{l}\text { EVD } \\
10 \\
\end{array}$ & $\begin{array}{l}\text { Iotanal } \\
26\end{array}$ & $\begin{array}{l}\text { GD } \\
18 \\
\end{array}$ & $\begin{array}{l}\text { EVD } \\
13 \\
\end{array}$ & $\begin{array}{l}\text { tocual } \\
31\end{array}$ \\
\hline $\begin{array}{l}\text { - alke zioke zion } \\
\text { - altijd uitsprask over }\end{array}$ & 0 & 2 & $2(6 \%)$ & 2 & 1 & $3(12 \%)$ & 2 & 1 & $3(10 \%)$ \\
\hline aboideongewchiktheid & 0 & 2 & $2(6 \%)$ & 3 & 2 & $5(19 \%)$ & 2 & 0 & $2(6 \%)$ \\
\hline $\begin{array}{l}\text { - proppose verauimduur } \\
\text { - mediacho boporking }\end{array}$ & 9 & 6 & $15(47 \%)$ & 1 & 0 & $1(4 \%)$ & 2 & 0 & $2(6 \%)$ \\
\hline $\begin{array}{l}\text { doorgeven } \\
\text { - rolatio mok work ma- }\end{array}$ & 12 & $13 *$ & $25(81 \%)$ & 5 & 4 & $9(35 \%)$ & 4 & $2 *$ & $6(19 \%)$ \\
\hline $\begin{array}{l}\text { gean } \\
\text { ovorlog pas ma too. }\end{array}$ & 16 & 12 & $28(88 \%)$ & 10 & 9* & $19(73 \%)$ & 5 & $2 *$ & $7(23 \%)$ \\
\hline $\begin{array}{l}\text { stemming } \\
\text { - moldea workgover van }\end{array}$ & 15 & 9 & $24(75 \%)$ & 6 & 7 & $13(50 \%)$ & 7 & 2 & $9(29 \%)$ \\
\hline $\begin{array}{l}\text { werkgobondea klacht } \\
\text { - rochetreake consulto- }\end{array}$ & 13 & 10 & $23(72 \%)$ & 12 & 7 & $19(73 x)$ & 4 & 6 & $10(32 \%)$ \\
\hline $\begin{array}{l}\text { man BOD } \\
\text { - cunatiove activitoiten }\end{array}$ & 17 & 14 & $31(97 \%)$ & 14 & 10 & $24(92 x)$ & 7 & 9 & $16(52 \%)$ \\
\hline bodrijfents & t & 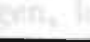 & & & & & 0 & 0 & 0 \\
\hline
\end{tabular}

- Finhor's oxwet toet $p<.05$ 


\subsubsection{De wensen ten aanzien van de uitvoering van het periodiekt onderzoek}

Hoewel gezondheidsrisico's en leeftijd door de bedrijfsarts worden gehanteerd als indicatie voor periodiek onderzoek (zie paragraaf 8.2.4.3), wordt dit slechts door œn enkeling gewenst. Een kwart wil bij periodiek onderzoek altijd een lichamelijk onderzoek verrichten, en dit is conform eigen wens.

Bijna driekwart van de bedrijfsartsen wil op groepsniveau rapporteren over de gegevens van periodieke onderzoeken. Er kan worden opgemerkt dat minder dan $20 \%$ van de bedrijfsartsen vaker periodiek onderzoek zou willen verrichten.

Ongeveer tweederde tot driekwart van de ondernemingsraden wenst dat het periodiek onderzoek plaatsvindt bij risicogroepen of boven een bepaalde leeftijd. De ondernemingsraad in GD-bedrijven is vaker dan de bedrijfsartsen de mening toegedaan dat bij het periodiek onderzoek bloedonderzoek moet plaatsvinden. Bijna de helft van de werknemers wenst dat bij elk periodiek onderzoek lichamelijk onderzoek plaatsvindt. Ruim een derde van de werknemers vindt dat periodiek onderzoek moet plaatsvinden boven een bepaalde leeftijd. De helft van de ondernemingsraden wenst dat vaker periodiek onderzoek plaatsvindt. Deze wens leeft minder bij bedrijfsartsen (in EVD-bedrijven statistisch significant) en werknemers (in GD. en EVD-bedrijven statistisch significant ten opzichte van ondernemingsraad). De wens dat bij elk periodiek onderzoek een duidelijke koppeling wordt gelegd met het werk, is het sterkst bij bedrijfsartsen. Opgemerkt kan worden dat over de gehele lijn gezien ondernemingsraden breder en diepgaander periodiek onderzoek wensen dan bedrijfsartsen (tabel 8.22).

Tabel 8.22. Wensen ten annien van bet periodiels onderzock

\begin{tabular}{|c|c|c|c|c|c|c|c|c|c|}
\hline & \multicolumn{3}{|c|}{ bedrijfserts } & \multicolumn{3}{|c|}{ ondornomingerued } & \multicolumn{3}{|c|}{ wertanemort } \\
\hline $\mathbf{N}$ & $\begin{array}{r}\text { GD } \\
17\end{array}$ & $\begin{array}{r}\text { EVD } \\
15\end{array}$ & $\begin{array}{l}\text { totend } \\
32\end{array}$ & $\begin{array}{r}\text { GD } \\
16\end{array}$ & $\begin{array}{l}\text { EVD } \\
10\end{array}$ & $\begin{array}{l}\text { totanal } \\
26\end{array}$ & $\begin{array}{l}\text { GD } \\
18 \\
\end{array}$ & $\begin{array}{l}\text { EVD } \\
13 \\
\end{array}$ & $\begin{array}{l}\text { totend } \\
31\end{array}$ \\
\hline \multicolumn{10}{|l|}{ - vaker periodiek onder- } \\
\hline $\begin{array}{l}\text { zook } \\
\text { - koppeling met work }\end{array}$ & 3 & 2 & $5(16 \%)$ & 7 & 5* & $12(46 \%)$ & $1^{*}$ & $1 *$ & $2(6 \%)$ \\
\hline vereist & 12 & 10 & $22(69 \%)$ & 9 & 3 & $12(46 \%)$ & 2 & 1 & $3(10 \%)$ \\
\hline $\begin{array}{l}\text { - alleen risicogroepen } \\
\text { - alleen boven cen be- }\end{array}$ & 3 & 2 & $5(16 \%)$ & 13 & 7 & $20(77 \%)^{*}$ & 6 & 5 & $11(35 \%)$ \\
\hline $\begin{array}{l}\text { pando leeftijd } \\
\text { - altijd lichnmelijk }\end{array}$ & 0 & 0 & 0 & 12 & 5 & $17(65 \%)$ & 7 & 5 & $12(39 \%)$ \\
\hline $\begin{array}{l}\text { onderzook verrichten } \\
\text { - altijd bloedonderzoek }\end{array}$ & 4 & 4 & $8(26 \%)$ & 9 & 4 & $13(50 \%)$ & 9 & 5 & $14(45 \%)$ \\
\hline verrichten & 1 & 6 & $7(22 \%)$ & $10 *$ & 5 & $15(58 \%)$ & 6 & 6 & $12(39 \%)$ \\
\hline - groeperapportago & 16 & 7 & $23(72 \%)$ & 5 & 5 & $10(38 \%)$ & - & - & \\
\hline - deelneme is vrijwillig & 17 & 9 & $26(81 \%)$ & 10 & 6 & $16(62 \%)$ & - & - & \\
\hline
\end{tabular}

- Fisher's exact teat $p<.05$ 


\subsubsection{De wensen ten aanzien van de uitvoering van het werkplekonderzoek}

De bedrijfsartsen willen een actief beleid voeren op de werkplek, en niet slechts reageren op vragen uit het bedrijf. Er bestaat de wens van betrokken worden van de BGD in de ontwerpfase van wijzigingen in het produktieproces. Wens en praktijk liggen hier ver uit elkaar.

Ook de ondernemingsraad en werknemers wensen een actieve(re) houding en rol van de BGD op de werkplek (tabel 8.23).

Tribel 8.23. Wensen len amnziten van het onderzoek op de werkplek

\begin{tabular}{|c|c|c|c|c|c|c|c|c|c|}
\hline \multirow[b]{2}{*}{$\mathbf{N}=$} & \multirow[b]{2}{*}{$\begin{array}{l}\text { OD } \\
17\end{array}$} & \multicolumn{2}{|c|}{ bedrijfsarts } & \multicolumn{3}{|c|}{ ondernemingsraed } & \multicolumn{3}{|c|}{ werknemers } \\
\hline & & $\begin{array}{l}\text { EVD } \\
15\end{array}$ & $\begin{array}{l}\text { totund } \\
32\end{array}$ & $\begin{array}{l}\text { GD } \\
16\end{array}$ & $\begin{array}{l}\text { EVD } \\
10\end{array}$ & $\begin{array}{l}\text { toteal } \\
26\end{array}$ & $\begin{array}{l}G D \\
18\end{array}$ & $\begin{array}{l}\text { EVD } \\
13\end{array}$ & $\begin{array}{l}\text { toteal } \\
31\end{array}$ \\
\hline $\begin{array}{l}\text { - cen actiof beloid } \\
\text { - bedrijfarts wil zelf } \\
\text { werkplekonderzook }\end{array}$ & 14 & 12 & $26(81 \%)$ & 8 & 8 & $16(64 \%)$ & 12 & 6 & $18(58 \%)$ \\
\hline $\begin{array}{l}\text { doon } \\
\text { - bedrijfuarts wil zolf }\end{array}$ & 4 & 6 & $10(31 \%)$ & - & - & - & - & - & - \\
\hline $\begin{array}{l}\text { werkplek bezocken } \\
\text { - al in ontwerpfuse }\end{array}$ & II & 12 & $23(72 \%)$ & - & - & - & - & - & - \\
\hline $\begin{array}{l}\text { betrekken van do BGD } \\
\text { - overleg plegen met af- } \\
\text { deling voordal onder- }\end{array}$ & 12 & 8 & $20(63 \%)$ & 9 & 8 & $17(65 \%)$ & 3 & 3 & $6(19 \%)$ \\
\hline zook start & 16 & 13 & $29(91 \%)$ & & & & 5 & 5 & $10(32 x)$ \\
\hline
\end{tabular}

\subsection{Samenvatting}

In dit hoofdstuk werd de professionele en de klantgerichte kwaliteit van BGZ beschreven. Professionele kwaliteit werd opgebouwd uit de aspecten: de werkwijze van de bedrijfsarts, het werkterrein van de BGD, de bruikbaarheid van advisering van de BGD, de taakuitvoering in de praktijk en het rendement van BGZ-kerntaken. De klantgerichte kwaliteit werd opgebouwd uit de aspecten: de ondersteunende rol van de BGD, de houding van de BGD, de ervaringen met de uitvoering van BGZ-taken, de samenwerking tussen BGD en bedrijf en de afstemming over de taakuitvoering tussen BGD en bedrijf.

Uit het onderzoek komt naar voren dat de BGD regelmatig contact heeft met het bedrijf.

\section{Professionele kwaliteit}

De GD-bedrijfsarts maakt vaker afspraken over rapportage dan de EVD-bedrijfsarts. Hij rapporteert ook vaker. Er wordt in het algemeen vaker gerapporteerd aan de directie dan aan de ondernemingsraad van het bedrijf.

Het bedrijf neemt vaker dan de BGD het initiatief om BGZ-activiteiten te entameren. De opstelling van de BGD is te karakteriseren als reactief, reagerend op signalen uit het bedrijf. De BGD wordt zelden ingeschakeld op algemeen beleidsterrein 
(nieuwbouw). De BGD houdt zich in hoofdzaak bezig met individu-gebonden problematiek. In zijn algemeenheid lijkt de BGD naast de kerntaken (en EHBO) weinig extra activiteiten te ontplooien.

De advisering van de BGD wordt door personeelszaken als goed bruikbaar ervaren. De ondernemingsraad is in het algemeen minder positief over de kwaliteit van advisering dan personeelszaken.

Ook door bedrijfsartsen, die geen formele verzekeringsgeneeskundige taak hebben, worden regelmatig uitspraken gedaan over de arbeids(on)geschiktheid van werknemers. Werknemers ervaren bij het periodiek onderzoek zelden een verband met het werk. De rol van de bedrijfsarts op de werkplek is meestal reactief, dat wil zeggen reageren op signalen en verzoeken van het bedrijf.

De BGZ-kerntaken hebben in de ogen van de ondernemingsraad maar weinig rendement. Het aanstellingsonderzoek wordt niet als instrument ervaren om arbeidsongeschiktheid te voorkomen, het spreekuur als instrument voor reïntegratie schiet tekort. De ondernemingsraad kent aan het periodiek onderzoek minder rendement toe dan de bedrijfsarts, en het werkplekonderzoek levert zelden een bijdrage aan de preventie van werkgebonden ziekten.

\section{Klantgerichte kwaliteit}

Tussen eenderde (GD-bedrijven) en bijna de helft (EVD-bedrijven) van personeelszaken is van mening dat de BGD in belangrijke mate een ondersteunende rol speelt bij de totstandkoming van het sociaal beleid.

De ondernemingsraad is minder vaak van mening dat de BGD in belangrijke mate het sociaal beleid ondersteunt. De BGD stelt zich objectief op en reageert vrij goed op vragen uit het bedrijf.

De BGD wordt als een laagdrempelige voorziening beschouwd, maar de houding van de BGD-medewerkers wordt niet altijd ervaren als klantvriendelijk, meer in GD- dan in EVD-bedrijven.

De uitvoering van het aanstellingsonderzoek en het periodiek onderzoek wordt door de werknemers als positief ervaren.

Opgemerkt kan worden dat bijna de helft naar aanleiding van het periodiek onderzoek ofwel geen advies kreeg ofwel een advies kreeg waar weinig mee kon worden gedaan.

Sociaal-medische begeleiding wordt in $10 \%$ van de GD-bedrijven en in ongeveer een derde van de EVD-bedrijven als controle ervaren. Volgens $90 \%$ van de ondernemingsraad in GD-bedrijven en ongeveer de helft van de ondernemingsraad in EVD-bedrijven heeft de BGD voldoende kennis van de werkomstandigheden.

De samenwerking tussen BGD en bedrijf wordt door BGD en bedrijf als positief ervaren.

De klant (ondernemingsraad en werknemers) en de bedrijfsarts hebben wensen over de uitvoering van de kerntaken, waaraan in de praktijk (nog)niet wordt voldaan. Met name is dit het geval voor het periodiek onderzoek en het onderzoek van de werkplek. De ondernemingsraad en de werknemers ondersteunen de wens van de 
bedrijfsarts van een minder nadrukkelijke sociaal-medische begeleidingsrol. De mening van personeelszaken hierover is niet bekend. 


\section{Hoofdstuk 9}

\section{Analyses.}

\section{De samenhang tussen bedrijfsarts- en bedrijfsvariabelen en aspecten van kwaliteit van BGZ}

\subsection{Inleiding}

In hoofdstuk 6 werd het onderzoeksmodel beschreven. Er werd een tweetal clusters van aspecten van kwaliteit onderscheiden (zie figuur 9.1).

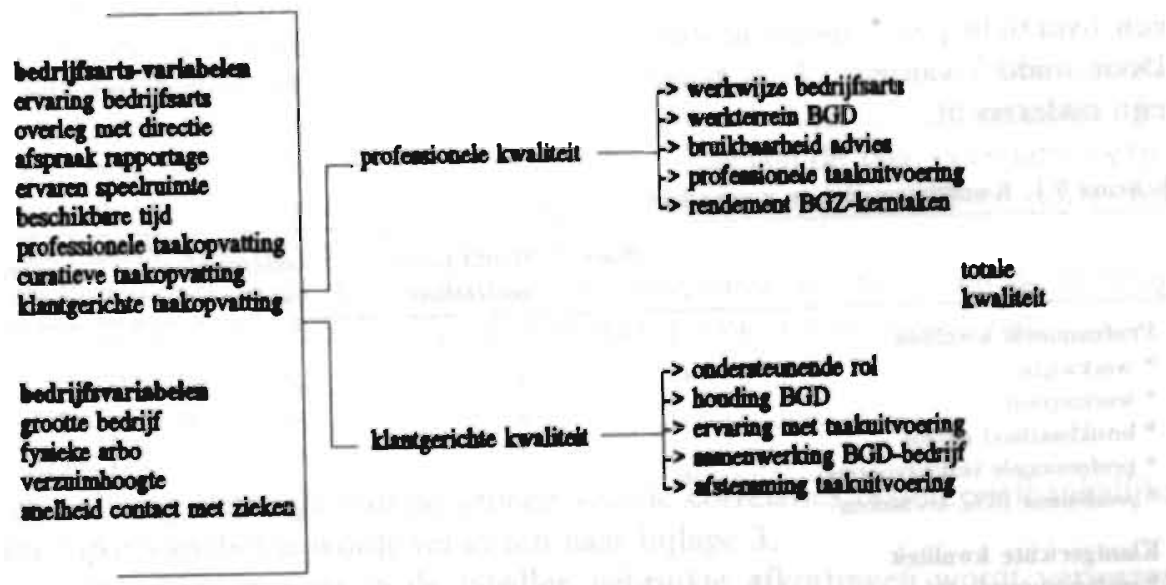

Figner 9.1. Het onderzoelssmodel

Het betreft aspecten van professionele kwaliteit (werkwijze en werkterrein van de bedrijfsarts, bruikbaarheid voor personeelszaken en ondernemingsraad van de advisering door de BGD, de uitvoering van taken volgens professionele wens en het rendement van taken), en het betreft aspecten van kJantgerichte kwaliteit (onder- 
steuning van personeelszaken en ondernemingsraad door de BGD, de houding van de BGD, de ervaring van de klant met de uitvoering van een aantal BGZ-taken, de samenwerking tussen BGD en bedrijf, en de afstemming tussen BGD en klant in taakuitvoering). In het onderzoek worden verder de termen professionaliteit en klantgerichtheid gebruikt.

Als factoren die mogelijk samenhangen met de onderzochte aspecten van kwaliteit werden onderscheiden bedrijfsarts- en bedrijfsgebonden variabelen. Als bedrijfsartsvariabelen gelden de ervaring van de bedrijfsarts, de mate waarin de bedrijfsarts overleg pleegt met de directie van het bedrijf, het al dan niet maken van afspraken door de BGD over rapportage aan het bedrijf, de door de bedrijfsarts ervaren speelruimte in het bedrijf, de beschikbare tijd voor de bedrijfsarts, en de taakopvatting van de bedrijfsarts (curatief, professioneel of klantgericht). Als bedrijfsgebonden-variabelen gelden de groolte van het bedrijf, de aanwezigheid van fysiek belastende arbeidsomstandigheden, de hoogte van het verzuim, en de snelheid waarmee de BGD contact heeft met zieken.

In dit hoofdstuk wordt onderzocht of en in hoeverre deze bedrijfsarts- en bedrijfsgebonden variabelen samenhangen met de ervaren en onderzochte aspecten van kwaliteit (vraag 2 van de probleemstelling, zoals vermeld in hoofdstuk 6). Er moet worden opgemerkt dat de onderscheiden aspecten van kwaliteit van BGZ niet in gelijke mate kunnen worden beoordeeld door de verschillende respondenten. Vandaar dat niet alle kwaliteitsaspecten bij elke respondent gemeten zijn. Schema 9.1 geeft een overzicht per respondent van de onderzochte aspecten van kwaliteit van BGZ. Door middel van een + is aangegeven welke aspecten bij betreffende respondent zijn onderzocht.

Schema 9.1. Kwaliteitsaspect en respondent

\begin{tabular}{|c|c|c|c|}
\hline bedrijfsarts & $\begin{array}{l}\text { Hoofd perso- } \\
\text { noelszaken }\end{array}$ & $\begin{array}{l}\text { ondernemings- } \\
\text { nand }\end{array}$ & werknemer \\
\hline $\begin{array}{l}\text { Professionele kwalitelt } \\
\text { " werkwijze } \\
\text { " werkterroin } \\
\text { " pruikbaarheid advies } \\
\text { " profossionelo takkuitvoering }\end{array}$ & $\begin{array}{l}+ \\
+ \\
+\end{array}$ & $\begin{array}{l}+ \\
+ \\
+ \\
+\end{array}$ & \\
\hline $\begin{array}{l}\text { Klantgerichte kwaliteit } \\
\text { " ondersteunendo rol } \\
\text { " houding BGD } \\
\text { " orvaring mot taluitvoering } \\
\text { " sameawerking BGD-bedrijf } \\
\text { - afstemning toukuitvoering }\end{array}$ & + & $\begin{array}{l}+ \\
+ \\
+ \\
+\end{array}$ & $\begin{array}{l}+ \\
+ \\
+\end{array}$ \\
\hline
\end{tabular}

Zoals reeds eerder werd vermeld, verschillen GD en EVD in een aantal opzichten van elkaar. Idealiter zouden de analyses dan ook separaat voor GD en EVD worden uitgevoerd. Gegeven de omvang van de respons wordt echter gestart met het 
onderzoeken van eventuele correlaties in de totale (GD en EVD samen) onderzoeksgroep. Van hieruit zal in paragraaf 9.5 , voor zover de omvang van de steekproef dit toelaat, worden ingegaan op enige opmerkelijke verschillen tussen GD en EVD.

Dit hoofdstuk start in paragraaf 9.2 met een beschrijving van de correlaties voor de totale groep tussen de onafhankelijke variabelen onderling en tussen de afhankelijke variabelen onderling (verstorende correlaties). In de twee paragrafen hierna worden, uitgaande van de bedrijfsarts- en bedrijfsgebonden variabelen (de onafhankelijke variabelen), de correlaties tussen deze variabelen en de onderzochte aspecten van professionaliteit (paragraaf 9.3) en klantgerichtheid (paragraaf 9.4) (de afhankelijke variabelen) onderzocht.

Als statistische grootheid om de onderlinge samenhang (correlatie) te meten, is gebruik gemaakt van de product-moment correlatiecoafficiënt (Pearson). Over de keuze van het significantieniveau kan het volgende opgemerkt worden. In navolging van Plantenga (1981) wordt in dit onderzoek bij de bespreking van correlaties tussen onafhankelijke en afhankelijke variabelen gekozen voor een significantieniveau tot .10. Het onderzoek kan namelijk gekenmerkt worden als toegepast en beleidsgericht onderzoek. De omvang van de steekproef kan in samenhang met het aantal variabelen relatief klein worden genoemd. Beide factoren zouden ertoe kunnen leiden dat het strikt hanteren van een significantieniveau alpha $<.05$ onnodig en onterecht voor beleidsvoerders toch relevante correlaties buiten het aandachtsveld houdt (de zgn. beta-fout (zie ook Nijhuis en Soeters 1983, Broersen et al. 1992)). In het onderzoek is nagegaan in hoeverre de kwaliteitsvariabelen gerelateerd zijn aan de onderscheiden bedrijfsarts- en bedrijfsvariabelen. Het aantonen van causale verbanden in een transversaal onderzoek als het onderhavige is niet mogelijk. Er worden dan ook slechts samenhangen beschreven. Gegeven de lage correlatiecoëfficiënten kan er slechts worden gesproken van indicaties voor hypothesen, en is het trekken van harde conclusies veelal niet mogelijk.

In de tabellen wordt naast de grootte van de correlaties de sterkte en de richting van het verband tussen betrokken variabelen aangegeven. Daarbij geldt dat:

$$
\begin{array}{llr}
+++1 & -\quad \mathrm{p}<.01 \\
++l- & .01<\mathrm{p}<.05 \\
+/ & .05<\mathrm{p}<.10
\end{array}
$$

Voor een volledig overzicht van de grootte van de correlaties tussen onafhankelijke en afhankelijke variabelen wordt verwezen naar bijlage 3.

Voor een uitwerking van de in de tabellen gebruikte afkortingen wordt verwezen naar bijlage 1 .

\subsection{Correlaties tussen de variabelen onderling}

In deze paragraaf worden de correlaties beschreven die er bestaan tussen de onafhankelijke variabelen onderling (paragraaf 9.2.1) en tussen de afhankelijke variabe- 
len onderling (paragraaf 9.2.2). Zoals vermeld, gaat het hier om de gehele onderzochte populatie, dat wil zeggen GD en EVD samen. In deze paragraaf worden alleen de correlaties vermeld met een significantie-waarde kleiner of gelijk .05 $(p<.05)$. Voor een volledig overzicht van de grootte van de correlaties tussen de variabelen onderling wordt verwezen naar bijlage 4 .

\subsubsection{Correlaties onafhankelijke variabelen onderling}

Twbel 9.1. Correleties tussen onahankelijke variabelen

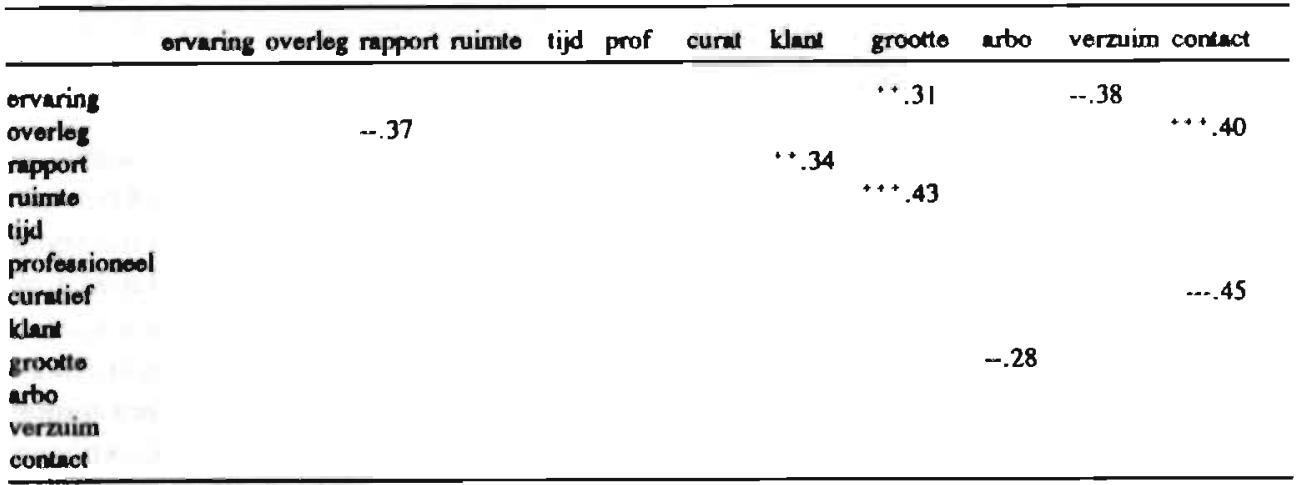

Naarmate de omvang van de bedrijven groter is, ervaart de bedrijfsarts meer speelruimte (ruimte), is hij langer voor het bedrijf werkzaam (ervaring), en komen er minder fysiek belastende arbeidsomstandigheden (arbo) voor. Naarmate de bedrijfsarts meer werkt volgens een klantgerichte opstelling (klant), maakt hij vaker afspraken over rapportage aan het bedrijf (rapport), en neemt hij minder snel contact op met zieke werknemers (contact). Naarmate de bedrijfsarts vaker overleg voert met de directie van het bedrijf (overleg), maakt hij minder vaak afspraken over rapportage aan het bedrijf, en neemt hij sneller contact op met zieken. Tot slot kan worden vermeld dat naarmate de bedrijfsarts langer voor het bedrijf werkzaam is, het verzuim lager is (verzuim).

\subsubsection{Correlaties afhankelijke variabelen onderling}

In zijn algemeenheid kan worden vastgesteld dat er een samenhang bestaat tussen de diverse aspecten van kwaliteit. Dit exploratieve onderzoek was ook opgezet om aspecten die cen (theoretisch) mogelijk verband kunnen hebben met respectievelijk professionele en klantgerichte kwaliteit te verkennen. De aandacht gaat daarbij vooral uit naar factoren die de gemeten aspecten van kwaliteit beïnvloeden, en naar mogelijke verschillen tengevolge van de BGD-organisatievorm. Het gaat niet om het bepalen van het kwaliteitsniveau.

Omdat separaat is onderzocht of en zo ja welke samenhang er bestaat tussen bedrijfsarts- en bedrijfsvariabelen en aspecten van kwaliteit (dat wil zeggen met de respectieve variabelen waaruit de kwaliteitsaspecten zijn samengesteld) hoeft de ge- 
constateerde samenhang tussen de afhankelijke variabelen onderling niet verstorend te zijn. De vastgestelde intercorrelaties duiden er op dat het begrip "kwaliteit" in algemene zin wordt gemeten, zonder dat alle aspecten naar elkaar duidelijk zijn afgegrensd.

In schema 9.1 werden de onderscheiden aspecten van kwaliteit genoemd. Betrokken aspecten zijn opgebouwd uit éen of meer variabelen. In paragraaf 9.2.2.1 worden de intercorrelaties beschreven van de variabelen per kwaliteitsaspect. Gezien het grote aantal variabelen, wordt in paragraaf 9.2.2.2 slechts op een beperkt aantal relevante en significante verbanden tussen de kwaliteitsaspecten ingegaan. Criteria hierbij waren de grootte van de correlatiecoéfficiẻnt en de relevantie van het verband in het kader van het onderzoek. Voor een volledig overzicht wordt verwezen naar bijlage 4 .

\subsubsection{Correlaties per kwaliteitsaspect}

(tabel 9.2a en 9.2b)

Met betrekking tot de professionele kwaliteit zijn 5 aspecten gemeten, te weten: werkwijze van de bedrijfsarts, werkterrein van de BGD, bruikbaarheid advisering, professionele uitvoering van kerntaken en het rendement van kerntaken. Elk aspect is opgebouwd uit eén of meer variabelen (lees: vragen).

Binnen het aspect werkwijze is er een samenhang tussen het op groepsniveau registreren van gegevens van het periodiek onderzoek en het registreren van groepsgegevens van het werkplekonderzoek.

Binnen het aspect werkerrein van de BGD is geen significante samenhang tussen de gemeten variabelen.

$\mathrm{Er}$ is geen samenhang tussen het bruikbaar vinden van de advisering van de BGD door personeelszaken en het bruikbaar vinden van de advisering van de BGD door de ondernemingsraad.

Binnen het aspect professionele taakuitvoering is er een samenhang tussen het naar professionele wens uit kunnen voeren van het periodiek onderzoek en het professioneel uit kunnen voeren van het werkplekonderzoek.

De rendementsoordelen hangen onderling sterk samen. Het toekennen van rendement door de ondernemingsraad aan BGZ-kerntaken kan worden gezien als een algemene blijk van waardering voor inzet door de BGD. Er is sprake van een algemeen rendementsoordeel.

Met betrekking tot de klantgerichte kwaliteit is ook een vijftal, uit ten of meer variabelen opgebouwde, aspecten onderzocht, te weten de ondersteunende rol van de BGD, de houding van de BGD, de ervaring van de klant met de uitvoering van een aantal BGZ-taken, de samenwerking tussen BGD en bedrijf, en de mate waarin kerntaken naar wens van de klant worden uitgevoerd.

Het ervaren van steun van de BGD door de ondernemingsraad hangt niet samen met het ervaren van steun van de BGD door personeelszaken. 
Binnen het kwaliteitsaspect ervaring met de uitvoering van BGZ-taken is er een marginaal significante samenhang tussen het ervaren van de verzuimbegeleiding van de BGD als controle door de ondernemingsraad en het ervaren van de verzuimbegeleiding als controle door werknemers.

Er is een samenhang tussen een consistente samenwerking tussen BGD en directie met een consistente samenwerking tussen BGD en personeelszaken.

Binnen het kwaliteitsaspect afstemming van de uitvoering van kerntaken is er een samenhang tussen het naar wens van de ondernemingsraad uitvoeren van de kerntaken en het naar wens van werknemers uitvoeren van kerntaken.

Voor de tabellen 9.2a tot en met 9.2c worden de aspecten van professionele kwaliteit genummerd van 1 tot en met 16 , en de aspecten van klantgerichte kwaliteit van a tot en met s. De cijfers respectievelijk letters hebben de volgende betekenis:

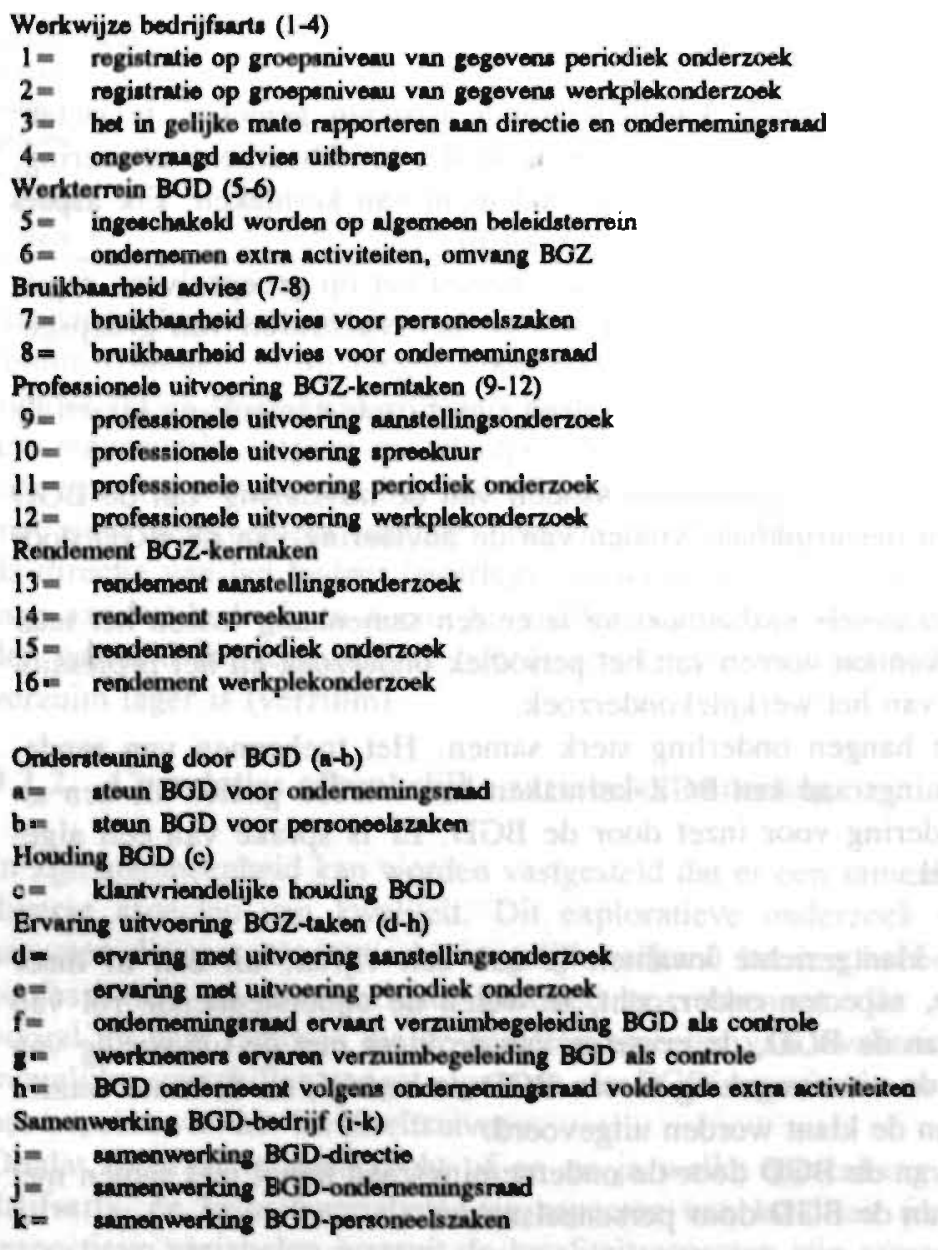


Afstemming tualuitvoering (1-s)

I = uitvoering anostellingsonderzoek nar wens ondernemingsrand

$\mathbf{m}=$ uitvoesing sanstellingsonderzokk nav wens worknemers

$\mathrm{n}=$ uitvooring spreakuur naver wens ondernemingsrand

$o=$ uitvoerins spreckuur nur wens workneman

$p=$ uitvoering periodiek onderzoek nar wons ondernemingsrand

$q=\quad$ uitvoering periodick onderzoek naw wens wertunomers

$\mathbf{r}=$ uirvoering werkplekonderzock nevr wens chdernemingsurad

= = uitvoering werkplekonderzosk nur went worknemen

Tubed 92. Correluties aspecten van professionele kwaliteit

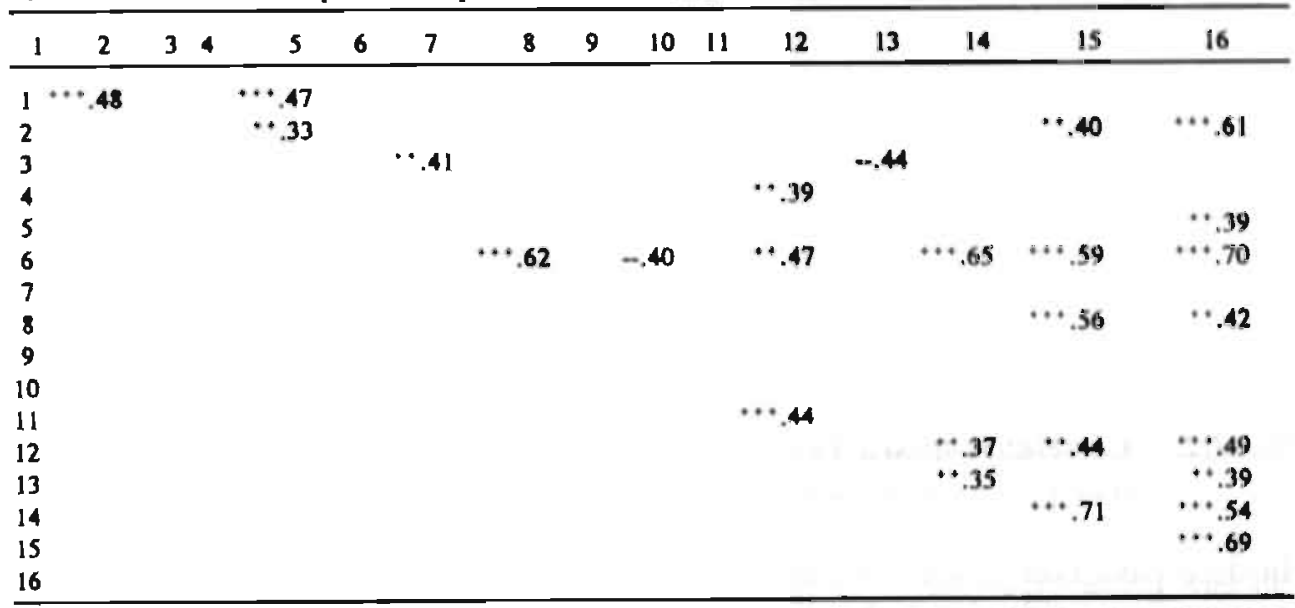

Trbel 9.2b. Correlaties aspecten van klantgerichte kwaliteil

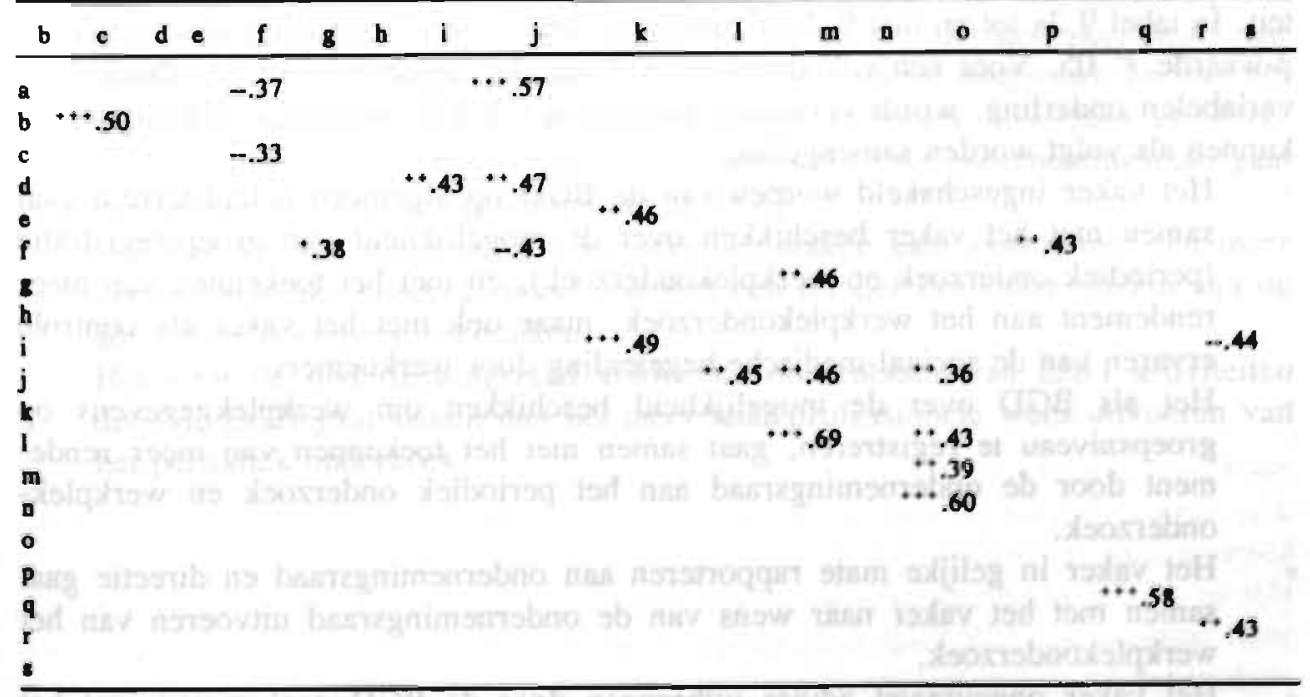


Tabel 9.2c. Correlaties tussen professionele en klantgerichte aspecten van kwaliteit

\begin{tabular}{|c|c|c|c|c|c|c|c|c|c|c|c|c|c|c|c|}
\hline & 1 & 3 & 4 & 5 & 6 & 7 & 8 & 9 & 10 & 11 & 12 & 13 & 14 & 15 & 16 \\
\hline - & $\cdots .36$ & & $\cdots .35$ & $\cdots+.57$ & $+\cdots .64$ & & $\cdots .71$ & & & & & & +38 & $\cdots .61$ & $+* .57$ \\
\hline b & & & & & & & & & & & & & & & \\
\hline c & & & +.36 & & & & & & & & & & +.33 & & \\
\hline d & & & & & & & & & & & $\cdots .36$ & & & & \\
\hline e & & & & & & & & & & & & & & & \\
\hline$r$ & & & & & & & -.41 & & & & & & & & \\
\hline 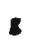 & & & $\cdots .36$ & $\cdots .43$ & & & & & & & & & & & \\
\hline h & & & & & & & & & & $\cdots .50$ & & & & & $\cdots 32$ \\
\hline i & & & & & & & & & & & & & & & \\
\hline j & & & & & $+* .68$ & &.+ .40 & & & & +.43 & & ++.36 & $* .43+$ & $\cdot+.47$ \\
\hline k & & $\because .38$ & & & & & & & .38 & & & & & & \\
\hline 1 &.- .53 & & & & & & & & & & & & & & \\
\hline m & & & & & & & & & & & & & & & \\
\hline$n$ & & & & & & & & & .49 & & & & & & \\
\hline 0 & & & & $\cdots .36$ & & & & & & $\cdots .34$ & & & & & \\
\hline $\mathbf{p}$ & -.39 & & & & & & & & & $\cdots .50$ & & & & & \\
\hline$q$ & & & & & $* .43$ & & & & & $\cdots .37$ & & & & & \\
\hline$r$ & & $\cdots .49$ & & & & & & & & & $\cdots .59$ & & & & \\
\hline 1 & & & & & & & -.47 & & & & $\cdots+.43$ & & & & \\
\hline
\end{tabular}

\subsubsection{Correlaties tussen kwaliteitsaspecten}

(tabel 9.2a tot en met 9.2c)

In deze paragraaf wordt een aantal correlaties beschreven dat er bestaat tussen de aspecten van professionele kwaliteit onderling, tussen de aspecten van kJantgerichte kwaliteit onderling, en tussen de aspecten van professionele en klantgerichte kwaliteit. In tabel 9.2a tot en met 9.2c worden relevante correlaties weergegeven met een p-waarde $<.05$. Voor een volledig overzicht van de correlaties van de afhankelijke variabelen onderling, wordt verwezen naar bijlage 4 . De belangrijkste bevindingen kunnen als volgt worden samengevat:

- Het vaker ingeschakeld worden van de BGD op algemeen beleidsterrein gaat samen met het vaker beschikken over de mogelijkheid van groepsregistratie (periodiek onderzoek en werkplekonderzoek), en met het toekennen van meer rendement aan het werkplekonderzoek, maar ook met het vaker als controle ervaren van de sociaal-medische begeleiding door werknemers.

- Het als BGD over de mogelijkheid beschikken om werkplekgegevens op groepsniveau te registreren, gaat samen met het toekennen van meer rendement door de ondernemingsraad aan het periodiek onderzoek en werkplekonderzoek.

- Het vaker in gelijke mate rapporteren aan ondernemingsraad en directie gaat. samen met het vaker naar wens van de ondernemingsraad uitvoeren van het werkplekonderzoek.

- Het vaker ongevraagd advies uitbrengen door de BGD gaat samen met het meer naar professionele wens kunnen uitvoeren van het werkplekonderzoek, maar ook met het vaker als controle ervaren door de werknemers van de verzuimbegeleiding door de BGD. 
Het uitvoeren van extra activiteiten door de BGD gaat samen met het vaker bruikbaar vinden van de advisering van de BGD door de ondernemingsiraad, met een meer naar wens van de bedrijfsarts kunnen uitvoeren van het werkplekonderzoek (voor het spreekuur geldt hier een negatief verband), met het vaker toekennen van rendement aan het spreekuur, het periodiek onderzoek en het werkplekonderzoek door de ondernemingsraad, en met een betere samenwerking tussen BGD en ondernemingsraad.

Het bruikbaar vinden van de advisering van de BGD door de ondernemingsraad gaat samen met het toekennen van meer rendement aan periodiek onderzock en werkplekonderzoek, en met het door de ondernemingsraad minder als controle ervaren van de verzuimbegeleiding door de BGD.

Het naar professionele wens kunnen uitvoeren van de kerntaken gaat wat betreft het spreekuur samen met een betere sarnenwerking tussen BGD en personeelszaken, maar ook met het minder naar wens van de ondernemingsraad uitvoeren van het spreekuur; wat betreft het periodiek onderzoek met het in de ogen van de ondernemingsraad voldoende doen door de BGD, met het uitvoeren van het periodiek onderzoek naar wens van ondernemingsraad en werknemers; wat betreft het werkplekonderzoek gaat dit samen met het toekennen van meer rendement aan de kerntaken, met een meer naar wens van ondernemingsraad en werknemers uitvoeren van het werkplekonderzoek, en met een betere samenwerking tussen BGD en ondernemingsraad.

- Het ervaren van meer steun van de BGD door de ondernemingsraad gaat samen met het minder als controle ervaren van de verzuimbegeleiding van de BGD, met een betere samenwerking tussen BGD en ondernemingsraad, met het vaker ingeschakeld worden op algemeen beleidsterrein van de BGD, met het ondernemen van extra activiteiten door de BGD, met het meer bruikbaar vinden van de advisering van de BGD door de ondernemingsraad, en met het toekennen van meer rendement aan spreekuur, periodiek onderzoek en werkplekonderzoek. Kortom, het ervaren van steun door de ondernemingsraad gaat samen met een actieve opstelling van de BGD.

Het ervaren van meer steun door personeelszaken gaat samen met een meer klantvriendelijke houding, maar ook met een minder bruikbaar vinden van de advisering door personeelszaken.

- Het voor de ondernemingsraad voldoende ondernemen van extra activiteiten door de BGD gaat samen met het meer naar professionele wens uitvoeren van het periodiek onderzoek. 


\subsection{Bedrijfsarts- en bedrijfsvariabelen en hun invloed op professionaliteit}

\subsubsection{Inleiding}

In deze paragraaf worden de correlaties beschreven tussen de onafhankelijke variabelen en professionaliteit. Eerst zal worden ingegaan op de correlaties tussen bedrijfsarts variabelen en professionaliteit (paragraaf 9.3.2), hierna op de correlaties tussen bedrijfsvariabelen en professionaliteit (paragraaf 9.3.3). Voor een volledig overzicht van de grootte van de correlaties tussen onafhankelijke en afhankelijke variabelen wordt verwezen naar bijlage 3 .

\subsubsection{Bedrijfsarts-variabelen en professionaliteit}

Achtereenvolgens zal in de paragrafen 9.3.2.1. tot en met 9.3.2.5 worden beschreven of, en zo ja welke invloed er bestaat tussen enerzijds bedrijfsarts-variabelen en anderzijds de volgende aspecten van professionele kwaliteit: de werkwijze van de bedrijfsarts (met als elementen groepsregistratie, rapportage door de bedrijfsarts aan directie en ondernemingsraad, en het ongevraagd adviseren door de BGD), het werkterrein van de BGD (bestaande uit de elementen het ingeschakeld worden van de BGD op algemeen beleidsterrein en het verrichten van extra activiteiten door de BGD buiten het kerntakenpakket om), de uitvoering van kerntaken naar professionele wens, de bruikbaarheid van advisering door de BGD voor ondernemingsraad en personeelszaken, en het rendement van de BGZ-kerntaken (aanstellingsonderzoek, spreekuur, periodiek onderzoek en werkplekonderzoek)

\subsubsection{De werkwijze van de bedrijfsarts}

Naarmate de bedrijfsarts langer werkzaam is voor het bedrijf worden de gegevens van het werkplekonderzoek minder vaak op groepsniveau geregistreerd. Mogelijk acht de bedrijfsarts als hij enige tijd voor het bedrijf werkzaam is, het niet meer nodig alle werkplekgegevens (op groepsniveau) te registreren.

Het maken van afspraken over rapportage aan het bedrijf door de BGD, en een meer professionele taakopvatting van de bedrijfsarts gaan samen met een vaker op groepsniveau registreren van de gegevens van het werkplekonderzoek. Er is een marginaal significant verband tussen het maken van afspraken over rapportage en de mate van het op groepsniveau registreren van gegevens die worden verkregen bij het periodiek onderzoek.

Het in gelijke mate rapporteren aan de directie van het bedrijf en de ondernemingsraad (rapportage DIR/OR) gaat (ook) samen met het maken van afspraken over rapportage en (marginaal significant) met een meer professionele taakopvatting. Een meer professionele taakopvatting gaat samen met een minder vaak ongevraagd advies uitbrengen door de BGD (tabel 9.3). 
Twhel 9.3. De werkwijze van de bedrijfsarts

\begin{tabular}{|c|c|c|c|c|}
\hline & registrutio PGO & rogistratio WP & ongevrangd advies & rapportage DIR/OR \\
\hline 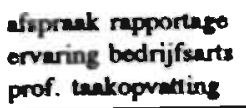 & $\cdot .26$ & $\begin{array}{r}\cdots .46 \\
-.40 \\
\cdots .31\end{array}$ & -.38 & $\begin{array}{l}\cdots .46 \\
\cdot .25\end{array}$ \\
\hline
\end{tabular}

\subsubsection{Het werkterrein van de $B G D$}

In hoofdstuk 7 werd vastgesteld dat vrijwel alle BGD'en een breed pakket van BGZ-activiteiten conform de Arbowet kunnen leveren. De vraag is nu in hoeverre bedrijven concreet gebruik maken van deze potentiële mogelijkheden. Er wordt onderzocht welke factoren bepalen dat de BGD wordt geconsulteerd als een produktieproces ingrijpend wordt gewijzigd, of als de organisatie van het werk sterk wordt veranderd (inschakelen algemeen beleid).

Ook is onderzocht of de BGD, naast de kerntaken (aanstellingsonderzock, spreek. uur, periodiek onderzoek en werkplekonderzoek) ook activiteiten ontplooit die een minder sterk individu gebonden karakter hebben, zoals groepsgerichte GVO (extra activiteiten).

Naarmate de bedrijfsarts een meer professionele taakopvatting heeft, worden er minder extra activiteiten uitgevoerd en wordt de BGD (marginaal significant verband) minder vaak ingeschakeld op algemeen beleidsterrein (tabel 9.4).

Tabel 9.4. Het werkderrein ven de BGD

\begin{tabular}{lll}
\hline & inechakelen algameen beloid & oxtra wetivitoiten \\
\hline $\begin{array}{ll}\text { professionele thakopvatting } \\
\text { curatiovo takopvetting }\end{array}$ & -.30 &.- .48 \\
& & -.34 \\
\hline
\end{tabular}

\subsubsection{De (professionele) uitvoering van BGZ-kerntaken}

In deze paragraaf wordt onderzocht welke factoren samengaan met een door de bedrijfsarts ervaren professionele taakuitoefening. Hangt dit primair samen met de taakopvattingen van de bedrijfsarts zelf?

Het antwoord is neen: er is geen verband tussen de taakopvatting van de bedrijfsarts en het naar professionele wens kunnen uitvoeren van de BGZ-kerntaken. Wel blijkt dat naarmate de bedrijfsarts langer voor het bedrijf werkzaam is hij het merendeel van de kerntaken (namelijk het aanstellingsonderzoek, het spreekuur en het werkplekonderzoek) minder naar eigen (professionele) wens kan uitvoeren.

Naarmate de bedrijfsarts meer tijd ter beschikking heeft, kan hij het spreekuur meer naar professionele wens uitvoeren. Dit laatste is ook het geval naarmate de bedrijfsarts minder speelruimte ervaart in het bedrijf (een mogelijke verklaring zou kunnen zijn dat de bedrijfsarts in dat geval terugvalt op zijn professionele autonomie) (tabel 9.5). 
Tabel 9.5. Professionele tankuitvoering BGZ-kerntaken

\begin{tabular}{lccc}
\hline & prof.uitvoering AK & prof.uitvoering BGS prof.uitvoering PGO & prof.uitvoering WP \\
\hline orvaring bedrijfserts & --.38 & -.30 & -.32 \\
aftprank repportage & -.38 & & \\
orvaren speolruimto & -.31 & -.33 & -24 \\
beechikbare tijd & & -.30 & -.24 \\
overleg met directio & & -.25 & \\
\hline
\end{tabular}

\subsubsection{De bruikbaarheid van advisering}

Er zijn geen significante verbanden tussen enerzijds bedrijfsarts-variabelen en anderzijds het door respectievelijk personeelszaken en ondernemingsraad bruikbaar vinden van de advisering van de BGD.

\subsubsection{Het rendement van BGZ-kerntaken}

Een belangrijk aspect van ervaren kwaliteit is het rendement van BGZ-activiteiten. Welke bedrijfsartsgebonden variabelen beïnvloeden dat de ondernemingsraad een hoog rendement toekent aan de BGD-taken: aanstellingsonderzoek, spreekuur, periodiek onderzoek en werkplekonderzoek?

Naarmate de bedrijfsarts meer speelruimte ervaart in het bedrijf kent de ondernemingsraad (marginaal significant) minder rendement toe aan het aanstellingsonderzoek. Naarmate er sprake is van een meer professionele taakopvatting van de bedrijfsarts, kent de ondernemingsraad aan het spreekuur minder rendement toe. Naarmate de bedrijfsarts meer tijd ter beschikking heeft wordt door de ondernemingsraad aan het periodiek onderzoek minder rendement toegekend, en ook is er een marginaal significant negatief verband tussen de ervaring van de bedrijfsarts en het toekennen van rendement door de ondernemingsraad aan het periodiek onderzoek. Naarmate de bedrijfsarts minder lang voor het bedrijf werkzaam is, en naarmate de bedrijfsarts vaker overleg pleegt met de directie van het bedrijf, wordt aan het werkplekonderzoek meer rendement toegekend (tabel 9.6).

Tulbel 9.6. Rendemeat ven BGZ-kerntaken

\begin{tabular}{|c|c|c|c|c|}
\hline & rendemerk AK & rendement BGS & rendemen PGO & rendement WP \\
\hline $\begin{array}{l}\text { orvaring bodrijfsarts } \\
\text { overlos mot directio } \\
\text { ervaren apselnuimts } \\
\text { howchikharo tijd } \\
\text { prof. taakopvalting } \\
\text { curatiovo Lakopvatting }\end{array}$ & -.30 & $\begin{array}{r} \\
. .33 \\
-.34\end{array}$ & $\begin{array}{r}-.33 \\
-.49\end{array}$ & $\begin{array}{r}* .34 \\
* .39\end{array}$ \\
\hline
\end{tabular}

Aan het einde van paragraaf 9.3.2 kunnen, in samenhang met de in paragraaf 9.2 vermelde intercorrelaties, de volgende samenvattende opmerkingen worden gemaakt. 
Het maken van afspraken over rapportage is op te vatten als uiting van klantgerichtheid, het zich als professional toetsbaar willen opstellen. Het maakt overleg met de directie van het bedrijf minder nodig. Er is een samenhang tussen het maken van afspraken over rapportage en het registreren van werkplekgegevens op groepsniveau, alsook met het in gelijke mate rapporteren door de BGD aan directie en ondernemingsraad. Naarmate de bedrijfsarts langer voor het bedrijf werkzaam is worden de gegevens van het werkplekonderzoek minder vaak op groepsniveau geregistreerd (het lijkt erop dat de BGD volstaat met een eenmalige inventarisatie). Er kan ook sprake zijn van een meer gericht zijn op andere dan werkplekactviteiten, gezien de correlatie tussen ervaring van de bedrijfsarts en de grootte van het bedrijf en het laag zijn van het verzuim. Het lijkt erop dat het interactieproces tussen BGD en bedrijf in het voordeel van de klant wordt beslist: er kan immers worden vastgesteld dat de bedrijfsarts die langer voor het bedrijf werkzaam is een aantal kerntaken minder naar professionele wens kan uitvoeren. Opmerkelijk in dit verband is dat naarmate de bedrijfsarts meer speelruimte ervaart hij het spreekuur (toch) niet naar professionele wens kan uitvoeren. Dit zou erop kunnen duiden dat de BGD (pas) speelruimte krijgt als de BGD een actieve sociaal-medische begeleidingsrol speelt.

Een professionele taakopvatting gaat samen met het ervaren van een isolationistische opstelling van de BGD, ongevraagd advies wordt minder vaak uitgebracht, de BGD onderneemt naast haar kerntaken weinig extra activiteiten, aan het spreekuur wordt door de ondernemingsraad weinig rendement toegekend.

Opvallend is dat er geen samenhang is tussen de bedrijfsarts-variabelen en het bruikbaar vinden van de advisering door respectievelijk personeelszaken en ondernemingsraad. Opmerkelijk is dat er een verschil is tussen ondernemingsraad en personeelszaken met betrekking tot het verband tussen bruikbaarheid advisering en ondersteuning: bruikbaarheid bij personeelszaken gaat samen met het ervaren van weinig steun, terwijl bij ondernemingsraden het bruikbaar vinden van advisering wel samengaat met het ondervinden van steun. Deze discrepantie is mogelijk te verklaren door te stellen dat de BGD aan personeelszaken ondersteuning geeft als zij zich nadrukkelijk bezighoudt met sociaal-medische begeleiding, terwijl de (bruikbaarheid van de) advisering voor de ondernemingsraad vooral wordt afgemeten aan andere dan sociaal medische begeleidingsactiviteiten De rendementsbeoordeling lijkt niet op taakniveau bepaald te worden. Er is sprake van een algemeen rendementsoordeel, niet zozeer van een echte effectiviteitsbeoordeling. Rendement lijkt door de ondernemingsraad te worden gebruikt als een maat voor door de BGD geleverde inspanningen en een actieve opstelling. Vooral als de BGD activiteiten ontplooit op het gebied van periodiek of werkplekonderzoek, wordt dit door de ondernemingsraad als steun ervaren. Het rendement van het werkplekonderzoek neemt af naarmate de bedrijfsarts langer voor het bedrijf werkzaam is, het rendement neemt toe naarmate de BGD vaker overleg pleegt met de directie van het bedrijf (dit laatste hangt samen met het sneller contact opnemen met zieken). Het kan erop wijzen dat de bedrijfsarts in het overleg met de directie van het bedrijf de haalbaarheid van werkplekonderzoek (en de oplossing van de hieruit resulterende 
problematiek) tevoren toetst, en daarmee de effectiviteit van zijn handelen vergroot. Het meer tijd ter beschikking hebben van de bedrijfsarts wordt, gezien het negatieve verband met het rendement van het periodiek onderzoek, blijkbaar niet omgezet in activiteiten op dat gebied.

\subsubsection{Bedrijfsvariabelen en professionaliteit}

Achtereenvolgens zal in de paragrafen 9.3.3.1. tot en met 9.3.3.5 worden beschreven of, en $z 0$ ja welke invloed er bestaat tussen enerzijds bedrijfs-variabelen en anderzijds de reeds in paragraaf 9.3.2. genoemde aspecten van professionele kwaliteit: de werkwijze van de bedrijfsarts, het werkterrein van de BGD, de uitvoering van kerntaken naar professionele wens, de bruikbaarheid van advisering door de BGD voor ondernemingsraad en personeelszaken, en het rendement van de BGZkerntaken (aanstellingsonderzoek, spreekuur, periodiek onderzoek en werkplekonderzoek)

\subsubsection{De werkwijze van de bedrijfsarts}

Naarmate de BGD minder snel contact opneemt met zieke werknemers (een minder nadrukkelijke sociaal medische begeleiding) worden de gegevens van het werkplekonderzoek vaker op groepsniveau geregistreerd.

$\mathrm{Er}$ is een marginaal significant positief verband tussen het op groepsniveau registreren van gegevens van het periodiek onderzoek en de mate waarin fysiek belastende arbeidsomstandigheden voorkomen.

Een hoger verzuim in het bedrijf gaat samen met het vaker ongevraagd advies uitbrengen door de BGD (tabel 9.7).

Tebel 9.7. De werkwijze van de bedriffsarts

\begin{tabular}{llll}
\hline & registratie PGO & rogistratie WP & ongevrangd advies \\
\hline $\begin{array}{l}\text { snolhoid contact mot zieken } \\
\text { fysioke arbo } \\
\text { vorzuimhoogto }\end{array}$ & $\bullet .30$ & -.31 & \\
\hline
\end{tabular}

\subsubsection{Het werkterrein van de BGD}

Naarmate het bedrijf groter is wordt de BGD vaker ingeschakeld op algemeen beleidsterrein (tabel 9.8).

Opgemerkt kan worden dat er geen samenhang is tussen de mate waarin fysiek belastende arbeidsomstandigheden voorkomen en het werkterrein van de bedrijfsarts. 


\subsubsection{De (professionele) uitvoering van BGZ-kerntaken}

Naarmate er meer fysiek belastende arbeidsomstandigheden in het bedrijf voorkomen, des te meer kan de bedrijfsarts het periodiek onderzoek en werkplekonderzoek naar eigen wens uitvoeren. Er is een marginaal significant negatief verband tussen de bedrijfsgrootte en het kunnen uitvoeren van het spreekuur en werkplekonderzoek naar professionele wens (tabel 9.8).

\subsubsection{De bruikbaarheid van advisering}

Er is geen samenhang tussen bedrijfsvariabelen en het bruikbaar vinden door personeelszaken van de advisering door de BGD.

Naarmate er meer fysiek belastende arbeidsomstandigheden in het bedrijf aanwezig zijn, wordt de bruikbaarheid van de advisering door de ondernemingsraad (OR) minder bruikbaar gevonden (tabel 9.8).

\subsubsection{Het rendement van BGZ-kerntaken}

Naarmate het verzuim in het bedrijf hoger is, kent de ondernemingsraad aan het spreekuur en het periodiek onderzoek meer rendement toe (tabel 9.8).

Tabel 9.8. Het werkterrein van de BGD / De professionele taakuitvoering / De bruikbarheid van advisering / Het rendement van BGZ-kerntaken

\begin{tabular}{|c|c|c|c|c|c|c|c|}
\hline & $\begin{array}{l}\text { inschakelen } \\
\text { igemeon } \\
\text { beleid }\end{array}$ & $\begin{array}{l}\text { prof.uitvoe- } \\
\text { ring BGS }\end{array}$ & $\begin{array}{l}\text { prof.uitvoo- } \\
\text { ring PGO }\end{array}$ & $\begin{array}{l}\text { prof.uitvoe- } \\
\text { ring WP }\end{array}$ & $\begin{array}{l}\text { bnikbanr } \\
\text { dvies voor } \\
\text { OR }\end{array}$ & $\begin{array}{l}\text { rendement } \\
\text { BGS }\end{array}$ & $\begin{array}{l}\text { rendernont } \\
\text { PCO }\end{array}$ \\
\hline grootte bedrijf & $\cdots+.48$ & -.29 & & -.26 & & & \\
\hline $\begin{array}{l}\text { fysieke arbo } \\
\text { verzaimboogto }\end{array}$ & & $\cdot .28$ & $\cdots .50$ & $\because .33$ & $\ldots .51$ & $\cdots .46$ & $\cdots .35$ \\
\hline
\end{tabular}

Aan het einde van paragraaf 9.3.3 kunnen de volgende samenvattende opmerkingen worden gemaakt.

Naarmate de BGD sneller contact opneemt met zieken wordt door de bedrijfsarts vaker overleg gevoerd met de directie van het bedrijf, maar worden de gegevens van het werkplekonderzoek minder vaak op groepsniveau geregistreerd. Mogelijk is er een onderscheid in bedrijfsartsen die meer sociaal medische begeleiding gericht zijn en meer preventiegericht zijn.

Een hoog verzuim in het bedrijf gaat samen met een meer actieve opstelling van de BGD: er wordt vaker ongevraagd advies uitgebracht, het werkplekonderzoek kan meer naar professionele wens worden uitgevoerd, en het rendementsoordeel van de ondernemingsraad over de BGD is positief. Een hoog verzuim wordt dus blijkbaar niet geduid als een signaal van falend rendement.

Het werkterrein van de bedrijfsarts wordt, naast een negatieve invloed van een professionele taakopvatting, wat betreft de bedrijfsvariabelen alleen bepaald door de grootte van het bedrijf. Opmerkelijk is dat er geen samenhang is met de arbeidsom- 
standigheden in het bedrijf. Het zijn ook de grote bedrijven waar de BGD veel speelruimte heeft, waar bedrijfsartsen vaak langer al werkzaam zijn, en waar (in vergelijking met de kleine bedrijven) fysiek belastende arbeidsomstandigheden minder een rol spelen.

Het voorkomen van fysiek belastende arbeidsomstandigheden leidt tot een discrepantie in kwaliteitsbeleving door bedrijfsarts en klant: de bedrijfsarts vindt dat hij het periodiek onderzoek en werkplekonderzoek meer naar professionele wens kan uitvoeren, terwijl de ondernemingsraad de advisering van de BGD in dit geval minder vaak bruikbaar vindt.

\subsection{Bedrijfsarts- en bedrijfsvariabelen en hun invloed op klantgerichtheid}

\subsubsection{Inleiding}

In deze paragraaf worden de correlaties beschreven tussen de onafhankelijke variabelen en klantgerichtheid. Eerst zal worden ingegaan op de correlaties tussen bedrijfsarts variabelen en klantgerichtheid (paragraaf 9.4.2), hierna op de correlaties tussen bedrijfsvariabelen en klantgerichtheid (paragraaf 9.4.3).

\subsubsection{Bedrijfsarts-variabelen en klantgerichtheid}

Achtereenvolgens zal in de paragrafen 9.4.2.1. tot en met 9.4.2.5 worden beschreven of, en zo ja welke invloed er bestaat tussen enerzijds bedrijfsarts-variabelen en anderzijds de volgende aspecten van klantgerichte kwaliteit: ondersteuning door de BGD in de ogen van resp. personeelszaken en ondernemingsraad, de houding van de BGD, de ervaring van ondernemingsraad en werknemers met de uitvoering van een aantal BGZ-taken (aanstellingskeuring, periodiek onderzoek, sociaal-medische begeleiding, en het voldoende doen van de BGD), de samenwerking tussen BGD en bedrijf en de afstemming in taakuitvoering (op operationeel niveau) tussen bedrijfsarts en klant (ondernemingsraad en werknemers).

\subsubsection{De ondersteuning door de $B G D$}

Wanneer ervaren personeelszaken en ondernemingsraad steun van de BGD, wanneer ervaren zij dat de BGD cen bijdrage levert aan het sociaal beleid?

Een meer professionele taakopvatting van de bedrijfsarts gaat samen met een ervaren van minder steun van de BGD door de ondernemingsraad. Opmerkelijk is dat er geen samenhang is tussen het ervaren van steun door personeelszaken en de bedrijfsarts-variabelen (tabel 9.9). 


\subsubsection{De houding van de $B G D$}

Naarmate er sprake is van een meer professionele taakopvatting van de bedrijfsarts, wordt de houding van de BGD als niet klantvriendelijk ervaren. Er is een marginal significant positief verband tussen een klantgerichte takopvatting van de bedrijfsarts en het als klantvriendelijk ervaren van de opstelling van de BGD (tabel 9.9)

Tabel 9.9. Ondersteuning door de BGD. Houdin BGD

ondersteuning voor ondernemingsrued howkling BGD

\begin{tabular}{lcc}
\hline professionelo takkopvatting & -.42 & -.30 \\
klantgerichto cuakopvatting & & .28 \\
\hline
\end{tabular}

\subsubsection{Ervaring van de klant met de uitvoering van BGZ-taken}

In deze paragraaf komt de waardering van de klant (werknemer en ondernemingsraad) over het aanstellingsonderzoek, het periodiek onderzoek en de sociaal medische begeleiding aan de orde.

Een hogere waardering door werknemers van het aanstellingsonderzoek gaat samen met een meer klantgerichte taakopvatting van de bedrijfsarts.

Het periodiek onderzoek wordt vaker als prettig ervaren als de bedrijfsarts vaker overleg pleegt met de directie van het bedrijf, als hij vaker afspraken maakt over rapportage, en naarmate er sprake is van een minder klantgerichte taakopvatting (alle genoemde verbanden zijn overigens marginaal significant).

Naarmate de ondernemingsraad de sociaal-medische begeleiding meer als controle ervaart (verzuimcontrole OR), heeft de bedrijfsarts een meer curatieve taakopvatting, en (marginaal significant) overlegt de bedrijfsarts vaker met de directie van het bedrijf en ervaart hij meer speelruimte.

Naarmate de bedrijfsarts vaker met de directie van het bedrijf overlegt, en (marginaal significant verband) hij een minder professionele taakopvatting heeft, ervaren werknemers de sociaal-medische begeleiding door de BGD meer als controle (verzuimcontrole WN).

Het in de ogen van de ondernemingsraad voldoende doen van de BGD gaat samen met een minder vaak overleg plegen met de directie van het bedrijf en met een meer tijd ter beschikking hebben van de bedrijfsarts. Naarmate de ondernemingsraad vaker vindt dat de BGD voldoende doet, is de bedrijfsarts langer werkzaam voor het bedrijf, en heeft hij een minder professionele taakopvatting (beide verbanden zijn marginaal significant) (tabel 9.10). 
Tabel 9.10. Ervaring taakuitvoering

\begin{tabular}{|c|c|c|c|c|}
\hline & ervaring $A K$ ervaring $P G O$ & $\begin{array}{l}\text { verauimcondrole } \\
\text { OR }\end{array}$ & $\begin{array}{l}\text { verzuimcontrale } \\
\text { WN }\end{array}$ & voldoende doen \\
\hline klankg. Lakkopvatting & $\cdots .31$ & & & \\
\hline overleg met directio & $\begin{array}{l}.27 \\
+31\end{array}$ & $\cdot .31$ & $+\cdots .34$ &.- .35 \\
\hline $\begin{array}{l}\text { orvaring bedrijfaurt } \\
\text { orvaron apeolruimto }\end{array}$ & & $\star .32$ & & .30 \\
\hline beschilkbaro tijd & & & & $* .34$ \\
\hline $\begin{array}{l}\text { prof. tukopvatting } \\
\text { curatieve takkopvatting }\end{array}$ & & $\cdots .45$ & -.28 & .31 \\
\hline
\end{tabular}

\subsubsection{De samenwerking tussen $B G D$ en bedriff}

Een consistente samenwerking tussen BGD en klant kan worden opgevat als een van de aspecten van klantgerichte kwaliteit. Er wordt onderzocht of er een samenhang is in samenwerkingsverbanden tussen BGD enerzijds en bedrijfspartners (personeelszaken, ondernemingsraad, directie) anderzijds.

$\mathrm{Er}$ is alleen een significante samenhang tussen het maken van afspraken over rapportage en het ervaren van een consistente samenwerking tussen BGD en personeelszaken (samenwerking BGD-PZ).

Het als consistent ervaren van de samenwerking tussen BGD en directie (DIR) van het bedrijf gaat (marginaal significant) samen met de frequentie waarmee de BGD overleg voert met de directie van het bedrijf, met het ervaren door de bedrijfsarts van meer speelruimte, en met het minder tijd ter beschikking hebben van de bedrijfsarts.

Het als consistent ervaren van de samenwerking tussen BGD en ondernemingsraad (OR) heeft een marginaal significant negatief verband met de ervaring van de bedrijfsarts (tabel 9.11).

Tubel 9.11. Samenwerking BGD-bedrijf

\begin{tabular}{|c|c|c|c|}
\hline & $\begin{array}{l}\text { samenwerking BGD. } \\
\text { directio }\end{array}$ & samenwerking BGD-OR & samenwerking BGD-PZ \\
\hline $\begin{array}{l}\text { orvaring belrijfarts } \\
\text { overlog mot directio } \\
\text { afsprack rapportage } \\
\text { ervaren speelruinte } \\
\text { beechikhare tijd }\end{array}$ & $\begin{array}{l}.33 \\
. .34 \\
. .33\end{array}$ & -.28 & $\therefore 39$ \\
\hline
\end{tabular}

\subsubsection{De afstemming tussen klant en BGD m.b.t. taakuitvoering}

De klantgerichte kwaliteit van dienstverlening komt binnen de taakuitvoering van BGZ-activiteiten het meest tot uiting als deze taakuitvoering door de klant (in dit geval de ondernemingsnad en werknemers) wordt ervaren als afgestemd op haar wensen en verwachtingen. 
Misschien ten overvloede wordt er nog op gewezen, dat niet gekeken is naar het afgestemd zijn van de taak in zijn geheel op wensen en verwachtingen. Het gaat om het afgestemd zijn op het uitvoeringsniveau van taken. Het gaat erom of de BGZtaken, ervan uitgaande dat zij terecht worden ingezet, conform wensen van de klant worden geoperationaliseerd.

Een meer curatieve taakopvatting van de bedrijfsarts gaat samen met het meer naar wens van de ondernemingsraad uitvoeren van het annstellingsonderzoek. Eir is een marginaal significant negatief verband tussen een professionele taakopvatting en het naar wens uitvoeren van het aanstellingsonderzoek.

Het naar wens van de werknemers uitvoeren van het aanstellingsonderzoek gast slechts marginaal significant samen met de ervaring van de bedrijfsarts.

Het meer overleg plegen met de directie van het bedrijf gaat samen met het meer naar wens van de ondernemingsraad uitvoeren van het spreekwur. Het meer tijd ter beschikking hebben van de bedrijfsarts gaat samen met het gevoel bij ondernemingsraad dat het spreekuur minder naar hun wens wordt uitgevoerd. Eir is een marginaal significant positief verband tussen het naar wens van de ondernemingsraad uitvoeren van het spreekuur en de ervaring van de bedrijfsarts.

Het naar wens van werknemers uitvoeren van het spreekuur hangt samen met cen meer klantgerichte taakopvatting van de bedrijfsarts.

Het naar wens van de ondernemingsraad uitvoeren van het periodiek onderzoek gaat samen met het vaker maken van afspraken over rapportage. Er is een marginaal significant negatief verband tussen het naar wens van de ondernemingsraad uitvoeren van het periodiek onderzoek en een langere werkervaring van de bedrijfsarts. Taakopvatting van de bedrijfsarts in het algemeen (niet discriminerend) en het ervaren van meer speelruimte door de bedrijfsarts hangen (allen marginaal significant) samen met het meer naar wens van de ondernemingsraad uitvoeren van het periodiek onderzoek.

Het naar wens van de werknemers uitvoeren van het periodiek onderzoek gaat eveneens samen met het vaker maken van afspraken over rapportage door de BGD. Daarnaast echter ook met een meer klantgerichte en professionele taakopvatting.

Het naar wens van de ondernemingsraad uitvoeren van het werkplekonderzoek daarentegen hangt in negatieve zin samen met het maken van afspraken over rapportage.

Het naar wens van de werknemers uitvoeren van het werkplekonderzoek hangt samen met het ervaren van minder tijd door de bedrijfsarts. Daarnaast bestaan er marginaal significante negatieve verbanden met de bedrijfsarts-variabelen: het maken van afspraken over rapportage en een curatieve c.q. klantgerichte taakopvatting (tabel 9.12). 


\begin{tabular}{|c|c|c|c|c|c|c|c|c|}
\hline & \multicolumn{8}{|c|}{ afstemming } \\
\hline & $\begin{array}{l}\text { AK- } \\
\text { OR }\end{array}$ & $\begin{array}{l}\text { AK- } \\
\mathbf{W N}\end{array}$ & $\begin{array}{l}\text { BGS- } \\
\text { OR }\end{array}$ & $\begin{array}{l}\text { BGS- } \\
\text { WN }\end{array}$ & $\begin{array}{l}\text { PGO- } \\
\text { OR }\end{array}$ & $\begin{array}{l}\text { PGO- } \\
\text { WN }\end{array}$ & $\begin{array}{l}\text { WP- } \\
\text { OR }\end{array}$ & $\begin{array}{l}\text { WP- } \\
\text { WN }\end{array}$ \\
\hline $\begin{array}{l}\text { ervaring bedrijfarts } \\
\text { overleg mot directie }\end{array}$ & & .30 & $\begin{array}{r}. .28 \\
\cdots .43\end{array}$ & & -.33 & & & \\
\hline $\begin{array}{l}\text { afeprank rapportage } \\
\text { ervaren speeiruimte }\end{array}$ & & & & & $\begin{array}{r}* .35 \\
* .29\end{array}$ & +.36 & --.36 & -.28 \\
\hline bewchikbare tijd & & & --.37 & & & & & --.36 \\
\hline curat. taakopvatting & $\because .46$ & & & &. .30 & & & -.26 \\
\hline klantg. taakopvatting & & & & 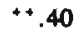 & $\cdot .28$ & $\cdots .53$ & & -.30 \\
\hline prof. taakopvatting & -.33 & & & & .30 & +.31 & & \\
\hline
\end{tabular}

Aan het einde van paragraaf 9.4.2 kunnen, in samenhang met de paragraaf 9.2 vermelde intercorrelaties, de volgende samenvattende opmerkingen worden gemaakt.

$\mathrm{Er}$ is geen samenhang bussen bedrijfsarts-variabelen en het ervaren van steun door personeelszaken. Het ervaren van steun door personeelszaken gaat samen met een meer klantvriendelijke opstelling door de BGD, maar tegelijkertijd ook met een zich meer autonoom opstellen door de BGD, hetgeen ten koste lijkt te gaan van de bruikbaarheid van advisering voor personeelszaken.

Het ervaren van steun door de ondernemingsraad hangt samen met een complex van andere aspecten van kwaliteit, die te maken hebben met werkwijze van de bedrijfsarts (gegevens van het periodiek onderzoek en werkplekonderzoek worden vaker op groepsniveau geregistreerd, de BGD adviseert vaker ongevraagd), werkterrein van de BGD (de BGD wordt vaker ingeschakeld op algemeen beleidsterrein, en de BGD onderneemt vaker extra activiteiten), en output van de BGD (de samenwerking tussen BGD en ondememingsraad wordt als meer consistent ervaren en aan de kerntaken kent de ondernemingsraad meer rendement toe). Een professionele taakopvatting van de bedrijfsarts gaat gepaard met het minder vaak ervaren van steun door de ondernemingsraad. Ook wordt in dat geval de houding van de BGD minder vaak als klantvriendelijk ervaren.

Er is cen samenhang tussen het ervaren van de sociaal medische begeleiding als controle door ondernemingsraad en werknemers. Ieder voor zich lijken ze echter door andere bedrijfsarts-variabelen te worden beïnvloed: het als controle ervaren van de sociaal medische begeleiding door de ondememingsraad gaat samen met een meer curatieve taakopvatting, terwijl het als controle ervaren van de sociaal medische begeleiding door werknemers samengaat met het vaker overleg plegen van de BGD met de directie van het bedrijf. Het lijkt er op dat het vaak overleggen met de directie uiting is van een meer nadrukkelijke sociaal-medische begeleidingsrol (o.a. gezien het verband met het sneller contact opnemen met zieken, en het in de ogen van de ondememingsraad niet voldoende doen door de BGD).

Een consistente samenwerking met personeelszaken gaat samen met het maken van afspraken over rapportage (een zichtbaar produkt en resultaat van BGZ-activiteiten).

Het maken van afspraken over rapportage gaat ook samen met het meer naar wens van ondernemingsraad en werknemers uitvoeren van het periodiek onderzoek, het gaat echter ook samen met het minder naar wens van werknemers uitvoeren van werkplek- 
onderzoek (een verklaring hiervoor zou kunnen zijn een discrepantie tussen verwachtingspatroon van de klant en realisatie in de praktijk).

Taakopvatting van de bedrijfsarts speelt een rol bij de mate waarin de taakuitvoering naar wens van werknemers plaatsvindt.

\subsubsection{Bedrijfsvariabelen en klantgerichtheid}

Achtereenvolgens $\mathrm{zal}$ in de paragrafen 9.4.3.1. tot en met 9.4.3.5 worden beschreven of, en zo ja welke invloed er bestaat tussen enerzijds bedrijfsvariabelen en anderzijds de in paragraaf 9.4.2 genoemde aspecten van klantgerichte kwaliteit.

\subsubsection{De ondersteuning door de BGD}

Het weinig voorkomen van fysiek belastende arteidsomstandigheden en een hoog verzuim gaan samen met cen gevoel bij de ondernemingsraad dat de BGD een onderstellnende rol speelt. Er is geen verband tussen bedrijfsvariabelen en de mate van ondersteuning in de ogen van personeelszaken (PZ) (tabel 9.13).

Twbel 9.13. Ondersteuning door BGD

\begin{tabular}{lcc}
\hline & ondersteuning voor OR & ondersteuning voor P2 \\
\hline $\begin{array}{l}\text { fysieke arbo } \\
\text { verzuimhoogle }\end{array}$ &.- .33 \\
\hline
\end{tabular}

\subsubsection{De houding van de BGD}

Er is geen samenhang tussen de bedrijfsvariabelen en de mate waarin personeelszaken de houding van de BGD als klantvriendelijk ervaart.

\subsubsection{Ervaring van de klant met de uitvoering van BGZ-taken}

Het omschrijven van de sociaal medische begeleiding door de ondememingsraad als controle gaat samen met een snel contact opnemen met zieken. Ook voor werknemers geldt dat het omschrijven van de sociaal medische begeleiding als controle samengaat met het snel contact opnemen met zieken door de BGD, maar ook met het groter zijn van het bedrijf.

Er zijn marginaal significante negatieve verbanden tussen het als prettig ervaren van het periodiek onderzoek en het voorkomen van fysiek belastende arbeidsomstandigheden en de hoogte van het verzuim.

Tot slot kan nog worden gewezen op een marginaal significant verband tussen het in de ogen van de ondernemingsraas voldoende doen door de BGD en in negatieve zin met het voorkomen van fysiek belastende arbeidsomstandigheden, en in positieve zin met de hoogte van het verzuim (tabel 9.14). 
Tabel 9.14. Ervaring Lankuitvoering

\begin{tabular}{|c|c|c|c|c|}
\hline & ervaring PGO & verzuimcontrole OR & verzuimcontrole $W N$ & voldoende doen \\
\hline grootle bedrijf & & & ++.35 & \\
\hline fysieke arbo & -.29 & & & -.29 \\
\hline verzuimhoogte & -.28 & & &. .26 \\
\hline contact zieken & & +4.36 & +.40 & \\
\hline
\end{tabular}

\subsubsection{De samenwerking tussen $B G D$ en bedrijf}

Het door de ondernemingsraad als consistent karakteriseren van de samenwerking tussen BGD en directie (DIR) gaat samen met het snel contact opnemen door de BGD met zieken. Een hoger verzuim gaat samen met een meer consistente samenwerking tussen BGD en ondernemingsraad (OR).

Naarmate het bedrijf kleiner is en de BGD sneller contact opneemt met zieken, wordt de samenwerking tussen personeelszaken (PZ) en BGD als consistenter ervaren. Beide verbanden zijn marginaal significant (tabel 9.15).

Tabel 9.15. Sumenwerking BGDbedrijf

\begin{tabular}{llll}
\hline & ammenwerking BGD-DIR & samenwerking BGD-PZ & samenwerking BGD-OR \\
\hline $\begin{array}{l}\text { grootte bedrijf } \\
\text { verzuimhoogle } \\
\text { contact zieken }\end{array}$ &. .31 & +.34 \\
\hline
\end{tabular}

\subsubsection{De afstemming tussen klant en BGD m.b.t. Laakuitvoering}

Als het verzuim laag is wordt het spreekuur vaker naar wens van de ondernemingsraad uitgevoerd.

In grotere bedrijven wordt het spreekuur meer naar wens van werknemers uitgevoerd (marginaal significant verband).

Naarmate er meer fysiek belastende arbeidsomstandigheden voorkomen in het bedrijf wordt het periodiek onderzoek vaker naar wens van de ondernemingsraad uitgevoerd. In kleinere bedrijven, en als er niet snel contact wordt opgenomen met zieken, wordt het periodiek onderzoek vaker naar wens van de werknemers uitgevoerd.

Het naar wens van de ondernemingsraad uitvoeren van het werkplekonderzoek gaat samen met het sneller contact opnemen met zieken (legitimeringsgrond?).

In kleine bedrijven, en naarmate er meer fysiek belastende arbeidsomstandigheden voorkomen, wordt het periodiek onderzoek vaker naar wens van de werknemers uitgevoerd (beide verbanden zijn marginaal significant) (tabel 9.16). 
Tubel 9.16. Afstemming taakuitvoering.

\begin{tabular}{|c|c|c|c|c|c|c|}
\hline & $\begin{array}{l}\text { afstemming } \\
\text { BOS-OR }\end{array}$ & $\begin{array}{l}\text { afstemming } \\
\text { BGS-WN }\end{array}$ & $\begin{array}{l}\text { afstemming } \\
\text { PGO-OR }\end{array}$ & $\begin{array}{l}\text { afstemming } \\
\text { PGO-WIN }\end{array}$ & $\begin{array}{l}\text { ufstemming } \\
\text { WP-OR }\end{array}$ & $\begin{array}{l}\text { afstemming } \\
\text { WP-WN }\end{array}$ \\
\hline grookte bedrijf & .31 & .24 & & -.30 & & -.25 \\
\hline $\begin{array}{l}\text { fysieke arbo } \\
\text { vernuimboogte }\end{array}$ & -.43 & & $\because .36$ & -38 & $\therefore .40$ & $\because .29$ \\
\hline
\end{tabular}

Aan het einde van paragraaf 9.4.3. kunnen, in samenhang met de in paragraal 9.2 vermelde intercorrelaties, de volgende samenvattende opmerkingen worden gemaakt.

$\mathrm{Er}$ is geen verband tussen bedrijfsvariabelen en het ervaren van steun door personeels= zaken.

Het ervaren van steun door de ondernemingsraad gaat samen met een hoog verzuim (gezamenlijk punt van aandacht voor ondememingsraad en BGD). Daarentegen ervaart de ondernemingsraad minder steun naarmate er meer fysiek belastende arbeidsomstandigheden voorkomen in het bedrijf. Dit wijst in elk geval op een duidelijke discrepantie ussen verwachting en realiteit.

Het door de ondernemingsraad en werknemers ervaren van de sociaal-medische begeleiding als controle, gaat samen met een snel contact opnemen met zieken, dus met een zichtbaar actieve sociaal-medische begeleidingsrol. Daamaast wordt sociaal medische begeleiding door werknemers in grote bedrijven vaker als controle ervaren.

Een goede samenwerkingsrelatie tussen BGD en directie van het bedrijf gaat sannen met het snel contact opnemen met zieken, een goede samenwerking tussen BGD en ondernemingsraad gaat samen met een hoog verzuim in het bedrijf. Ondernemingsraad en BGD hebben dan mogelijk een onomstreden gezamenlijk aandachtspunt.

De samenhang tussen het naar wens van de klant uitvoeren van de kerntaken en bedrijfsvariabelen laat geen eenduidig beeld zien.

\subsection{BGD-organisatievorm en kwaliteit van BGZ}

\subsubsection{Inleiding}

Reeds een aantal malen is erop gewezen dat GD en EVD wezenlijk van elkaar verschillen in positie in en ten opzichte van het bedrijf. EVD'en hebben een positie die vergelijkbaar is met die van een intern organisatieadviseur. Het verwachtingspatroon zal dan ook verschillen. In hoofdstuk 7 en 8 is een aantal verschillen tussen GD en EVD beschreven. In deze paragraaf wordt ingegaan op twee duidelijke verschilpunten tussen GD en EVD, namelijk de grootte van het te verzorgen bedrijf en het verzuim (hoogte van het verzuim en de snelheid waarmee de BGD contact opneemt met zieken). Er wordt onderzocht of deze verschillen tussen GD en EVD van invloed zijn op de samenhang tussen bedrijfsarts- en bedrijfsvariabelen enerzijds en professionaliteil en klantgerichtheid anderzijds. Tevens is op basis van bestudering van de correlatiematrix een selectie gemaakt van opmerkelijke bevindingen c.q. verschillen ussen GD en EVD in samenhang tussen onafhankelijke variabelen en kwaliteit. Het betreft dan de bedrijfsarts-variabelen ervaring en taakopvatting. 
In de paragrafen 9.5.2 tot en met 9.5.5 zal achtereenvolgens worden ingegaan op verschillen tussen GD en EVD m.b.t. de samenhang tussen enerzijds bedrijfsgrootte, verzuim, ervaring van de bedrijfsarts en taakopvatting van de bedrijfsarts met anderzijds professionaliteit en klantgerichtheid.

Misschien ten overvloede wordt er nogmaals op gewezen dat, gegeven de beperkte omvang van de onderzochte groep, kritisch gekeken moet worden naar eventuele verschillen tussen GD en EVD. Om te onderzoeken of het verschil tussen de correlatiecoefficiènten van variabelen in resp. GD- en EVD-bedrijven statistisch significant is, is gebruik gemaakt van de z-toets voor twee correlatiecoefficiënten (tweezijdig getoetst, alpha <.05).

\subsubsection{Bedrijfsgrootte en kwaliteit: GD en EVD}

Tussen GD en EVD bestaat een significant verschil in samenhang tussen bedrijfsgrootte en het gevoel van controle bij werknemers van de uitvoering van de sociaalmedische begeleiding. In EVD-bedrijven gaat het ervaren van de sociaal medische begeleiding door werknemers als controle samen met het kleiner zijn van het bedrijf, terwijl bij GD-bedrijven er een samenhang is met het groter zijn van het bedrijf (tabel 9.17).

Tabel 9.17. Bedrifsgrootte en kwaliteit: GD versus EVD

\begin{tabular}{|c|c|c|c|}
\hline & & vern & \\
\hline & GD & & EVD \\
\hline grootto bedrijf & $\begin{array}{ll} & * .40 \\
\mathrm{~N}= & (18) \\
\mathrm{u}= & \end{array}$ & $2.10^{*}$ & $\begin{array}{r}-.43 \\
(11)\end{array}$ \\
\hline
\end{tabular}

$u=\mathrm{z}$-score correlntiecoëfficiënten; $*=\mathrm{p}<.05$

Er lijkt sprake van een interactie tussen bedrijfsgrootte en het ervaren van verzuimbegeleiding als controle door werknemers.

\subsubsection{Verzuim en kwaliteit: GD en EVD}

Tussen GD en EVD bestaan significante verschillen in samenhang tussen de hoogte van het verzuim en de volgende kwaliteitsaspecten: het door werknemers als prettig ervaren van de uitvoering van het aanstellingsonderzoek en het periodiek onderzoek, en het in de ogen van de ondernemingsraad voldoende ondernemen door de BGD van extra activiteiten.

Daamaast bestaan tussen GD en EVD significante verschillen in de samenhang tussen de snelheid waarmee de BGD contact heeft met zieke werknemers en de kwaliteitsaspecten: het ervaren van steun van de BGD door personeelszaken (PZ), het door de ondernemingsraad ervaren van de sociaal-medische begeleiding als controle, en de samenwerking tussen BGD en ondernemingsraad (OR) (tabel 9.18). 
Thel 9.18. Veruin en Imaliteit: GD versus EVD

\begin{tabular}{|c|c|c|c|c|c|c|c|c|c|c|}
\hline & \multicolumn{2}{|c|}{ ervaring AK } & \multicolumn{2}{|c|}{ ervaring PGO } & \multicolumn{2}{|c|}{ voldoende doen } & \multicolumn{2}{|c|}{ exIn activiteiten } & \multicolumn{2}{|c|}{$\begin{array}{l}\text { verzuimeontrole } \\
\text { WN }\end{array}$} \\
\hline & GD & EVD & GD & EVD & GD & EVD & GD & EVD & GD & EVD \\
\hline $\begin{array}{r}\text { verzuimhoogte } \\
\mathrm{N}= \\
\mathrm{u}=\end{array}$ & $\begin{array}{l}.13 \\
(21)\end{array}$ & $\begin{array}{l}-6 \\
(10)\end{array}$ & $\begin{array}{l}(-) .17 \\
(17)\end{array}$ & $\begin{array}{l}-91 \\
(9)\end{array}$ & $\begin{array}{l}0.49 \\
(19)\end{array}$ & $\begin{array}{l}(-) .45 \\
(9)\end{array}$ & $(14)$ & $\begin{array}{l}(-1) \cdot 41 \\
(7)\end{array}$ & $\begin{array}{l}.05 \\
\text { (18) }\end{array}$ & $\begin{array}{l}\cdots 58 \\
(9)\end{array}$ \\
\hline
\end{tabular}

\begin{tabular}{|c|c|c|c|c|c|c|}
\hline & \multicolumn{2}{|c|}{ ondersteuning BGD voer PZ } & \multicolumn{2}{|c|}{ verzuimeuntrok OR } & \multicolumn{2}{|c|}{ amenwerking BGD-OR } \\
\hline & GD & EVD & GD & EVD & GD & EVD \\
\hline conted zicken $\begin{aligned} N & = \\
U & =\end{aligned}$ & $\begin{array}{l}* 38 \\
(21)\end{array}$ & $\begin{array}{l}.55 \\
(9)\end{array}$ & $\begin{array}{l}(-) .25 \\
(16)\end{array}$ & $\begin{array}{l}\cdots 69 \\
(9)\end{array}$ & $\begin{array}{l}.24 \\
(16) !\end{array}$ & $\begin{array}{l}-.69 \\
(9)\end{array}$ \\
\hline
\end{tabular}

u $=\mathrm{z}$-scoire tussen correlatiocoēfficiērnen: $* \mathrm{p}<.05$

(-) botekent cen negatief vertand, $p>.10$

In GD-bedrijven gaat een hoger verzuim samen met het vaker in de ogen van de ondernemingsraad voldoende doen door de BGD, terwijl in EVD-bedrijven hiertussen geen significant verband is, al is de richting van het verband wel omgekeerd. Deze tegenstelling geldt ook voor de samenhang tussen verzuimhoogte en het ondernemen van extra activiteiten door de BGD. Het verschil tussen GD- en EVDbedrijven is in het laatste geval marginaal significant.

In GD-bedrijven is er geen verband tussen de verzuimhoogte en het door de werknemers als prettig ervaren van het aanstellingsonderzoek en het periodiek onderzoek, terwijl in EVD-bedrijven een hoger verzuim samengaat met het door de werknemers als niet prettig ervaren van de uitvoering van het aanstellingsonderzoek en het periodiek onderzoek. In EVD-bedrijven ervaren werknemers de verzuimbegeleiding van de BGD meer als controle naarmate het verzuim hoger is.

Het sneller contact opnemen met zieken gaat in GD-bedrijven samen met het ervaren van meer steun door personeelszaken, terwijl in EVD-bedrijven het sneller contact opnemen met zieken (marginaal significant) samengaat met het ervaren van minder steun door personeelszaken. Tevens gaat in EVD-bedrijven het sneller contact opnemen met zieken samen met het door de ondernemingsraad vaker ervaren van de verzuimbegeleiding als controle en met een minder goede samenwerking tussen BGD en ondernemingsraad. In GD-bedrijven is er geen significante samenhang tussen de snelheid van het contact opnemen met zieken en resp. het ervaren door de ondernemingsraad van de sociaal medische begeleiding als controle en de samenwerking tussen BGD en ondernemingsraad.

Alvorens de geconstateerde verschillen te bespreken, is nadere bestudering van de intercorrelaties van de afhankelijke variabelen per BGD-organisatievorm noodzakelijk (tabel 9.19). 
In GD-bedrijven gaat het als controle ervaren van de sociaal-medische begeleiding samen met de werkwijze en het werkterrein van de BGD: groepsregistratie en ingeschakeld worden op algemeen beleidsterrein. Als de ondernemingsraad de sociaal medische begeleiding als controle ervaart, vindt de bedrijfsarts vaker dat hij zijn spreekuur niet naar professionele wens kan uitvoeren. Het lijkt erop dat de GD-bedrijfsarts geen nadrukkelijke c.q. controlerende sociaal-medische begeleidingsrol wenst te vervullen. In EVD-bedrijven worden deze verbanden niet gevonden. Het ervaren van de verzuimbegeleiding als controle staat in EVD-bedrijven veel minder op zichzelf, en gaat samen met een negatieve beoordeling van een aantal andere kwaliteitsaspecten, zoals: het minder vaak ondernemen van extra activiteiten door de BGD, het minder bruikbaar vinden van de advisering van de BGD door de ondernemingsraad (N.B. overigens vindt personeelszaken de advisering wel bruikbaar als de sociaal medische begeleiding door de ondernemingsraad als controle wordt ervaren), en een minder consistente samenwerking tussen BGD en ondernemingsraad.

Tabel 9.19. Correlaties tussen bet ervaren van de verzuimbegeleiding als controle en de bruikhaarheid van advisering van de BGD voor personeelszaken met andere afhankelijke variabelen per BGD-orzanisathevorm

\begin{tabular}{|c|c|c|c|c|c|}
\hline & \multicolumn{2}{|c|}{ GD } & \multirow[b]{2}{*}{$\mathbf{u}$} & \multicolumn{2}{|c|}{ EVD } \\
\hline & $\mathbf{R}$ & $\mathbf{N}$ & & $\mathbf{R}$ & $\mathbf{N}$ \\
\hline \multicolumn{6}{|c|}{ Ondememingsrand orvant verzuimbegeleiding ala controle: } \\
\hline - registratio periodiek onderzoek & $\cdots .54$ & $(15)$ & $2.12 *$ & $(-) .48$ & (8) \\
\hline - bruikbar alviea voor personoelszaken & .00 & (18) & 1.64 & $\because .69$ & (8) \\
\hline - bruikbaur alvies voor onlernerningsraad & -.31 & (14) & 0.87 & -.66 & (8) \\
\hline - extra activiteiten & .38 & (13) & $2.74 *$ & --.80 & (8) \\
\hline - samenwerking BGD-OR & .17 & (18) & $6.16^{*}$ & -0.99 & (10) \\
\hline - prof. uitveering BGS & -.79 & $(16)$ & $3.15^{*}$ & .45 & (9) \\
\hline \multicolumn{6}{|c|}{ Werknemers orvaren verzuimbegeleiding als controle: } \\
\hline - rogistratio workplekonderzoek & $\cdots .54$ & (16) & $2.08 *$ & $(-) .40$ & (9) \\
\hline - inschakelen BGD bij algemeen beleid & $\cdots .42$ & $(17)$ & 0.23 & .33 & (10) \\
\hline - ongovragd alvies BGD & .20 & $(17)$ & 1.66 & $\cdots .75$ & (10) \\
\hline \multicolumn{6}{|c|}{ Bruikhear dvies van do BGD voor personeelszaken: } \\
\hline - extra activiteiten & .12 & (13) & 1.80 & -.70 & (8) \\
\hline - bnikhaar alvies voor ondernemingsmad & $(-) .10$ & (14) & 1.57 & -.81 & (6) \\
\hline - ondersteuning voor porsoneolszaken & $-\ldots .69$ & (24) & 0.26 & -.63 & (ii) \\
\hline - (klentvriendelijke) houding & $(-) .15$ & (24) & 1.50 & -.65 & (11) \\
\hline - verzuimcontrolo OR & .00 & (18) & 1.64 & $\because .69$ & (B) \\
\hline - anmenwerking BGD-OR & .25 & (18) & $2.14^{*}$ & -.69 & (8) \\
\hline
\end{tabular}

$\mathbf{R}=$ corrolatiecoêfficiënt;

$\mathrm{u}=\mathrm{z}$-scom tussen corrolatiocoöfficiênten: $*$ significant bij $\mathrm{p}<$.0S

( - ) botokent een negatief vortwand, echter $p>.10$

In EVD-bedrijven is er sprake van een tegenstelling tussen personeelszaken en ondernemingsraad ten aanzien van het bruikbaar vinden van de advisering van de BGD. Naarmate personeelszaken de advisering van de BGD meer bruikbaar vindt, vindt de ondernemingsraad de advisering minder bruikbaar. Wat de een als bruik- 
bare advisering ervaart, wordt door de ander als niet bruikbaar ervaren. Dit maakt voor de BGD het uitbrengen van bruikbare advisering voor de klant, zijnde beide partijen, wel erg moeilijk. Ook gaat het meer bruikbaar vinden van de advisering door personeelszaken samen met het minder ondernemen van extra activiteiten door de BGD, met het vaker als niet klantvriendelijk karakteriseren van de houding van de BGD, met een minder goede samenwerking tussen BGD en ondernemingsraad, met het vaker door de ondernemingsraad als controle ervaren van de social medische begeleiding, en met het ervaren van minder steun van de BGD door personeelszaken. In GD-bedrijven wordt alleen het laatste verband gevonden.

De in deze paragraaf besproken verschillen tussen GD en EVD kunnen worden teruggevoerd op een verschil in verwachtingspatroon van de BGD en ten opzichte van de BGD. In GD-bedrijven wenst de bedrijfsarts geen nadrukkelijke sociaal-medische begeleidingsrol. Zolang hij de positie van extern adviseur kan blijven bekleden. wordt sociaal medische begeleiding door de klant niet als controle ervaren. Naarmate de BGD vaker ongevraagd advies uitbrengt, is de ondernemingsraad vaker van mening dat de BGD voldoende doet. Wordt de bedrijfsarts tezeer betrokken bij het algemeen beleid van de onderneming en vindt er veel registratie van groepsgegevens plaats, dan wordt de positic van de bedrijfsarts in de ogen van ondernemingsraad en werknemers blijkbaar meer als bedrijfspartner en daarmee als minder onafhankelijk ervaren, en leidt dit tot een gevoel van controle in de vitvoering van de sociaal medische begeleiding. Een hoog verzuim vormt in GD-bedrijven blijkbaar een legitimeringsgrond voor de BGD om extra activiteiten te ontplooien naast haar kerntaken. Mogelijk vormt een hoog verzuim een onomstreden gemeenschappelijk aandachtspunt tussen BGD en bedrijf, en worden "alle" inspanningen van de BGD gewaardeerd. Het valt op dat de hoogte van het verzuim niet direct samenhangt met het al dan niet ervaren van de verzuimbegeleiding als controle door de ondernemingsraad.

In EVD-bedrijven komt de BGD daarentegen pas toe aan extra activiteiten wanneer zij zichtbaar resultaat heeft bereikt met sociaal medische begeleiding, in de vorm van een laag verzuim. Een hoog verzuim zet andere activiteiten in EVD-bedrijven verder onder druk en gaat gepaard met een negatief imago van de bedrijfspartners. Er is wel een samenhang tussen hoogte van het verzuim en het door werknemers ervaren als controle van de sociaal medische begeleiding in EVD-bedrijven. Werknemers in EVD-bedrijven lijken de hoogte van het verzuim te beschouwen als graadmeter voor speelruimte van de BGD. Bij een laag verzuim kan de BGD wel door werknemers gewenste activiteiten ontplooien zoals periodiek onderzoek. Is het verzuim hoog, dan ervaren werknemers sociaal medische begeleiding als centrole. Opmerkelijk is ook dat naarmate de bedrijfsarts vaker ongevraagd advies uitbrengt (bij GD-bedrijven positief gewaardeerd) de werknemers sociaal medische begelejding vaker als controle ervaren.

Er kan dan ook worden geconcludeerd dat niet alleen de feitelijke, maar ook de door de klant ingeschatte positie van de BGD van invloed is op de wijze: waarop tegen de taakuitvoering in het algemeen en sociaal medische begeleiding in het bij- 
zonder wordt gekeken. Zo kan het dat in GD-bedrijven een hoog verzuim in het bedrijf een positieve uitstraling heeft op de activiteiten van de BGD en de kwaliteitsbeleving van de klant, terwijl in EVD-bedrijven een hoog verzuim wordt ervaren als een tekortschieten van de BGD in haar hoofdtaak (sociaal medische begeleiding).

\subsubsection{Ervaring van de bedrijfsarts en kwaliteit: GD en EVD}

De verwachting is dat bedrijfsartsen naarmate zij langer voor een bedrijf werkzaam zijn, er beter in slagen BGZ meer afgestemd op de wensen van de klant te leveren. Met andere woorden, er mag worden verwacht dat er een positief verband is tussen ervaring en klantgerichte aspecten van kwaliteit.

Dit verband is in zekere mate wel aanwezig in EVD-bedrijven, echter niet in GDbedrijven.

Er is een negatief (niet significant) verband tussen ervaring van de bedrijfsarts en het in de ogen van de ondernemingsraad voldoende doen door de BGD in GD-bedrijven, terwijl in EVD-bedrijven er een significant positief verband is tussen werkervaring en het volgens de ondernemingsraad voldoende ondernemen van extra activiteiten door de BGD. Ook voert de EVD-bedrijfsarts die langer werkzaam is, het aanstellingsonderzoek meer naar wens van ondernemingsraad en werknemers uit, terwijl in GD-bedrijven een grotere ervaring in het bedrijf samengaat met het minder naar wens van werknemers uitvoeren van het aanstellingsonderzoek (tabel 9.20).

Trbel 9.20. Ervering bedrlfiserts en kwalleit: GD versus EVD

\begin{tabular}{|c|c|c|c|c|c|c|}
\hline & \multicolumn{2}{|c|}{ voldoende doen } & \multicolumn{2}{|c|}{ aftemming AK-OR } & \multicolumn{2}{|c|}{ afstemming AK-WN } \\
\hline & GD & EVD & GD & EVD & GD & EVD \\
\hline $\begin{array}{l}\text { ervaring } \\
\text { bedrijfearts } \mathrm{N}= \\
\mathrm{u}=\end{array}$ & $\begin{array}{c}(-) .26 \\
(17)\end{array}$ & $\begin{array}{c}\cdots .84 \\
(9)\end{array}$ & $\begin{array}{l}(-) .42 \\
(11)\end{array}$ & $\stackrel{+.66}{(8)}$ & $\begin{array}{c}-.66 \\
(16)\end{array}$ & $\begin{array}{c}\cdots .62 \\
(9)\end{array}$ \\
\hline
\end{tabular}

$\mathrm{u}=\mathrm{z}$-acoro hussen correlatiocob̈ficiēnt; $*$ significant bij p $<.05$

( - ) betekent negatief verthud, $p>.10$

Voor een verklaring van de geconstateerde verschillen is nadere bestudering van de intercorrelaties van de afhankelijke variabelen per BGD-organisatievorm noodzakelijk (tabel 9.21).

In GD-bedrijven gaat het in de ogen van de ondernemingsraad voldoende ondernemen van extra activiteiten door de BGD samen met het vaker uitbrengen van ongevraagd advies door de BGD, maar ook met een in de ogen van de ondernemingsraad minder consistente samenwerking tussen BGD en directie van het bedrijf. In EVD-bedrijven bestaat deze samenhang niet. In EVD-bedrijven gaat het in de ogen van de ondernemingsraad voldoende doen samen met het minder naar eigen wens van de bedrijfsarts zelf kunnen uitvoeren van het periodiek onderzoek en werkplekonderzoek. 
In GD-bedrijven vormt het naar wens van de ondernemingsraad uitvoeren van het aanstellingsonderzoek (afstemming AK-OR) cen onderdeel van een cluster van positieve cordelen over de ervaren kwaliteit, terwijl in EVD-bedrijven het naar wens van de ondernemingsraad uitvoeren van het aanstellingsonderzoek samengaat met cen aantal negatieve cordelen over kwaliteitsaspecten.

Uit deze tegenstelling tussen GD en EVD lijkt een wat grotere autonomie, een meer vasthouden aan de professionaliteit van de GD-bedrijfsarts te spreken. Het lijkt erop dat de EVD-arts ervaring omzet in een opstelling, warbij het bedrijfsbelang meer voorop komt te staan. De nadruk komt te liggen op sociaal medische begeleiding en selectie.

Tubd 9.21. Correbties tussen de variabelen "voldoende extre BGD-ctiviteilen", ea "ulvoerias van Lat aanstellingsonderzoek mar mess van ondernemingsrand ea werknemers" met andere afhankelijke varlabelen per BGD-organisatievora

\begin{tabular}{|c|c|c|c|c|c|}
\hline & \multicolumn{2}{|c|}{ GD } & \multirow[b]{2}{*}{$\mathbf{u}$} & \multicolumn{2}{|c|}{ EVD } \\
\hline & $\mathbf{R}$ & $\mathbf{N}$ & & $\mathbf{R}$ & $\mathbf{N}$ \\
\hline \multicolumn{6}{|c|}{ BGD ondernoemt voldoende oxtrn sctiviteiten: } \\
\hline - prof. uitvoening PGO & $(-) .35$ & $(15)$ & 1.27 & -75 & (9) \\
\hline - prof. uirvoering WP & $(-) .04$ & (17) & 1.50 & -.65 & (9) \\
\hline - ongevrangd advies door BGD & $* .42$ & $(19)$ & $1.95^{*}$ & $(-) .45$ & (9) \\
\hline - sumenwerking BGD-directio &.- .44 & $(17)$ & 1.90 & .39 & (10) \\
\hline \multicolumn{6}{|l|}{ Afstemming AK-OR: } \\
\hline - (kluntvriendelijke) houding & $(-) .04$ & $(11)$ & 1.86 & -.80 & (6) \\
\hline - veraimcontrole OR & -.49 & $(10)$ & $2.18 *$ & $* .63$ & (8) \\
\hline - rendement PGO & -.61 & (11) & $2.67^{*}$ & $* .67$ & (8) \\
\hline - samenwerking BOD-OR & $\cdots .80$ & $(10)$ & $3.14^{*}$ & -.63 & (8) \\
\hline - onderstcuning voor OR & $* .58$ & (11) & $2.17^{*}$ & -.52 & (8) \\
\hline - ervaring $\mathbf{A K}$ & $* .62$ & $(10)$ & 1.71 & $(-) .27$ & (8) \\
\hline $\begin{array}{l}\text { Afstomming } \mathbf{A K}-\mathbf{W N} \text { : } \\
\text { - ervering } \mathbf{A K}\end{array}$ & $\cdots .60$ & (15) & 2.12 & $(-) .35$ & (9) \\
\hline
\end{tabular}

$\mathbf{R}=$ correlatiecoëfficiënt;

$\mathrm{u}=\mathrm{z}$-score tussen correlatiecoëfficiènten; $*$ sienifican bij $\mathrm{p}<.05$

$(-)$ beteken negatief vertand, $p>.10$

\subsubsection{Taakopvatting van de bedrijfsarts en kwaliteit: GD versus EVD}

In hoofdstuk 7 is besproken dat bedrijfsartsen naar taakopvatting kunnen worden onderscheiden in drie categorieën: bedrijfsartsen met een professionele, met een curatieve en met een klantgerichte taakopvatting. Er was geen verband aantoonbaar tussen taakopvatting en BGD-organisatievorm.

In deze paragraaf wordt onderzocht of de invloed van taakopvatting op aspecten van kwaliteit verschillend is voor resp. GD en EVD (tabel 9.22). 
Er kan geen statistisch significant verschil tussen GD en EVD worden aangetoond met betrekking tot correlatiecoëfficiënten tussen een professionele of klantgerichte taakopvatting en kwaliteitsaspecten.

Ten aanzien van de correlaties tussen een curatieve taakopvatting en kwaliteitsaspecten, is er wel sprake van een aantal (significante) verschillen tussen GD en EVD. In EVD-bedrijven gaat een meer curatieve taakopvatting van de bedrijfsarts samen met het minder vaak ondernemen van extra activiteiten door de BGD, met een minder goede samenwerking tussen BGD en ondernemingsraad, met een minder vaak registreren van werkplekgegevens op groepsniveau, met een meer naar professionele wens uitvoeren van het spreekuur, met een meer naar wens van de ondernemingsraad uitvoeren van het werkplekonderzoek. Ook zijn er, in vergelijking met de GD-bedrijven niet significant verschillende, verbanden tussen een curatieve taakopvatting en het voor personeelszaken meer bruikbaar vinden van de advisering van de $B G D$ en het vaker door de ondernemingsraad ervaren van verzuimbegeleiding als controle.

In GD-bedrijven gaat een meer curatieve taakopvatting samen met het meer bruikbaar vinden van de advisering van de BGD door de ondernemingsraad, en met het ervaren van meer steun van de BGD door de ondernemingsraad (tabel 9.22).

Tahel 9.22. Curaleve tankopvatting bedrijfsarts en kwaliteit: GD versus EVD

\begin{tabular}{|c|c|c|c|c|c|c|c|c|c|c|c|c|}
\hline \multicolumn{3}{|c|}{1} & \multicolumn{2}{|c|}{12} & \multicolumn{2}{|c|}{13} & 14 & 15 & \multirow{2}{*}{$\begin{array}{c}6 \\
\text { GD EV } \\
\text { D }\end{array}$} & 17 & \multirow{2}{*}{$\frac{18}{\text { GD EVD }}$} & \multirow{2}{*}{$\frac{\| 9}{G D \text { EVD }}$} \\
\hline & GD & EVD & $G D$ & EVD & GD & EVD & GD EVD & GD EVD & & GD EVD & & \\
\hline$S=$ & .11 & $\begin{array}{l}.81 \\
-- \\
\end{array}$ & .32 & $\begin{array}{c}.78 \\
- \\
\end{array}$ & $\dddot{0}^{34}$ & $\begin{array}{l}.62 \\
- \\
\end{array}$ & $\begin{array}{ll}.09 & .68 \\
(\cdot) & \cdots \\
\end{array}$ & $\begin{array}{ll}.48 & 60 \\
- & \because \\
\end{array}$ & $\begin{array}{ll}.03 & .63 \\
(-) & \ddots \\
\end{array}$ & \begin{tabular}{ll}
.08 & .78 \\
\hdashline..
\end{tabular} & $\begin{array}{ll}.62 & .57 \\
* & - \\
\end{array}$ & $\begin{array}{ll}.68 & .33 \\
\cdots & (-) \\
\end{array}$ \\
\hline$N=$ & (12) & (7) & (15) & (9) & (22) & (13) & (2I) (II) & (14) $(9)$ & $(20)(9)$ & (15) (9) & (11) (9) & (15) (9) \\
\hline $\mathrm{u}=$ & & $.06 *$ & & $75 *$ & & $76 *$ & $2.16^{*}$ & $2.40^{*}$ & 1.62 & 1.93 & $2.54^{*}$ & $2.34^{*}$ \\
\hline
\end{tabular}

$S=$ sterkto on richting significantio; $\mathbf{u}=\mathbf{z}$-score hussen correlatiecoefficiênten

" = significant bij p <.05

(-) betekent oon nogatief verhand, $\mathrm{p}>.10$

Id cijfern hobben de volgende betekeais:

1. ondernemen van oxtra wctiviteiten

2. amenwerking BGD-OR

3. smooperogistrutio workplokgegovens

4. prof. uitvoering BOS

5. afstemming WP-OR

6. bruikbaar advies voor PZ

7. verzuimcontrole $\mathrm{OR}$

8. bruikbaar advies voor $O R$

9. onderstouning voor $\mathrm{OR}$

Voor een verklaring van deze verschillen is nadere bestudering van de intercorrelaties van de afhankelijke variabelen per BGD-organisatievorm noodzakelijk (tabel 9.23). 
In EVD-bedrijven gaat het op groepsniveau registreren van werkplekgegevens samen met het vaker ervaren van de houding van de BGD als klantvriendelijk, en met een beter naar wens van ondernemingsraad en werknemers uitvoeren van het periodiek onderzoek. In GD-bedrijven gaat de groepsregistratie van werkplekgegevens samen met het vaker door werknemers karakteriseren van de sociaal medische begeleiding als controle.

Het ondermemen van extra activiteiten door de BGD gaat in GD-bedrijven samen met een meer naar wens van de ondernemingsraad uitvoeren van het werkplekonderzoek, terwijl in EVD-bedrijven dit samengaat met een minder naar wens van de ondernemingsraad uitvoeren van het werkplekonderzoek.

Een goede samenwerking tussen BGD en ondernemingsraad gaat in EVD-bedrijven samen met het minder bruikbaar vinden van de advisering door personeelszaken (al eerder werd gewezen op het tegengestelde verwachtingspatroon van personeelszaken en ondernemingsraad in EVD-bedrijven). In GD-bedrijven ontbreekt dit verband.

Tabei 9.23. Correlaties tussen de variabelen "groepsregistratile werkplekgegevens", "het ondernemen van extre activiteiten door de BGD", en "semeawerking BGD-ondememingsirand" mett andere whunkelijke variabelen per BGD-organisatievorm

\begin{tabular}{|c|c|c|c|c|c|}
\hline & \multicolumn{2}{|c|}{ GD } & \multirow[b]{2}{*}{$\mathbf{u}$} & \multicolumn{2}{|c|}{ EVD } \\
\hline & $\mathbf{R}$ & $\mathbf{N}$ & & $\mathbf{R}$ & $\mathbf{N}$ \\
\hline \multicolumn{6}{|l|}{ Groepsregistratie werkplekgegovens: } \\
\hline - (klantrriendelijke) houding & -.35 & (21) & $2.35^{*}$ & $\because .63$ & (9) \\
\hline - afsternming PGO-OR & $(-) .08$ & (16) & $2.05^{*}$ & $\cdots .76$ & (8) \\
\hline afstemming PGO-WN & .06 & (21) & $2.27^{\star}$ & $\cdots .79$ & (10) \\
\hline - verzuimcontrole WN & $* .54$ & (16) & $2.08 *$ & $(-) .40$ & (9) \\
\hline \multicolumn{6}{|l|}{ Extrn sctiviteiten: } \\
\hline $\begin{array}{l}\text { - afstemming WP-OR } \\
\text { Samenwerking BGD-OR: }\end{array}$ & ${ }^{*} .63$ & (12) & $2.85^{*}$ & --.75 & (7) \\
\hline $\begin{array}{l}\text { Samenwerking BGD-OR: } \\
\text { - bruikbear alvio voor personelszaken }\end{array}$ & .25 & (18) & $2.14^{\circ}$ & -.69 & (8) \\
\hline
\end{tabular}

$R=$ correlatiecoeffficiènt; $(-)=$ negatiof verband, $p>.10$

$u=z$-score tussen correlatiecoëfficiëten; * $=$ significant bij $p<.05$

Een curatieve taakopvatting van de bedrijfsarts laat een tegengesteld beeld zien in GD- en EVD-bedrijven. Gaat in GD-bedrijven een curatieve taakopvatting positief samen met een aantal klantgerichte aspecten van kwaliteit, in EVD-bedrijven wordt een curatieve taakopvatting sterk verbonden aan een nadrukkelijke sociaal-medische begeleidingsrol, en - al dan niet via dit verband - met een negatieve waardering door de ondernemingsraad van een aantal aspecten van kwaliteit. De vraag kan worden gesteld of dit het gevolg is van de aan de BGD door het bedrijf toegekende positie of het gevolg van een door de BGD zelf gekozen invulling van een curatieve taakopvatting. 


\subsection{Samenvatting en conclusie}

In dit hoofdstuk is de invloed van bedrijfs- en bedrijfsarts-variabelen op een aantal professionele en klantgerichte aspecten van kwaliteit onderzocht. Tevens is op een aantal verschillen tussen GD en EVD ingegaan.

In zijn algemeenheid kan worden gesteld dat er, gezien de beperkte omvang van de onderzochte populatie en de gevonden correlaties, geen uitspraken kunnen worden gedaan over de causaliteit van gevonden verbanden. Nader onderzoek is hiervoor nodig. De doelen van dit exploratieve onderzoek waren een algemene verkenning van het voorkomen van een tweetal clusters van aspecten van kwaliteit (professionaliteit en klantgerichtheid), een eerste oriēntatie met betrekking tot factoren gekoppeld aan de bedrijfsarts of het bedrijf die met deze aspecten van kwaliteit samenhangen, en het exploreren van eventuele verschillen in ervaren kwaliteit tussen GD en EVD.

Bij de keuze van de aspecten van kwaliteit is zo strikt mogelijk aansluiting gezocht bij de, binnen wettelijke kaders, vigerende concrete taakuitvoering van de BGD. In dit hoofdstuk stonden bij de beschrijving van de resultaten de aspecten van kwaliteit centraal. In deze samenvattende paragraaf worden de resultaten beschreven met het centraal stellen van de factoren die van invloed zijn op de beschreven aspecten van kwaliteit. Hiermee komt de nadruk meer te liggen op eventuele beleidsmatige implicaties van de bevindingen.

\section{Bedrilfsarts-gebonden factoren}

Naarmate de bedrijfsarts langer werkzaam (ervaring) is voor het bedrijf, wordt een aantal professionele aspecten van kwaliteit negatief ervaren: de bedrijfsarts kan zijn kerntaken minder naar professionele wens uitvoeren, de gegevens van het werkplekonderzoek worden minder vaak op groepsniveau geregistreerd en aan het werkplekonderzoek wordt door de ondernemingsraad minder rendement toegekend. Het zou erop kunnen duiden dat als resultante van het interactieproces tussen BGD en bedrijf de nadruk komt de liggen op andere dan werkplek-gerelateerde activiteiten. Er is geen significante invloed van de ervaring van de bedrijfsarts op de onderzochte klantgerichte aspecten van kwaliteit. Als opmerkelijk verschil tussen GD en EVD komt naar voren dat ervaring in EVD-bedrijven wel leidt tot een in de ogen voldoende doen van de BGD naast haar kerntaken, en dat het aanstellingsonderzoek meer naar wens van ondernemingsraad en werknemers wordt uitgevoerd. Geconcludeerd werd dat de GD-bedrijfsarts zich meer leek vast te houden aan zijn professionaliteit.

Naarmate de bedrijfsarts vaker overleg voert met de directie van het bedrijf, is er sneller contact door de BGD met zieke werknemers. Het vaker overleggen met de directie van het bedrijf gaat ook samen met het toekennen van meer rendement aan het werkplekonderzoek. Dit kan erop wijzen dat de BGD in het overleg met de directie de haalbaarheid van werkplekonderzoek en de oplossing van de hieruit voortvloeiende problematiek te voren toetst, en daarmee de effectiviteit van het handelen vergroot. Het vaker overleggen met de directie gaat overigens ook samen 
met een negatieve beleving van een tweetal klantgerichte kwaliteitsaspecten: de verzuimbegeleiding van de BGD wordt meer als controle ervaren, en de BGD onderneemt volgens de ondernemingsraad onvoldoende extra activiteiten naast haar kerntaken.

Naarmate er vaker afspraken over rapportage aan het bedrijf worden gemaakt, is er vaker sprake van een klantgerichte taakopvatting van de bedrijfsarts. Er is een duidelijke samenhang met de werkwijze van de bedrijfsarts: gegevens van het periodiek onderzoek en werkplekonderzoek worden vaker op groepsniveau geregistreerd, en er wordt vaker in gelijke mate aan directie en ondernemingsraad gerapporteerd. Als er afspraken worden gemaakt over het rapporteren aan het bedrijf wordt de samenwerking tussen BGD en personeelszaken consistenter, en het periodiek onderzoek wordt meer naar wens van de klant uitgevoerd. Daarentegen wordt het werkplekonderzoek in dit geval minder naar wens van de klant uitgevoerd. Dit kan erop wijzen dat de BGD op het medische terrein sec (periodiek onderzoek) aan de verwachtingen kan voldoen, echter dat ten aanzien van het werkplekonderzoek er een discrepantie optreedt tussen praktijk en wens c.q. verwachting.

In grote bedrijven ervaart de bedrijfsarts meer speelruimte. Opmerkelijk is dat deze grotere speelruimte niet samengaat met het gevoel van grotere professionele autonomie, integendeel, de bedrijfsarts vindt dat hij het spreekuur minder naar eigen professionele wens kan uitvoeren. De marginaal significante verbanden tussen het ervaren van meer speelruimte met resp. een betere samenwerking tussen BGD en directie en het door de ondernemingsraad ervaren van de verzuimbegeleiding als controle, versterken de mogelijke verklaring dat de BGD pas meer speelruimte ervaart als zij tenminste een nadrukkelijke sociaal-medische begeleidingsrol speelt.

Naarmate de bedrijfsarts meer tijd ter beschikking heeft onderneemt hij voldoende extra activiteiten. Het is echter de vraag of de bedrijfsarts deze tijdsruimte omzet in door de klant gewaardeerde activiteiten. Als de bedrijfsarts veel tijd ter beschikking heeft vindt hij dat hij het spreekuur meer naar professionele wens kan uitvoeren, maar de klant denkt hier anders over: in tegenstelling met de bedrijfsarts vindt de ondernemingsraad dat het spreekuur minder naar haar wens wordt uitgevoerd. Ook wordt aan het periodiek onderzoek minder rendement toegekend, en het werkplekonderzoek wordt minder naar wens van werknemers uitgevoerd.

De invloed van de taakopvaiting van de bedrijfsarts op de onderzochte aspecten van kwaliteit is verschillend.

Naarmate er sprake is van een meer professionele taakopvatting wordt weliswaar het periodiek onderzoek vaker naar wens van de klant uitgevoerd, maar daar staat een groot aantal negatieve ervaringen van de klant tegenover: de ondernemingsraad ervaart minder steun van de BGD, de houding van de BGD wordt niet als klantvriendelijk ervaren, aan het spreekuur wordt minder rendement toegekend. De bedrijfsarts lijkt in dat geval op afstand te opereren: ongevraagd advies wordt niet gegeven, de BGD onderneemt geen extra activiteiten en wordt weinig ingeschakeld voor niet-individugebonden activiteiten. Anders gezegd, een professionele houding wordt als afwachtend en afstandelijk ervaren, de bedrijfsarts trekt zich terug in zijn professionele ivoren toren. 
Een curatieve taakopvatting heeft geen significante samenhang met aspecten van professionele kwaliteit. Naarmate er sprake is van een meer curatieve taakopvatting ervaart de ondernemingsraad de verzuimbegeleiding vaker als controle. Er treden echter opmerkelijke verschillen op tussen GD en EVD. Gaat in GD-bedrijven een curatieve taakopvatting van de bedrijfsarts samen met het vaker bruikbaar vinden van de advisering door de ondernemingsraad en met het ervaren van meer steun van de BGD door de ondernemingsraad, in EVD-bedrijven wordt een curatieve taakopvatting van de bedrijfsarts door de klant als negatief ervaren: de ondernemingsraad ervaart de verzuimbegeleiding als controle, de samenwerking tussen BGD en ondernemingsraad is minder consistent. De nadruk komt te liggen op sociaal medische begeleiding, een door de EVD-bedrijfsarts en personeelszaken gewenste activiteit, het gaat echter ten koste van het (kunnen) ondernemen van extra activiteiten. Opmerkelijk is wel dat een curatieve taakopvatting in GD-bedrijven samengaat met het minder, in EVD-bedrijven met het meer naar wens van de ondernemingsraad uitvoeren van het werkplekonderzoek.

Een meer klantgerichte taakopvatting van de bedrijfsarts gaat samen met het minder snel contact opnemen met zieken, en het vaker maken van afspraken over rapportage. Het lijkt erop dat klantgerichtheid wordt geïnterpreteerd als zich meer richten naar de wens van ondernemingsraad en werknemers: spreekuur en periodiek onderzoek worden meer naar hun wens uitgevoerd, en (zij het marginaal significant) de houding van de BGD wordt als klantvriendelijk ervaren.

\section{Bedrijfsgebonden factoren}

In grotere bedrijven komen r.inder fysiek belastende arbeidsomstandigheden voor. De bedrijfsarts ervaart meer speelruimte, en de bedrijfsarts in grote bedrijven is daar vaak al langer werkzaam. Naarmate het hedrijf groter is, wordt de bedrijfsarts vaker ingeschakeld op algemeen beleidsterrein. De werknemers ervaren de verzuimbegeleiding van de BGD in grote bedrijven vaker als controle. Er treedt een verschil op tussen GD- en EVD-bedrijven, dat erop wijst dat er een interactie is tussen bedrijfsgrootte en het ervaren van de verzuimbegeleiding als controle door werknemers. In GD-bedrijven wordt de sociaal medische begeleiding meer als controle ervaren naarmate het bedrijf groter is, terwijl in EVD-bedrijven dit het geval is naarmate het bedrijf kleiner is. Opgemerkt kan worden dat in het onderzoek meer EVD-bedrijven groter waren dan GD-bedrijven.

Naarmate er in het bedrijf meer fysiek belastende arbeidsomstandigheden voorkomen kan de bedrijfsarts het periodiek onderzoek en werkplekonderzoek meer naar eigen wens uitvoeren. De ondernemingsraad ervaart echter in bedrijven met veel fysiek belastende arbeidsomstandigheden minder steun van de BGD, advisering wordt ook minder bruikbaar gevonden, en (via een marginaal significant verband) de ondernemingsraad vindt dat de BGD onvoldoende extra activiteiten ontplooit. Deze bevindingen wijzen op een discrepantie tussen beleving in de praktijk en hetgeen de ondernemingsraad (in dit soort bedrijven) van de BGD verwacht. Opmerkelijk is dat er geen samenhang is tussen de arbeidsomstandigheden in het bedrijf en het werkterrein van de BGD. 
Naarmate hel verzuim in het bedrijf hoger is ontstaat er een positief beeld van de door de BGD geleverde zorg. Ook de BGD zelf ervaart meer armslag, zij brengt vaker ongevraagd advies uit, het werkplekonderzoek kan meer naar eigen wens worden uitgevoerd. Ook de ondernemingsraad oordeelt positief: aan het spreekuur en het periodiek onderzoek wordt meer rendement toegekend, de ondermemingsraad ervaart meer steun van de BGD, en er is een betere samenwerking tussen BGD en ondernemingsraad. Het negatieve verband tussen een hoog verzuim en het naar wens van de ondernemingsraad uitvoeren van het spreekuur, kan erop wijzen dat bij een hoog verzuim de ondernemingsraad van de BGD meer activiteiten verwacht, maar niet of althans niet uitsluitend op het terrein van sociaal medische begeleiding/spreekuur. Er is echter wel sprake van centrasterend beeld tussen GD- en EVD-bedrijven. Genoemde positieve verbanden gelden uitsluitend voor GD-bedrijven. In GD-bedrijven vormt een hoog verzuim mogelijk een onomstreden gezamenlijke aandachtspunt voor de BGD en de ondernemingsraad, een legitimatie voor de BGD om activiteiten te ontplooien. In EVD-bedrijven wordt een hoog verzuim daarentegen gezien als uiting van falend rendement.

Naarmate de BGD sneller contact opneemt met zieke werknemers, voert de bedrijfsarts vaker overleg met de directie van het bedrijf. Deze zichtbare uiting van sociaal medische begeleiding gaat logischerwijs samen met hel ervaren van de verzuimbegeleiding door ondernemingsraad en werknemers als controle, en ook met een betere samenwerking tussen BGD en directie. Er treedt echter een verschil op tussen GD- en EVD-bedrijven, dat niet alleen verklaard kan worden door een feitelijk verschil tussen de uitvoering van sociaal-medische begeleiding, maar die ook te maken heeft met de door de klant ingeschatte (en misschien ook ingenomen) positic van de BGD.

Er kan worden opgemerkt dat een aantal verwachte verbanden tussen bedrijfsartsen bedrijfsgebonden factoren en kwaliteitsaspecten niet werd gevonden. Zo blijkt dat noch de aard van de arbeidsomstandigheden, noch de bedrijfsgrootte van invloed zijn op de omvang van de BGZ-activiteiten. Blijkbaar bepaalt de klant (en haar problemen) maar in beperkte mate de breedte van de geleverde BGZ. Ook bleken geen van de onafhankelijke variabelen van invloed te zijn op het al dan niet ervaren van steun van de BGD door personeelszaken. Met uitzondering van een negatieve samenhang tussen het voorkomen van fysiek belastende arbeidsomstandigheden en het bruikbaar vinden van de advisering door de ondernemingsraad, bepalen de onderzochte bedrijfsarts- en bedrijfsvariabelen blijkbaar niet de bruikbaarheid van de advisering van de BGD bij de klant (personeelszaken en ondernemingsraad). De rendementsbeoordeling lijkt niet op taakniveau bepaald te worden. Er is sprake van een algemeen rendementsoordeel, niet zozeer van een echte effectiviteitsbeoordeling. Rendement lijkt door de ondernemingsraad te worden gebruikt als cen maat voor door de BGD geleverde inspanningen en een actieve opstelling. Vooral als de BGD activiteiten ontplooit op het gebied van periodiek of werkplekonderzoek, wordt dit door de ondernemingsraad als steun ervaren. Er is een samenhang tussen het ervaren van de sociaal medische begeleiding als controle door ondernemings- 
raad en werknemers. Ieder voor zich lijken ze echter door andere bedrijfsarts-variabelen te worden beinvloed: het als controle ervaren van de sociaal medische begeleiding door de ondernemingsraad gaat samen met een meer curatieve taakopvatting van de bedrijfsarts, terwijl het als controle ervaren van de sociaal medische begeleiding door werknemers samengaat met het vaker overleg plegen van de BGD met de directie van het bedrijf.

Er kunnen aanmerkelijke verschillen worden vastgesteld in ervaren kwaliteit (hoofdstuk 8) en hiermee samenhangende factoren tussen GD- en EVD-bedrijven (hoofdstuk 9). De organisatiewijze van BGZ blijkt van wezenlijke betekenis voor de door alle betrokken partijen ervaren kwaliteit van BGZ. Ook blijkt de organisatiewijze van BGZ van belang voor de eventuele samenhang tussen bedrijfsarts- en bedrijfsgebonden variabelen en de ervaren kwaliteit van BGZ. Met betrekking tot een aantal items werden deze verschilpunten verder uitgewerkt. Het betreft: bedrijfsgrootte, verzuim, ervaring en taakopvatting van de bedrijfsarts.

De belangrijkste conclusie is dat aspecten van professionele kwaliteit anders en door andere factoren (bedrijfsarts- en/of bedrijfsgebonden) worden beïnvloed dan klantgerichte aspecten van kwaliteit. Dit maakt bij het ontwikkelen van kwaliteitszorg binnen BGD'en een evenwichtige opbouw langs twee sporen, enerzijds gericht op professionaliteit en anderzijds gericht op klantgerichtheid, noodzakelijk.

In het volgende hoofdstuk 10 wordt een korte beschouwing gegeven van de meest opmerkelijke resultaten. 


\section{Hoofdstuk 10}

\section{Beschouwing. \\ De twee sporen van kwaliteitszorg: professionaliteit en klantgerichtheid}

\subsection{Inleiding}

In het onderzoek wordt de noodzaak aangegeven dat BGD'en zich profileren en marktgericht opstellen. BGD'en hebben daarbij te maken met een klantsysteem, dat is samengesteld uit diverse participanten, met soms tegengestelde belangen. Het onderzoek maakt de problemen die ontstaan bij het afstemmingsproces dat plaatsvindt tussen BGD en klantsysteem, manifest. Naast deze vraag naar klantgerichte kwaliteit van bgz, wordt aan BGD'en ook gevraagd aan te geven of en hoe zij professioneel vorm en inhoud geven aan bij de klant bestaande BGZ-problemen. Wat is de meerwaarde van BGZ, spelen BGD'en adequat in op relevante arboproblemen met hun diensten?

Over de kwaliteit van BGZ wordt veel gesproken, maar er is slechts weinig onderzoek naar gedaan. Onderzoek op dit gebied beperkt zich tot het onderzoeken van deelaspecten van kwaliteit van BGZ, en tot het evalueren van de kwaliteit van BGZ vanuit een beperkte optiek van één van de partijen, die bij de totstandkoming van BGZ zijn betrokken (Tanke 1985, Ruinen 1985a, Smulders 1980, Plomp 1987c, FNV 1980, Dijkstra 1985, Draaisma et al. 1991, De Haas 1980).

In dit onderzoek wordt tezelfdertijd de mening over de kwaliteit van BGZ bij de leverancier van BGZ en bij de ontvangers van BGZ onderzocht. Niet in abstracte termen, maar aan de hand van concrete taken en taakuitvoering. Tevens kan erop worden gewezen dat in dit onderzoek de ervaren kwaliteit van BGZ werd onderzocht bij verschillende BGD-organisatievormen (GD en EVD). Er kan worden vastgesteld dat de bevindingen in dit onderzoek, voor zover betrokken deelaspect in ander onderzoek werd onderzocht, aansluiten bij de bevindingen uit ander onderzoek (Draaisma et al. 1991, Plomp 1987c). Dit ondersteunt de kwaliteit van de gegevens van dit onderzoek. Het onderzoek kan de aanzet vormen tot verder onderzoek naar de kwaliteit van BGZ, en de concrete vertaling hiervan in kwaliteitszorg door BGD'en.

Het laatste woord over de kwaliteit van BGZ is met het onderzoek zeker nog niet gezegd. De ondervertegenwoordiging van de grote EVD'en, de (beperkte) omvang 
van de steekproef, het exploratieve karakter van dit transversale onderzoek, het gegeven dat het onderzoek een momentopname is van een veld dat fors in beweging is, het slechts meenemen van twee BGD-organisatievormen (GD en EVD), en het beschouwen van een beperkt aantal aspecten van kwaliteit van BGZ, vragen om relativering van de bevindingen.

Er moet nogmaals worden benadrukt dat het onderzoek niet tot doel had een beeld te geven van het kwaliteitsniveau van geleverde BGZ in absolute zin.

Paragraaf 10.2 geeft een samenvatting van de belangrijkste bevindingen. In paragraaf 10.3 worden bouwstenen van kwaliteitszorg voor een BGD aan de hand van de resultaten van het onderzoek kritisch doorgelicht. In paragraaf 10.4 wordt, aan de hand van bespreking van enige binnen de beroepsgroep levende actuele topics, een bespiegeling gegeven over het spanningsveld professionaliteit-klantgerichtheid. Het hoofdstuk wordt afgerond met een aantal aanbevelingen.

\subsection{De belangrijkste conclusies}

BGZ opereert in een complex relatie-netwerk. In dit relatienetwerk worden door de BGD contacten onderhouden met het bedrijf, maar ook met andere zorginstanties, de beroepsgroep en de overheid. De BGD-activiteiten moeten gericht zijn op de doelstelling van BGZ: de bevordering en bescherming van gezondheid van allen die beroepsarbeid verrichten, voor zover die verband houdt met de arbeid, het arbeidsmilieu en de arbeidsgemeenschap (DGA 1979). Bij de totstandkoming van BGZ en bij de beïnvloeding van de kwaliteit van BGZ spelen meerdere partijen een rol. Naast de leverancier van zorg, zijn dat de werkgever, de werknemers en hun vertegenwoordiging, de overheid en de beroepsgroep. Voorwaarde voor kwaliteit van BGZ is een adequaat samenspel tussen deze partijen.

Kwaliteit van BGZ werd in dit onderzoek gedefinieerd als het op professioneel verantwoorde en klantgerichte wijze leveren van BGZ. De vraag naar de kwaliteit van de afstemming tussen aanbod van BGD-diensten en binnen het bedrijf bestaande relevante arboproblematiek c.q. -wensen, kwam in dit onderzoek niet aan de orde.

Kwaliteitszorg van een BGD zal zich dan ook moeten bewegen langs twee sporen. Aan de ene kant dient vorm te worden gegeven aan de ontwikkeling van professionaliteit. Aan de andere kant dienen klantgerichte aspecten van kwaliteit verder te worden ontwikkeld. De noodzaak van een evenwichtige opbouw van kwaliteit op deze twee fundamenten, blijkt in dit onderzoek. Er moet worden opgemerkt dat de beoordeling van de kwaliteit van BGZ door de klant plaatsvindt bij het in feite ontbreken bij de klant van een referentiekader of van vergelijkingsmateriaal.

Het verschil tussen GD en EVD in positie in en ten opzichte van het bedrijf, komt ook tot uiting in een aantal aspecten van ervaren kwaliteit. In EVD-bedrijven houdt de BGD zich volgens de ondernemingsraad en werknemers vrijwel uitsluitend bezig met SMB-activiteiten. Het spreekuur wordt hier bijna volledig aan besteed. Deze SMB-rol wordt door personeelszaken sterk gesteund en gewaardeerd. Het gaat 
echter ten koste van diverse, voor ondernemingsraad en werknemers, relevante aspecten van kwaliteit. Ook konden duidelijke verschillen tussen GD en EVD worden geconstateerd in omvang van en soort inzet van mensen en middelen. Dit wijst op een samenspraak tussen BGD en bedrijf over de gewenste dienstverlening en de daarbij benodigde menskracht en middelen. Het kan als het ware worden geduid als resultante van het interactieproces tussen BGD en bedrijf.

Bedrijfsvariabelen in het algemeen, en de aard van de arbeidsomstandigheden in het bijzonder, bleken slechts van geringe betekenis voor ervaren kwaliteit. De vrang kan worden gesteld wat hiervan de betekenis dient te zijn op de trend, die momenteel binnen BGZ kan worden geconstateerd, naar een branche-gerichte organisatie van BGZ. De individuele taakopvatting van de bedrijfsarts bleek van belang voor meerdere aspecten van ervaren kwaliteit. Er werden drie dimensies gevonden waarop bedrijfsartsen zich in hun taakopvattingen onderscheiden, te weten curatief (met o.a. als kenmerk curatieve ervaring en wensen), professioneel (met o.a. als kenmerk de eigen mening doorslaggevend te laten zijn), en klantgericht (met o.a. als kenmerk een klantvriendelijke opstelling). Ter vergelijking: Draaisma et al 1991 komen in hun onderzoek ook tot een drietal karakteristieken van werkwijze van de bedrijfsarts, door hun respectievelijk genoemd "bedrijfs- en werkgerichtheid", "wederzijdse afstemming BGD-clientorganisatie" en "individugerichtheid". Een curatieve taakopvatting representeert bij GD-bedrijven de "artsen-rol", bij EVD-bedrijven een nadrukkelijke SMB-rol. Een professionele takopvatting blijkt samen te gaan met een weinig actieve opstelling van de BGD.

\subsection{Bouwstenen kwaliteitszorg: professionaliteit en klantgerichtheid. De betekenis van marketing}

\subsubsection{Inleiding}

In deze paragraaf wordt een beschouwing gegeven van de betekenis van marketing bij het ontwikkelen van kwaliteitszorg binnen BGD'en. In deze beschouwing wordt getracht een synthese tot stand te brengen tussen de gegevens uit het onderzoek, gegevens uit de literatuur en bevindingen uit de dagelijkse BGZ-praktijk.

Het onderzoek legt het spanningsveld dat optreedt tussen enerzijds professionaliteit en anderzijds klantgerichtheid duidelijk bloot. De vraag is hoe BGD'en diensten kunnen leveren die beide dimensies van kwaliteit voldoende waarborgen. De noodzaak voor BGD'en om zich in dit spanningsveld te profileren met hun diensten en dienstverlening wordt in de literatuur beschreven (zie hoofdstuk 2). Een tweetal crises versterkten de noodzaalk hiertoe: een crisis in de gezondheidszorg waardoor grenzen aan de zorg en de professionaliteit worden gesteld, en een crisis in het bedrijfsleven, met veranderingen in arbeid en de organisatie van de arbeid. In organisaties zal een permanente dynamiek te verwachten zijn, met als kenmerken: marktgerichtheid, flexibiliteit en individuele carrières. Dat zal de nodige verandervaardigheid vragen, ook binnen BGD'en. 
De kritiek die door de klant werd geuit had als gemeenschappelijk kenmerk dat BGD'en te weinig toegankelijk en ontvankelijk werden beschouwd voor wensen en behoeften van de klant. De noodzaak van integratie van marketing-denken en marketing-instrumenten in de BGZ werd hiermee onderstreept. Ook uit het onderzoek komt de noodzaak van klantgerichtheid naar voren in het kader van ervaren kwaliteit, zowel bij de zorgverlener als de zorgontvanger.

Gewaakt moet echter worden voor een onevenwichtige opbouw van professionaliteit en klantgerichtheid ten koste van de eerste dimensie. De professionaliteit vormt immers de legitimatie voor het bestaan van BGD'en. Aanvullende eis is wel dat de kwaliteit van de diensten die de BGD levert adequaat is, en dat de BGD met haar diensten inspeelt op relevante problematiek bij haar klanten. Anders gezegd, de professionaliteit van BGZ moet tot uitdrukking komen in de kwaliteit van haar produkt (de diensten), in haar positie als adviseur, en in haar op kwaliteitsbevordering gerichte activiteiten zoals intercollegiale toetsing en protocollering van BGZ, het opstellen van een professioneel statuut, het vaststellen en volgen van een beroepscode. De klantgerichtheid moet tot uitdrukking komen in de wijze waarop met de klant wordt omgegaan, de wijze waarop diensten worden verleend (de dienstverlening) en de aansluiting van de samenstelling van een dienstenpakket op wensen en behoeften van de klant.

De infrastructuur, de communicatie- en informatiestromen dienen afgestemd te zijn op beide pijlers van kwaliteit.

Centrale elementen in de marketing van BGD-diensten zijn het analyseren van de markt (wie zijn mijn klanten c.q. doelgroep(en), aan welke diensten bestaat behoefte), het onderzoeken hoe de BGD daarop kan inspelen (profilering en positionering, benutten van marketinginstrumenten, sterkte-zwakte analyse van BGD en omgeving), en het onderhouden van de relaties door de BGD met de klant (relatie-marketing). Anders geformuleerd (naar analogie van Van der Hart 1986): BGD'en zullen op strategisch niveau een marktvisie moeten ontwikkelen (vaststellen van hun mission en de hieruit voortvloeiende concretisering in doelstellingen), op tactisch niveau de wegen moeten aangeven warlangs deze marktvisie kan worden gerealiseerd (bijvoorbeeld pakket- en prijsdifferentiatie), en op operationeel niveau op een klantgerichte wijze diensten moeten verlenen en de relaties met de klant moeten onderhouden. Dit laatste aspect kan zijn weerslag vinden in het werken volgens contractmanagement, en met het periodiek monitoren van de ervaren kwaliteit door middel van het SERVQUAL-model. Het voordeel van deze laatste methodiek is dat ook een vertaalslag mogelijk is van lacunes in de bij de klant ervaren kwaliteit naar de organisatie van de BGD. Er moet wel worden opgemerkt dat het SERVQUALmodel vooral zijn toepassing heeft in de beoordeling door de klant van de kwaliteit van Étn dienst. Aanpassing aan de BGD-organisatie, die meerdere diensten levert, zal nodig zijn.

In de paragrafen 10.3.2 tot en met 10.3.4. wordt de rol van marketing bij het ontwikkelen van kwaliteitszorg binnen BGD'en verder uitgewerkt op drie onder- 
scheiden niveaus: het strategisch, tactisch en operationeel niveau (Van der Hart 1986). Misschien ten overvloede wordt nog opgemerkt dat kwaliteitszorg c.q. beleid een integraal onderdeel dient te zijn van het algemene beleid van een BGD. en niet als een separate en geîsoleerde activiteit. Kwaliteitszorg als een permanent cluster van activiteiten gericht op het toetsen, het bewaken en het bevorderen van de kwaliteit van geleverde BGZ.

\subsubsection{BGD en marketing op strategisch niveau: de mission}

Het vaststellen van de mission van de BGD, de reden van en voor het bestaan van de BGD, is van wezenlijke betekenis. Een mission heeft hierbij de functie van intern richtsnoer voor het handelen, en de functie van externe profilering en positionering. Dit belang kan worden geîllustreerd met de volgende passage uit "Alice in Wonderland". Op een gegeven moment ontwikkelt zich tussen de kat en Alice de volgende dialoog: "Would you tell me, please which way I ought to go from here?" "That depends a good deal on where you want to get to", said the Cat. "I don't much care where...", said Alice. "Then it doesn't matter which way you go", said the Cat. ".....so long as I get somewhere", Alice added as an explanation. "Oh, you're sure to do that", said the Cat, "if you only walk long enough".

Uit het onderzoek komt een beeld naar voren waarin geen sprake is van een duidelijke formulering van de mission van de BGD. Zeker binnen de onderzochte EVDbedrijven is het de vraag of een discussie op gang komt tussen BGD en bedrijf over mission van de BGD en hieruit voortvloeiende doelstellingen van de BGD. Daarnaast ligt de nadruk nog sterk op het uitsluitend willen aanbieden van "totaalpakketten BGZ", met andere woorden er vindt geen marktsegmentering of -positionering plaats op basis van marktonderzoek.

Binnen GD-bedrijven wordt de globale doelstelling van BGZ (zie 10.2) vaak gehanteerd als aansluitingsgrond bij een BGD, BGZ als element van het in het bedrijf vigerende sociaal beleid. Bij de uitwerking van de aansluitingsgrond in de vorm van een contract, blijkt de invloed van de professional op de inhoud van dit contract groot. Er wordt in de praktijk wel vaak onderhandeld, zonder dat dit echter tot een gevoel bij de klant leidt dat hij invloed heeft gehad.

Uit het onderzoek blijkt dat explicitatie noodzakelijk is van het verwachtingspatroon van de diverse doelgroepen die samen de klant vormen, en van de positie die de BGD hierbij inneemt of wil innemen. De vraag hierbij is of BGD'en kunnen en willen voldoen aan alle verwachtingen van de diverse doelgroepen.

Directies en personeelszaken van de bedrijven verwachten primair SMB-activiteiten. Daarnaast worden individu-gerichte, medische onderzoeken zoals het aaristellingsonderzoek en het periodiek onderzoek gewenst. De verwachtingen van de ondernemingsraad in GD en EVD-bedrijven lijken verschillend. Binnen GD-bedrijven worden door de ondernemingsraad activiteiten van de BGD in het kader van verzuimbeheersing niet van de hand gewezen, terwijl in EVD-bedrijven er bij de ondernemingsraad een sterke afwijzende houding bestaat ten opzichte van de verzuimactiviteiten van de BGD. Mogelijk dat binnen GD-bedrijven van de zijde van 
de BGD in het algemeen (te) weinig aandacht is voor verzuim, in EVD-bedrijven (te) veel aandacht voor verzuimbeheersing. Deze discrepantie kan ook te maken hebben met de positie van waaruit de bedrijfsarts opereert.

De ondernemingsraad verwacht van de BGD een actieve opstelling op de werkplek, en dat er vaker (dan nu in de praktijk gebeurt) periodiek onderzoek plaatsvindt.

Naar onze mening zullen, om een evenwichtige opbouw van professionaliteit en klantgerichtheid tot uitdrukking te laten komen in de strategische marktvisie van de $B G D$, een explicitatie van de wensen van de klant, en het maken van keuzen van doelgroepen noodzakelijk zijn. Het zal niet mogelijk zijn om met standaardpakketten "de" klant tevreden te stellen. Het risico dat hierbij wel dreigt is het uitkleden van het zorgkarakter van BGZ. Een oplossing zou kunnen zijn het in gezamenlijk overleg tussen BGD'en, overheid, werkgevers- en werknemersorganisaties vaststellen van een minimum-omvang en -niveau van BGZ-diensten. Wettelijke verplichtingen (implementatie Kaderrichtlijn 89/391/EEG) en voorstellen dienaangaande van de Federatie (1991) en Wilders (1991) namens de FNV kunnen hierbij als uitgangspunt dienen. Nieuwe ontwikkelingen en wetenschappelijk gefundeerde kennis van de relatie mens-arbeid, dienen een invloed te hebben op de samenstelling van een dergelijk "kerntakenpakket", en maken flexibiliteit naast standaardisatie noodzakelijk. Naast deze bodemvoorziening kan de BGD met de onderscheiden doelgroepen van de klant (werknemers, werkgever) of anderszins (in het kader van experimentele en wetenschappelijke ontwikkelingen) in projectvorm diensten aanbieden. De meerwaarde voor de klant zal door de BGD aangegeven moeten worden.

\subsubsection{BGD en marketing op tactisch niveau: het realiseren van de doelstellingen}

De inhoud van de contracten tussen bedrijf en BGD blijft meestal beperkt tot het opnemen van een globale taakbeschrijving en een financiële paragraaf. Flexibiliteit wordt niet automatisch ingebouwd, een moment van evaluatie of te nemen stappen bij wijziging van het contract maken zelden onderdeel uit van het contract. De meeste bedrijfsartsen zouden wel jaarlijks de dienstverlening evalueren met de directie van het bedrijf.

Uit het onderzoek komt een spanningsveld naar voren tussen BGD en klant in verwachtingspatroon. BGD'en kunnen, individuele bedrijfsartsen willen, niet altijd inspelen op wensen van de klant. Een sterke nadruk op de professionaliteit wordt door de klant als niet klantvriendelijk ervaren, en leidt ertoe dat de BGD een weinig initiêrende en actieve rol vervult. Met betrekking tot SMB kan worden vastgesteld dat de meeste bedrijfsartsen een minder nadrukkelijke rol wensen. Voor bedrijfsartsen zou het spreekuur ook een belangtijke rol moeten spelen bij het opsporen en begeleiden van werkgebonden klachten. De praktijk laat echter zien dat werk of werkomstandigheden zelden onderwerp van gesprek zijn tijdens het spreekuur. In tegenstelling tot de.expliciete wens van de klant naar (meer) periodieke 
onderzoeken, krijgen periodieke onderzoeken volgens de leverancier van BGZ (al) te veel aandacht. Als BGD'en periodieke onderzoeken uitvoeren, wordt een duidelijke relatie met het werk wenselijk geacht. De klant ervaart deze relatie echter zelden of nooit. Immers, in dit onderzoek werd volgens $96 \%$ van de werknemers niet naar het werk gekeken.

De hiervoor beschreven duidelijke discrepanties in verwachtingspatroon tussen de doelgroepen van de klant onderling en die tussen BGD en bedrijf, dwingen BGD'en keuzen te maken. Een positief gegeven hierbij is dat de klant in het algemeen de BGD goed toegankelijk vindt in de ruime betekenis van het woord. Er wordt geen drempel ervaren om de BGD te consulteren, werknemers hebben veel vertrouwen in de bedrijfsarts. In het algemeen neemt de BGD een afwachtende houding aan. Er wordt ingespeeld op door de klant aangedragen problemen. Dit kan als negatief en positief worden geduid. Negatief, omdat vanuit de professie gezien relevante problemen hierdoor mogelijk onderbelicht blijven. Positief, omdat dit een uiting kan zijn van een klantgerichte opstelling van de BGD. Vooral is het een pragmatische houding, de resultante van het interactieproces tussen BGD en bedrijf. De uiteindelijke kwaliteit van BGZ (het resultaat), is immers sterk afhankelijk van de door het bedrijf gegeven speelruimte en de medewerking om arboproblemen op te lossen (vergelijk Plomp 1987c, Reubsaet et al 1988).

De hoofdmoot van de BGD-activiteiten speelt zich af op het individuele niveau, het patientencontact. Legitimatie voor zijn handelen ontleent de bedrijfsarts primair aan zijn medicus zijn (vergelijk Plomp 1987c).

Zowel bedrijfsarts als ondernemingsraad/personeelszaken zijn van mening dat de samenwerking binnen het bedrijf met de diverse arbopartners goed is. Het door Plomp (1991) geschetste negatieve beeld dat BGD en ondernemingsraad van elkaar hebben, naar zijn zeggen op basis van het ontkennen van de wederzijdse verschillen met betrekking tot gestelde doelen en functie, wordt in dit onderzoek niet bevestigd.

Bij GD-bedrijven bestaan er verschillen in opvatting over de gewenste financiering van $\mathrm{BGZ}$ tussen de directie van de BGD en personeelszaken.

Naar onze mening zullen BGD'en met hun (benoemde) kJanten duidelijke afspraken moeten maken over bevoegdheden en verantwoordelijkheden. De klant is koning, als het gaat om de prioriteitsstelling van arbo-problemen die aandacht vragen. De BGD'en hebben het primaat ten aanzien van de vertaling van deze wensen en behoeften in een professioneel verantwoord en getoetst, binnen de mogelijkheden (personeel en materieel) van de BGD passend, dienstenpakket. De klant mag van de BGD maatwerk vragen, zowel wat betreft de omvang en samenstelling van zorg, als wat betreft de prijsstelling: pakket- en prijsdifferentiatie, contractmanagement. De klant mag van de BGD een deskundige en klantgerichte aanzet verwachten die leidt tot oplossing van gesignaleerde problematiek. 


\subsubsection{BGD en marketing op operationeel niveau: het leveren van BGZ in}

de praktijk

Er bestaat cen duidelijk onderscheid tussen de wijze waarop GD'en en EVD'en in de praktijk BGZ leveren, en hoe zij contacten onderhouden met het bedrijf. Het zou hier te ver voeren om in details hierop in te gaan (zie hoofdstuk 8 en 9). Er wordt volstaan met het wijzen op een tweetal verschilpunten:

- sociaal-medische begeleiding: minder dan 10\% van de werknemers bij GD-bedrijven, en bijna een derde van de werknemers in EVD-bedrijven ervaart de SMB van de BGD als controle. In GD-bedrijven gaan inschakeling op algemeen beleidsterrein en registratie van gegevens op groepsniveau samen met een gevoel bij ondernemingsraad en werknemers dat ze gecontroleerd worden. In GD-bedrijven leidt het karakteriseren van de SMB als controle (door ondernemingsraad/werknemers) i.t.t. de situatie in EVD-bedrijven niet tot een overall negatieve waardering van de BGD;

- taakuitvoering en -waardering: In GD-bedrijven bestaat er bij de ondernemingsraad waardering voor een $B G D$ die ongevraagd advies uitbrengt. De samenwerking tussen de BGD en de ondernemingsraad in GD-bedrijven wordt als minder goed ervaren naarmate de bedrijfsarts langer voor het bedrijf werkzaam is. In GD bedrijven voldoet de BGD niet aan de verwachtingen van de ondernemingsraad m.b.t. periodiek onderzoek. In GD-bedrijven is het in gelijke mate rapporteren aan de ondernemingsraad een kwestie van afspraken maken, bij EVD-bedrijven wordt dit bepaald in het overleg tussen directie en bedrijfsarts en de door de bedrijfsarts ervaren speelruimte in het bedrijf.

Naast deze verschillen tussen GD en EVD bestaan er ook overeenkomstige bevindingen. Voor GD'en en EVD'en geldt dat de adviesfunctie zich meestal beperkt tot individueel gerichte problematiek. De BGD wordt maar weinig geconsulteerd bij algemene beleidsthema's. In het algemeen is de ondernemingsraad minder tevreden over de kwaliteit van advisering van de BGD dan personeelszaken. De professionele kwaliteit van de adviesfunctie van de BGD wordt als goed ervaren, daarentegen laat een aantal klantgerichte aspecten zoals snelheid van rapportage en follow-up te wensen over. Het rendement dat de ondernemingsraad toekent aan de kerntaken BGZ (aanstellingsonderzoek, spreckuur, periodiek onderzoek, werkplekonderzoek) is meer uiting van waardering voor geleverde inspanning en opheffen van het adagium "onbekend maakt onbemind" dan dat hiermee een werkelijke output-meting plaatsvindt. De klant (ondernemingsraad, personeelszaken) ondervindt doorgaans steun van de BGD bij de totstandkoming van het sociaal beleid. Grosso modo achten personeelszaken en ondernemingsraad de BGD in staat een onafhankelijke positie in te nemen en objectief te adviseren. Tussen de BGD en de klant bestaan er discrepanties in de afstemming van taken: bedrijfsartsen wensen een kleinere rol bij SMB in tegenstelling tot personeelszaken. Werknemers en ondernemingsraad hebben de wens dat de BGD vaker periodiek onderzoek verricht dan dat bedrijfsartsen zelf dit wensen, bedrijfsarts en ondernemingsraad hebben de wens dat er meer tijd 
en gelegenheid is voor werkplekonderzoek. Gemeenschappelijk is het gevoel dat aanstellingskeuringen teveel aandacht krijgen. Bedrijfsartsen onderscheiden zich in hun taakopvattingen op een drietal dimensies: curatief, professioneel en klantgericht (zie paragraaf 10.2). De taakopvatting van de bedrijfsarts is van belang voor professionele en klantgerichte aspecten van de ervaren kwaliteit van BGZ. Een professionele taakopvatting wordt als niet klantvriendelijk ervaren, en gaat samen met een weinig actieve en initiërende opstelling van de bedrijfsarts.

Naar onze mening dient kwaliteitszorg, met als hoofdelementen professionaliteit en klantgerichtheid, integraal onderdeel uit te maken van het dagelijkse werk. Zij dient verankerd te worden in de organisatie zelf. In een dienstverlenings- of activiteitenplan dienen de doelen van de BGD te worden geoperationaliseerd. In een dergelijk plan moet worden aangegeven met welke instrumenten (BGZ-taken) de gewenste doelen kunnen worden bereikt, wie daarvoor wordt ingezet, welke middelen daarvoor nodig zijn, het planningstraject, en de voortgangs- en resultatenbewaking. Het vastleggen hiervan maakt dienstverlening toetsbaar, en beter toegankelijk voor bijsturing. Door in een dergelijk plan tevens de feedback naar de organisatie en een evaluatie op te nemen, is een ingang tot meer klantgerichte-kwaliteitsbewaking gegeven. Dit kan verder worden uitgewerkt door de dienstverlening aan de aangesloten bedrijven systematisch en steekproefsgewijs te evalueren op de door Parasuraman et al (1986) opgestelde "cliënt-kwaliteitscriteria" (SERVQUAL). Tevens kunnen in het werkplan tussen BGD en bedrijf afspraken worden gemaakt over de gewenste wijze van communicatie en informatie.

De aanwezigheid van verschillende klanten (en dus verschillende wensen) onderstreept de noodzaak dat BGD'en duidelijke en concrete afspraken maken over de diensten die ze leveren en de dienstverlening, de wijze waarop ze dit zullen doen.

Omdat de legitimatie van het BGZ-handelen nadrukkelijk ligt op het medische aspect, zal dit de kern van de activiteiten moeten vormen, natuurlijk met een duidelijke relatie met werk en werkomstandigheden.

\subsection{Bespiegelingen rond het vraagstuk: spanningsveld professionaliteit-klantgerichtheid}

Sprekend over kwaliteit van BGZ valt in het onderzoek de aanwezigheid van een aantal spanningsvelden op. Er kan een spanningsveld optreden door verschillen in prioriteitsstelling door de verschillende klanten in het klantsysteem, door verschillen in prioriteitsstelling tussen het klantsysteem en de BGD, en door verschil in prioriteitsstelling door medewerkers binnen de BGD. Ook verschillen in waardering van BGZ-diensten door de leden van het klantsysteem leiden tot een mogelijk spanningsveld. De vraag is hoe BGD'en het beste kunnen omgaan met deze spanningsvelden. Ligt een antwoord op deze vraag in een meer dan tot nog toe beantwoorden aan de vraag van de klant? Ligt de oplossing in een verdere professionalisering van BGZ? Of moeten BGD'en hun taak anders gaan opvatten? Plomp (Plomp 1991b) 
stelt dat de sleutel voor het adequaat opereren van professionals in relatie tot hun cliënten ligt in het kunnen onderscheiden en combineren van respectievelijk de rol van expert, de rol van adviseur of gezondheidkundig pleitbezorger, en de rol van organisatiegenoot.

In de volgende paragrafen wordt het thema professionaliteit versus klantgerichtheid verder uitgewerkt.

\subsubsection{BGZ volgens de snit van de klant}

De Arbowet laat (de kwaliteit van) BGZ de resultante zijn van het samenspel tussen werkgever en werknemer. BGD'en moeten zelf aan de bedrijven hun meerwaarde bewijzen. Marktgericht denken vindt langzamerhand een ingang. Maar is het realistisch om te veronderstellen dat BGD'en BGZ op maat kunnen leveren voor al hun klanten?

Technologische en sociaal-economische ontwikkelingen in het bedrijfsleven hebben verregaande repercussies op de kwaliteit van de arbeid (zie onder andere hoofdstuk 2). Van BGD'en, die zich bewegen op het snijpunt van gezondheidszorg en bedrijfsleven, wordt verwacht dat zij inspelen op de veranderde en zich nog steeds veranderende vraagstellingen (STG 1991). Er is een duidelijke afname van fysiek belastende arbeid, van oudsher een van de kernaandachtsgebieden van BGZ, en een forse toename van stress-gerelateerde klachten. De vraag is gerechtvaardigd of BGD'en in de huidige situatie, en bij de huidige financieringswijze, over voldoende andere deskundigheid en middelen beschikken om een adequaat antwoord te geven op deze nieuwe vraagstelling. Het onderzoek laat zien dat deskundigheid op dit gebied nog geen vertaling heeft gekregen in mensen of middelen.

BGD'en opereren in een complex relatie-netwerk, in een veld met ten dele tegengestelde belangen. Onderwerp van zorg en aandacht zijn meestal de werknemers, terwijl de werkgever de opdrachtgever en financier van BGZ is. Uit het onderzoek wordt duidelijk dat er sprake is van diverse klanten c.q. doelgroepen van de BGD, met ieder een verschillende vraagstelling! Grofweg gekarakteriseerd opteert personeelszaken van de bedrijven voor SMB-activiteiten door de BGD, de ondernemingsraad wenst een algemeen beleidsondersteunende rol van de BGD, met nadruk op activiteiten op de werkplek, terwijl de individuele werknemers tot slot individu-gerichte zorg verwachten. Opmerkelijk is de scherpe tegenstelling in verwachtingspatroon tussen personeelszaken en ondernemingsraad van EVD-bedrijven. In beeldspraak geformuleerd: het leveren van een maatpak door de BGD aan bedrijven volstaat niet, omdat het pak door meerdere mensen moet worden gedragen. Het leveren van meerdere pakken is niet haalbaar. Het is niet te betalen, het maakt het BGZ-relatienetwerk weliswaar bonter, maar onderstreept en scherpt eventuele tegenstellingen verder aan.

Het aantonen van de (meer)waarde van BGZ kan in conflict komen met de medische ethiek en met de door bedrijven aangereikte problematiek (Plomp 1987c). BGD'en bewegen zich namelijk voor een belangrijk deel op het gebied van "delicate" en gezondheidkundige problemen met een grote onzekerheidsfactor. Zonder 
schending van professionele codes, zoals het medisch beroepsgeheim, moet door BGD'en worden aangegeven welke bijdrage zij leveren aan de oplossing van individuele en bedrijfsproblematiek.

Tot slot moet nog worden geduid op het specifieke zorg- en longitudinale karakter van BGZ: BGZ als instrument om op groepsniveau de gezondheid van de werkende mens te bewaken c.q. om ziekte te voorkomen. Het synergistisch effect van het integraal ("arbobreed) uitvoeren van BGZ gaat verloren als het leveren van BGZ op maat wordt vertaald in het leveren van BGZ met mate, met het zich beperken tot het leveren van deelpakketten.

De vraag of de BGD BGZ op maat kan leveren, kan op grond van het voorgaande niet zondermeer met ja of neen worden beantwoord. BGD'en zullen expliciet een keuze moeten maken, welke diensten zij willen leveren, en aan welke klanten. Explicitatie naar de diverse klanten toe van de mogelijkheden, maar ook de onmogelijkheden van de BGD met betrekking tot verwachtingen van de klant. Het streven dient daarbij gericht te zijn op het leveren van een maatpak voor het hele bedrijf. Dit maatpak is echter samengesteld uit diverse onderdelen. Het ontbreken van essentiële onderdelen van het pak, of een slechte keuze van de kleuren en de schakering van onderdelen, leveren hoogstens een clownspak op.

\subsubsection{BGZ volgens de snit van de professional}

Kwaliteit van BGZ kenmerkt zich door een synthese van professioneel verantwoorde dienstverlening (de vertaling door de professional van door de klant aangedragen problemen in een activiteitenplan) en een klantgerichte communicatie met en informatie naar het bedrijf.

Door de NVAB en LVSG worden diverse activiteiten ondernomen om de professionele kwaliteit verder te ontwikkelen (LVSG 1991, NVAB 1989i, NVAB 1989j). Het gaat dan om de ontwikkeling van een beroepscode voor bedrijfsartsen, van protocollering van BGZ-taken zoals het aanstellingsonderzoek, en van introductie in de sociale geneeskunde van intercollegiale toetsing als methodiek om proceskwaliteit van BGZ-handelen te verbeteren. Deze ontwikkelingen zijn van eminent belang voor de professie, zij ontleent hieraan immers haar positie en legitimatie om als deskundig adviseur van werkgevers en werknemers op te treden. Immers, de feitelijke kern van het domein van BGZ waarover tussen BGD, werkgevers en werknemers algemene overeenstemming bestaat, is de individuele medische zorg. De betrokkenheid van de BGD bij andere aangelegenheden, zoals ondersteuning van het algemeen beleid, varieert sterk. Een dergelijke inbreng wordt ook niet door alle groeperingen van de klant gewenst. Het dilemma waarmee de bedrijfsarts wordt geconfronteerd is dat van enerzijds betrokkenheid en anderzijds autonomie.

Ook in dit onderzoek wordt bevestigd dat de positie van waaruit naar de BGD wordt gekeken de waardering van de dienstverlening bepaalt (vergelijk Plomp 1987 c en Tanke 1985). Voor personeelszaken is vooral een actieve SMB-rol van belang, de ondernemingsraad wenst een bredere inbreng. 
De dominantie van de professional blijkt in dit onderzoek bij de totstandkoming van contracten tussen BGD en bedrijf. De bedrijven blijken zelden substantiële invloed te hebben gehad bij de inhoud van het contract, de invloed beperkt zich tot het regelen van financiële zaken. Rond de helft van de GD-bedrijven zou meer invloed wensen op het takenpakket van de BGD en de wijze waarop diensten moeten worden verleend. De professionele taakopvatting is ook uiting van produktgerichtheid en zich concentreren op de eigen (BGD-)organisatie. Eigen initiatieven worden niet ontplooid, er wordt niet ongevraagd advies uitgebracht, er wordt geen brede BGZzorg geleverd. De ondernemingsraad ervaart weinig steun van de BGD als de bedrijfsarts een professionele takkopvatting heeft, en ook personeelszaken vertaalt een professionele taakopvatting als niet klantvriendelijk, dat wil zeggen met weinig ruimte voor de klant om zijn problematiek in te brengen. Een eenzijdige ontwikkeling van de professionaliteit zal dan ook op termijn tot verlies van het contact met de klant leiden omdat geen of onvoldoende communicatie tussen BGD en klant tot stand komt. Het zal de bedrijfsarts verder opsluiten in zijn ivoren toren: hierbij goed kunnen overzien hoe het zou moeten, maar weinig of geen gehoor vindend. Een evenwichtige ontwikkeling van zowel professionaliteit als klantgerichtheid is dan ook van belang voor duurzame relaties tussen BGD en bedrijf.

\subsubsection{BGZ, een kwestie van een andere taakopvatting. Socianl-medische begeleiding als voorbeeld?}

Uit de positie van BGD'en vloeit logischerwijs voort dat het dienstenpakket van BGD'en zich regelmatig wijzigt en aanpast aan veranderde arboproblematiek en veranderde vraagstelling van de klant. Sociaal-medische begeleiding is hiervan een goed voorbeeld. Niet in het minst door impulsen van de overheid (motie Beylen Geerts, Najaarsoverleg 1990) kreeg SMB voor BGD'en een minder vrijblijvend karakter. In deze paragraaf komt aan de orde of en zo ja onder welke voorwaarden BGD'en er goed aan doen in te spelen op deze ontwikkeling, waarin integratie moet plaatsvinden van tot dusver gescheiden circuits in de begeleiding van zieke werknemers.

De discussie over de schadelijkheid voor de vertrouwensrelatie tussen arts en patient bij het in eén persoon integreren van de sociaal-medische begeleiding is reeds oud (Bleeksma 1985). De unieke scheiding tussen behandeling en controle in $\mathrm{Ne}$ derland, bracht twee circuits tot stand. Het ene, het curatieve circuit, dat de patiēnt als het ware in bed legde omdat hij ziek was, en het andere, het verzekeringsgeneeskundig kader, dat de patient weer tot cliënt en participant van het arbeidsproces probeerde te maken en de patient dus als het ware uit zijn bed probeerde te krijgen. De zieke werknemer krijgt met een scala van artsen te maken. De vraag naar geîntegreerde gevalsbehandeling kon dan ook niet uitblijven. Dat hierbij diverse partijen zich primus inter pares achtten, lag ook voor de hand. De overheid koos medio 1991 voor een systeem waarbij alle betrokken partijen meer op hun verantwoordelijkheden konden worden aangesproken: werkgevers, werknemers, en de uitvoerende instanties van de sociale verzekeringen (TAV, TZ, TBA), BGD'en 
kregen een belangrijke rol toegewezen bij de begeleiding van het initiële verzuim (tot zes weken). De NVAB nam reeds eind 1990 een voorschot op de uitkomst van de politieke discussie, door een beleid voor te stellen waarbij de bedrijfsarts ook bij de begeleiding van het verzuim een spilfunctie zou krijgen. De angst voor schade van de vertrouwenspositie komt echter cok in dit voorstel naar voren. Immers, claimbeoordeling of conflictueuze situaties dienen de zorg van een ander te zijn. Is deze angst, op basis van het onderzoek, terecht?

Allereerst blijkt uit het onderzoek dat de ontwikkelingen op dit gebied snel gatan. Ten tijde van het onderzoek bevroedde nog geen $10 \%$ van de directies van BGD'en dat dit wel eens opgelegd zou kunnen worden, al toonde rond de helft zich wel voorstander van een combinatietaak bedrijfsarts-verzekeringsgeneeskundige. Uit tabel 10.1 kan de mening worden gelezen van respectievelijk bedrijfsarts, directie BGD, personeelszaken en ondernemingsraad over de mogelijke schadelijkheid van een combinatiefunctie. Opmerkelijk is dat de klant het combineren van BGZ en verzekeringsgeneeskunde in éen hand, schadelijker acht voor de vertrouwensrelatie arts-patiënt, dan de leveranciers van BGZ zelf (statistisch niet significant). Met name de ondernemingsraad verwacht dat de combinatiefunctie schadelijk is. Het contrast in de mening tussen ondernemingsraad en bedrijfsarts in EVD-bedrijven is groot.

Tabel 10.1. Invloed verzekeringsgeneeskundige taak op de arts-patiznt relatie. Deze invked wordt schadelijk geacht door:

\begin{tabular}{|c|c|c|c|c|c|}
\hline & & bedrijfsarts & personeelszaken & directie BCFD & ondernemingsraad \\
\hline GD & $N=$ & 17 & 20 & 32 & 16 \\
\hline & & $7(41 \%)$ & $10(50 \%)$ & $5(16 \%)$ & $13(81 \%)$ \\
\hline EVD & $N=$ & $\begin{array}{c}15 \\
0\end{array}$ & $\begin{array}{l}12 \\
3(43 \%) \|\end{array}$ & $\begin{array}{l}20 \\
3(17 \%)\end{array}$ & $\begin{array}{l}10 \\
7(70 \%)\end{array}$ \\
\hline
\end{tabular}

I non-respons EVD-hedrijven

Waar hangt het nu in de praktijk van af of ondernemingsraad c.q. werknemers de verzuimbegeleiding van de BGD als controle ervaren? Komt dit door de manier waarop taken worden uitgevoerd, of is de mening hierover meer de resultante van de (voor)oordelen die samenhangen met de inschatting van de positie van de BGD door ondernemingsraad en werknemers? Beiden blijken van belang. Het snel contact opnemen met zieken en een hoog verzuim gaan in EVD-bedrijven, waar de combinatiefunctie bedrijfsarts-verzekeringsgeneeskundige algemeen voorkomt, samen met het ervaren van de verzuimbegeleiding als controle door onderneimingsraad en werknemers. Maar er speelt meer. Er kon worden vastgesteld dat de BGD in GD-bedrijven wordt geaccepteerd als een extern adviseur die erin kan slagen met de verschillende klanten in het bedrijf een consistente samenwerking op te bouwen, zonder dat dit ten koste gaat van de een of de ander. In de onderzochte EVD-bedrijven daarentegen bleek het niet mogelijk voor de BGD cen consistente samenwerking op te bouwen met het klantensysteem als geheel: als de ondernemingsraad de samenwerkingsrelatie tussen BGD en personeelszaken als consistent schetst, 
schetst zij tegelijkertijd de samenwerking tussen de BGD en haarzelf als niet consistent. De BGD in EVD-bedrijven is als onderdeel van het bedrijf per definitie partij, onderdeel van het systeem, en wordt gedwongen een positie in te nemen, waarbij recht moet worden gedaan aan zowel personeelszaken als ondernemingsraad. Het als controle ervaren van verzuimbegeleiding wordt vaker beter verklaard door deze "machtsstrijd" tussen personeelszaken en ondernemingsraad in EVDbedrijven. Speelt de BGD in welke zin dan ook een ondersteunende rol voor de ondernemingsraad, dan wordt de verzuimbegeleiding niet als controle ervaren.

Ook bij GD-bedrijven kan het belang van de positie van de BGD worden vastgesteld op de lading die aan de verzuimbegeleiding wordt gegeven. De BGD in grotere GD-bedrijven, waar de BGD vaker de BGZ-gegevens op groepsniveau registreert, en waar de BGD vaker wordt ingeschakeld op algemeen beleidsterrein, wordt in de ogen van de klant ook partij door de positie die zij dan gaat innemen (van extern naar intern adviseur). De werknemers ervaren in dit geval de verzuimbegeleiding van de BGD vaker als controle. Met andere woorden, het integreren van de SMB in één persoon vraagt de nodige manoeuvreer-kunst tussen enerzijds wel SMB-activiteiten ontplooien, maar anderzijds ook invulling geven aan de andere BGZ-taken, zonder dat dit moet leiden tot te sterke vereenzelviging met c.q. betrokkenheid van de BGD bij het bedrijfsgebeuren. Een zekere professionele distantie lijkt wenselijk om de SMB-rol in éen persoon te kunnen integreren.

\subsection{Aanbevelingen}

In deze afsluitende paragraaf worden op basis van het onderzoek en persoonlijke visie enige aanbevelingen gedaan. Aan de orde komt welke bijdrage de overheid, de beroepsgroep en de BGD'en zelf kunnen leveren aan de totstandkoming van een kwaliteitszorg binnen BGD'en die recht doet aan de eigen professionaliteit en aan de wensen en behoeften van de klant.

\subsubsection{De overheid}

De overheid trekt zich terug ten aanzien van de bewaking van de kwaliteit van $\mathrm{BGZ}$. $\mathrm{Er}$ is cen ontwikkeling te onderkennen van wettelijke erkenning door de Minister naar onafhankelijke certificering door een private instantie. De overheid volstaat met het aangeven van minimum-normen ten aanzien van de kwaliteit van zorg. In dit kader zal vooral een zwaardere eis worden gesteld ten aanzien van de multidisciplinaire professionaliteit van diensten die arbozorg leveren. Het streven is erop gericht diensten te formeren, die in potentie het brede arboterrein kunnen bestrijken, maar naar bedrijven toe bestaat slechts, mede afhankelijk van de omvang en inhoud van de arborisico's, de verplichting tot afname van een beperkt (kern)takenpakket (een op schrift gestelde arborisico-inventarisatie en - evaluatie, verzuimbegeleiding en arbeidsgezondheidkundig (periodiek) onderzoek (Mulock Houwer 1992). Deze taken zullen bedrijven moeten betrekken van een dienst met 
het hoogste deskundigheidsniveau. De overige BGZ-taken, voor zover nodig gebleken uit de risicobepaling of rechtstreeks voortvloeiend uit de wet, kan de werkgever onderbrengen bij wie hem goeddunkt, zij het dat dit onder controle en toezicht van de Arbeidsinspectie staat. De huidige verplichte bedrijven moeten hun volledige zorg betrekken bij een gecertificeerde dienst.

Het onderzoek maakt duidelijk dat er bij BGZ partijen zijn betrokken, die een verschillend belang hebben ten aanzien van relevant geachte aspecten van kwaliteit. Naar onze mening is dan ook een meer nadrukkelijke, actief-stimulerende en coordinerende rol van de overheid noodzakelijk, onder andere door (financiële) ondersteuning van wetenschappelijk onderzoek op arbogebied (Bayens 1992, Van Dijk 1992).

De overheid acht de zorg voor goede arbeidsomstandigheden in de eersie plaats de taak en de verantwoordelijkheid van werkgevers en werknemers in de bedrijven. De overheid stimuleert en handhaaft de naleving van de basisnormen, stuurt waar zorg(uitbreiding) achterblijft, zij ziet haar taak als voorwaardenscheppend, het is haar verantwoordelijkheid om de maatschappelijke doelstellingen die moeten worden gerealiseerd te definiëren.

De resultaten van het op het niveau van de sociale partners ontwikkeld beleid op het terrein van arbeidsomstandigheden en sociale zekerheid (gedacht kan worden aan de povere effecten van de WAGW en haar voorloper, alsmede de resultaten van een onderzoek naar de effectiviteit van de "interventies" van de Arbeidsinspectie op de arbeidsomstandigheden in bedrijven (DGA 1992)), zijn van dien aard en beperkte betekenis, dat het legitiem is de vraag te stellen naar het rendement van het hiervoor geschetste beleid van de overheid. Wil de overheid daadwerkelijk werk maken van terugdringing van arbeidsgebonden verzuim en arbeidsongeschiktheid, dan kan zij zich niet vrijblijvend opstellen. Aan het samenspel werkgeverwerknemers kan de overheid concreet arbo-inhoud geven als zij zorg draagt voor een adequate financiering van arbozorg en de daarvoor noodzakelijke deskundigheid.

In dit kader gunstige ontwikkelingen zijn het aannemen van de motie van het kamerlid Beylen Geerts, waarin werd uitgesproken dat een vorm van BGZ voor alle werknemers verplicht gesteld moet worden, en de implementatie van de Kaderrichtlijn 89/391/EEG in de Arbowet, waarmee beleidsvoering en ondersteuning door geregistreerde arbodeskundigen op arbogebied expliciet gemaakt zal worden (Feringa et al 1992, Kwantes 1992, Van Blijswijk 1992). Van belang is dan wel dat het deskundigheidsniveau, dat als bodemniveau binnen de bedrijven door de overheid wordt vereist, voldoende is, omdat anders de binnen een bedrijf aangewezen arbodeskundige, zoals Van den Burg (Van den Burg 1992) het verwoordt, meer de kenmerken heeft van een "preventie-padvinder". 


\subsubsection{De beroepsgroep}

De NVAB kan een belangrijke rol spelen bij de vormgeving aan kwaliteitszorg. Zij heeft hiertoe ook al duidelijk initiatieven genomen, bijvoorbeeld door het opstellen van een beroepscode en het formuleren van consensus-beleid ten aanzien van aanstellingskeuringen. Bij uitstek kan zij stimulerend en coördinerend optreden bij het tot stand brengen van protocollen van relevante BGZ-taken. Ondersteund door wetenschappelijke instituten, DGA, en stichting kwaliteit BGZ (SKB) en overkoepelende organisaties van de verschillende BGD-organisatievormen, dienen protocollering en het ontwikkelen van methoden voor proces- en produktkwaliteit verder gestalte te krijgen.

Daarnaast zal de opleiding voor bedrijfsartsen beter moeten aansluiten bij de huidige eisen. Een door Wolvetang, bij zijn afscheid als cursusleider van de bedrijfsartsenopleiding, in 1989 gedaan voorstel tot wijziging van de opleiding (en in 1992 verder uitgewerkt door de Commissie Onderwijs en Opleiding van de NVAB, NVAB 1992d), doet meer recht aan een kwalitatief verantwoorde scholing van bedrijfsartsen. Zijn model, dat kan worden gekenschetst als een leermeester-gezelscenario, geeft betere mogelijkheden om praktijkervaring op te doen die wordt getoetst aan de ervaring en kwaliteit van senior-bedrijfsartsen. Dit laat overigens bredere inbreng in de opleiding of nascholing van het marketingdenken, marketinginstrumenten, en een strategisch- en probleemgerichte advisering onverlet.

\subsubsection{De BGD'en}

Binnen BGD'en moet er systematische aandacht komen voor kwaliteitszorg, dat wil zeggen dat het management vorm en inhoud geeft aan zorg voor kwaliteit en dit vastlegt in een kwaliteitsbeleid. Dit beleid moet passen binnen het algemene beleid van de BGD (missie, marktsegmenten). Verwacht kan worden dat BGD'en, naast basistaken met een min of meer longitudinaal en langerlopend karakter (het aspect "zorg"), vaker projectgebonden zullen moeten gaan werken. Dit stelt eisen aan de flexibiliteit, ge dynamiek van de BGD-organisatie, het maakt veranderingsbereidheid en bekwaamheid van BGD-medewerkers noodzakelijk. Dit moet onder andere tot uiting komen in het kwaliteitsbeleid. Er moet worden vastgelegd welke doelen en welke resultaten de BGD wil behalen. De resultaatindicatoren moeten van belang zijn voor de klant. Om het kwaliteitsdenken binnen BGD'en gestalte te geven, dienen er in de voorwardenscheppende zin door het management op beheersmatig en uitvoeringsgebied ondersteunende maatregelen genomen to worden (Federatie 1990c).

Op heheersmatig gebied kan worden gedacht aan: scholing van medewerkers (opleidingsplan), het aanstellen van een kwaliteitsmanager, het houden van functioneringsgesprekken met medewerkers om lacunes in de dienstverlening op te sporen. het beheer (richtlijnen voor gebruik en onderhoud) van faciliteiten (zoals apparatuur, bibliotheek, wachtruimte etc). 
Op uitvoeringsgebied dient aandacht te worden gegeven aan de zogenaamde centrale functies (acquisitie, klachtenbehandeling, contract, vaststellen werkplannen, opstellen protocollen, procedures en werkinstructies, document- en archiefbeheer), de kerntaken van de BGD, en de klantgerichtheid van de medewerker. De nadruk moet liggen op het stimuleren van kwaliteitsbewustzijn, het creëren van de bereidheid van de BGD-medewerker zich te verantwoorden en de wensen en behoeften van de klant centraal te stellen. Het management kan blijk geven van haar bereidheid om de klant centraal te stellen door op systematische wijze de diensten en de dienstverlening te evalueren. Dit kan in de vorm van periodieke gesprekken met bedrijven, een klachtenbehandelingsprocedure, of toepassing van het SERVQUALmodel (Parasuraman et al 1986).

De individuele BGD-medewerker moet het klantgericht zijn in zijn dagelijks werk opnemen. Intercollegiale toetsing per functiegroep of kwaliteitskringen voor BGZteams, kunnen een bijdrage leveren aan een verbetering van met name de proceskwaliteit van BGZ, te weten van: de interne en externe dienstverlening, het persoonlijk functioneren, en de gebruikte methodieken en instrumenten warmee BGZ wordt geleverd. Het nadeel van toetsing blijft dat het een retrospectieve vorm van kwaliteitsborging is. Het dient dus in samenhang te worden gezien met activiteiten die gericht zijn op het bevorderen van de kwaliteit van zorg.

Het vastleggen van de afgesproken diensten en dienstverlening tussen BGD en bedrijf in een werk- of dienstverleningsplan, maakt BGZ toetsbaar en beheersbaar.

Kwaliteitszorg is een continu proces. Met als inzet de klant en zijn arboproblemen, moet in dit proces worden gestreefd naar optimalisering van de kwaliteit van het gevoerde beleid, de gehanteerde beheersingsmethodieken, en de benodigde vakkennis, vaardigheden en attitude.

Kwaliteitszorg vraagt een aanpak langs twee sporen. Aan de ene kant moeten activiteiten worden gericht op een permanente verhoging van de professionele kwaliteit, aan de andere kant moet er een continue aandacht zijn voor klantgerichte kwaliteit. BGZ heeft expliciet te maken met deze twee aspecten van kwaliteit. Het kan ook anders worden geformuleerd. Naast de outputkwaliteit (de kwaliteit van de dienst) bestaat er de proceskwaliteit (de dienstverlening).

De resultaten van dit onderzoek bevestigen het beeld dat de BGD, de bedrijfsarts nog teveel opereert vanuit de ivoren toren van de BGD. De prioriteit bij kwaliteitszorg van BGD'en zal (voorlopig) gelegd moeten worden bij de verhoging van klantgerichte aspecten van kwaliteit, zonder natuurlijk professionele kwaliteit uit het oog te verliezen. De toepassing en integratie van de marketing-mentaliteit en de marketinginstrumenten binnen de BGD op alle niveaus (integrale kwaliteitszorg), kan hieraan een waardevolle bijdrage leveren. De bereidheid van de professional zich te verantwoorden is cruciaal voor het kunnen laten welslagen van kwaliteitszorg. Een verantwoordingsbereidheid naar de klant, maar ook naar de BGD, naar de beroepsgroep. 


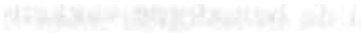

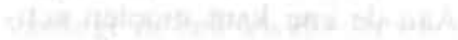

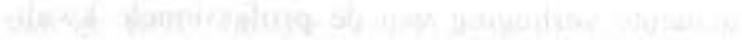

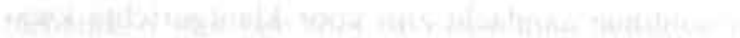

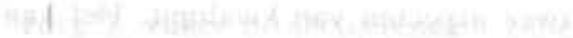

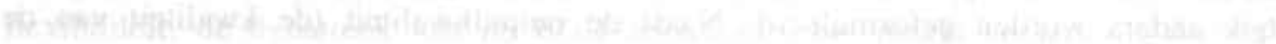

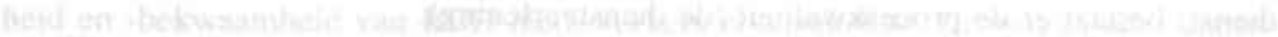

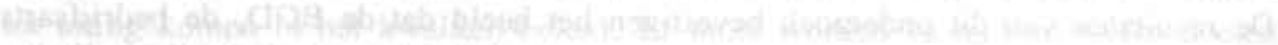

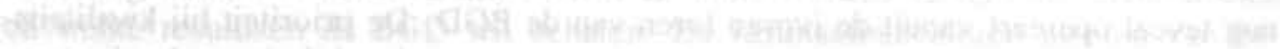

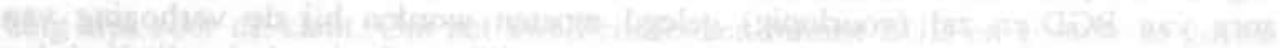

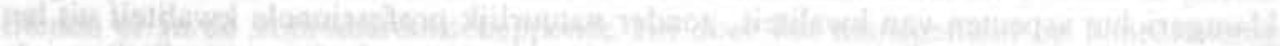

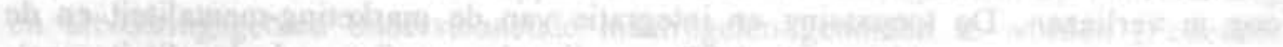

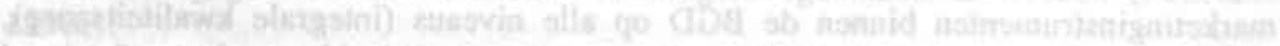

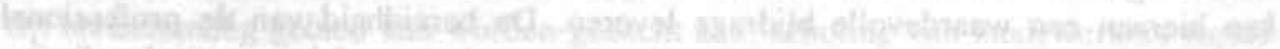

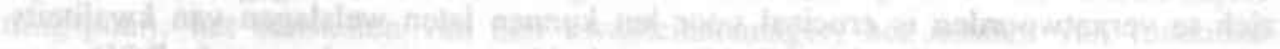

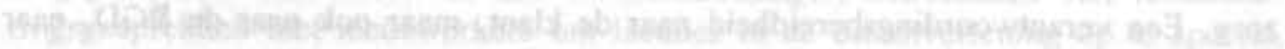

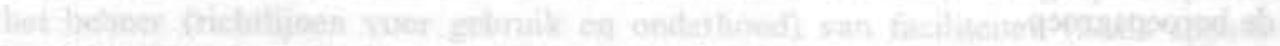

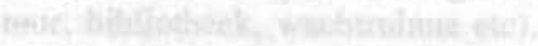




\section{Samenvatting}

In dit exploratieve, transversale onderzoek wordt de kwaliteit van de bedrijfsgezondheidszorg (BGZ) beschreven zoals die wordt ervaren door leverancier en ontvanger. Bij deze beschrijving wordt de aspectbenadering gehanteerd, dat wil zeggen dat hier aspecten worden beschreven die mogelijk een positieve invloed hebben op het kwaliteitsniveau van BGZ zonder dat een definitie in strikte zin van kwaliteit wordt gegeven.

Het kwaliteitsniveau wordt langs twee sporen benaderd: professionaliteit en klantgerichtheid, waarbij de doelstelling van BGZ, namelijk het "leveren van een bijdrage aan het optimaliseren van de gezondheid van de werkende mens" steeds als achtergrond dient voor de beoordeling van de ervaren kwaliteit.

Als belangrijkste leveranciers van BGZ gelden de bedrijfsgezondheidsdiensten (BGD'en). Zij opereren binnen een complex relatienetwerk van partijen die soms tegengestelde belangen hebben en de kwaliteit van BGZ kunnen beïnvloeden (zie figuur 1).

De ontvangers van BGZ zijn primair de werknemers, maar met de werkgever gaan BGD'en dienstverleningscontracten aan.

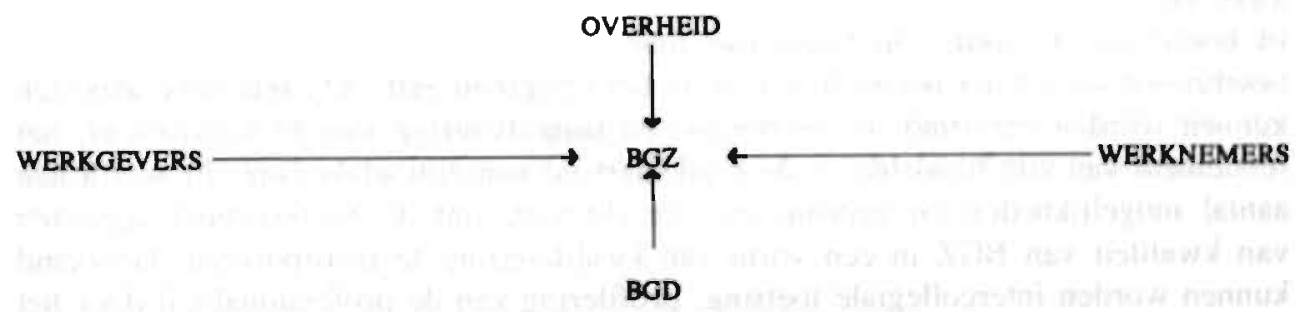

Figuw 1. Partijen die de kwaliteil van BGZ kunnen beïavloeden

De spanningsvelden die in dit netwerk kunnen optreden zijn als volgt te onderscheiden:

- verschillen in verwachtingspatroon bij klanten (werkgevers en werknemers)

- verschillen in verwachtingspatroon bij BGD'en enerzijds en klanten anderzijds

- verschillen in verwachtingspatroon bij de binnen BGD'en opererende Arbodeskundigen

- verschillen in waardering van BGZ door de klanten.

Deze spanningsvelden kunnen in positieve zin worden beïnvloed wanneer BGD'en zich duidelijk profileren. Het is voor de BGD'en vanzelfsprekend en ook noodzakelijk dat ze zich voortdurend bezinnen op de vraag welke diensten zij moeten leve- 
ren. Dit geldt eens te meer nu in het afgelopen decennium sterke veranderingen (crises zo men wil) zijn opgetreden op een tweetal terreinen waarmee de BGD'en logischerwijs - ze bevinden zich immers op het snijpunt van de gezondheidszorg en het bedrijfsleven - werden geconfronteerd, namelijk veranderingen in de gezondheidszorg en veranderingen in (de organisatie) van arbeid. Door zowel de leverancier als ontvanger werd kritiek geuit dat BGD'en onvoldoende (snel) inspeelden op de veranderde behoefte en wensen.

Hoofdstuk 2 beschrijft de kritiek van de klant (werkgever, werknemers), de beroepsgroep (NVAB) en de overheid. In hun kritiek hebben deze groepen gemeen dat BGD'en onvoldoende toegankelijk waren voor wensen en behoeften van klanten. Onvoldoende traden BGD'en in overleg met de klant, onvoldoende slaagden zij erin wensen van klanten in concrete BGZ-activiteiten te vertalen. BGD'en slaagden er onvoldoende in hun "toegevoegde waarde" te bewijzen.

Hoewel het onderzoek de rol van de overheid niet behandelt, beschrijft hoofdstuk 5 de (veranderde) rol en invloed van de overheid (en wetgeving) op (de kwaliteit van) BGZ. De overheid treedt terug. Dit is een trend die internationaal kan worden waargenomen. De verantwoordelijkheid voor een goed arbeidsomstandighedenbeleid wordt gelegd bij de sociale partners en op bedrijfsniveau in het samenspel werkgever-werknemer. De overheid volstaat met het formuleren van minimumeisen en een gewenste situatie.

De in dit onderzoek gekozen tweesporen-benadering van de kwaliteit van BGZ onderscheidt twee clusters van kwaliteitsaspecten: professionele en klantgerichte aspecten.

In hoofdstuk 3 wordt, op basis van literatuuronderzoek, de kwaliteit van BGZ beschreven vanuit het perspectief van de beroepsgroep zelf. Als relevante aspecten kunnen worden genoemd: de werkwijze en taakuitvoering van de bedrijfsarts, het rendement van zijn handelen en de bruikbaarheid van zijn advisering. Er wordt een aanta! mogelijkheden en instrumenten beschreven, om de professionele aspecten van kwaliteit van BGZ in een vorm van kwaliteitszorg te incorporeren. Genoemd kunnen worden intercollegiale toetsing, profilering van de professionaliteit door het formuleren van beroepscodes, en protocollering van BGZ-taken.

In hoofdstuk 4 wordt het begrip marketing besproken. Marketing zou aan de BGZ een kwalitatieve bijdrage kunnen leveren. Enerzijds ligt deze bijdrage in het expliciteren van een klantgericht dienstenpakket, anderzijds in het benadrukken van het belang van klantgerichte aspecten van kwaliteit voor een "totaal" kwaliteitsoordeel. Het SERVQUAL-model biedt een mogelijkheid om een aantal essentiële klantgerichte kwaliteitsaspecten te inventariseren, met name op het operationele niveau van BGD-activiteiten. Industriële marketingprincipes, waar reeds veel ervaring mee is opgedaan, zijn niet zondermeer van toepassing binnen de dienstverlening, aangezien er een aantal essentiële verschillen is tussen het leveren van een dienst en het maken van een produkt. Alvorens marketing te kunnen toepassen binnen BGD'en, zal een aantal knelpunten moeten worden opgelost. BGD'en zullen de diensten die 
zij willen leveren en de doelgroepen die zij willen bereiken duidelijk moeten benoemen, BGD'en zullen moeten leren de klant meer expliciet te betrekken bij het formuleren van behoeften en een hieruit resulterend dienstenaanbod, en BGD'en zullen het belang moeten erkennen van de beoordeling van de dienstverlening door de klant voor de kwaliteit van BGZ.

De vraagstelling van het onderzoek is tweeledig. In de eerste plaats wordt geprobeerd de vraag te beantwoorden hoe leverancier en ontvanger van BGZ de kwaliteit van BGZ ervaren op de respectieve aspecten professionaliteit en klantgerichtheid. Daarnaast is onderzocht welke bedrijfs- en bedrijfsartsvariabelen samenhangen met de ervaren kwaliteit. Op een aantal verschillen tussen BGD-organisatievormen (respectievelijk de gezamenlijke bedrijfsgezondheidsdienst (GD) en enkelvoudige bedrijfsgezondheidsdienst (EVD)) wordt gewezen. Bij de keuze van de variabelen is zoveel mogelijk gekeken naar de taken en taakuitvoering van de bedrijfsarts, zoals deze worden genoemd in de Arowet, en zoals deze concreet worden uitgevoerd.

De doelen van dit exploratieve onderzoek waren een algemene verkenning van het voorkomen van een tweetal clusters van aspecten van kwaliteit (professionaliteit en klantgerichtheid), een eerste oriëntatie met betrekking tot factoren gekoppeld aan de bedrijfsarts of het bedrijf die met deze aspecten van kwaliteit samenhangen, en het exploreren van eventuele verschillen in ervaren kwaliteit tussen GD en EVD.

De onderzoekgegevens werden verkregen door schriftelijke enquêtering van een steekproef uit de directies van BGD'en, bedrijfsartsen van BGD'en, hoofden personeelszaken, voorzitters werknemersvertegenwoordigingen en werknemers van technische diensten. Aan alle respondenten werd hun mening gevraagd over verschillende aspecten van de ervaren kwaliteit van BGZ, geleverd aan een concreet en benoemd bedrijf. Overigens kan worden opgemerkt dat de onderscheiden aspecten van kwaliteit van BGZ niet in gelijke mate kunnen worden beoordecld door de respectieve respondenten. In figuur 2 wordt het onderzoeksmodel weergegeven. 


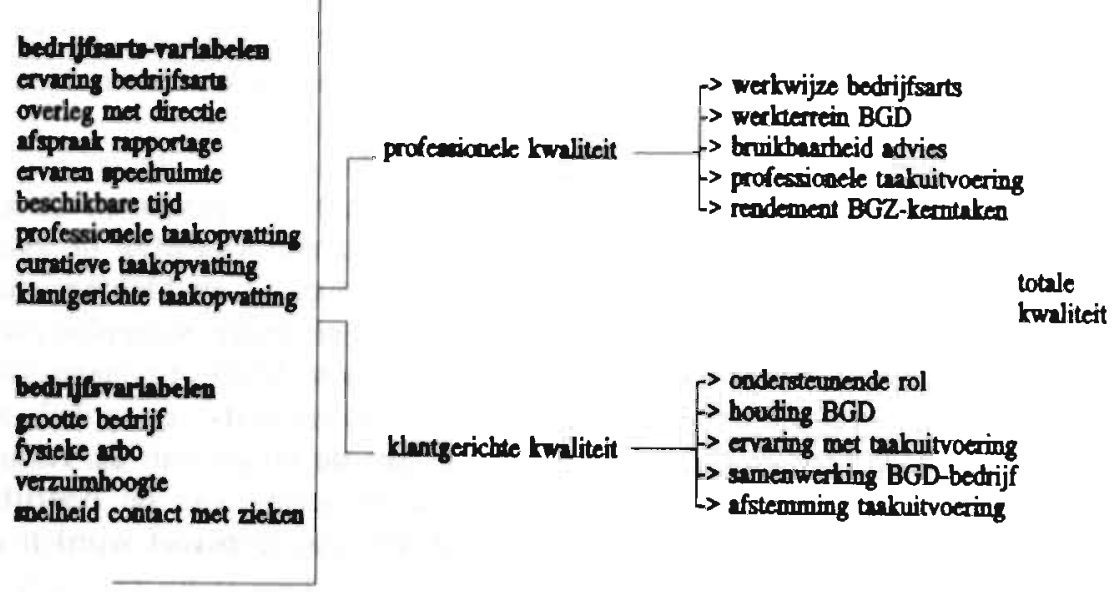

Flguur 2. Het onderzoeksmodel

Hoofdstuk 7 geeft een beschrijving van het BGZ-relatienetwerk. Als opmerkelijke bevindingen kunnen worden genoemd de dominantie van de professional bij de totstandkoming van het contract tussen BGD en bedrijf en de discrepantie in gewenste financiering van $B G Z$ en de organisatie van de verzekeringsgeneeskundige taak tussen leverancier en klant. Het interactieproces tussen BGD en bedrijf en het hieruit resulterende dienstenpakket leidt tot een andere inzet van mensen en middelen. Overigens lijkt het erop dat in de onderzochte EVD-bedrijven de discussie over vorm en inhoud van de gewenste dienstverlening niet expliciet plaatsvindt.

De bedrijfsartsen in dit onderzoek kunnen op basis van hun taakopvattingen over BGZ worden onderscheiden in drie groepen: bedrijfsartsen met een curatieve taakopvatting (met onder andere als kenmerken curatieve ervaring en wensen), professionele taakopvatting (met onder andere als kenmerk de eigen mening doorslaggevend te laten zijn), en klantgerichte taakopvatting (met onder andere als kenmerk een klantvriendelijke opstelling).

In hoofdstuk 8 worden de onderzochte aspecten van kwaliteit van BGZ beschreven. De kwaliteit wordt, zoals reeds werd aangegeven, beschreven langs twee sporen. Het ene spoor leidt langs een aantal aspecten van professionele kwaliteit, het andere spoor langs een aantal aspecten van klantgerichte kwaliteit.

De belangrijkste bevindingen met betrekking tot de professionele kwaliteit kunnen als volgt worden samengevat.

De BGD heeft regelmatig contact met het bedrijf. De GD-bedrijfsarts maakt vaker afspraken over rapportage dan de EVD-bedrijfsarts. Hij rapporteert ook vaker. Er wordt in het algemeen vaker gerapporteerd aan de directie dan aan de onderne- 
mingsraad van het bedrijf. Het bedrijf neemt meestal zelf het initiatief om BGZactiviteiten te entameren. De opstelling van de BGD is te karakteriseren als reactief, reagerend op signalen uit het bedrijf. De BGD houdt zich in hoofdzaak bezig met individugebonden problematiek, en zij wordt zelden ingeschakeld op algemeen beleidsterrein, zoals bijvoorbeeld bij nieuwbouw. In zijn algemeenheid lijkt de BGD nasst de kerntaken (en EHBO) weinig extra activiteiten te ontplooien. De advisering van de BGD wordt door personeelszaken als goed bruikbaar ervaren. De ondernemingsraad is in het algemeen minder positief over de kwaliteit van advisering dan personeelszaken. Ook door bedrijfsartsen, die geen formele verzekeringsgeneeskundige taak hebben, worden regelmatig uitspraken gedaan over de arbeids(on)geschiktheid van werknemers. Werknemers ervaren bij het periodiek onderzoek zelden een verband met het werk. De rol van de bedrijfsarts op de werkplek is meestal reactief, dat wil zeggen dat hij zal reageren op signalen en verzoeken van het bedrijf. De BGZ-kerntaken hebben in de ogen van de ondernemingsraad maar weinig rendement.

De belangrijkste bevindingen met betrekking tot de klantgerichte kwaliteit kunnen als volgt worden samengevat.

Eenderde (GD-bedrijven) tot de helft (EVD-bedrijven) van personeelszaken is van mening dat de BGD in belangrijke mate een ondersteunende rol speelt bij de totstandkoming van het sociaal beleid. De ondernemingsraad is minder vaak dan personeelszaken van mening dat de BGD in belangrijke mate het sociaal beleid ondersteunt. De BGD wordt als een laagdrempelige voorziening beschouwd, maar de houding van de BGD-medewerkers wordt, meer in GD- dan in EVD-bedrijven, niet altijd ervaren als klantvriendelijk.

De uitvoering van het aanstellingsonderzoek en het periodiek onderzoek wordt door de werknemers als positief ervaren. Sociaal-medische begeleiding (SMB) wordt in $10 \%$ van de GD-bedrijven en in ongeveer een derde van de EVD-bedrijven als controle ervaren. Volgens $90 \%$ van de ondernemingsraad in GD-bedrijven en ongeveer de helft van de ondernemingsraad in EVD-bedrijven heeft de BGD voldoende kennis van de werkomstandigheden. De samenwerking tussen BGD en bedrijf wordt door BGD en bedrijf als positief ervaren.

De klant (ondernemingsraad en werknemers) en de bedrijfsarts hebben wensen over de uitvoering van de kerntaken, waaraan in de praktijk (nog)niet wordt voldaan. Met name is dit het geval bij het periodiek onderzoek en het werkplekonderzoek. De ondernemingsraad en de werknemers ondersteunen de wens van de bedrijfsarts van een minder nadrukkelijke SMB-rol. De mening van personeelszaken hierover is niet bekend.

In hoofdstuk 9 wordt de invloed onderzocht van een aantal bedrijfsarts- en bedrijfsvariabelen op de onderzochte aspecten van kwaliteit van BGZ.

In zijn algemeenheid kan worden gesteld dat er, gezien de beperkte omvang van de onderzochte populatie en de gevonden correlaties, en het transversale karakter van 
het onderzoek geen uitspraken kunnen worden gedaan over de causaliteit van gevonden verbanden. Nader onderzoek is hiervoor nodig.

De bevindingen laten zich als volgt samenvatten:

\section{Bedriffsarts-gebonden factoren}

Naarmate de bedrijfsarts langer werkzaam is voor het bedrijf (ervaring), wordt een aantal professionele aspecten van kwaliteit negatief beleefd. Er is geen significante invloed van de ervaring van de bedrijfsarts op de onderzochte klantgerichte aspecten van kwaliteit. Als opmerkelijk verschil tussen GD en EVD komt naar voren dat in EVD-bedrijven ervaring van de bedrijfsarts wel samengaat met een mening van de ondernemingsraad dat de BGD naast haar kerntaken voldoende doet.

Naarmate de bedrijfsarts vaker overleg voen met de directie van het bedrijf, is er sneller contact door de BGD met zieke werknemers. Het vaker overleggen met de directie van het bedrijf gaat ook samen met het toekennen van meer rendement aan het werkplekonderzoek. Dit kan erop wijzen dat de de BGD in het overleg met de directie de haalbaarheid van werkplekonderzoek en de oplossing van de hieruit voortvloeiende problematiek van tevoren toetst, en daarmee de effectiviteit van het handelen vergroot. Het vaker overleggen met de directie gaat overigens ook samen met een negatieve beleving van een tweetal klantgerichte kwaliteitsaspecten: de verzuimbegeleiding van de BGD wordt meer als controle ervaren, en de BGD onderneemt volgens de ondernemingsraad onvoldoende extra activiteiten naast haar kerntaken.

Naarmate er meer afspraken over rapportage aan het bedrijf worden gemaakt, is er vaker sprake van een klantgerichte taakopvatting van de bedrijfsarts. Als er afspraken worden gemaakt over het rapporteren aan het bedrijf wordt de samenwerking tussen BGD en personeelszaken consistenter, de bedrijfsarts rapporteert ook vaker in gelijke mate aan directie en ondernemingsraad. Op het medisch terrein sec (in casu periodiek onderzoek) blijkt de BGD beter aan de verwachtingen te kunnen voldoen dan op het terrein van werkplekonderzoek, waar een discrepantie optreedt tussen praktijk en wens c.q. verwachting.

In grote bedrijven ervaart de bedrijfsarts meer speelruimte. Opmerkelijk is dat deze grotere speelruimte niet sa!nengaat met het gevoel van grotere professionele autonomie. Het lijkt erop dat de BGD pas meer speelruimte ervaart als zij tenminste een nadrukkelijke SMB-rol speelt.

Naarmate de bedrijfsarts meer tijd ter beschikking heeft onderneemt hij vaker extra activiteiten. Hij zet deze tijdsruimte echter niet om in door de klant gewaardeerde activiteiten, zoals werkplekonderzoek.

De invloed van de taakopvatting van de bedrijfsarts op de onderzochte aspecten van kwaliteit is verschillend.

Een professionele taakopvatting gaat samen met een groot aantal negatieve ervaringen van de klant, zoals het minder steun ervaren van de BGD door de ondernemingsraad, en het als niet klantvriendelijk ervaren van de houding van de BGD. Een professionele houding wordt als afwachtend en afstandelijk ervaren. 
Een curatieve taakopvatting heeft geen significante samenhang met aspecten van professionele kwaliteit. De invloed van een curatieve takopvatting van de bedrijfsarts op de klantgerichte kwaliteit is verschillend tussen GD en EVD. In GD-bedrijven gaat een curatieve taakopvatting van de bedrijfsarts samen met het vaker bruik. baar vinden van de advisering door de ondernemingsraad en met het ervaren van meer steun van de BGD door de ondernemingsraad, terwijl in EVD-bedrijven een curatieve taakopvatting van de bedrijfsarts door de klant als negatief wordt ervaren: de ondernemingsraad ervaart de verzuimbegeleiding als controle, de samenwerking tussen BGD en ondernemingsraad is minder consistent. De nadruk komt te liggen op SMB, een door de EVD-bedrijfsarts en personeelszaken gewenste activiteit. Het gaat echter ten koste van het (kunnen) ondernemen van extra activiteiten.

Een meer klantgerichte takopvatting van de bedrijfsarts gaat samen met het minder snel contact opnemen met zieken, en het vaker maken van afspraken over rapportage. Het lijkt erop dat klantgerichtheid wordt geïnterpreteerd als het zich meer richten naar de wens van ondernemingsraad en werknemers.

\section{Bedriifsgebonden factoren}

In grotere bedrijven komen minder fysiek belastende arbeidsomstandigheden voor. Naarmate het bedrijf groter is, wordt de bedrijfsarts vaker ingeschakeld op algemeen beleidsterrein. In GD-bedrijven wordt de sociaal medische begeleiding meer als controle ervaren naarmate het bedrijf groter is, terwijl in EVD-bedrijven dit het geval is naarmate het bedrijf kleiner is. Er lijkt dus sprake van een bepaalde band. breedte in bedrijfsgrootte waarbinnen SMB door werknemers als controle wordt ervaren.

Naarmate er in het bedrijf meer fysiek belastende arbeidsomstandigheden voorkomen kan de bedrijfsarts het periodiek onderzoek en werkplekonderzoek meer naar eigen wens uitvoeren. De ondernemingsraad ervaart echter in bedrijven met veel fysiek belastende arbeidsomstandigheden minder steun van de BGD, advisering wordt ook minder bruikbaar gevonden. Er lijkt sprake van een discrepantie tussen beleving in de praktijk en hetgeen de ondernemingsraad (in dit soort bedrijven) van de BGD verwacht. Opmerkelijk is dat er geen samenhang is tussen de arbeidsomstandigheden in het bedrijf en het werkterrein van de BGD.

Naarmate het verzuim in het bedrijf hoger is, ontstaat er een positief beeld van de door de BGD geleverde zorg. De BGD zelf ervaart meer armslag en de ondernemingsraad oordeelt positief over een aantal professionele en klantgerichte aspecten van kwaliteit. Er is echter wel sprake van een contrasterend beeld tussen GD- en EVD-bedrijven. In GD-bedrijven is er sprake van een positief verband tussen de hoogte van het verzuim en de ervaren kwaliteit, terwijl in EVD-bedrijven het omgekeerde het geval is. In GD-bedrijven vormt een hoog verzuim mogelijk een onomstreden gezamenlijk aandachtspunt voor de BGD en de ondernemingsraad; een legitimatie voor de BGD om activiteiten te ontplooien. In EVD-bedrijven wordt een hoog verzuim daarentegen gezien als uiting van falend rendement.

Naarmate de BGD sneller contact opneemt met zieke werknemers, voert de bedrijfsarts vaker overleg met de directie van het bedrijf. Deze zichtbare uiting van 
SMB gaat samen met het ervaren van de verzuimbegeleiding door ondernemingsraad en werknemers als controle, en ook met een betere samenwerking tussen BGD en directie. Er treedt echter een verschil op tussen GD- en EVD-bedrijven, dat niet alleen verklaard kan worden door een feitelijk verschil tussen de uitvoering van sociaal-medische begeleiding, maar dat ook te maken heeft met de door de klant ingeschatte (en misschien ook ingenomen) positie van de BGD.

Er kan worden opgemerkt dat een aantal verwachte verbanden tussen bedrijfsartsen bedrijfsgebonden factoren en kwaliteitsaspecten niet werd gevonden. Zo blijkt dat noch de aard van de arbeidsomstandigheden, noch de bedrijfsgrootte van invloed zijn op de omvang van de BGZ-activiteiten. Blijkbaar bepaalt de klant (en diens problemen) maar in beperkte mate de breedte van de geleverde BGZ. Ook bleken de onderzochte bedrijfsarts- en bedrijfsvariabelen niet van invloed te zijn op het al dan niet ervaren van steun van de BGD door personeelszaken. Met uitzondering van een negatieve samenhang tussen het voorkomen van fysiek belastende arbeidsomstandigheden en het bruikbaar vinden van de advisering door de ondernemingsraad, bepalen de onderzochte bedrijfsarts- en bedrijfsvariabelen blijkbaar niet de bruikbaarheid van de advisering van de BGD bij de klant (personeelszaken en ondernemingsraad).

De rendementsbeoordeling lijkt niet op taakniveau bepaald te worden. Er is sprake van een algemeen rendementsoordeel, niet zozeer van een echte effectiviteitsbeoordeling. Rendement lijkt door de ondernemingsraad te worden gebruikt als een maat voor door de BGD geleverde inspanningen en een actieve opstelling. Vooral als de BGD activiteiten ontplooit op het gebied van periodiek onderzoek of werkplekonderzoek, wordt dit door de ondernemingsraad als steun ervaren.

Er is een samenhang tussen het ervaren van de SMB als controle door ondernemingsraad en werknemers. Ieder voor zich lijken ze echter door andere bedrijfsarts-variabelen te worden beïnvloed: het als controle ervaren van de SMB door de ondernemingsraad gaat samen met een meer curatieve takopvatting van de bedrijfsarts, terwijl het als controle ervaren van de SMB door werknemers samengaat met het vaker overleg plegen van de BGD met de directie van het bedrijf.

De kwaliteit van BGZ wordt verschillend ervaren in GD- en EVD-hedrijven. Ook de invloed van bedrijfsarts- en bedrijfsvariabelen op het kwaliteitsniveau van BGZ blijkt te worden beinnvloed door de organisatiewijze van BGZ (GD of EVD). Met betrekking tot een aantal items werden deze verschilpunten verder uitgewerkt. Het betreft: bedrijfsgrootte, verzuim, ervaring en taakopvatting van de bedrijfsarts.

De belangrijkste conclusie is dat aspecten van professionele kwaliteit anders en door andere factoren (bedrijfsartsvariabelen en/of bedrijfsgebonden variabelen) worden beïnvloed dan klantgerichte aspecten van kwaliteit. Dit maakt bij het ontwikkelen van kwaliteitszorg binnen BGD'en een evenwichtige opbouw langs twee sporen noodzakelijk, enerzijds gericht op professionaliteit en anderzijds gericht op klantgerichtheid. 
De resultaten van het onderzoek worden in hoofdstuk 10 aan een beschouwing onderworpen. Het onderzoek legt een aantal spanningsvelden voor de BGD duidelijk bloot. BGD'en hebben te maken met een klantsysteem waarin prioriteiten niet uniform worden gesteld en waarin BGZ-activiteiten verschillend worden gewaardeerd. Oplossingen voor de BGD om uit dit hieruit resulterende spanningsveld te geraken, kunnen gezocht worden in pogingen om meer aan de vraag van de klant te beantwoorden langs twee sporen, te weten en in een verdere uitbouw van professionaliteit, $2 n$ in de ontwikkeling van andere taken c.q. taakopvattingen, die meer aansluiten bij de wens van de klant. Het belang voor de BGD om bij kwaliteitszorg een evenwichtig beleid te voeren, enerzijds gericht op professionele kwaliteit en anderzijds gericht op klantgerichte kwaliteit, wordt in het laatste hoofdstuk verder uitgewerkt.

Ten aanzien van de vragen of BGD'en meer aan de vraag van de klant kunnen beantwoorden dan tot nu toe het geval is geweest en of BGD'en BGZ op mat kunnen leveren, kan worden geconstateerd dat er sprake is van meerdere klanten. BGD'en zullen een keuze moeten maken uit de diensten die ze willen leveren en de klanten die ze willen bereiken. Er treedt hierbij een spanningsveld op tussen het willen leveren van integrale zorg door de professional en de, eventueel vanuit kostenoverwegingen versterkte, tendens dat klanten slechts geïsoleerde diensten vragen, waarbij de samenhang in BGZ onder druk komt te staan.

Professionaliteit dient verder te worden ontwikkeld door protocollering van BGZ, door het ontwikkelen van een beroepscode en beroepsprofiel (voor alle binnen de BGD opererende disciplines), en door het toepassen van toetsingsinstrumenten van professionele kwaliteit, zoals intercollegiale toetsing. Een belangrijke rol is weggelegd voor de opleidingsinstituten $\mathrm{CBO}$, SKB en overkoepelende organisaties van BGD'en alsook in het kader van kwaliteitstoetsing op te richten, certificatie-instituten.

De zowel binnen de beroepsgroep als binnen de maatschappij verschuivende opvattingen ten opzichte van SMB en de rol hierin van BGD'en, dwingen BGD'en tot positiebepaling en eventueel bijstelling in hun taakopvattingen. Het in eén hand uitvoeren van verzekeringsgeneeskundige en bedrijfsgeneeskundige taken lijkt mogelijk, mits aan een aantal voorwaarden wordt voldaan, namelijk dat de BGD zich niet uitsluitend tot deze SMB-rol beperkt, en mits de BGD een autonome positie voldoende kan waarborgen.

Het onderzoek wordt afgesloten met het formuleren van enkele aanbevelingen met betrekking tot kwaliteitszorg binnen BGD'en. Zowel de overheid, als de beroepsgroep kunnen naast de BGD'en zelf een waardevolle bijdrage leveren om professionele en klantgerichte kwaliteit van BGZ vorm en inhoud te geven. Van de overheid wordt een meer sturende en verplichtende rol verwacht. De beroepsgroep kan een voortrekkersrol vervullen in een verdere ontwikkeling van professionele kwaliteit van BGZ. De $B G D$ 'en zelf moeten een kwaliteitszorg ontwikkelen die een evenwichtige opbouw kent van professionaliteit en klantgerichtheid. 

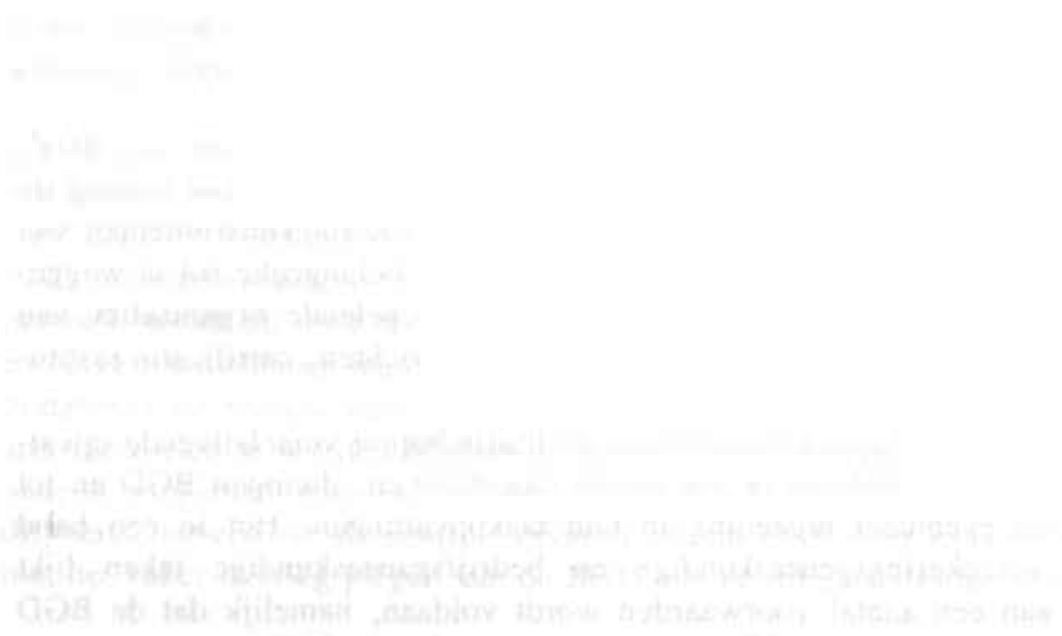

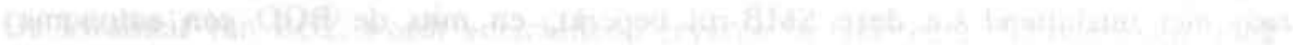

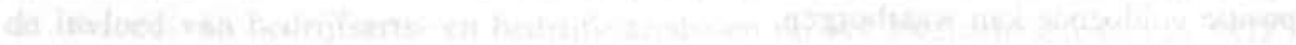

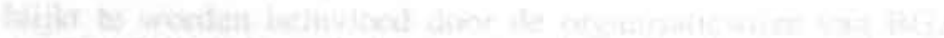

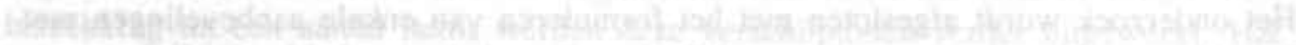

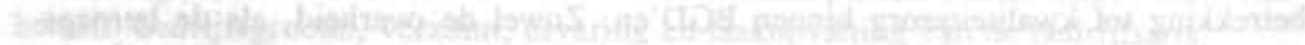

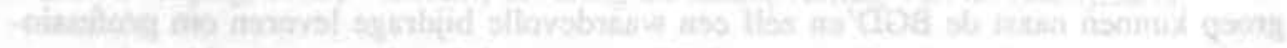

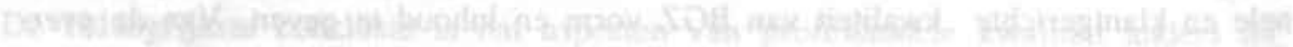

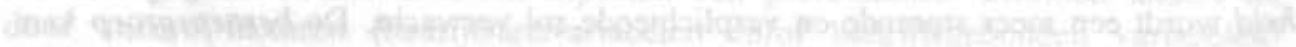

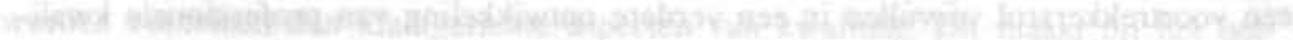

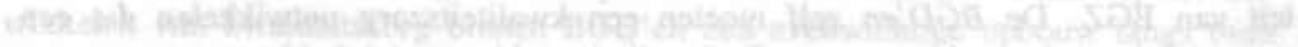

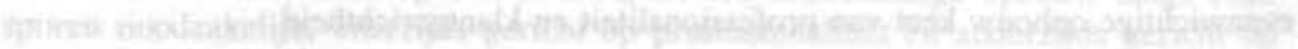

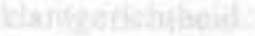




\section{Summary}

The quality of occupational health care $(\mathrm{OHC})$ as it is experienced by providers and recipients is described in this explorative cross-sectional study, by means of component analysis. That means that a description is given of aspects that may influence the quality level of $\mathrm{OHC}$ positively, while no definition is given of quality in the narrow sense of the word.

An opinion about the quality of $\mathrm{OHC}$ experienced should be considered against the background of the objectives of OHC: 'to contribute to the optimum health of the working individual'. In this study quality of $\mathrm{OHC}$ is approached along two tracks: professionalism and orientation towards the client.

Occupational Health Services (OHS's) work in a complex network of contacts, and in a sphere of activity where interests are partly incompatible. In establishing OHC, and in influencing its quality several parties play a part (see figure 1).

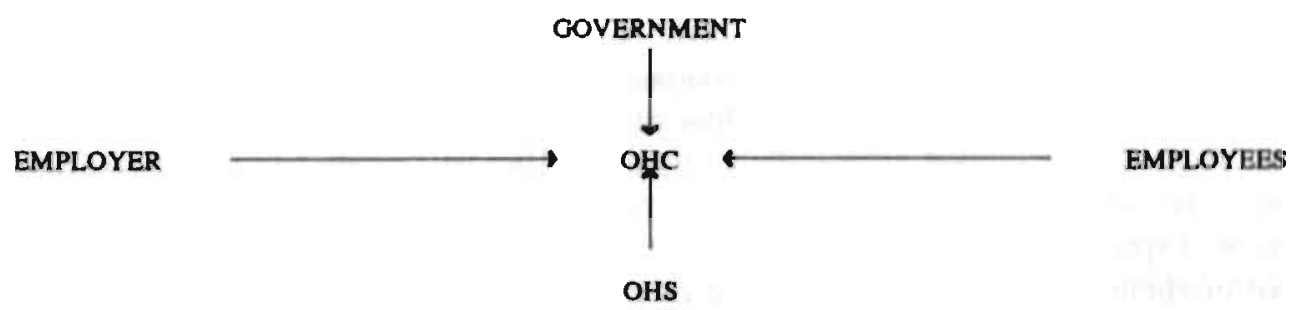

Figure 1. Parties that may infuence the quality of $\mathrm{OHC}$.

There are several areas of tension: in the differences in appreciation of OHC by the clients (employers and employees), and in the expectations

- among the clients in the client system;

- between OHS and clients;

- between the different experts on working conditions in the employ of the OHS;

The solution is to be found in the OHS's clearly stressing their distinctive features.

The reflection implied and continuously required for OHS's concerning the kind of services they have to provide was intensified by the great changes (or crises) that have occurred during the past decade in two areas that OHS's logically had to cope with as they are at the crossroads of health care and business. It concerned changes in health care, and in (the organization) of labour.

There was criticism by providers and recipients of $\mathrm{OHC}$ as a manifestation of insufficient promptness in anticipating changed needs and desires. 
Chapter 2 describes the criticism of clients, the professional group and the government. The common factor in their criticism was that OHS's have been insufficiently accessible to the needs and desires of their clients. There was insufficient consultation with the client, and OHS's insufficiently succeeded in translating clients' desires in actual $\mathrm{OHC}$ activities.

Although this study does not deal extensively with the government's role, chapter 5 describes the (changing) part and influence of the government (and legislation). Government withdraws, which is an international trend. Responsibility for a sound working conditions policy is passed to the employers' organizations and trade unions, and at company level it is passed to the combined action of the employer and the workers. Government confines itself to formulating minimum requirements and a description of the desired situation. Quality testing of the care provided or of the attention paid to the working conditions does not take place directly.

In the two-track approach of the quality of $\mathrm{OHC}$ two clusters of quality aspects are distinguished: professional and client-oriented aspects.

Chapter 3 describes, on the basis of a literature survey, the quality of $\mathrm{OHC}$ from the perspective of the professional group. Relevant aspects are: the occupational physician's method of working and the performance of his task, the efficiency of his actions and the usefulness of his advice.

A number of possibilities and instruments are described that may incorporate the professional aspects of quality of $\mathrm{OHC}$ in a type of quality assurance. In this respect peer review, stressing professionalism as a distinctive feature by formulating professional codes and protocolling of $\mathrm{OHC}$ tasks can be mentioned.

In chapter 4 the marketing concept is discussed. In OHC marketing might contribute to its quality. This can be done by making a package of client-oriented services more explicit on the one hand, and on the other hand by highlighting the significance of client-oriented components of quality for an overall quality assessment.

The SERVQUAL-model offers the opportunity to list a number of elemental clientoriented quality aspects, in particular at the working level of OHS's activities.

Well-tried industrial marketing principles cannot be applied as a matter of course in service provision, as there are a number of fundamental differences between service provision and the manufacture of goods.

There are a number of bottlenecks to be dealt with before marketing principles may be applied in OHS's. After all, the package of services of OHS's still seems to be insufficiently defined, the distinctive features of OHS's still seem to be insufficiently stressed, there is too much emphasis on professionalism in infrastructure and thinking at the expense of client-oriented service provision, and there is an aversive attitude towards applying a mix of marketing instruments.

The presentation of the question is twofold. Firstly, an attempt is made to answer the question how $\mathrm{OHC}$ providers and recipients experience the quality of $\mathrm{OHC}$ concerning professionalism and client-related service provision respectively. Secondly, attention is paid to the question which company variables and occupatio- 
nal physician variables are coupled with the quality experienced. A number of differences between organizational forms of OHS's (joint occupational health services and plant occupational health services (JOHS and POHS) are pointed out. The research data were obtained by questionnaires completed by a random sample of the management of OHS's, occupational physicians of OHS's, heads of personnel, chairmen of workers representatives organizations, and workers in technical departments. All respondents were asked to give their opinions about different aspects of the quality of $\mathrm{OHC}$ experienced, which was provided to an actual company mentioned by name. This made it possible to study the question how the $\mathrm{OHC}$ provider is to tailor service provision to the recipient's needs.

Chapter 7 describes the OHC network of contacts. Remarkable findings include the dominance of the professional when the contract is made. and the discrepancy in the desired financing and organization of OHC between provider and customer. The package of services resulting from the dialogue between OHS's and companies will lead to different employment of people and means. It seems though that in POHS's there is no explicit discussion on form and content of the service desired.

In the conception of their tasks three aspects may be distinguished among occupational physicians: a curative conception (including features such as curative experience and desires), a professional conception (including the feature that their personal opinion is of overriding importance), and a client-oriented comprehension (including the feature of a customer-friendly attitude).

In this research a study is made of the relationship between a number of factors related to occupational physicians and companies on the one hand, and professional and client-oriented factors of OHC quality on the other hand (see figure 2). In choosing the variables a close link was made - as far as possible - to the tasks and the performance of tasks by an occupational physician as they are described in the Dutch Occupational Health and Safety Act (Arbowet), and as they are performed in practice.

In chapter 8 the quality experienced from professionalism on the one hand and customer-orientation on the other hand is described. It should be mentioned that the different aspects of quality of OHC experienced cannot be equally assessed by the respective respondents. 


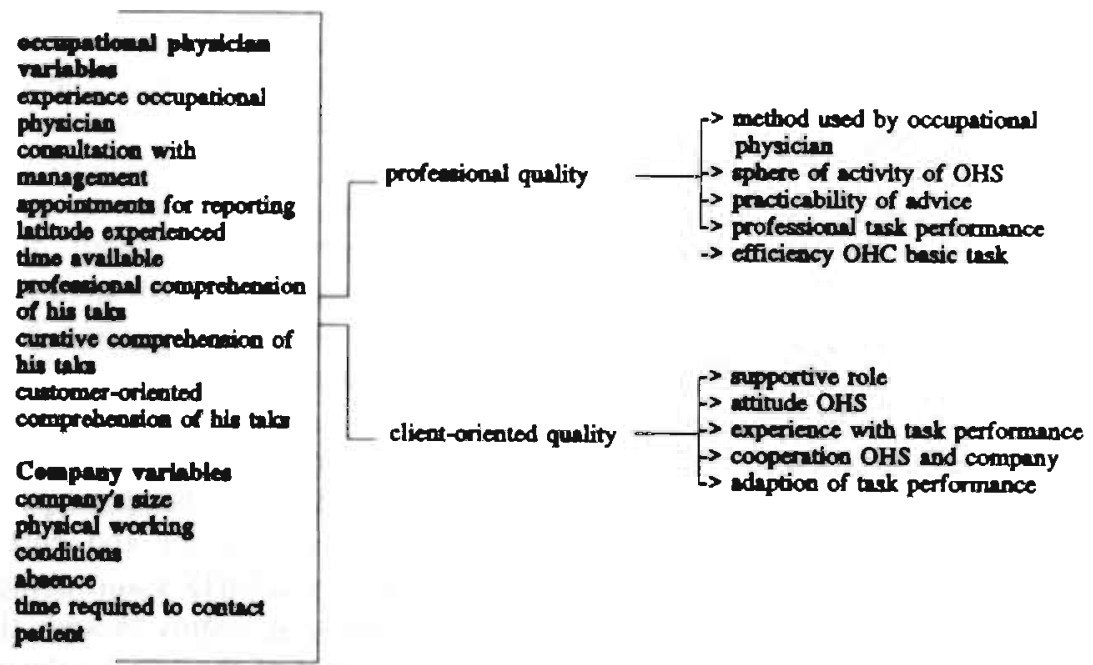

Flgure 2. The research model

The principal findings related to professional quality can be summarized as follows. There are frequent contacts between OHS's and companies. An occupational physician of a JOHS makes more appointments for reporting than the occupational physician of a POHS. He reports more often. In general, reports are more often presented to the management than to the works council. The initiative to start on OHC activities is taken more frequently by the company than by the OHS. OHS's are seldom called in when activities on general policy are concerned (e.g. new buildings, reorganization). OHS's are primarily concerned with issues relating to the individual. Advice by OHS's is considered quite useful by personnel departments. In general the works councils are less positive about the quality of the advice than the personnel departments. Occupational physicians who formally do not have the task of claim assessment of social securities, however, frequently give their meaning on the workers'(in)ability to work. Employees seldom experience a relationship between periodic health check-ups and their work.

The occupational physician's role in the workplace is usually a reactive one, i.e. he responds to signals and requests by the company. In the perspectives of the works councils the basic tasks of OHC are not very effective.

The most striking findings related to client-oriented quality can be summarized as follows.

One-third to half of the personnel departments involved in this study are of the opinion that to a considerable extent the OHS's have a supportive role in the development of a social policy. 
In the opinion of the works councils the OHS's' supportive role in social policy is less marked.

The OHS's are considered to be easily accessible services, but the attitude of their employees is not always experienced as customer-friendly. In general, apart from its basic tasks and first aid task the OHS's seem to develop few extra activities.

The implementation of the pre-employment health screening and a periodic health check-up is experienced positively by workers.

In 10 per cent of the companies with JOHS and in one-third of the companies with a POHS socio-medical counselling (SMC) is experienced as a kind of control. According to 90 per cent of the works councils of companies with a JOHS and about 50 per cent of the works councils of companies with a POHS have adequate knowledge of working conditions. Both OHS and company experience their cooperation positively.

The client (works council and workers) and the occupational physician have wishes that are not (yet) complied with in practice. Such is the case, in particular, with the periodic health check-up and the examination of the workplace. The works council and the workers support the occupational physician's wish of a less prominent socio-medical counselling (SMC). The opinions of the personnel departments on this issue are unknown.

Chapter 9 surveys the influence of a number of occupational physician variables and company variables on the quality aspects of $\mathrm{OHC}$ that were studied. Considering the cross-sectional character of this study, generally it can be said that no opinion can be given on the causality of the connections found. The findings can be summarized as follows.

\section{Occupational physician related factors}

When an occupational physician has worked for a company for a longer period (experience), a number of professional aspects are valued negatively. There is no significant influence of the occupational physician's experience on the clientoriented aspects of quality. As a remarkable difference between a JOHS and POHS emerged the fact that experience in POHS-companies resulted, in their opinion, in sufficient other activities of the OHS apart from its basic tasks.

The more an occupational physician consults the management of a company, the sooner contacts are established between the OHS and the workers who are sick. Frequent consultation with the company's management goes together with attributing more succes to the examination of the workplace. This may indicate that in their consultations with the management the OHS tests the feasibility of the examination of the workplace in advance as well as the solution to the problems resulting from it, and in doing so, it increases the effectiveness of its activities. Frequent consultation with the management, however, also goes together with two client-oriented quality aspects that are valued negatively: absence counselling by the OHS is more often perceived as a check on the workers, and, according to the 
works council the OHS does not launch sufficient extra activities apart from its basic tasks.

The more frequently arrangements are made about reporting to the company, the more frequently the occupational physician has a client-oriented conception of his task. There is also a relationship with the occupational physician's method of working. If arrangements are made about reporting to the company, the cooperation between the OHS and the personnel department becomes more consistent. It turned out that expectations are met more satisfactorily by the OHS's in the sheer medical field (periodic health check-up), than in the examination of the workplace, where a discrepancy occurs between practice and aspiration or expectation.

In large companies the occupational physician experiences more latitude. It is remarkable that more latitude does not go together with the feeling that there is more professional autonomy. It seems that the OHS experiences more latitude when its function is aimed explicitly at SMC.

The more time the occupational physician has available, the more activities he will undertake. However, he does not translate the time available into activities that are appreciated by the client.

The influence of the occupational physician's comprehension of his task on the aspects of quality studied varies.

A more professional comprehension of his task goes together with a larger number of negative experiences by the client, such as sensing less support from the OHS by the works councils, and perceiving the attitude of the OHS as non-clientoriented. A professional attitude is experienced as a waiting and reserved attitude.

There is no significant relationship between a curative comprehension of one's task and aspects of professional quality. The more an occupational physician has a curative comprehension of his task the more absence counselling is felt as a check on the workers. Nonetheless, remarkable differences occur between POHS's and JOHS's.

In JOHS's an occupational physician's curative comprehension of his task corresponds with the works council considering his advice more often useful as well as with experiencing more support from the OHS. POHS, however, tend to experience the occupational physician's curative comprehension of his task negatively: the works council perceives absence counselling as a check on the workers, the cooperation between the OHS and the works council is less consistent. SMC is emphasized. Usually, this activity is the ambition of the POHS-occupational physician and the personnel department, and it is at the expense of (the possibility of) undertaking extra activities.

A more client-oriented comprehension of the occupational physician's task corresponds with less soon contacting workers who are sick, and more frequent arrangements about reporting. It seems that a client-oriented attitude is interpreted as the occupational physician being oriented towards the wishes of the works council and workers. 


\section{Company related factors}

In larger companies less physically aggravating circumstances occur. The occupational physician experiences more latitude, and he has often worked there for a longer period. The larger the company, the more often the occupational physician will be called in in the field of general policy. In large companies the workers consider absence counselling by the OHS as a check on them. There is a difference between JOHS's and POHS's, which indicates that there is an interaction between company size and the workers experiencing absence counselling as a check on them.

The more physically aggravating circumstances occur in a company, the more an occupational physician will be allowed to carry out periodic health check-ups and examinations of the workplace according to his own wishes. Still, works councils in these companies experience less support from the OHS, and counselling is considered less useful.

There seems to be a discrepancy between what is experienced in practice and what the works councils expect from the OHS. It is remarkable that there is not any relationship between the working conditions in the company and the sphere of activity of the occupational health services.

The greater the absenteeism in the company, the more positive the image of the care provided by the OHS. The OHS itself experiences more elbow room, and a number of professional and client-oriented aspects of quality are assessed positively by the works council. There is, however, a contrast between JOHS's and POHS's. In companies with a JOHS there is a positive relationship between the extent of absenteeism and the quality experienced, whereas the opposite can be seen in companies with a POHS.

Possibly, in companies with a JOHS a high percentage of absenteeism is an unquestioned mutual point of interest for OHS and works council, a legitimation for OHS to develop activities. In companies with a POHS a high percentage of absenteeism is considered as a sign of a lack of efficiency.

The sooner OHS contacts sick workers, the more consultation there is between occupational physician and the company's management. This perceptible expression of SMC logically goes together with the works council and the workers experiencing absence counselling as a check on the workers, as well as a better cooperation between the OHS and the management. Nonetheless, there is a difference between companies with a JOHS and those with a POHS, which cannot merely be explained by the actual difference in performing socio-medical counselling, but which also has to do with the OHS's position as it is estimated (and maybe taken) by the client.

It can be said that a number of expected relationships between occupational physician related factors and company related factors and aspects of quality was not found. It turned out, that neither the characteristics of the working conditions, nor the size of the company influence the size of $\mathrm{OHC}$ activities. Apparently the client and his problems determine only to a limited extent the quantity of $\mathrm{OHC}$ supplied. 
It was also found that the occupational physician variables and the company variables were not of any influence to whether the personnel department experienced support or not from the OHS. Save a negative relationship between the prevalence of physically aggravating circumstances and the fact that the works council considers the counselling useful, for the client (personnel department and works council) the occupational physician variables and the company variables apparently do not determine the usefulness of advising by the OHS.

Efficiency does not seem to be assessed on task level. There is a general efficiency assessment, and not a real assessment of effectiveness. It seems that efficiency is used by the works council as a measure for the efforts made by the OHS and an active attitude. When the OHS develops activities in the sense of periodic health check-ups and examination of the workplace this in particular is experienced as support by the works council.

There is a relationship between the works council and the workers experiencing SMC as a check on workers. Each in itself, however, seems to be influenced by different occupational physician variables: where the works council experiences SMC as a check on the workers when it goes together with the occupational physician having a more curative comprehension of his task, the workers themselves experience SMC as a check on them when it goes together with frequent consultation between OHS and the company's management.

Considerable differences may be established between companies with a JOHS and those with a POHS in the quality experienced (chapter 8) and related factors. The organizational structure of $\mathrm{OHC}$ seems to have essential consequences for the quality of OHC experienced by all parties involved. It was also found that the organizational structure of OHC had a major impact on a possible relationship between the quality experienced of $\mathrm{OHC}$ and the occupational physician variables and company variables. For a number of items, such as company size, absence, experience and the occupational physician's comprehension of his task, these differences were worked out into more detail.

The main conclusion is that aspects of professional quality are influenced in a different way and by other factors (occupational physician related or company related) than client related aspects of quality. Therefore, a balanced, two track advancement is required in developing quality assurance in OHS's. On the one hand it should be aimed at professionalism and on the other hand it should be client- oriented.

In chapter 10 consideration is given to the results of the study. It clearly reveals a number of areas of tension for the OHS. OHS's have to deal with a client system, where priorities are not established uniformly and where OHC activities are valued differently. Possible solutions for the OHS to get out of the area of tension resulting from this, can be looked for in efforts to comply with the client's wishes even more. This should be done along two tracks, which are a further development 
of professionalism and the development of different tasks or comprehension of tasks that are better geared to the client's wishes. The importance for the OHS to pursue a balanced policy in quality assurance - on the one hand aimed at professional quality and on the other hand at client oriented quality - is elaborated on in the final chapter.

Concerning the question whether OHS's are capable of meeting the client's needs more than it was done so far, and whether OHS's can provide OHC cut to standard, it can be ascertained that there are different types of clients. OHS's will have to select the services they wish to provide and the clients they wish to reach. This creates an area of tension between the professional wishing to provide integral care and the trend - possibly intensified by considerations of cost - that clients only ask for isolated services, which puts a pressure on the coherence in OHC.

Professionalism should be developed further by protocolling OHC, by developing a professional code and a professional profile (for all disciplines working in the OHS), and by applying testing tools for professional quality, such as peer review.

An important role is reserved for the training institutes, as well as for institutes yet to be established - where certificates can be obtained within the framework of quality testing (certificate-institutes).

Shifting opinions both in the professional group and society towards SMC and the OHS's role in this activity, are forcing the OHS to pay attention to position-finding and, if necessary, adjustment of the comprehension of its tasks. Performing tasks related to health insurance and tasks related to occupational medicine seems to be possible, provided that a number of conditions are met, i.e. that the OHS will not restrict itself to its SMC role, and that the OHS can sufficiently guarantee an autonomous position.

In conclusion, some recommendations concerning quality assurance in OHS's are given. In addition to the efforts of the OHS's, useful contributions can be made by the government as well as the professional group themself, to give form and content to the quality of OHC. The government is supposed to steer and impose more. The professional group can do pioneering work in further developing professional quality of OHC. The OHS's themselves should develop quality assurance featuring a well-balanced structure of professionalism and client-orientation. 


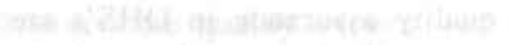

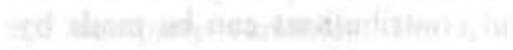

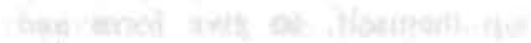

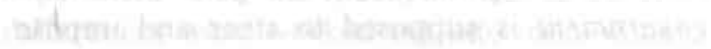

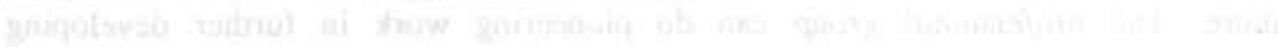

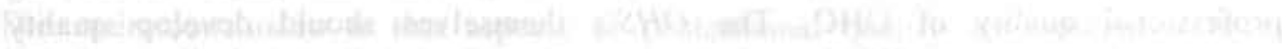

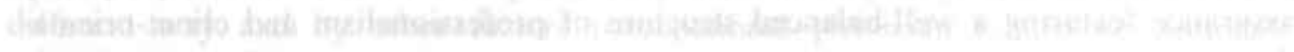

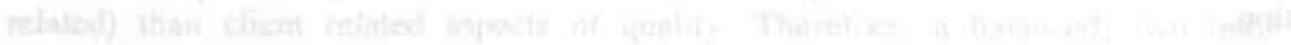

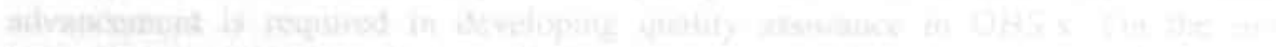

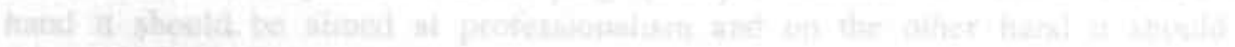

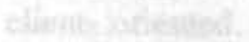

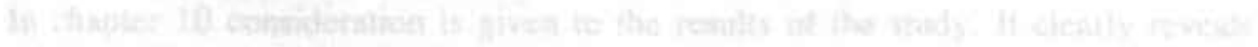

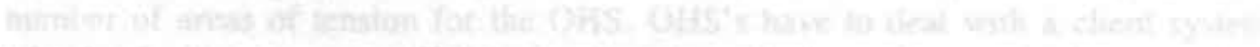

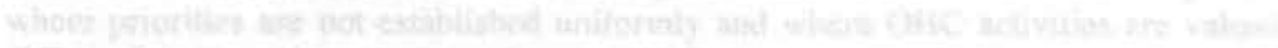

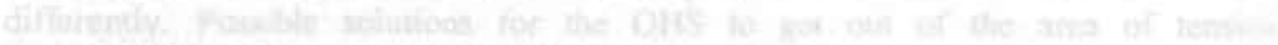

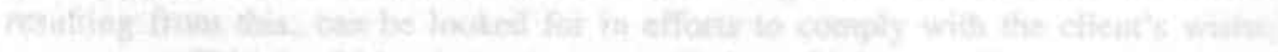

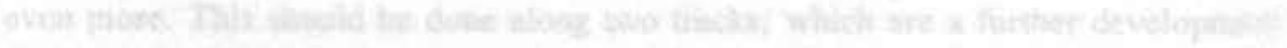




\section{Literatuurlijst}

Allegro, J.T., Verschuren, M. Harmonisatie van de regelgeving op het gebied van de arbeidsomstandigheden. Arbeidsomstandigheden 66, Arbo 90,1990, 343-348.

Altink, W.M.M. et al. De praktijk van werving en selectie anno 1989. Gids voor Personcelsmanagement 11, 1989, 23-25.

Anderson, O.W. Quality Measurement and Control in Physician Decision Maling; the State of the Art. Health Services Research 17:2, 1982, 126-155.

Andriessen, J.H.T.H. et al. Kleine bedrijven en arbeidsomstandighedenbeleid. Een verkennend onderzoek in enkele bedrijfstakken. Tilburg, Instituut voor Arbeidsvraagstukken 1985.

Anthony, R.N., Herzlinger, R.E. Management Control in non-profit Organizations. Irwin Homewood III., revised edition 1980.

Arboraad, Advies betreffende de deskundige diensten. Deel 1: Bedrijsgezondheidsdiensten en Bedrijfsveiligheidsdiensten. Zoetermeer 1984.

Arboraad, Advies termijnplanning uitbouw Bedrijfsgezondheidszorg. Zoetermeer, Arboraad-rapport 18, 1986.

Arboraad, Adviestaken op het gebied van het welzijn. Zoetermeer, 1989.

Arboraad, Deskundige diensten. Arbobulletin 5, 1990, 24.

Arboraad, Samenstelling en taken Arboraad. NVAB-infobulletin 21, 3, 1990, 27-30.

Arboraad, Advies hoofden deskundige diensten. Zoetermeer, Arboraad-rapport 61, 1990.

Attekum van, A.M.N.G. De relatie tussen huisarts en bedrijfsarts. Instituut Sociale Geneeskunde Nijmegen 1983.

Baars, E., Het bedrijfsgezondheidkundig spreekuur - Een enquete bij NV Interpolis. Nijmegen Instituut Sociale Geneeskunde 1984.

Baart, A. et al. Inleiding lot de commerciele economie. Groningen, Wolters Noordhoff, 1982.

Baas, A.R. Kleine bedrijuen, grote zorgen. Amsterdam, CORVU, 1989.

Babakus, E., Mangold, W.G. Adapting the SERVQUAL Scale to Hospital Services: An Emperical Investigarion. Health Services Research 26:6 (february 1992), 767-786.

Baidjoe, P.R.S. Werk en werksituatie van bedrijsartsen: werkplekbezoek. Leiden Nederlands Instituut voor Preventieve Geneeskunde/TNO, 1983.

Bayens, G. Het Arbo-jaarplan in de prakijk. Maandblad Arbeidsomstandigheden 64,1, 1988, 30-37 en 5, 1988, 317-318

Bayens, G. Arbo-jaarverslagen nader bekeken. Maandblad Arteidsomstandigheden 64 , 2, 1988, $91-95$

Bayens, G. Arbozorg is mooi, maar wie verzorgt de deskundigen? Maandblad Arbeidsomstandigheden 68, 7/8, 1992, 443-445. 
Beer de, P.H.M. Onafhankelijkheid van de bedrijfsarts. Tijdschrift voor Sociale Gezondheidszorg 64, 22, 1986, 693-696

Bemmel van, J., Lei van der, J. Koppeling van kennis aan informatie. Medisch Contact 29/30, 1988, 887-892

Berg van den, S.A. Oriëntatie Organisatiekunde Veranderkunde. Leiden Nederlands Instituut voor Preventieve Geneeskunde/TNO 1984.

Bergh-Braam van den, A.H.M. Verplegingswetenschap in Nederlands perspectief. Inaugurele rede Maastricht Rijksuniversiteit Limburg 1986.

Berk, R.C.L. De veranderde taak van de bedrijfsverpleegkundige. Maandblad Arbeidsomstandigheden 64, 7/8, 1988, 464-466

Berkel, J. et al. Gezondheidszorg over een andere boeg? Medisch Contact 42, 18, 1987, 571-574

Bernackj, E.J. et al. Participation in a Periodic Physical Examination Program and Group Health Care Utilization and Costs. Journal of Occupational Medicine, 30, 12, 1988, 949-951

Bersee, A.P.M. De hoofdlijnen van het kwaliteitsbeleid. WVC licht de Kamer in. Medisch Contact 45, 45,1990, 1337-1338

Berwick, D.M. Health Services Research and Quality of Care. Medical Care, 27, 8, 1989, 763-771

Bieman den, P.C.M. De sociaal-medische begeleiding in de praktijk van de verzekeringsgeneeskundige. Medisch Contact 44,9, 1989, 296-297

Bieman den, P.C.M. Preventie, een visie vanuit de sociale verzekeringsgeneeskunde. Maandblad Arbeidsomstandigheden 66,9, 1990, 635-637

Bigos, S.J. Preplacement Worker Testing and Selection Considerations. Ergonomics $30,2,1987,249-251$

Blanken, A.J., Meulen van der, H. Samenwerking tussen universiteit en de eerste lijn bedrijfskundig benaderd. Medisch Contact 42, 39, 1987, 1236-1238

Bleeksma, J. Zijn ziektewetkontroles door de bedrijfsarts schadelijk voor zijn vertrouwensrelatie met de werknemers? Amsterdam CORVU 1986

Blesgraaf, E. et al. Uniformiteit bij aanstellingskeuringen. Nijmegen, Instituut Sociale Geneeskunde, 1984

Blijswijk van, M. Integraal beleidsplan is bevestiging van uitgangspunten in Arbowet. Maandblad Arbeidsomstandigheden 68, 2, $1992,75-77$.

Block, D.L. How will we be remembered? Joumal of Occupational Medicine, 29, 7, $1987,605-609$

Bloemarts, J.C.M.G. Arrikel 3 en de positie van werkgevers, werknemers en deskundige diensten. Maandblad Arbeidsomstandigheden 64,5, 1988, 324-325

Boden, L.I. Impact of Workplace Characteristics on Cost and Benefits of Medical Screening. Journal of Occupational Medicine, 28,8, 1986, 751-756

Boer de, L. Kwaliteitsbewaking-en bevordering in de bedriffsgezondheidszorg. Tijdschrift voor Sociale Gezondheidszorg 59, 18, 1981, 636-638

Bogaard van den, C.J.M. Kwaliteit huisartsgeneeskunde. Mogelijkheden om te komen tot een garantie voor kwaliteit van de door de huisarts verleende zorg. Rijswijk, Geneeskundige Hoofdinspectie 1988. 
Bollen, J.M. Op weg naar een gezonde, menswriendelijke onderneming. Maandblad Arbeidsomstandigheden 63, 7/8, 1987, 443-446

Booms, B.H., Bitner, M.J. Marketing Strategies and Organization Structures for Services Firms. Marketing of Services. Chicago American Marketing Association, Special Conference Proceedings 1981.

Boorder de, Tj. Zou Coronel nu tevreden zijn? Inaugurele reden Maastricht Rijksuniversiteit Limburg 1983

Boorder de, $\mathrm{Tj}$. Bedrijfsgezondheidszorg: mag het een onsje meer zijn? Tijdschrift Sociale Gezondheidszorg 64, 19, 1986, 615

Bouter, L.M. et al. Epidemiologie en informatica. De "epimatische" valkuil. Medisch Contact 44, 40, 1989, 1294-1296

Bouwman, H.A. Kwaliteit verzekerd? Tijdschrift voor Verzekeringsgeneeskunde 27, 6, 1989,161

Brand, A.Chr.I. Evaluatie in de hulpverlening, toetsen als methode en proces. Alphen a/d Rijn, Samson Sociale en Culturele Reeks 1974

Brandsma-van der Laan, M. Kwaliteitsbewaking in de sociale geneeskunde. Leiden Nederlands Instituut voor Preventieve Geneeskunde/TNO, 1985

Brandt-Rauf, P.W. Ethical Conflict in the Practice of Occupational Medicine. British Journal of Industrial Medicine 46, 1989, 63-66.

Brock, R.H. Quality of Care-Assessment: a Comparison of Five Methods of Peer Review. U.S. Department of Health, Education and Welfare Rockville 1973

Broere, F.P., Verbrugge, R.W. Marketing voor specialisten. Medisch Contact 43, 46, $1421-1423$ en $47,1463-1466$

Broersen, J.P.J. et al. Periodiek bedrijfsgezondheidkundig onderzoek. Middel en maatstaf. Amsterdam CORVU 1989

Broersen, J.P.J. et al. Periodiek Bedrijfsgezondheidkundig Onderzoek: referentiegegevens als maatstaf bij de beoordeling van groepen (II). Referentiepopulatie als controlegroep. Tijdschrift Sociale Gezondheidszorg 70, 3, 1992, 203-214.

Brown, S.W., Swartz, T.A. Consumer and Provider Expectations and Experiences in Evaluating Professional Service Quality. Joumal of the Academy of Marketing Sciences, 1989, 189-195.

Brown, S.W., Swartz, T.A. A Gap Analysis of Professional Service Quality. Joumal of Marketing, vol. 53, 1989, 92-98

Bruggen van der, H.D. Kosten/opbrengsten onderzoek bedrijfsgezondheidsdienst. Bedrijfsgeneeskundige Dagen 1975

Bruins Slot, J.H.W. Ambtenaren op het spreekuur. Nijmegen, Instituut Sociale Geneeskunde 1984

Bruins Slot, J.H.W. Naar een betere organisatie van de preventie in relatie tot arbeid en arbeidsomstandigheden. Medisch Contact 43, 51/52, 1988, 1593-1596

Bruins Slot, J.H.W. Preventiegericht verzekeren van arbeidsongeschiktheid. Maandblad Arbeidsomstandigheden 65, 11, 1989, 692-698

Budde, J., Witting, U. Funktion und Rechtliche Stellung des Betriebsartzes in Privatwirtschafilichen Untermehmen. Dortmund, Schriftenreihe der Bundesanstalt fur Arbeitsschutz. Sonderschrift S13 1984.

Buijs, P.C. Sociaal-medische begeleiding. Medisch Contact 43, 38, 1988, 1131-1136 
Buijs, P.C. Sociaal-medische begeleiding: modegril of uitdaging? Maandblad Arbeidsomstandigheden 66, 7/8, 1990, 539-544.

Buiting, J.M. Kwaliteit van zorg. Commentaar bij de brief van WVC. Medisch Contact 45, 45, 1990, 1339-1340.

Buiting, J.M. Groeien in verantwoording: kwaliteit en toetsing vanuit een juridisch perspectief. Utrecht Symposium "Intercollegiale toetsing in de sociale geneeskunde" LVSG 1991.

Bult, J.A.H. Kwaliteitsaspecten van het werk van de bedriifsgezondheidsdienst. Amsterdam CORVU, 1987

Burg van den, H.C.J., Inleiding ter gelegenheid van het symposium van de Federatie van Gezamenlijke Bedrijssgezondheidsdiensten. Amsterdam 1992.

Burger, G.C.E. Arbeids- en bedrijfsgeneeskunde. H.E. Stenfert Kroese BV Leiden 1974.

Buyse, J. et al. De menselijke organisatie. Intermediair 26, 15, 1990, 29-33.

Centraal Begeleidingsorgaan voor de Intercollegiale Toetsing, Lexicon Kwaliteitbevordering. Utrecht CBO, 1988

Centraal Begeleidingsorgaan voor de Intercollegiale Toetsing, Lexicon van Amerikaanse Gezondheidszorgbegrippen. Utrecht CBO 1989

CNV, Werken aan arbeidsomstandigheden. Handleiding Arbowet. Utrecht CNV 1985 COB, Op weg naar een betere dienstverlening. 's Gravenhage COB/SER 1989

Casparie, A.F. Medical Audit in de VS: een voorbeeld voor medische toetsing in ons land? Nederlands Tijdschrift voor Geneeskunde 121, 16, 1977, 684-688

Casparie, A.F. Kwaliteit in de gezondheidszorg. Huidige inzichten en toekomstige ontwikkelingen. Medisch Contact 44, 14, 1989, 477-482

Casparie, A.F., Everdingen van, J.J.E. Maatstaven voor goede zorg: viff jaar later. Medisch Contact 44, 50, 1989, 1654-1656

Casparie, A.F. et al. Kwaliteitbevordering en kwaliteitsbewaking: een taak van de wetenschappelijke verenigingen? Medisch Contact 44, 45, 1989, 1478-1481

Casparie, A.F. Inleiding op het symposium "Intercollegiale toetsing in de sociale geneeskunde". Utrecht LVSG 1991.

Cense, W.H. Uitdagend perspectief. Medisch Contact 42, 41, 1987, 1292-1295

Cense, W.H. De arts als toetsbare professional. Medisch Contact 43,1, 1988, 9-10

Cense, W.H. Op de bres voor kwaliteit. Medisch Contact 44, 18, 1989, 596

Centrale Raad voor de Volksgezondheid, Structuurnota Gezondheidszorg. 's Gravenhage, Ministerie voor Volksgezondheid en Milieuhygiëne 1975

Chapman, D. The Vanguard and Rearguard: Occuparional Medicine Revisits Its Future. Journal of Occupational Medicine 30, 2, 1988, 124-134.

Collings, G.H. Examining the Occupational in Occupational Medicine. Journal of Occupational Medicine, 26,7, 1984, 509-513.

Commissie Structuur en Financiering gezondheidszorg ("Commissie Dekker"), Bereidheid tot verandering. 's Gravenhage 1987.

Commissie Onderzoek Aanstellingskeuringen (commissie Hessel), Maarschappelijke aspecten van aanstellingskeuringen. Tijdschrift voor Sociale Gezondheidszorg 50, suppl. 4, 22, 1972, 3-15. 
Cottaar, J.A.M. Kwaliteit van bedrijfsgezondheidszorg gezien door een werkgever. Maandblad Arbeidsomstandigheden 65,9, 1989, 544

Darby, M.R., Kami, E. Free Competition and the Optimal Amount of Fraud. Joumal of Law and Economics 16, april, 1973, 67-86.

Desouza, G. Kwaliteit van dienstverlening moet beter bestuurd worden. HRM-select, 4, 1989, 47-56.

Delden van, P. Kwaliteit in dienstverlening. Personeelswetenschappen, 9, 1988, 22-27.

Dickerson, O.B. A New Model for Employer-Provided Health Educarion Programs. Joumal of Occupational Medicine, 25, 6, 1983, 471-474.

Dijk van, F.J.H. Bedrijfsgezondheidszorg, een stap achteruit, twee stappen vooruit? Tijdschrift voor Sociale Gezondheidszorg, 67, 2, 1989, 40-46.

Dijk van, F.J.H. Een visie vanuit de bedrijfsgezondheidszorg. Maandblad Arbeidsomstandigheden, 66, 9, 1990, 631-634.

Dijk van, B., Jaspers, Fr.C.A. Strategisch beleid in ziekenhuizen. Medisch Contact 43, 42, 1988, 1269-1273.

Dijk van, F.J.H. Een nationaal programma of een nationaal instituut. Maandblad Arbeidsomstandigheden 66, 11, 1990, 753-756.

Dijk van, F.J.H. et al. Herwaardering van het model belasting-belastbaarheid. Tijdschrift voor Sociale Gezondheidszorg 68, 1, 1990, 3-10.

Dijk van, F.J.H. Onderzoek veiligheid, gezondheid en welzijn bij de arbeid bedreigd. Maandblad Arbeidsomstandigheden 68, 1, 1992, 39-40.

Dijkstra, A. Bedrijfsgezondheidkundig onderzoek naar ongunstige arbeidsomstandigheden met behulp van vragenlijsten. Tijdschrift voor Sociale Gezondheidszorg 59, 6, 1981, 158-163.

Dijkstra, A. De bedrijfsarts tussen spreekkamer en werkplek. Leiden Nederlands Instituut voor Preventieve Geneeskunde/TNO, 1985.

Dijkstra, A. et al. Naar een signaleringssysteem in de bedrijfsgezondheidszorg. Uitwerking van enkele aspecten van het "Model Bedrijfsgezondheidszorg". Leiden Nederlands Instituut voor Preventieve Geneeskunde/TNO 1978.

Directoraat Generaal van de Arbeid, De toekomst van de bedrijfsgezondheidszorg. 's Gravenhage 1979.

Directoraat Generaal van de Arbeid, Taak, bevoegdheid en verantwoordelijkheid van de bedriffsarts en de bedrijfsverpleeglandige. NVAB-infobulletin 14, 1, 1983, 7-9.

Directoraat Generaal van de Arbeid, Bedrijfsgezondheidszorg voor het vervoerswezen in Nederland. DGA-reeks S38, 1988.

Directoraat Generaal van de Arbeid, Bedriifsgezondheidszorg voor de intramurale gezondheidszorg in Nederland. DGA-reeks, S39, 1988

Directoraat Generaal van de Arbeid, Bedrijssezondheidszorg voor de bouwnijverheid in Nederland. DGA-reeks, S40, 1988

Directoraat Generaal van de Arbeid, Overheid en Arbowet. Een onderzoek naar ervaringen in de prakijk. DGA-reeks S70, 1989

Directoraat Generaal van de Arbeid, Beleidsvoomemens inzake bedrijfsgezondheidszorg (stelselwijziging bedriifsgezondheidszorg en bedriffsveiligheidszorg, eerste fase). 's Gravenhage 1989. 
Directoraat Generaal van de Arbeid, De positie en taken van de bedrijfsverpleegkundige. DGA-reeks $\$ 791990$.

Directoraat Generaal van de Arbeid, Adviesaanvraag inzake een voorstel tot modemisering van de wettelijke regeling van de bedrijfsgezondheidszorg en het te voeren beleid. DGA/90/0263b, 1990.

Directoraat Generaal van de Arbeid, De Arbeidsinspectie over de (werk)vloer. Een participerende observatiestudie van de interventie in arbeidsorganisaties. DGA-reeks S142, 1992.

Docter, H.J. "Wie het kleine niet eert..." Amsterdam CORVU 1987.

Docter, H.J. Het periodiek bedrijfsgezondheidkundig onderzoek, een waardevolle onderzoek-methode, als het goed gebeun... Tijdschrift voor Sociale Gezondheidszorg $66,3,1988,87-88$.

Donabedian, A. Explorations in Quality Assessment and Monitoring. Michigan Health Administration Press Ann Arbor 1980, 1982 en 1985.

Doppegieter, R.M.S. Patientendossier en de Wet Persoonsregistraties. Medisch Contact 44, 42, 1989, 1379-1383.

Doppegieter, R.M.S. Persoonsregistratie en de rechten van de patient. Medisch Contact 45, 39, 1990, 1149-1151.

Draaisma, D. et al. Van ivoren toren naar glazen huis. Deel 1 en 2. Leiden Nederlands Instituut voor Preventieve Geneeskunde/TNO interne notitie, 1990.

Draaisma, D. et al. Kwaliteit en effectiviteit van bedrijfsezondheidszorg. Eerste deelonderzoek: het oordeel van de beroepsbeoefenaren. NIPG/TNO Leiden, S101-1, 1991.

Dunning, A.J. Het medisch handelen als proces. "Medische besliskunde". Medisch Contact 39,9, 1984, 269-271.

Durinck, J.R., Munnik, J.P.A. Herhaald meten in het algemeen preventief onderzoek. Groningen, dissertatie 1978.

Dyck van, J.J.J., Hoof van, J.A.P. Kwaliteit van de arbeid. Een sociologische verkenning. Leiden Stenfert Kroese 1980.

Dyck van, J.J.J., Hoof van, J.A.P. Het vermoeide arbeidsbestel. Een sociaalculturele verkenning van crisisverschijnselen. Leiden Samsonreeks Arbeidsverhoudingen 1977.

E.E.G., Richtlijn van de Raad van 12/06/89 betreffende de tenuitvoerlegging van maatregelen ter bevordering van de verbetering van de veiligheid en de gezondheid van de werknemers op het werk. Publicatieblad EEG L183/1, 89/391/EEG.

Ekker, L.W. Wat vindt de verzuimer ervan? Verzuimbegeleiding versus ziektecontrole. Nijmegen Instituut Sociale Geneeskunde 1976.

Elsinga, E. Marktelementen in de gezondheidszorg. Medisch Contact 42,9, 1987, 271275.

Evans, C.E. et al. Heeft voortgezet schriftelijk onderwijs wel nut voor de medische praktijk? JAMA, 6, 1987, 230-234.

Everdingen van, J.J.E. Consensusontwikkeling; een vergelijking tussen de VS en Nederland. Nederlands Tijdschrift voor Geneeskunde 129, 40, 1985, 1935-1938. 
Everdingen van, J.J.E. et al. Consensusontwikkelingen en intercollegiale toetsing van het medisch handelen in ziekenhuizen. Tijdschrift voor Sociale Gezondheidszorg 65, 23, 1987, 735 .

F.N.V. Bedrijfsgezondheidszorg vanuit de werknemers gezien. Resultaten van een enquête onder kaderleden van de Industriebond FNV. Amsterdam FNV 1980.

F.N.V. Naar volwaardig werk in de industrie. Amsterdam FNV 1984.

F.N.V. Arbeidsomstandighedenwet en Ondernemingsraad. Terugblik en een blik vooruit. De Veiligheid 61, 6, 1985, 267-291.

F.N.V. Werknemers en bedrijfsgezondheidszorg. Naar een goede verhouding ondernemingsraad en bedrijfsgezondheidsdienst. Amsterdam FNV 1986.

Faes, W., Tilborgh van, C. Markering van diensten. Een handboek voor praktisch management. Deventer Kluwer 1984.

Federatie Gezamenlijke Bedrijfsgezondheidsdiensten, Strategische issues voor de Federatie. Interne notitie 1990.

Federatie Gezamenlijke Bedrijfsgezondheidsdiensten, Total Quality Management. Workshop voor Bedrijfsgezondheidsdiensten. 's Gravenhage 1990.

Federatie van Gezamenlijke Bedrijfsgezondheidsdiensten, Werkboek kwaliteitszorg bedrijfsgezondheidsdiensten. 's Gravenhage 1990.

Felser, Chr. Taakstelling van de OR en de VGW-commissie. Amsterdam Veiligheidsinstituut 1985.

Feringa, B., Kooten van, E. EG-kaderrichtlijn leidt tot wijziging Arbowet. Maandblad Arbeidsomstandigheden 67, 10, 1991, 665-668.

Fielding, J.E. The Proof of the Health Promotion Pudding is.... Journal of Occupational Medicine 30,2, 1988, 113-115.

Fielding, J.E. Occupatinal Health Physicians and Prevention. Joumal of Occupational Medicine 33, 3, 1991, 314-326.

Flick, H. Steuerung der Kleinstbetriebe bei der Betriebsanzlichen Versorgung. Arbeitsmedizin, Sozialmedizin, Prāventivmedizin 21, 7, 1986, 191-194.

Flipo, J.P. Service Firms: Interdependence of External and Internal Marketing Strategies. European Joumal of Marketing 20.8, 5-14.

Floor, K., Raay van, F. Marketing-communicariestrategie. Leiden/Antwerpen Stenfert Kroese 1989

Fontus, H.M., Levy, B.S. Physician-based Surveillance of Occupational Disease: Developing a Methodology I. Journal of Occupational Medicine 29, 8, 1987, 688-691.

Fontus, H.M. et al. Physician-based Surveillance of Occupational Disease: Developing a Meihodology II. Joumal of Occupational Medicine 31, 11, 1989, 929-933.

Fraterman, A. Bedrijfsgezondheidszorg en bedrijfsarts. Een werkgeversvisie. Tijdschrift voor Sociale Gezondheidszorg 64, 22, 1986, 700-703.

Frissen, M.A.G. Partijen in de gezondheidszorg maken afspraken over kwaliteit. Medisch Contact 45, 27/28, 1990, 871-872.

Geen van, F. De waarde van een waarde: een begin van een inventarisatie. Leiden Nederlands Instituut voor Preventieve Geneeskunde/TNO 1983. 
Geers, A.J.C.M. Recht en humanisering van de arbeid. Deventer Kluwer, dissertatie 1988.

Gelderman, P.W. Informatie als basis voor medische zorg en drager van kwaliteit. Medisch Contact 45, 31/32, 1990, 931-933.

Gemeenschappelijk Medische Dienst (GMD), Verzekeringsgeneeskundig kader. Amsterdam GMD 1984.

Geval, P. Marketing in de non-profit sector. Tijdschrift voor GVO 7, 4, 1990, 6-7.

Gevers, J.K.M. Wetgeving inzake de bedrijfsezondheidszorg in de EEG, deel I. Tijdschrift voor Sociale Gezondheidszorg 60, 10, 1982, 259-266.

Gevers, J.K.M. Wetgeving inzake de bedrijfsgezondheidszorg in de EEG, deel II. Tijdschrift voor Sociale Gezondheidszorg 60, 11, 1982, 282-285.

Gevers, J.K.M. Eg-beleid en arbeidsomstandigheden. Maandblad Arbeidsomstandigheden 62, 12, 1986, 754-755.

Gevers, J.K.M. De nieuwe ILO-normen inzake de bedrijfsgezondheidszorg. Sociaal Maandblad Arbeid 5, 1986, 414-419.

Gevers, J.K.M. Bedrijfsgezondheidszorg in internationaal perspectief. Maandblad Arbeidsomstandigheden 62, 2, 1986, 95-96.

Gevers, J.K.M. Medische keuringen. Nederlands Tijdschrift voor Geneeskunde 132, 22, 1988, 1018-1021.

Gevers, J.K.M. Gezondheidsrechtelijke aspecten van aanstellingskeuringen. Nederlands Tijdschrift voor Geneeskunde 132, 19, 1988, 462-465.

Giessen, A.G.M. et al. De behoefie aan standaardisering en uniformering bij de praktiserende bedrijfsarts. Instituut Sociale Geneeskunde Nijmegen 1986.

Gils van, M.R. De BGD als staf/lijn organisatie. Maandblad Arbeidsomstandigheden $64,9,1988,515-519$.

Griensven, J.G.M. Needs en demands in de Nederlandse bedrijfsgezondheidszorg. Amsterdam CORVU 1987.

Griffioen, M.C., Oosten van, M.C. Bloedonderzoek bij periodiek bedrijfsgezondheidkundig onderzoek. Amsterdam CORVU 1991.

Griner, P.F., Glaser, R.J. Misuse of Laboratory Tests and Diagnostic Procedures. The New England Journal of Medicine, 18, 1982, 1336-1339.

Grinwis, P., Keuning, D. Het besturen van non-profit organisaties: de aandacht waard. Deventer, Nive 1985.

Groenen, J. et al. Beschrijving van opleidingsprogramma's ten behoeve van de bedrijfsgezondheidszorg. SBOB Leiderdorp 1984

Groenen, J. et al. Elementen van bedrijfsgezondheidszorg in andere opleidingen dan die ror basis-arts. SBOB Leiderdorp 1984

Grol, R.P.T.M. Kwaliteitsbewaking in de huisartsgeneeskunde. Effecten van onderlinge toetsing. Nijmegen Nijmeegs Huisartseninstituut dissertatie 1987.

Grol, R.P.T.M., Schellevis, F. Onderlinge toetsing. Over de werving en motivering van huisartsen voor toetsingsactiviteiten. Medisch Contact 41, 51/52, 1986, 16771679.

Grol, R.P.T.M., Mesker, P. Huisarts en toetsing. Theorie en praltijk van onderlinge roetsing. Nijmegen Nijmeegs Huisartseninstituut 1984. 
Grol, R.P.T.M. et al. Consensus over consensus. Een kritische beschouwing van de procedure van de CBO-consensusoniwikkeling. Nederlands Tijdschnift voor Geneeskunde, 134, 24, 1990, 1186-1189.

Grônroos, Chr. Strategic Management and Marketing in the Service Sector. Cambridge Marketing Science Institute, report no. 83-104, 1982.

Grönroos, Chr. Relationship Approach to Marketing in Service Context: the Marketing and Organizational Behavior Interface. Journal of Business Research 20, 1, 1990, 3-13.

Grönroos, Chr. Service Management and Marketing. Managing the Moments of Truth in Service Competition. Lexington Books Massachusetts 1990.

Grootendorst, G. Registratie in de bedrijfsgezondheidszorg. Leiden Nederlands Instituut voor Preventieve Geneeskunde/TNO 1980.

Grünwald-Schindl, C.A., Kraan-Jetten, A. Evaluatie van en voor overheidsbeleid: een overzicht van vormen en benaderingen. Beleid en Maatschappij, 5, 1985, 128-138.

Gulden van der, J.W. Streven naar maarwerk. Sleutelen aan de vragenlijst PBGO. Tijdschrift voor Sociale Gezondheidszorg 68, 4, 1990, 199-200.

Gulden van der, J.W., Senden, Th.F. Stage bedrijfsgezondheidszorg in de Nijmeegse basisartsopleiding. Maandblad Arbeidsomstandigheden 65, 4, 1989, 241-244.

Gulden van der, J.W., Senden, Th.F. Gebruik van PBGO-gegevens voor onderzoek van knelpunten in de relatie mens en arbeid. Maandblad Arbeidsomstandigheden 66, $1,1990,17-21$.

Gulden van der,J.W. et al. De sociale geneeskunde in de eerste fase van de artsenopleiding. Tijdschrift voor Sociale Gezondheidszorg 68, 1, 1990, $45-49$.

Haas de, F.C.C. Bedrijfsgezondheidszorg bij de gemeente Nijmegen. Nijmegen Instituut Sociale Geneeskunde 1980.

Habbema, J.D.F. Beslissingsondersteunende technieken voor de kliniek. Nederlands Tijdschrift voor Geneeskunde 132, 8, 1988, 343-349.

Hage, G. Volvo nieuwe stijl. Intermediair 26, 15, 1990, 5-9.

Hagendoorn, L.M. Kwaliteitszorg binnen de instellingen. Medisch Contact 44, 16, 1989, 539-542.

Hall, J.A., Dornan, M.C. What Patients like about Medical Care and how often they are asked: a Meta-analysis of the Satisfaction Literature. Soc. Sci. Med. 27, 1, 1988, 935-939.

Hall, P. et al. Relationship berween Work Environment and Anamnestic Health Status. Use of Predictors, Indicators and Indices for the Evaluation of Medical and Environmental Factors. Scandinavian Joumal of Work en Environmental Health 1, 1975, 233-242.

Halperin, W.E. et al. Medical Screening in the Workplace: Proposed Principles. Journal of Occupational Medicine 28, 8, 1986, 547-552.

Hart van der, H.C.W. Leveren zonder prijssignaal. Een studie naar de toepassing van marketingbeginselen in organisaties zonder winstoogmerk. Helmond, dissertatie TU Eindhoven 1983.

Hart van der, H.W.C. Markagerichtheid bedrijfsgezondheidsdienst. Eindhoven Stichting Arbouw 1986. 
Hart van der, H.W.C. Marktgerichtheid voor bedrijfsgezondheidszorg. Maandblad Arbeidsomstandigheden 64, 9, 1988, 521-525.

Hart van der, H.W.C. Bedreigingen en kansen in de marka voor bedrijfsgezondheidszorg. Berg en Dal 1991.

Harteloh, P.P.H. Kwaliteit van zorg. Concepten en methoden. Rotterdam, 1990.

Harteloh, P.P.M. et al. Het definiëren van "kwaliteit van zorg". Medisch Contact 46, $1,1991,18-20$

Harteloh, P.P.M. en Casparie, A.F. Kwaliteit van zorg. Van een zorginhoudelijke benadering naar een bedrijfskundige aanpak. VUGA 's Gravenhage/ De Tijdstroom Lochem 1991.

Hattinga Verschure, J.C.M. Het verschijnsel zorg. Lochem De Tijdstroom 1977.

Have ten, H.A.M.J. Historisch-filosofische achtergronden van sociale gezondheidszorg. Tijdschrift voor Sociale Gezondheidszorg 61,23, 1983, 892-897.

Have ten, H.A.M.J. Gezondheid en haar wetenschappen. Nederlands Tijdschrift voor Geneeskunde 131, 29, 1987, 1274-1278.

Have ten, H.A.M.J. Gezondheidswetenschappen en de krisis in de gezondheidszorg. Tijdschrift voor Gezondheidswetenschappen 3, 1, 1988, 4-9.

Heerdink, C.F.M. et al. Protocolgebruik in de huisartsprakijk. Wat doen huisartsen met protocollen? Medisch Contact 45, 22, 1990, 717-720.

Hees van, O.S. De bedrijfsarts, werkgever en werknemers: een complexe driehoeksverhouding. Maandblad Arbeidsomstandigheden 63, 11, 1987, 682-686.

Hees van, O.S. Het periodiek bedrijsgezondheidkundig onderzoek. Oude wijn in nieuwe zakken. Tijdschrift voor Sociale Gezondheidszorg 66, 6, 1988, 197-199.

Hees van, O.S. PBGO en marketing, de kwaliteit van een BGZ-produkt. Maandblad Arbeidsomstandigheden 65, 9, 1989, 533-540.

Hefting, M. et al. Bedrijfsgeneeskundige en verzekeringsgeneeskundige aspecten van de aanstellingskeuring. Tijdschrift voor Verzekeringsgeneeskunde 25, 1987, 112-114.

Hensel, J.S. Service Quality Improvement and Control: a Customer based Approach. Journal of Business Research 20, 1, 1990, 43-55.

Herschel, J.G.,Peters, J.H. "Hospital audit", een haalbaar model? Medisch Contact $33,1978,1567-1570$.

Heskett, J.L. Lessons in the Service Sector. Harvard Business Review, March-April 1987, 118-126.

Hessel, P.A., Zeiss, E. Evaluation of the Periodic Examination in the South African Mining Industry. Joumal of Occupational Medicine 30, 7, 1988, 580-586.

Heutink, J.E. De bedrijfsarts in opleiding. Leiden Nederlands Instituut voor Preventieve Geneeskunde/TNO 1988.

Heuvel van de, W.J.A., Jenniskens, P.A.H. Getallen over het bedrijfsgeneeskundig spreekuur. Tijdschirif voor Sociale Gezondheidszorg 52, 1974, 122-129.

Heuvel van de, W., Persoon, J. Werkaspecten van het sociaal-geneeskundig beroep. Onderzoek bij drie categorièn sociaal-geneeskundigen. Enkele aspecten van taakopvatring en beroepsuitoefening. Tijdschrift voor Sociale Gezondheidszorg 50, $1972,84-87$

Heuvel van de, W., Persoon, J. Sociaal-geneeskundig beroep een "tweede" keus? Tijdschrift voor Sociale Gezondheidszorg 50, 1972, 48-52. 
Heyde van der, M.N. et al. De beslisboom in de heelkunde. Medisch Contact 38, 21, $1983,621-622$.

Hoekstra, P., Verzellenberg, L.N.J. Kwaliteitskringen in de gezondheidszorg? Medisch Contact 37, 11, 1982, 317-320.

Hoeven van der, J. Evaluation of a Programme of Periodic Medical Examination. Eindhoven dissertatie 1971.

Hofstede, G. "Management Control of Public and Nor-For-Profit Activities". Accounting Organizations and Society 6, 3, 1981, 193-211.

Holland, W.H. Evaluation of Health Care. Oxford Medical Publishers 1983.

Hoogendoom, J. Jaren negentig, de uisdaging voor personeelsmanagement. Gids voor Personeelsmanagement 12, 1989, 11-14.

Hoopen ten, A.J. Medische registratie, terminologie en doelen. Tijdschrift voor Sociale Gezondheidszorg 57, 1979, 69-73.

Houwaart, E. Hygienisten in de negentiende eeuw 1. Tijdschrift voor Sociale Gezondheidszorg $61,8,1983,258-265$.

Houwaart, E. Hygienisten in de negentiende eeuw II. Tijdschrift voor Sociale Gezondheidszorg 61, 9, 1983, 295-308.

Houwaart, E. Hygienisten in de negentiende eeuw III. Tijdschrift voor Sociale Gezondheidszorg 61, 10, 1983, 335-349.

Hulshof, C.T.J. et al. Het periodiek bedriffsezondheidkundig onderzoek (PBGO). Ervaringen van deelnemers. Tijdschrift voor Sociale Gezondheidszorg 68, 2, 1990, 8793.

Hulst, L.A. Commissie ter bestudering van het probleem van de maatschappelijke betekenis van keuringen. Medisch Contact 8, 1953, 731-736.

Hunfeld, G. Arbeidsongeschiktheid vroeger en nu. Tijdschrift voor Sociale Gezondheidszorg 62, 13, 1982, 523-529.

Jacobs, H.J.M. Algemeen periodiek geneeskundig onderzoek. Nijmegen Instituut Sociale Geneeskunde 1980.

Jacobs, Ph., Chovil, A. Economic Evaluation of Corporate Medical Programs. Joumal of Occupational Medicine 25, 4, 1983, 273-278.

Jacobs, Ch.M. et al. Measuring the Quality of Patient Care. The Rationale for Outcome Audit. Cambridge Ballinger Publishing Company 1976.

Jacques, P. Elementen voor een kosten-batenanalyse in de arbeldsgeneeskunde. Brussel 1988.

Jakobs, J.J. Kwaliteit door samenwerking; de samenwerking van arbo-deskundigen in de prakijk. Deventer GITP 1989.

Janssen, R.T.J.M., Rutten, F.F.H. Consumenteninvloed in de gezondheidszorg: utopie of werkelijkheid? Een economische benadering. Tijdschrift voor Sociale Gezondheidszorg 64, 10, 1986, 329-333.

Jenniskens, P.A.H. Is de bedrijsarts wel onafhankelijk gezien de beinvloeding door het bedrij? Metamedica 53, 1974, 54-58.

Jenniskens, P.A.H. Modelleren van bedriffsgezondheidszorg. Breda, BGD WestBrabant 1982.

Jones, G.R. Governing Customer-Service Organization Exchange. Joumal of Business Research 20, 1, 1990, 23-30. 
Jong de, G.A. Van sociale geneeskunde naar sociale gezondheidszorg. Tijdschrift voor Sociale Gezondheidszorg 59, 23, 1981, 843.

Jong de, G.A. Gezondheidszorg en crisis. Tijdschrift voor Sociale Gezondheidszorg 62, 24, 1984, 958-961.

Jong de, G.A. Kennis is macht, maar macht is meer dan kennis. De betekenis van onderzoek voor beleid. Tijdschrift voor Sociale Gezondheidszorg 63, 4, 1985, 140-150. Juran, M., et al. Quality Control Handbook. New York McGraw-Hill Book Company 1974.

Kaiser, C.P. Het verzekeringsgeneeskundig handelen en de verzuimduur. Universitaire Pers Maastricht. Dissertatie, 1992.

Kaluzny, A.D. Quality Assurance as a Managerial Innovation. A Research Perspective. Health Services Research 17, 1982, 253-268.

Kamphuis, M.A. Werk en werksituatie van bedrifsartsen: de aanstellingskeuring. Leiden Nederlands Instituut voor Preventieve Geneeskunde/TNO 1982.

Kamphuis, P.L., Hamers, P. Experiment "Bedrijfsgezondheidszorg voor Onderwijspersoneel" (EBO). Geïntegreerd rapport over het eerste experimenteerjaar, het tweede experimenteerjaar, het derde experimenteerjaar. Instituut voor sociaal-wetenschappelijk onderzoek (IVA) Tilburg 1988, 1989, 1990.

Kasdorp, J.P. Certificatie: een keurmerk voor gezondheidszorg. Medisch Contact 44, 20, 1989, 673-676.

Kasdorp, J.P., Schrijvers, G. Deregulering, een recept voor de gezondheidszorg? Tijdschrift voor Sociale Gezondheidszorg 62, 10, 1984, 390-402.

Kasper, J.D.P. Marktgerichte marketing: taalkundig slordigheidje of bittere noodzaak? Maastricht, inaugurele rede Rijksuniversiteit Limburg 1990.

Kastelein, W.R. Het inzagerecht van de patient. Een inventarisatie van jurisprudentie. Medisch Contact 44, 41, 1989, 1327-1330.

Kerkhoff, A.H.M. Sociale geneeskunde is geen vak. Tijdschrift voor Gezondheid en Politiek 11, 1987, 45-47.

Kessener, A.W. Een huis zonder blinden. Kwaliteit van zorg. Medisch Contact 44, 23, 1989, 783-785.

Kessner, D.M., Kalb, C.E. A Strategy for Evaluating Health Services (Tracer Srategy). Washington 1973.

Kesteren van, N.J.J. Artikel 3, een visie vanuit werkgeverskringen. Maandblad Arbeidsomstandigheden 64, 4, 1988, 239-241.

Klaver, J.,Vusse van de, A. Invoering Arbowet had sneller gekund. Maandblad Arbeidsomstandigheden $64,12,1988,737-739$.

Kleinman, G.D. Occupational Health and Safery. The Swedish model. Joumal of Occupational Medicine,26, 12, 1984, 901-905.

Kloks, D., Levie, H. Het functioneren van VGW-commissies. Deel 1: Overschakelen van vergader- naar doecultuur. Maandblad Arbeidsomstandigheden 67, 3, 1991, 153157.

Kloks, D., Levie, H. Het functioneren van VGW-commissies. Deel 2: VGW-commissie, partner in Arbobeleid. Maandblad Arbeidsomstandigheden 67, 4, 1991, 229-233. 
Knepper, S. Epidemie van arbeidsongeschilaheid. Jaarverslag GMD 1988. Medisch Contact 44, 46, 1989, 1521-1522.

Knepper, S. Sociaal-medische begeleiding. Een kwestie die niet alleen artsen aangaat. Medisch Contact 45, 5, 1990, 143-146.

Knepper, S. "Medische" oplossingen voor sociaal-economische problemen? Medisch Contact 45, 21, 1990, 671-672.

Knepper, S. Reintegratie in de prattijk van de AAW/WAO. Maandblad Arbeidsomstandigheden $66,9,1990,622-626$.

Knepper, S. Nog meer arbeidsongeschiken. Jaarverslag 1989 GMD. Medisch Contact 45, 45, 1990, 1341-1343.

Knippenberg van, A., Siero, F. Multivariate analyse. Beknopte inleiding en toepassingen. Deventer, Van Loghum Slaterus 1980.

Koch, W.A.M. Bedrijfsgezondheidszorg, een eerste echelonsvoorziening? NVAB info, 17, 3, 1986, 19-22.

Koninklijke Nederlandse Maatschappij tot bevordering der Geneeskunst, Rapport van de commissie "Taak bedrijfsarts". Beschrijvingsbrief Algemene Ledenvergadering KNMG 20/12/1969.

Koninklijke Nederlandse Maatschappij tot bevordering der Geneeskunst, De kwaliteit van de medische beroepsuitoefening. Medisch Contact 35, 28, 1980, 849-855.

Koninklijke Nederlandse Maatschappij tot bevordering der Geneeskunst, Gezondheidszorg bij beperka middelen. Medisch Contact 41, 12, 1986, 357-373

Koninklijke Nederlandse Maatschappij tot bevordering der Geneeskunst, Ontwerp document gezondheidsbeleid. Medisch Contact 44, 29/30, 1989, 973-977.

Koninklijke Nederlandse Maatschappij tot bevordering der Geneeskunst, Kwaliteit gezondheidszorg afhankelijk van samenspel van alle betrokkenen. Medisch Contact 44, 40, 1989, 1282-1285.

Koninklijke Nederlandse Maatschappij tot bevordering der Geneeskunst, Discussienota "Keuringen". Aanzet tot een algemeen aanvaarde beleidslijn als basis voor overeenkomsten, gedragscodes en wetgeving. Medisch Contact 44, 42, 1989, 13681373.

Koninklijke Nederlandse Maatschappij tot bevordering der Geneeskunst, Reorganisatie uitvoering sociale verzekeringen. Medisch Contact 44,44, 1989, 1432.

Koninklijke Nederlandse Maatschappij tot bevordering der Geneeskunst, CSG: opleiding arbeids- en bedrijfsgeneeskunde. Medisch Contact 45, 11, 1990, 376-371.

Koninklijke Nederlandse Maatschappij tot bevordering der Geneeskunst, CSG, toekomstplannen. Medisch Contact 45, 49, 1990, 1483-1485.

Koninklijke Nederlandse Maatschappij tot bevordering der Geneeskunst, Partijen in de gezondheidszorg maken afspraken over kwaliteit. Medisch Contact 45, 27/28, 1990, 871-875.

Koninklijke Nederlandse Maatschappij tot bevordering der Geneeskunst, Nota "Werken aan zorgvernieuwing". Medisch Contact 45, 45, 1990, 1355-1360.

Koninklijke Nederlandse Maatschappij tot bevordering der Geneeskunst, CSG, Opleiding arbeids- en bedrijfsgeneeskunde. Medisch Contact 46, 27/28, 1991, 860-864. 
Koopman, A.W.H. Werk en werksituatie van bedrijfsartsen: gericht periodiek geneeskundig onderzoek. Leiden Nederlands Instituut voor Preventieve Geneeskunde/TNO 1982.

Koot, W.T.M. Analyse van organisatiestructuren. De geldigheid en bruikbaarheid van de Aston-studies. Alphen a/d Rijn Samson 1981.

Korevaar, K., Soeterbroek, F. Arbeidsomstandigheden en CAO-beleid. Tijdschrift voor Arbeidsvraagstukken, 5, 1, 1989, 62-70.

Kort de, W.L.A.M. Overheid en (periodiek) geneeskundig onderzoek: enige plannen voor de nabije toekomst. NVAB-info 19, 2, 1988, 30-33.

Kort de, W.L.A.M. De aanstellingskeuring: een selectie-instrument? 's Gravenhage DGA-reeks S53, 1988.

Korstjens, G. Arboplatform ziet het licht. Maandblad Arbeidsomstandigheden 64, 11, 1988, 658-663.

Korstjens, G. Gedeukt imago. Maandblad Arbeidsomstandigheden 65, 10, 1989, 583.

Kotek, W. Het onderwerp "BGZ" in de niet medische pers. Een impressie van kranteknipsels. Leiden Nederlands Instituut voor Preventieve Geneeskunde/TNO 1981.

Kotler, Ph., Clarke, R.N. Marketing for Health Care Organizations. New Yersey Prentice Hall 1987.

Kramer, A.W.M. et al. Het toetsen van kennis in de beroepsopleiding tot huisarts. Medisch Contact 45, 7, 1990, 220-222.

Krijgsman, E.S. Periodiek geneeskundig onderzoek. Poging tot inventarisatie. Mening van de consument. Nijmegen Instituut Sociale Geneeskunde 1980.

Kroonen, A.,Boot, J.M. Markelementen in de gezondheidszorg. Over het stellen van randvoonwaarden. Medisch Contact 42, 30, 1987, 931-933.

Kruyt, J.W. Het ziekenhuis als producent. Medisch Contact 40,40, 1985, 1243-1245.

Kuin, R. Regering en oppositie niet ontevreden over arbobeleid. Maandblad Arbeidsomstandigheden 63, 12, 1987, 769-773.

Kuiper, J.P. Het zal onze zorg zijn. Inleiding tot de gezondheidkunde: basis voor een inclusieve gezondheidszorg. Assen Van Gorcum 1975.

Kuiper, J.P. Humanisering van de arbeid. Redactie C. de Galan, M.R. van Gils, P.J. van Strien. Van Gorcum Assen 1983.

Kuiper, R. De leest van de bedrijfsarts. Nijmegen Instituut Sociale Geneeskunde 1982.

Kuiper, J.P. Vertoont het belastingsmodel ideologische trekken? Tijdschrift voor Sociale Gezondheidszorg 63, 14, 1985, 579-580.

Kuipers, H. Kwaliteitsbeleid en kwaliteit van de arbeid vanuit een sociotechnische invalshoek. Utrecht Nive kwaliteitsdag 1990.

Kuitenbrouwer, F. Testbatterij. De kwetsbare positie van de keurling. Personeelswetenschappen 12, 1988, 57-60.

Kumpe, T., Bolwijn, P.T. Fabrieken met een toekomst. Informatie 32, 11, 1990, 837847.

Kunst, P. en Lemmink, J.(eds) Quality Management in Services. Van Gorcum Assen/Maastricht 1992.

Kwantes, J.H. Europese wet- en regelgeving. Maandblad Arbeidsomstandigheden 65, 10, 1989, 623-624. 
Kwantes, J.H. EG-kaderrichslijn leidt tot nieuwe voorschriften Arbowet. Maandblad Arbeidsomstandigheden 68, 3, 1992, 187-188.

LOD, werkgroep standaardisatie, rapporiage subcommissie werkplekactiviteiten. 's Gravenhage 1989

LOD, werkgroep standaardisatie, rapportage subcommissie spreekuur. 's Gravenhage 1989

LOD, werkgroep standaardisatic, rapportage subcommissie periodiek onderzoek. 's Gravenhage 1989

LOD, werkgroep standaardisatie, rapportage subcommissie aanstellingskeuring. 's Gravenhage 1989.

LVSG, Kwaliteitszorg in de sociale geneeskunde. Beleidsnotitie van de LVSG Utrecht 1989.

Laane, W.L.J.M., Vuister, F.M. Medisch-resultaat-management. Medisch Contact 45, $31 / 32,1990,936-938$.

Lahaye, D. Arbeidsgeneeskunde in kleine bedrijven. Tijdschrift voor Sociale Gezondheidszorg 59, 15, 1981, 523.

Lahaye, D. Arbeidsgeneeskunde in discussie. Tijdschrift voor Sociale Gezondheidszorg $62,14,1984,549$.

Lamers, L. Adviesaanvrage inzake sociaal-medische begeleiding bij ziekse en arbeidsongeschiktheidsregeling. 's Gravenhage ministerie SoZaWe 1983.

Lamers, L. Het aandeel van bedriifsgezondheidszorg bij de uitvoering van de wetgeving inzake sociale zekerheid. Tijdschrift voor Sociale Gezondheidszorg ,62, 5, 1984, 190-193.

Lammeren van, B. Instituut De zachte kern van MANS. Personeelswetenschappen 13, 1985, 15-17.

Lammers, C.J. Organisaties vergelijkenderwijs. Utrecht Het Spectrum 1983.

Langeard, E. et al. Service Marketing: New Insights from Consumers and Managers.

Cambridge Marketing Science Institute 1981.

Lappe, M. Ethical Issues in Testing for differential Sensitivity to Occupational Hazards. Journal of Occupational Medicine 25, 11, 1983, 797-808.

Lapré, R.M. Is de gezondheidszorg het waard? Over de relatie economie-geneeskunde en het zoeken naar een hoger rendement. Tijdschrift voor Sociale Gezondheidszorg 61, 23, 1983, 899-903.

Leeflang, P.S.H., Beukenkamp, P.A. Probleemgebied marketing, een managementbenadering. Leiden Stenfert Kroese 1987.

Leenen, H.J.J. Kwaliteitsbewaking in de gezondheidszorg. Medisch Contact 34, 29. 1979, 931-938.

Leenen, H.J.J. Deskundigheid als element in het systeem van gezondheidszorg. Tijdschrift voor Sociale Gezondheidszorg 59, 10, 1981, 332-333.

Leeuw de, A.C.J. Organisaties: management, analyse, ontwerp en veranderingen; een systeemvisie. Assen Van Gorcum 1982.

Leeuwen van, M. Ant en arbeidssatisfactie. Medisch Contact 43, 18, 1988, $551-555$.

Leuftink, A.E. Wie het kleine niet eert... Tijdschrift voor Sociale Gezondheidszorg 58, 1980, suppl, 58-60. 
Leun van der, J.C. Een onderzoek naar enkele gevolgen van afkeuring bij aanstelling. Nijmegen Instituut Sociale Geneeskunde 1981.

Levie, $\mathrm{H}$. Werknemers en bedrijfsgezondheidszorg. Maandblad Arbeidsomstandigheden $64,4,1988,257-258$.

Levie, H. Bent $u$ echt zover dat werknemers meer zijn dan het object van uw zorg? Maandblad Arbeidsomstandigheden.65, 9, 1989, 549-550.

Leyssen, H.L. Het bedrijfsgezondheidkundig spreekuur. Haarlem De Erven F. Bohn Dissertatie 1972.

Lindeboom, R.D. De macht van de "arts" en de macht van "de baas". Maandblad Arbeidsomstandigheden 63, 7/8, 1987, 449-455.

Lingen van, B. et al. Kwaliteit van verpleegkundige zorg in verpleeghuizen. Een meetinstrument. Lochem De Tijdstroom 1990.

Londen van, J. Arbeid en gezondheid, gezondheidsbedrijf en bedrijfsleven. Tijdschrift voor Sociale Gezondheidszorg 62, 5, 1984, 187-189.

Lourijsen, E.C.M.P. et al. De medische aanstellingskeuring. Een inventarisatie van de mate waarin en de wijze waarop Nederlandse bedrijven en artsen medische aanstellingskeuringen (laten) verrichten. 's Gravenhage DGA-reeks S53-1 1989.

Lourijsen, E.C.M.P. et al De praktijk van de medische aanstellingskeuring in Nederland. Een samenvattend verslag van een aantal onderzoeken naar de omvang, uitvoering en kwaliteit van medische aanstellingskeuringen. 's Gravenhage DGAreeks \$53-3, 1991.

Lovelock, Chr.H. Service Marketing. Text, Cases \& Readings. New Yersey Prentice Hall Inc. 1984.

Lowenthal, G. Medical Center Worker Preplacement Screening: a Follow-up study. Journal of Occupational Medicine 28, 6, 1986, 451-452.

Luke, R.D., Boss, R.W. Barriers Limiting the Implementation of Quality Assurance Programs. Health Services Research 16, 3, 1981, 305-313.

Lunshof, T. Meenwaarde van bedriifsgezondheidszorg bij ziekteverzuim. Tijdschrift voor Sociale Gezondheidszorg 66, 2, 1988, 51-55.

Lunshof, T. Het tandem-model. Maandblad Arbeidsomstandigheden 66, 9, 1990, 643645.

Lysonski, S., Lombardo, H.B. Organizing for Service Marketing: the Impact of Customer Contact and Environmental Uncertainty. Proceedings XIVthe EMAC Conference Bielefeld 1985, 559-569.

Maasen, J.H.W. Verzuimbegeleiding en overspanning. Nijmegen Instituut Sociale Geneeskunde 1985.

Maassen, J.H.W. Psychosociale opvang in het bedrijf. Tijdschrift voor Sociale Gezondheidszorg 64, 24, 1986, 784-789.

Magnus, D. Versuch der Kosten-Nutzen-Analyse einer Werkartichen Abteilung. Arbeitsmedizin Sozialmedizin Präventivmedizin 8, 1985, 185-187.

Makens, P.K., McEachem, J.E. Applications of Industrial Quality Improvement in Health Care. Journal of Occupational Medicine 32, 12, 1990, 1177-1183. 
Marcelissen, F.H.G. et al. De vragenlijst voor periodiek bedrijfsgezondheidkundig onderzoek III: Methoden voor het gebruik van referentiegegevens. Tijdschrift voor Sociale Gezondheidszorg 66, 3, 1988, 115-120.

Meer van der, J. Moeilijke keuzen aan het ziekbed: reken niet op de besliskunde. Nederlands Tijdschrift voor Geneeskunde 132, 8, 1988, 336-337.

Mehl, J. Die Arbeitsmedizin in Frankreich. Arteitsmedizin Sozialmedizin Präventivmedizin 24, 1989, 212-217.

Meijer, E. De "onafhankelijkheid" van de bedrijfsarts. Tijdschrift voor Sociale Gezondheidszorg 65, 10, 1987, 338-339.

Mertens, A.Th.L.M. De medicus in de individuele gezondheidszorg, de sociale gezondheidszorg, de welzijnszorg. Tijdschrift voor Sociale Gezondheidszorg 60, 1, 1982, 2-9.

Metz, W. Bedrijfsgezondheidszorg, kan het beter? Symposium cursus Arbeids- en bedrijfsgeneeskunde Nijmegen 1985.

Meuwissen, I.R.V.M. Intercollegiale toetsing in de verzekeringsgeneeskunde. Utrecht SSG 1985.

Millar, J.D. Screening and Monitoring: Tools for Prevention. Journal of Occupational Medicine 28, 8, 1986, 544-546.

Miller, A.B. Synthesis of Papers on Biological Monitoring, Case Studies in Screening, and Social and Economic Issues. Journal of Occupational Medicine 28, 8, 1986, 782-788.

Mindak, W., Folger, R. Toward Integration of Marketing and Organization Behavior in the Service Economy. Journal of Business Research 20, 1990, 1-2.

Minderhoud, P., Wilthagen, A. De street-level bureaucraat. Intermediair 25, 20, 1989, 49-55

Mulock Houwer, E.J. Kaderrichslijn en modernisering arbo-zorg. Maandblad Arbeidsomstandigheden $68,7 / 8,1992,448-451$.

NIA, Arbojaarboek 1989. Bijzondere regelingen, Amsterdarn 1989, 394-399.

NIA, Nieuwe grenzen aan arbeidsomstandigheden. Europese richtlijnen en hun invloed op de Nederlandse situatie. Amsterdam NIA 1990.

NRV, Discussienota begrippenkader kwaliteit beroepsuitoefening. Zoetermeer 1986.

NRV, Rappon Bedrijfsgezondheidszorg. Zoetermeer, commissie bedrijfsgezondheidszorg van de NRV 1987.

NVAB, Bedrijfseneeskunde van de toekomst. Symposium Tijdschrift voor Sociale Gezondheidszorg 46, 14, suppl.2, 1968, 1-92.

NVAB, De plaats en organisatie van de bedrijfsgeneeskunde in de Nederlandse gezondheidszorg van de toekomst. Tijdschrift voor Sociale Gezondheidszorg 53, 13, suppl.2,1975, 3-26.

NVAB, Periodiek geneeskundig onderzoek. NVAB-info 10, 1, 1979, 2-7.

NVAB, Charta van de bedrijfsgezondheidszorg in Europa. NVAB-info 12, 3, 1981, 3-18.

NVAB, Standpuntbepaling ten aanzien van taken van de bedrijfsarts met betrekking tot het ziekteverzuim. NVAB-info 12, 1, 1981, 4-6.

NVAB, Kontaken en samenwerking NVAB-NVVK. NVAB-info 13, 4, 1982, 3-6. 
NVAB, Taak, bevoegdheid en verantwoordelijkheid van de bedrijfsarts en de bedriffsverpleegkundige. NVAB-info, 14, 3, 1983, 7-9.

NVAB, Jaarrede voorzitter 1983. NVAB-info 14, 4, 1983, 2-8.

NVAB, Erkenning van afdelingen van bedrijfsgezondheidszorg van basisgezondheidsdiensten. Tijdschrift voor Sociale Gezondheidszorg 62, 9, 1984, 384.

NVAB, Toetsen van bedrijfsgezondheidsdiensten. NVAB-info, 15,4, 1984, 22-25.

NVAB, Jaarrede voorzitter 1984. NVAB-info 15, 2, 1984, 8-14.

NVAB, Nota over het samenwerken van bedrijfsverpleegkundige en bedriffsarts in de $B G D$. NVAB-info 15,2 , 1984, 19-28.

NVAB, Nota: Plaats en taak van de arbeidshygiëne in het kader van de Arbowet, gezien vanuit de bedriifsgezondheidszorg. NVAB-info 16, 4, 1985, 31-33.

NVAB, De werkerreinafbakening van de bedrijfsgezondheidsdiensten. NVAB-info $16,4,1985,5-16$.

NVAB, Bedriffsezondheidszorg. Een plaatsbepaling in het beleid van de onderneming. NVAB-info 16, 3, 1985, katern.

NVAB, BGZ in de problemen, de hand in eigen boezem. Jaarrede voorzitter 1987.

NVAB, De verzekeringsgeneeskundige en bedrijfseneeskundige functieopdeling of integratie. NVAB-info, 18, 3, 1987, 16-18.

NVAB, Motie 1975 betreffende aanstellingskeuring. NVAB-info 19, 2, 1988, 9.

NVAB, Jaarrede voorzitter 1988. NVAB-info 19,2,1988, 4-8.

NVAB, BGZ in perspectief. Nota commissie structuur NVAB 1988.

NVAB, Beleidsplan NVAB. NVAB 1989.

NVAB, Naar een andere wijze van advisering door de Arboraad. NVAB-info 20, 2, 1989, 26-30.

NVAB, Samenvatting van de interdepartementale werkgroep aanstellingskeuringen. NVAB-info 20, 3, 1989, 9-12.

NVAB, Beroepscode voor bedrijfsartsen. NVAB 1989.

NVAB, Aanstellingskeuringen door bedrijfsartsen. NVAB 1989.

NVAB, Kabinetsstandpunt met betrekking tot de medische keuring bij aanstelling. NVAB-info 21, 2, 1990, 10-16.

NVAB, Beleidsplan NVAB. NVAB 1990.

NVAB, Voorstel tot modernisering van de wettelijke regeling van de bedrijfsgezondheidszorg en het te voeren beleid. NVAB-info 21, 3, 1990, 3-11.

NVAB, Preventie van arbeidsongeschiksheid: een bijdrage vanuit de bedrijfsgezondheidszorg. NVAB-info 21, 4, 1990, 3-8.

NVAB, Beleidsplan 1991-1994. NVAB 1991.

NVAB, Beleidsplan 1992-1995. NVAB 1992.

NVAB, KNMG-discussiestuk: Artsen en arbeidsongeschiktheid. NVAB-info 23, 1, 1992, 3-17.

NVAB, Bedrijfsgezondheidszorg in politieke belangstelling. NVAB-info 23, 1, 1992 , 20-29.

NVAB, Verslag van de Commissie Onderwijs. NVAB-info 23, 1,1992, 29-35.

NVAB/NVVG, Naar een verbeterde samenwerking. Eindrapport van de commissie samenwerking bedrijfsarts-verzekeringsgeneeskundige NVAB-info 20, 4, 1989, 3-12. 
NVAB/NVVK/NVvA, De plaatsbepaling van de bedrijfsgeneeskunde, de veiligheidskunde en de arbeidshygiène in relatie tot elkaar. Gezamenlijke nota van NVAB, NVVK en NVvA, Maandblad Arbeidsomstandigheden 64, 5, 1988, 304-305.

NVVG, Verzuimpreventie. Rapport van de commissie ziekteverzuim van de NVVG, Amsterdam NVVG 1989.

NVVG, Verslag van de Ledenvergadering: "Zorg voor kwaliteit". Tijdschrift voor Verzekeringsgeneeskunde 28, 1990, 185-188.

Nijhuis, F.J.N., Soeters, J. Ziekteverzuim, arbeidsongeschiktheid en de organisatie van de arbeid. Tijdschrift voor Sociale Gezondheidszorg 61, 19, 1983, 686-693.

Nijhuis, F.J.N., Haesen, J.W.H. De positie en taken van de bedrijfsverpleegkundige. Onderzoek uitgevoerd door Rijksuniversiteit Limburg in opdracht van het DGA, Maastricht, 1990, SZW \$79

Offerhaus, L. Aansprakelijkheid voor beroepsfouten, een taboe doorbroken? Nederlands Tijdschrift voor Geneeskunde 134, 33, 1990, 1583-1585.

Oostendorp, Y., Kromhout, H. Model voor werkplekonderzoek naar de blootstelling aan chemische stoffen. Wageningen 1985.

Oostendorp, Y. et al. Algemeen werkplekonderzoek in Nederland. Tijdschrift voor Sociale Gezondheidszorg 65, 24, 1987, 798-802.

Oosterom van, A. Het sociaal team in de bedriifsgezondheidszorg. BGZ-samenwerking bij de NS. Medisch Contact 35, 12, 1980, 356-358.

Overheid, Wet, houdende bepalingen tot beveiliging bij den arbeid in het algemeen en bij het verblijven in fabrieken in het bijzonder (Veiligheidswet 1934). Staatsblad 352.

Overheid, Besluit tot vaststelling van een algemene maatregel van bestuur, als bedoeld in de artikelen 6 en 7 der Veiligheidswet 1934 ("Veiligheidsbesluit voor fabrieken of werkplaatsen 1938"). Staatsblad 872.

Overheid, Wet van 19 februari 1959 tot aanvulling van de Veiligheidswet 1934 en de Stuwadoorswet met bepalingen omtrent preventieve gezondheidszorg in de bedrijven. Staatsblad 56.

Overheid, Besluit van 20 juli 1961 tot vaststelling van een Algemene maatregel van bestuur, als bedoeld in artikel 8a, zesde lid van de Veiligheidswet 1934 en 12 quater, zesde lid van de Stuwadoorswet (Besluit eisen bedriifsgezondheidsdiensten). Staatsblad 235.

Overheid, Besluit van 20 juli 1961 tot vaststelling van een algemene maatregel van bestuur, als bedoeld in antikel 8 a eerste lid van de Veiligheidswet 1934 (Besluit aanwijzing ondernemingen bedrijfsgezondheidsdiensten). Staatsblad 236.

Overheid, Wet van 25 maan 1971 tot wijziging van de Veiligheidswet 1934. Staatsblad 225.

Overheid, Besluit van 13 november 1974 tot vaststelling van een algemene maatregel van bestuur, als bedoeld in artikel 20f, tweede lid onder c en $20 \mathrm{~m}$, zevende lid, van de Veiligheidswet 1934 (Besluit eisen bedrijfsgezondheidsdiensten). Staatsblad 741. 
Overheid, Besluit van 13 november 1974 tot vaststelling van een algemene maatregel van bestuur, als bedoeld in artikel 20c, eerste lid, van de Veiligheidswet 1934 (Besluit verplichtstelling van bedrijfsgezondheidsdiensten). Staatsblad 740.

Overheid, Wet van 8 november 1980 houdende bepalingen in het belang van de veiligheid, de gezondheid en het welzijn in verband met de arbeid (Arbeidsomstandighedenwet). Staatsblad 664.

Overheid, Wet van 26 november 1987, houdende wijzigingen van de Arbowet en van de Wet op de gevaarlijke werktuigen met betrekking tot deregulering en enige andere onderwerpen. Staatsblad 535.

Overheid, Besluit Restgroepen 1990.

Parasuraman, A. et al. A Conceptual Model of Service Qaulity and its Implications for Future Research. Journal of Marketing, vol. 49, 1985, Fall, 33-46.

Parasuraman, A. et al. SERVQUAL; A Multiple Item Scale Measuring Customer Preceptions of Service Quality. Report 86-108, Marketing Science Institute Cambridge 1986.

Parasuraman, A. et al. A Multi-sector Study of Customer Service Expectations. Interne notitie 1990.

Parkinson, D.K., Grennan, M.J. Establishment of Medical Surveillance in Industry: Problems and Procedures. Journal of Occupational Medicine 28, 8, 1986, 772-777.

Peeters, M. Welzijn in de Arbowet. De WEBA-methodiek als hulpmiddel om functies te beoordelen en te verbeteren. Personeelsbeleid 26, 2, 1990, 77-80.

Peters, E., Senden, Th. De bedrijfsarts van morgen: regisseur of acteur? Maandblad Arbeidsomstandigheden 64, 10, 1988, 610-613.

Peters, J.H. et al. Management in de gezondheidszorg. Hoofdstuk 6-10. Bohn Scheltema \& Holkema Utrecht/Antwerpen 1986.

Petit, J.J., Heuvel van den, J. Automatiseren: waarom niet het medisch dossier? Medisch Contact 45, 31/32, 1990, 933-935.

Philipsen, H. Het medisch oordeel: besliskunde of speltheorie? Tijdschrift voor Sociale Gezondheidszorg 57, 1979, 838-842.

Pieters, H.M., Jacobs, H.M. Hulpverlening aan huisartsen in opleiding getoetst. Een gedetailleerde consultobservatie. Medisch Contact 38,49, 1983, 1539-1542.

Plomp, H.N. Onduidelijkheid over de rol van de bedrijfsarts. Meningen en gedragingen van werknemers ten sanzien van de bedrijfsgezondheidsdienst. Tijdschrift voor Sociale Gezondheidszorg 64, 22, 1986, 704-708.

Plomp, H.N. Het bedriifsgezondheidkundig spreekuur onderzocht. Tijdschrift voor Sociale Gezondheidszorg 65, 1, 1987, 8-14.

Plomp, H.N. Tussen raderen. De positie van bedrijfsartsen. Tijdschrift voor Gezondheid en Politiek 1987, 27-30.

Plomp, H.N. Bedrijven en bedrijfsgezondheidsdiensten. Een studie naar het verloop en de determinanten van professionaliseringstendensen. Amsterdam VU-uitgeverij dissertatie 1987.

Plomp, H.N. Een sterke professionele identiteit, voorwaarde yoor het strategisch handelen van de bedrijfsgezondheidszorg. Maandblad Arbeidsomstandigheden 64, 9. 1988, $511-514$. 
Plomp, H.N. Deskundige dienst en OR hebben negatief beeld van elkaar. Maandblad Arbeidsomstandigheden 67, 6, 1991, 397-400.

Plomp, H.N. De bedrijfsarts tussen Klantgerichtheid en professie. Lezing t.g.v. de studieconferentie "De bedrijfsarts, tussen klantgerichtheid en professie", Scheveningen 1991.

Pool, J. Besluitvorming in organisaties. "Know how" en "know who". Intermediair 22, 42, 1986, 45-49.

Prins, R. Sickness Absence in Belgium, Germany (FR) and the Netherlands. Amsterdam NIA 1990, Proefschrift Rijksuniversiteit Limburg.

Prins, R. Op dit terrein is meer overdacht dan onderzocht. Maandblad Arbeidsomstandigheden 66, 9, 1990, 637-639.

Putten van, D.J., Oversloot, J.S. Model Bedrijfsezondheidszorg. Srandaardformulieren voor het vastleggen van gezondheidsgegevens; werkwijze en problemen in de prakijk. Leiden Nederlands Instituut voor Preventieve Geneeskunde/TNO 1984.

Putten van, D.J., Oversloot, J.S. Periodiek onderzoek in de bedrijfsgezondheidszorg. Opzet en inhoud van het APO en PBGO op een 50 ial BGD'en. Tijdschrift voor Sociale Gezondheidszorg 64, 21, 1986, 676-680.

Putten van, D.J. et al. De vragenlijst voor periodiek bedrijfsgezondheidkundig onderzoek 1 . Achtergronden van de vragenlijst en het gebruik ervan bij een periodiek onderzoek voor bouwvakkers. Tijdschrift voor Sociale Gezondheidszorg 66, 1, 1988, 3-8.

Putten van, D.J., et al. De vragenlijst voor periodiek bedrijfsgezondheidkundig onderzoek II: Het wijzigen van antwoorden van werknemers door bedrijfsartsen. Tijdschrift voor Sociale Gezondheidszorg 66, 2, 1988, 57-61.

Rantanen, J. Risk Assessment and the Setting of Priorities in Occupational Health and Safety. Scandinavian Joumal of Work Environmental Health 7, suppl. 4, 1981, 8490.

Rathmel, J.M. Marketing in the Service Sector. Cambridge Winthrop Publishers Inc. 1974.

Razenberg, P.P.A. Oordelen: theorieèn en strategieën. Tijdschrift voor Verzekeringsgeneeskunde 28, 1990, 139-144.

Reekum van, G. Kwaliteit van dienstverlening. PBGO kan gebaat zijn bij merkenstrategie of keurmerk. Maandblad Arbeidsomstandigheden 65, 9, 1989, 529-532.

Reerink, E. Kwaliteitsbewaking in het ziekenhuis. Van patiënt naar consument. Medisch Contact 40, 41, 1985, 1279-1280.

Reerink, E., Schweizer, A.Th. Kwaliteitsbevordering van het specialistisch handelen in ziekenhuizen. Leiden Stafleu-reeks 1980.

Reijniers, K. Bedrijfsgezondheidszorg in een neergaande konjunktuur. Tijdschrift voor Sociale Gezondheidszorg 61, 3, 1983, 106-11.

Reinalda, W.H.P.M. Onderlinge toetsing als instrument voor professionalisering. Maandblad Arbeidsomstandigheden 65, 9, 1989, 545-549.

Reubsaet, T.J.M. et al. De Arbowet in uirvoering. Een onderzoek naar ervaringen in de praktijk. Tilburg, Instituut Toegepaste Sociale wetenschappen (ITS) 1988. 
Rijen van, A.J.G., Veen van, E.B. Omgaan met persoonsgegevens. Medisch Contact 45, 39, 1990, 1152-1155.

Rijssen-Moll van, M.Th. Bedrijfsgezondheidszorg in Nederland. een exploratief onderzoek naar voorzieningen op het terrein van de bedrijfsgezondheidszorg in Nederland. Nijmegen Instituut Sociale Geneeskunde 1982.

Rijssen-Moll van, M.Th. Arbeid, welzijn en politiek in de vorige eeuw. Maandblad Arbeidsomstandigheden 63, 4, 1987, 240-242.

Rijssen-Moll van, M.Th. Sociale wetgeving in Nederland tussen 1850 en 1905. Nijmegen Instituut Sociale Geneeskunde 1983.

Roo de, A.A.,Moll, J.W. Naar een geregelde nascholing van artsen. Medisch Contact 43, 1, 1988, $21-24$.

Roos, J. Protocol toverkol? Medisch Contact 38, 22, 1983, 653-654.

Roos de, A.J. Heden en toekomst van de bedrijfsgezondheidszorg in een maatschappij in verandering. Maandblad Arbeidsomstandigheden 63, 7/8, 1987, 433-438.

Roscam Abbing, H.D.C. Kwaliteitsbewaking en -bevordering in de gezondheidszorg; evenwicht tussen wetgeving en zelf ordenen. Nederlands Tijdschrift voor Geneeskunde $134,17,1990,865-869$.

Rozemond, P., Felser, Chr. Tweede landelijke VGW-dag. Maandblad Arbeidsomstandigheden 66, 12, 1990, 865-866.

Ruinen, G.F.T. Ervaringen van werknemers over hun bedrijfsgezondheidszorg. Amsterdam CORVU 1985

Ruinen, G.F.T. Plaats en functie van de gemeentelijke bedrijfsgezondheidszorg. Amsterdam CORVU 1985.

Rutten, F.F.H. Marketing Strategies for Publicly Financed Health Care Systems. Health Policy 7, 1987, 135-148.

SOZAWE, Een Arbo-dienst aan de arbeid. Evaluatierapport BGD-Oost-Gelderland. 's Gravenhage 1989.

SOZAWE, Een sollicitant is ook een mens. Rapport van de commissie Hessel. 's Gravenhage SOZAWE verslagen en rapporten nr. 5, 1977.

Sanders, H.W.A. Het vastleggen, bewaren en gebruiken van medische gegevens. Medisch Contact 45, 39, 1990, 1155-1159.

Schendelen van, M.C.P.M. Hoe zorgwelkend is de crisis? Tijdschrift voor Sociale Gezondheidszorg 62, 24, 1984, 955-958.

Schilling, R.S.F. The Role of Medical Examination in Protecting Worker Health. Joumal of Occupational Medicine 28, 8, 1986, 553-557.

Schreurer, J.G. De bedrijfsgezondheid in de onderneming van de toekomst. Maandblad Arbeidsomstandigheden 64, 9, 1988, 525-529.

Schreurs, J.G.M. Het doen van de aanstellingskeuring. Maandblad Arbeidsomstandigheden 65, 7/8, 1989, 452-455.

Scott, W.R. Managing the Professional Work. Three Models of Control for Health Organizations. Health Services Research 17, 1982, 213-240.

Selbach, T. Bedrijfsverpleegkundige en/of arbeidshygiënist(e)? Maandblad Arbeidsomstandigheden 65, 12, 1989, 733-735.

Selbmann, H.K. et al. Quality Assessment of Medical Care. Gerlingen Bleicher Verlag 1982. 
Senden, Th.F., Kolk, J.J. BGZ-protocollen voor instellingen in de gezondheidszorg. Arbovisie 5, 2, 1989, 11-12.

Sengers, W.J. Wat gek dat verplicht medisch onderzoek geoorloofd is. Medisch Contact 30, 46, 1975, 1461-1465.

Shostack, G.L. Breaking Free from Product Marketing. Journal of Marketing 41, April 1977, 73-80.

Sijtsma, F.M. Systeemdenken en sociale geneeskunde. Nijmegen Instituut Sociale Geneeskunde 1985.

Slikke van der, J.B. Evaluatie PGO oudere werknemers $K L M$. Leiden Nederlands Instituut voor Preventieve Geneeskunde/NO 1982.

Smid, W. Ontwikkelingen Arbowet en rol bedrijfsans. Maandblad Arbeidsomstandigheden 64, 2, 1988, 105-108.

Smid, W. Directie Socinal Arbeidsbeleid nader belicht. Maandblad Arbeidsomstandigheden 64, 7/8, 1988, 470-474.

Smulders, P.G.W. De visie van werknemers in drie bedrijven op bedrijfsgezondheidszorg. Tijdschrift voor Sociale Gezondheidszorg 58, 7, 1980, 273-280.

Snook, S.H. Approaches to Preplacement Testing and Selection of Workers. Ergonomics 30, 2, 1987, 241-247.

Soeterbroek, F. Vakbeweging slaat nieuwe wegen in. Maandblad Arbeidsomstandigheden 65, 6, 1989, 363-367.

Spijkerboer-Mons, A.C.M. Goed adviseren als bedrijfarts. Amsterdam CORVU 1990. Spit, W.J.L. De onafhankelijke deskundige moet niet op de stoel van de ondernemer gaan zitten. Maandblad Arbeidsomstandigheden 62, 11, 1986, 687-688.

Spreeuwers, D. Louis Heijermans (1873-1938) en de opkomst van de arbeids- en bedrijfsgeneeskunde. Nederlands Tijdschrift voor Geneeskunde 132, 30, 1988, 14031406.

Sprundel van, Th.J.M. Informatiebronnen voor het management in een non-profit instelling. Een aanzet tot een sociale informatica. Leiden Stenfert Kroese 1982.

Steeg van der, H.J., Jaspers, Fr.C.A. Management en professie. Blok of blolkkade? Medisch Contact 41, 35, 1986, 1105-1106.

Stichting ter bevordering van Onderwijs in de Bedrijfsgezondheidszorg, Elementen van bedrijfsgezondheidszorg in andere opleidingen dan die tot basisants. Leiderdorp 1984.

Stichting ter bevordering van Onderwijs in de Bedrijfsgezondheidszorg, Beschrijving van opleidingsprogramma's ten behoeve van de bedrijfsgezondheidszorg. Leiderdorp 1983.

Stichting van de Arbeid, Arbeidsverhoudingen en vakbondswerk in de onderneming. Stichting van de Arbeid 1990.

Stille, W. Het bedrijf als object van bedrijfsgezondheidszorg. Amsterdam CORVU 1987.

Stolte, J.B. Kwaliteitsbewaking in de gezondheidszorg. Nederlands Tijdschrift voor Geneeskunde 121, 16, 1977, 670-675.

Streng, J.C. Wie volgt? Profilering van de verzekeringsgeneeskunde en het sociaal medisch toezicht. Tijdschrift voor Verzekeringsgeneeskunde 27, 1989, 79-83. 
Streng, J.C., Vermeij, E. Kritische succesfactoren voor de "sociaal-medische functie" in de sociale verzekeringen. Tijdschrift voor Verzekeringsgeneeskunde 27, $1989,172-180$.

Sturmans, F. et al. Naar een gezonde werkomgeving. Epidemiologie binnen de bedrijfsgezondheidszorg. Nijmegen Dekker \& van de Vegt 1982.

Stuurgroep Toekomstscenario's Gezondheidszorg Arbeid, gezondheid en welzijn in de toekomst. Toekomstscenario's arbeid en gezondheid 1990-2010. Scenariorapport opgesteld in opdracht van de Stuurgroep Toekomstscenario's Gezondheidszorg. Bohn Stafleu van Loghum Houten/Antwerpen 1991.

Swartz, T.A., Brown, S.W. Consumer and Provider Expectations and Experiences in Evaluating Professional Service Quality. Joumal of the Academy of Marketing Sciences, 1989, 189-194.

Tanke, G.M.H. Beeld van de bedrijfsgezondheidszorg. Enkele observaties betreffende plaats en taak van de bedrijfsgezondheidszorg in 7 arbeidsorganisaties. Amsterdam CORVU 198.5.

Thunissen, M.J.B.A. Het bedrijfsgezondheidkundig spreekuur. Consultvoering en methodisch werken. Amsterdam CORVU 1991.

Thunissen, M.J.B.A., Lebbink, M. Groeiende behoefie aan VGW-deskundigheid. Maandblad Arbeidsomstandigheden 66, 6, 1990, 463-465.

Tielens, V.C.L. Het Nederlands Huisartsgenootschap en kwaliteitsbewaking in de huisartsgeneeskunde. Medisch Contact 44, 22, 1989, 748-750.

Tijhuis, B.H.A. Wie begeleidt de arbeidsongeschilte werknemer? Nijmegen Instituut Sociale Geneeskunde 1984.

Tijsse Klasen, F. Bedrijfsveiligheid en bedrijfsgezondheidszorg in Italie. Geschiedenis van en kritiek op het regelgevend kader. Tijdschrift voor Toegepaste Arbowetenschap 1, 3, 1988, 2832.

Tijssen, I.M.J.G., Senden, J.W.J. Is doelmatigheid van onderzoek in bedrijfsgezondheidszorg te vergroten? Optimale rapportage geen garantie voor succes. Maandblad Arbeidsomstandigheden 65, 10, 1989, 609-611.

Til van, M.J. Spreekuurregistratie. Een analyse van systematisch geregistreerde gegevens van het bedrijfsgezondheidkundig spreekuur. Nijmegen Instituut Sociale Geneeskunde 1982.

Timmer, M., Koten, J.W. Over de kwaliteitseisen en de kwaliteitsbewaking ten aanzien van de verzekeringsgeneeskunde. Tijdschrift voor Sociale Gezondheidszorg 62, 7, 1984, 259-271.

Turnhout, M.J.G.C. Bedrijfsgezondheidszorg en wetenschappelijk onderzoek. Een analyse van twaalf jaren Tijdschrift voor Sociale Gezondheidszorg. Nijmegen Instituut Sociale Geneeskunde 1984.

Tweede Kamer, Verandering Vercekerd. TK, 1987-1988, 19945.

Tweede Kamer, Arbowet voor de deregulering.

- TK zitting 1976-1977; 144973 Mernorie van toelichting:

- TK zitting 1978-1979; 144975 Memorie van antweord;

- TK zitting 1978-1979; 144978 Gewijzigd ontwerp van wet;

TK zitting 1978-1979; 144979 Eindverslag;

TK zitting 1979-1980; 1449711 Nota n.a.v. het eindverslag: 
- Openbare commissie vergadering van de Vaste Commissie voor Sociale Zaken d.d. $3 / 3 / 80$ en $12 / 3 / 80$;

TK zitting 1979-1980; Handelingen 13/5/1980;

- $\quad$ TK zitting 1979-1980; 14497 x; Nota van wijzigingen en moties.

Tweede Kamer, Arbowet na de deregulering.

- TK vergaderjaar 1986-1987; 19 824b Wijziging van de Artowet en van de Wet op de gevaarlijke werktuigen met betrekking tot deregulering en enige andere onderwerpen. Advies van de Raad van State.

- TK vergaderjaar 1986-1987; 198243 Idem, Memorie van toelichting;

- TK vergaderjaar 1986-1987; 198244 Idem, Voorlopig verslag;

- TK vergaderjaar 1986-1987; 198245 Idem, Memorie van antwoord;

- Eerste Kamer, vergaderjaar 1987-1988, 19 824, nr. 56: Voorlopig verslag van de vaste commissie voor sociale zaken en werkgelegenheid (3/11/87); en idem: 19824 , nr. 56a: Memorie van antwoord;

TK Handelingen Arbowet 24 november 1987;

TK Handelingen Arbowet 17 juni 1987.

Urk van, G.R. Aanstellingskeuring, ziekeverzuim en karakter der sociale geneeskunde. Medisch Contact 24, 30, 1969, 837-840.

Vaas, S. Arbeids- en bedrijfskunde en artikel 3 van de Arbowet. Maandblad Arbeidsomstandigheden 64, 3, 1988, 191-193.

Vandenbroucke, J.P. De halsstarrigheid van een professie. Nederlands Tijdschrift voor Geneeskunde 133, 51, 1989, 2540-2542.

Veeneklaas, P.G., Lodewijks, B.C.I. Verwachingen van werkgevers ten aanzien van de rol van de BGD bij reorganisaties. Nijmegen Instituut Sociale Geneeskunde 1988.

Veerdonk van de, J.J.M. Bedrijfsgezondheidszorg is geen eenheidsworst: aanpak bedrijfstakgewijs noodzakelijk. Maandblad Arbeidsomstandigheden 64, 3, 1988, 161166.

Veld in 't, J. Analyse van organisatieproblemen. Amsterdam Elsevier 1983.

Verbrugge, R.W., Broere, F.P. Reclame in de gezondheidszorg. Medisch Contact 44, $50,1989,1661-1663$.

Verbrugge, R.W., Broere, F.P. Commerciele initiatieven in de gezondheidszorg. Medisch Contact 44, 46, 1989, 1507-1509.

Verburg, P. Enkele bedrijfskundige aspecten van de kwaliteitszorg in de gezondheidszorg. Tijdschrift voor Sociale Gezondheidszorg 59, 18, 1981, 642-648.

Verhage, Br., Cunningham, W.H. Grondslagen van het marketing management. Leiden Stenfert Kroese 1984.

Verhoef, C. Enkele steekproeven genomen uit twee groepen werknemers uit verschillende bedrijven die deelnamen aan het Algemeen Periodiek Geneeskundig Onderzoek (A.P.G.O.). Opiniepeiling onder in Nederland werkende bedrijfsarisen. Leiden Nederlands Instituut voor Preventieve Geneeskunde/TNO 1978.

Verzuu, W.J. Zorgstandaarden en toetsing medisch handelen. Ervaringen met PSRO's. Medisch Contact 43, 17, 1988, 519-523.

Vliert van de, E. De vrijheidsgraden van de beklemde bedriffsarts. Een organisatlepsychologische visie. Tijdschrift voor Sociale Gezondheidszorg 64, 22, 1986, 708-711. 
Voskamp, P. Welzijnsbepalingen in de Arbowet. Maandblad Arbeidsomstandigheden 63, 11, 1987, 665-668.

Voskamp, P. Deregulering Arbowet afgerond. Maandblad Arbeidsomstandigheden 64, 1, 1988, 11-15.

Voskamp, P. Ergonomiebepalingen in de Arbowet vereisen nog veel voorbereidingen. Maandblad Arbeidsomstandigheden 64, 7/8, 1988, 467-469.

Vreeman, R.L. Artsen en arbeiders. Werknemersbelangen en de bedrijfsgezondheidszorg. Tijdschrift voor Sociale Gezondheidszorg 64, 22, 1986, 697-700.

Vries de, J. et al. Kwaliteitskringen onderzocht. 't is niet alles goud wat er blinkt. Gids voor Personeelsmanagement 3, 1990, 40-45.

Vrooland, V. Arbo 90 laat kentering zien in visies en instrumentarium. Maandblad Arbeidsomstandigheden 66, 1990, 349-355.

Vuori, H.V. Optimal and Logical Quality: two Neglected Aspects of the Quality of Health Services. Medical Care 18, 10, 1980, 975-985.

Vuori, H.V. Quality Assurance of Health Services. Public Health in Europe 16, WHO Copenhagen 1982.

WVC, Vooronrwerp Wet op de beroepen in de individuele gezondheidszorg. WVC 1981.

WVC, Nota "Over de ontwikkeling van gezondheidsbeleid: feiten, beschouwingen en beleidsvoornemens" (Nota 2000). 1986.

Wachter de, M.A.M. Ethische aspecten van de aanstellingskeuring. Maandblad Arbeidsomstandigheden 65, 7/8, 1989, 459-461.

Wamdorff, D.K. et al. Medische besliskunde in Nederland. Medisch Contact 43, 39, $1988,1174-1178$.

Wamer, K.E. et al. Economic Implications of Workplace Health Promotion Programs: Review of the Literature. Joumal of Occupational Medicine 30, 2, 1988, 106112.

Webb, S.B. Objective Criteria for Evaluating Occupational Health Programs. AJPH, $65,1,31-37$.

Weggeman, M. et al. Ondernemen binnen de ondermeming. Het creèren van speelnuimte. Deventer Kluwer 1987.

Weggeman, M. Leiding geven aan professionals vereist een aangepaste managementstijl. Harvard Holland Review 1989

Weijenberg. W.M. Onduidelijkheid in rol BGD. Bedrijfsgezondheidszorg tussen vraag en aanbod. Personcelsgids 12, 1985, 27-29.

Wely van, P.A. De procedure bij het keuren van sollicitanten. Amsterdann dissertatie 1972.

Wely van, P.A. Enkele kanttekeningen bij het thema: de onafhankelijkheid van de bedrijfsarts. Metamedica 53, 1974, 59-61.

Wely van, P.A. Advies bedrijfsgezondheidszorg. Tijdschrift voor Sociale Gezondheidszorg 58, 1980, 156-159.

Wely van, P.A. Wordt bedrijfsgezondheidszorg gebruikt voor produktiebevordering? Tijdschrift voor Sociale Gezondheidszorg 60, 5, 1982, 90-93. 
Wely van, P.A. Gezondheid en zorg in bedreigde bedrijven. Tijdschrif voor Sociale Gezondheidszorg 62, 24, 1984, 963-965.

Wijmen van, F.C.B. Recht op kwaliteit. Inaugurele reden Maastricht Rijksuniversiteit Limburg 1983.

Wijngaarden van, D.A. De verzuimbenadering op een onderneming (rood aker), waar de bedrijfsarts tevens gedurende 10 weken de verzekeringsgeneeskunde doet. Leiden Nederlands Instituut voor Preventieve Geneeskunde/TNO 1979.

Wilders, M.M.W. Problemen met kwaliteit bedrijsgezondheidszorg. Voordracht NSC-studieconferentie "De bedrijfsarts tussen klantgerichtheid en professie". Scheveningen 1991.

Willems, J.H.B.M. Beroepsziekten in het licht van de officiele cijfers. Tijdschrift voor Sociale Gezondheidszorg 63, 10, 1985, 402-409.

Willems, J.H.B.M. Enige bespiegelingen over (de toekomst van) de bedrijfsarts in Nederland. Maandblad Arbeidsomstandigheden 63, 7/8, 1987, 429-432.

Willems, J.H.B.M. Nieuwe ontwikkelingen met betrekking tot bedrijfsgeneeskundig onderzoek. NVAB-info 19, 2, 1988, 22-25.

Willems, J.H.B.M. Overwegingen bij een preventief beleid in de sociale verzekeringsgeneeskunde. Tijdschrift voor Verzekeringsgeneeskunde 27, 1989, 139-144.

Willems, J.H.B.M. Bedrijfsarts en verzekeringsgeneeskundige: een paar aparn! Tijdschrift voor Sociale Gezondheidszorg 68, 6, 1990, 268-270.

Willems, J.H.B.M. Sociale verzekeringsgeneeskunde en bedriifsgezondheidszorg: een weg naar de toekomst? Tijdschrift voor Sociale Gezondheidszorg 68, 4, 1990, 191-198.

Willems, J.H.B.M. Knappe koppen, slimme jongens. Maandblad Arbeidsomstandigheden $66,10,1990,708-711$.

Willems, J.H.B.M., Buma, S. Melding van beroepszieken als instrument voor de beleidsvoering op ondernemingsniveau. Maandblad Arbeidsomstandigheden 64, 4, 1988, 242-244.

Willems, J.H.B.M. et al. DGA kent nieuwe directie gezondheid. Maandblad Arbeidsomstandigheden $64,2,1988,75-83$.

Wink, A. Op weg naar de arbodienst. Tijdschrift voor Sociale Gezondheidszorg 60, 9, $1982,206-213$.

Winter, C.R. Veruim, uitspraken van werknemers en latere arbeidsongeschiktheid. Leiden Nederlands Instituut voor Preventieve Geneeskunde/TNO 1983.

Winter, C.R. et al. De vragenlijst voor periadiek bedrijfsgezondheidkundig onderzoek IV: Kwaliteit en structuur. Tijdschrift voor Sociale Gezondheidszorg 66, 4, 1988, 143-147.

Winter de, C.R., Dijkstra, A. De bedrijfsarts over zijn werk. Leiden Nederlands Instituut voor Preventieve Geneeskunde/TNO 1985.

Wissema, J.G. Unitmanagement. Het decentraliseren van ondernemerschap. Assen Van Gorcum 1987.

Wittgens, H. Wie Effeldiv sind Arbeitsmedizinische Vorsorgeuntersuchungen? Arbeitsmedizin Sozialmedizin Präventivmedizin 8, 1986, 221-223.

Wolvetang, H. Wat kunnen ondememeningsraden verwachten van deskundige diensien? NVAB-infobulletin 16, 3, 1985 
Wolvetang, H. Verzuimbegeleiding en ziektecontrole. Nijmegen Instituut Sociale Geneeskunde 1978.

Wolvetang, H. Periodiek onderzoek: wie wel, wie niet? Tijdschrift voor Sociale Gezondheidszorg 58, 1980, 63-65.

Wolvetang, H. De regelgeving rond de opleiding. "Keurslijf of visie op een toekomst?". Berg en Dal 1989.

Wulms, P.J.M. Bedriffsgeneeskundig onderzoek en her zinvol registreren van gegevens. Nijmegen Instituut Sociale Geneeskunde 1982.

Zeithaml, V.A. et al. Communication and Control Processes in the Delivery of Service Quality. Cambridge Marketing Science Institute report 87-100, 1987.

Zeithaml, V.A. et al. Delivering Quality Service. Balancing Customer Perceptions and Expectations. The Free Press McMillan Publishers London 1990.

Zielhuis, R.L. De toekomst der arbeidstoxicologie. Tijdschrift voor Sociale Gezondheidszorg 62, 14, 1984, 568-572.

Zielhuis, R.L. Onderzoek draagt werkelijk bij aan de kwaliteit van de arbeid. Maandblad Arbeidsomstandigheden 63, 2, 1987, 94-97.

Zielhuis, R.L. Arbeidsgezondheid(s)kundig onderzoek: verschuivende grenzen? Tijdschrift voor Sociale Gezondheidszorg 65, 10, 1987, 314-327.

Zielhuis, G.A. et al. Bedriifsgezondheidszorg en epidemiologisch onderzoek. Tijdschrift voor Sociale Gezondheidszorg 62, 4, 1984, 106-112.

Zoest, A.C. Viff jaar samenwerking en overleg voor betere arbeidsomstandigheden. Maandblad Arbeidsomstandigheden 64, 10, 1988, 583-587.

Zuidema, H. Professionele criteria ten behoeve van het stellen van prioriteiten in de bedriffsgeneeskunde. Tijdschrift voor Sociale Gezondheidszorg 61, 4, 1983, 152-155.

Zwam van, H.J. De Arbowet historisch bezien. Maandblad Arbeidsomstandigheden 62, 4, 1986, 222-227.

Zwam van, H.J. Maastricht, de enige echte fabrieksstad. De parlementaire enquête van 1887. Maandblad Arbeidsomstandigheden 63, 1, 1987, 40-42.

Zwam van, H.J. Kanttekeningen bij opzet en inhoud Veiligheidsbesluit Restgroepen. Maandblad Arbeidsomstandigheden 67, 2, 1991, 111-115. 


\section{Bijlage 1. \\ Lijst van gehanteerde afkortingen}

\begin{tabular}{|c|c|c|}
\hline AAW & $=$ & Algemene Arbeidsongeschiktheidswet \\
\hline ABP & $=$ & Algemeets Burgerlijk Pensioenfonds \\
\hline AK & $=$ & A winstellingskeurung \\
\hline AMVB & $=$ & Agemene Martregel van Bectuur \\
\hline ARAR & $=$ & Algemeen Rijksaribtenaren Reglement \\
\hline Arbo & $=$ & Arbeidromstandigheden \\
\hline BGBoniw & $=$ & Bedrijfsgezondheidszorg voor do bollwnijvertheid \\
\hline BGD & $=$ & Bedrijfigezondheidsdionst \\
\hline BOS & $=$ & Bedrijfsgezondheidlandig spreakuur \\
\hline BaZ & $=$ & Bedrijifsgezondheidszzorg \\
\hline BIG & $=$ & Wet voor de bercepen in de individuole geitomlheidszors \\
\hline BEW & $=$ & College van Burgemeesters en Wechoulers \\
\hline CAO & $=$ & Collectieve Arbeidsovenenkomst \\
\hline CARGO & $=$ & Commissie Arteidsgezondheidkundig onderzoek: \\
\hline CBE & $=$ & Commissie Bercepwethiek bedrijfsartsen \\
\hline CBO & $=$ & Central Begeleidingsorgaan voor intercollegiale toetsing \\
\hline CBS & $=$ & Contral Burowu Statistiek \\
\hline CNV & $=$ & Christelijk Nationaal Vakverbond \\
\hline $\begin{array}{l}\text { Conluct } \\
\text { zieken }\end{array}$ & $=$ & Snelheid contact mat zieken \\
\hline COPIH & $=$ & Commissie Opsporing en Preventie Ischenische Hartziektets \\
\hline CSG & $=$ & College voor sociale geneeskunde \\
\hline Curat. & $=$ & Curatieve \\
\hline CvBA & $=$ & College van bijstand en advies van de bedrijfegenoekkundo \\
\hline DGA & $=$ & Directoraat Generad van do Artoid \\
\hline DIR & $=$ & Directie \\
\hline $\mathrm{ECO}$ & $=$ & Electrocendiogram \\
\hline (E)EG & $=$ & Europese Economische Gemeenschap \\
\hline EHBO & $=$ & Eerste hulp bij ongevallen \\
\hline EVD & $=$ & Enkelvoudige bedrijfsgezondheidsdiend \\
\hline Federatio & $=$ & Federatio van gezamenlijke bedrijfsgezondheidsdienten \\
\hline FNV & $=$ & Foderatie Nederlandso Vakbeweging \\
\hline GAK & $=$ & Gemeenschappelijk Administraiekentoor \\
\hline GD & $=$ & Gezamenlijke bedrijfsgezondheidsdienst \\
\hline GG\&GGD & $=$ & Afdeling bedrijfsgezondheidszorg vin gemeente(n) \\
\hline GITP & $=$ & Gerneenschappelijk instituut voor toegepasto psychologie \\
\hline GMD & $=$ & Gemeenschappelijke Medische Dient \\
\hline GVO & $=$ & Gezondheidsveorlichting en -Opvoeding \\
\hline ICD & $=$ & International Classification of Divensen \\
\hline ICHPPC & $=$ & Intemational Classification of henth Problems in Patient Care \\
\hline no & $=$ & International Labour Organization \\
\hline ISO & $=$ & International Standard Organization \\
\hline JOHS & $=$ & Joint occupational hedth service \\
\hline Klang. & $=$ & Klanigerichte \\
\hline KNMG & $=$ & Koninklijke Nederlandse Masischappij tot Boverdering der Cleneeskunst \\
\hline LOD & $=$ & Landelijk overleg directeuren van gezamenlijke bedrijfsgezondheidadiensuen \\
\hline LVSG & $=$ & Landelijke Vereaiging voor sociral geneeskundigen \\
\hline MvA & $=$ & Memorie van entwoord \\
\hline MvT & $=$ & Memorie van toelichting \\
\hline NEN & $=$ & Nederlandse Europese nom \\
\hline
\end{tabular}




\begin{tabular}{|c|c|c|}
\hline NIA & $=$ & Nederiands Instituut voor Arbeidsomstandigheden \\
\hline NIPG & $=$ & Noderlands Instituut voor Preventieve Gezondheidszorg \\
\hline NRV & $=$ & Nationale rand voor de volkssgezondbeid \\
\hline NVAB & $=$ & Nederlandse vereniging voor arbeids- en bedrijfsgezondheidszorg \\
\hline NVVG & $=$ & Nederlandse vereniging voor verzekeringsgeneaskunde \\
\hline $\mathrm{OHC}$ & $=$ & Occupational health care \\
\hline OHS & $=$ & Occupational health service \\
\hline OR & $=$ & Ondernemingsraed \\
\hline POO & $=$ & Periodiek onderzoek \\
\hline POHS & $=$ & Plent occupational health service \\
\hline PR & $\equiv$ & Public Relations \\
\hline Prof. & $=$ & Professioncle \\
\hline PSRO & $=$ & Profossional Standards Reviow Organizations \\
\hline $\mathbf{P Z}$ & $=$ & Personeolszaken \\
\hline RBB & $=$ & Rijks Bedrijfsgezondheids- en Bedrijfsveiligheidsdienst \\
\hline SBOB & $=$ & Stichting ter bevordering van onderwijs in de bedrijfsgezondheidszorg \\
\hline \multicolumn{2}{|c|}{ SERVQUAL= } & Sorvice Quality Model \\
\hline SKB & $=$ & Stichting Kwaliteitsbevordering bedrijfsgezondheidszorg \\
\hline SMC & $=$ & Socio-medical counselling \\
\hline SOZAWE & $=$ & Ministorio van sociale zuken en werkgelegenhoid \\
\hline TAV & $=$ & Wet Terugdringing Arbeidsongeschiktheidsvolume \\
\hline TBA & $=$ & Wa Terugdringing Beroep op Arbeidsongeschiktheidsregelingen \\
\hline TK & $=$ & Tweede Kamer \\
\hline TZ & $=$ & Wa Terugdringing Ziekteverzuim \\
\hline VBR & $=$ & Veiligheidshesluit Restgroepen \\
\hline VGW & $=$ & Veiligheid, Gezondheid, Welzijn \\
\hline VNO & $=$ & Verbond van Nederlandse ondernemingen \\
\hline WAOW & $=$ & Wot arbeidgehandicapte werknomer \\
\hline WAO & $=$ & Wot arbeidsongeschiktheid \\
\hline $\mathbf{W N}$ & $=$ & Werknomers \\
\hline WP & ш & Workplekonderzock \\
\hline
\end{tabular}




\section{Bijlage 2 . \\ Constructie variabelen}

Alle variabelen zjoi zodunig geconstneerd dal, naurmale de scoro hoger is "betrokken variabele vaker voorkomt. Voorteeld: Naanmate de score hoger is, werk de bedrijfsarts langer voor betrokken bexlrijf (varialwele. "ervaring")

\section{Onafhankelijke variabelen}

\section{A. Bedrificurtsvariahelen}

1. Emaring ven de bedrijfserts:

Vrang: Sadent welk juar verzorgt de bealrijfsaits voor Jit bedrijf de BGZ?

2. Overlegs met de directic van het bedrijf: Vraag: Heeft u als bedrifsarts regelmatig coniact met de directie van dit bedrijf?

\section{Het anken van afsprakein over rapportage:}

Vrang: Zijn er afspraken gemankt over de wijze van rapportage an dit bedrijf?

4. De door de bedrijfsarts ervaren speelruimte: Vragg: Ervanrt u (de bedrijfsarts) in dit bedrijf cen consistent sumenwerkingsheleid met resp. ondemeningsraad, veiligheidsdienst en directie?

5. De beschilchare tijd volgens de bedrijfsarts:

Vrang: Wordt de voor de BGD ter beschikking staande tijd als (nim) vokloende ervaren?

6. De tankopvalting van de bedriffsarts:

Vrag: Onderstaand volgen een auntal statemeits.

Aan do bedrijfsarts werd gevraagd an te geven in welke mate hij het met het gestolde (on)eens was.

- Ik richt mij als bedrijfisurts vooral op individueel gerichte taken;

- Kwalitutief govede BGZ kenmerkt zich door technische competentie van de zorgverleners;

- Een bedrijfsurts verkeert steeds in een spanningsveld tussen de belangen van de werkgever en die van de werknemer;

- Ik vind dat tegenwoordig veel mensen een lage verauimurempel bethen;

- Over de toekomst van de BGZ hen ik somber;

- Een bedrijfsarts dient zelf regelmatig werkplekonderzock to verrichten;

- Ik vind dal een bedrijfsarts best een atheromcyste mas verwijderen;

- Het hervatten na ziekte vind ik primir de verantwoordelijkheid van betrokkene zelf;

- Kwalitatief goede BGZ vereist cen tevoren tussen
BCiD en bexlnji afgesproken "dienstverleningsplian":

- De doelstelling van BCZ dlient purallel to loperi med de doelstellingen van het bexlrijf;

- De keuze berinjfsarts te worden is voor mij pen securdaire keuze geweesl:

- Weirnemers weten veelal nird welke taken de BOD heeft;

- De combiratiefunctie bedrijfsints-verzekeningsgneeskundige schaadi de vertronwensrelatie artspatient:

- Ik ervar bij het tot stand brengen vmi reintegra ties in do regel to weirig modewerking van do kani van het bedrijf:

- Als hedrijfarts vind ik dat ik bij arbeidscondticten op de werkplek yelf actief een gesprek tussen worknerner en leiding moes bevorderen en bijwonen:

- Overleg met personeelszuken en maatschappelijk werk in het zgn. Sociaal Mexlisch Team trevordert de kwaliteit van BG?;

- Werkgevers weten veelal nitt welke taken do BCD heef:

- Het is belungrijk dat oen bedrijfsarts ook cura lieve ervaring heeft:

- Als bexlrijfsarts dien ik bij mijn alvisering rekening te houden met economische haalbaarheid;

- Mijn hedrijfsgenceakunlige alviezen worden meestal opgevolgd:

- Als bodrijfunts zit ik veelaj klem tussen de wensen van de directie van het bedrijf en mijin directie (van de BGD):

- Frequent kortdurend veraim beschouw ik als cen uihing van oen slechte inefficiënte organisatie van het bedriif;

- Werknemers hebhen invkeal op de inhoud van de te leveren BGZ;

- Als het scenomisch slechit gut met Én yan mijn bedrijven, neern ik zelf corduct op om te kijken of ik iets ken doen;

- Ik sch familie-omstandigheden en legitienn racken voor verzaim bij an overigens gezonde patient:

- De BGD is het beste in stal aan te geven welke bedrijfsgeneeskundige taken voor een gegeven bodrijf nodig zijn. 
In hoofdutuk 7.4.2. wordt beachreven boe on clustering in con Jriotal tuakopvattingen beef pleutngevonden, to weten: professioneel, klantgericht on curatief. Zie verder ook bijlage 3 voor de relevante correlaties.

\section{B. Bedriffsvariabelen}

1. De grootle van het bedrij:

Vrang: Hooved medewerkers telt de onder de zorg van do BOD vallende ventiging op dit moment?

2. Het voorkomen van fysiek belastende arbeidsomstandigheden:

Vrang: Spelen in uw hedrijf bon of meer van do volgende bolastende fuctoren oon rol: lichamelijke helasting; klimutologischo helasting; microbiologische belasting: toxicologische belasting.

3. De hoogte van het verzuim:

Vrang: Hoe hoog was in 1985 on 1986 het gemiddekle verzuimpercentinge in het totale bedrijf?

4. De snelheid van contact tussen BGD en zieken?

Vrang: Hoo anel is er contact humen BGD on werknemer, naclat dozo zich hoeft ziek gemold?

\section{Afhankelijke variabelen}

\section{A. Professionele kwaliteit}

\section{Werkwilze van de hedriffserts}

Vragon:

Registrztle perlodiels onderzoek

- Worden de gegevens van het periodiek onderzoek zodanit geregistreend dat het mogelijk is een of meer van de volgendo zaken to realiseren?

1. Analyses op groepsniveau

2. Hox antonon van oen causeal vertiand ziektoIwerk(milieu)

Registratie werkplekonderzoek

- Worden de gegovens van hex werkplekonderzoek zxhanig goregistreord dat eon of meer van de volgende aspecten haalbaar is/zijn?

1. Werkplekken to volgen in de tijd

2. Analyses to verrichten op groepsniveau

3. Causale vertuandon klach//work ann to tonon

In gelijke mate rapporteren an directie/onderneaingrered

- Rapporteert de BCD over geanonimiseerde (groepe) gegevens wan:

- do directio van hat bedrijf

- de onderneningarad

Ongevranad advies

- Adviseert do BGD PZ wel exns engevrangd?
2. Werkterrein van de BGD:

Vragen:

Inschakelen algemeen beleid

- Als bet bedrijf de BGD consulteert, betreft het dan regelmatig problemen op én of meer van de volgende gebieden?

- (materiëlo) subeidsomstandighoden

- prychosociale problemen

* automatisering

- individuele problennatiek van cen van de medewerkers

* nieuwbouw of verbouwingsvoorstellen

* (re)organisatie

Extra activiteiten

- Do ondernemingsrand is het er (zeer) mee eens dat do BGD bij bun ieks doet an:

* het goven van voorlichting over gezondheid en gezond leven

- het meewerken an revalidatie, d.w.z. heo herplaatsen van werknemers met een tijdelijke of blijvende medische beperking

- het verlenen van cerste bulp bij ongevallen en ziekte (EHBO)

- het meowerken an goede arteidsverhoudingen in het bedrijf

- het opsporen van on bet verrweklen van (het vermmeden op) het voorkomen van beroepsziekten binnen resp. an het bedrijf.

3. De bruikhaarheid van advisering:

Vragen:

- Als de ondernemingsmard cen probleem bij de BCD heef angekuart, was zij toen tovreden over ón of meer van do volgende zaken?

* de inhoud van hel advies

- de snelheid warmee her advies uitgebracha werd

- de manier waerop het alvies uitgebracht werd (mpportage)

- de mate waarin door de BGD opvolging van het alvies door het bedrijf gucontroleend werd?

- Wa vindt do ondernemingsirad/personeolszaken van de kwaliteit van advisering door de BGD? is dexe:

- voor hot bedrijf doorgeans goed bruikhas

- speelt deze in op actuele problematiek

- word or in de tijd gezien valkenende snel alvies uitgebrachit

- is het advies doxorguens voor iederven in bogrijpelijke vorm opgesteld

- houdt het mlvies volklowde rekening met het bedrijf(shelang)

4. Profescionele uitvoering BGZ-kermtolken:

Dit is de verschilscore tussen de praktijk vin de be. 
drijfauts on de door de bedrijfsarts gewenste situatie. Het gant om de volgende taken: constellingskeuring, sproekuur, periodiek onderzoek en werkplekonderzok (prof. uitvoering AK/BGS/ PGO/WP)

Vragen:

- In wolke male vindi, volgens de bednjfsierts, in betrokken bedrijf bij het manstellingsonderzock in de praktijk hed volgende plants, respectievelijk zou bet wenselijk zijn dat hat volgende in de praktijk zou platuvinden?

- becordeling of de keurling pest in de groep warin hij gant werken

- beoordeling of een keurling hot werk goestelijk ankan

- hat op de hoogto brengen van de werkgever van de medische beperkingen van de keurling

- hat bij vermoedon van oen hoger verzuim niex goedkeuren van de keurling

- bij twijfel over de geschiktheid voor de gevraygde functie, hat voordeel van de Imijel an de keurling goven

- het als enigo mensen keuren voor botrokken bedrijf

- het als bedrijfsarts meeselecteren, als or moerdere kandideten voor een functie zijn.

- In welke mate vindt in de praktijk volgers do bedrijfsarts bij het spreekuur het volgende plats, respectievelijk zou hot wenselijk zijn dat hot volgendo platsvind?

- bij dit bedrijf ziet de bedrijfsents elke zieks werknemer

- ook als niet-verzekeringsgeneeskundige doet do bedrijfsurts een uitsprakk over arbeids(on)geschilatheid

- stelt de bedrijfsarts het bedrijf op do hoogte van de vermoedelijke duur van het verauim

- In welke mate vindt volgens de bedrijfsurts in de praktijk bij hat periodiek orderzoek het volgende plasts, respectievelijk zou het wenselijk zijn dat het volgende platsvindr?

- allo werknemers boven cen bepakde leefijd nemen deel an periodiek onderzoek

- bij het periodiek onderzoek vindt altijd lichnmolijk onderzock plate

- bij hot periodiek onderzock vind ook invasief (blood) onderzook plaats.

- In melke mate vindt volgens de bedrijfsarts in de praktijk bij hat werkplekonderzoek het volgendo plaals, respoctievelijk zos hat wenselijk zijn dat hed volgende platisvindt?

- or worti ien ennzien van werkplekonderzock een sctief beleid gevoerd

- werkplekonderzoek vonin een - in de tijd gezien - essentieel onderdeel van zjin werk.

\section{Het rendement van BGZ-kerataken:}

Hel betreft hat rendement volgens de ondernomingsrand van de volgeacle taken: anstellingsonderzoek, spreokuur, periodiek: onderzoek en workplekonderwosk. (rendement AK/BGS/PGO/ WP)

Vngen:

- Heft de ondememingsirnad hot idee dat sindi de BCD voor het bedrijf aanstellingsonderzoeken verriclhe er:

- minder werknemers on mexlische rodenen overgeplantsit moesten worden

- minuler werknemers blijvend ongeschikt werden voor hus hunctie (aigekeurd werden)

- minder zieken zijn.

- Hoeft de ondernemingsraal het idee dat sinds het bedrijf bij dexe BOD is angesloten door activiteiten van het spreckuur bón of meer van de volgende zuken in belangrijke male gerealiseenl is/zijn:

- reintegratie, d.w.z. hervalting m ziekte, sneller verloop:

- reintegratio beter afgestend op het bedrijf verloopt;

- revaliciation d.w.z. het starten in ziekte in aangepast werk, vaker voorkoml;

- hel badrijf beter op de hoogte is van medische beperkingen van werknemers;

- hat hedrijf meer keninis heeft gekregen van gezondheidsbedreigende situaties in het bedrijf;

- meer inxicht is vorkregen in wat do BGD wel en niet kun;

- de tevredenheid met de BGD is loegenomen?

- Heef de ondernemingernaed het ilee dat de BCD door periodiek onderzock tén of meer van de volgende zaken in belangrijke mate heeft geraa liseerd?

- meer bekerilheid hoeft gegeven over wat een BGD well en niet kan;

- een beter contact heeft gekregen mol de werk. gever:

- een beter contact heeft gekregen mat de werknemers:

- gezondheidsrisico's in het bedrijf heeft opgepoord;

- gezondlweidahodreigende finctoren in la bodrij hoeft opgespoord;

- er minder zieken zijn;

- er meer werkgebonden problematiek is opgespoord.

- Heeft de ondernemingsraul ba dee da ninds ba bodrijf bij deze BGD is annzealoten door activiteiten van het werkplekonderzok ben of moer van de volzende zeken in belaggrijke mate gerealiseend is/zijn:

- meer kemis over gezmalheidsbedreigende situmien is verkegen; 
- er moer is gedarn un arbeidsplantsverbetering;

- or minder werkgebonden ziektes voorkomen.

\section{B. Klantgerichte kwaliteit}

1. De ondersteunende rol van de BGD:

Dit betreft zowel de visie van de voorzitter van de ondernemingsraed als van het hoofd personeelsza. ken.

Vragen:

- Is hed hoofd personoelszaken resp. de voorzitter van de ondememingsraed ven mening dat de BGD binnen hat bedrijf en belangrijke ondersteunende rol speelt in het sociaal beleid?

- Is hat hoofd personeelszaken resp. de voorzitter van de ondernemingaraad van mening dat de BGD in het bedrijf:

- voldoende inspeelt op gezondheidlkundige problemen dio zich in het bedrijf voordoen;

- zich vokloende chuidelijk en vasthoudend opatolt in zaken die vernuit gezondheidkundig oogpant ongewerst of ontoelnathuar zijn;

- zich voldoendes onpartijdig on objectief opstelt in kwesties die omstrexlen zijn;

- alequar rengeen op verzoeken en verwachtinzon die vamuit hex bedrijf ann do BGD worden gesteld;

- voljownde tenigmekling yeeft over zaken die gezondheidkundig van belang zijn;

- volkioende contact en foeling heeft mer (verte. genwoordigern) van het personeel.

\section{De houding ven de BGD:}

\section{Vrang:}

- How orvaar personeelszaken de houding van de BGD ten optichte van het bedrij?

- klantvriendelijj:

- ma nimito voor aigen inbreng vasuili het hedrijf:

- met nimte voor eigen inbreng van de indivithrolo patien:

\section{De ervaring aet uitvoering BG2-tnken:}

He saut om de orvaring van worknemers met de uitvooring van hot mentellingsonderzoak, hot periodiek onderzoek (ervaring AK/PCO) en de verauimbegoloiding, alaook do orvaring van to ondernemingsrand rnet de verzaimbegeleiding (resp. verzuiescontrole $W N$ on verzuimcontrole $(\mathrm{OR}$ ) on of de BCD voldoende doen (voldoende doen).

Vragen:

- Zijh werknomon zeor tevralen over de manier wavrop zij gekeurd worden (inel in correct)?

- Hest do werknemer hat porieliak andorzock ali prettig orvaren?
- Wal zijn de ervaringen van werknemers met de begeleikling tijdens ziekte door de BGD? Wordt deze als controle ervaren?

- Wat zijn de ervaringen van de ondememingsraad mex de begeleiding van zieken door de BGD? Wordt deze als controle ervaren?

- De ondememingsrand vinxt dat de BGD bij hun bedrijf meer zou moten doen an:

- bet geven van voorlichting over gezondheid en gezond leven;

- het meewerken an revalidatie, d.w.z. het herplaatsen van werknenners met een tijdelijke of blijvende medische beperking;

* het verlenen van cerste hulp bij ongevallen en ziekte (EHBO)

- bet meewerken an goede arbeidsverhoudingen;

- het opsporen van en het vermelden van (het vernoeden op) het voorkomen van beroeps. ziekten binnen resp. het bedrijf.

\section{De samenwerking BGD-bedrijf:}

Dit betreft achtereenvolgens de samenwerking van de BGD met de directie van het bedrijf, met de ondememingsraad en mol personeelszaken.

Vragen:

- Heeft do ondememingsraud het wlee dat er een consistent samenwerkingsbeloid bestant mussen de BGD en:

- de directie;

* de ondernemingsmad;

* de afdeling personeelszaken.

5. De male van afstemming bij de uitvoering yen kerntaken tussen leverancier en ontvanger van BGZ:

Dit is de verschilscore tussen de praktijk van de uitvoering van de kerrlaken door de hedrijfsarts en de wens vain respectiovelijk cradememingsrand en werknemers. Het gaul dian om hot annstellingsonderzock, sproskutur, periodiek onderzoek en werkplekonderzock (arstemuning AK-OR, AK-WN, BGS-OR, BGS-WN, PGO-OR, PGO-WN, WPOR, WP.WN.

Vragen:

- In welke mate voert de bedrijfsarts in do praktijk van het enstollingsonderzoek hot volgende wit, respetievelijk vinden ankememingstaed on werknemers hat wetselijk dal do hedrijfsarts:

- beoordeelt of do keurling past in de gmep wharin hij gist werken:

- bekijkt of en keurling hed werk geestelijk curkan;

- de werkgever op de hoogte brengt van de modische beperkingen van de keurling:

- als wordi verwacht del de keurling vaker zal 
gown verzuimen, hij de keurling niet goedkeurt;

- bij twijfel over de geschiktheid voor de gevragade functie, het roordeel van de twijfel un de keurling geett;

- de enige is die mensen keurt voor di bedrijf;

- meeselecteert als er meerdere kandidaten voor een functio zijn in dit bealrijf.

- In welke mate voert de bedrijfsarts in de praktijk van het spreakur het volgende uit, respectiove. lijk vinden ondernemingsraed en werknemers het wensolijk dat de bedrijfarts:

- elko zieko werknemer ziet;

- ook als niet-verzekteringsgeneeskundige oen uitsprakk doet over do arbeids(on)geschiktheid van werknomers;

- het bedrijf op de hoogte stelt van de vermoedelijke duur van con verzuim.

- In welke mate voent de bedirijfsarts in de praktijk van bet periodick onderzoek het volgende uit, respectievelijk vinden ondernemingsraed on werknemen hot wenselijk dat de bedrijfsarts:

- alleen poriodick onderzook verrich bij worknemer boven een beprakle leeftijd;

* bij periodiek onderzoek cen lichumelijk onderzoek uitvoert;

- bij periodiak onderzoek ook (invasiof) bloedonderzoek uitvoert.

- In welke mato voert de bedrijfsarts in de praktijk van het werkplekonderzoek het volgende uit, respectievelijk vinden ondememingarand en werlanemers het wenselijk dat de bedrijfsurts:

- cen actiof beleid voert ten anzien van werkplekonderzoek;

* in zijn werk veel tijd boateedt an werkplekonderzock. 
Bijlage 3.

Correlatiematrix: GD èn EVD samen

A. Aspecten van professionele kwaliteit

\begin{tabular}{|c|c|c|c|c|c|c|c|c|c|c|c|c|c|c|c|c|}
\hline & 1 & 2 & 3 & 4 & 5 & 6 & 7 & 8 & 9 & 10 & 11 & 12 & 13 & 14 & 15 & 16 \\
\hline 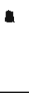 & $\begin{array}{r}.15 \\
.19 \\
(36)\end{array}$ & $\begin{array}{c}-.40 \\
.008 \\
(36)\end{array}$ & $\begin{array}{r}-.21 \\
10 \\
(39)\end{array}$ & $\begin{array}{r}-.14 \\
.23 \\
(31)\end{array}$ & $\begin{array}{r}.16 \\
.20 \\
(31)\end{array}$ & $\begin{array}{r}.09 \\
.35 \\
(20)\end{array}$ & $\begin{array}{r}.21 \\
.13 \\
(30)\end{array}$ & $\begin{array}{r}-.13 \\
.29 \\
(19)\end{array}$ & $\begin{array}{r}-.38 \\
.03 \\
(25)\end{array}$ & $\begin{array}{r}-.30 \\
.04 \\
(33)\end{array}$ & $\begin{array}{r}-.06 \\
.38 \\
(30)\end{array}$ & $\begin{array}{r}-.32 \\
.03 \\
(33)\end{array}$ & $\begin{array}{r}.00 \\
.49 \\
(26)\end{array}$ & $\begin{array}{r}-.23 \\
.13 \\
(26)\end{array}$ & $\begin{array}{r}-.33 \\
.05 \\
(26)\end{array}$ & $\begin{array}{r}-.34 \\
.05 \\
(26)\end{array}$ \\
\hline b & $\begin{array}{r}. .13 \\
.23 \\
(36)\end{array}$ & $\begin{array}{r}.03 \\
.41 \\
(36) \\
\end{array}$ & $\begin{array}{r}-15 \\
.19 \\
(39)\end{array}$ & $\begin{array}{r}.06 \\
.38 \\
(31)\end{array}$ & $\begin{array}{r}.09 \\
31 \\
(31)\end{array}$ & $\begin{array}{r}.19 \\
21 \\
(20)\end{array}$ & $\begin{array}{r}-.18 \\
.17 \\
(30)\end{array}$ & $\begin{array}{r}.03 \\
.46 \\
(19)\end{array}$ & $\begin{array}{r}-.05 \\
.40 \\
(25)\end{array}$ & $\begin{array}{r}-.25 \\
.08 \\
(33)\end{array}$ & $\begin{array}{r}.12 \\
.27 \\
(30)\end{array}$ & $\begin{array}{r}.12 \\
.26 \\
(33)\end{array}$ & $\begin{array}{r}.17 \\
.21 \\
(26)\end{array}$ & $\begin{array}{r}.11 \\
.30 \\
(26) \\
\end{array}$ & $\begin{array}{r}.13 \\
.26 \\
(26)\end{array}$ & \begin{tabular}{|r|}
.39 \\
.02 \\
$(26)$ \\
\end{tabular} \\
\hline $\bar{c}$ & $\begin{array}{r}.26 \\
.06 \\
(35) \\
\end{array}$ & $\begin{array}{c}.46 \\
.003 \\
(36) \\
\end{array}$ & $\begin{array}{l}.46 \\
.002 \\
(38)\end{array}$ & $\begin{array}{r}.03 \\
.43 \\
(31)\end{array}$ & $\begin{array}{r}.08 \\
.34 \\
(31)\end{array}$ & $\begin{array}{r}. .03 \\
.45 \\
(20)\end{array}$ & $\begin{array}{r}.21 \\
.13 \\
(30)\end{array}$ & $\begin{array}{r}-.25 \\
.15 \\
(19)\end{array}$ & $\begin{array}{r}-.38 \\
.03 \\
(23)\end{array}$ & $\begin{array}{r}. .04 \\
.41 \\
(33)\end{array}$ & $\begin{array}{r}-.09 \\
.31 \\
(30)\end{array}$ & $\begin{array}{r}.06 \\
.37 \\
(33)\end{array}$ & $\begin{array}{r}-.22 \\
.14 \\
(26)\end{array}$ & $\begin{array}{r}-.19 \\
.18 \\
(26) \\
\end{array}$ & $\begin{array}{r}-.11 \\
.30 \\
(26) \\
\end{array}$ & $\begin{array}{r}-.04 \\
.42 \\
(26) \\
\end{array}$ \\
\hline d & $\begin{array}{r}.06 \\
.37 \\
(36)\end{array}$ & $\begin{array}{r}.12 \\
.25 \\
(36)\end{array}$ & $\begin{array}{r}.11 \\
.25 \\
(39)\end{array}$ & $\begin{array}{r}-.13 \\
.24 \\
(31)\end{array}$ & $\begin{array}{r}.04 \\
.43 \\
(31)\end{array}$ & $\begin{array}{r}.01 \\
.49 \\
(20)\end{array}$ & $\begin{array}{r}.01 \\
.49 \\
(30)\end{array}$ & $\begin{array}{r}-27 \\
.14 \\
(19)\end{array}$ & $\begin{array}{r}-.31 \\
.06 \\
(25)\end{array}$ & \begin{tabular}{|r}
-.33 \\
.03 \\
$(33)$
\end{tabular} & $\begin{array}{r}.04 \\
.42 \\
(30)\end{array}$ & $\begin{array}{r}.04 \\
.42 \\
(33)\end{array}$ & $\begin{array}{r}-.30 \\
.07 \\
(26)\end{array}$ & \begin{tabular}{|r|}
-.25 \\
.11 \\
$(26)$
\end{tabular} & $\begin{array}{r}-.10 \\
.31 \\
(26)\end{array}$ & $\begin{array}{r}-.02 \\
.46 \\
(26)\end{array}$ \\
\hline 0 & $\begin{array}{r}.14 \\
.21 \\
(34) \\
\end{array}$ & $\begin{array}{r}.18 \\
.15 \\
(34) \\
\end{array}$ & $\begin{array}{r}.14 \\
.20 \\
(37) \\
\end{array}$ & $\begin{array}{r}.12 \\
.26 \\
(31) \\
\end{array}$ & $\begin{array}{r}.03 \\
.44 \\
(31) \\
\end{array}$ & $\begin{array}{r}-.14 \\
.27 \\
(20) \\
\end{array}$ & $\begin{array}{r}23 \\
.11 \\
(30) \\
\end{array}$ & $\begin{array}{r}-.36 \\
.07 \\
(18) \\
\end{array}$ & $\begin{array}{r}.13 \\
.27 \\
(24) \\
\end{array}$ & \begin{tabular}{|r|}
.30 \\
.05 \\
$(32)$ \\
\end{tabular} & $\begin{array}{r}-.11 \\
.29 \\
(29) \\
\end{array}$ & $\begin{array}{r}-.24 \\
.09 \\
(32) \\
\end{array}$ & \begin{tabular}{|r|}
-.06 \\
.39 \\
$(25)$ \\
\end{tabular} & $\begin{array}{r}-.18 \\
.19 \\
(25) \\
\end{array}$ & $\begin{array}{c}-.49 \\
.006 \\
(25) \\
\end{array}$ & $\begin{array}{r}.21 \\
.16 \\
(25) \\
\end{array}$ \\
\hline f & $\begin{array}{r}. .02 \\
.45 \\
(36) \\
\end{array}$ & \begin{tabular}{|r|}
.31 \\
.03 \\
$(36)$ \\
\end{tabular} & $\begin{array}{r}.25 \\
.06 \\
(39) \\
\end{array}$ & $\begin{array}{r}-.38 \\
.02 \\
(31)\end{array}$ & $\begin{array}{r}-.30 \\
.05 \\
(31) \\
\end{array}$ & $\begin{array}{r}-.48 \\
.02 \\
(20) \\
\end{array}$ & $\begin{array}{r}.12 \\
.27 \\
(30)\end{array}$ & $\begin{array}{r}-.31 \\
.10 \\
(19) \\
\end{array}$ & $\begin{array}{r}-.15 \\
.23 \\
(25) \\
\end{array}$ & \begin{tabular}{|r|}
.10 \\
.30 \\
$(33)$ \\
\end{tabular} & $\begin{array}{r}-.07 \\
.37 \\
(30) \\
\end{array}$ & $\begin{array}{r}-.07 \\
.34 \\
(33) \\
\end{array}$ & $\begin{array}{r}-.04 \\
.42 \\
(26) \\
\end{array}$ & \begin{tabular}{|r|}
-.33 \\
.05 \\
$(26)$ \\
\end{tabular} & $\begin{array}{r}-.20 \\
.16 \\
(26) \\
\end{array}$ & $\begin{array}{r}-.19 \\
.17 \\
(26) \\
\end{array}$ \\
\hline 8 & $\begin{array}{r}-.08 \\
.32 \\
(35) \\
\end{array}$ & $\begin{array}{r}-.10 \\
.28 \\
(35) \\
\end{array}$ & $\begin{array}{r}-.11 \\
.26 \\
(38) \\
\end{array}$ & $\begin{array}{r}15 \\
.22 \\
(30) \\
\end{array}$ & \begin{tabular}{|r|}
.17 \\
.19 \\
$(30)$ \\
\end{tabular} & $\begin{array}{r}-.34 \\
.07 \\
(19) \\
\end{array}$ & $\begin{array}{r}.07 \\
.36 \\
(29) \\
\end{array}$ & \begin{tabular}{|r|}
.16 \\
.26 \\
$(18)$ \\
\end{tabular} & $\begin{array}{r}-.15 \\
.24 \\
(24)\end{array}$ & $\begin{array}{r}.13 \\
.24 \\
(32) \\
\end{array}$ & $\begin{array}{r}-.21 \\
.14 \\
(29) \\
\end{array}$ & $\begin{array}{r}.10 \\
.30 \\
(32)\end{array}$ & $\begin{array}{r}-.13 \\
.26 \\
(25) \\
\end{array}$ & $\begin{array}{r}.34 \\
.05 \\
(25)\end{array}$ & $\begin{array}{r}.05 \\
.40 \\
(25) \\
\end{array}$ & $\begin{array}{r}.12 \\
.29 \\
(25) \\
\end{array}$ \\
\hline h & $\begin{array}{r}20 \\
.12 \\
(36) \\
\end{array}$ & $\begin{array}{r}.23 \\
.09 \\
(16) \\
\end{array}$ & $\begin{array}{r}.14 \\
.19 \\
(39) \\
\end{array}$ & $\begin{array}{r}-10 \\
.29 \\
(31) \\
\end{array}$ & $\begin{array}{r}.10 \\
.29 \\
(31) \\
\end{array}$ & $\begin{array}{r}-.17 \\
.24 \\
(20) \\
\end{array}$ & $\begin{array}{r}.26 \\
.09 \\
(30)\end{array}$ & \begin{tabular}{|r|}
-.35 \\
.07 \\
$(19)$ \\
\end{tabular} & $\begin{array}{r}.09 \\
.33 \\
(25) \\
\end{array}$ & $\begin{array}{r}.00 \\
49 \\
(33) \\
\end{array}$ & \begin{tabular}{|r|}
.08 \\
.34 \\
$(30)$ \\
\end{tabular} & $\begin{array}{r}.18 \\
.16 \\
(33) \\
\end{array}$ & $\begin{array}{r}.00 \\
.49 \\
(26) \\
\end{array}$ & $\begin{array}{r}.02 \\
.46 \\
(26)\end{array}$ & $\begin{array}{r}.06 \\
38 \\
(26) \\
\end{array}$ & $\begin{array}{r}.16 \\
.22 \\
(26) \\
\end{array}$ \\
\hline $\mathbf{i}$ & $\begin{array}{r}.24 \\
.10 \\
(31) \\
\end{array}$ & \begin{tabular}{|r|}
.16 \\
.19 \\
$(31)$ \\
\end{tabular} & $\begin{array}{r}-.18 \\
.16 \\
(33) \\
\end{array}$ & \begin{tabular}{|r|}
.07 \\
34 \\
$(36)$ \\
\end{tabular} & $\begin{array}{c}48 \\
.001 \\
(36) \\
\end{array}$ & $\begin{array}{r}.06 \\
.39 \\
(22) \\
\end{array}$ & $\begin{array}{r}.00 \\
.49 \\
(35) \\
\end{array}$ & \begin{tabular}{|r|}
.14 \\
.26 \\
$(23)$ \\
\end{tabular} & $\begin{array}{r}-.21 \\
.16 \\
(25) \\
\end{array}$ & $\begin{array}{r}-.29 \\
.05 \\
(33) \\
\end{array}$ & $\begin{array}{r}-.23 \\
.11 \\
(30) \\
\end{array}$ & $\begin{array}{r}-.26 \\
.07 \\
(33) \\
\end{array}$ & $\begin{array}{r}-.06 \\
.37 \\
(30) \\
\end{array}$ & $\begin{array}{r}.15 \\
.22 \\
(30)\end{array}$ & $\begin{array}{r}.18 \\
.17 \\
(30) \\
\end{array}$ & $\begin{array}{r}.21 \\
.13 \\
(30) \\
\end{array}$ \\
\hline j & $\begin{array}{r}.30 \\
.06 \\
(30)\end{array}$ & $\begin{array}{r}.22 \\
.12 \\
(.10) \\
\end{array}$ & $\begin{array}{r}.09 \\
30 \\
(32) \\
\end{array}$ & $\begin{array}{r}.01 \\
.48 \\
(35) \\
\end{array}$ & $\begin{array}{r}-.09 \\
.31 \\
(35)\end{array}$ & \begin{tabular}{|r|}
.09 \\
.35 \\
$(21)$ \\
\end{tabular} & $\begin{array}{r}-.13 \\
.24 \\
(34)\end{array}$ & $\begin{array}{c}-.51 \\
.007 \\
(23)\end{array}$ & $\begin{array}{r}.16 \\
.22 \\
(25) \\
\end{array}$ & $\begin{array}{r}-.10 \\
.29 \\
(32) \\
\end{array}$ & $\begin{array}{c}.50 \\
.003 \\
(29) \\
\end{array}$ & $\begin{array}{r}.33 \\
.03 \\
(32) \\
\end{array}$ & $\begin{array}{r}.04 \\
.43 \\
(29) \\
\end{array}$ & $\begin{array}{r}.13 \\
.24 \\
(29) \\
\end{array}$ & $\begin{array}{r}-.02 \\
.46 \\
(29) \\
\end{array}$ & $\begin{array}{r}.12 \\
.27 \\
(29) \\
\end{array}$ \\
\hline $\bar{k}$ & $\begin{array}{r}.05 \\
.40 \\
(29) \\
\end{array}$ & \begin{tabular}{|r|}
.02 \\
.45 \\
$(29)$ \\
\end{tabular} & $\begin{array}{r}.15 \\
.21 \\
(31) \\
\end{array}$ & $\begin{array}{c}.49 \\
.002 \\
(33) \\
\end{array}$ & $\begin{array}{r}.08 \\
.34 \\
(33) \\
\end{array}$ & $\begin{array}{r}.29 \\
.10 \\
(21) \\
\end{array}$ & $\begin{array}{r}.02 \\
.45 \\
(32) \\
\end{array}$ & \begin{tabular}{|r|}
01 \\
.47 \\
$(22)$ \\
\end{tabular} & $\begin{array}{r}.00 \\
.50 \\
(24) \\
\end{array}$ & $\begin{array}{r}.28 \\
.06 \\
(31) \\
\end{array}$ & $\begin{array}{r}.06 \\
.38 \\
(28) \\
\end{array}$ & \begin{tabular}{|r|}
38 \\
.02 \\
$(31)$ \\
\end{tabular} & $\begin{array}{r}.20 \\
.16 \\
(28) \\
\end{array}$ & \begin{tabular}{|c|}
.46 \\
.007 \\
$(28)$ \\
\end{tabular} & $\begin{array}{r}.35 \\
.03 \\
(28) \\
\end{array}$ & $\begin{array}{r}.24 \\
.11 \\
(28) \\
\end{array}$ \\
\hline 1 & $\begin{array}{r}.21 \\
.11 \\
(36) \\
\end{array}$ & $\begin{array}{r}-.31 \\
.03 \\
(36) \\
\end{array}$ & $\begin{array}{r}.09 \\
.21 \\
(39)\end{array}$ & $\begin{array}{r}.21 \\
.13 \\
(31) \\
\end{array}$ & $\begin{array}{r}-.19 \\
.16 \\
(31)\end{array}$ & $\begin{array}{r}.19 \\
.20 \\
(20) \\
\end{array}$ & $\begin{array}{r}.19 \\
.16 \\
(30) \\
\end{array}$ & $\begin{array}{r}.13 \\
.29 \\
(19) \\
\end{array}$ & $\begin{array}{r}.03 \\
.44 \\
(25) \\
\end{array}$ & $\begin{array}{r}.10 \\
.29 \\
(33) \\
\end{array}$ & \begin{tabular}{|r|}
.06 \\
.38 \\
$(30)$ \\
\end{tabular} & $\begin{array}{r}-.10 \\
.29 \\
(33) \\
\end{array}$ & $\begin{array}{r}-.24 \\
.12 \\
(26) \\
\end{array}$ & $\begin{array}{r}.12 \\
.28 \\
(26) \\
\end{array}$ & $\begin{array}{r}.11 \\
.31 \\
(26) \\
\end{array}$ & $\begin{array}{r}-.13 \\
.26 \\
(26) \\
\end{array}$ \\
\hline & $\begin{array}{l}\text { do be } \\
\text { ikbar } \\
\text { ision } \\
\text { evi } \\
\text { jerich } \\
\text { o van } \\
\text { omen } \\
\text { imho } \\
\text { id }\end{array}$ & $\begin{array}{l}\text { rap } \\
\text { ijfer } \\
\text { jid v } \\
\text { inak } \\
\text { copv } \\
\text { thak } \\
\text { of tho } \\
\text { sick } \\
\text { te } \\
\text { ect m }\end{array}$ & $\begin{array}{l}\text { uppe } \\
\text { trvare } \\
\text { hedr } \\
\text { atting } \\
\text { ng } \\
\text { alting } \\
\text { astekes }\end{array}$ & $\begin{array}{l}\text { iken } \\
\text { hat } \\
\text { poelr } \\
\text { arts } \\
\text { arbei }\end{array}$ & $\begin{array}{l}\text { odrtin } \\
\text { Irijr } \\
\text { ate }\end{array}$ & lig! & n & $\begin{array}{l}1= \\
2= \\
3= \\
4= \\
5= \\
6= \\
7= \\
8= \\
9= \\
10= \\
11= \\
12= \\
13= \\
14= \\
15= \\
16=\end{array}$ & cascl & $\begin{array}{l}d v \\
d v \\
\text { de } \\
\text { de }\end{array}$ & (ror & $\begin{array}{l}\text { won } \\
\text { ern } \\
\text { edri } \\
\text { erio } \\
\text { erk } \\
\text { ler }\end{array}$ & $\begin{array}{l}\text { rake } \\
\text { nger } \\
\text { ngut } \\
\text { ezot } \\
\text { on }\end{array}$ & $\begin{array}{l}\text { ing } \\
\text { eidku } \\
\text { bock } \\
\text { bek }\end{array}$ & ig & kuur \\
\hline
\end{tabular}


B. Aspecten van khatgerichte kwaliteit

\begin{tabular}{|c|c|c|c|c|c|c|c|c|c|c|c|c|c|c|c|c|c|c|c|}
\hline & 1 & 2 & 3 & 4 & 5 & 6 & 7 & 8 & 19 & 10 & 11 & 12 & 13 & 14 & 15 & 16 & 17 & 18 & 19 \\
\hline & $\begin{array}{r}-181 \\
.20 \\
(25) \\
\end{array}$ & \begin{tabular}{|}
.12 \\
.27 \\
$(30)$ \\
\end{tabular} & $\begin{array}{l}-11 \\
.27 \\
(32)\end{array}$ & $\begin{array}{r}45 \\
\text { (31) }\end{array}$ & $\begin{array}{r}.21 \\
.16 \\
(26)\end{array}$ & $\begin{array}{r}18 \\
.20 \\
(25)\end{array}$ & $\begin{array}{l}.21 \\
.15 \\
(27)\end{array}$ & $\begin{array}{r}.30 \\
.97 \\
(26) \\
\end{array}$ & $\begin{array}{r}21 \\
17 \\
(23)\end{array}$ & $\begin{array}{r}-28 \\
09 \\
(25)\end{array}$ & $\begin{array}{r}-.08 i \\
.35 i \\
(24)\end{array}$ & $\begin{array}{r}30 \\
10 \\
199\end{array}$ & $\begin{array}{l}.30 \\
.08 \\
(25) \\
\end{array}$ & $\begin{array}{r}28 \\
08 \\
(26) \\
\end{array}$ & $\begin{array}{r}15 \\
.20 \\
(33)\end{array}$ & $\begin{array}{l}33 \\
.05 \\
(25) \\
\end{array}$ & $\begin{array}{r}19 \\
15 \\
037\end{array}$ & $\begin{array}{r}.07 \\
37 \\
(24)\end{array}$ & $\begin{array}{r}.08 \\
.34 \\
(30)\end{array}$ \\
\hline & $\begin{array}{r}.02 \\
.45 \\
(25) \\
\end{array}$ & $\begin{array}{r}.02 \\
.45 \\
(30) \\
\end{array}$ & $\begin{array}{r}.07 \\
35 \\
(32) \\
\end{array}$ & $\begin{array}{r}-.04 \\
42 \\
(31)\end{array}$ & \begin{tabular}{|l|}
27 \\
09 \\
$(26)$ \\
\end{tabular} & $\begin{array}{r}31 \\
06 \\
(25) \\
\end{array}$ & $\begin{array}{l}.34 \\
.04 \\
(27) \\
\end{array}$ & $\begin{array}{l}35 \\
04 \\
26)\end{array}$ & $\begin{array}{r}.33 \\
.07 \\
23 \\
\end{array}$ & $\begin{array}{r}-18 \\
.20 \\
(23) \\
\end{array}$ & $\begin{array}{r}.06 \\
37 \\
24)\end{array}$ & $\begin{array}{r}.23 \\
17 \\
(19) \\
\end{array}$ & \begin{tabular}{|r|}
11 \\
30 \\
$253)$ \\
\end{tabular} & \begin{tabular}{|l|}
43 \\
.01 \\
$26)$ \\
\end{tabular} & $\begin{array}{r}-.06 \\
.36 \\
(33)\end{array}$ & $\begin{array}{l}20 \\
17 \\
(3)\end{array}$ & $\begin{array}{r}10 \\
.28 \\
(33)\end{array}$ & $\begin{array}{l}14 \\
.25 \\
(24)\end{array}$ & $\begin{array}{r}.00 \\
49 \\
(40)\end{array}$ \\
\hline 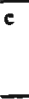 & $\begin{array}{r}.06 \\
.39 \\
(25) \\
\end{array}$ & $\begin{array}{r}-.01 \\
.48 \\
(30) \\
\end{array}$ & $\begin{array}{r}-06 \\
37 \\
(32)\end{array}$ & $\begin{array}{r}.16 \\
.20 \\
(31) \\
\end{array}$ & $\begin{array}{l}31 \\
06 \\
(26) \\
\end{array}$ & $\begin{array}{r}.00 \\
50 \\
(25) \\
\end{array}$ & $\begin{array}{r}.10 \\
31 \\
(27) \\
\end{array}$ & $\begin{array}{r}20 \\
.17 \\
(26) \\
\end{array}$ & $\begin{array}{r}.02 \\
.47 \\
(23)\end{array}$ & \begin{tabular}{r|}
.24 \\
.13 \\
$(25)$ \\
\end{tabular} & $\begin{array}{l}.391 \\
03 \\
(24)\end{array}$ & $\begin{array}{r}.00 \\
49 \\
(19)\end{array}$ & $\begin{array}{r}.26 \\
11 \\
(25)\end{array}$ & {$\left[\begin{array}{c}-.22 \\
.14 \\
(26)\end{array}\right]$} & $\begin{array}{r}16 \\
18 \\
(33)\end{array}$ & $\begin{array}{l}35 \\
04 \\
25)\end{array}$ & $\begin{array}{r}.36 \\
.02 \\
(33) \\
\end{array}$ & $\begin{array}{l}36 \\
04 \\
24)\end{array}$ & $\begin{array}{r}-28 \\
.97 \\
(10)\end{array}$ \\
\hline d & $\begin{array}{r}-12 \\
.29 \\
(25)\end{array}$ & $\begin{array}{r}-.24 \\
.10 \\
(30)\end{array}$ & $\begin{array}{r}-.17 \\
.18 \\
(32)\end{array}$ & $\begin{array}{r}.02 \\
.46 \\
(31)\end{array}$ & \begin{tabular}{|r|}
22 \\
14 \\
$(26)$ \\
\end{tabular} & $\begin{array}{r}32 \\
.06 \\
(25)\end{array}$ & $\begin{array}{r}.16 \\
.21 \\
(27)\end{array}$ & $\begin{array}{r}.05 \\
.40 \\
(26) \\
\end{array}$ & $\begin{array}{r}.314 \\
.06 \\
(23) \\
\end{array}$ & \begin{tabular}{r|}
.06 \\
38 \\
$(25)$ \\
\end{tabular} & $\begin{array}{r}.05 \\
.41 \\
(24)\end{array}$ & $\begin{array}{r}20 \\
20 \\
(19) \\
\end{array}$ & $\begin{array}{r}15 \\
.24 \\
(25) \\
\end{array}$ & \begin{tabular}{|r|}
.29 \\
.13 \\
$26]$
\end{tabular} & $\begin{array}{r}.02 \\
45 \\
(33) \\
\end{array}$ & $\begin{array}{r}29 \\
08 \\
(25)\end{array}$ & $\begin{array}{r}=69 \\
.30 \\
(33)\end{array}$ & $\begin{array}{r}16 \\
.23 \\
(24)\end{array}$ & $\begin{array}{r}09 \\
31 \\
(30)\end{array}$ \\
\hline 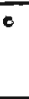 & $\begin{array}{r}-12 \\
.29 \\
(24)\end{array}$ & $\begin{array}{r}. .06 \\
.38 \\
(30) \\
\end{array}$ & $\begin{array}{r}. .06 \\
.36 \\
(32)\end{array}$ & $\begin{array}{r}.05 \\
.41 \\
(30)\end{array}$ & $\begin{array}{r}.08 \\
36 \\
(25)\end{array}$ & $\begin{array}{r}.15 \\
25 \\
(24)\end{array}$ & \begin{tabular}{|r|}
00 \\
49 \\
$(26)$ \\
\end{tabular} & $\begin{array}{r}34 \\
.05 \\
{[25]}\end{array}$ & $\begin{array}{r}.33 \\
.07 \\
(22)\end{array}$ & \begin{tabular}{r|}
.12 \\
.28 \\
$(24)$
\end{tabular} & $\begin{array}{l}11 \\
.32 \\
(23)\end{array}$ & \begin{tabular}{|r|}
09 \\
37 \\
$(18)$ \\
\end{tabular} & \begin{tabular}{|r|}
05 \\
41 \\
$(24)$ \\
\end{tabular} & {$\left[\begin{array}{l}.37 \\
04 \\
(25)\end{array}\right.$} & $\begin{array}{l}.10 \\
.29 \\
(32)\end{array}$ & $\begin{array}{r}.00 \\
50 \\
(24) \\
\end{array}$ & $\begin{array}{r}01 \\
4 ? \\
(32)\end{array}$ & $\begin{array}{l}09 \\
.35 \\
(23)\end{array}$ & $\begin{array}{r}-.36 \\
.03 \\
(29)\end{array}$ \\
\hline$f$ & $\begin{array}{r}.42 \\
.02 \\
(25)\end{array}$ & $\begin{array}{r}-.12 \\
.26 \\
(30) \\
\end{array}$ & $\begin{array}{r}.30 \\
.05 \\
(32)\end{array}$ & $\begin{array}{r}.23 \\
.11 \\
(31)\end{array}$ & $\begin{array}{r}08 \\
35 \\
(26) \\
\end{array}$ & $\begin{array}{r}.04 \\
43 \\
(25) \\
\end{array}$ & $\begin{array}{l}.28 \\
.048 \\
(27) \\
\end{array}$ & $\begin{array}{r}.3 i \\
.06 i \\
(26 i\end{array}$ & $\begin{array}{r}.01 \\
.48 \\
(23) \\
\end{array}$ & \begin{tabular}{|r|}
.23 \\
.14 \\
$(25)$ \\
\end{tabular} & $\begin{array}{r}26 \\
.11 \\
(24) \\
\end{array}$ & $\begin{array}{r}.33 \\
.09 \\
(19) \\
\end{array}$ & $\begin{array}{r}.23 \\
13 \\
(29)\end{array}$ & $\begin{array}{r}01 \\
48 \\
263 \\
\end{array}$ & $\begin{array}{r}.08 \\
.33 \\
(339) \\
\end{array}$ & \begin{tabular}{|r|}
301 \\
.07 \\
$(25)$ \\
\end{tabular} & $\begin{array}{l}31 \\
04 \\
(33)\end{array}$ & $\begin{array}{r}01 \\
48 \\
(24)\end{array}$ & \begin{tabular}{|c|}
.08 \\
.34 \\
$(30)$ \\
\end{tabular} \\
\hline 8 & $\begin{array}{r}.23 \\
.14 \\
(24) \\
\end{array}$ & $\begin{array}{r}-.18 \\
.18 \\
(29)\end{array}$ & $\begin{array}{r}.02 \\
.45 \\
(31)\end{array}$ & $\begin{array}{r}.15 \\
.22 \\
(.10)\end{array}$ & \begin{tabular}{|r|}
.19 \\
.18 \\
$(25)$ \\
\end{tabular} & \begin{tabular}{|l|}
5 \\
01 \\
$(24)$ \\
\end{tabular} & $\begin{array}{r}24 \\
11 \\
(26) \\
\end{array}$ & $\begin{array}{l}.00 \\
.49 \\
(25)\end{array}$ & $\begin{array}{r}.03 \\
.44 \\
(22)\end{array}$ & $\begin{array}{r}.15 \\
.23 \\
(24) \\
\end{array}$ & $\begin{array}{r}10 \\
.32 \\
(23) \\
\end{array}$ & \begin{tabular}{|r|}
46 \\
03 \\
$(18)$ \\
\end{tabular} & $\begin{array}{c}06 \\
.39 \\
(24) \\
\end{array}$ & \begin{tabular}{|l|}
.14 \\
.26 \\
$(25)$ \\
\end{tabular} & $\begin{array}{l}.07 \\
.35 \\
(32)\end{array}$ & \begin{tabular}{|l|}
30 \\
.08 \\
$(24)$ \\
\end{tabular} & {$\left[\begin{array}{r}.02 \\
46 \\
02\end{array}\right.$} & $\begin{array}{r}40 \\
44 \\
271\end{array}$ & $\begin{array}{r}-26 \\
09 \\
(29)\end{array}$ \\
\hline h & $\begin{array}{r}.01 \\
.47 \\
(25) \\
\end{array}$ & $\begin{array}{r}.0 .3 \\
4 \\
(30)\end{array}$ & \begin{tabular}{|l|}
.28 \\
.06 \\
$(32)$ \\
\end{tabular} & $\begin{array}{l}.31 \\
.05 \\
(31) \\
\end{array}$ & $\begin{array}{r}-32 \\
.06 \\
(26) \\
\end{array}$ & $\begin{array}{r}.00 \\
50 \\
(25) \\
\end{array}$ & $\begin{array}{r}-19 \\
17 \\
(27) \\
\end{array}$ & $\begin{array}{r}-.25 \\
11 \\
(26) \\
\end{array}$ & $\begin{array}{r}-.081 \\
36 \\
(23) \\
\end{array}$ & $\begin{array}{r}11 \\
30 \\
(25) \\
\end{array}$ & $\begin{array}{r}.00 \\
.49 \\
(24) \\
\end{array}$ & $\begin{array}{c}.07 \\
39 \\
(19) \\
\end{array}$ & $\begin{array}{r}.12 \\
.28 \\
(25) \\
\end{array}$ & \begin{tabular}{|r|}
23 \\
13 \\
$(26)$ \\
\end{tabular} & $\begin{array}{l}40 \\
.01 \\
(33)\end{array}$ & \begin{tabular}{|l}
.28 \\
.051 \\
$(25)$
\end{tabular} & $\begin{array}{c}.53 \\
.001 \\
(93)\end{array}$ & $\begin{array}{r}-.08 \\
.36 \\
(24)\end{array}$ & $\begin{array}{r}-30 \\
.05 \\
(30)\end{array}$ \\
\hline 1 & $\begin{array}{r}.19 \\
.16 \\
(29) \\
\end{array}$ & $\begin{array}{r}.01 \\
.47 \\
(35) \\
\end{array}$ & $\begin{array}{r}-.07 \\
.34 \\
(37) \\
\end{array}$ & $\begin{array}{r}.10 \\
.28 \\
(33) \\
\end{array}$ & $\begin{array}{r}.04 \\
.42 \\
(28) \\
\end{array}$ & $\begin{array}{r}.23 \\
.11 \\
(29) \\
\end{array}$ & $\begin{array}{r}.35 \\
.03 \\
(29) \\
\end{array}$ & \begin{tabular}{|c|}
.03 \\
.44 \\
$(30)$ \\
\end{tabular} & $\begin{array}{r}.14 \\
.25 \\
(27)\end{array}$ & $\begin{array}{r}-.02 \\
46 \\
(29) \\
\end{array}$ & $\begin{array}{r}-.31 \\
.06 \\
(27) \\
\end{array}$ & $\begin{array}{r}.27 \\
.13 \\
(19) \\
\end{array}$ & \begin{tabular}{|r|}
.25 \\
.11 \\
$(25)$ \\
\end{tabular} & \begin{tabular}{|r|}
31 \\
.06 \\
$(26)$ \\
\end{tabular} & $\begin{array}{r}.24 \\
.09 \\
(33) \\
\end{array}$ & $\begin{array}{r}-29 \\
12 \\
(25) \\
\end{array}$ & $\begin{array}{r}.30 \\
04 \\
(33)\end{array}$ & $\begin{array}{r}.17 \\
.21 \\
(24)\end{array}$ & $\begin{array}{r}-.251 \\
.09 \\
(39) \\
\end{array}$ \\
\hline j & \begin{tabular}{|r|}
-.33 \\
.04 \\
$(29)$ \\
\end{tabular} & $\begin{array}{r}. .00 \\
.50 \\
(34) \\
\end{array}$ & $\begin{array}{r}-.13 \\
.23 \\
(36) \\
\end{array}$ & \begin{tabular}{|r|}
18 \\
.16 \\
$(32)$ \\
\end{tabular} & \begin{tabular}{|r|}
-.29 \\
.07 \\
$(27)$ \\
\end{tabular} & \begin{tabular}{|r|}
.23 \\
.12 \\
$(28)$ \\
\end{tabular} & \begin{tabular}{|r|}
-.10 \\
.30 \\
$(28)$ \\
\end{tabular} & $\begin{array}{r}.29 \\
.06 \\
(29) \\
\end{array}$ & \begin{tabular}{|r|}
.17 \\
.19 \\
$(27)$ \\
\end{tabular} & \begin{tabular}{|r|}
.05 \\
.40 \\
$(28)$ \\
\end{tabular} & \begin{tabular}{|r|}
-.00 \\
.49 \\
$(26)$ \\
\end{tabular} & $\begin{array}{r}-15 \\
27 \\
(19) \\
\end{array}$ & $\begin{array}{r}.00 \\
.49 \\
(25) \\
\end{array}$ & \begin{tabular}{|r|}
.03 \\
.41 \\
$(25)$ \\
\end{tabular} & $\begin{array}{r}.20 \\
13 \\
(32) \\
\end{array}$ & $\begin{array}{l}36 \\
.04 \\
(24)\end{array}$ & $\begin{array}{r}15 \\
.20 \\
(32) \\
\end{array}$ & $\begin{array}{r}.23 \\
.14 \\
(23) \\
\end{array}$ & $\begin{array}{r}.29 \\
.06 \\
(29) \\
\end{array}$ \\
\hline $\mathbf{k}$ & \begin{tabular}{|r|}
.35 \\
.04 \\
$(27)$ \\
\end{tabular} & \begin{tabular}{|r|}
.19 \\
.15 \\
$(32)$ \\
\end{tabular} & $\begin{array}{r}.22 \\
.10 \\
(34) \\
\end{array}$ & $\begin{array}{r}.02 \\
.45 \\
(31) \\
\end{array}$ & \begin{tabular}{|r|}
-.28 \\
.08 \\
$(26)$ \\
\end{tabular} & \begin{tabular}{|r|}
-17 \\
.20 \\
$(27)$ \\
\end{tabular} & $\begin{array}{r}.02 \\
.45 \\
(27) \\
\end{array}$ & $\begin{array}{r}.26 \\
.09 \\
(28) \\
\end{array}$ & \begin{tabular}{|r}
-.01 \\
.47 \\
$(25)$ \\
\end{tabular} & \begin{tabular}{|r|}
.34 \\
.04 \\
$(27)$ \\
\end{tabular} & \begin{tabular}{|r|}
.12 \\
.29 \\
$(26)$ \\
\end{tabular} & \begin{tabular}{|r|}
20 \\
.21 \\
$(18)$ \\
\end{tabular} & $\begin{array}{r}-09 \\
35 \\
(24) \\
\end{array}$ & \begin{tabular}{|r|}
-43 \\
02 \\
$(25)$ \\
\end{tabular} & $\begin{array}{r}16 \\
.19 \\
(31) \\
\end{array}$ & $\begin{array}{r}16 \\
23 \\
(24) \\
\end{array}$ & $\begin{array}{r}.06 \\
.38 \\
(31) \\
\end{array}$ & $\begin{array}{r}-10 \\
312 \\
(23) \\
\end{array}$ & \begin{tabular}{|r|}
.20 \\
.16 \\
$(28)$ \\
\end{tabular} \\
\hline 1 & $\begin{array}{r}-.05 \\
.40 \\
(25)\end{array}$ & \begin{tabular}{|r|}
.07 \\
.35 \\
$(30)$ \\
\end{tabular} & \begin{tabular}{|r|}
-.15 \\
.21 \\
$(32)$ \\
\end{tabular} & $\begin{array}{r}-.12 \\
.26 \\
(31)\end{array}$ & \begin{tabular}{|r}
.17 \\
.20 \\
$(26)$ \\
\end{tabular} & \begin{tabular}{|l}
.36 \\
.04 \\
$(25)$ \\
\end{tabular} & $\begin{array}{r}.40 \\
.02 \\
(27)\end{array}$ & \begin{tabular}{|r|}
-.12 \\
.28 \\
$(26)$ \\
\end{tabular} & $\begin{array}{c}.60 \\
.001 \\
(23) \\
\end{array}$ & \begin{tabular}{|r|}
-19 \\
18 \\
$(25)$ \\
\end{tabular} & \begin{tabular}{|r|}
.32 \\
.06 \\
$(24)$ \\
\end{tabular} & \begin{tabular}{|r|}
.12 \\
.31 \\
$(19)$ \\
\end{tabular} & \begin{tabular}{|r|}
-.01 \\
48 \\
$(25)$ \\
\end{tabular} & $\begin{array}{r}.13 \\
.27 \\
(26) \\
\end{array}$ & $\begin{array}{r}-.12 \\
.26 \\
(33) \\
\end{array}$ & \begin{tabular}{|r|}
-.20 \\
.17 \\
$(25)$ \\
\end{tabular} & \begin{tabular}{|r|}
.38 \\
.02 \\
$(33) !$ \\
\end{tabular} & $\begin{array}{r}40 \\
03 \\
(24)\end{array}$ & $\begin{array}{r}21 \\
.13 \\
(30) \\
\end{array}$ \\
\hline
\end{tabular}

a-ervaring bedrijfarts (in betrokken hodrij) $b=o v e r l e g$ met directie bedrijf

c =afiprask over repporinge an hat hodrijf $d=$ door de bedrijfearts ervaren speelruimte e ebeschikbare tijd voor bedrijferts

f-profeasionele tuekcopvatting

$g=$ curatieve takkopvatting

h=klent gerichte unkopvanting

i=grootte van hat bedrijf

$j=$ voorkomen fysiek belastende arbeidsomstandigheden

$k=$ verzuimhoorte

I = melheid contuct mat ricken
1 = seuts BGD voor ondernemingurned

$z=$ steun BGD voor pernoneetszalcen

3 =kkiantvriendelijke houding BOD

$4=$ grvaring ma uitwoering andellingsonderzock

$S=$ ervaring mat vitwocting: periodiek onderzock

$6=$ ondernemingsrand ervant verzuimbegeleiding BCD aff comprole

7 =werknemers ervaren verzuimbegeteiding BCD alir controle

8 - BGD) onderneemt volgens OR voldoende extra, nctiviteiten

$9=$ enmenwerking BCL)-diroctie

10 - samenswerkings BGD-ondernemingurend

II =samenwerking BOD-personcelszaken

12 =uitvocting amstellingsonderzoek niar wens ondernemingsraud 13 =uidvoering censtellingsonderzock nus wens verknemeris 14 =uitvoerinjs cpreckuur mes wens ondernemingurad 15 - uit voering spredkvur new wens werknemsers

16 myitvoering periodick onderznek near wens ondernemingarand

17 =uityoering perindiek onderzock near wens werknemers

18 evitvoering werkplekonderzock nes wens onderseming srand

19 - exiksering werkplekonderzock nus wens werknemers 
Bijlage 4.

\section{Correlatiematrix: Onafhankelijke en afhankelijke variabelen: Onderlinge correlaties}

A. Onafhankelijke variabelen oaderling

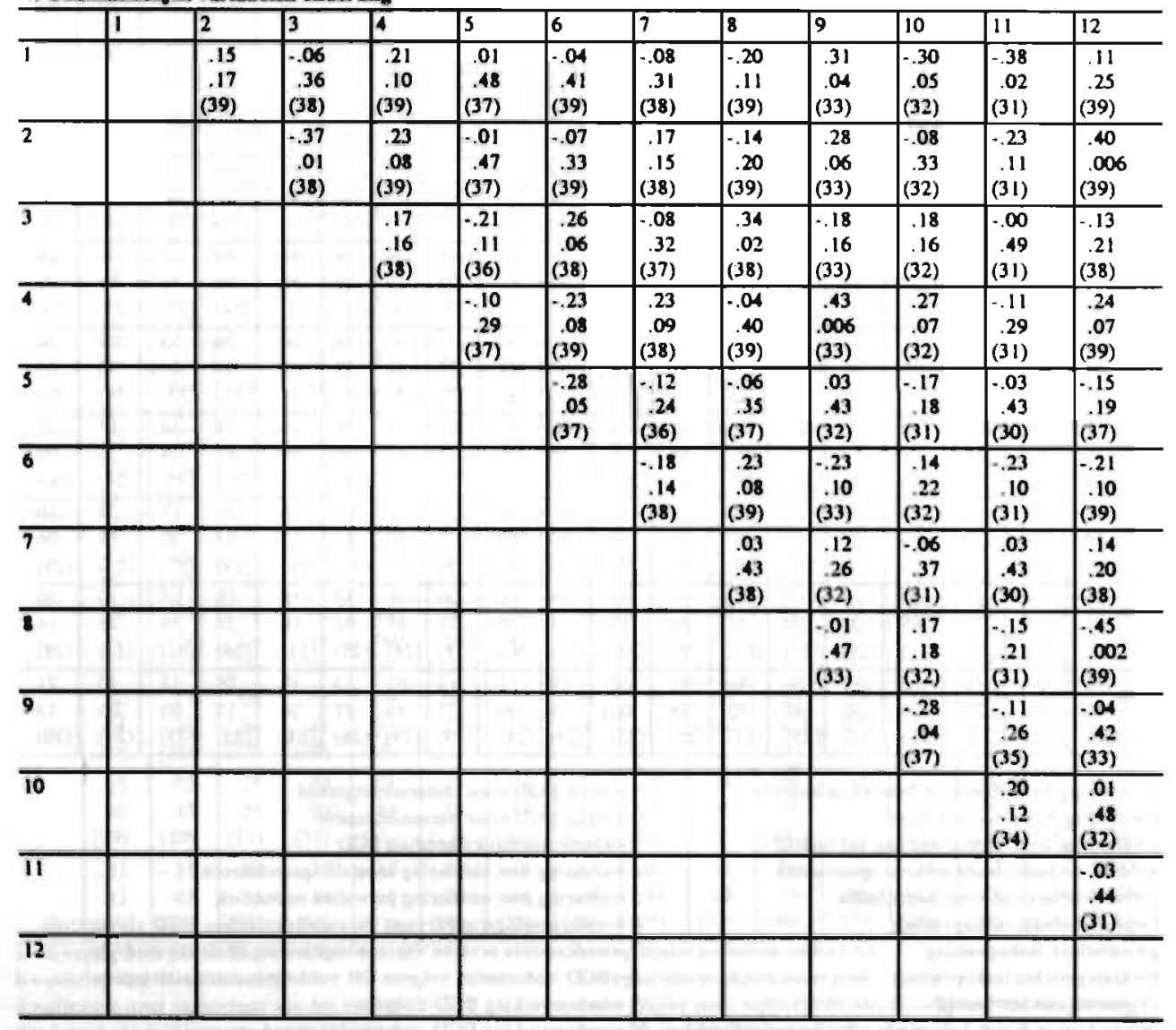

I = ervaring hodrijfarts (in boumktion hodrijn

2 = overleg mod diroctie van het bodrijf

3i= afsprank over rapportage man het bedrijr

4= door de bedrijfsarth ervaren apeetruimte

S- beschikbare tijd voor bedrijfsarts

6- professionele tagkopvatting

7.- curatiove tackopvatting

8- klanterichte taskopvaltiag

9. growkte van hat bodrijf

10- voorkomen van fysiak belattende artheidamsundighedea

11 i = verzuimhoogte

12 = aclheid contact mot zieken 
B. Amankelijke variabelea onderlings. Aspecten va profescionele kwaliteit onderling.

\begin{tabular}{|c|c|c|c|c|c|c|c|c|c|c|c|c|c|c|c|c|}
\hline & 1 & 2 & 3 & 4 & 5 & 6 & 7 & 8 & 9 & 10 & 11 & 12 & 13 & 14 & is & 16 \\
\hline$I$ & $\begin{array}{c}\mathbf{X} \\
(1)\end{array}$ & & & & & & & & & & & & & & & \\
\hline 2 & \begin{tabular}{|l|}
48 \\
.002 \\
$(34)$ \\
\end{tabular} & $\begin{array}{c}X \\
(2)\end{array}$ & & & & & & & & & & & & & & \\
\hline 3 & \begin{tabular}{|r|}
20 \\
13 \\
$(36)$ \\
\end{tabular} & $\begin{array}{r}.27 \\
.06 \\
(36) \\
\end{array}$ & \begin{tabular}{|l}
$x$ \\
$(3)$ \\
\end{tabular} & & & & & & & & & & & & & \\
\hline$\overline{4}$ & $\begin{array}{r}03 \\
45 \\
(29) \\
\end{array}$ & $\begin{array}{r}.21 \\
.14 \\
(29) \\
\end{array}$ & $\begin{array}{r}.16 \\
.19 \\
(31) \\
\end{array}$ & $\begin{array}{r}X \\
(4)\end{array}$ & & & & & & & & & & & & \\
\hline 5 & $\begin{array}{l}.47 \\
.005 \\
(29) \\
\end{array}$ & $\begin{array}{r}.33 \\
.04 \\
(29) \\
\end{array}$ & $\begin{array}{r}.10 \\
.29 \\
(31) \\
\end{array}$ & $\begin{array}{l}.27 \\
.06 \\
(35) \\
\end{array}$ & $\begin{array}{c}X \\
(5)\end{array}$ & & & & & & & & & & & \\
\hline 6 & $\begin{array}{r}.23 \\
.18 \\
(18) \\
\end{array}$ & $\begin{array}{r}.25 \\
.15 \\
(19) \\
\end{array}$ & $\begin{array}{r}.05 \\
.41 \\
(20) \\
\end{array}$ & $\begin{array}{r}.14 \\
.26 \\
(22) \\
\end{array}$ & \begin{tabular}{|l|}
.28 \\
.10 \\
$(22)$ \\
\end{tabular} & \begin{tabular}{|l}
$X$ \\
$(6)$
\end{tabular} & & & & & & & & & & \\
\hline 7 & $\begin{array}{r}. .03 \\
.44 \\
(28) \\
\end{array}$ & $\begin{array}{r}.22 \\
.13 \\
(28) \\
\end{array}$ & $\begin{array}{l}.41 \\
.01 \\
(30) \\
\end{array}$ & $\begin{array}{r}.02 \\
45 \\
(34) \\
\end{array}$ & $\begin{array}{l}08 \\
33 \\
(34) \\
\end{array}$ & $\begin{array}{r}.14 \\
.28 \\
(21) \\
\end{array}$ & $\begin{array}{r}X \\
(7) \\
\end{array}$ & & & & & & & & & \\
\hline 8 & \begin{tabular}{|r|}
.20 \\
.22 \\
$(17)$ \\
\end{tabular} & $\begin{array}{r}17 \\
.25 \\
(18) \\
\end{array}$ & $\begin{array}{r}.26 \\
.15 \\
(19) \\
\end{array}$ & $\begin{array}{r}.01 \\
.48 \\
(22) \\
\end{array}$ & $\begin{array}{r}21 \\
19 \\
(21) \\
\end{array}$ & $\begin{array}{l}.62 \\
.006 \\
(16) \\
\end{array}$ & $\begin{array}{r}.25 \\
.15 \\
(20) \\
\end{array}$ & $\begin{array}{c}X \\
(8)\end{array}$ & & & & & & & & \\
\hline$\overline{9}$ & $\begin{array}{r}-.11 \\
.32 \\
(23) \\
\end{array}$ & $\begin{array}{r}.04 \\
.43 \\
(23) \\
\end{array}$ & $\begin{array}{r}.06 \\
.38 \\
(25) \\
\end{array}$ & \begin{tabular}{|r|}
.05 \\
.42 \\
$(23)$ \\
\end{tabular} & $\begin{array}{r}.07 \\
.37 \\
(23) \\
\end{array}$ & $\begin{array}{r}.14 \\
.31 \\
(15) \\
\end{array}$ & $\begin{array}{r}.34 \\
.06 \\
(22) \\
\end{array}$ & $\begin{array}{r}17 \\
28 \\
(15) \\
\end{array}$ & $\begin{array}{c}X \\
(9) \\
\end{array}$ & & & & & & & \\
\hline 10 & \begin{tabular}{|l}
.00 \\
.50 \\
$(31)$ \\
\end{tabular} & $\begin{array}{r}03 \\
44 \\
(31) \\
\end{array}$ & \begin{tabular}{|r|}
.13 \\
.23 \\
$(33)$ \\
\end{tabular} & \begin{tabular}{|l|}
.25 \\
.09 \\
$(31)$ \\
\end{tabular} & $\begin{array}{r}-.15 \\
.21 \\
(31) \\
\end{array}$ & $\begin{array}{r}.40 \\
.04 \\
(20) \\
\end{array}$ & $\begin{array}{r}.07 \\
.35 \\
(30) \\
\end{array}$ & $\begin{array}{r}.01 \\
.48 \\
(19) \\
\end{array}$ & $\begin{array}{r}.22 \\
15 \\
(25) \\
\end{array}$ & $\begin{array}{c}X \\
(10) \\
\end{array}$ & & & & & & \\
\hline 11 & $\begin{array}{r}-.11 \\
.30 \\
(28) \\
\end{array}$ & $\begin{array}{r}.09 \\
.09 \\
(28) \\
\end{array}$ & $\begin{array}{r}-.16 \\
.19 \\
(30) \\
\end{array}$ & $\begin{array}{r}.09 \\
.32 \\
(28) \\
\end{array}$ & $\begin{array}{r}.31 \\
.05 \\
(29) \\
\end{array}$ & \begin{tabular}{|r|}
30 \\
.11 \\
$(19)$ \\
\end{tabular} & \begin{tabular}{|r}
.12 \\
.28 \\
$(27)$ \\
\end{tabular} & $\begin{array}{r}.27 \\
.14 \\
(18) \\
\end{array}$ & $\begin{array}{r}.16 \\
.23 \\
(24) \\
\end{array}$ & $\begin{array}{r}-.26 \\
.08 \\
(30) \\
\end{array}$ & \begin{tabular}{|c}
$\mathbf{X}$ \\
(1II)
\end{tabular} & & & & & \\
\hline 12 & $\begin{array}{r}-.01 \\
.47 \\
(31) \\
\end{array}$ & $\begin{array}{l}.25 \\
.09 \\
(31) \\
\end{array}$ & \begin{tabular}{|l|}
.10 \\
.28 \\
$(33)$ \\
\end{tabular} & \begin{tabular}{|l|}
.39 \\
.02 \\
$(31)$ \\
\end{tabular} & \begin{tabular}{|r|}
.11 \\
.28 \\
$(31)$ \\
\end{tabular} & \begin{tabular}{|r|}
.47 \\
.02 \\
$(20)$ \\
\end{tabular} & $\begin{array}{r}.04 \\
41 \\
(30) \\
\end{array}$ & \begin{tabular}{|l}
.19 \\
.22 \\
$(19)$ \\
\end{tabular} & $\begin{array}{r}.29 \\
.08 \\
(25) \\
\end{array}$ & $\begin{array}{r}.07 \\
.34 \\
(33) \\
\end{array}$ & $\begin{array}{l}44 \\
.007 \\
(30) \\
\end{array}$ & \begin{tabular}{|c}
$X$ \\
$(12)$ \\
\end{tabular} & & & & \\
\hline 13 & \begin{tabular}{|r}
-.22 \\
.15 \\
$(24)$ \\
\end{tabular} & $\begin{array}{r}.12 \\
.28 \\
(25) \\
\end{array}$ & $\begin{array}{r}-.44 \\
.01 \\
(26) \\
\end{array}$ & \begin{tabular}{|r|}
-.25 \\
.10 \\
$(28)$ \\
\end{tabular} & $\begin{array}{r}. .06 \\
.38 \\
(28) \\
\end{array}$ & \begin{tabular}{|r|}
.17 \\
.23 \\
$(22)$ \\
\end{tabular} & $\begin{array}{r}.12 \\
.28 \\
(27) \\
\end{array}$ & $\begin{array}{r}.00 \\
50 \\
(23) \\
\end{array}$ & $\begin{array}{r}.03 \\
.44 \\
(20) \\
\end{array}$ & $\begin{array}{r}.01 \\
.48 \\
(26) \\
\end{array}$ & $\begin{array}{r}.27 \\
.10 \\
(24) \\
\end{array}$ & $\begin{array}{r}.17 \\
.20 \\
(26) \\
\end{array}$ & $\begin{array}{c}x \\
(13) \\
\end{array}$ & & & \\
\hline 14 & \begin{tabular}{|r|}
-.20 \\
.18 \\
$(24)$ \\
\end{tabular} & $\begin{array}{r}.13 \\
.27 \\
(25) \\
\end{array}$ & $\begin{array}{r}-.21 \\
.15 \\
(26) \\
\end{array}$ & \begin{tabular}{|r|}
.27 \\
.08 \\
$(28)$ \\
\end{tabular} & \begin{tabular}{|r|}
.27 \\
.09 \\
$(28)$ \\
\end{tabular} & $\begin{array}{c}.65 \\
.001 \\
(22) \\
\end{array}$ & $\begin{array}{r}.13 \\
.26 \\
(27) \\
\end{array}$ & $\begin{array}{r}.24 \\
.14 \\
(23) \\
\end{array}$ & $\begin{array}{r}.42 \\
.03 \\
(20) \\
\end{array}$ & $\begin{array}{r}.07 \\
.37 \\
(26) \\
\end{array}$ & \begin{tabular}{|r|}
.13 \\
.27 \\
$(24)$ \\
\end{tabular} & \begin{tabular}{|r|}
37 \\
.03 \\
$(26)$ \\
\end{tabular} & $\begin{array}{r}.33 \\
03 \\
(30) \\
\end{array}$ & $\begin{array}{c}x \\
(14)\end{array}$ & & \\
\hline 15 & $\begin{array}{r}-.07 \\
.37 \\
(24) \\
\end{array}$ & $\begin{array}{l}.40 \\
.02 \\
(25) \\
\end{array}$ & $\begin{array}{r}-.00 \\
.50 \\
(26) \\
\end{array}$ & \begin{tabular}{|r|}
.19 \\
.17 \\
$(28)$ \\
\end{tabular} & \begin{tabular}{|r|}
.26 \\
.09 \\
$(28)$ \\
\end{tabular} & $\begin{array}{c}.59 \\
.002 \\
(22) \\
\end{array}$ & $\begin{array}{r}.20 \\
.16 \\
(27) \\
\end{array}$ & \begin{tabular}{|l|}
.56 \\
.003 \\
$(23)$ \\
\end{tabular} & $\begin{array}{r}31 \\
.09 \\
(20) \\
\end{array}$ & $\begin{array}{r}.06 \\
.39 \\
(26) \\
\end{array}$ & $\begin{array}{r}.09 \\
34 \\
(24) \\
\end{array}$ & $\begin{array}{r}.44 \\
.01 \\
(26) \\
\end{array}$ & $\begin{array}{r}.25 \\
09 \\
(30) \\
\end{array}$ & \begin{tabular}{l|}
71 \\
.000 \\
$(30)$ \\
\end{tabular} & $\begin{array}{c}x \\
\text { (115) }\end{array}$ & \\
\hline 16 & $\begin{array}{r}.28 \\
.09 \\
(24) \\
\end{array}$ & $\begin{array}{l}.61 \\
.001 \\
(25) \\
\end{array}$ & \begin{tabular}{|r|}
.06 \\
.39 \\
$(26)$ \\
\end{tabular} & $\begin{array}{r}.06 \\
.38 \\
(28) \\
\end{array}$ & $\begin{array}{r}.39 \\
.02 \\
(28) \\
\end{array}$ & $\begin{array}{c}.70 \\
.000 \\
(22)\end{array}$ & $\begin{array}{r}.08 \\
35 \\
(27) \\
\end{array}$ & $\begin{array}{r}.42 \\
.02 \\
(23) \\
\end{array}$ & $\begin{array}{r}10 \\
34 \\
620) \\
\end{array}$ & $\begin{array}{r}.22 \\
14 \\
(26) \\
\end{array}$ & $\begin{array}{r}21 \\
.16 \\
(24) \\
\end{array}$ & $\begin{array}{c}49 \\
005 \\
(26)\end{array}$ & $\begin{array}{r}39 \\
02 \\
(30) \\
\end{array}$ & $\begin{array}{c}34 \\
001 \\
(30)\end{array}$ & $\begin{array}{l}69 \\
000 \\
(30)\end{array}$ & $x$ \\
\hline
\end{tabular}


B. Amankelije variabelen onderling: Aspecten van klnntgerichte kwabiteil ondering

\begin{tabular}{|c|c|c|c|c|c|c|c|c|c|c|c|c|c|c|c|c|c|c|c|}
\hline & $a$ & $b$ & c & d & e & $f$ & 8 & \begin{tabular}{|l|} 
\\
\end{tabular} & $i$ & $\mathrm{j}$ & $\mathbf{k}$ & 1 & $\mathbf{m}$ & $n$ & 0 & $p$ & 9 & $\boldsymbol{r}$ & 5 \\
\hline - & $x$ & $\begin{array}{r}.27 \\
.09 \\
(26)\end{array}$ & \begin{tabular}{|r|}
.32 \\
.05 \\
$(28)$ \\
\end{tabular} & $\begin{array}{r}.12 \\
.29 \\
(24) \\
\end{array}$ & $\begin{array}{r}-.09 \\
.35 \\
(20)\end{array}$ & \begin{tabular}{|r|}
-.37 \\
.03 \\
$(28)$ \\
\end{tabular} & $\begin{array}{r}-.02 \\
.46 \\
(21)\end{array}$ & $\begin{array}{r}-.21 \\
.14 \\
(29)\end{array}$ & $\begin{array}{r}.05 \\
.41 \\
(27) \\
\end{array}$ & $\begin{array}{c}.57 \\
.001 \\
(28)\end{array}$ & $\begin{array}{l}.27 \\
.09 \\
(26)\end{array}$ & $\begin{array}{r}.19 \\
.22 \\
(19) \\
\end{array}$ & \begin{tabular}{|r|}
-.01 \\
.49 \\
$(20)$ \\
\end{tabular} & $\begin{array}{r}-.06 \\
.40 \\
(25)\end{array}$ & $\begin{array}{r}.02 \\
.47 \\
(25)\end{array}$ & $\begin{array}{r}-.24 \\
.13 \\
(23)\end{array}$ & $\begin{array}{r}-.04 \\
.42 \\
(23)\end{array}$ & $\begin{array}{r}.13 \\
.27 \\
(24)\end{array}$ & $\begin{array}{r}-10 \\
.31 \\
(25)\end{array}$ \\
\hline b & & $\mathbf{X}$ & $\begin{array}{l}.50 \\
.001 \\
(35) \\
\end{array}$ & $\begin{array}{r}-.01 \\
.48 \\
(30)\end{array}$ & $\begin{array}{r}-.27 \\
.10 \\
(25) \\
\end{array}$ & $\begin{array}{r}-.21 \\
.15 \\
(26) \\
\end{array}$ & $\begin{array}{r}-.24 \\
.12 \\
(26) \\
\end{array}$ & $\begin{array}{r}-.12 \\
.27 \\
(27)\end{array}$ & $\begin{array}{r}.05 \\
.40 \\
(24) \\
\end{array}$ & $\begin{array}{r}.33 \\
.05 \\
(26) \\
\end{array}$ & $\begin{array}{r}.09 \\
.34 \\
(24)\end{array}$ & $\begin{array}{r}.14 \\
.31 \\
(16)\end{array}$ & \begin{tabular}{|r|}
.13 \\
.29 \\
$(22)$ \\
\end{tabular} & $\begin{array}{r}.22 \\
.16 \\
(23) \\
\end{array}$ & $\begin{array}{r}.06 \\
.38 \\
(30)\end{array}$ & $\begin{array}{r}-.10 \\
.33 \\
(21)\end{array}$ & $\begin{array}{r}.03 \\
.45 \\
(27)\end{array}$ & $\begin{array}{r}.04 \\
.43 \\
(22)\end{array}$ & $\begin{array}{r}.08 \\
.34 \\
(30)\end{array}$ \\
\hline c & & & $x$ & $\begin{array}{r}-.11 \\
.27 \\
(32) \\
\end{array}$ & $\begin{array}{r}-.33 \\
.05 \\
(27) \\
\end{array}$ & $\begin{array}{r}-.33 \\
.04 \\
(28) \\
\end{array}$ & $\begin{array}{r}-.05 \\
.41 \\
(28) \\
\end{array}$ & $\begin{array}{r}-.32 \\
.05 \\
(29)\end{array}$ & $\begin{array}{r}-.06 \\
.38 \\
(26) \\
\end{array}$ & $\begin{array}{r}.24 \\
.11 \\
(28) \\
\end{array}$ & $\begin{array}{r}.22 \\
.14 \\
(26) \\
\end{array}$ & $\begin{array}{r}-.13 \\
.31 \\
(18) \\
\end{array}$ & \begin{tabular}{|l|}
-.01 \\
.48 \\
$(24)$ \\
\end{tabular} & \begin{tabular}{|r}
.08 \\
.35 \\
$(25)$ \\
\end{tabular} & $\begin{array}{r}.03 \\
.43 \\
(32) \\
\end{array}$ & $\begin{array}{r}-.19 \\
.20 \\
(23)\end{array}$ & $\begin{array}{r}-.09 \\
.32 \\
(29)\end{array}$ & $\begin{array}{r}-.09 \\
.34 \\
(24)\end{array}$ & $\begin{array}{r}.28 \\
.06 \\
(32) \\
\end{array}$ \\
\hline d & & & & $X$ & $\begin{array}{r}.20 \\
.15 \\
(29) \\
\end{array}$ & $\begin{array}{r}.00 \\
.49 \\
(24) \\
\end{array}$ & $\begin{array}{r}-.19 \\
.16 \\
(29)\end{array}$ & $\begin{array}{r}.15 \\
.24 \\
(25)\end{array}$ & $\begin{array}{r}.43 \\
.02 \\
(22)\end{array}$ & $\begin{array}{r}.47 \\
.01 \\
(24)\end{array}$ & \begin{tabular}{|r|}
.06 \\
.38 \\
$(23)$ \\
\end{tabular} & $\begin{array}{r}.38 \\
.06 \\
(18)\end{array}$ & $\begin{array}{r}.23 \\
.14 \\
(24)\end{array}$ & $\begin{array}{r}.28 \\
.10 \\
(24) \\
\end{array}$ & $\begin{array}{r}.29 \\
.06 \\
(31)\end{array}$ & $\begin{array}{r}.12 \\
.30 \\
(22)\end{array}$ & $\begin{array}{r}.16 \\
.21 \\
(28)\end{array}$ & $\begin{array}{r}.24 \\
.14 \\
(23)\end{array}$ & $\begin{array}{r}.12 \\
.26 \\
(31)\end{array}$ \\
\hline 0 & & & & & $x$ & \begin{tabular}{|r|}
.07 \\
.39 \\
$(20)$ \\
\end{tabular} & $\begin{array}{r}.08 \\
.36 \\
(25)\end{array}$ & $\begin{array}{r}.17 \\
.23 \\
(21)\end{array}$ & $\begin{array}{r}.38 \\
.06 \\
(18)\end{array}$ & $\begin{array}{r}.06 \\
.40 \\
(20)\end{array}$ & $\begin{array}{r}.46 \\
.03 \\
(19) \\
\end{array}$ & $\begin{array}{r}.35 \\
.09 \\
(16)\end{array}$ & \begin{tabular}{|r|}
.19 \\
.21 \\
$(21)$ \\
\end{tabular} & $\begin{array}{r}-.03 \\
.46 \\
(20)\end{array}$ & $\begin{array}{r}-.16 \\
.22 \\
(26)\end{array}$ & $\begin{array}{r}-.15 \\
.28 \\
(18)\end{array}$ & $\begin{array}{r}-.03 \\
.45 \\
(23)\end{array}$ & $\begin{array}{r}-.06 \\
.40 \\
(19)\end{array}$ & $\begin{array}{r}-.18 \\
.19 \\
(26)\end{array}$ \\
\hline$f$ & & & & & & 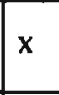 & $\begin{array}{r}.38 \\
.05 \\
(21) \\
\end{array}$ & $\begin{array}{r}.11 \\
.29 \\
(29)\end{array}$ & $\begin{array}{r}.06 \\
.39 \\
(26)\end{array}$ & $\begin{array}{r}-.43 \\
.01 \\
(28)\end{array}$ & $\begin{array}{r}-.13 \\
.27 \\
(26) \\
\end{array}$ & $\begin{array}{r}.09 \\
.36 \\
(18) \\
\end{array}$ & \begin{tabular}{|r|}
.11 \\
.33 \\
$(19)$ \\
\end{tabular} & $\begin{array}{r}.30 \\
.07 \\
(25) \\
\end{array}$ & $\begin{array}{r}.29 \\
.08 \\
(25)\end{array}$ & $\begin{array}{r}.43 \\
.02 \\
(23)\end{array}$ & $\begin{array}{r}.05 \\
.42 \\
(23)\end{array}$ & $\begin{array}{r}.03 \\
.44 \\
(24)\end{array}$ & $\begin{array}{r}-.01 \\
.48 \\
(25) \\
\end{array}$ \\
\hline 8 & & & & & & & $x$ & $\begin{array}{r}.03 \\
.44 \\
(22) \\
\end{array}$ & $\begin{array}{r}.08 \\
.37 \\
(19) \\
\end{array}$ & $\begin{array}{r}-.10 \\
.33 \\
(21) \\
\end{array}$ & $\begin{array}{r}-.00 \\
.50 \\
(20) \\
\end{array}$ & $\begin{array}{r}.30 \\
.14 \\
(15) \\
\end{array}$ & \begin{tabular}{|l|}
.46 \\
.02 \\
$(20)$ \\
\end{tabular} & $\begin{array}{r}-.20 \\
.19 \\
(21) \\
\end{array}$ & $\begin{array}{r}.09 \\
.32 \\
(27) \\
\end{array}$ & $\begin{array}{r}.05 \\
.42 \\
(20) \\
\end{array}$ & $\begin{array}{r}-19 \\
.19 \\
(25) \\
\end{array}$ & $\begin{array}{r}-.34 \\
.07 \\
(20) \\
\end{array}$ & $\begin{array}{r}-.12 \\
.27 \\
(27) \\
\end{array}$ \\
\hline h & & & & & & & & $x$ & $\begin{array}{l}.11 \\
.29 \\
(27)\end{array}$ & $\begin{array}{r}-.07 \\
.37 \\
(29)\end{array}$ & $\begin{array}{r}-.24 \\
.11 \\
(27) \\
\end{array}$ & $\begin{array}{r}-.24 \\
.16 \\
(19)\end{array}$ & $\begin{array}{r}-.13 \\
.30 \\
(20) \\
\end{array}$ & $\begin{array}{r}.09 \\
.33 \\
(26) \\
\end{array}$ & $\begin{array}{r}.23 \\
.13 \\
(26)\end{array}$ & $\begin{array}{r}.29 \\
.09 \\
(24)\end{array}$ & $\begin{array}{r}.35 \\
.05 \\
(24)\end{array}$ & $\begin{array}{r}.24 \\
.12 \\
(25)\end{array}$ & $\begin{array}{r}.05 \\
.40 \\
(26) \\
\end{array}$ \\
\hline 1 & & & & & & & & & $X$ & $\begin{array}{r}.14 \\
.24 \\
(27) \\
\end{array}$ & \begin{tabular}{|c|}
.19 \\
.006 \\
$(25)$ \\
\end{tabular} & $\begin{array}{r}.05 \\
.43 \\
(17) \\
\end{array}$ & $\begin{array}{r}.11 \\
.33 \\
(18) \\
\end{array}$ & $\begin{array}{r}.26 \\
.11 \\
(23) \\
\end{array}$ & $\begin{array}{r}.15 \\
.25 \\
(23) \\
\end{array}$ & $\begin{array}{r}.32 \\
.08 \\
(21) \\
\end{array}$ & $\begin{array}{r}.28 \\
.11 \\
(21) \\
\end{array}$ & $\begin{array}{r}.04 \\
.42 \\
(23) \\
\end{array}$ & $\begin{array}{r}. .44 \\
.02 \\
(23) \\
\end{array}$ \\
\hline j & & & & & & & & & & $\mathbf{X}$ & $\begin{array}{r}-.03 \\
.45 \\
(27) \\
\end{array}$ & $\begin{array}{r}.45 \\
.03 \\
(18) \\
\end{array}$ & \begin{tabular}{|l|}
.46 \\
.02 \\
$(19)$ \\
\end{tabular} & $\begin{array}{r}.00 \\
.50 \\
(25)\end{array}$ & $\begin{array}{r}.36 \\
.04 \\
(25)\end{array}$ & $\begin{array}{r}. .07 \\
.38 \\
(23)\end{array}$ & $\begin{array}{r}-.16 \\
.24 \\
(23)\end{array}$ & $\begin{array}{r}.31 \\
.07 \\
(24)\end{array}$ & $\begin{array}{r}.11 \\
30 \\
(25)\end{array}$ \\
\hline $\mathbf{k}$ & & & & & & & & & & & $x$ & $\begin{array}{r}. .31 \\
.11 \\
(17)\end{array}$ & $\begin{array}{r}-.40 \\
.05 \\
(18)\end{array}$ & $\begin{array}{r}-.15 \\
.25 \\
(24)\end{array}$ & $\begin{array}{r}-.27 \\
.10 \\
(24)\end{array}$ & $\begin{array}{r}.13 \\
.28 \\
(22)\end{array}$ & $\begin{array}{r}.19 \\
.19 \\
(22)\end{array}$ & $\begin{array}{r}.12 \\
.30 \\
(23)\end{array}$ & $\begin{array}{r}.04 \\
.43 \\
(24)\end{array}$ \\
\hline I & & & & & & & & & & & & $\mathbf{X}$ & $\begin{array}{l}.69 \\
.001 \\
(19) \\
\end{array}$ & $\begin{array}{r}.28 \\
.13 \\
(19) \\
\end{array}$ & $\begin{array}{r}.43 \\
.03 \\
(19)\end{array}$ & $\begin{array}{r}.04 \\
.43 \\
(19)\end{array}$ & $\begin{array}{r}-.28 \\
.13 \\
(19)\end{array}$ & $\begin{array}{r}-.00 \\
.50 \\
(18)\end{array}$ & $\begin{array}{r}.02 \\
46 \\
(19)\end{array}$ \\
\hline m & & & & & & & & & & & & & $\mathbf{X}$ & $\begin{array}{r}.21 \\
.19 \\
(20) \\
\end{array}$ & $\begin{array}{r}.39 \\
.03 \\
(25)\end{array}$ & $\begin{array}{r}-.11 \\
33 \\
(19) \\
\end{array}$ & $\begin{array}{r}-.24 \\
.13 \\
(24)\end{array}$ & $\begin{array}{r}-.08 \\
.37 \\
(19)\end{array}$ & $\begin{array}{r}.18 \\
.20 \\
(25) \\
\end{array}$ \\
\hline n & & & & & & & & & & & & & & $X$ & $\begin{array}{c}.60 \\
.001 \\
(26)\end{array}$ & $\begin{array}{r}-.00 \\
.50 \\
(24)\end{array}$ & $\begin{array}{r}-.12 \\
.29 \\
(24)\end{array}$ & $\begin{array}{r}-.17 \\
.21 \\
(25)\end{array}$ & $\begin{array}{r}-.05 \\
.41 \\
(26)\end{array}$ \\
\hline 0 & & & & & & & & & & & & & & & $x$ & $\begin{array}{r}.22 \\
.16 \\
(24) \\
\end{array}$ & $\begin{array}{r}-.06 \\
.37 \\
(30)\end{array}$ & $\begin{array}{r}.31 \\
.07 \\
(25)\end{array}$ & $\begin{array}{r}.09 \\
.31 \\
(33) \\
\end{array}$ \\
\hline P & & & & & & & & & & & & & & & & $x$ & $\begin{array}{c}.58 \\
.002 \\
(24)\end{array}$ & $\begin{array}{r}.05 \\
.40 \\
(23)\end{array}$ & $\begin{array}{r}-.06 \\
.38 \\
(24)\end{array}$ \\
\hline 9 & & & & & & & & & & & & & & & & & $\mathbf{X}$ & $\begin{array}{r}11 \\
30 \\
(23)\end{array}$ & $\begin{array}{l}-.04 \\
.41 \\
(30)\end{array}$ \\
\hline $\mathbf{r}$ & & & & & & & & & & & & & & & & & & $x$ & $\begin{array}{l}43 \\
.02 \\
(25)\end{array}$ \\
\hline
\end{tabular}


$1=$ registratic periodiek onderzock

$2=$ regintmatie werkplekonderzock

3 = in gelijke mute rapporteren ans de directie/ondernemingerand

$4=$ ongevrangd edviveren

$3=$ ingeschakeld bij agemeen beleid

$6=$ extra activiteiten

7 = bruikhen sdvisa voor peranoel soukea

8 = bruikher actviea voor ondernemingsraed

9 - professionele vitvoering anntellingsonderzock

$10=$ professionele uitvoering upreckuur

11 - professionele vitvoering periodick onderzoek

12 = professionele uitvoering werkplekonderzoek

13 = rendemeat untellingronderzoek

14 = rendement epreckuur

15 = rendemeal periodiek onderzock

16 = rendement werkplekonderzock

- = Eeun BGD voor oodernemingeraed

$b=$ steuin BCD voor personeelwaken

$c=$ klantvriendelijke houding BGD

$\mathrm{d}=$ ervaring mel uitvoering aunstellingsonderzock

$e=$ ervaring mat uitvoering periodick onderzock

$f=$ ondernemiagarand ervanit verzuimbegeleiding BCD als controle

$g=$ werknemeri ervaren verzuimbegeleiding BGD ds controte

$\mathbf{h}=$ BGD anderneemt volgens ondernemingsrand voldoencke extra activiteiten

i= samenvwerking BGD-directie

j= lamenwerking BCD-ondermemingaraed

$\mathrm{k}=$ emenwerking BGD-personcelszuken

I = uitvoering anallingsonderzock nar wens ondernemingerued

$m=$ vitvoering aandell ingsonderzock naur wens werknemers

$\mathrm{n}=$ uitvoering eprockuur naar wens ondememingarand

$O=$ uitvoering apreckuur naw wens werknemers

$p=$ uitvoering periodick onderzock nasu wens ondernemingarand

$q=$ vitvoering periodick onderzoek naur wens werknemers

p= uitvoering werkplekonderzock nan wens onderneminguraed

I= uitvoering werkplekonderzock naer wens werknemers 
B. Amankelike variabelen: Profestonele versus klantgerichte aspecten.

\begin{tabular}{|c|c|c|c|c|c|c|c|c|c|c|c|c|c|c|c|c|}
\hline & 1 & 2 & 3 & 4 & 5 & 6 & 7 & 8 & 9 & 10 & 11 & 12 & 13 & 14 & 15 & 16 \\
\hline $\bar{a}$ & $\begin{array}{r}.34 \\
.06 \\
(23)\end{array}$ & $\begin{array}{r}36 \\
.04 \\
(24)\end{array}$ & $\begin{array}{r}.27 \\
.10 \\
(25) \\
\end{array}$ & $\begin{array}{r}.35 \\
.04 \\
(27)\end{array}$ & $\begin{array}{c}.57 \\
.001 \\
(27)\end{array}$ & $\begin{array}{c}.64 \\
.001 \\
(21)\end{array}$ & $\begin{array}{r}.05 \\
.40 \\
(26)\end{array}$ & $\begin{array}{c}.71 \\
.000 \\
(23)\end{array}$ & $\begin{array}{r}.02 \\
.47 \\
(20)\end{array}$ & $\begin{array}{r}.05 \\
.41 \\
(25) \\
\end{array}$ & $\begin{array}{r}. .33 \\
.06 \\
(23)\end{array}$ & \begin{tabular}{|r|}
.30 \\
.08 \\
$(25)$ \\
\end{tabular} & $\begin{array}{r}-.12 \\
.26 \\
(29) \\
\end{array}$ & $\begin{array}{r}.38 \\
.02 \\
(29) \\
\end{array}$ & $\begin{array}{c}.61 \\
.000 \\
(29)\end{array}$ & $\begin{array}{c}.57 \\
.001 \\
(29)\end{array}$ \\
\hline b & $\begin{array}{r}-.08 \\
.35 \\
(28)\end{array}$ & $\begin{array}{r}.17 \\
.20 \\
(28)\end{array}$ & $\begin{array}{l}-.23 \\
.11 \\
(30)\end{array}$ & $\begin{array}{r}.16 \\
.18 \\
(34)\end{array}$ & \begin{tabular}{|r}
.08 \\
.32 \\
$(34)$
\end{tabular} & $\begin{array}{r}.21 \\
.18 \\
(21)\end{array}$ & $\begin{array}{l}-.68 \\
.000 \\
(35)\end{array}$ & $\begin{array}{r}.26 \\
14 \\
(20)\end{array}$ & $\begin{array}{r}-.30 \\
.09 \\
(22)\end{array}$ & $\begin{array}{r}.05 \\
.41 \\
(30)\end{array}$ & $\begin{array}{r}-.07 \\
.36 \\
(27) \\
\end{array}$ & \begin{tabular}{|r|}
-.02 \\
.47 \\
$(30)$
\end{tabular} & \begin{tabular}{|r}
-.24 \\
.11 \\
$(27)$
\end{tabular} & \begin{tabular}{|r|}
.30 \\
.07 \\
$(27)$
\end{tabular} & $\begin{array}{r}.17 \\
.20 \\
(27)\end{array}$ & $\begin{array}{r}.05 \\
.41 \\
(27)\end{array}$ \\
\hline c & $\begin{array}{r}.16 \\
.19 \\
(30)\end{array}$ & $\begin{array}{r}.15 \\
.21 \\
(30)\end{array}$ & $\begin{array}{r}. .16 \\
.20 \\
(32)\end{array}$ & $\begin{array}{r}.36 \\
.02 \\
(36)\end{array}$ & $\begin{array}{r}18 \\
.15 \\
(36) \\
\end{array}$ & $\begin{array}{r}.17 \\
.22 \\
(22)\end{array}$ & $\begin{array}{r}-.26 \\
.07 \\
(35)\end{array}$ & $\begin{array}{r}.07 \\
.39 \\
(22)\end{array}$ & $\begin{array}{r}-.07 \\
.38 \\
(24)\end{array}$ & $\begin{array}{r}.04 \\
.42 \\
(32)\end{array}$ & $\begin{array}{r}.11 \\
.28 \\
(29)\end{array}$ & \begin{tabular}{|r}
.14 \\
.22 \\
$(32)$
\end{tabular} & $\begin{array}{r}-.13 \\
.25 \\
(29)\end{array}$ & $\begin{array}{r}.33 \\
.04 \\
(29)\end{array}$ & $\begin{array}{r}.02 \\
.45 \\
(29)\end{array}$ & $\begin{array}{r}.01 \\
.47 \\
(29)\end{array}$ \\
\hline $\bar{d}$ & $\begin{array}{r}.15 \\
.22 \\
(29)\end{array}$ & $\begin{array}{r}.31 \\
.05 \\
(29)\end{array}$ & $\begin{array}{l}.12 \\
.26 \\
(31)\end{array}$ & $\begin{array}{r}.00 \\
.50 \\
(31)\end{array}$ & $\begin{array}{r}.17 \\
.18 \\
(31)\end{array}$ & $\begin{array}{r}.32 \\
.09 \\
(19)\end{array}$ & $\begin{array}{r}.26 \\
.09 \\
(30)\end{array}$ & $\begin{array}{r}.08 \\
.37 \\
(19)\end{array}$ & $\begin{array}{r}.03 \\
.44 \\
(24)\end{array}$ & $\begin{array}{r}16 \\
.19 \\
(31)\end{array}$ & $\begin{array}{r}.13 \\
.25 \\
(28)\end{array}$ & \begin{tabular}{|r|}
.36 \\
.02 \\
$(31)$
\end{tabular} & $\begin{array}{r}-.19 \\
.19 \\
(25)\end{array}$ & $\begin{array}{r}.09 \\
.33 \\
(25)\end{array}$ & $\begin{array}{r}-.02 \\
.46 \\
(25)\end{array}$ & $\begin{array}{r}.19 \\
.18 \\
(25)\end{array}$ \\
\hline $\bar{c}$ & $\begin{array}{r}. .24 \\
.12 \\
(25)\end{array}$ & $\begin{array}{r}27 \\
10 \\
(24)\end{array}$ & $\begin{array}{r}.12 \\
.29 \\
(26)\end{array}$ & $\begin{array}{r}-.28 \\
.09 \\
(26)\end{array}$ & $\begin{array}{r}-16 \\
.22 \\
(26)\end{array}$ & $\begin{array}{r}-.09 \\
.37 \\
(16)\end{array}$ & $\begin{array}{r}.27 \\
.09 \\
(25)\end{array}$ & $\begin{array}{r}.06 \\
.41 \\
(15)\end{array}$ & $\begin{array}{r}.14 \\
.27 \\
(21)\end{array}$ & $\begin{array}{r}-.01 \\
.48 \\
(26)\end{array}$ & $\begin{array}{r}-.23 \\
.13 \\
(23) \\
\end{array}$ & $\begin{array}{r}-.18 \\
.19 \\
(26)\end{array}$ & $\begin{array}{r}.05 \\
.41 \\
(21)\end{array}$ & $\begin{array}{r}-.23 \\
.16 \\
(21)\end{array}$ & $\begin{array}{r}.09 \\
.35 \\
(21)\end{array}$ & $\begin{array}{r}.04 \\
.43 \\
(21)\end{array}$ \\
\hline$f$ & $\begin{array}{r}.16 \\
.23 \\
(23)\end{array}$ & $\begin{array}{r}-.26 \\
.11 \\
(24)\end{array}$ & $\begin{array}{r}.06 \\
.40 \\
(25) \\
\end{array}$ & $\begin{array}{r}.04 \\
.43 \\
(27)\end{array}$ & $\begin{array}{r}.10 \\
32 \\
(27)\end{array}$ & $\begin{array}{r}.16 \\
.24 \\
(21)\end{array}$ & $\begin{array}{r}.15 \\
.23 \\
(26)\end{array}$ & $\begin{array}{r}. .41 \\
.03 \\
(22)\end{array}$ & $\begin{array}{r}-.05 \\
.42 \\
(19)\end{array}$ & $\begin{array}{r}-.33 \\
.05 \\
(25)\end{array}$ & $\begin{array}{r}.21 \\
.17 \\
(23)\end{array}$ & \begin{tabular}{|r}
.06 \\
.39 \\
$(25)$
\end{tabular} & $\begin{array}{r}-.15 \\
.21 \\
(29)\end{array}$ & $\begin{array}{r}-.22 \\
.13 \\
(29)\end{array}$ & $\begin{array}{r}-.26 \\
.09 \\
(29)\end{array}$ & $\begin{array}{r}-.10 \\
.31 \\
(29)\end{array}$ \\
\hline $\mathbf{8}$ & $\begin{array}{r}.19 \\
.18 \\
(25) \\
\end{array}$ & $\begin{array}{r}.02 \\
.46 \\
(25) \\
\end{array}$ & $\begin{array}{r}.24 \\
.12 \\
(27) \\
\end{array}$ & $\begin{array}{r}.36 \\
.03 \\
(27) \\
\end{array}$ & $\begin{array}{r}.43 \\
.01 \\
(27) \\
\end{array}$ & $\begin{array}{r}-.09 \\
.38 \\
(16) \\
\end{array}$ & $\begin{array}{r}-.09 \\
.34 \\
(26)\end{array}$ & $\begin{array}{r}-.28 \\
.13 \\
(18) \\
\end{array}$ & $\begin{array}{r}-.36 \\
.06 \\
(20) \\
\end{array}$ & $\begin{array}{r}-.14 \\
.25 \\
(27) \\
\end{array}$ & $\begin{array}{r}-.02 \\
.46 \\
(25) \\
\end{array}$ & $\begin{array}{r}-.01 \\
.48 \\
(27) \\
\end{array}$ & \begin{tabular}{|r|}
20 \\
.19 \\
$(22)$ \\
\end{tabular} & $\begin{array}{r}.07 \\
.38 \\
(22) \\
\end{array}$ & $\begin{array}{r}-.01 \\
.48 \\
(22)\end{array}$ & $\begin{array}{r}.08 \\
.36 \\
(22) \\
\end{array}$ \\
\hline h & $\begin{array}{r}.08 \\
.35 \\
(24) \\
\end{array}$ & $\begin{array}{r}.19 \\
.18 \\
(25) \\
\end{array}$ & $\begin{array}{r}-.21 \\
.15 \\
(26) \\
\end{array}$ & $\begin{array}{r}-12 \\
.27 \\
(28) \\
\end{array}$ & $\begin{array}{r}.28 \\
.07 \\
(28) \\
\end{array}$ & $\begin{array}{r}.04 \\
.42 \\
(22) \\
\end{array}$ & $\begin{array}{r}-.06 \\
.39 \\
(27) \\
\end{array}$ & $\begin{array}{r}.31 \\
.08 \\
(23) \\
\end{array}$ & $\begin{array}{r}.17 \\
.24 \\
(20) \\
\end{array}$ & $\begin{array}{r}-.12 \\
.27 \\
(26) \\
\end{array}$ & $\begin{array}{l}.50 \\
.007 \\
(24) \\
\end{array}$ & $\begin{array}{r}.27 \\
.09 \\
(26) \\
\end{array}$ & $\begin{array}{r}.28 \\
.07 \\
(30) \\
\end{array}$ & \begin{tabular}{|r|}
.10 \\
.30 \\
$(30)$ \\
\end{tabular} & $\begin{array}{r}.19 \\
.15 \\
(30)\end{array}$ & $\begin{array}{l}.32 \\
.04 \\
(30)\end{array}$ \\
\hline $\bar{i}$ & $\begin{array}{r}.04 \\
14 \\
(21) \\
\end{array}$ & $\begin{array}{r}.00 \\
49 \\
(22) \\
\end{array}$ & $\begin{array}{r}.03 \\
.45 \\
(23) \\
\end{array}$ & $\begin{array}{r}-.03 \\
43 \\
(26) \\
\end{array}$ & $\begin{array}{r}-19 \\
.18 \\
(25) \\
\end{array}$ & $\begin{array}{r}.30 \\
.10 \\
(20)\end{array}$ & $\begin{array}{r}-.19 \\
.18 \\
(24)\end{array}$ & $\begin{array}{r}.21 \\
.17 \\
(22) \\
\end{array}$ & $\begin{array}{r}.15 \\
.27 \\
(18) \\
\end{array}$ & $\begin{array}{r}.03 \\
.45 \\
(23) \\
\end{array}$ & $\begin{array}{l}.29 \\
.11 \\
(21) \\
\end{array}$ & $\begin{array}{r}.10 \\
.33 \\
(23) \\
\end{array}$ & $\begin{array}{r}-18 \\
.18 \\
(27) \\
\end{array}$ & $\begin{array}{r}.00 \\
.49 \\
(27) \\
\end{array}$ & $\begin{array}{r}.04 \\
.42 \\
(27)\end{array}$ & $\begin{array}{r}-.03 \\
.45 \\
(27)\end{array}$ \\
\hline 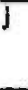 & $\begin{array}{r}12 \\
30 \\
(23)\end{array}$ & $\begin{array}{r}.28 \\
.05 \\
(24)\end{array}$ & $\begin{array}{r}.18 \\
20 \\
(25)\end{array}$ & $\begin{array}{r}.23 \\
.12 \\
(27)\end{array}$ & $\begin{array}{r}.17 \\
.20 \\
(27)\end{array}$ & $\begin{array}{c}.68 \\
.000 \\
(21)\end{array}$ & $\begin{array}{r}.03 \\
.45 \\
(26)\end{array}$ & $\begin{array}{r}.40 \\
.03 \\
(22)\end{array}$ & $\begin{array}{r}.15 \\
.27 \\
(19)\end{array}$ & $\begin{array}{r}-.10 \\
.32 \\
(25)\end{array}$ & $\begin{array}{r}.14 \\
.26 \\
(23)\end{array}$ & $\begin{array}{r}.43 \\
.02 \\
(25)\end{array}$ & $\begin{array}{r}.04 \\
.41 \\
(29)\end{array}$ & $\begin{array}{r}.36 \\
.03 \\
(29)\end{array}$ & $\begin{array}{r}43 \\
.01 \\
(29)\end{array}$ & $\begin{array}{l}.47 \\
.005 \\
(29)\end{array}$ \\
\hline$k$ & $\begin{array}{r}.33 \\
.07 \\
(22) \\
\end{array}$ & $\begin{array}{r}.22 \\
.16 \\
(23)\end{array}$ & $\begin{array}{r}.38 \\
.04 \\
(24)\end{array}$ & $\begin{array}{r}.07 \\
.36 \\
(25)\end{array}$ & $\begin{array}{r}-.08 \\
.35 \\
(25)\end{array}$ & $\begin{array}{r}.34 \\
.07 \\
(20)\end{array}$ & $\begin{array}{r}.29 \\
.09 \\
(24)\end{array}$ & $\begin{array}{r}12 \\
30 \\
(20) \\
\end{array}$ & $\begin{array}{r}.03 \\
.45 \\
(18)\end{array}$ & $\begin{array}{r}.38 \\
.04 \\
(24)\end{array}$ & $\begin{array}{r}-.22 \\
.17 \\
(22)\end{array}$ & $\begin{array}{r}-.03 \\
.44 \\
(24)\end{array}$ & $\begin{array}{r}-13 \\
.26 \\
(27) \\
\end{array}$ & $\begin{array}{r}.11 \\
.29 \\
(27) \\
\end{array}$ & $\begin{array}{r}.13 \\
.26 \\
(27)\end{array}$ & $\begin{array}{r}.03 \\
.44 \\
(27)\end{array}$ \\
\hline 1 & $\begin{array}{r}.53 \\
.02 \\
(17)\end{array}$ & $\begin{array}{r}.08 \\
38 \\
(18) \\
\end{array}$ & $\begin{array}{r}.32 \\
.09 \\
(19)\end{array}$ & $\begin{array}{r}16 \\
.28 \\
(17)\end{array}$ & $\begin{array}{r}.40 \\
.05 \\
(18)\end{array}$ & $\begin{array}{r}.12 \\
33 \\
(15)\end{array}$ & $\begin{array}{r}.15 \\
.30 \\
(16)\end{array}$ & $\begin{array}{l}.30 \\
.15 \\
(14)\end{array}$ & $\begin{array}{r}.20 \\
20 \\
(19)\end{array}$ & $\begin{array}{r}.04 \\
43 \\
(19)\end{array}$ & $\begin{array}{r}.13 \\
.29 \\
(19)\end{array}$ & $\begin{array}{r}.14 \\
.28 \\
(19) \\
\end{array}$ & $\begin{array}{r}.19 \\
.21 \\
(19)\end{array}$ & \begin{tabular}{|r|}
.00 \\
.50 \\
$(19)$ \\
\end{tabular} & $\begin{array}{r}14 \\
.29 \\
(19)\end{array}$ & $\begin{array}{r}16 \\
25 \\
(19) \\
\end{array}$ \\
\hline $\mathrm{m}$ & $\begin{array}{r}.01 \\
.49 \\
(23)\end{array}$ & $\begin{array}{r}11 \\
32 \\
(23) \\
\end{array}$ & $\begin{array}{r}-.34 \\
.05 \\
(23) \\
\end{array}$ & $\begin{array}{r}.14 \\
.26 \\
(23) \\
\end{array}$ & $\begin{array}{r}.19 \\
.20 \\
(23) \\
\end{array}$ & $\begin{array}{r}.34 \\
.11 \\
(15) \\
\end{array}$ & $\begin{array}{r}.04 \\
.43 \\
(22)\end{array}$ & $\begin{array}{r}.19 \\
.24 \\
(15) \\
\end{array}$ & $\begin{array}{r}-32 \\
.06 \\
(25)\end{array}$ & $\begin{array}{l}-.33 \\
.05 \\
(25) \\
\end{array}$ & $\begin{array}{r}.17 \\
.22 \\
(24) \\
\end{array}$ & $\begin{array}{r}.08 \\
.35 \\
(25) \\
\end{array}$ & $\begin{array}{r}.13 \\
.29 \\
(20) \\
\end{array}$ & $\begin{array}{r}-.21 \\
.18 \\
(20) \\
\end{array}$ & $\begin{array}{r}15 \\
.26 \\
(20)\end{array}$ & $\begin{array}{r}.18 \\
.22 \\
(20) \\
\end{array}$ \\
\hline $\bar{n}$ & $\begin{array}{r}.15 \\
.24 \\
(24) \\
\end{array}$ & $\begin{array}{r}-14 \\
.25 \\
(25)\end{array}$ & $\begin{array}{r}-.12 \\
.28 \\
(26) \\
\end{array}$ & $\begin{array}{r}.28 \\
.09 \\
(24) \\
\end{array}$ & $\begin{array}{r}.22 \\
.15 \\
(24) \\
\end{array}$ & $\begin{array}{r}13 \\
.29 \\
(30) \\
\end{array}$ & $\begin{array}{r}.24 \\
.13 \\
(23) \\
\end{array}$ & $\begin{array}{r}.08 \\
37 \\
(19) \\
\end{array}$ & $\begin{array}{r}.10 \\
34 \\
(19) \\
\end{array}$ & $\begin{array}{l}. .49 \\
.006 \\
(26) \\
\end{array}$ & $\begin{array}{r}.17 \\
.22 \\
(24) \\
\end{array}$ & $\begin{array}{r}.01 \\
.48 \\
(26) \\
\end{array}$ & $\begin{array}{r}-.21 \\
.15 \\
(26) \\
\end{array}$ & $\begin{array}{r}-.01 \\
.48 \\
(26) \\
\end{array}$ & $\begin{array}{r}.09 \\
.32 \\
(26) \\
\end{array}$ & $\begin{array}{r}.01 \\
.48 \\
(26) \\
\end{array}$ \\
\hline 0 & $\begin{array}{r}.14 \\
.23 \\
(31) \\
\end{array}$ & $\begin{array}{r}.18 \\
.17 \\
(31) \\
\end{array}$ & $\begin{array}{r}.04 \\
.42 \\
(33) \\
\end{array}$ & $\begin{array}{r}-15 \\
22 \\
(31)\end{array}$ & $\begin{array}{r}.36 \\
.02 \\
(31) \\
\end{array}$ & $\begin{array}{r}35 \\
.06 \\
(20) \\
\end{array}$ & $\begin{array}{r}-.01 \\
.47 \\
(30)\end{array}$ & $\begin{array}{r}.04 \\
.44 \\
(19)\end{array}$ & $\begin{array}{r}.05 \\
.41 \\
(25)\end{array}$ & $\begin{array}{r}-.16 \\
.19 \\
(33)\end{array}$ & $\begin{array}{r}.34 \\
.03 \\
(30) \\
\end{array}$ & $\begin{array}{r}.11 \\
.27 \\
(33)\end{array}$ & $\begin{array}{r}.11 \\
.30 \\
(26) \\
\end{array}$ & $\begin{array}{r}.05 \\
.40 \\
(26) \\
\end{array}$ & $\begin{array}{r}.26 \\
.10 \\
(26)\end{array}$ & $\begin{array}{r}27 \\
.10 \\
(26)\end{array}$ \\
\hline p & $\begin{array}{r}-.09 \\
.35 \\
(22) \\
\end{array}$ & $\begin{array}{r}-39 \\
.04 \\
23) \\
\end{array}$ & $\begin{array}{r}-.27 \\
.10 \\
(24) \\
\end{array}$ & $\begin{array}{r}-11 \\
32 \\
(22) \\
\end{array}$ & $\begin{array}{r}-.29 \\
.09 \\
(23) \\
\end{array}$ & $\begin{array}{r}.28 \\
12 \\
(19)\end{array}$ & $\begin{array}{r}.10 \\
.33 \\
(21) \\
\end{array}$ & $\begin{array}{r}-12 \\
32 \\
(18) \\
\end{array}$ & $\begin{array}{r}.16 \\
26 \\
(19) \\
\end{array}$ & $\begin{array}{r}-.01 \\
.49 \\
(24)\end{array}$ & $\begin{array}{c}50 \\
.006 \\
(24) \\
\end{array}$ & $\begin{array}{r}04 \\
43 \\
(24) \\
\end{array}$ & $\begin{array}{r}.25 \\
.12 \\
(24) \\
\end{array}$ & $\begin{array}{r}.05 \\
.40 \\
(24) \\
\end{array}$ & $\begin{array}{r}-.20 \\
.17 \\
(24)\end{array}$ & $\begin{array}{r}03 \\
.45 \\
(24) \\
\end{array}$ \\
\hline 9 & $\begin{array}{r}. .02 \\
.46 \\
(28) \\
\end{array}$ & $\begin{array}{r}.03 \\
.45 \\
(28) \\
\end{array}$ & $\begin{array}{r}.17 \\
.19 \\
(30) \\
\end{array}$ & $\begin{array}{r}.01 \\
.48 \\
(28) \\
\end{array}$ & $\begin{array}{r}-.24 \\
.11 \\
(29) \\
\end{array}$ & $\begin{array}{r}43 \\
03 \\
(19) \\
\end{array}$ & $\begin{array}{r}-24 \\
.11 \\
(27) \\
\end{array}$ & $\begin{array}{r}.28 \\
13 \\
(18) \\
\end{array}$ & $\begin{array}{r}.03 \\
44 \\
(24) \\
\end{array}$ & $\begin{array}{r}.05 \\
.41 \\
(30) \\
\end{array}$ & $\begin{array}{r}.37 \\
.02 \\
(30) \\
\end{array}$ & $\begin{array}{r}.24 \\
10 \\
(30) \\
\end{array}$ & $\begin{array}{r}.21 \\
16 \\
(24) \\
\end{array}$ & $\begin{array}{r}.23 \\
.14 \\
(24) \\
\end{array}$ & $\begin{array}{r}.14 \\
.26 \\
(24)\end{array}$ & $\begin{array}{r}.06 \\
.39 \\
(24) \\
\end{array}$ \\
\hline $\mathbf{r}$ & $\begin{array}{r}10 \\
.32 \\
(23) \\
\end{array}$ & $\begin{array}{r}.30 \\
.08 \\
(24) \\
\end{array}$ & $\begin{array}{l}.49 \\
.007 \\
(25)\end{array}$ & $\begin{array}{r}19 \\
.19 \\
(24) \\
\end{array}$ & $\begin{array}{r}-07 \\
.38 \\
(33) \\
\end{array}$ & $\begin{array}{r}03 \\
45 \\
(30) \\
\end{array}$ & $\begin{array}{r}.02 \\
.47 \\
(22) \\
\end{array}$ & $\begin{array}{r}.02 \\
46 \\
(19) \\
\end{array}$ & $\begin{array}{r}.00 \\
.50 \\
(19)\end{array}$ & $\begin{array}{r}.19 \\
18 \\
(25) \\
\end{array}$ & $\begin{array}{r}.26 \\
12 \\
(23) \\
\end{array}$ & $\begin{array}{c}59 \\
.001 \\
(25)\end{array}$ & $\begin{array}{r}-.23 \\
.13 \\
(25)\end{array}$ & $\begin{array}{r}-.21 \\
.16 \\
(25)\end{array}$ & $\begin{array}{r}11 \\
31 \\
25)\end{array}$ & $\begin{array}{r}.16 \\
.22 \\
(25) \\
\end{array}$ \\
\hline I & $\begin{array}{r}.05 \\
.39 \\
(31)\end{array}$ & $\begin{array}{r}.25 \\
.09 \\
(31)\end{array}$ & $\begin{array}{r}.15 \\
.20 \\
(33) \\
\end{array}$ & $\begin{array}{r}.03 \\
.44 \\
(31)\end{array}$ & $\begin{array}{r}.09 \\
31 \\
(31) \\
\end{array}$ & $\begin{array}{r}.16 \\
.26 \\
20) \\
\end{array}$ & $\begin{array}{l}13 \\
.25 \\
(30)\end{array}$ & $\begin{array}{r}.47 \\
.02 \\
(19)\end{array}$ & $\begin{array}{r}.05 \\
41 \\
(25) \\
\end{array}$ & $\begin{array}{r}.02 \\
46 \\
(33) \\
\end{array}$ & $\begin{array}{r}.22 \\
.12 \\
(30) \\
\end{array}$ & $\begin{array}{c}4,3 \\
.006 \\
(33)\end{array}$ & $\begin{array}{r}.09 \\
33 \\
(26) \\
\end{array}$ & $\begin{array}{r}.05 \\
.40 \\
(26)\end{array}$ & $\begin{array}{r}-.21 \\
.16 \\
(26)\end{array}$ & \begin{tabular}{|l}
.14 \\
.25 \\
$(26)$ \\
\end{tabular} \\
\hline
\end{tabular}


I = registratic periodick onderzock

2 = registratie werkplekonderzock

$3=$ in gelijke mate rapporteren an directie en ondernemingarasd

$4=$ ongevreagd adviakeren

$5=$ ingeschakeld bij $\mathbf{d g e m e e n}$ beleid

$6=$ extra ectiviteiten

7 = bruikbaar advies voot personeclszaken

$8=$ bruikbaar advies voor ondernemingaresd

9) = professionele uikvocring anstellingsonderzock

$10=$ professioncle uitvoering spreekuur

11 = professioncle uitvoering periodick onderzock

12 - professionele uitvoering werkplekonderzock

13 = rendexest ennstellingsonderzock

14 = rendement preckuur

$15=$ rendement periodick onderneck

16 = rendement werkplekanderzock

$a=$ steun BCD voor onderneiningraed

$b=$ steun BGD vonr personcelsuaken

$\mathrm{c}=$ klantriendelijke houding BGD

$d=$ ervaring met uitvocring anstellingsonderzock

e = ervaring mel uitvoering periodick onderzock

$f=$ ondernemingsrajed ervart verzuimbegeleiding BGD ds controle

$g=$ werknemers ervaren verzuimbegeleiding $B G D$ ats controte

$h=B G D$ onderseemt volgens ondernemingsrand voldoende exira activiteiten

$i=$ sumenwerking BGD-directic

$\mathrm{j}=$ samenwerting BCD-ondememingtread

$\mathrm{k}=$ samenwerking BOD-personeclsaken

I = uitvosering asutellingsonderzock nes wens ondernemingsruse

$m=$ uitvocring anstellingwonderzoek navr wens werknemers

$\mathrm{n}=$ vitvoering epreckuur nas wens ondernemingsraed

$\mathrm{o}=$ uitvoering eprockuur nas wens werknemers

$p=$ uitvoering periodick onderzoelk nenr went ondernemingsraad

$q=$ virvoering periodick onderzock nav wens werknemers

$r$ = uitvoering werkplekonderzock newr wens ondernemingarand

s = uitvoering werkplekondepock ness wens werknemers 


\section{Dankwoord}

Zou je nog een keer aan het schrijven van een proefschrift beginnen met de kennis van nu, met het weten hoeveel tijd en inspanning je dat kost, was een veel aan mij gestelde vraag gedurende de afgelopen jaren, en het antwoord was steevast: zeker weten. Het waarom is dat het maken van een proefschrift in vele opzichten je leven verrijkt, je kennis vergroot, je netwerk van contacten uitbreidt, en het je dwingt tot het buiten je eigen kleine wereldje stappen. Ik ben er blij om dat ik dit niet allemaal alleen heb hoeven doen.

Mijn dank gaat in de eerste plaats uit naar mijn co-promotor dr. F. Nijhuis. Beste Frans, Ehre wem Ehre gebührt, maar dit proefschrift was zeker niet in deze vorm en met deze inhoud zonder jouw permanente ondersteuning tot standgekomen. We hebben in levendige discussies menig boompje opgezet over bedrijfsgezondheidszorg, en als dit echte boompjes waren geweest zou het probleem van het tropisch regenwoud tot het verleden behoren. Tot in de kleine uurtjes passeerden diverse ideeën over de gewenste organisatie en inhoud van BGZ de revue. Met ijzeren volharding bleef je sleutelen aan wat je eens noemde mijn "braziliaanse schrijfstijl". Daarnaast wil ik mijn promotores, prof. dr. Tj. de Boorder en prof. dr. H. van der Hart danken voor hun vakspecifieke inbreng. Voor mij was het bij elkaar komen van twee werelden, twee vakgebieden, namelijk bedrijfsgezondheidszorg en marketing, zeer boeiend, niet in de laatste plaats door jullie inbreng.

Ik ben dankbaar dat ik bij mijn eerste schreden door de jungle van kwaliteitszorg en marketing over waardevolle gidsen kon beschikken. Zonder de vakinhoudelijke en methodologische steun van prof. dr. J. Kasper, prof. dr. E. Reerink en prof. dr. F. van Wijmen zou ik beslist verdwaald zijn. En ook in een latere fase wezen prof. F. van Dijk en prof. H. Philipsen mij de meest begaanbare weg naar mijn doel, waarvoor mijn dank.

Ook wil ik Richel Lousberg die de gegevens heeft ingevoerd in de computer en diverse analysen heeft uitgevoerd bedanken.

De leesbaarheid van dit proefschrift heeft aan kwaliteit gewonnen dankzij het kritische commentaar van $\mathrm{M}$. Heesbeen, die tevens de vertaling van de samenvatting in het Engels verzorgde. Voor de kwaliteit van de lay-out zorgde Isel van Noppen. Beiden wil ik danken dat zij van een rijstebrij van woorden een alleszins eetbare vlaai hebben gemaakt.

Maar mijn meeste dank gaat toch uit naar mijn vrouw, Hannie.

Steeds weer bood je mij de tijd en gelegenheid om in alle rust aan het proefschrift te werken. Als vanzelfsprekend paste je je aan als ik weer eens achter de computer moest gaan werken, je leefde mee met elke stap die ik moest maken om het einddoel te bereiken, je hebt mij geen moment het idee gegeven dat voor jou mijn 
proefschrift een last was, terwijl er toch de zorg is voor een gezin met drie kinderen. Lieve Hannie, ik draag dit boek, dat gaat over kwaliteit van zorg, dan ook op aan jou. Want als er een is die het predicaat "topkwaliteit" verdient, dan ben jij het !

En lieve Martijn, Nicky, Sander, papa is nu echt doctor. De computer is nu jullie speelgoed.

Het noemen van namen heeft altijd het risico van het ten onrechte niet noemen van personen. Degene die tot deze vergeten categorie behoort, bied ik bij voorbaat mijn excuses aan.

Ton 


\section{Curriculum Vitae}

De auteur van dit proefschrift werd op 23 juni 1955 geboren te Wateringen (ZuidHolland). In 1973 werd het gymnasium B diploma behaald aan het Henric van Veldekecollege te Maastricht. In 1980 werd de studie Geneeskunde aan de Katholieke Universiteit Nijmegen afgesloten. Dankzij een zeer stimulerende stage bij de heer H. Wolvetang werd zijn belangstelling gewekt voor de bedrijfsgezondheidszorg. De opleiding tot bedrijfsarts werd in 1984 eveneens aan de Katholieke Universiteit Nijmegen afgerond. Zijn onderzoeksscriptie had tot onderwerp "De samenwerking tussen huisarts en bedrijfsarts".

Sedert 1980 is hij als bedrijfsarts werkzaam bij de Stichting Bedrijfsgezondheidzorg en Bedrijfsveiligheidszorg Zuid-Limburg, waar hij sedert dit jaar als adjunctdirecteur de eindverantwoordelijkheid heeft voor medisch-inhoudelijke zaken en de kwaliteit van dienstverlening. Als bedrijfsarts heeft en had hij de zorg voor een groot aantal bedrijven en organisaties uit diverse branches in de regio ZuidLimburg.

Sedert 1987 verzorgt hij de supervisie voor bedrijfsartsen in opleiding. Van 1984 tot 1987 was hij als onbezoldigd universitair docent parttime verbonden aan de Capaciteitsgroep Arbeidsgeneeskunde van de Rijksuniversiteit Limburg. De aanstelling werd verleend vanwege de betrokkenheid bij het wetenschappelijk onderzoek, en vond plaats in het kader van een uitwisselingsprogramma tussen de BGD ZuidLimburg en de Rijksuniversiteit Limburg.

Daarnaast was de auteur tussen 1981 en 1992 bestuurslid van de Koninklijke Nederlandsche Maatschappij tot bevordering der Geneeskunst (KNMG), afdeling Maastricht, eerst als secretaris, en later als voorzitter. In 1991 werd ter gelegenheid van de opening van het Academisch Ziekenhuis Maastricht mede onder zijn leiding een symposium georganiseerd onder de titel "Kwaliteit van zorg, de patiēnt centraal". Auteur is sedert 1993 bestuurslid van de Stichting Maastricht Vestingstad met als aandachisgebied Public Relations.

De auteur is getrouwd en heeft drie kinderen. 
